

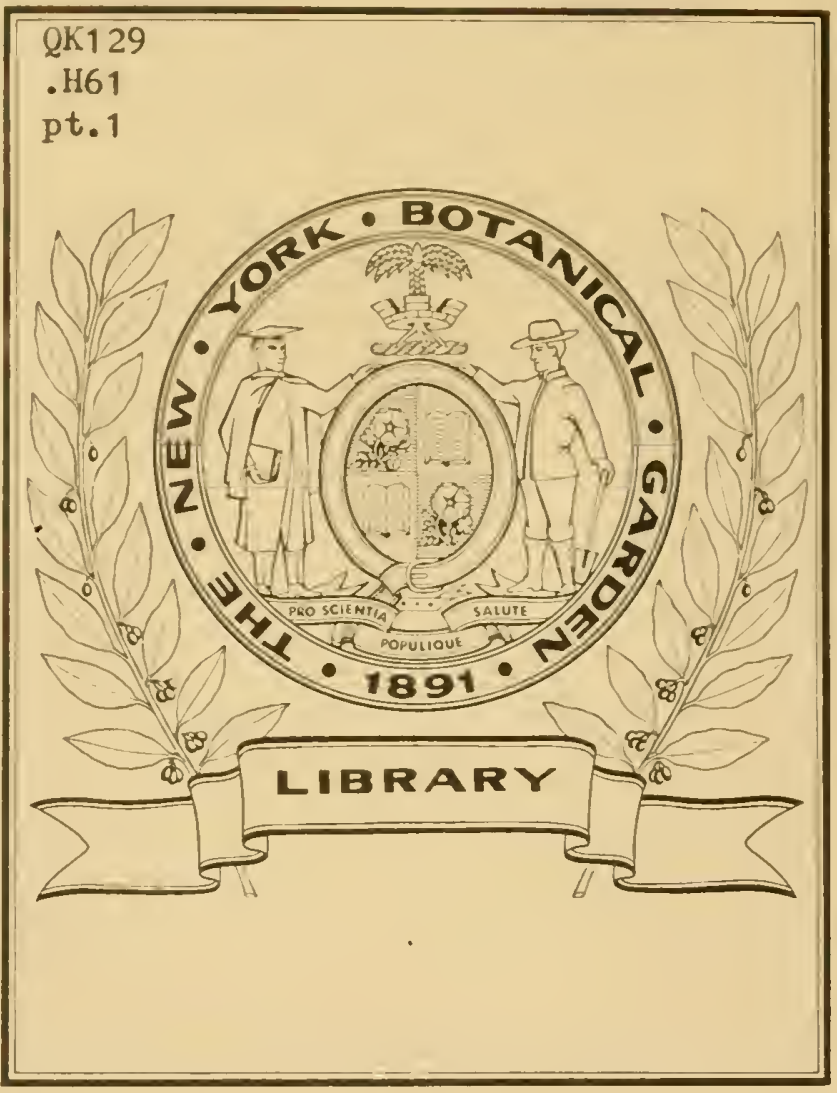




. 



$$
\text { . }
$$




\section{STATE MUSEUM}

JoHN M. ClaRkE, Director

Memoir 15

\section{WILD FLOWERS OF NEW YORK}

I N T WO PARTS

BY

HOMER D. HOUSE

State Botanist

Part I

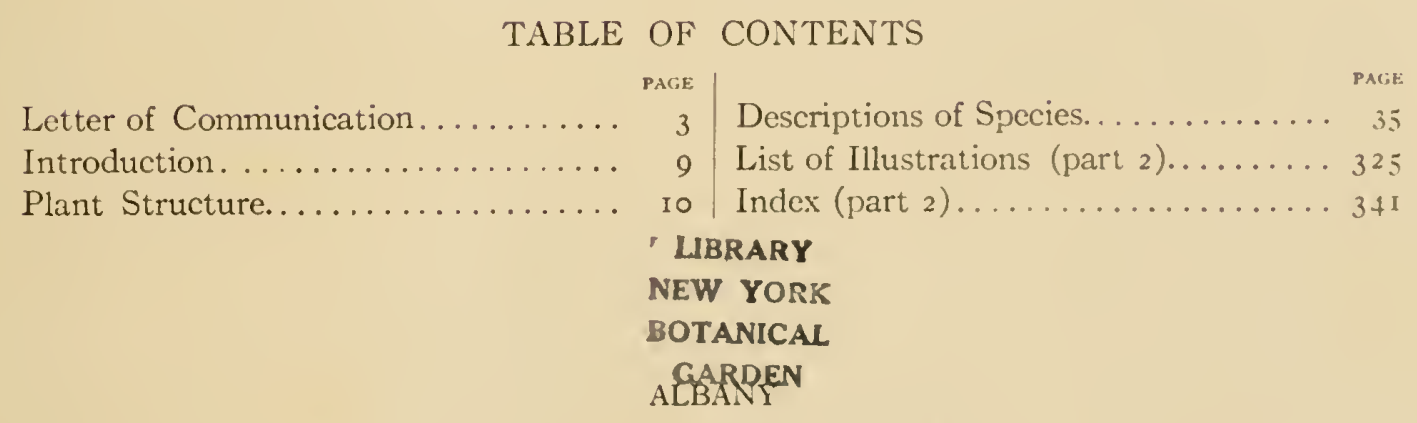

THE UNIVERSITY OF THE STATE OF NEW YORK

1918 
THE UNIVERSITY OF THE STATE OF NEW YORK

Regents of the University

With years when terms expire

(Revised to July 1, 1918)

i926 Pliny T. Sexton LL.B. LL.D. Chancellor - - - Palmyra

I927 Albert Vander Veer M.D. M.A. Ph.D. LL.D.

Iice Chancellor Albany

1922 Chester S. Lord M.A. LL.D. $-{ }_{-}-{ }_{-}-$Brooklyn

I930 William Nottinghail M.A. Ph.D. LL.D. - - - Syracuse

i92 I Francis M. Carpenter - $-{ }^{-}-{ }_{-}-$- Mount Kisco

I923 Abrail I. Elkes LL.B. D.C.L. $-{ }_{-}-{ }_{-}-$New York

1924 Adelibrt Moot LL.D. $-c_{-}-c_{-}-$Buffalo

1925 Charles B. Alexander M.A. LL.B. LL.D. Litt.D. Tuxedo

I9I9 John Moore LL.D. - $-{ }_{-}-{ }_{-}-{ }_{-}$- Elmira

I928 Walter Guest Kellogg B.A. Ll.D. - - - - Ogdensburg

I920 JAMEs BrRne B.A. LL.B. LL.D. - - - - - New York

i929 Herbert L. Bridgmax M.A. $-c_{-}-{ }_{-}-$Brooklyn

- President of the University and Commissioner of Education

JohN H. Finley M.A. LL.D. L.H.D.

Deputy Commissioner and Assistant Commissioner for Elementary Education

Thomas E. Finegan M.A. Pd.D. LL.D.

Assistant Commissioner and Director of Professional Education

Acgustus S. Downixg M.A. L.H.D. LL.D.

Assistant Commissioner for Secondary Education

Charles F. Wheelock B.S. LL.D.

Director of State Library

JAMES I. WYyer, JR, M.L.S.

Director of Science and State Museum

John M. Clarke D.Sc. LL.D.

Chiefs and Directors of Divisions

Adninistration, HiraM C. CASE

Agricultural and Industrial Education, Lewis A. Wilsox

Archives and History, Janes Sullivan M.A. Ph.D.

Attendance, James D. Sullivan

Educational Extension, Williay R. Watson B.S.

Examinations and Inspections, George M. Wiley M.A

Law, Frank B. Gilbert B.A., Counsel

Library School, Frank K. WALTER M.A. M.L.S.

School Buildings and Grounds, Frank H. Wood M.A.

School Libraries, Sherman Williams Ph.D.

Visual Instruction, Alfred W. Abrans Ph.B. 


\section{LE'T'TER OF COMMUNICATION}

\section{The Honorable John II. Finley \\ SIR: \\ President of the University}

New York State Musenm January 30,1918

The seientifie survey of this State, established in 1836 under the title " The Natural History of New York," embraces in its monumental reports two volumes treating of the flora of the State. These volumes, prepared by the distinguished botanist, John Torrey, bear the inscription: Flora of the Stute of New York; Comprising Full Descriptions of All the Indigenous and Naturalized Plants IItherto Disconered in the State, with Remurks on Their Economical and Medical Properties (I8+3). The species deseribed in this work were entirely of the phenogamous or flowering plants. Until that time no summary of the New York flora had been brought together: and the service rendered to the people of the State by the publication of this compendium was of a high order and was received with enthusiastie appreciation. Doetor Torrey's books served the needs of the time and expressed the state of its knowledge of the New York flora.

Seventy-five years have passed, and in that long streteh of time botanieal seience has grown widely and apace. The field of cryptogramie botany, that which deals with the flowerless plants, the mushrooms, mosses, lichens and their kind, was not entered in these early reports; it was obseure ancl little understood; its mostly inconspieuous growths did not attract the eye or invite the observer; nor were its important relations to the eeonomy of the eommunity even suspeeted.

The early official botanical investigations of the State were formally terminated by the publication of John Torrey's reports. Not till is 86 did the need of continuous official attention to this department of science mect 
the recognition of the Regents of the University. In that year Charles Horton Peck was designated to take charge of such botanical collections as had accumulated in the State Museum, and not long thereafter Mr Peck was officially appointed the State Botanist. To the botanical service of the State Mr Peck thereafter dedicated himself without reserve for the rest of his long life. He added much to the store of knowledge of the flowering plants, but the veiled world of the flowerless plants the more invited him and to it he specially gave his labors; leaving behind him a harvest of knowledge of them and a repute for his intricate researches which ranks him high on the roll of great botanists. Doctor Peck spared no effort, however, to increase the store of knowledge of all the flora of the State and he is the creator of the large state herbarium. After fifty years of unstinted devotion to his science and to his State, Doctor Peck fell asleep in honor, in the year 1917 .

Since the date of Torrey's report, the flowering plants have been the subject of study in all parts of the Commonwealth. Botanical societies and local students have multiplied; records have grown; the demand for information has greatly increased; but there has been no reliable exposition of such information accessible to these students.

It has been with this purpose of meeting a wide demand and of setting forth with such excellence as present knowledge and perfected modes of illustration could afford, that the present work, The Wild Flowers of New York, has been projected. The undertaking, bound to be an arduous one, has not been entered upon hastily. The advice of the leading botanists of this State and country was sought as to its timeliness, its scope, mode of presentation and illustration. The interested public will find it to be not a highly technical guide, couched in closely analytical descriptions, but a comparatively brief text, untechnical so far as the theme permits, accompanied by color illustrations made from the growing plants. The present State Botanist, Dr Homer D. House, is the responsible author of the work; he has not only prepared the text and its arrangement, but has supervised in detail the color photography; he has accompanied the photographers 
into the field on every visit and has selected every subject which is here reproduced.

The color illustrations must speak for themselves. 'They have been exceuted with most painstaking care by the quadricolor process, and the living and growing plants have been reproduced in their colors as near to those of nature as now seems possible. Credit for the printing and binding of the work should be given to the J. B. Lyon Company of Albany, but the Matthews-Northrup Company of Buffalo and the Zeese-Milkinson Company of New York are to be accredited with the quality and making of the color plates.

As such, then, these volumes are griven to the people of the State and as such, we believe, they would have this service rendered.

Very respectfully

JOHN M. CLARKE

Director 
. 
One who is upon the gray ocean at this season of the year when, in the woods and at the roadsides in the State of New York, the wild flowers are beginning to redeem their promises of life, appreciates as never before how much these quiet, persistent pioneers of the fields eontribute in seent, color and form to the making of that which is summed up in the name New York; even as the heather to the making of that eountry whose headlands are now dimly emerging from the level sea. The sight of a spray of these native flowers, sueh as many a page in this book earries, would be as a twig borne back in ancient times to the ark - a sign that, though the flood of war has overwhelmed many valleys, the elemental proeesses of life go forward undisturbed in the "Empire State." Whatever the eeonomie value or imputed harm of these aborigines, first settlers, later immigrants and vagrants which together eonstitute the Flora of the State, it is desirable from every point of view, sinee they are our near, most weleome but sometimes intrusive neighbors, that we should know their faces, their habits and their capacities for good or warning of ill. It is a great realm of life within the State of which the State as a whole should acknowledge the possession.

I have unusual satisfaction in finding it my official opportunity to say an introduetory word to this notable and distinguished work, beeause it is the record of a possession which the Director of the State Museum, Dr John M. Clarke, has enabled the State to make. It has a great practical value, but it has another value in making perennial and keeping in perpetual domestic bloom, in home and sehoolhouse and library, flowers that blossom but a few days or weeks in the wild state in which they have been so skilfully and sympathetically discovered by Doctor House. I am proud that the State has made possible such a publication and that The University of the State of New York has been able to exeeute the eommission with such success.

On the Atlantic Ocean

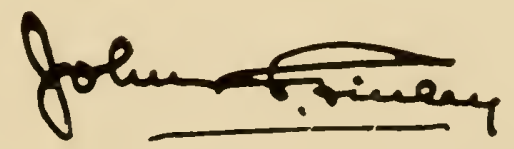

May I9I8

President of the Unizersity 



\title{
WILD FLOWERS OF NEW YORK
}

\author{
INTRODL'C'TION
}

The State of New York possesses a large variety of herbaceous and shrubby plants with conspicuous flowers, which may be classed under the rather broad and indefinite term of "wild flowers." For the purposes of this work only a few of the shrubs, such as the Mountain Latrel, Azalea and Labrador Tea have been included, the thought being to present mainly herbaccous plants with conspicuous flowers.

Anyone who has observed the natural vegetation in such unlike parts of the State as the salt marshes and pine barrens of I.ong Island, the higher Adirondack and Catskill mountains or the woodlands of the western counties must have been impressed by the obvious difference in the wild flowers of those several sections, and especially by the fact that very few of the wild flowers which bloom between early spring and late autumn in the Adirondacks are to be found on Long Island.

Such differences in the character of the vegetation of widely separated portions of the State are explained partly by soil conditions and partly by differences in climate. Located with the ocean at one side and the great inland lakes at the other, the State is favorcd by conditions of atmospheric moisture (relative humidity, rainfall and snowfall) which make it climatically a forest region, and hence favorable for a luxuriant varicty of herbaceous and shrubby plants; a region in which forests would naturally dominate all other vegetation if not cut down. The temperature conditions along the southern coast of the State are modified by the ocean, and to some extent on the west by the Great Lakes, while the elevated mountain masses of the Adirondack and Catskill regions produce cooler summers and shorter growing seasons.

I am indebted to Mr Edward A. Eames of Buffalo for photographs and autochromes of certain orchids, to Mr G. A. Bailey of Geneseo, and Mr O. O. Nylander of Caribou, Me., for additional photographs and to Mr Louis R. Robbins, former assistant to State Botanist, for assistance in the preparation of the text and illustrations for the chapter on Plant Structure. 


\section{PLANT STRUCTURE ${ }^{1}$}

No one who loves plants, either cultivated or wild, has failed to note how they differ from one another in shape, size, color and arrangement of the flowers, the leaves and other parts. These features are essentially the same in all individuals of a given species, but differ greatly in individual plants not belonging to the same species or variety.

To express these differences requires a terminology that is familiar largely only to those who have studied botany. The fact that it is practically impossible to describe a plant accurately without the use of a certain number of these special terms is a great impediment to a broad familiarity with our wild flowers on the part of all those who would like to study them with the aid of botanical guides. Because of the great variety of flowering plants and the minuteness of the flowers on many of them, the difficulty of identification is even greater than that connected with the study of bird and animal life.

The following brief summary of the terms necessary to an accurate description of a flowering plant, taken alone, means little to the average reader. Taken in connection with the plants as they are found growing and carefully studied, these terms, as soon as understood, place one on a footing of easy familiarity with the wild flowers, so that an accurate description as given in books means something definite and enables one to decide if the given description applies to the plant under consideration. Supplemented by illustrations, a study of the terminology used enables the student to acquire a much wider knowledge of our wild flowers.

\section{Leaves}

The leaf is an essential organ of all plants which live independently, that is, are not parasitic upon other plants (like the Dodder) or saprophytic upon dead plant remains (like the Indian Pipe). The leaf manufactures

'The cuts in this scetion are adapted from Gray's Lessons in Botany. Copyright by Asa Gray. Reproduced by permission of the American Book Company, publishers. 
food for the plant, gives off excess water (transpiration) and is the breathing organ of the plant. To accomplish these functions the leaf is built up by a complex arrangement of cells and is variously modified in different groups of plants to meet the external conditions of environment and competition by other plants.

The parts of a leaf are designated as blade, petiole and stipules. The leaf blade (figure IA) is the broadly expanded portion, although in some species the leaf blade is very narrow or even threadlike. The petiole (figure I B) is the stalk which supports the

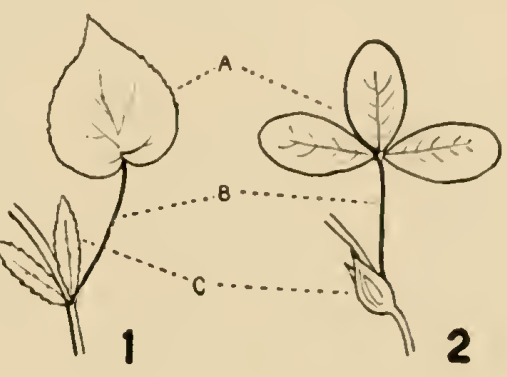
blade, and may be lacking in some cases, when the leaf is said to be sessile. The stipules (figure IC) are small, leaflike organs at the base of the petiole, and are best typified by the rose leaf. Frequently the stipules encircle the stem at the base of the petiole and often they are entirely lacking or fall away so soon after the leaves expand that they are not found when the plant is in bloom.

Terms of leaf outline: The various shapes of leaf blades may be expressed by the following terms:

Subulate; awl-shaped, without visible expansion of blade, and usually tapering to the apex (figure 3 ).

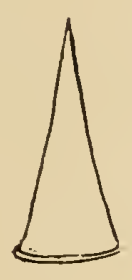

3

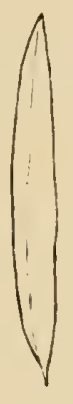

4

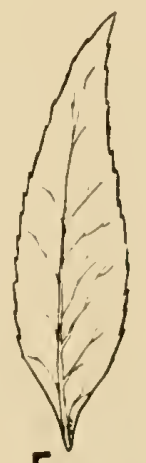

5

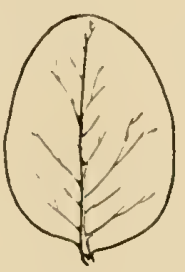

6

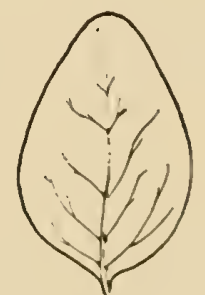

7

Linear, or ribbon-shaped; elongated and several times longer than wide (figure 4 ). 
Lanceolate; in which the leaf blade is three times as long as wide, or longer, and broadest at or below the middle (figure 5).

Oblong; in which the blade is somewhat longer than wide, broadest in the middle or with sides almost parallel (figure 6).

Ovate; shaped like an egg; that is, broadest below the middle or near the base (figure 7 ).

Elliptical; rounded at both ends, somewhat longer than wide (figure 8).

Orbicular or rotund; in which the blade is nearly or quite circular in outline (figure 9).
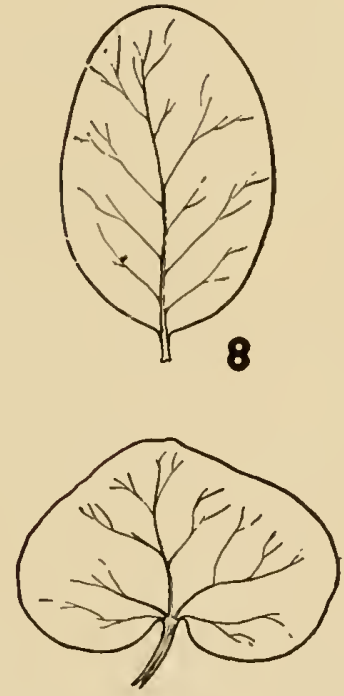

10

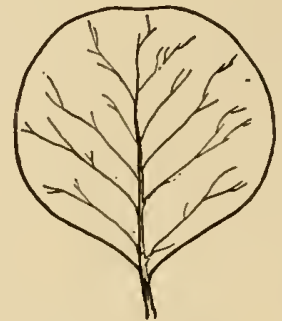

9 (figure II).

Consideration of a few leaf blades

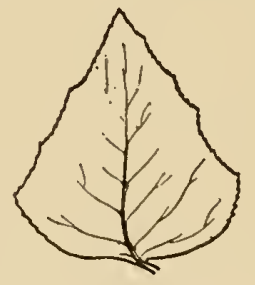

11 broader than long, with a heart-shaped base (figure Io).

Deltoid; triangle-shaped, similar to ovate but conspicuously broadened at the base and pointed at the apex shows immediately that these terms are not always sufficient to express accurately the shape and we may have recourse to combinations of terms, such as oblong-lanceolate, ovate-lanceolate (figure 13 ), etc.

Reniform; in which the blade is

The shape of leaf blades which are broadest above the middle may be expressed by the following terms:

Obovate; ovate in shape, but broadest near the apex or above the middle (figure 14).

Oblanceolate; lanceolate in shape but broadest above the middle or near the apex (figure I $_{5}$ ).

Spatulate; in which the blade is oblanceolate or obovate in shape with the base conspicuously elongated (figure I2). 
Terms applied to the apex of the leaf:

Obcordate; broad and heart-shaped at the apex (figure 16).

Emarginate; with a slight depression at the somewhat narrowed afpex (figure 17 ).

Retuse; terminating in a semicircular end, the center of which is somewhat indented (figure I8).

Truncate; with a flat or abrupt apex (figure I9).

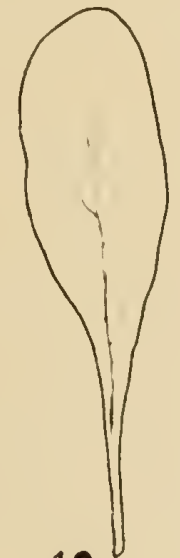

12

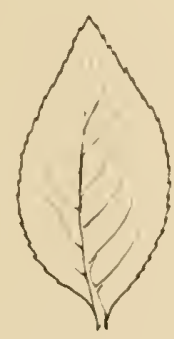

13

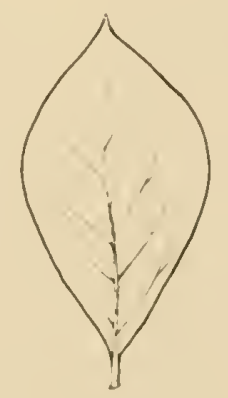

14

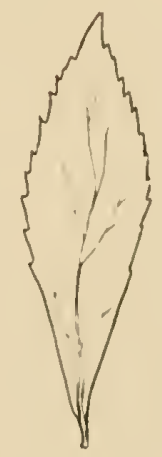

15

Acuminate; when the apex of the blade is longer than broad (figure 20). Acute; when the apex of the blade is about as broad as long (figrure 2 I ) Obtuse or blunt; when the apex is much broader than long (figure 22).

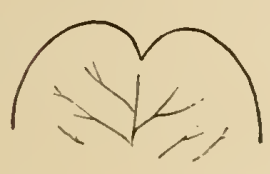

16

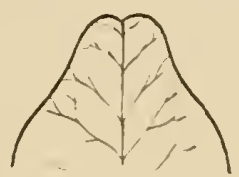

17

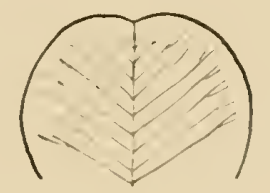

18

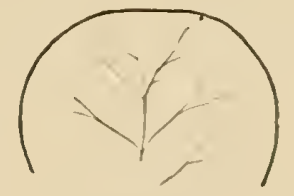

19

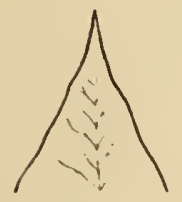

20

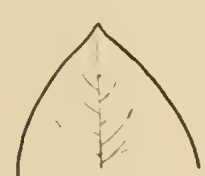

21

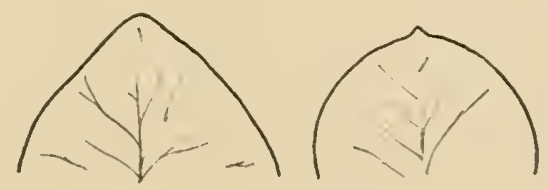

22

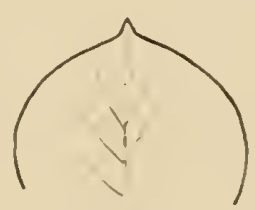

24 

23).

Mucronate; when the apex is terminated by a short blunt tip (figure

Cuspidate; when the tip of the blade is hard and stiff (figure 24 ).

Terms upplied to the base of the leaf:

The terms truncate, acuminate, acute, obtuse (defined above) may also be applied to the shape of the base of the leaf blade, in addition to the following:

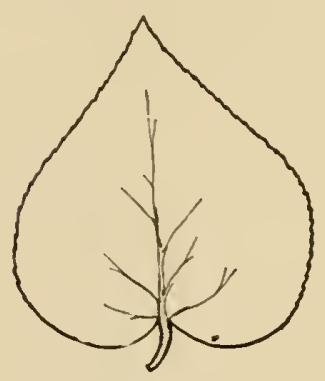

25

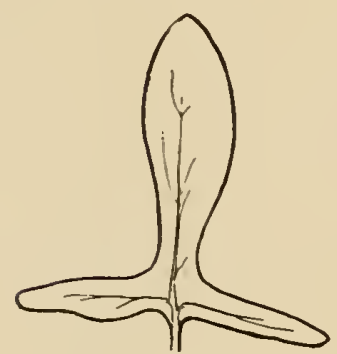

29

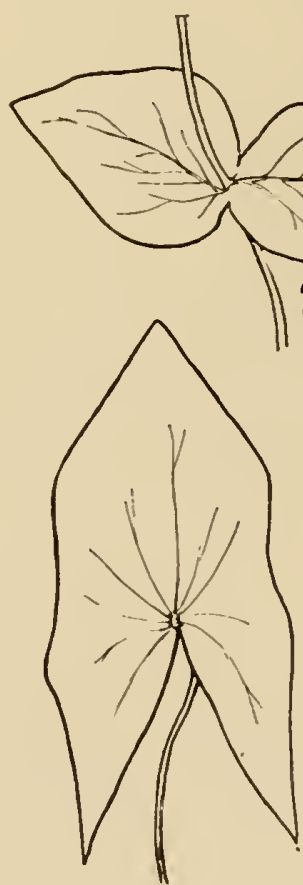

30
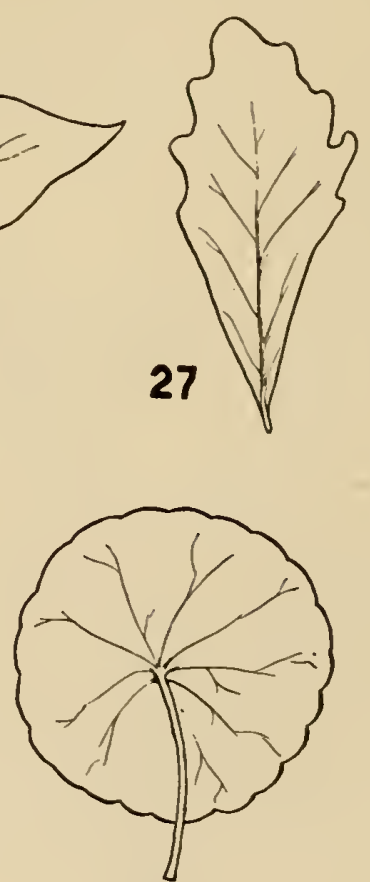

31
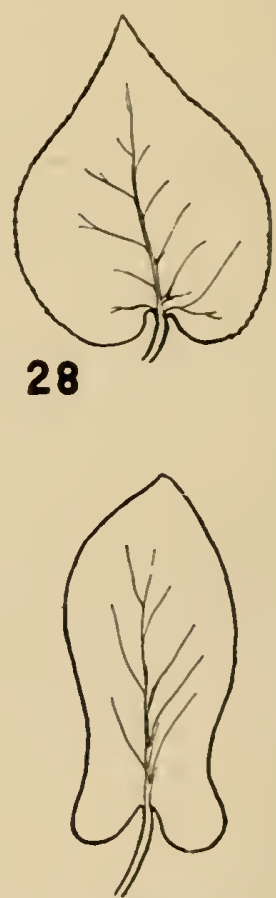

32

Cordate; heart-shaped (figure 25).

Cuneate, or wedge-shaped; when the sides of the leaf blade taper to an acute angle at the base (figure 27 ).

Auriculate, when the depression at the base of the blade is deep and produces on either side conspicuous basal lobes (figures 28 and 32 ).

Sagittate; when the basal lobes point downward like the head of an arrow (figure 30).

Hastate; when the basal lobes are turned outward (figure 29). 
Peltate; a rounded leaf blacke with the petiole attached at or near the middle of the lower surfaee (figure $3 \mathrm{I}$ ).

Perfoliate; when the bases of leaf blades meet and join around the stem of the plant (figure 26).

Terms applied to the marginal segmentation of lenf blades:

Sinuate; when the marginal lobes of the leaf blacle present a wavy outline (figure 33 ).

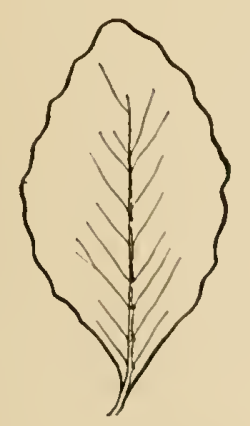

33

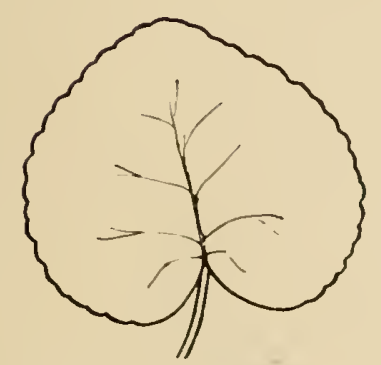

36

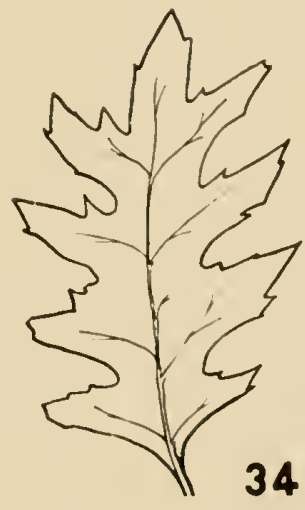

34

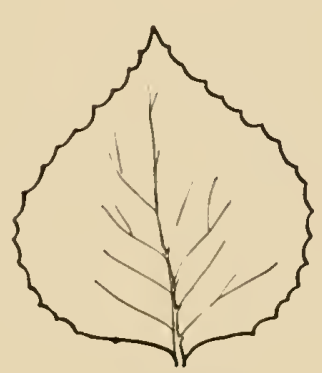

37

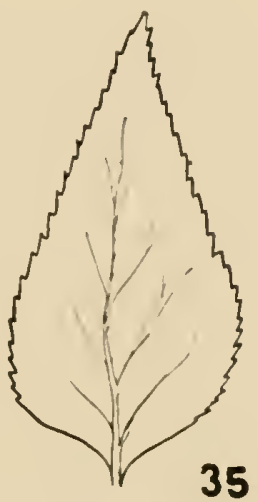

35

Pinnately lobed; when the tissue between the veinlets is cut out nearly to the midrib of the leaf and the divisions are arranged like the pinnae of a feather (figure 34 ).

Palmate; when the blade is decply divided nearly or quite to a common base (figure 38 ). 
Serrate (figure 35); when the margin is sharply toothed with coarse teeth, like a saw. When the teeth are rounded inward or are convex, the

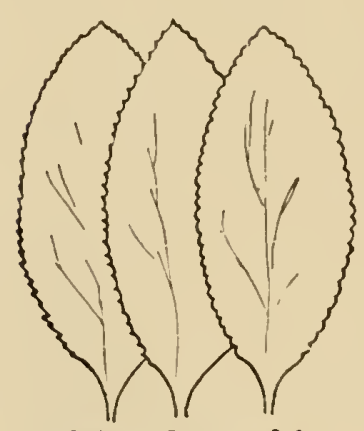

$39 \quad 40 \quad 41$ margin is said to be dentate (figure 37). When the margin is formed of rounded teeth it is said to be crenate (figure 36). If the teeth are very small, the diminutives of the above terms are used, namely, serrulate (figure 39), denticulate (figure to) and crenulate (figure $+\mathrm{I}$ ).

Compound leares:

When a leaf possesses several divisions or segments upon a common petiole or rachis, it is said to be compound. The distinction between a simple leaf, which is deeply divided, and a compound leaf, rests upon the presence of distinct articulation between the leaf segment of the compound leaf and the petiole. Compound leaves may be pinnate (figure +2 ), when the leaflets are arranged on either side of a common petiole (Ash, Rose, Walnut etc.) or palmately compound (figure 43 ), when the leaflets all join the petiole at its summit (Horse-chestnut).

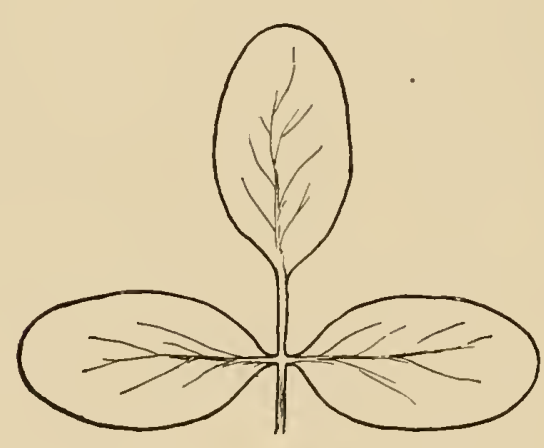

42

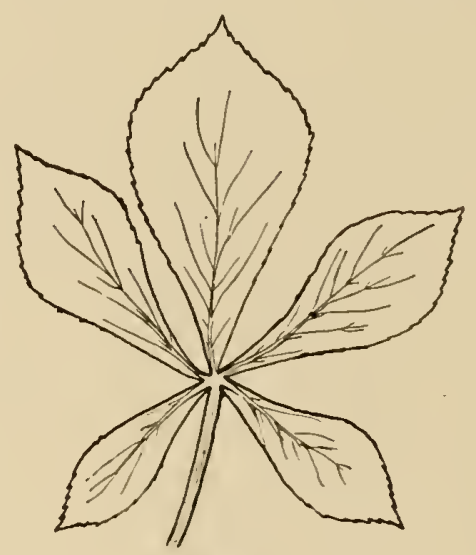

43

Leaf arrangement:

Alternate, when the leaves are arranged one at a node and each leaf is opposite and above the preceding leaf; spirally arranged, when the nodes 
are not opposite; and opposite when the leaves are in pairs opposite each other on the same node. When several leaves are inserted on the same node they are said to be whorled or verticillate.

\section{Flowers}

The flower of a plant is a group of organs (figure 44 ) which exist for the purpose of producing seed. The parts of a flower fall into two general groups: those which ac tually function as seed producers (essential organs), and those which act as protective organs or organs for the attraction of insects (floral envelops or perianth). These might also be designated as nonessential organs, since they are lacking in certain flowers.

The essential organs consist of two parts, the pistils (figure $4+\mathrm{A}$ ) and the stamens (figure $4+\mathrm{D}, \mathrm{E}$ ), often designated as the pistillate and staminate parts of a flower; and when a

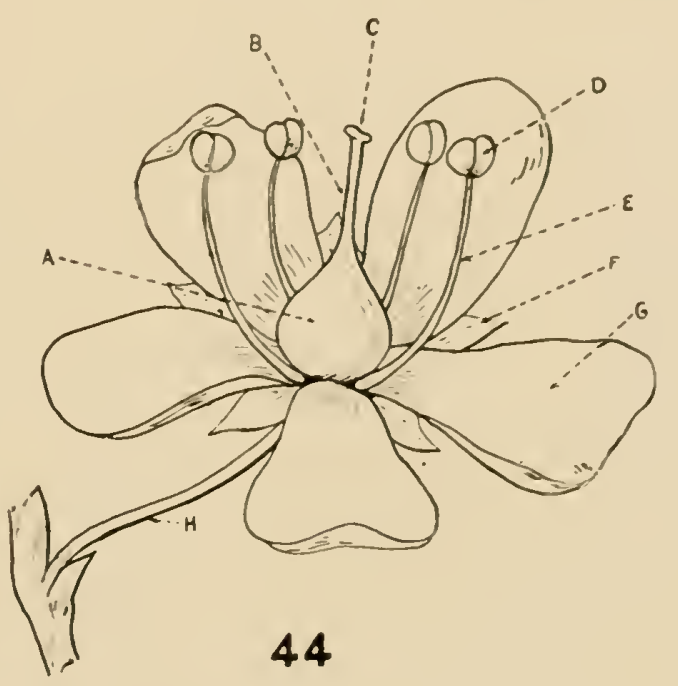
flower contains only pistils it is called a pistillate flower, and when it contains only stamens it is called a staminate flower.

When both stamens and pistils are present in the same flower, it is said to be perfect. If, in addition, the flower possesses the floral envelops. calyx and corolla, it is called a complete flower. Hence a flower which lacks any of these sets of organs is incomplete (that is, if it lacks either calyx or corolla); if it lacks either stamens or pistils it is imperfect.

The perianth or floral enielopes:

The ideal flower contains two sets of floral envelops, the calyx (figure $+4 F$ ) and the corolla. In some flowers the corolla is entirely or partly divided into a certain number of divisions, each of which is called 
a petal (figure $44 \mathrm{G}$ ). They are usually but not always brightly colored. Subtending or beneath the corolla is the calyx, which is usually, but not always, green, and is likewise in many plants divided into a number of distinct parts or sepals. When an incomplete flower has but one set of floral envelopes, it is usually the petals (or corolla) which are lacking, and in such cases the calyx may be brightly colored and function as a corolla (a petaliferous calyx).

\section{The essential organs:}

The number and arrangement of stamens varies in different kinds of plants, but nearly always a stamen consists of a filament or stalk (figure $44 \mathrm{E}$ ), which bears at its apex the anther (figure $44 \mathrm{D}$ ), or pollen-bearing sac. The shape of the anther, and the manner by which it dehisces, or opens to emit the pollen, likewise varies in different groups of plants.

The pistil (figure $4+\mathrm{A}-\mathrm{C}$ ), or seed-bearing organ, consists of an ovary (figure $44 \mathrm{~A}$ ), stigma (figure $44 \mathrm{C}$ ) and style (figure $44 \mathrm{~B}$ ). The ovary is at

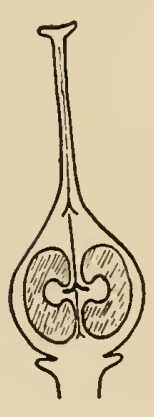

45

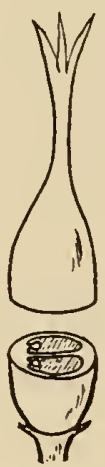

46 the base of the pistil and contains the ovules or eggs, which after fertilization ripen into seeds. The ovary usually contains several or many ovules, but may contain as few as a single ovule. The stigma is that part of the pistil which acts as a receptive organ for pollen in the process of pollination. Its surface is usually moist and minutely granular and its position and shape are dependent upon the mode of pollination (insects or wind)

made use of by the particular plant. The style connects the stigma and ovary. It may be long or short, slender or stout, or sometimes entirely lacking when the stigma is situated directly upon the ovary.

The ovary itself may contain one or several chambers or cells (figures 45-47), and very frequently the number of chambers in the ovary and the 
lobes or divisions of the stigma bear a direct relationship to the number of petals, sepals and stamens. The term carpel (or carpophyllum) is used to designate the seed-bearing leaf. A carpel may be a pistil of itself, or it may be a constituent of a more complex pistil. In either case, a carpel is the homologue of a leaf. The surface within the ovary to which the ovules are attached is called the placenta.

Simple pistils may be solitary, or several together on a common receptacle within the flower, as in the Buttercup. A compound pistil consists of two, three or more carpels united into one body.

The apex of the flowering stem, which supports the flower, is designated as the receptacle.

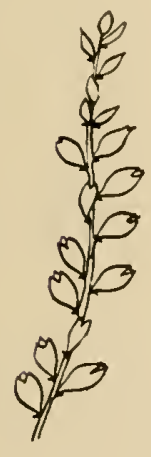

48

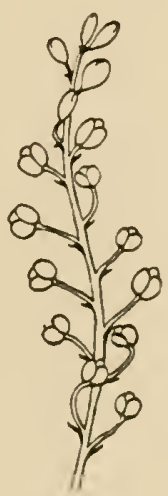

49

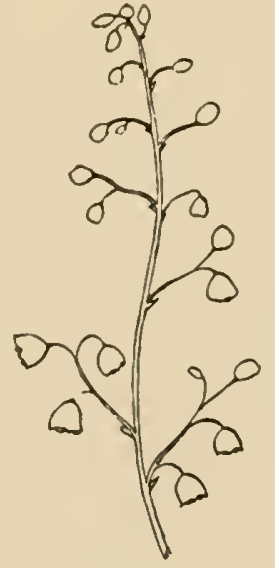

50

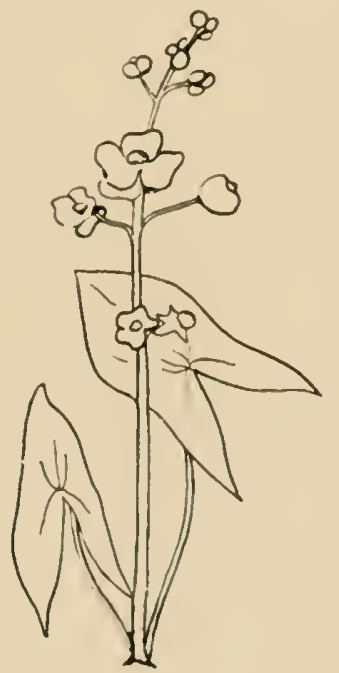

51

Arrangement of flowers:

Flowers are either solitary or clustered, but their arrangement varies in different kinds of plants, and may even vary to some extent in the same species. The arrangement or disposition of the flowers may be designated as the inflorescence. The following are the most frequent arrangements of flowers:

Spike (figure $4^{8}$ ), in which the flowers are arranged along the flowering 
stem, and sessile (that is, without stalks) or with very short stalks (pedicels). When the flowering stem is naked (devoid of leaves) and rises directly from the root or crown of the plant, it is called a scape (figure $5 \mathrm{I}$ ).

Raceme (figure 49), in which the flowers are arranged along a flowering stem and each flower possesses a distinct stalk or pedicel. The lower pedicels may be somewhat longer than the upper ones.

Umbel (figure 52), when the flowers arise from the same point, which is usually the apex of the flowering stem or of a lateral flowering stalk, and

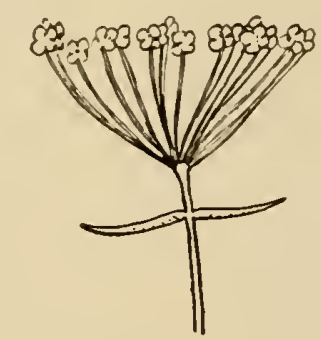

52

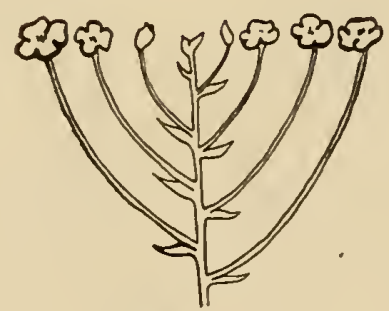

54

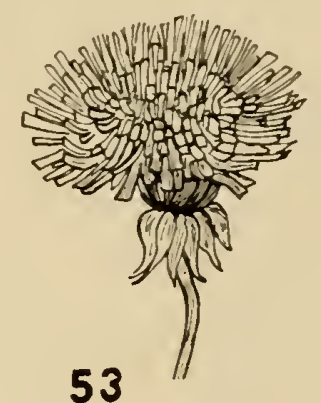

53

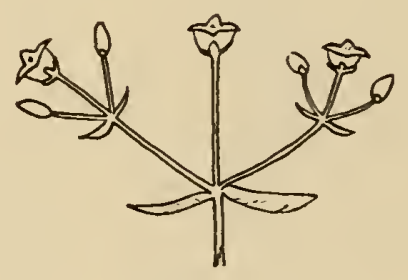

55

radiate like the rays of an umbrella. If the radiating stalks of such an inflorescence bear smaller umbels at their tips, it is called a compound umbel.

Corymb [corymbose] (figure 54), when the branches of an inflorescence are of unequal length, but the lower or outer ones are longest so that they all form a flat-topped, or nearly flat-topped, cluster.

Cyme (figure 55), when the flowers each terminate an axis or stem arising successively from a new axis or stem. 
A spadix is a spikelike inflorescence with a fleshy stalk ancl with sessile flowers; the floral leaf or bract which subtends it or surrounds it partially is called the spathe (Skunk Cabbage, Wild Calla).

A panicle, or compound raceme (figure 50), is formed by the arrangement of flowers along the plant stem, similar to a raceme, but each flower stem has two or more branches.

Head (figure 53), an arrangement of flowers compactly on a common receptacle and surrounded by bracts (involucral bracts).

Modification and arrangement of the perianth:

Among the simpler groups of flowering plants the perianth is wanting, as in the Cat-tail and Willow. In the Sweet Flag, Oak and others, the perianth consists of a few scales, but in the higher plants, the perianth appears as a conspicuous portion of the flower, as in the Lily. Finally, as in the Rose family, there appears a clearly differentiated calyx and corolla.

In the simpler types of flowers, the sepals, petals and the stamens arise at the top of the receptacle. Such flowers are called hypogynous, meaning the insertion of these parts below the ovary (figure 56 ).

When the basal portion of the receptacle is continued upward, forms a cup-shaped growth around the ovary and bears the sepals, petals and stamens upon its margin, the flower is called perigynous (figures 57 and 59), meaning the insertion of the parts of the flower around the ovary.

Frequently the growth of the receptacle adheres to the ovary, and the sepals, petals and stamens appear to arise from above the position of the ovary, in which case the flower is called epigynous (figure 58), meaning above the ovary.

There may be varying degrees of cohesion or union of the parts of one or both of the floral envelopes (perianth). When the sepals are united with each other the calyx is said to be gamosepalous, while a gamopetalous corolla (figures 62,63,64 and 65) refers to a union of the petals, as in the flower of the Morning-glory.

The degree of coalescence or union of parts of a gamopetalous corolla. 


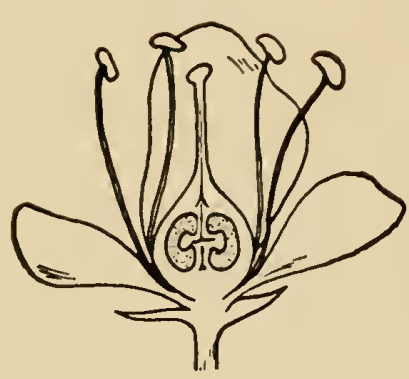

56

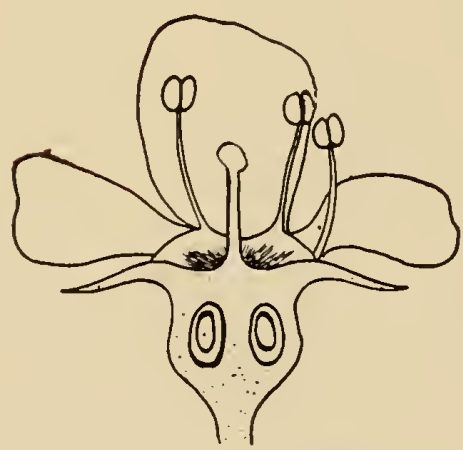

58

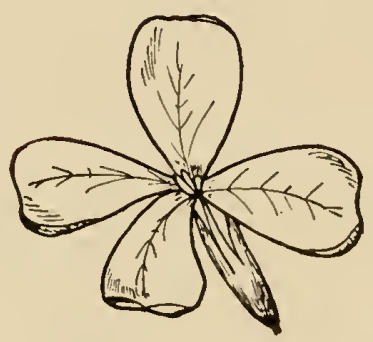

60
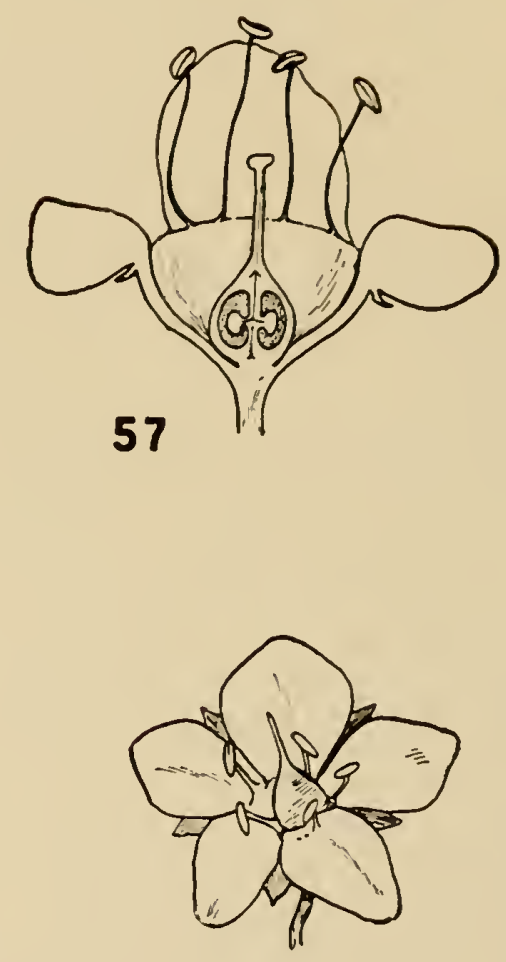

59

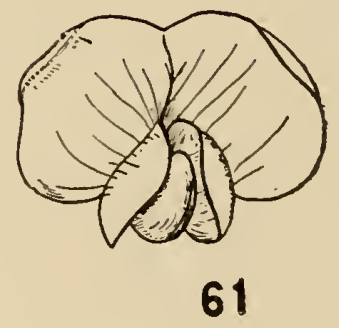


varies in different flowers. When the calyx or corolla is divided almost to the base it is said to be parted (figure 63); when divided to about the middle it is said to be cleft (figure 64); when still less separated it may be said to be lobed or toothed (figure 65 ); or if entire on the margin it is said to be entire (figure 62).

When the parts of each set of organs of a flower are alike or equal in size, the flower is said to be regular, which means that the petals are alike, the sepals are alike and the stamens are alike. A symmetrical flower is one in which the sepals, petals and stamens are of the same number; unsymmetrical when there are unequal numbers in each cycle, that is, an unequal number of sepals, petals or stamens.

Certain groups of plants may often be recognized by the form of the corolla of some of its members. This character seems to be quite constant and the names of several large or important families of flowering plants are derived from this source. Of these groups we may mention the cruciferous (figure 60) type of flower of the Mustard family (Cruciferae), in which there are four spreading petals forming a cross, as in the flower of the Spring Cress ( $\mathrm{Cardamine} b u 1 \mathrm{bos}$ ); the labiate corolla (figure 66) of the Mint family (Labiatae) in which the corolla is more or less two-lipped; the papilionaceous type of flower (figure 61) of the Pea family (Leguminosae), in which the petals are characteristically grouped into two lateral (wing) petals, a single upper (banner) petal and a pair of lower petals, often more or less united to form the keel.

\section{Stamens:}

The general characteristics of the stamens have already been described. In the stamens, as in the case of the petals and sepals, the number and arrangement are subject to great variation in different kinds of plants. Monandrous refers to a flower with a single or solitary stamen; polyandrous to a flower containing several stamens. The stamens may be monodelphous, in which the filaments are united into a tube, as in the IVild Lupine (figure 67 ), or the stamens may be diadelphous (figure 68), which means two sets 

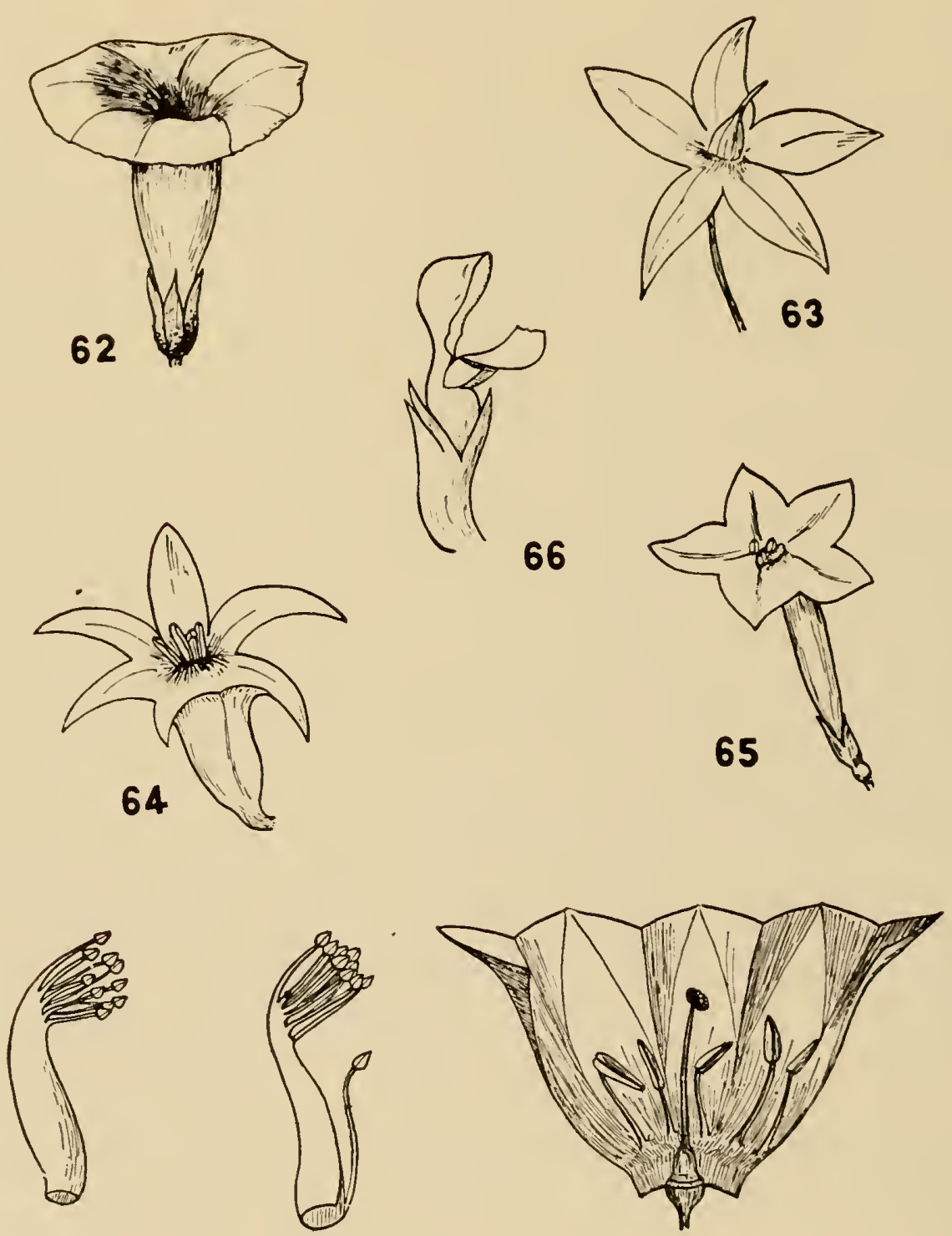

67

68

69

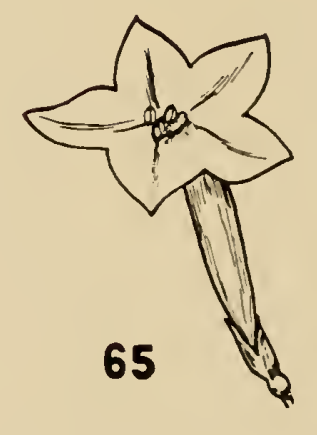


of united stamens. In this form of arrangement there may be a union of the filaments of all the stamens except one, whieh is a common diarlelphous arrangement of stamens in many of the speeies of the Bean family. When there are several sets of united stamens, the arrangement is said to be polydelphous.

Adnation or union of the stamens with other parts of the flower is of frequent oeeurrence, and the terms employed depend upon the degree of adnation, or the absenee of it, namely, hypogynous (meaning beneath the pistil), applied to parts, ineluding stamens, whieh are inserted or borne on the reeptacle of the flower (figure 56). This is the absenee of adnation and indieates an mnmodified type. Perigynous (around the pistil) implies an adnation whieh earries up the apparent origin or place of insertion of the parts of the flower to some clistanee above or away from the reeptaele and thus placing the insertion around instead of beneath the pistil (figure 57 ). Epigynous (on the pistil), where the adnation is eomplete to the very top of the ovary (figure $5^{8}$ ).

When the stamens are borne upon the eorolla, or upon the tube of the corolla, they are said to be epipetalous (figure 69 ), and when they are borne upon the pistil, as in the Orehid family, they are said to be gynandrous.

The most important part of a stamen is the anther (figure ${ }_{+} \mathrm{D}$ ), whieh eontains the pollen. It normally eonsists of two lobes or sacs; but as eaeh sae is often, and in most of our common flowers, divided into two cavities, it appears to possess in sueh instances four pollen sacs. For the diseharge of the pollen, the cells of a normal anther open along a definite line, usually extending from top to bottom. This suture or line of dehiseence may be lateral or marginal, or eentrally located.

In the genus Solanum, to whieh the Potato belongs, in most members of the Heath family (Erieaeeae), in Polygala, and eertain other speeies, the anther cells open only by a hole or pore (figure $7 \mathbf{I}$ ). In the Blueberry, Cranberry ete. the pore-bearing tip of the anther cell is prolonged eonsiderably, often into a slender tube. In the Barberry, and in most other members of that family, and in the Lauraeeae, the whole face of each anther 
cell separates by a continuous line, forming a kind of door, which is attached at the top, and turns back, as if on a hinge; and the anther is said to open by uplifted valves (figure 72). In the Sassafras and certain other members of the Lauraceae, each lobe of the anther opens by two smaller valves, like trapdoors.

The attachment of the anther to the filament (or stalk) presents three

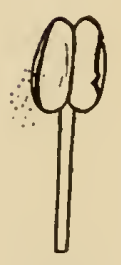

70

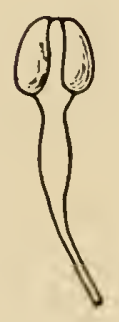

73

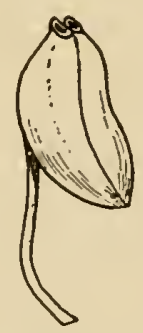

71

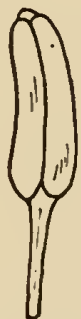

74

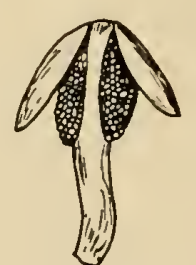

72

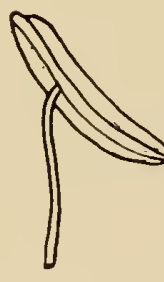

75 different modes, frequently connected by gradation: Innate (figure 70), in which the anther is a direct continuation of the axis of the filament, the cells usually opening by marginal slits, and the lobes or cells of the anther project neither inward nor outward; adnate (figure 73), in which the anther is a direct continuation of the filament but having the anther cells adherent to the anterior or posterior face of the filament; the Wild Ginger (Asarum) furnishes a good example of this, on account of a prominent prolongation of the connective or tip of the filament (figure 74); versatile (figure 75),

when the anther is attached at some part only of its back or front to the tip of the filament, on which it lightly swings when the pollen is discharged; examples of this are seen in members of the Lily family, the grasses, Evening Primrose (Oenothera biennis) and others.

\section{Pollination}

The structure of most flowers affords an excellent indication of the device used for the transference of pollen from one flower to another (pollination). Long ago it was assumed that Nature wished no flower to be fertilized by its own pollen, but in the light of present knowledge we know 
this is not wholly true. 'The subject of pollination of flowers by insects received a great light through the investigations of Charles Darwin ant the publication in I 862 of his well-known book on the fertilization of orchids by the aid of insects.

As we understand the matter today, it appears that flowers are habitually intercrossed (flowers of the same species), and that there are manifold structural adaptations which secure or favor this interchange of pollen. Separation of sexes (stamens and pistils) is a direct adaptation to crosspollination, rendering it necessary between individuals with dioecious flowers, and favoring it in most plants with monoecious and polygamous flowers. Strictly, close fertilization can take place in hermaphroditic flowers only.

Flowers depend upon certain external agencies for the transference of pollen from one flower to the flower on another plant. These agencies are wind (anemophilous flowers) and insects (entomophilous flowers). Other agencies are of minor importance, although water must be considered in connection with some aquatic plants.

Wind-pollinated flowers are mostly dull in color, destitute of odor and nectar, since these qualities attract insects. Wind-pollinated flowers usually have the sexes separated, the flowers borne in great abundance and have very light pollen. Most of our common trees (the Pines, Oaks, Hickories etc.) depend upon wind for the transference of pollen, as do also the grasses, sedges, Plantain and others.

Insect-pollinated flowers are correlated with showy coloration (including white, which is most showy at dusk), odor or secretion of nectar. Structural adaptations of the flower in reference to insect visitation are wonderfully various, and most of these are found upon investigation to favor, or often to necessitate, cross-pollination. The range of these variations is too extensive to be treated here. Literature upon this subject is easily available and most textbooks of botany contain chapters upon the subject.

After pollination the pollen grain germinates upon the surface of the 
stigma, sends a tube down through the tissue of the stigma and style and discharges into the ovulc a male nucleus which unites with a nucleus in the embryo sac of the ovule, fertilizing the ovule, and stimulating its development into an embryonic plant. By a process of hardening of the coats of the ovule its devclopment is arrested and the seed is produced.

\section{The Fruit}

The fruit of a plant (in the case of our flowering plants) consists of the matured pistil (or gynoecium), including also whatever parts of the perianth or other floral organs may be joined to it. Fruits are of various degrees of simplicity or complexity, and may consist of a matured simple ovary, a cluster of such ovaries, at least when they are somewhat coherent, or a ripened ovary with calyx and other floral parts consolidated with it.

The pericarp, or seed vessel, is the ripened ovary and should therefore accord in structure with the ovary from which it is derived. In the devclopment of a simple ovary into a simple fruit certain alterations sometimes take place, either by the abortion or obliteration of certain parts, or by accessory growth. The dehiscence is the method by which a pericarp opens to discharge its seeds and may be regular (normal) or irregular (abnormal). The word "pod" is frequently applied to dehiscent pericarps.

A capsule is a dehiscent pericarp formed of two or more carpels. Such carpels are septicidal (figure 80) when the dehiscence is such that the carpel is divided into its constituent carpels. Members of the St John's-wort family afford a good example of this method as do also Rhododendron and Kalmia. Carpels arc called loculicidal (figurc 79) when each of the component carpels splits down its dorsal suture, as in Iris, Hibiscus, Oenothera etc.

Kinds of fruits. For ordinary purposes it is sufficient to classify fruits in to four classes:

I Simple fruits, those which result from the ripening of a single pistil.

2 Aggregate, those of a cluster of carpels of one flower crowded into a mass. 
3 Accessory fruits, where the principal mass consists of the surroundings or support of cither a simple or an aggregate fruit.

4 Multiple or collcctive fruits, formed by the union or compact aggregation of the pistils of several flowers.

\section{Simple Fruits}

Upon the basis of texture, simple fruits may be designated as dry fruits, stone fruits and baccate fruits.

Dry fruits which are dehiscent:

Follicle (figure 78 ), a pod formed by a simple pistil, and dehiscent along one line (suture, and almost always the inner or ventral suture), as in the Columbine, Marsh Marigold, Milkweed and Dogbane.

Legume (figure 77), a pod formed of a simple pistil which is dehiscent by both sutures, so dividing it into two pieces or valves. The fruits of the Bean or Pea family are of this sort. Some members of this family (Meibomia), however, have legumes reduced to indehiscent achenes, joined together end to end, and to which a special term "loment" (figure 76 ) is applied.

Capsule (figures 79 and 8o), a pod

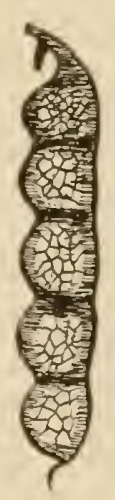

76

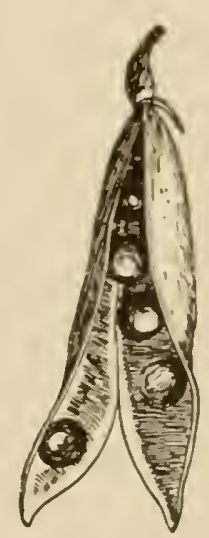

77

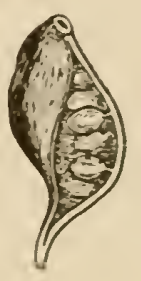

78

or dehiscent fruit, of any compound pistil. The modes of regular dchiscence are mentioned above in the paragraph on dehiscence, and it remains here to describe two modifications of the capsule, namely, the pyxis, in which the dehiscence is along a circular line, cutting off the upper part as a lid. examples of which are seen in the common Plantain. Purslane and Henbane, small plants or weeds not illustrated in this work: and the silique, a narrow, two-valved capsule, with two parietal placentae, from which the 
valves separate in dehiscence, as in the Mustard family, where there is usually a false partition stretched across between the two placentac.

Dry fruits which are indehiscent:

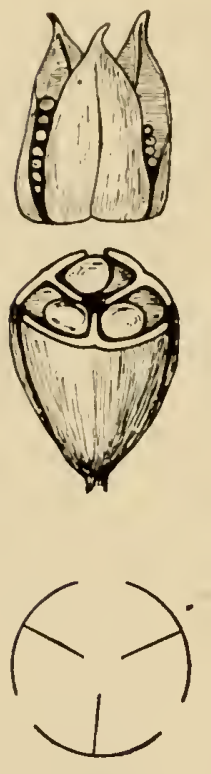

79

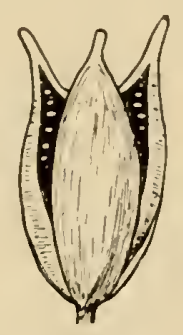
provided with a wing. In the Ash, the wing is terminal; in the Elm, the wing surrounds the body of the pericarp; and the Maple fruit is a double samara or pair of such fruits.

Achene (figures 8I-88), a general term for all one-seeded, dry and hard, seedlike fruits. The best examples are the fruits of the Buttercup, Anemone, Clematis and Avens. The style sometimes remains on the fruit as a long and feathery tail (Dandelion, figure 85 ), and in others merely as a short hook (Buttercup, figures 86 and 87 ). In the Compositae (Sunflower family) the tube of the calyx is joined with the surface 80 of the ovary, and its border or upper edge appears as a crown or cup, or a set of teeth or of scales, or very often as a tuft of bristles or hairs, called the pappus (figures $82-84,88)$.

Utricle, a dry achenelike fruit with a thin and bladdery loose pericarp, like that of the Goosefoot (Chenopodium).

Caryopsis or grain, differs from the achene in having the seed completely filling the cell and its thin coats firmly consolidated throughout with the very thin pericarp. This term is applied to the fruits of the grass family, including Indian corn and all other cereals.

Nut, a hard one-celled and one-seeded, indehiscent fruit which finds its best examples in the fruit of the Hazel, Beech, Oak, Chestnut etc. The smaller nutlike fruits of the Borrage family and of the Mint family are usually called nutlets. 
Stone fruits:

Drupe (figures 90 and 92), of which the best examples are the fruit of the Cherry, Plum, Peach etc., are one-seecled or rarely two-seeded, in the ripening of which the outer portion of the pericarp lecomes fleshy or pulpy and the inner portion becomes much hardened. The term is also commonly applied to similar fruits of the Hackberry, Cornus, Rhamnus etc. In the case of the Blackberry (figure 89) and Raspberry, the several pericarps of the aggregate fruit are called drupelets.

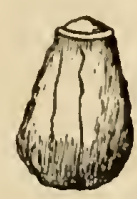

81

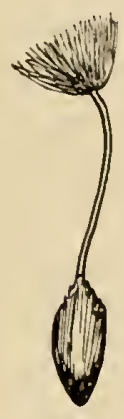

85

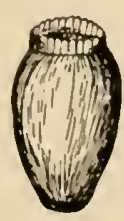

82

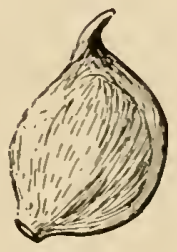

86

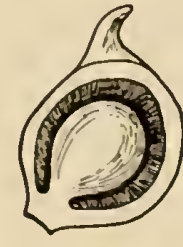

87

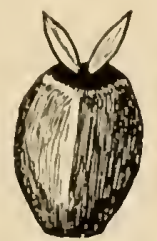

83

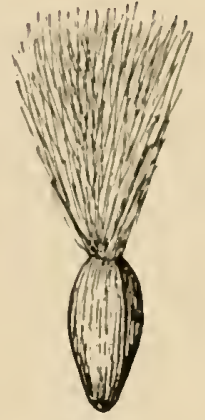

88

Pome (figure 9I), the name of the fruit of the Apple, Pear, Quince etc., which are fleshy fruits, composed of two to several carpels, of parchmentlike texture (or hard in the Thorn Apples), inclosed in flesh which has developed from the inclosing calyx and receptacle. Indeed, the fruit of the Thorn Apple might well be called a "several-seeded drupe."

Pepo, or Gourd-fruit, a type of fruit typified by the Melon, Squash, Cucumber, Gourd and other members of that family. 
Berry [baccate] (figure 93), a simple fruit in which the pericarp is fleshy throughout and without a hardened inner coat. The fruit of the Grape, Currant, Gooseberry, Cranberry, Banana and Tomato furnish good examples.

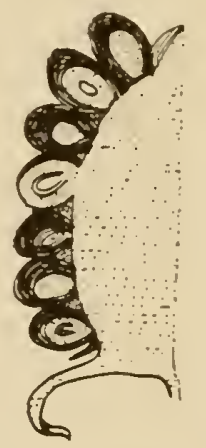

89

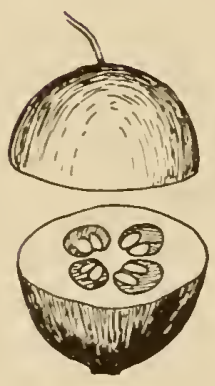

93

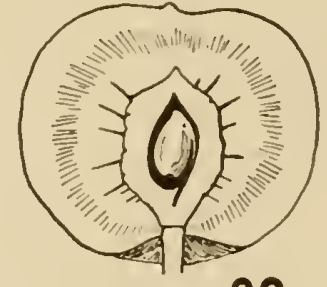

90
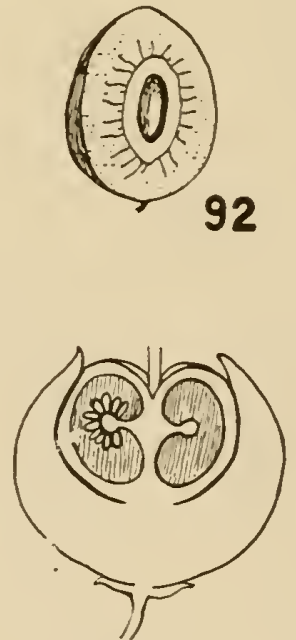

94
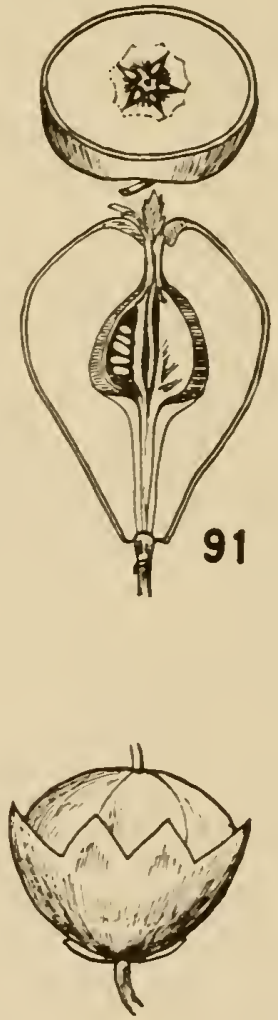

95

\section{Aggregate Fruits}

Aggregate fruits are those in which a cluster of carpels, all belonging to one flower, are crowded on the receptacle into one mass, as in the Blackberry (figure 89) taken as a whole. They may be aggregates of any kind of simple fruits. But when dry and not coherent, the mass would simply be described as a head or spike of carpels (or achenes, as in Buttercup, Anemone etc.). 


\section{Accessory liruits}

Accessory fruits are those in which some conspicuous patrt of the fruit is derived from some portion not organically connected with the ovary or pistil. This part might be called a pseudocarp, and this condition may occur either in simple, in aggregate, or in multiple fruits. The Wintergreen (Gaultheria proc umbens) affords a good example (figures 9) and 95), the fleshy part of the fruit being the enlarged calyx. Likewise the torus, although not conspicuous, may be said to be an accessory part of the fruit of the Blackberry, being the fleshy or pulpy center of the fruit. In the Strawberry it is very conspicuous and comprises the sole edible part of the fruit, the achenes or true fruits being dispersed over the surface and comparatively insignificant.

\section{Multiple or Collective Fruits}

Multiple or collective fruits are those which result from the aggregation of several flowers into one mass. The simplest of these is the fruit of the Partridge Berry (Mitchella repens) and certain Honeysuckles (Lonicera) formed of the ovaries of two blossoms united into one fleshy fruit. More typical examples of this are seen in the Pineapple fruit, the Mulberry and others. 



\section{WILD FLOWERS OF NEW YORK DESCRIPTIONS OF SPECIES \\ Cat-tail Family}

Typliaccae

Broad-leaved Cat-tail

Typha latifolia Linnacus

Figure I

A marsh or aquatic plant, usually growing in thick colonies from creeping perennial rootstocks provided with fibrous roots. Stems stout, round in cross-section, glabrous, + to 8 feet high. Leaves numerous, linear, flat, swordlike, sheathing the stem at the base and rather stiffly ascending. Flowers monoccious, that is, staminate and pistillate flowers separate but on the same plant; densely crowded into terminal spikes; the staminate spikes uppcrmost and scarcely or but slightly separated from the dark brown or nearly black pistillate spike, cach 3 to 12 inches long and often an inch or more thick. Perianth of the individual flowers composed merely of bristles which subtend two to seven stamens (in the staminate spike), or a small, short-stalked ovary (in the pistillate spikes). Mingled among the stamens and pistils are bristly hairs, and among the pistillate flowers many sterile flowers with clavate tips. The fruit consists of many small nutlcts, surmounted by the persistent bristles which aid in wind dissemination of the secds when the head of fruit breaks up.

Common everywhere in marshes and swamps, and also in Europe and Asia. Flowering in June and July; fruit ripe in August and September, frequently persistent until the following spring.

The Narrow-leaved Cat-tail (Typha angust ifolia Linnacus), is more abundant in marshes along the coast, but is sometimes found inland. The leaves are narrower than those of the preceding specics, being onesixth to one-half of an inch wide; spikcs lighter brown in color, not so thick, and the staminate and pistillate spikes separated from one another. 


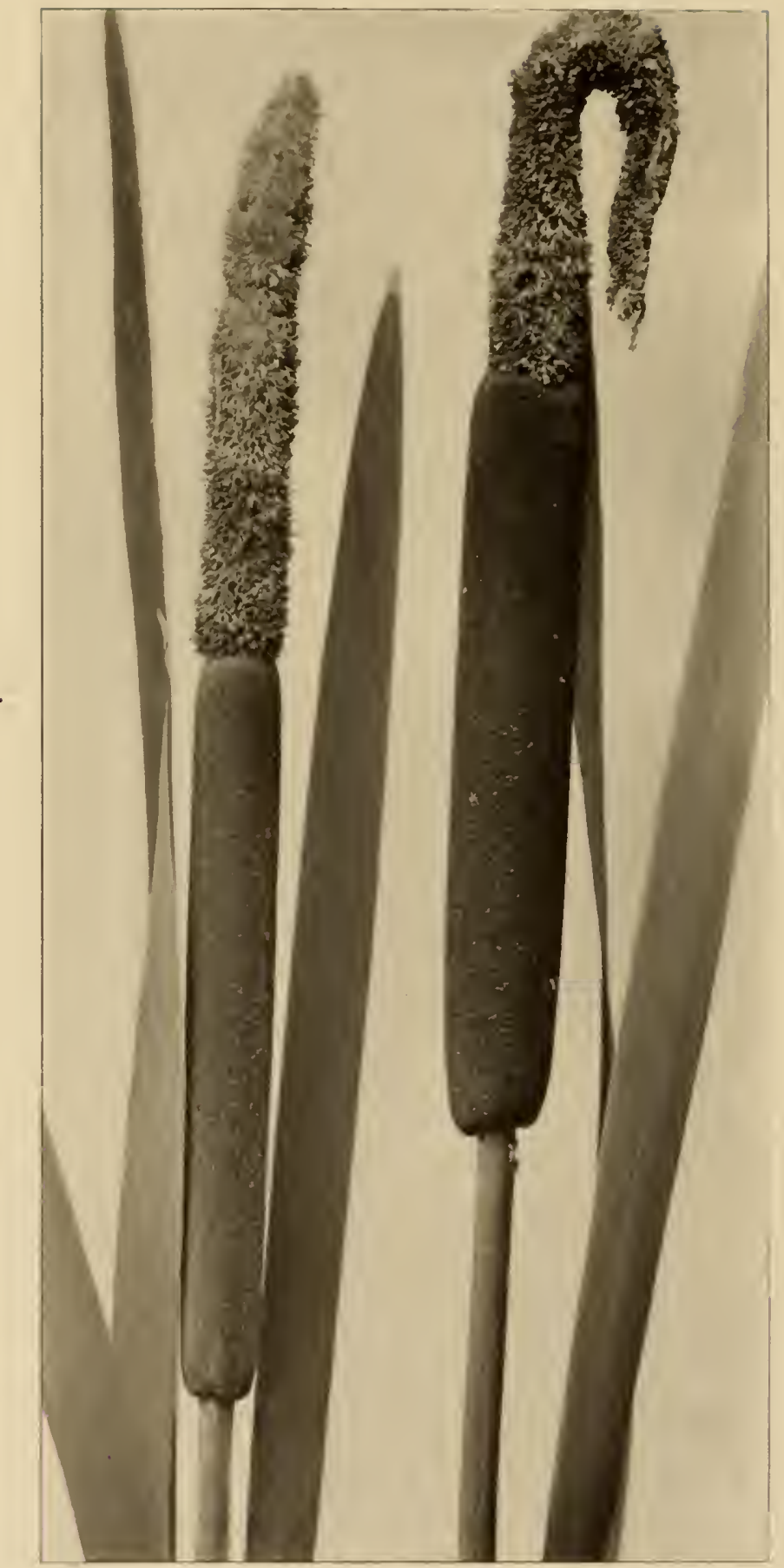

Figure I

Broad-leared Cat-tail

(Typha latifolia Linnacus) 


\section{Water Plantain Family}

A 1 is maceac

\section{Broad-leaved Arrowhead}

Sagittaria latifolia Willdcnow

$$
\text { Plate I }
$$

A perennial aquatic herb with thickencd base and numcrous long, fibrous roots. Lcaves long petioled and extremcly variable in form and size, sometimes wider than long and obtusc, somctimes lincar-lanccolatc and acuminate at the apex; the basal lobcs of the lcaf bladcs onc-quarter to one-half as long as the blade. Flowcrs monoccious or sometimes dioecious, pediceled and borne near the summits of the scapcs in verticels of three, the staminate usually uppermost, each verticel subtcnded by three bracts. Calyx of threc persistcnt scpals. Stamcns numcrous: anthers two-cclled, dehiscent by latcral slits. Pistillate flowcrs with numerous distinct ovarics and somctimes with imperfect stamcns. The ovaries ripen into a globose or compact head of achencs, cach achene broadly winged on both margins, with a bcak about one-third its lcngth and horizontal or ncarly so.

Common in shallow water almost everywherc and offercd by dcalers in native plants for colonizing lily ponds and shallow watcrs. Such situations are scarcely complete without its prescnce. Flowering from July to September.

There are several closely related spccies such as Sagit taria cuncat a Sheldon, with a minute beak to the achene, which is crect over the rentral wing: Sagitt aria pubescens Muhlenberg, which is strongly pubcsccnt; Sagittaria graminea Michaux, which has long-petiolcd, linear, lanceolate or elliptical leaf blades, acute at both ends, and much smaller flowcrs than S. latifolia, and other less abundant species. A nearly related genus is Alisma, represented in our range by the very common $\mathrm{Al}$ isma subcordatum Rafinesque (American Water Plantain), with oblong, elliptic, oval or ovate leaf blades which are cuneate, truncate or cordate at 
the base, the flowering scapes rather tall, bearing numerous branches and pedicels in whorls of three to ten, with very small, white flowers. Like most other members of the Alismaceae, it inhabits shallow water or muddy places.

\section{Sedge Family}

Cyperaceae

\section{Sheathed Cotton Grass or Hare's Tail Rush}

\section{Eriophorum callithrix Chamisso}

Plate 2a

The Cotton Grass may be regarded not so much as a wild flower as one of the most ornamental of the sedges, since it is not a true grass. It is an inhabitant of cold, mossy bogs. The stiff culms, forming tussocks, rise eight to twenty inches above the surface of the bog and each culm bears at the summit a solitary spikelet of small, perfect flowers; each flower with six scalelike divisions, three stamens and a three-cleft style. Within the scalelike perianth are numerous soft, white bristles, which become greatly elongated in fruit, at which time the bog where the plant is growing becomes beautiful with hundreds or thousands of these waving white plumes.

Common in sphagnum bogs from Newfoundland to Alaska, south to Massachusetts, Pennsylvania and Wisconsin. Flowering in early spring, the white plumes being at their best in June or, in the far north, in July.

The Sheathed Cotton Grass is but one of a number of related species which add much to the beauty of our wet meadows, swamps and bogs in summer. Perhaps even more abundant in the north is the Thin-leaved Cotton Grass (Eriophor u m viridicarinat um (Engelmann) Fernald) with five to thirty nodding white plumes, and the Virginia Cotton Grass (Eriophorum virginicum Linnaeus), in which the soft bristles of the mature plume are of a dingy brown color. 
WILD FLOWERS OF NEW YORK

Memoir 15 N. Y. State Museum

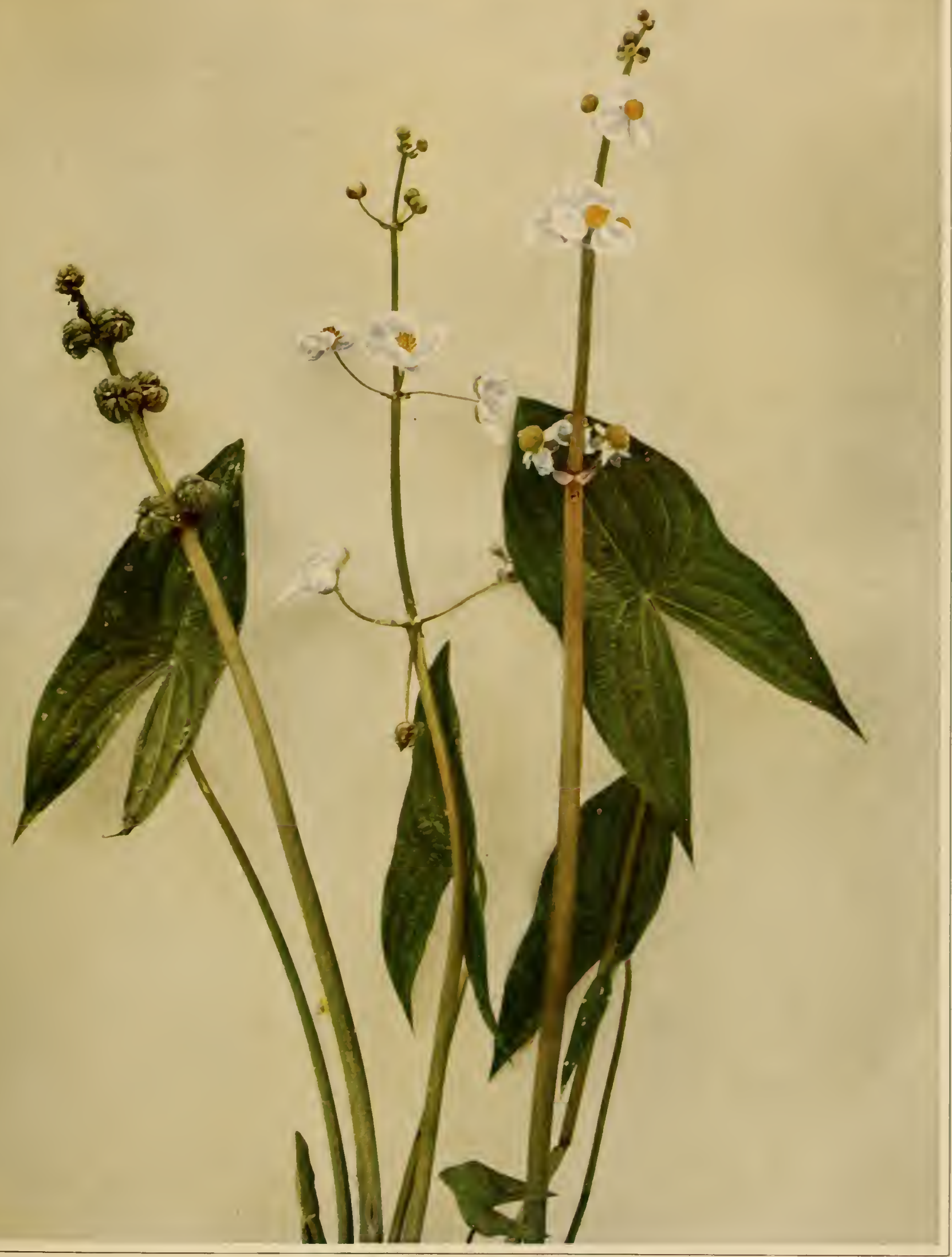

BROAD-LEAVED ARROWHEAD

Sagittaria latifolia 


\section{.}




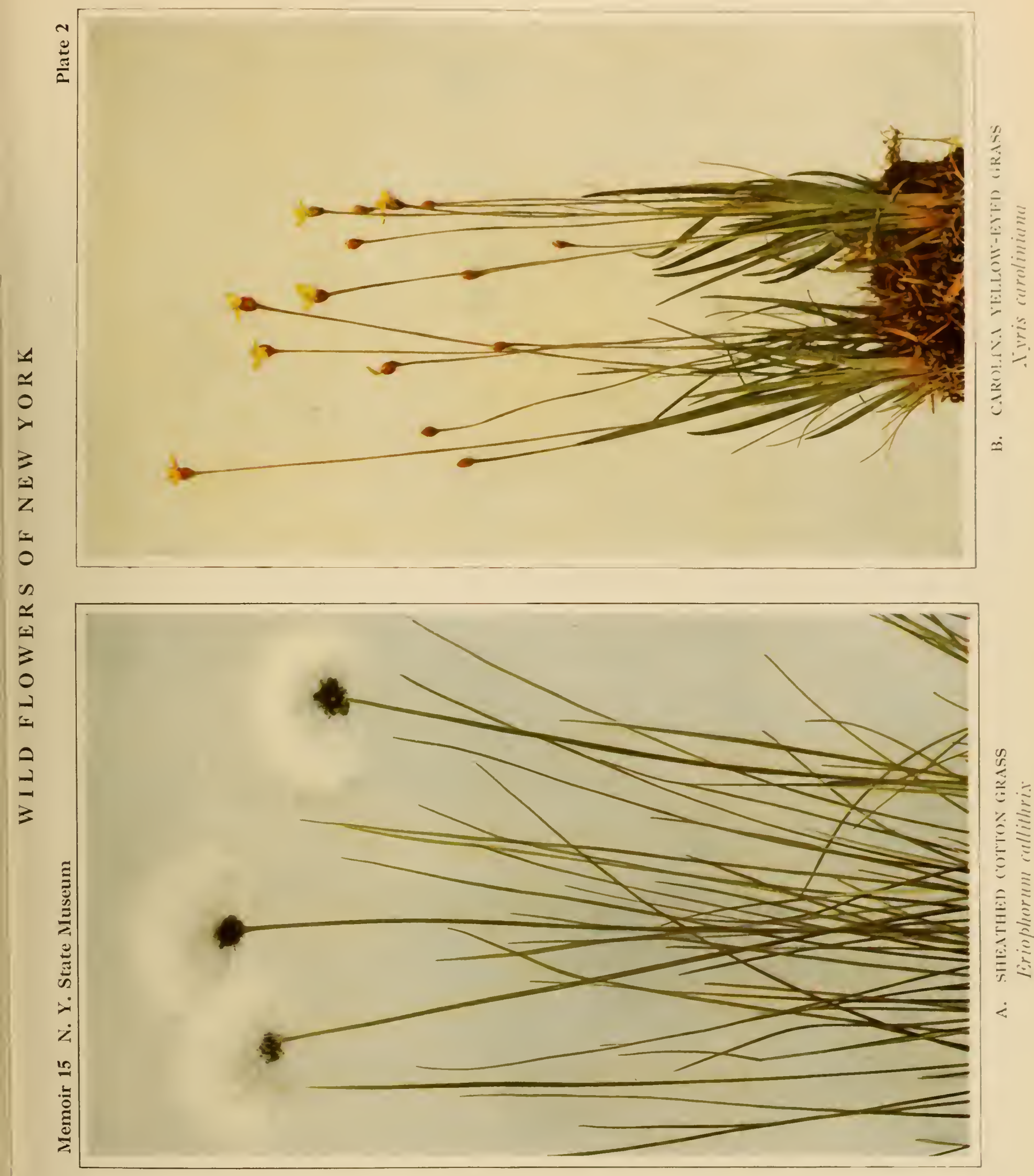




\section{Arum Family}

A r a c c a c

\section{Jack-in-the-pulpit; Indian Turnip \\ A risnema triphyllum (Linnaeus) Torrcy \\ Plate 3}

A perennial herb, $\mathbf{I}$ to 3 feet tall, from a rounded, acrid corm. Leaves one or two, nearly erect, and cxceeding the scape, three-foliate, the segments or leaflets pale grcen bcneath, ovate, acute, roundcd or pointcd at the base, 3 to 8 inches long, I to 3 inches wide, unfolding with the flowers. Flowers dioccious, borne on the basal part of the club-shaped spadix, which is naked, blunt and green or purple above; spathe green and purple-striped, curving in a broad flap over the top of the spadix, long pointed, sometimes whitish with green stripes or almost uniformly greenish. The crowded ovaries of the pistillate flowers ripen into a cluster of bright-red, shining, globose berries.

A common plant of moist woods and thickets, flowering from early spring until June. The fruit ripens in July, and in late summer the leaves frequently wither and die, leaving the stalks of bright-red berries conspicuous objects in the woods.

Two closely related species are sometimes recognized, A r i s a e m a p u s i 11 u m (Peck) Nash, with leaves green beneath, a cylindrical spadix and spathe deep brown to almost black in color; A r is a e m a s t e wa r d s o n i B Britton, with a conspicuously fluted spathe which is whitish below and green or green-striped toward the tip, but otherwise resembling A. pusill u m.

The Green Dragon or Dragon-root (A r is a e ma dra con ti u m (Linnaeus) Schott) (figure II) has solitary leaves divided into five to seventeen segments, and a narrow greenish or whitish, long-pointed spathe enwrapping the spadix, the upper part of which tapers into a slender appendage exserted I to 7 inches beyond the spathe. The mature berries are reddish-orange in color. This plant is less abundant than the Jack-inthe-pulpit, and much less conspicuous. 


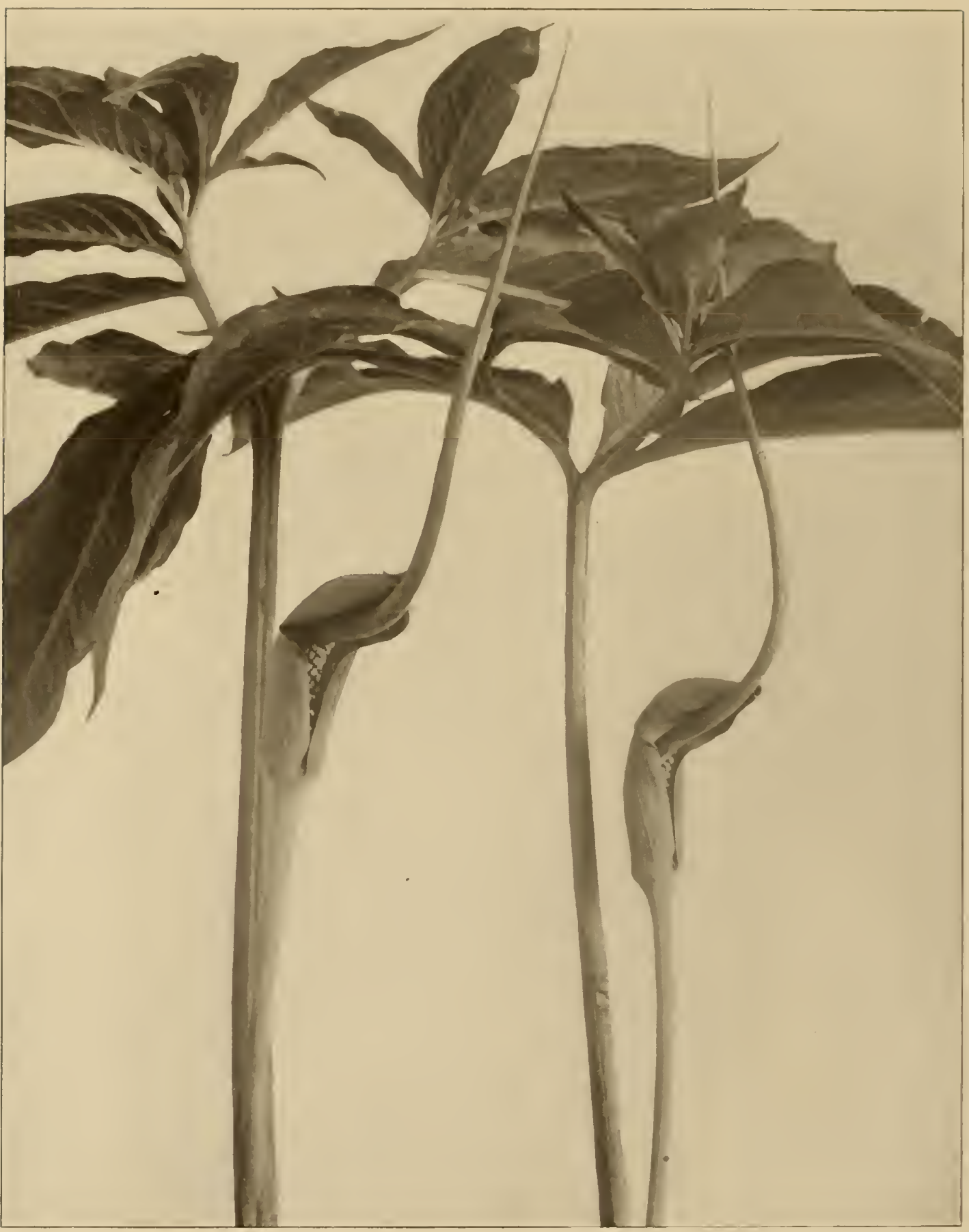

Figure II

Green Dragon or Dragon-root

(Arisaema dracontium (Linnaeus) Schott) 
WILD ILOWERS OF NEW YORK

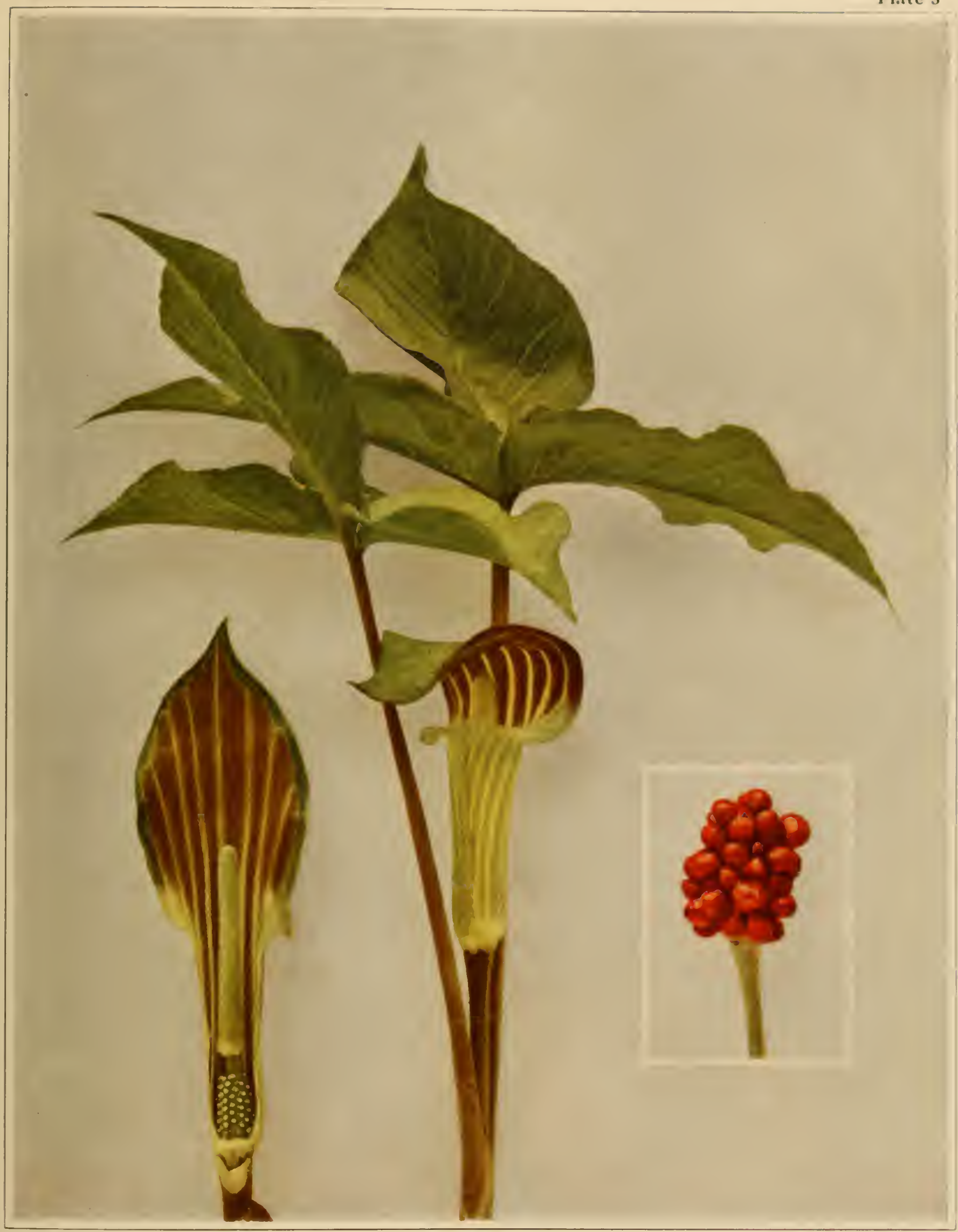




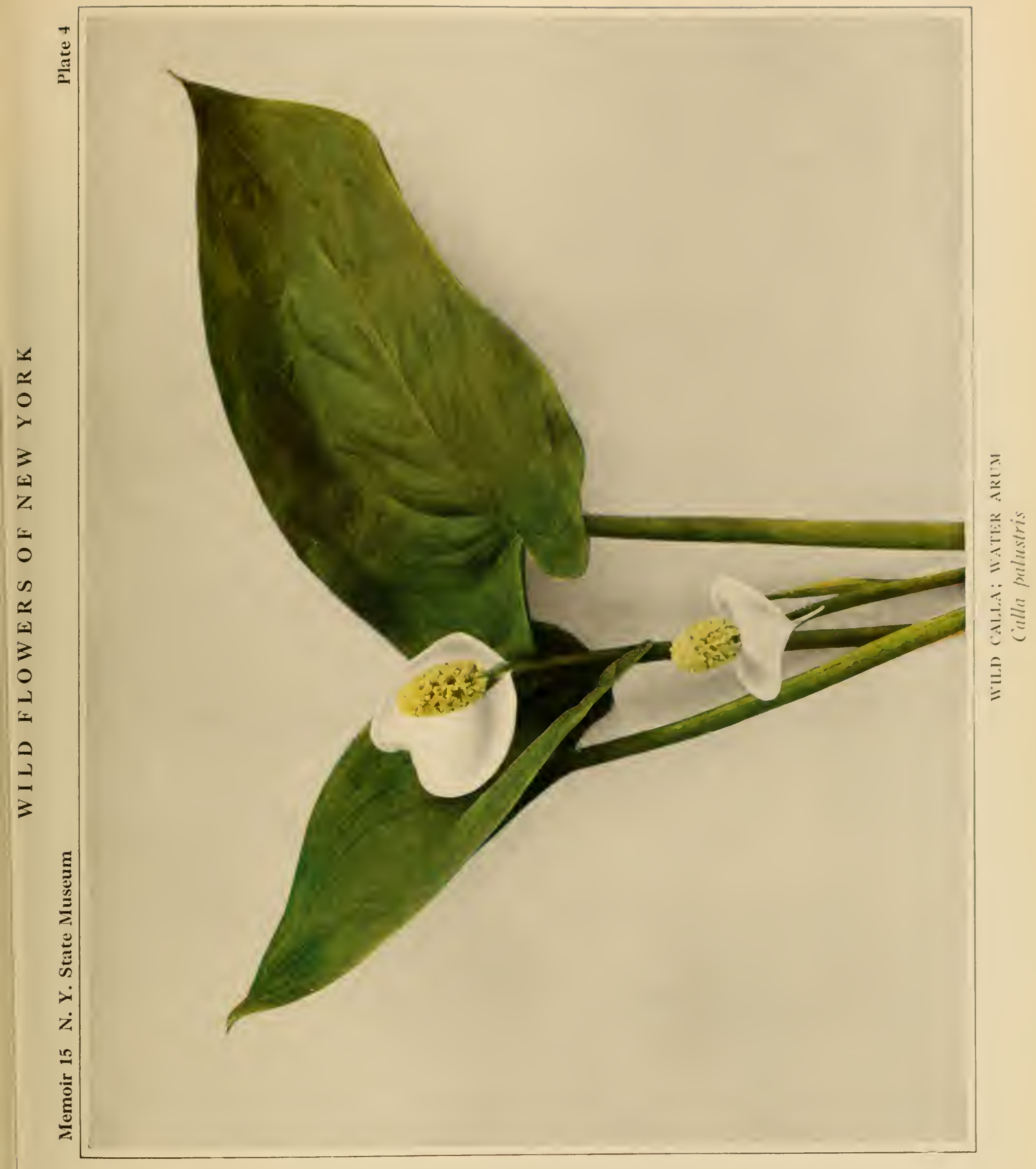


. 


\section{Wild Calla; Water Arum \\ Calla palustris Linnacus \\ Plate 4}

A perennial herb of swamps and bogs with long, acrid rootstocks, covered with sheathing scales and with fibrous roots at the nodes, from which arise numerous petioled leaves with thick, entire, glossy green, broadly ovate or suborbicular leaf blades 2 to 5 inches wide, cuspidate or pointed at the apex and deeply cordate at the base. Flowering scapes about as long as the petioles, sheathed at the base, bearing at the summit an ovate-lanceolate or elliptic, acuminate, open spathe, white within and greenish without, sometimes with a second spathe nearly opposite the first and smaller in size, or rarely the two of equal size. Spadix cylindric. much shorter than the spathe, densely covered with perfect flowers, or the uppermost flowers staminate. The individual flowers on the spadix possess usually six stamens and no perianth. Ovaries ripening into a large head of red berries.

Frequent in swamps and bogs, especially northward. Rare in the southern part of the State. Flowering from late May to early July, the fruit ripening from June to August.

\section{Skunk Cabbage \\ Spathyema foetida (Linnaeus) Rafinesque \\ Plate 5}

A fetid herb, and the first plant to flower in the spring. The leaves are large, ovate, cordate, numerous in dense crowns, becoming in summer I to 3 feet long and I foot wide, but at flowering time scarcely beginning to unfold. Rootstock thick, descending, terminating in whorls of fleshy fibers. Spathe preceding the leaves, erect, 3 to 6 inches high, I to 3 inches in diameter, convolute, firm and fleshy, often one-fourth to one-half of an inch thick in the middle, pointed, completely inclosing the spadix, brown to greenish yellow, usually mottled, its short scape usually below the surface. 
Spadix about I inch in diameter, entirely covered by the perfect flowers, greatly enlarged and sometimes 6 inches in diameter in fruit. The perianth of each flower consists of four hooded sepals.

A common plant of low, wet woods, meadows and swamps. When the spathes first appear, they possess little of the rank odor which characterizes them when older and which renders them objects of opprobrium. They appear almost before the last snowdrifts have disappeared and indicate the first awakening of plant life in spring.

The Arum family (Araceae), to which belong the Jack-in-the-pulpit, the Wild Calla, and the Skunk Cabbage, also contains several other native plants usually found in wet or damp places. The Green Water Arum (P e 1 t a n d r a virginica (Linnaeus) Kunth) with bright-green, hastate-sagittate leaves, often $\mathrm{I}$ to 2 feet long and 3 to 8 inches wide, possesses an inconspicuous green spathe, 4 to 8 inches long, with a strongly involute undulate margin. The Golden Club (O r on t i u m a quat i c u m Linnaeus), found only in a few localities in the southern part of the State, possesses a cylindric, golden yellow spadix, from which the spathe falls at flowering time.

The Sweet Flag, Calamus or Flagroot (A c or us cala mus Linnaeus) (figure III) belonging also to this family is a common plant of wet meadows, with long, linear, flaglike leaves and the spathe a leaflike extension of the scape, the spadix spikelike, 2 to 3 inches long and about one-half of an inch in diameter, compactly covered with minute greenish yellow flowers.

\section{Yellow-eyed Grass Family}

$\mathrm{X}$ y ridacea e

\section{Carolina Yellow-eyed Grass}

Xyris caroliniana Walter

Plate $2 \mathrm{~b}$

A small, tufted, grasslike plant of wet meadows and bogs, with numerous fibrous roots and flat, linear, grasslike leaves + to $\mathrm{I} 5$ inches long. Flowering scapes as long or usually much longer than the leaves. Sometimes over a foot tall, bearing at the summit a dense, ovoid, obtuse spike 

WILD FLOWIRS OF X゚EW YORK

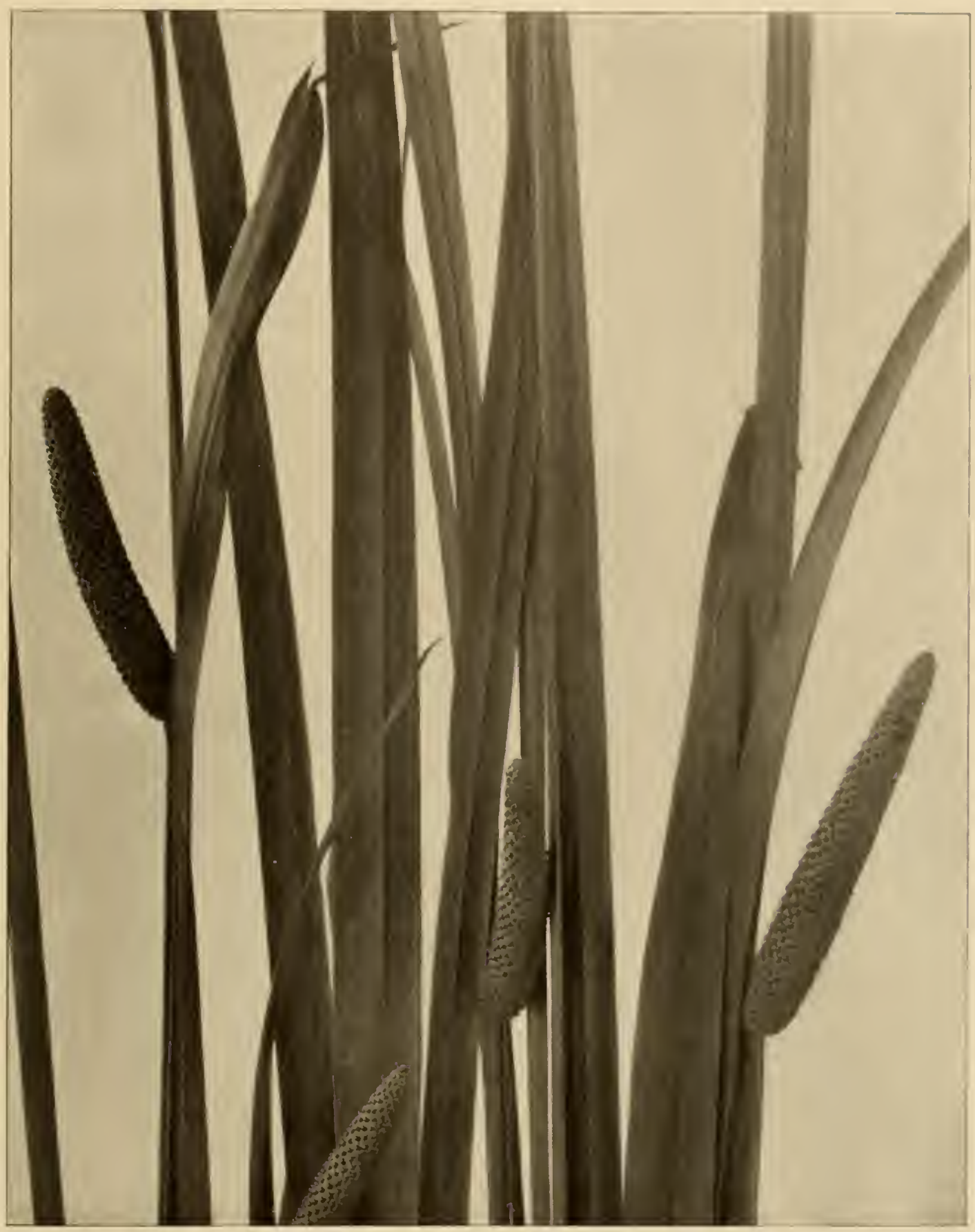

Figure III

Sweet Flag, Calamus or Flagroot

(A corus calamus Linnacus) 
of coriaceous, overlapping bracts or scales. Flowers bright yellow, about onc-fourth of an inch broad, on short, slender pcduncles; each flower consisting of thrce oblong divisions to the corolla, three stamens inserted on the corolla and a thrce-branched style. Flowers appearing from the axils of the bracts comprising the spikc.

In swamps, bogs and borders of streams from Maine to Florida and Louisiana, mostly near the coast. Flowering from June to August; in Ncw York usually flowering in July.

Several closely related species are recognized by botanists. X y r is f 1 e x 11 o s a Nuhlenberg, of about the same rangc, has the scapes bulbousthickencd at the base. X y ris mo n t a n a H. Ries, in bogs from Nova Scotia to Michigan and Pennsylvania, is frequent in the mountainous parts of New York, and resembles very closely the Carolina Yellow-eyed Grass.

\section{Pipewort Family}

Erioc a u 1 a ce a e

\section{Seven-angled Pipewort \\ Eriocaulon septangulare Withering \\ Plate $6 a$}

A small, tufted plant with pellucid, fenestrate-nerved leaves arising from the crown, I to 3 inches long. Flowering scapes weak, twisted, usually about seven-angled, I to 8 inches tall, or when submersed, both the leaves and the scapes considerably elongated, bearing at the summit a small subglobose head of woolly white flowers, interspersed with numerous bracts; most of the flowers staminate and about one-eighth of an inch long, the few pistillate flowers scarcely more than half as large.

In still water and on shores of ponds, lakes and streams, usually where it is sandy, from Newfoundland to Minnesota, Florida and Texas. Usually in flower in this State in July and August. In the south are numerous other species of this and related genera. 


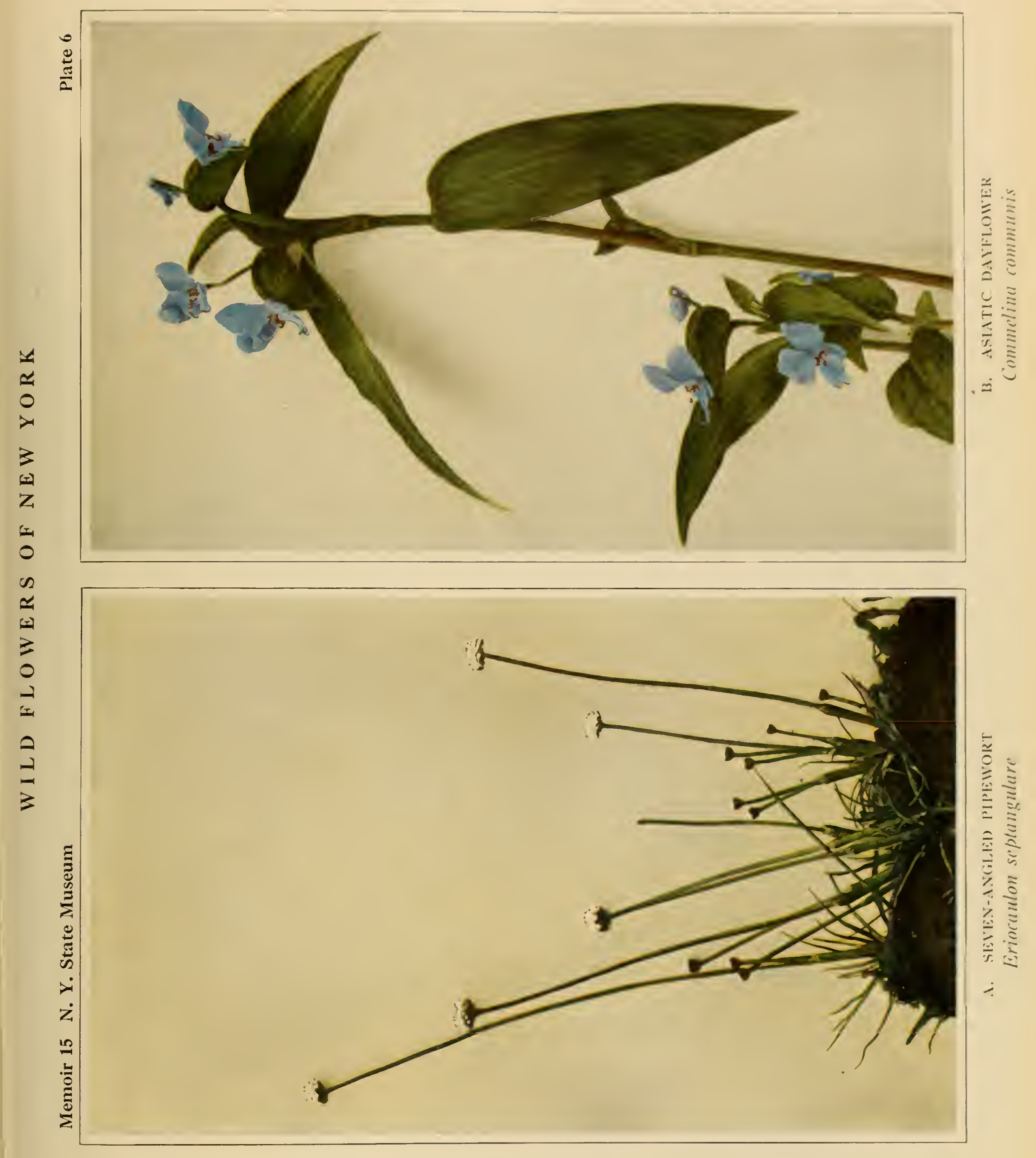




\section{-}

. 


\section{Spiderwort Family}

Commelinaceac

\section{Asiatic Dayflower}

\section{Commelina communis I.innaeus}

Plate $6 \mathrm{~b}$

A glabrous plant with decumbent or asecnding branching stems, often rooting at the nodes, I to 3 feet long with numerous oblong-lanecolate leaves 3 to 5 inches long and $I$ to $1 \frac{1}{2}$ inches wide, acuminate at the tips and narrowed or rounded at the base, smooth and dark green, the stem with white-membranous, green-veined sheaths below each leaf. Flowers toward the ends of the branches or stems, each subtended by green leaflike spathes about I inch long, deep blue, one-half of an inch broad or broader, irregular, consisting of three sepals and three petals, two of them much larger than the third; three fertile stamens, one of them incurved and its anther larger than the others. In addition there are three sterile stamens. Fruit a small, two-celled capsule, each eell with two seeds; seeds compressed, dark brown and roughened.

A native of Asia, eommonly naturalized or adventive in southern New York and southward, and oceasionally appearing farther north. Sometimes ealled "Wandering Jew."

\section{Spider Lily; Spiderwort \\ Tradescantia virginiana Linnaeus Plate 7}

A tall, smooth or slightly pubescent plant, belonging to the same family as the Dayflower, often I to 3 feet tall, with long, linear or linearlaneeolate, long-pointed leaves, often a foot long and one-half to i inch wide, usually more or less channeled along the middle. Flowers in terminal umbels or clusters on slender pedicels, one-half to 2 inches long: blue or purplish, rarely white, I to 2 inches broad with three small sepals, three large, obovate, similar petals, and six equal and fertile stamens. 
In rich soil, mostly in woods and thickets, from southern New York, Ohio and South Dakota, south to Virginia and Arkansas. A common plant in cultivation farther north where it is a frequent escape to roadsides and fence rows. Although of great beauty, the flowers are of brief duration, and the delicate petals soon wither, the flowers being followed by others until all the numerous buds of each cluster have bloomed. With us it usually flowers in June and July or sometimes as late as August, especially since not all the stems appear to reach maturity at the same time.

\section{Pickerel Weed Family}

Pontederiacea e

\section{Pickerel Weed}

Pontederia cordata Linnaeus

Plate 8

A perennial aquatic herb, rising from a thick, horizontal rootstock, with thick, glossy, dark-green, ovate to lanceolate leaves, cordate-sagittate, truncate or narrowed at the base, 2 to Io inches long, I to 6 inches wide, the apex and basal lobes obtuse. Flowering stems erect, I to 4 feet tall, glandular-pubescent above, one-leaved, with several sheathing, bractlike leaves at the base. Flowers blue, ephemeral, numerous, in a dense head or spike (spadix) subtended by a thin bractlike spathe. Each flower is tubular, about one-fourth of an inch long, curved, two-lipped, the upper lip composed of three ovate lobes, of which the middle one is the longest, and with two yellow spots at the base within, the lower lip of three linearoblong spreading lobes. Stamens six, the filaments, anthers and style bright blue. After flowering, the lobes and upper part of the perianth tube wither above, while the persistent base hardens around the fruit.

Frequent along the borders of ponds and streams and shallow margins of lakes, where it flowers from June to September, usually at its best in August. One of the most attractive of our native aquatic plants.

The Pickerel Weed belongs to the Pontederiaceae, represented in our flora by but one other genus, the Mud Plantains (Heteranthera), with 


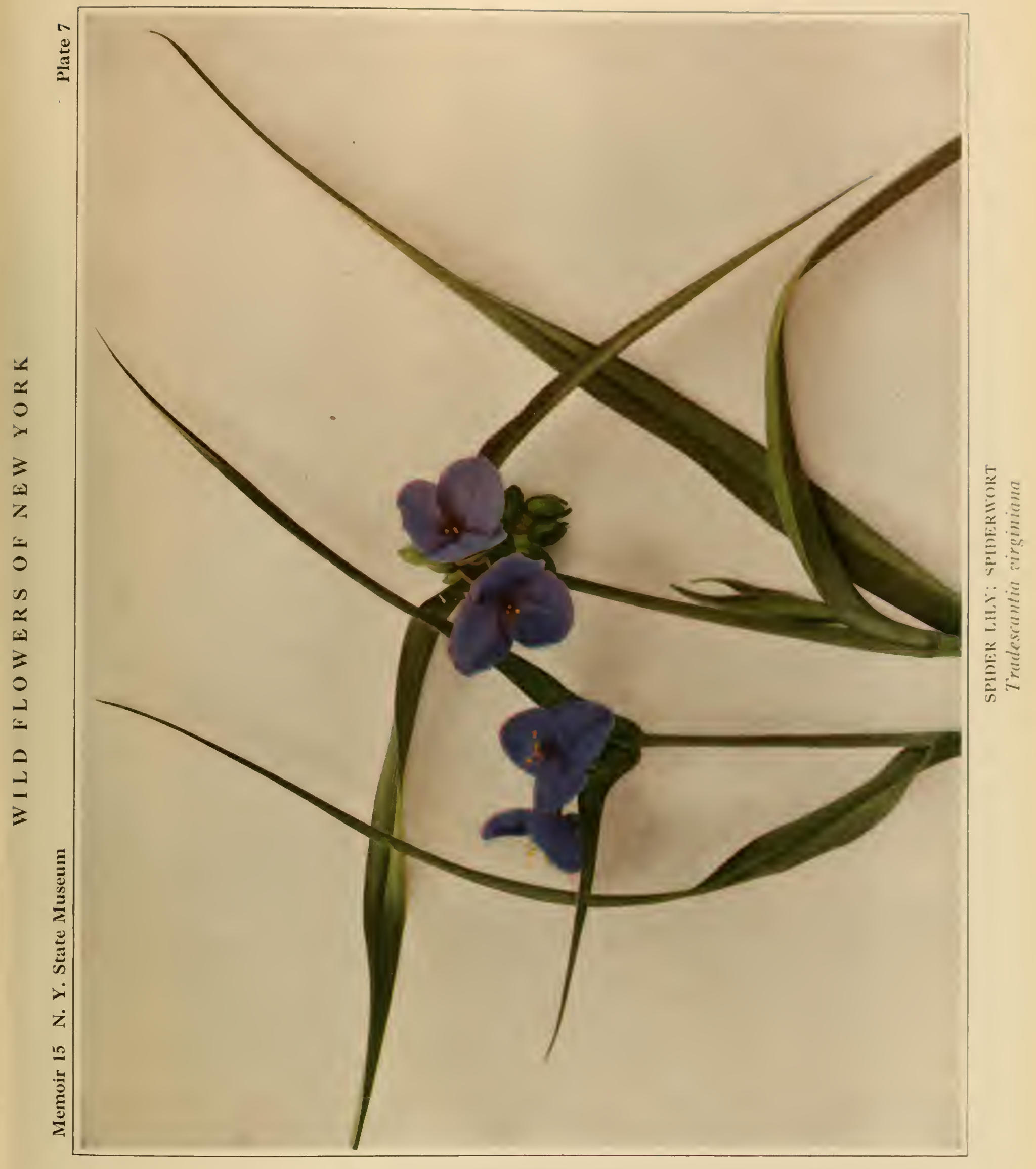





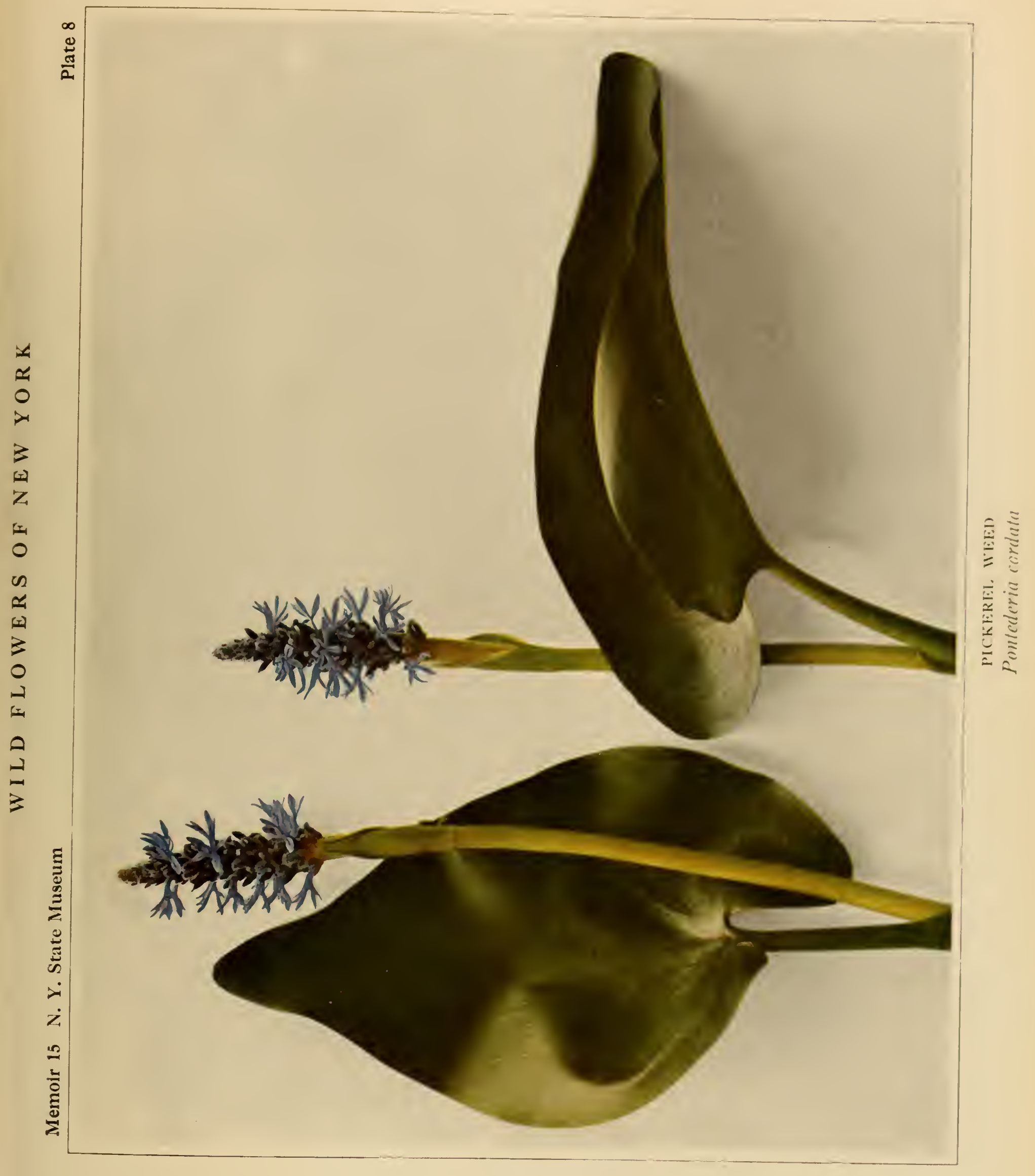



two species of small, inconspicuous herbs of shallow water or wet muddy shores.

\section{Bunchflower Family}

Melanthaceac

\section{Glutinous Triantha or False Asphodel \\ Triantha glutinosa (Michaux) Baker Plate on}

A percnnial, herbaceous plant, somewhat bulbous at the base; stems 6 to 20 inches high, viseid pubescent with black glands, bearing a few leaves near the base: most of the leaves basal and tufted, linear and grasslike, 2 to 7 inches long. Flowers numcrous in an oblong raceme at apex of the stem, subtended by minute involucral bracts, each flower about one-fourth of an inch broad, the perianth white, divided into six nearly equal oblong segments; stamens six, with pink or reddish anthers; fruit a small oblong capsule, the tiny seeds with a curved appendage at each end.

An inhabitant of sphagnum or marly bogs from Newfoundland to Minnesota, Michigan and the southern Allcghanies. By no means a common plant, and one which the wid flower connoisseur always likes to locate, and which repays by its rarity rather than its bcauty the incvitable journey to the boggy place where it grows.

\section{Glaucous Anticlea}

\section{Anticlea chlorantha (Richardson) Rydberg Plate ga}

A slender, herbaceous, percnnial plant from a membranous coated, ovoid bulb which is about an inch long. Stems slender, 6 inches to 3 feet tall; leaves linear, one-eighth to seven-eighths of an inch wide, kecled, the lower ones + to 12 inches long, the upper ones much shorter. Inflorescence a simple, open raceme or large, loose panicle, t to 12 inches long. with slender, ascending branches. Flowers perfect, greenish or ycllowish, about three-fourths of an inch broad; perianth segments oval or obovate, obtuse, bearing a large obcordatc gland just above the short claw, the 
perianth persistent and adnate to the lower part of the ovary after withering. Fruit an oblong, threc-celled capsule, about I inch long.

An inhabitant of marshes, bogs and moist places, New Brunswick to Vermont, New York, Manitoba and Missouri. Flowering in August. Not so rare as the Glutinous Triantha, but usually growing in similar locations.

\section{Bunchflower}

\section{Melanthium virginicum Linnaeus}

Plate ro

A rather tall, leafy, herbaceous plant, perennial by a thick rootstock; stems slender to somewhat stout, 2 to 5 feet high. Leaves linear, acuminate, often a foot long, but only one-third to I inch wide, the lower ones sheathing the stem, the upper ones smaller and sessile. Inflorescence a many-flowered panicle, 6 to i $\delta$ inches long, pubescent; flowers about threefourths of an inch broad, greenish yellow, turning brown with age; perianth of six spreading, separate, persistent segments, each segment consisting of an oblong, obtuse, flat blade, sometimes obcordate, about twice as long as the claw, and bearing two dark glands at its base; stamens shorter than the segments and adnate to them; fruit a three-lobed capsule, about twothirds of an inch long.

In meadows, wet woods and marshes, Rhode Island to southern New York and Minnesota, south to Florida and Texas. Flowering in July and August.

The Bunchflower is not a common plant in New York, and is found only in a few localities in the southern part of the State. Two closely related species are equally uncommon and also restricted to the southern part of the State. These are: (I) the Crisped or Broad-leaved Bunchflowcr (M e la n th i u m latif oli u m Desvaux), with broader leaves and the blade of the perianth segments undulate, crisped and scarcely longer than the claw; (2) the Pine-barren Oceanorus (O c e a n o r us le i m a $n$th o ides (A. Gray) Small), with linear, blunt leaves, the outer ones becoming fibrous, and small whitish flowers with oblong perianth segments, which are sessile. 
WILD FLOWERS OF NEW YORK

Menoir 15 N. Y. State Museum

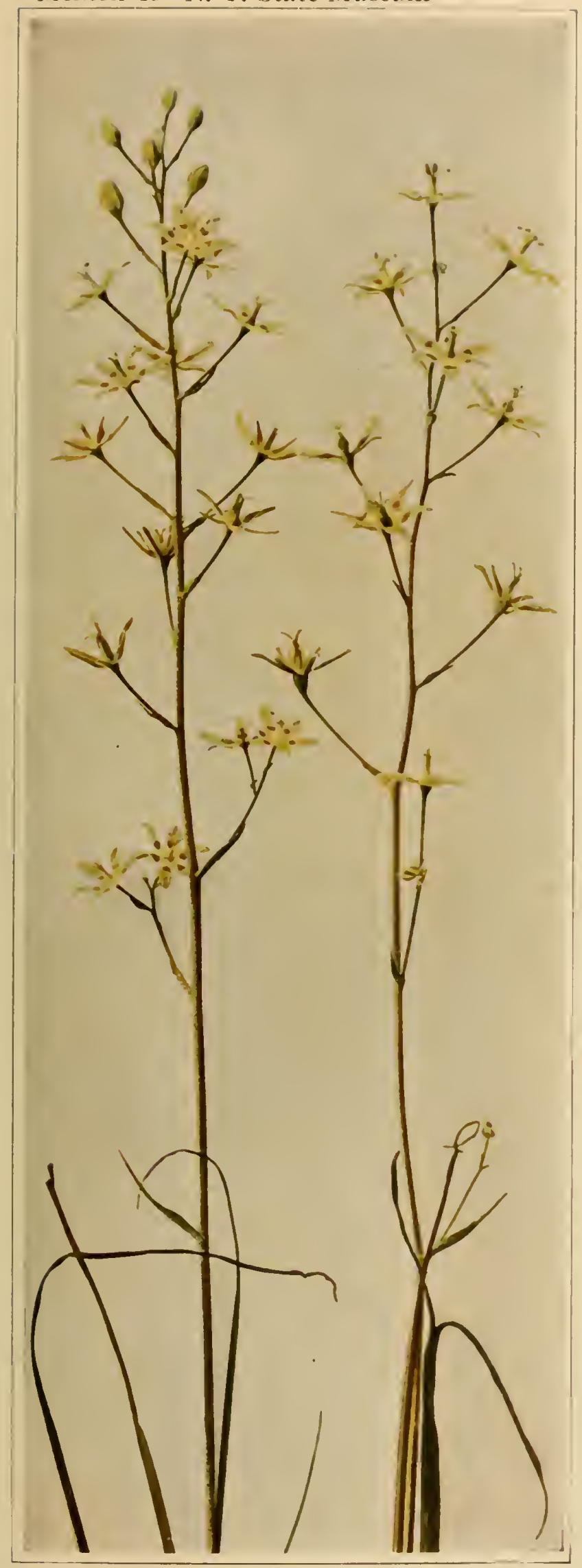

A. GLAUCOUS ANTICLEA Anticlea chlorantha
Plate"

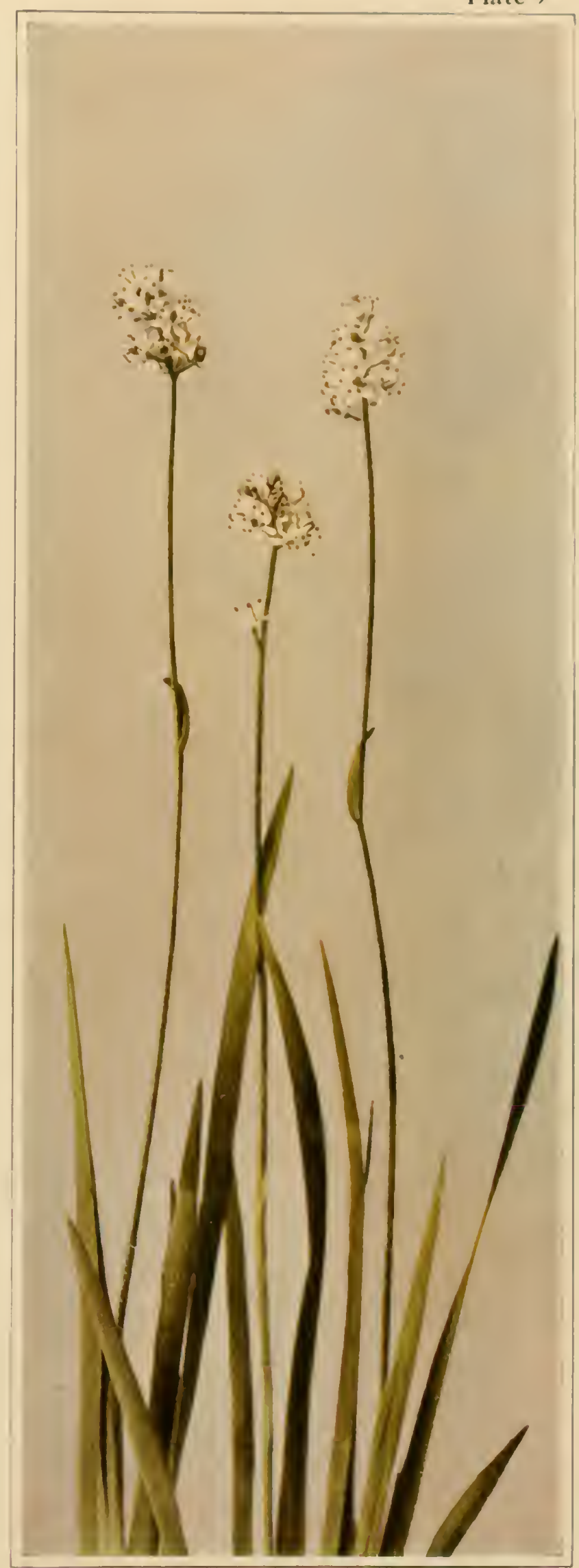

B. GLLTIYOES TRIANTHA: FALSE ASPHODEL Triantha glutinosa 

WILD FLOWERS OF NEW YORK

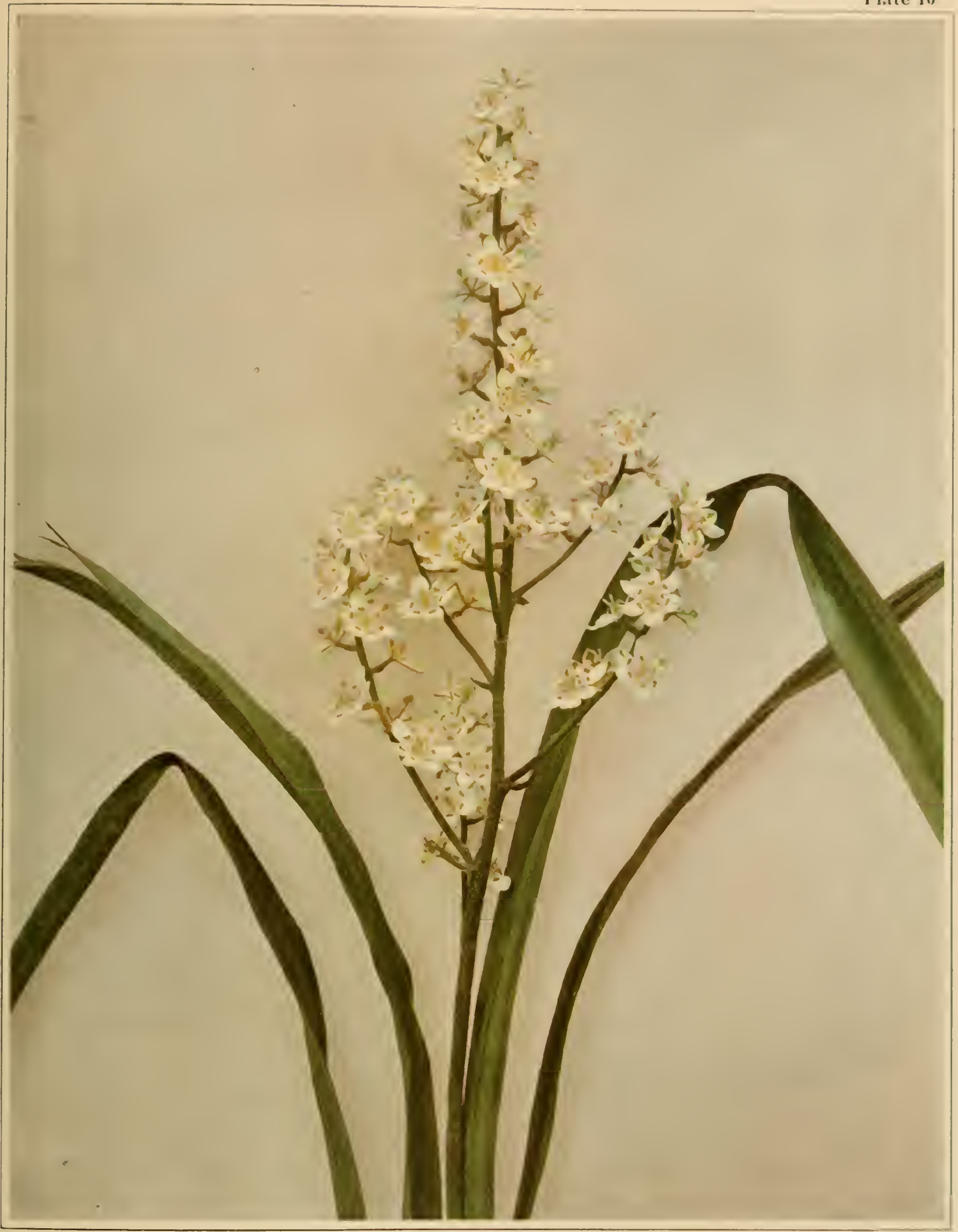

BLYCIIFLOWER

Melantlium rirginicum 


\section{American White Hellebore; Indian Poke \\ Teratrum iiride Linnacus \\ Plate if}

A tall, leafy, perennial herb; stem simple and branehed only in the inflorescence, stout, 2 to 8 feet tall, from a poisonous, perennial, ercet rontstock 2 to + inches long and I to 2 inehes thick with numerous fleshy-fibrous roots. Leaves alternate, elasping, strongly veined and plaited, all pointed at the apex; the lower leaves broadly oval or elliptic, 5 to 12 inches long, 3 to 6 inehes wide; the upper ones successively narrower and shorter, those of the infloreseence very small; stem and infloresecnee pubeseent. Flowers greenish or greenish yellow, two-thirds to 1 inch broad arranged in a manyflowered paniele at the summit of the stem, the paniele of ten 8 to 20 inehes long, its lower branches spreading or drooping. Segments of the perianth six, without glands or elaws, oblong or oblancelate, eiliate-serrulate, twice as long as the curved, yellow stamens which are six in number and opposite the perianth segments. Fruit a three-lobed, three-eelled, many-seeded eapsule, three-fourths to I inch long and one-third to one-half of an ineh thick.

In swamps and wet woods, New Brunswick, Quebec and Ontario to Minnesota, south to Georgia and Tennessee. Flowering in May and June, or July in the far north.

\section{Lily Family}

Liliaceac

\section{Day Lily}

\section{Hemerocallis fuli'a Linnaeus \\ Plate 12}

A tall, glabrous herb with fibrous roots, usually, growing in dense elusters. Leaves mostly basal, linear, erect or spreading, I to 2 feet long and one-half to two-thirds of an inch wide, channeled and tapering to an acute tip. Flowering seapes leafless, 2 to 5 feet tall, bearing a few short bracts above, and six to fifteen flowers on short pedicels. Perianth 
funnelform, tawny-orange, + to 5 inches long, opening for a day, its lobes oblong, somewhat spreading, netted-veined, the three outer nearly flat and more acute; the three inner ones undulate on their margins and blunt. Stamens six, inserted at the top of the perianth tube, shorter than the lobes of the perianth and declined. Fruit an oblong, thick-walled, threeangled, wrinkled capsule.

Native of Europe and Asia. Frequent in cultivation in this country and commonly escaped to meadows, along streams and roadsides or persistent in old yards and cemeteries. A flower of early introduction into the eastern states where it has made itself quite at home as an escape, and thrives and spreads with amazing rapidity under favorable conditions.

The Yellow Day Lily (H e me r o c a 11 is f 1 a va Linnaeus), with yellow flowers, their lobes parallel-veined, is occasionally found near old gardens and on roadsides, but not so frequently as the tawny-orange flowered Day Lily.

\section{Red Lily; Wood Lily; Philadelphia Lily \\ Lilium philadelphicum Linnaeus \\ Plate I 3}

Stems $\mathrm{I}$ to 3 feet tall from a bulb about $\mathrm{I}$ inch in diameter and composed of numerous narrow, jointed, fleshy scales. Leaves lanceolate, acute at both ends, or the lower leaves sometimes obtuse, in whorls of three to eight on the stem, or a few of the upper leaves alternate, thin, with finely roughened margins. Flowers one to five at summit of stem, erect, 3 to + inches high; perianth reddish orange, its six equal segments spatulate, somewhat spreading, pointed or obtuse, one-half to I inch wide, gradually narrowed below, spotted with purple toward the base; stamens six, about as long as the club-shaped style. Capsule oblong-ovoid, I to 2 inches long.

In rather dry woods and thickets, more often in sandy regions than elsewhere, Maine and Ontario to North Carolina and West Virginia. 
WILD FLOWERS OF NEWYORK

Memoir 15 N. Y. State Museum

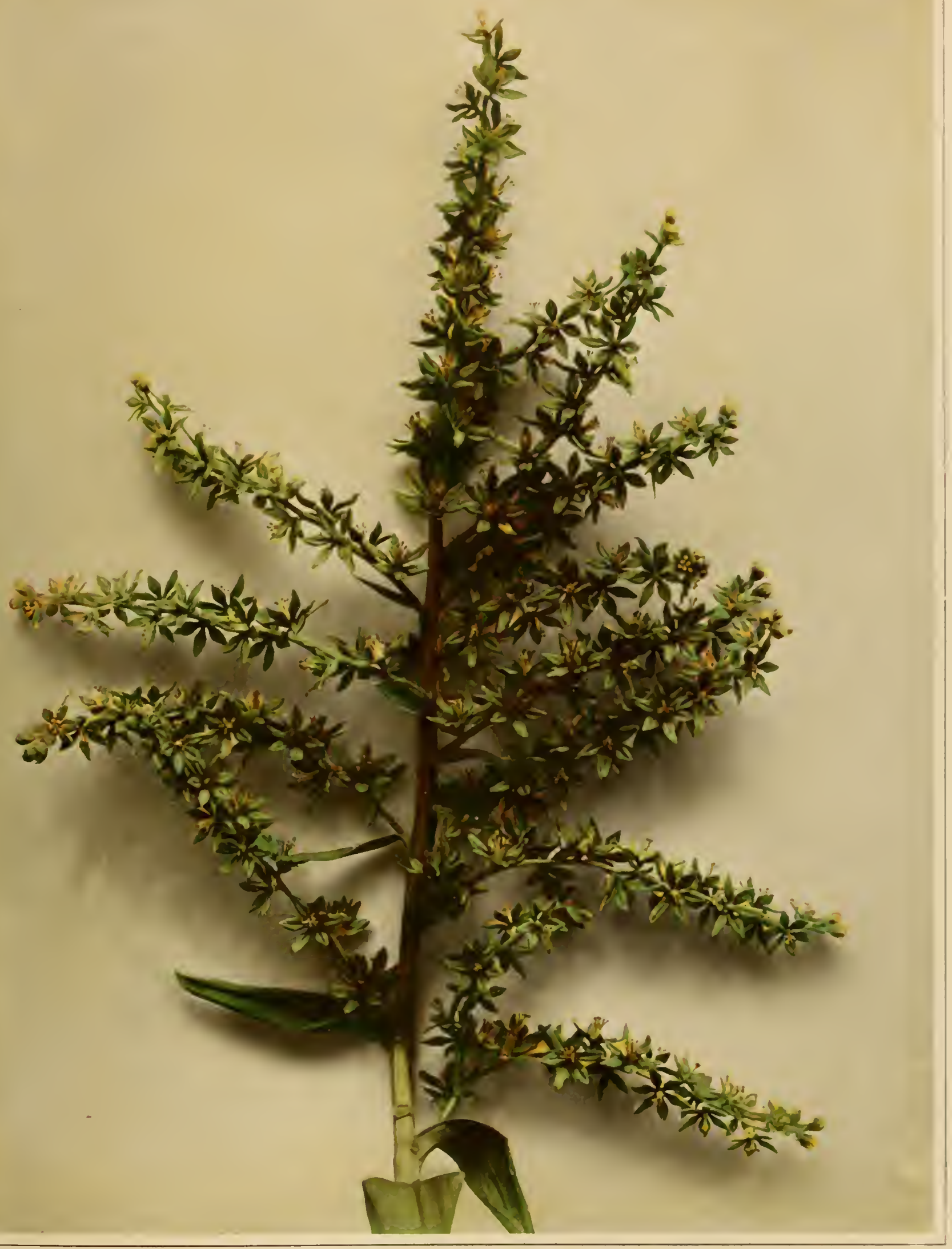

AMERICAN WHITE HELLEBORE; INDIAN POKE

leratrum siride 


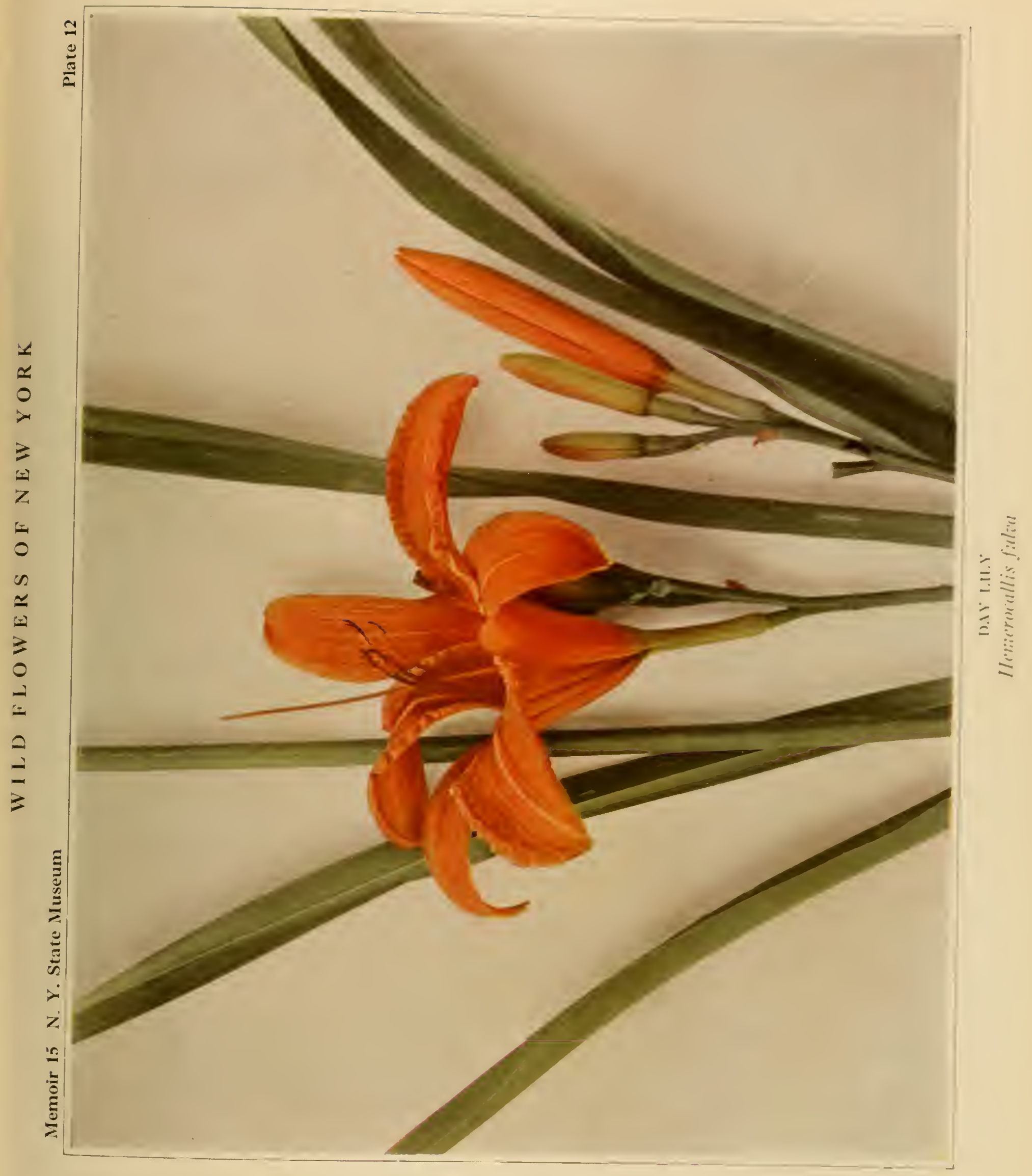


WILD FLOWERS OF NEW YORK

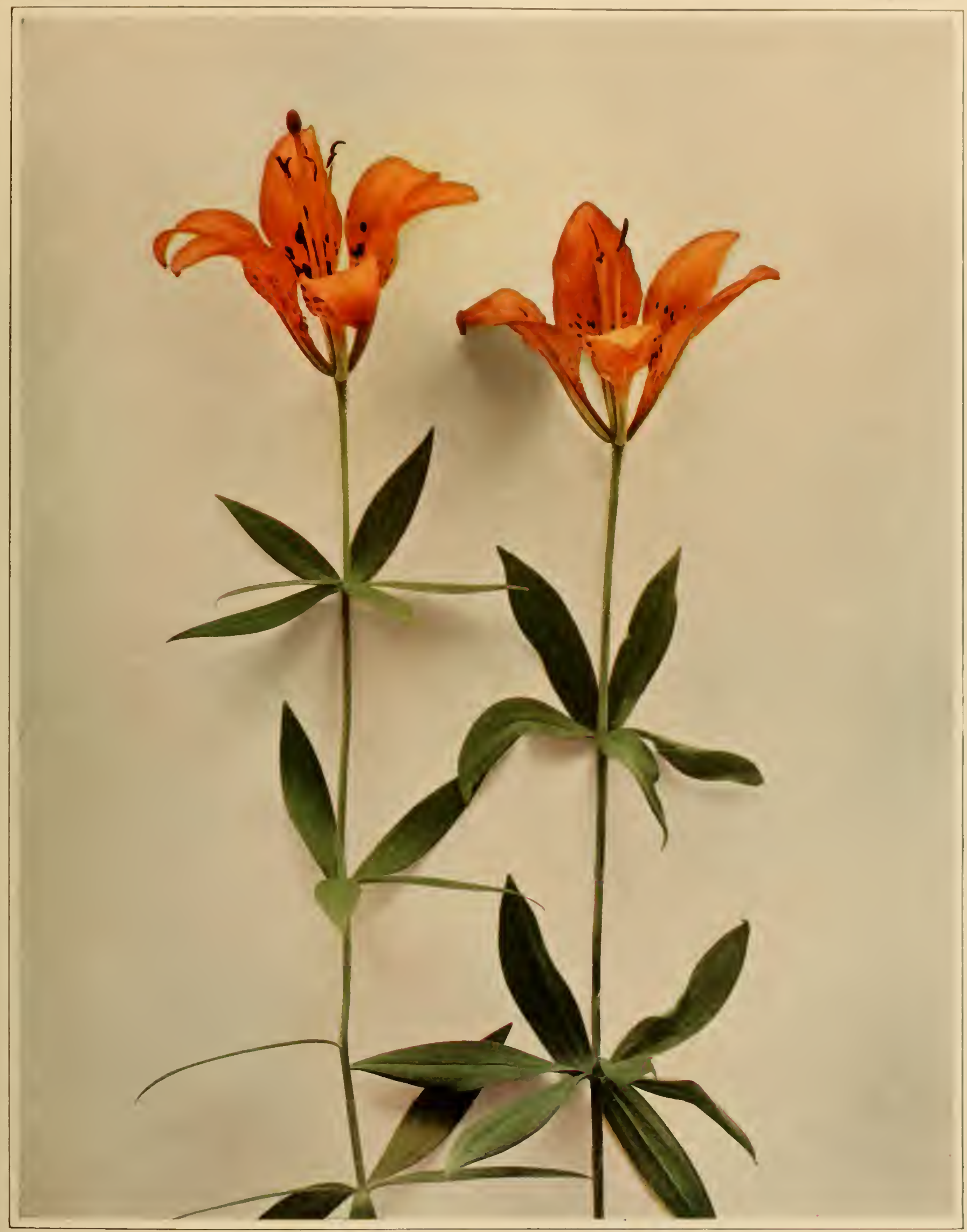

RED, WOOD OR PHILADELPHIA LILY

Lilium philadelphicum 


\section{Wild Yellow Lily; Canada or Nodding Lily Lilium conulense Linnateus \\ Pate 14}

Stems 2 to 5 feet tall, from a stout rootstock hearing several subglobose. scaly, white bulbs. Leaves in whorls of four to ten or some of them alternate, lanceolate or oblong-lanceolate, acuminate, 2 to 6 inches long, onefourth to $1 \frac{1}{4}$ inches wide, fincly roughened on the margins and on the veins beneath. Flowers one to sixteen, nodding on long peduncles at the top of the stem; perianth segments 2 to 3 inches long, yellow or red, usually thickly spotted, recurved or spreading; fruit an oblong, crect capsule 1 to 2 inches long.

Common in swamps, moist meadows, and ficlds, Nova Scotia to Minnesota, Georgia, Alabama and Nebraska. Flowering in July and August. A common and most attractive wild flower of the east, mo:e abundant than the Turk's-cap Lily (L i l i u m su p e r b u m Linnacus). which has similar but usually larger flowers, usually orange-red and purplespotted, more strongly recurved flower segments and leaves smooth and not roughened on the margins or veins as in $L$. c a $n$ a $d$ e $n \mathrm{se}$.

\section{Yellow Adder's-tongue; Dog's-tooth Violet}

Erythronium americanum Ker

$$
\text { Plate } 153
$$

A low, herbaceous plant arising from a deeply buried corm which propagates by offshoots; the simple stem 6 to 12 inches long, bearing a pair of equal or somewhat unequal, oblong or oblong-lanceolate, flat leaves, dark glossy green, usually mottled with brown, sometimes green all over, narrowed into clasping petioles; the flower stem arising from between the leaves, bearing a single nodding flower: perianth yellow or rarely purplish-tinged, the segments oblong, seven-eighths to 2 inches long, about one-fourth of an inch wide or less, recurved, dotted within, the three inner ones auricled at the base; style club-shaped; capsule obovoid. 
In moist woods and thickets, Nova Scotia to Ontario and Minncsota south to Florida and Arkansas. Flowering in April and May.

One of the commonest and best known of our spring flowers, coming in company with the Hepatica, Spring Beauty, and Squirrel Corn, but usually in its prime a little later than these. The whitc Dog's-tooth Violct (E r y thron i um a $1 \mathrm{~b}$ id um Nuttall), with leaves less or not at all spotted and pinkish whitc flowers, is very rare.

\section{Ague or Colicroot; Star Grass}

\section{Aletris farinosa Linnaeus \\ Plate 16}

Leaves mostly basal, lanceolatc and spreading, forming a dense cluster, lanceolate, long pointed, narrowed at the base, pale yellowish green, 2 to 7 inches long, one-fourth to I inch wide. Roots numerous, tough and very bitter. Stem or scape I to 3 feet tall, bearing a few distant bractlike leaves. The terminal raceme of flowers + to I 2 inches long; flowers erect on short pedicels subtended by small bracts; perianth tubular-oblong, sixlobed, whitc or the short lobes yellowish, about one-fourth to one-third of an inch long and less than half as thick, mealy-roughened without; capsules ovoid, about onc-sixth of an inch long, inclosed by the witheringpersistent perianth.

In dry, mostly sandy soil, Maine to Ontario and Minnesota, south to Florida and Arkansas. Flowering in June and July. In New York rarely seen except in the sandy regions adjacent to the coast. Extremely abundant on sterile sandy fields like the Hempstead plains of Long Island, where it is very conspicuous in early summer. It possesses a number of vernacular names, such as Ague Grass, Blazing Star, Bitter Grass, Crow Corn, Mealy Starwort, Aloeroot, Starroot, Huskroot, and others. 
W I LD FLOWERS OF NEW YORK

Memoir 15 N. Y. State Museum

Plate 14

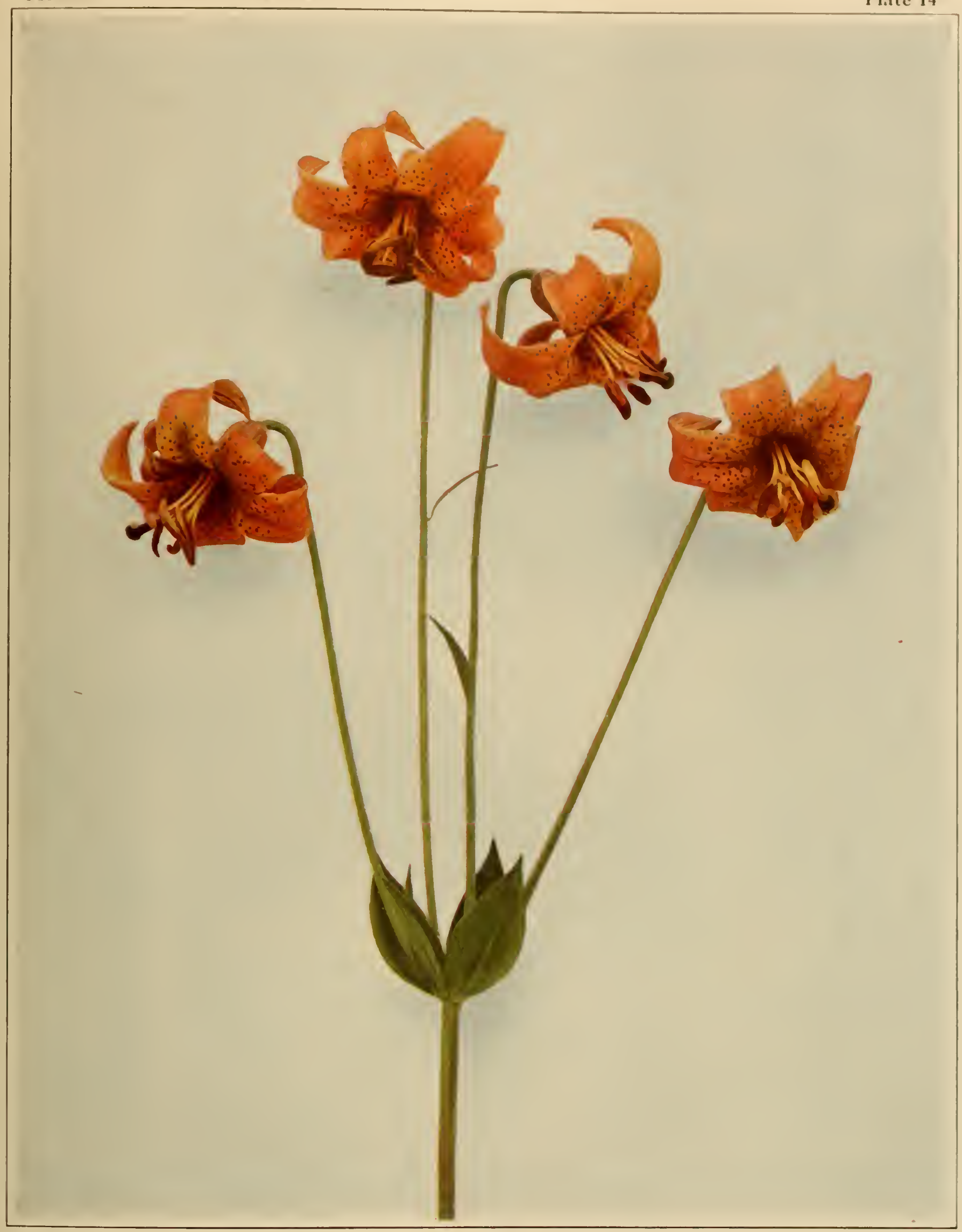

WILD YELLOW LILY; CANADA OR NODDING LILY

Lilium canadense 


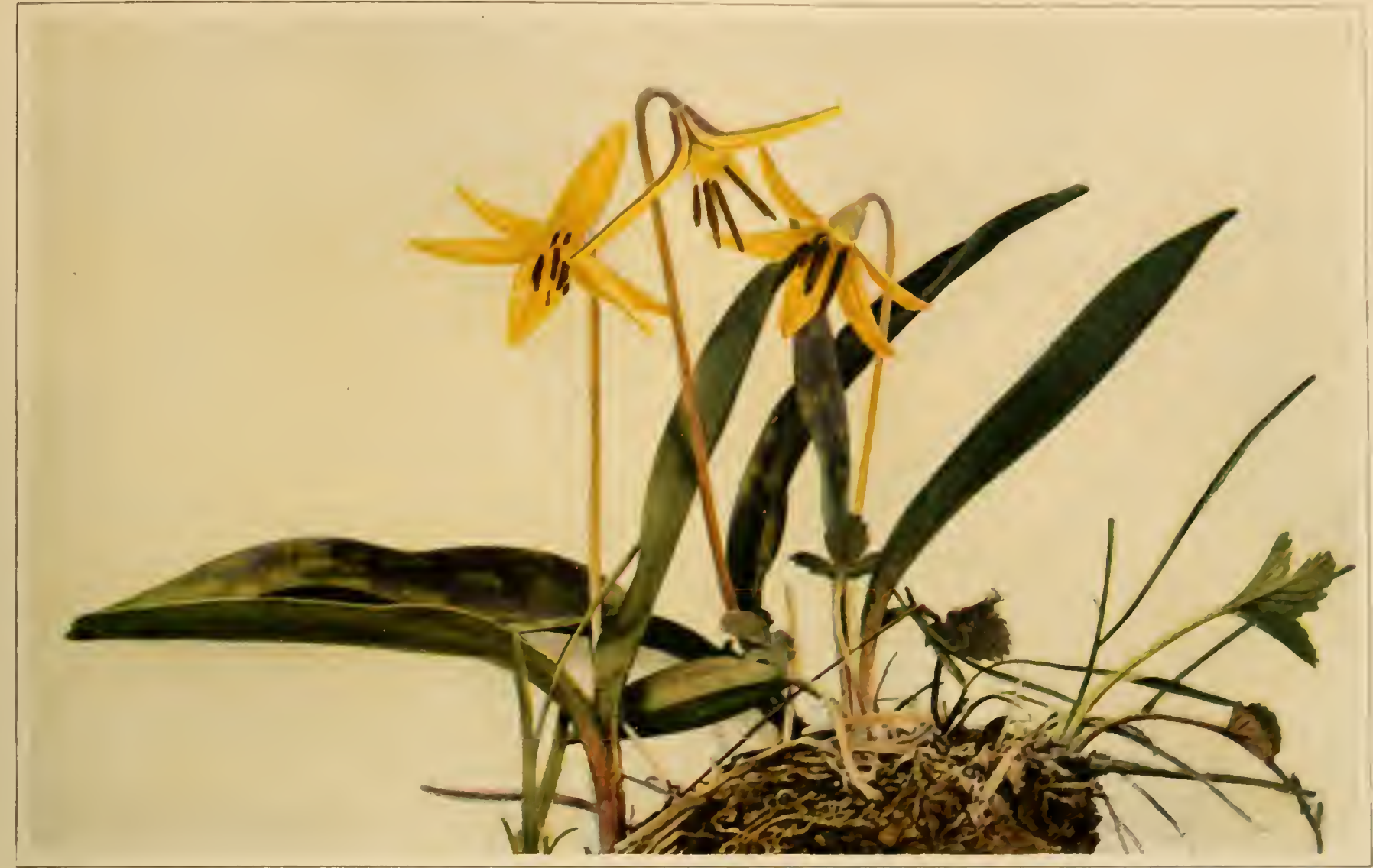

A. YELLOW ADIER'S-TONGI'E; DOG'S-TOOTH VIOLET Erythronimm americanum

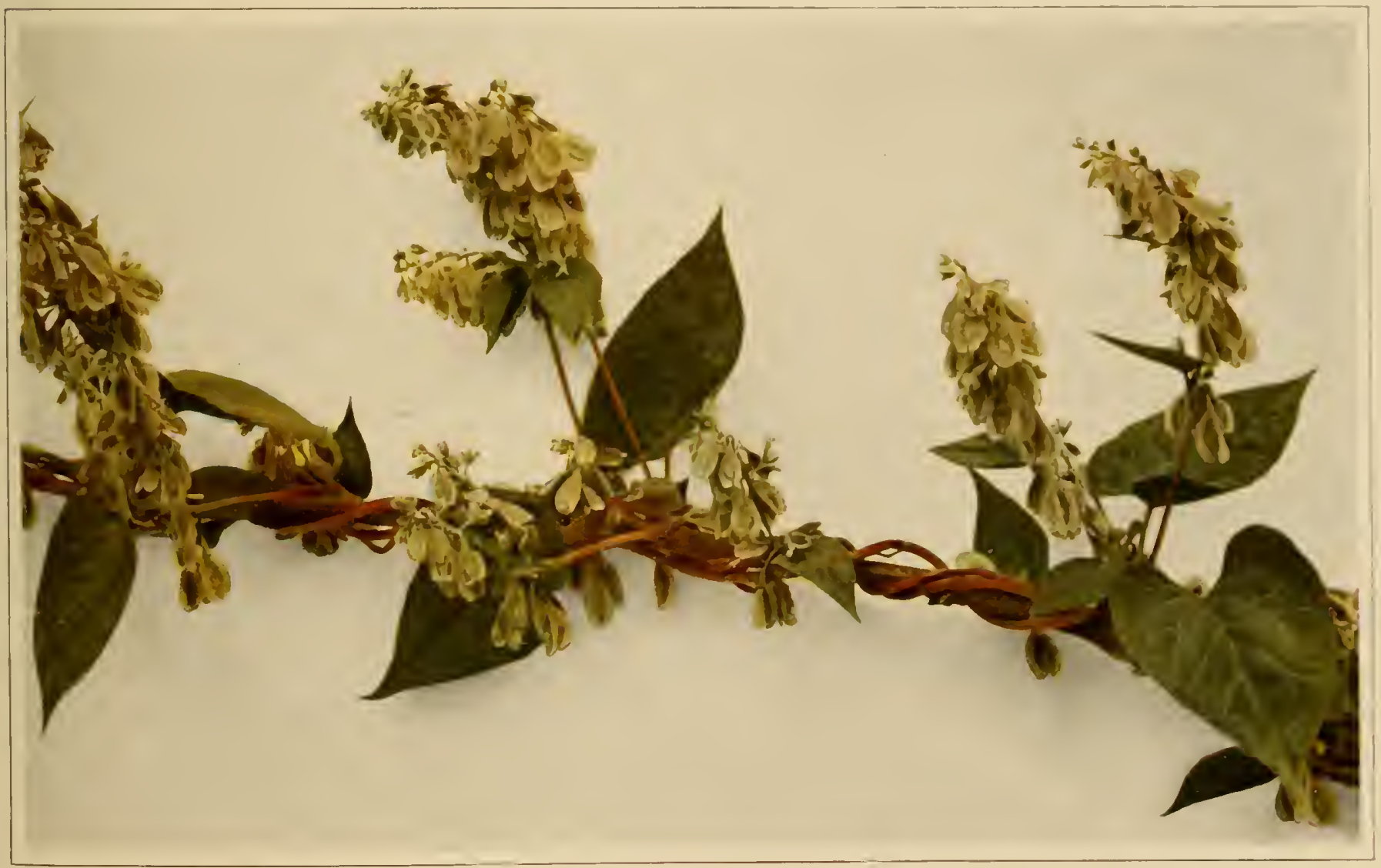

B. CLIMIANG FALSE BLCKWHEAT

Bylderdykia scandens 


\section{-}


WILD FL, OWERS OF NEW YORK

Memoir 15 N. Y. State Museum

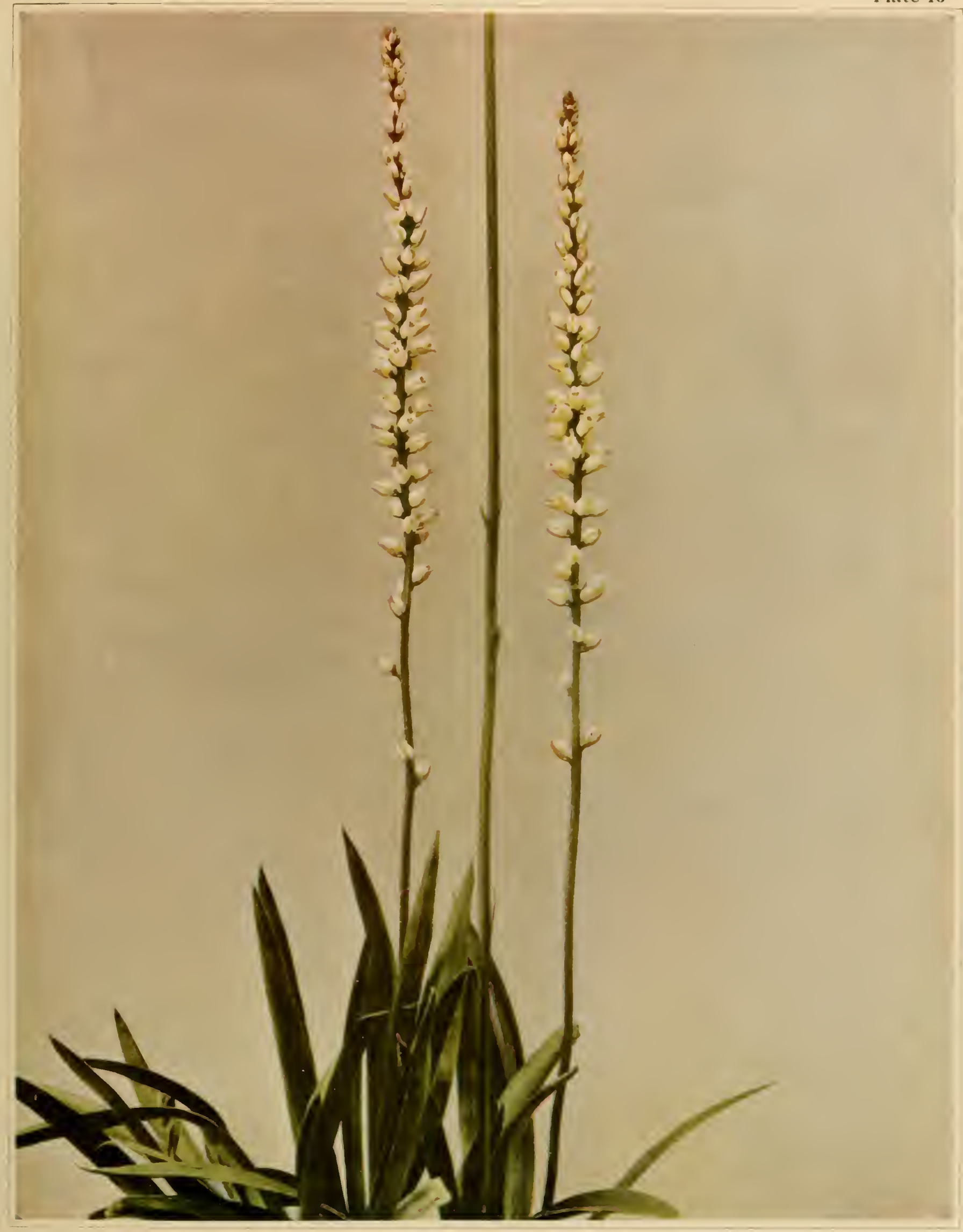

AGUE OR COLICROOT: STAR GRASS

Aletris farinosa 


\section{Lily of the Valley Family}

Convallariaceac

Yellow Clintonia; Dogberry

\section{Clintonia borealis (Aiton) Rafinesque}

Plate 17

Flowering scape or stem 6 to 15 inches high, with two to five (usually three), oval, oblong or obovate, thin, glossy green leaves at the base, their petioles sheathing the base of the stem which arises from a slender rootstock. Leaves ciliate, 5 to 8 inches long, and $1 \frac{1}{2}$ to $3 \frac{1}{2}$ inches wide. Flowers three to six, forming an umbel at the top of the stem, sometimes a sccondary cluster of flowers below the top, drooping, greenish yellow, three-fourths to I inch long, on pedicels about as long as the flowers; perianth segments distinct, six in number, equal and somewhat spreading, the six stamens about as long as the perianth. Fruit an oval, dark blue, shining berry about one-fourth of an inch in diameter.

In moist woods and thickets, Newfo:mdland to Manitoba, south to North Carolina and Wisconsin. Very common in the rich, moist woodlands of northern New York, but rare or absent from the coastal region. Flowering from the latter part of May until the last of June. The fruit ripe in September.

The White Clintonia (C 1 int on i a $u$ mbellulat a (Michaux) Torrey), with smaller white flowers, not drooping, and black berries, leaves and scapes more pubescent but otherwise similar, which is common in the southern Appalachians, reaches New York in the southwestern counties of the State.

\section{Wild or False Spikenard; False Solomon's-seal}

Tagnera racemosa (Linnaeus) Morong

Plate is

Stem slender or stout, erect or ascending, sometimes zigzag, i to 3 feet tall, simple, bearing numerous alternate, sessile or nearly sessile oblonglanceolate or oval, acuminate leaves, 3 to 6 inches long, I to 3 inches wide, 
which are finely pubescent, especially beneath, and sometimes also above, their nuargins minutely ciliate. Rootstock rather thick and fleshy with numerous long, fibrous roots, the scars of former stems irregular and ringlike. Flowers white; many, forming a large terminal panicle, I to + inches long; each flower about 2 lines broad; perianth of six oblong, equal, separate. spreading segments. Fruit a red, aromatic berry about 3 lines in diameter and speckled with purple. In Bergen swamp occurs a variety with three to six purple stripes like the fruit of $\mathrm{Y}$. s t e $11 \mathrm{at}$ a.

In moist woods and thickets, Nova Scotia to British Columbia, south to Georgia, Missouri and Arizona.

The Star-flowered Solomon's-seal ( $\mathrm{T}$ ag nera stell a t a (Linnaeus) Morong) is scarcely less abundant, but seems to prefer thickets and banks with more moisture. The leaves are smaller and narrower, the flowers fewer in number, larger, white, and racemed; the berries green with six black stripes, or entirely black.

\section{Three-leaved Solomon's-seal}

\section{Vagnera trifolia (Linnaeus) Morong} Plate $32 \mathrm{a}$

Stem and leaves glabrous from a slender, elongated rootstock, the erect stem 2 to 5 inches high with two to four (usually three) oval, oblong or oblong-lanceolate, sessile leaves 2 to 5 inches long, one-half to 2 inches wide with sheathing bases. Flowers white, few, racemed at the top of the stem; perianth segments oblong or oblong-lanceolate, obtuse, finally somewhat reflexed and longer than the stamens. Fruit a dark-red berry about one-fourth of an inch in diameter.

In bogs and wet woods, Newfoundland to British Columbia, south to Connecticut, New Jersey, Pennsylvania and Michigan. Usually abundant in sphagnum under or near spruces and tamaracks, and therefore rare outside the mountainous sections of the State except on the margins of bogs and mossy swamps where the spruce and tamarack abound, as, for instance, Cicero swamp in Onondaga county, and Bergen swamp in Genesee county. as well as numerous other swamps of similar character throughout the State. 
WILD FLOWERS OF NEW YORK

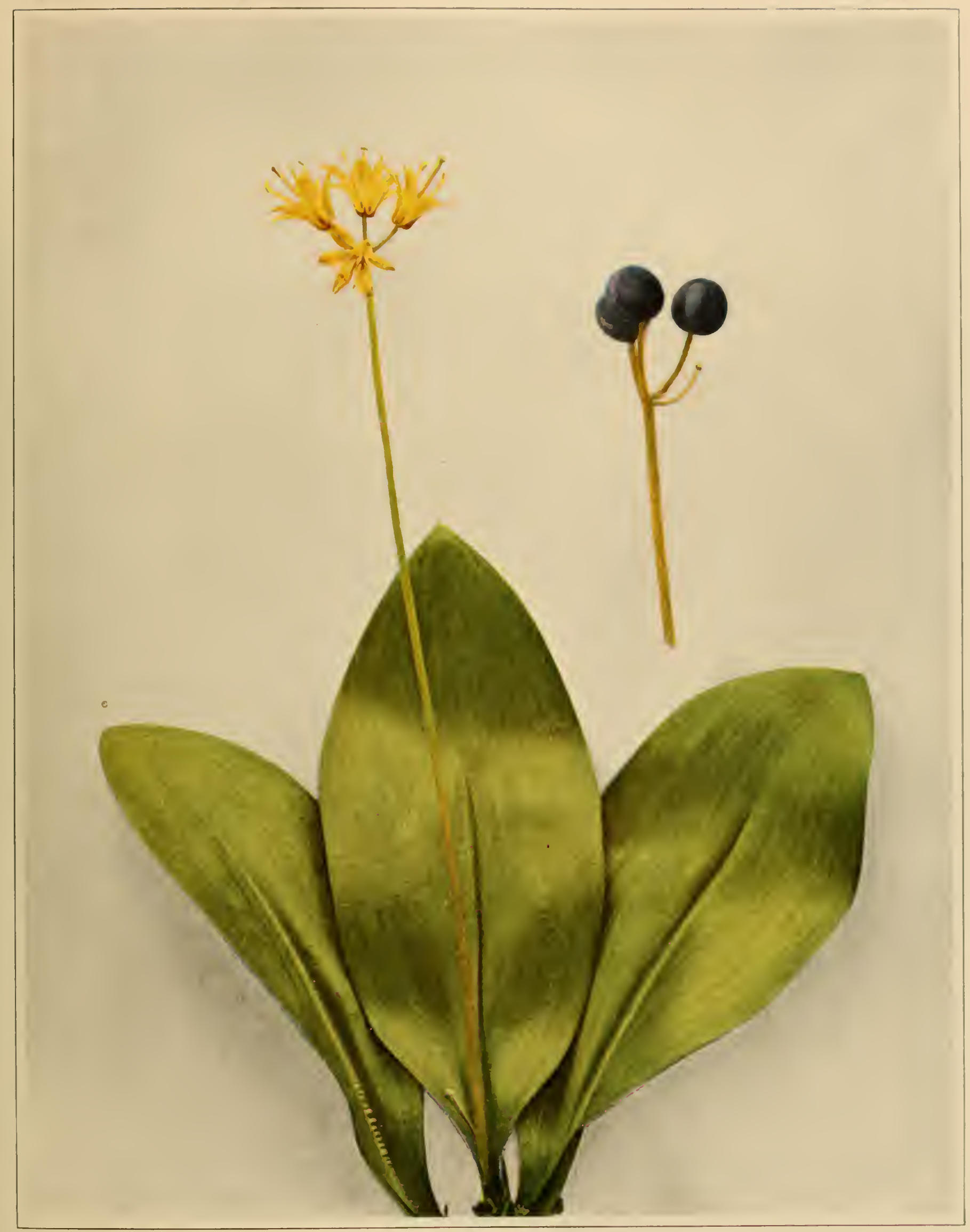

YELLOW CLINTONIA; DOGBERRY

Clintonia borealis 


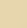


WILD FLOWERS OF NEW YOR K

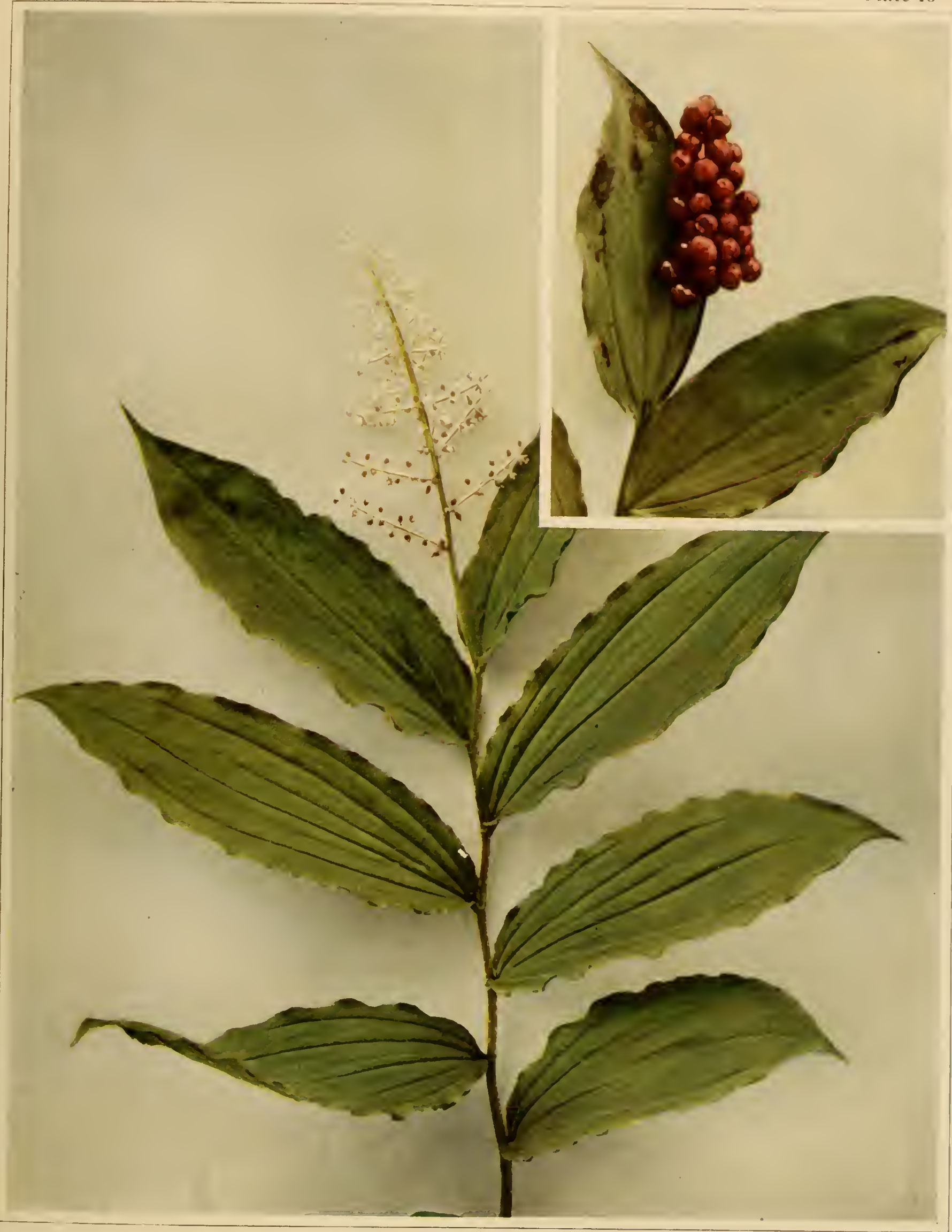

WILD OR FALSE SPIKENARD; FALSE SOLOMON'S-SEAL 



\section{False or Wild Lily of the Valley \\ Two-leaved Solomon's-seal \\ Unifolium conudense (Desfontaines) Greene \\ Plate t9}

A low, herbaceous perennial with slencler rootstock, and slender, erect and often zigzag stem, 2 to 7 inches high, bearing one to three (usually two) ovate or ovate-lanceolate, pointed leaves, eordate at the base and sessile or short-petioled; stem!ess plarits frequent and consisting of a single leaf on a petiole $\mathrm{I}$ to $f$ inches long arising from the rootstock. Flowers white, numerous, forming a rather dense terminal raceme, I to 2 inehes long; perianth about one-fifth of an inch broad with four spreading, separate segments, which slightly exceed the four stamens in length; fruit a cluster of pale-red, speckled berries, each with one or two seeds.

In moist woods and thickets, Newfoundland to the Northwest Territory of Canada, south to the mountains of North Carolina, Tennessec, Iowa and South Dakota. Flowering in May and June.

A common wild flower of most parts of New York, especially in the moist cool forests of the northern and mountainous sections.

\section{Sessile-leaved Bellwort \\ Uiularia sessilifolia Linnaeus Plate $20 a$}

Stems slender, glabrous, 4 to 12 inches high, naked or with one or two leaves below the fork. Leaves oblong or oblong-lanceolate, I to 3 inches long when they mature, thin, sessile, acute at each end, slightly rough-margined, pale or glaucous beneath; flowers greenish yellow, twothirds to $\mathrm{I} \frac{1}{4}$ inches long; the six perianth segments smooth, the stamens shorter than the styles; anthers blunt; fruit a sharply three-angled eapsule, narrowed at both ends, about I inch long and two-thirds as thick.

In moist woods and thickets, usually most abundant where the soil is sandy, New Brunswick and Ontario to Minnesota, south to Georgia 
and Arkansas. Except in the coastal region and other sections of the State with sandy soil, this small-flowered bellwort is not so abundant as U. grandiflora and U. perfoliata.

\section{Large-flowered Bellwort Unularia grandiflora J. E. Smith Plate $20 \mathrm{~b}$}

An erect herb with smooth, leafy, forked stem from a perennial rootstock; stem with one or two leaves below the fork, 6 to 20 inches high. Leaves perfoliate, oblong, oval or ovate, pubescent beneath, glabrous above, . becoming 2 to 5 inches long, acute at the apex, rather smaller and often scarcely unfolded at flowering time; flowers solitary at the ends of the branches, peduncled, drooping, narrowly bell-shaped, lemon-yellow, I to $\mathbf{I} \frac{1}{2}$ inches long, perianth segments six, distinct, smooth on both sides or very slightly granular within; stamens six, longer than the styles which are united to about the middle; anthers linear, the connective blunt; fruit a three-angled, truncate capsule, about one-half of an inch long.

In rich upland woods, Quebec to Ontario, Minnesota, Georgia and Kansas. Flowering in April and May. A common flower of most sections, especially in rich woodlands. In the Ontario lowlands and Hudson valley it is largely replaced by the Perfoliate Bellwort ( $U$ v u laria perf o 1 i a t a Linnaeus), which differs chiefly in having smooth and glaucous foliage, and slightly smaller flowers with the perianth segments papillose within.

\section{Sessile-leaved Twisted-stalk}

\section{Streptopus roseus Michaux}

Figure IV

Stems I to 3 feet high from a short, stout rootstock covered with fibrous roots. Branches usually three or four in number and obliquely ascending, all leafy and sparingly pubescent. Leaves alternate, thin, many-nerved, ovate or ovate-lanceolate, 2 to $+\frac{1}{2}$ inches long, long pointed at the apex, sessile, rounded or slightly clasping the stem at the base, green on both 


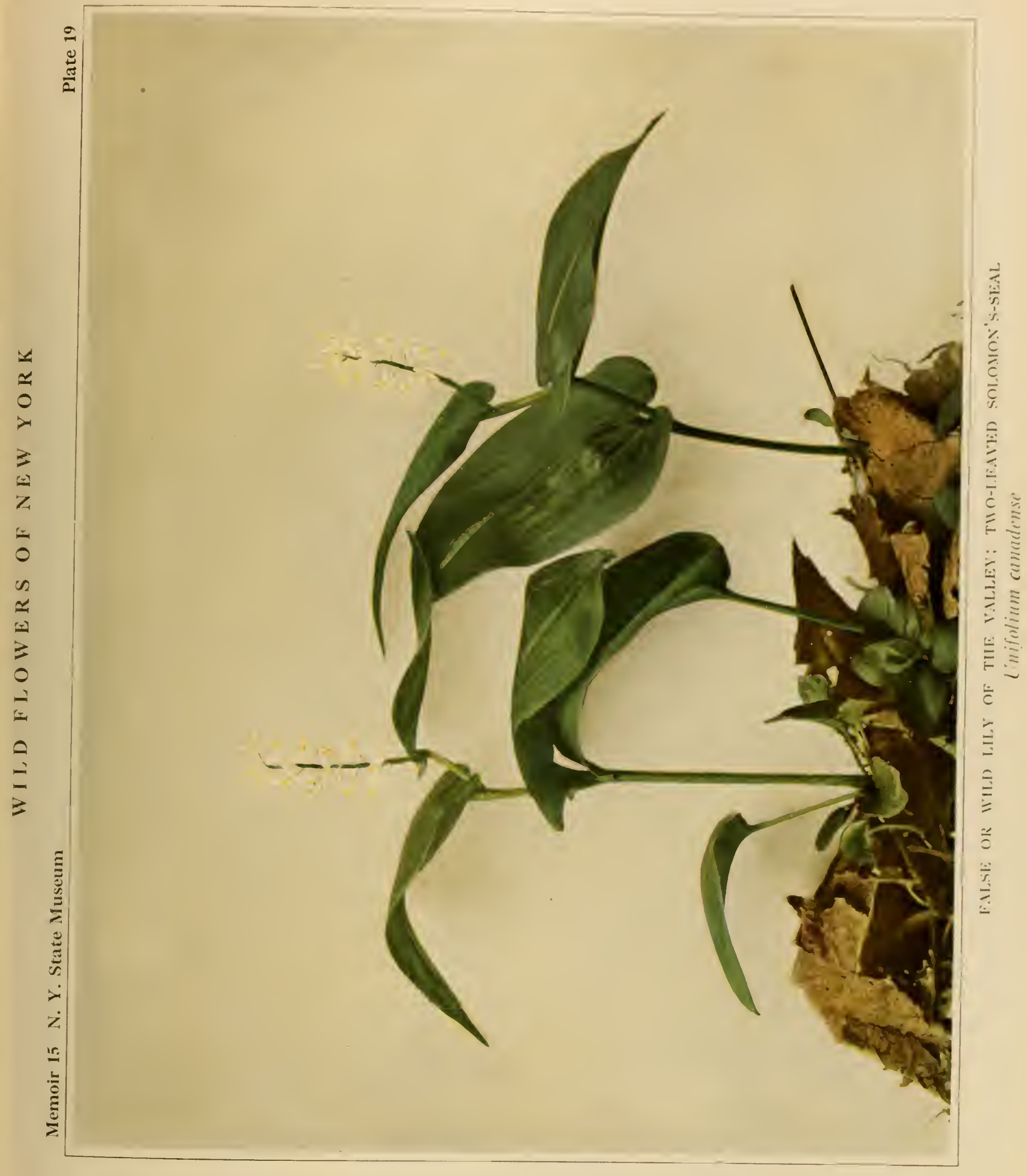





$$
\frac{y}{\frac{y}{y}+\frac{1}{x}}
$$


$-$ 
sides, but usually paler beneath, their margins finely ciliate. Flowers purple or rose colored, about one-third of an inch long, slenderpeduncled, solitary or two together from the axil of each of the upper leaves on slender peduncles, one-half to I inch long, the peduncle bent or twisted at about the middle; perianth bell-shaped, its six segments lanceolate and pointed, their tips somewhat recurved or spreading. Stamens six, shorter than the perianth. Fruit a globose, red berry about one-third of an inch or less in diameter.

In moist woods, Newfoundland to Manitoba, Georgia and Michigan. Flowering in May and June.

The Clasping-leaved Twisted-stalk (Streptopus a mplexifolius (Linnaeus) De Candolle) is similar but the leaves are clasping around the stem at their bases, glaucous or whitish beneath and the flowers are greenish white in color.

The Hairy Disporum (D is p or $u$ m la $n u g$ in os $u m$ (Michaux) Nichols.) resembles the Twisted-stalks in manner of growth, but the leaves are somewhat narrower and not clasping and the flowers are solitary or few together at the ends of the branches, one-half to three-fourths of an inch long and greenish in color. It is found in woods in western New York.

\section{Hairy Solomon's-seal \\ Polygonatum biflorum (Walter) Elliott \\ Plate 2I}

Stems slender, smooth, arching, often zigzag above from a thick, horizontal, jointed rootstock, bearing the raised orbicular scars of the stems of former years; stem naked below, above bearing six to many opposite or nearly opposite, oval or ovate leaves, 2 to 4 inches long, one-half to 2 inches wide, acute or acuminate at the apex, narrowed or obtuse at the base, pale or pubescent beneath, glabrous above, the upper leaves commonly narrower than the lower; flowers in drooping, axillary clusters of one to four (often two), perianth greenish or greenish yellow, tubular, one-third to one-half of an inch long, with six short lobes; the six stamens shorter than the tube, their anthers sagittate and filaments minutely roughened. Fruit a dark blue, pulpy berry about one-fourth of an inch in diameter. 


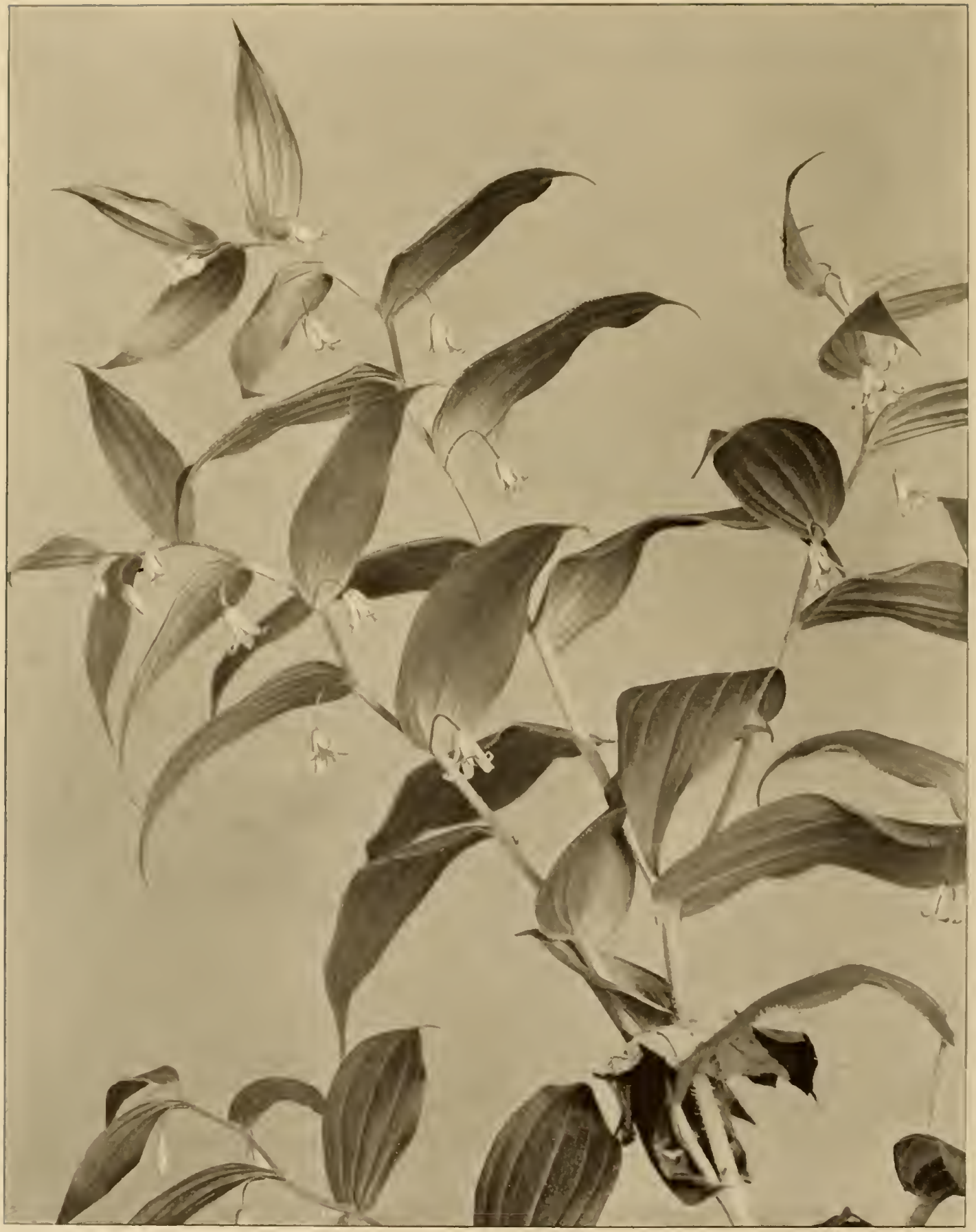

Figure IV

Sessile-leaved Twisted-stalk

(Streptopus roseus Michaux) 

- 
A common but not showy plant of woods and thickets from New Brunswick to Ontario and Michigan, south to F'lorida and Tennessee.

Resembling this but usually larger in every way, with glabrous leaves and smooth filaments, is the Smooth or Giant Solomon's-scal (Polygon a $\mathrm{t}$ m com m t a tu m (Roemer \& Schultes) Dictrich), which ranges northeastward only to Rhode Island, New Hampshire and Ontario. It seems to prefer moist thickets and woods along streams and on bottomlands, while the Hairy Solomon's-seal is more commonly met with in rich upland woods.

\section{Wake-robin Family}

Trilliaceae

\section{Indian Cucumber Root}

\section{Medeola rirginiana Linnaeus}

Plate 22

A slender, erect, unbranched herb from a perennial rootstock I to 3 inches long; stem I to $2 \frac{1}{2}$ feet high, loosely covered with deciduous wool, bearing the lower whorl of leaves above the middle or, in flowerless plants, at the summit; leaves of the lower whorl sessile, 2 to 5 inches long, I to 2 inches wide; acuminate at the apex, narrowed at the base, three to fivenerved; leaves of the upper whorl I to 2 inches long, one-half to I inch wide, short petioled or sessile, often turning reddish at the base; umbel of two to nine flowers on filiform pedicels, I inch long or less, declined in flower, erect or ascending in fruit; perianth segments one-fourth to onehalf of an inch long, obtuse, the six equal segments recurved, the three long styles recurved. Fruit a dark blue or purplish berry one-fourth to one-half of an inch in diameter.

In moist woods and thickets, Nova Scotia to Ontario, Minnesota, Florida and Tennessee. Flowering in May and June. Fruit ripe in September. 
The thick, tuberlike, white rootstock is brittle with numerous slender fibrous roots and has the odor and taste of cucumbers.

\section{Red Trillium; Wake-robin or Birthroot}

\section{Trillium erectum Linnaeus}

Plate 23a

Stem rather stout, 8 to $\mathbf{I} 6$ inches high, from a thick, short rootstock. Leaves rather dark green, very broadly rhombic, 3 to 7 inches long, often as wide or wider, sessile or nearly so, acuminate at the apex, narrowed at the base, peduncle I to 4 inches long, erect or nearly so, bearing a single, umpleasantly scented, large flower; sepals lanceolate, acuminate, spreading, one-half to $\mathrm{I} \frac{1}{2}$ inches long; petals lanceolate to ovate, acute, spreading, equalling the sepals or a little longer, dark purplish-red, varying to pink; greenish, white, or reddish yellow in certain aberrant forms; anthers longer than the filaments and exceeding the stigmas; ovary purple with shortspreading or recurved styles; fruit an ovoid, somewhat six-lobed, reddish berry, I inch thick or less.

In woods and thickets, Nova Scotia to Ontario, south to North Carolina and Tennessee.

\section{White Trillium; Large-flowered Wake-robin \\ Trillium grandiflorum (Michaux) Salisbury \\ Plate 23b}

A glabrous, erect, unbranched herb from a stout, perennial, short, scarred rootstock, 8 to 18 inches high; bearing at the top of the stem three light-green, broadly rhombic-ovate or rhombic-oval leaves, 2 to 6 inches long, acuminate at the apex, narrowed and sessile at the base, peduncle erect or nearly so, I to 3 inches long, bearing a single flower 2 to 3 inches broad. The three sepals lanceolate, pointed and spreading. Petals three, erect-spreading, oblanceolate, obovate, or rarely ovate-oblong, obtuse or cuspidate, thin, strongly veined, white, usually turning pink with age, much longer than the sepals. Stamens six. with yellow anthers which are 
WILD FLOWERS OF NEW YORK

Memoir 15 N. Y. State Museum

Plate 22

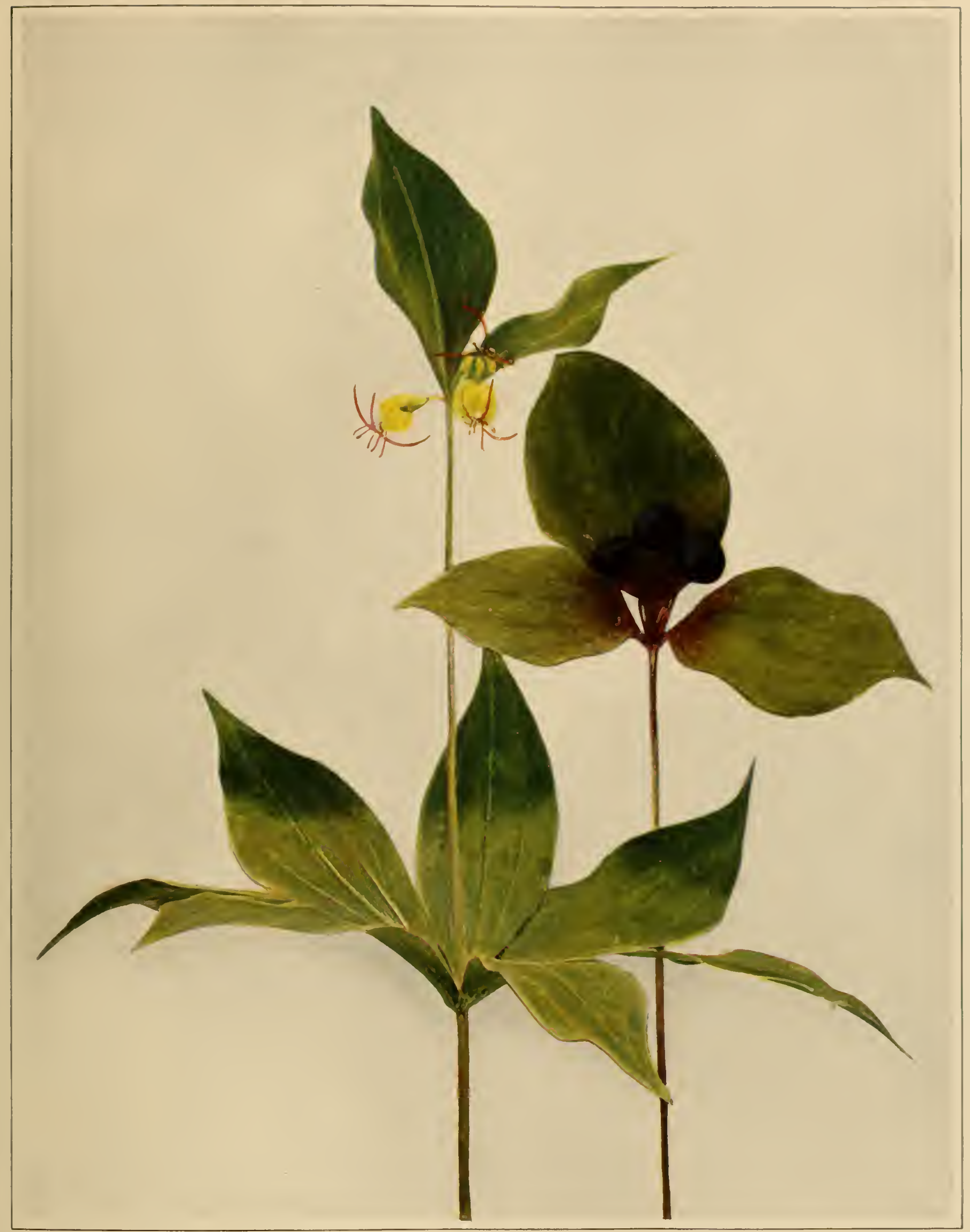

INDIAN CUCUMBER ROOT

Medeola virginiana 

W I L D F L O WERS OF NEW YORK

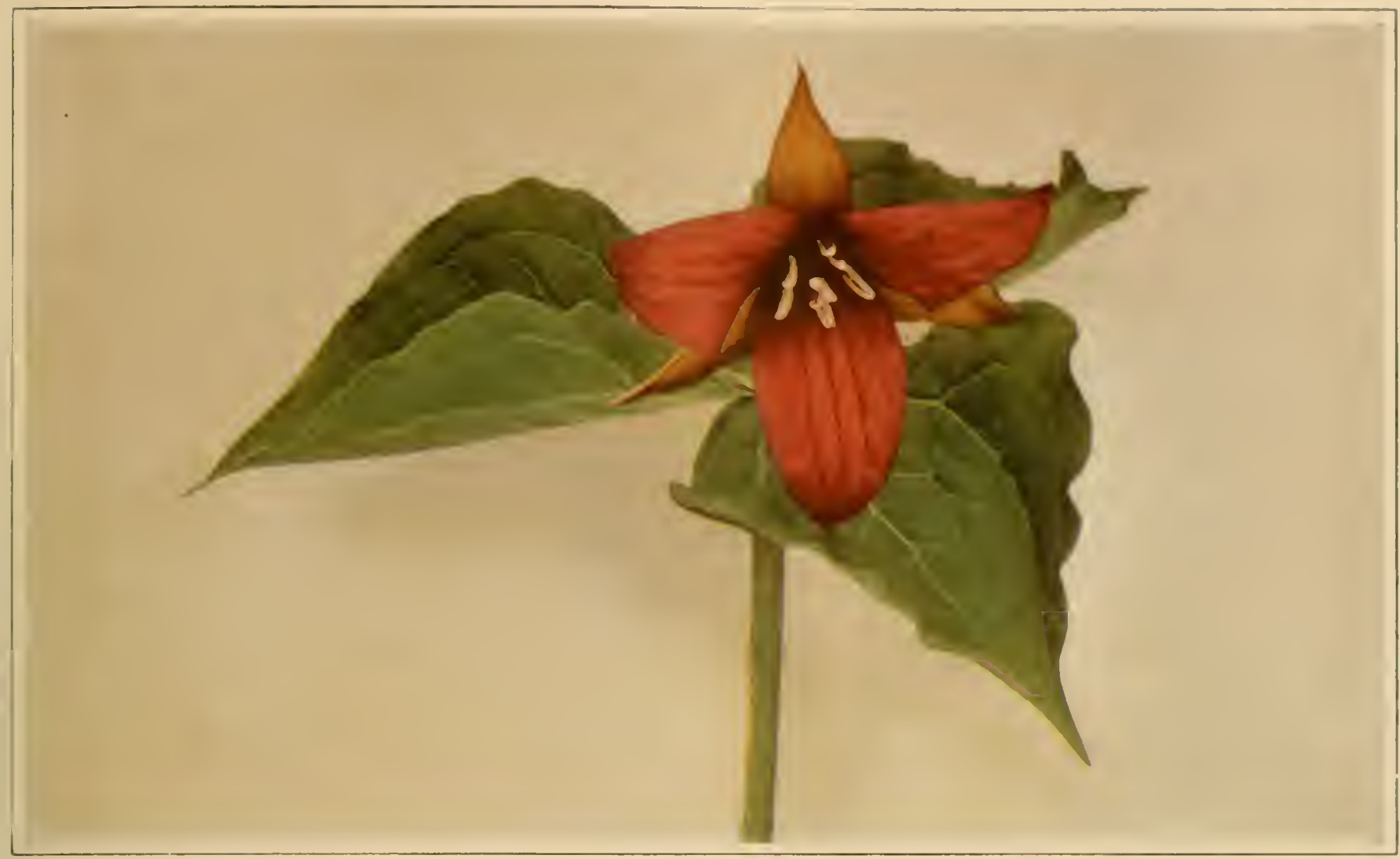

A. RED TRILLIUM; WAKE-ROBIN OR BIRTIIROOT Trillium erectum

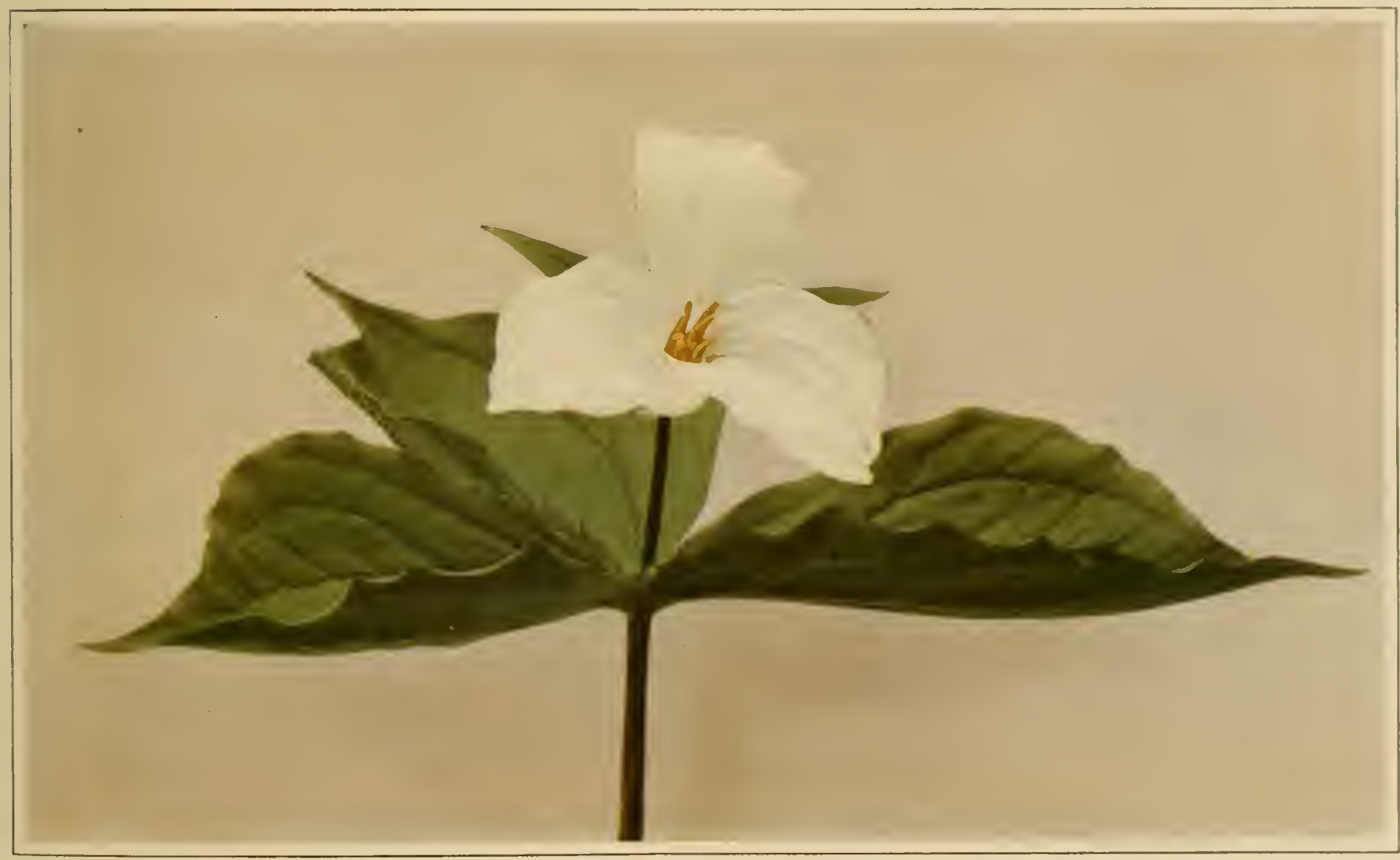

B. WHITE TRILLIUM; LARGE-FLOWERED WAKE-ROBIN Trillium grandiflorum 
about one-half of an inch long; the three styles slender and ascending. Fruit a globose, black, slightly six-lobed berry, three-fourths to 1 inch in diameter.

In rich woods, preferring ravines and wooded upland slopes, Quebec to Ontario and Minnesota, south to North Carolina and Missouri.

Various monstrous forms sometimes occur with two to several longpetioled leaves, double flowers, and even forms with green, variegated or leaflike petals.

\section{Painted Wake-robin}

\section{Trillium undulatum Willdenow}

Plate 243

Stem slender, 8 to 20 inches high, bearing three ovate, petioled, bluish green, waxy leaves, 3 to 8 inches long, 2 to 5 inches wide, long-acuminate at the apex, obtuse or rounded at the base. Flowers on erect or somewhat inclined peduncles, I to $2 \frac{1}{2}$ inches long; sepals lanceolate, acuminate, threefourths to $\mathbf{I} \frac{1}{4}$ inches long, spreading; petals ovate or ovate-lanccolate, acuminate or acute, white and marked with magenta veins at the base, thin, and longer than the sepals, widely spreading, wavy-margined; the ovoid ovary with three slender spreading styles, ripening into an ovoid, obtusc, bluntly three-angled bright red shining berry.

Common in woods, especially low, moist or cool, sandy woodlands, Nova Scotia to Ontario and Wisconsin, south to Georgia and Missouri. Flowers in May and usually a few days later than the white or red trilliums.

\section{Nodding Wake-robin \\ Trillium cernuım Linnaeus \\ Plate $24 \mathrm{~b}$}

Stems rather slender, 8 to 20 inches high; leaves pale green, broadly rhombic, acuminate at the apex, narrowed at the base, sessile or with very short petioles, peduncle one-half to $\mathrm{I} \frac{1}{2}$ inches long, recurved beneath the leaves and bearing a single drooping flower about I to $1 \frac{1}{4}$ inches broad, sepals lanceolate or ovate-lanceolate, acuminate, petals white or pinkish, 
ovate-lanecolate or oblong-laneeolate, rolled backward, wavy-margined, two-thirds to 1 ineh long, as long or longer than the sepals; anthers about as long as the subulate filaments and overtopping the stout, reeurved styles, ovary whitish, ripening into an ovoid reddish-purple berry.

In rieh, usually low woodlands Newfoundland to Ontario and Manitoba, south to Georgia and Missouri. Flowering in May or in the extreme northern part of its range in June, usually about ten days later than the white or red trilliums.

\section{Amaryllis Family}

A m a r y 11 id a c e a e

\section{Yellow Star Grass \\ Hypoxis hirsuta (Linnaeus) Coville \\ Plate 25}

A low, perennial herb with the leaves all basal, narrowly linear, oneeighth to one-fourth of an ineh wide, more or less villous and mostly longer than the flowering stems, from an ovoid or globose eorm, one-fourth to one-half of an ineh in diameter; flowering stems erect, slender, villous above, usually glabrous below, 2 to 6 inehes high, bearing at the summit an umbel of one to seven flowers; perianth six-parted, its segments narrowly oblong, spreading, equal or nearly so, obtuse, bright yellow within, greenish and villous without, one-fourth to one-half of an ineh long; stamens somewhat unequal; the style rather shorter than the stamens and three-angled, the stigma decurrent on the angles; eapsules in fruit about one-eighth of an ineh in diameter, the black seeds angled.

In dry, espeeially sandy soil, in fields, thiekets and open woods, Maine to Ontario, Assiniboia, Kansas, Florida and Texas. Flowering in May and June, but frequently putting up additional flowering seapes as late as August and September. 

- 
WILD FLOWERS O I NEW YORK

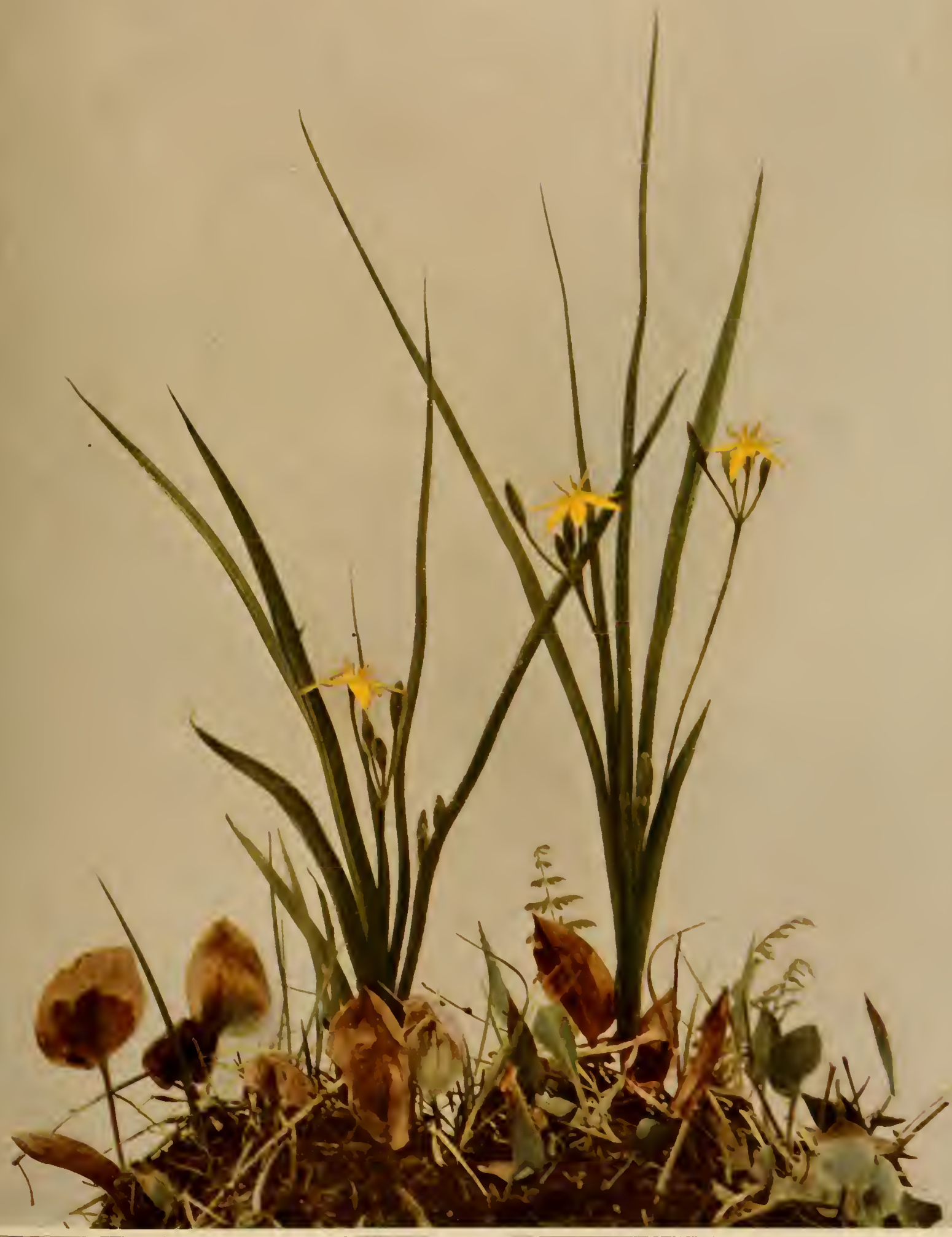

YELLOW STAR GRASS

Hypoxis hirsuta 
- 


\author{
Iris Family \\ Iriclaceac \\ Larger Blue Flag \\ Iris a'ersicolor Linnaeus \\ Plate 26
}

Stems round and smooth, erect, sometimes flexuous, 2 to 3 feet tall, often branched above, leafy; leaves ereet, shorter than and ehicfly upon the lower part of the stem, somewhat glaueous, one-half to $1_{4}^{1}$ inehes wide; rootstock horizontal, thick, fleshy, covered with the fibrous roots. Flowers several, the perianth consisting of six, clawed segments united below into a tube, the three outer ones dilated, reflexed, violet-blue, variegated with yellow, green and white; crestless, spatulate, 2 to 3 inches long, and wider and longer than the three inner segments; the ovary below the perianth tube, in fruit becoming an oblong, obscurcly three-lobed eapsule, I to $\mathbf{I} \frac{1}{2}$ inches long; divisions of the style petallike, arching over the stamens, bearing the stigmas immediately under their two-lobed tips.

In marshes, thiekets and wet meadows, common along streams and ponds, Newfoundland to Manitoba, south to Florida and Arkansas.

\title{
Narrow Blue Flag; Poison Flagroot \\ Iris prismatica Pursh \\ Plate 27
}

More slender in every way than Iris versicolor Linnaeus, with a tuberous-thickened rootstock; stem I to 3 feet tall, bearing two or three very narrow, almost grasslike leaves usually less than one-fourth of an inch wide; flowers one or two at summit of each stem, blue, veined with yellow on slender pedicels; outer perianth segments one-half to 2 inches long, smooth and devoid of a crest, the inner segments smaller and narrower; the perianth tube about one-fourth of an inch long above the ovary. Fruit a narrowly oblong capsule, acute at each end and sharply three-angled, I to $\mathrm{I} \frac{1}{2}$ inches long. 
Marshes, wet meadows and swamps, mainly near the coast from Nova Scotia to Pennsylvania and Georgia. Flowering in May and June.

\section{Pointed Blue-eyed Grass}

\section{Sisyrinchium angustifolium Miller}

Plate $28 \mathrm{a}$

Perennial and tufted, stems stiff and erect, pale green and glaucous, t to 18 inches high. Leaves pointed, about half as long as the stems, about one-sixth of an inch or less wide. Stem simple or rarely branched, winged, the edges minutely serrulate. Flowers deep violet-blue, one-half of an inch broad, umbellate from a pair of erect, green or slightly purplish bracts (spathe), the outer bract rather less than twice the length of the inner one, the six spreading segments of the perianth oblong and aristulate at the tip. Capsules subglobose, often purplish tinged, about one-fourth of an inch in diameter or less.

In fields and on hillsides, Newfoundland to Saskatchewan, British Columbia, Virginia, Nebraska, Colorado and Utah. Flowering from May to July.

There are four other species of blue-eyed grass in New York State: S. mucron a tum Michaux, S. a ren icola Bicknell, S. gra minoides Bicknell and S. a t la n ticum Bicknell.

\section{Orchid Family}

Orchidace a e

The members of the Orchid family in New York State, of which several are described and illustrated here, constitute a very important number of our wild flowers and call for a description of the family. They are all perennial herbs with corms, bulbs or tuberous roots and entire, sheathing leaves, in some species reduced to scales. Flowers perfect, irregular, solitary, spiked or racemed. Perianth consisting of six segments, the three outer (sepals) similar or nearly so, two of the inner ones (petals) lateral, alike; the third inner one (lip) unlike the other two, often markedly 
W I L D F L O WERS O F NEW YORK

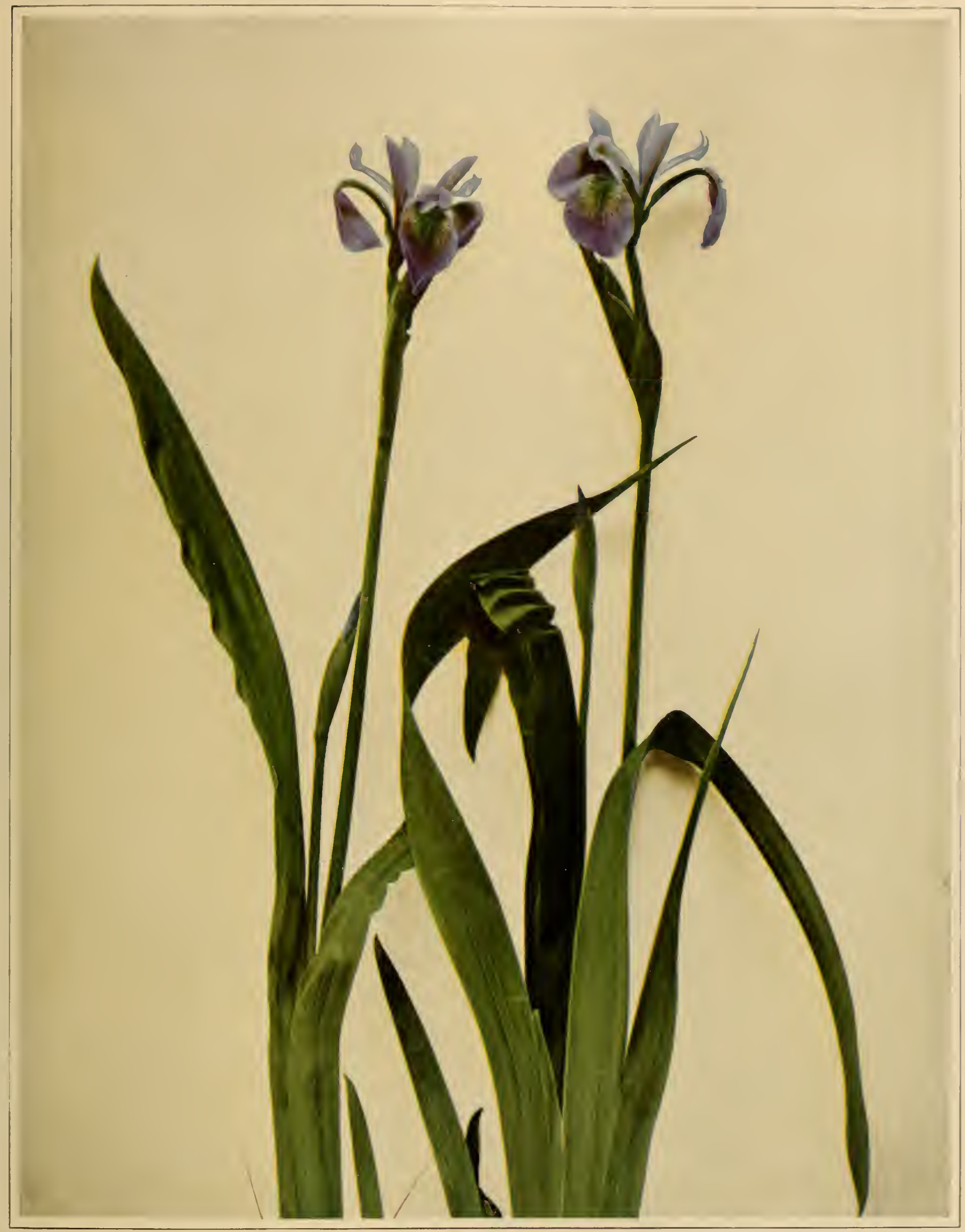

LARGER BLUE FLAG

Iris i'ersicolor 
$$
\text { - }
$$ 
WILD FLOWERS O Li NEWYORK

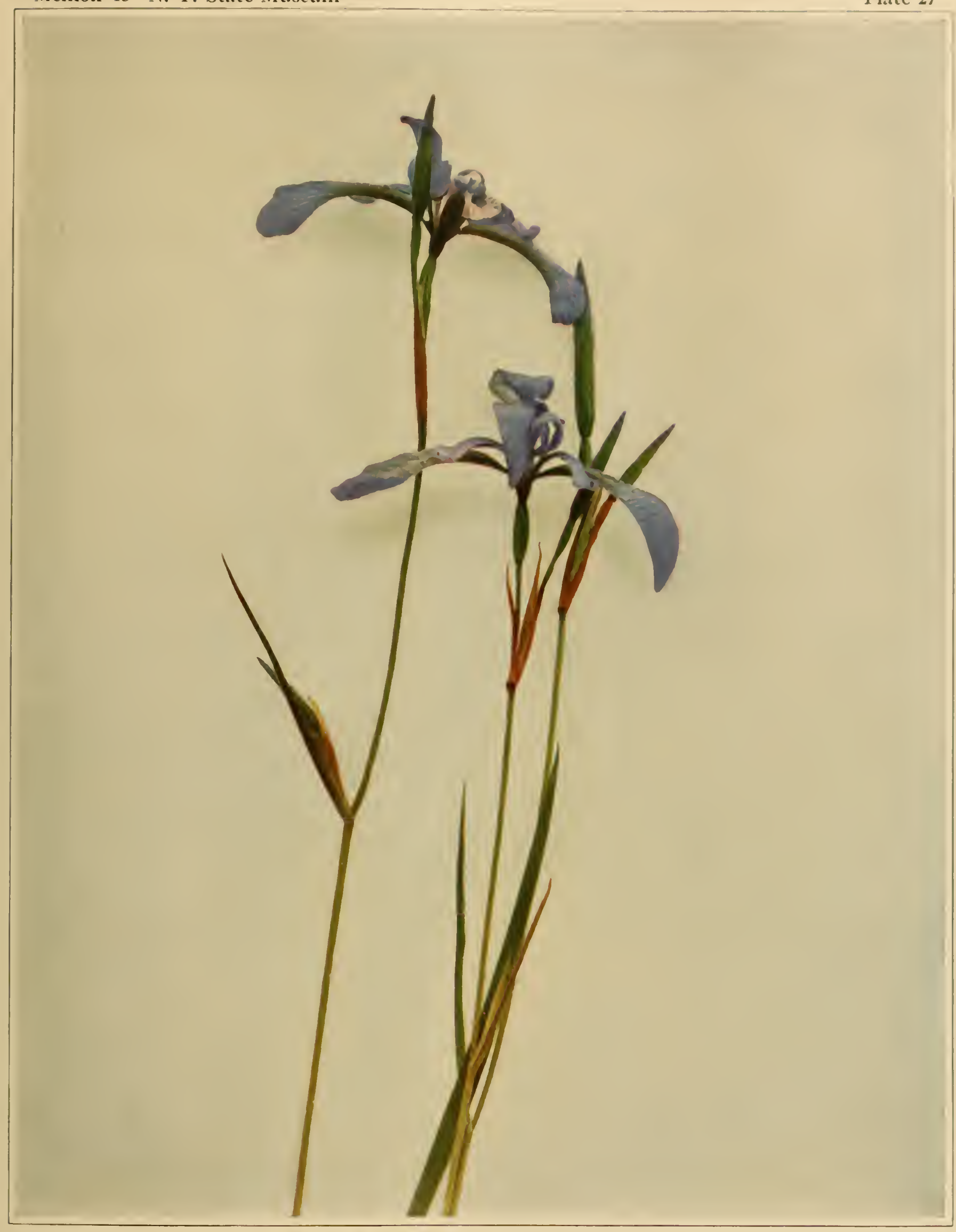

NARROI BLUE FLAG; POISON FLAGROOT Iris prismatica 



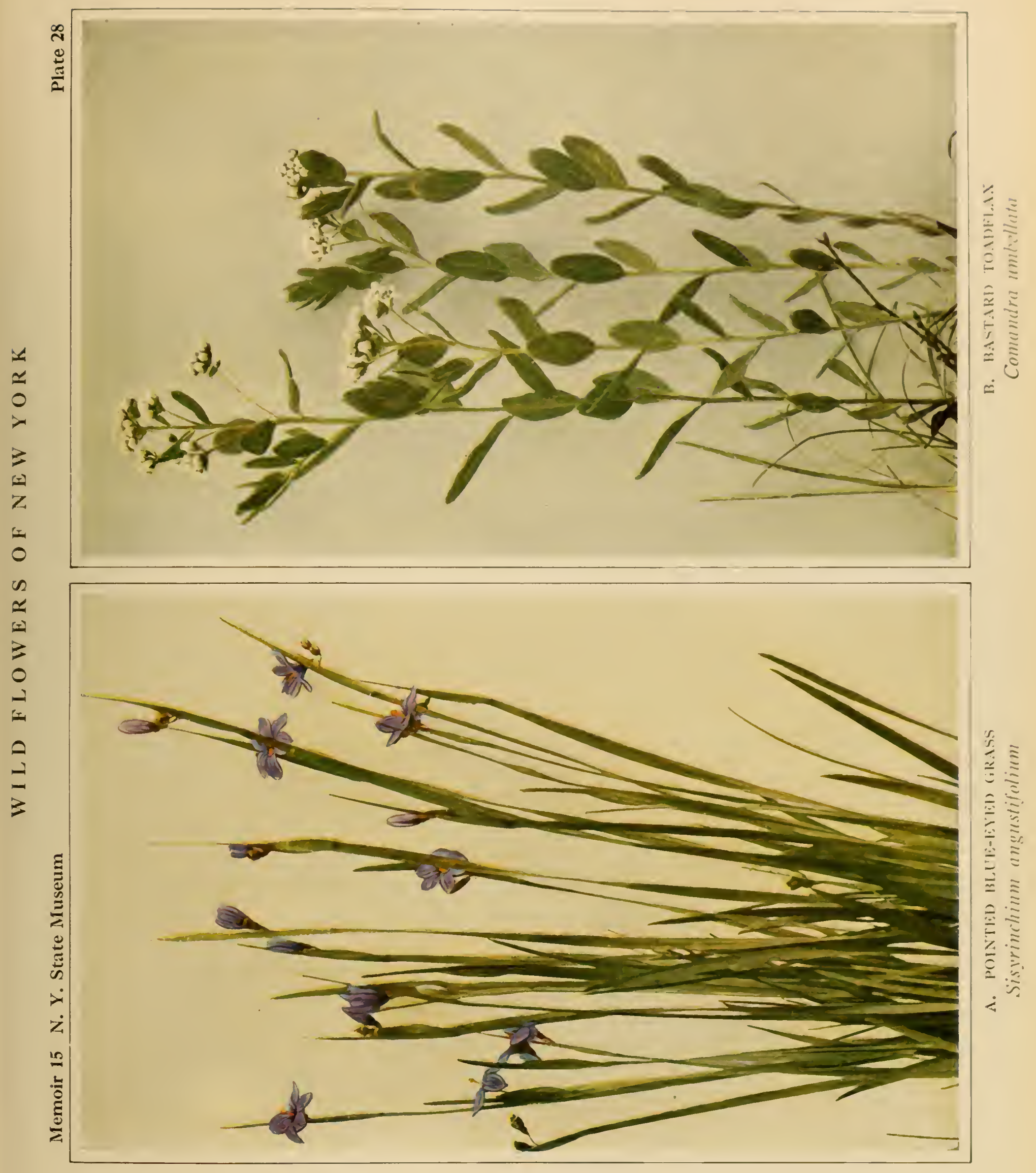


so, usually larger, often spurred. Stamens variously united with the style into an unsymmetrical column, usually one anther, sonetimes two, each two-celled; the pollen in two to eight pear-shaped, usually stalked masses (pollinia), united by elastic threads, the masses waxy or powdery and attached at the base to a viscid disc (gland). Style often terminating in a beak (rostellum) at the base of the anther or between its sacs. Stigma a viscid surface, facing the lip beneath the rostellum, or the cavity between the anther sacs (clinandrium). Ovary inferior, usually long and sometimes twisted, three-angled, one-celled. Seeds very numerous and minute, usually spindle shaped.

\section{Small White Lady's-slipper \\ Cypripedium candidum Willdenow \\ Plate 29}

This is one of the rarer Lady's-slippers of the east, with rather stiffly erect stems 6 to 12 inches high. Leaves three to five, elliptic or lanceolate, pointed, 3 to 5 inches long, two-thirds to $1 \frac{1}{2}$ inches wide; flowers solitary or very rarely two on a stem; sepals lanceolate, as long or longer than the lip, greenish, spotted with purple; petals somewhat longer and narrower than the sepals, wavy-twisted, greenish; lip white, striped with purple or magenta inside, about three-fourths of an inch long.

In marly bogs and low meadows, sometimes in sphagnum bogs, New York and New Jersey to Kentucky, Minnesota, Missouri and Nebraska. Flowering in Jume and July.

\section{Showy Lady's-slipper \\ Cypripedium reginue Walter \\ Plate 30}

The largest and most showy of our native orchids, with a stout, villoushirsute stem, I to 3 feet high, leafy to the top. Leaves large, 3 to 8 inches long, I to 4 inches wide, elliptic in shape, acute. Flowers I to 3 ; sepals round-ovate, white, the lateral ones united for their entire length; petals somewhat narrower than the sepals, white, lip much inflated, I to 2 inches long, white, variegated with crimson and white stripes. 
In swamps and open wet woods, Newfoundland to Ontario, Minnesota and Georgia. Flowering in June and July, more rarely in August in the far north. Known also as IThip-poor-will's Shoe.

It is doubtful if any wild flower surpasses this in beauty. It has been gathered so extensively for its flowers in some localities that it has become rather rare. It is one of the plants that above all others needs protection in the way of education that will lead lovers of wild flowers to admire its beauty where it grows, and to use caution in picking.

\section{Yellow or Downy Lady's-slipper \\ Cypripedium pubescens Willdenow \\ Plate 3I}

Stems tall and leafy, I $\frac{1}{2}$ to $2 \frac{1}{2}$ feet high; leaves oval or elliptic 3 to 6 inches long, I $\frac{1}{2}$ to 3 inches wide, pointed; sepals ovate-lanceolate, usually longer than the lip, yellowish or greenish yellow and striped with purple, petals narrower, usually twisted and elongated; lip much inflated, subglobose, I to 2 inches long, pale yellow to bright yellow and sometimes with purple lines, a tuft of white, jointed hairs inside at the top; sterile stamen triangular, the thick, somewhat triangular stigma incurved.

In rich woods and thickets, Nova Scotia to Ontario and Minnesota, Alabama and Nebraska. This species is usually regarded as a form of Cy pripedium parvif 1 or u m Salisbury, which has a small, laterally compressed lip one-half to three-fourths of an inch long. Since numerous intermediate forms occur it is probable that they represent forms of a single variable species.

\section{Ram's-head Lady's-slipper}

Criosanthes arietina (R. Brown) House

(Cypripedium arietinum $\mathrm{R}$. Brown)

Plate 32b and Figure V

Stems 6 to 12 inches high, with three or four elliptic or lanceolate leaves 2 to 4 inches long, one-third to 3 inches wide, one-flowered; sepals 
W I L D F L O WERS OF NEW YORK

Memoir 15 N. Y. State Museum

Plate 29

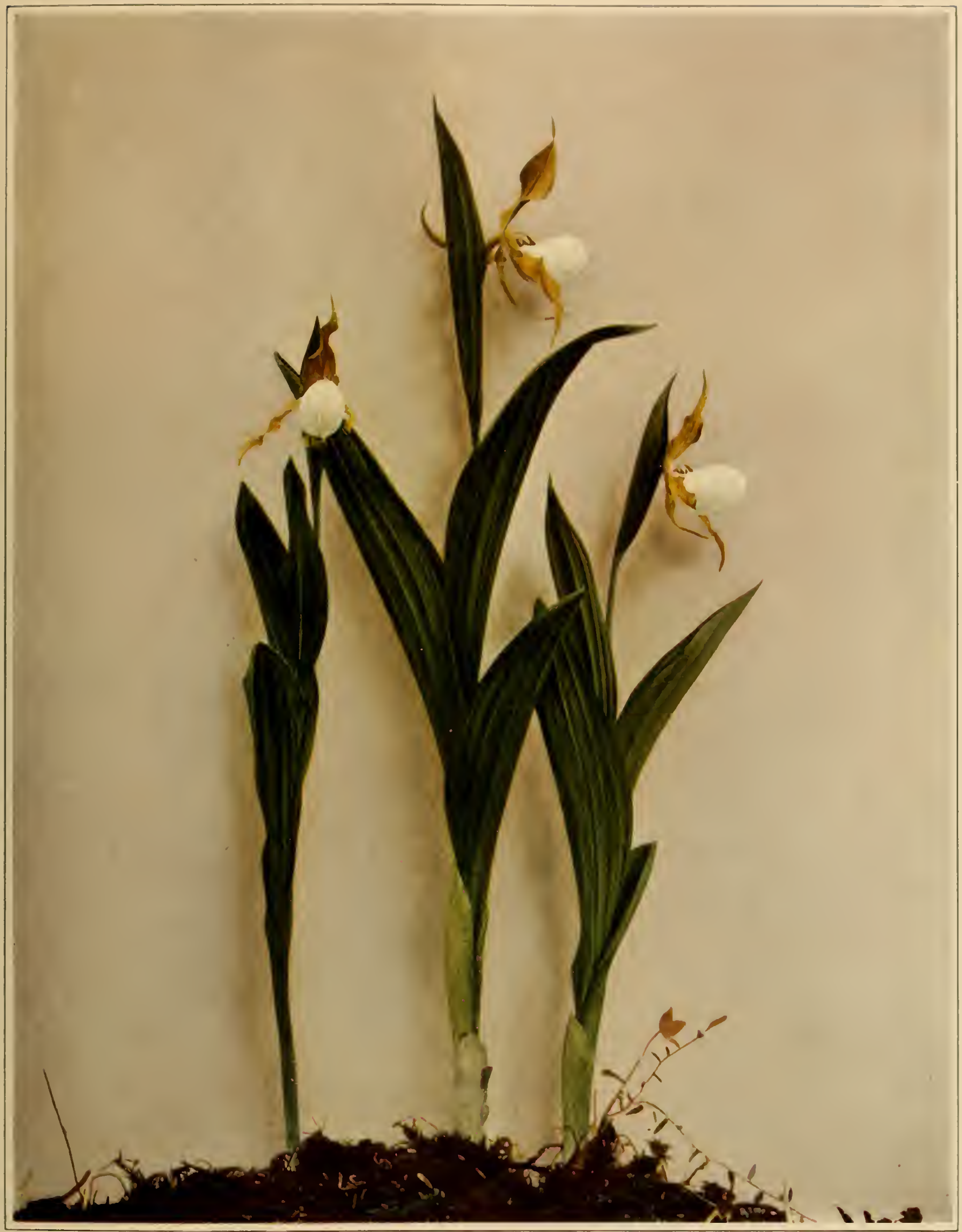

SMALL WHITE LADY'S-SLIPPER

Cypripedium candidum 


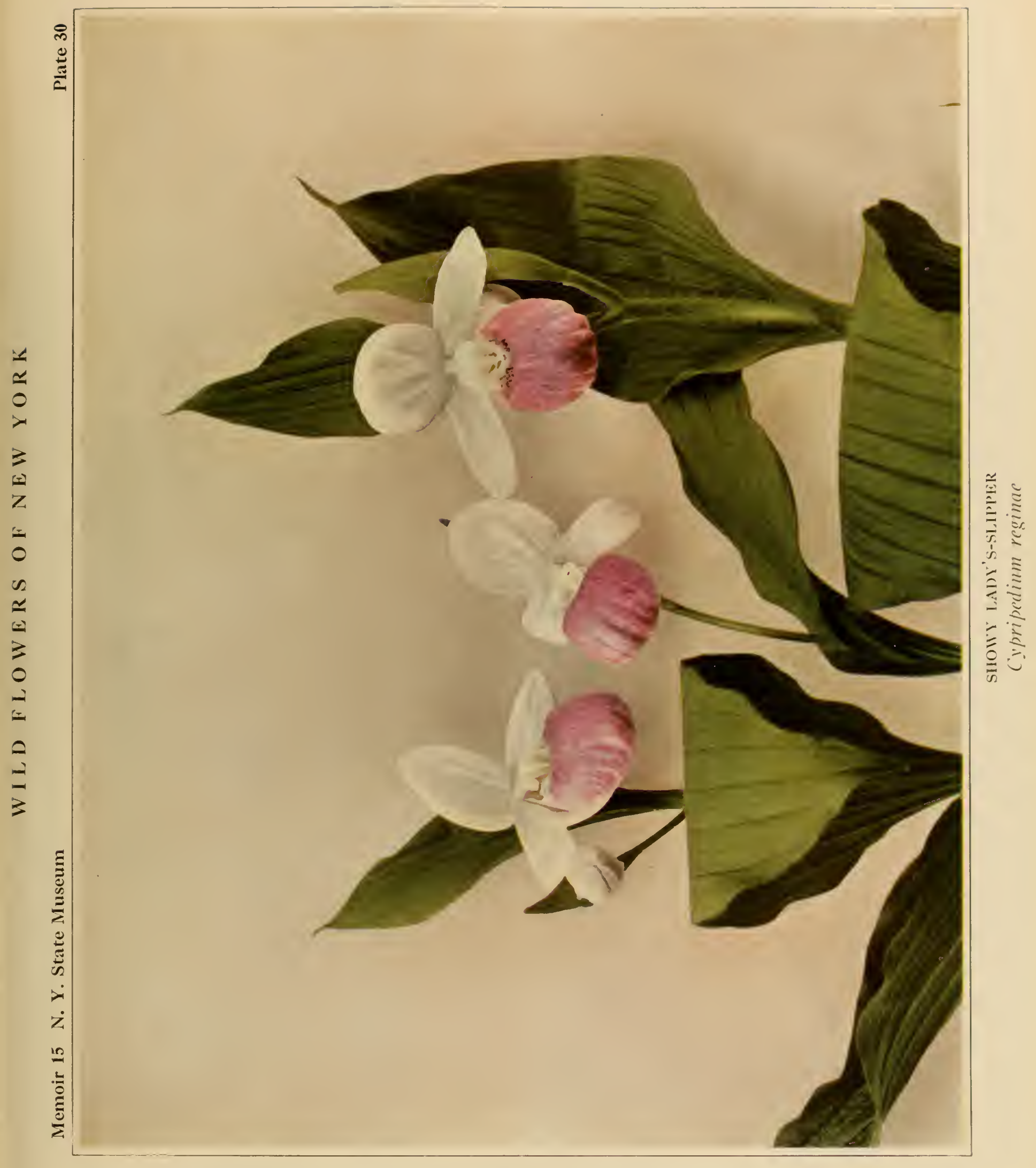





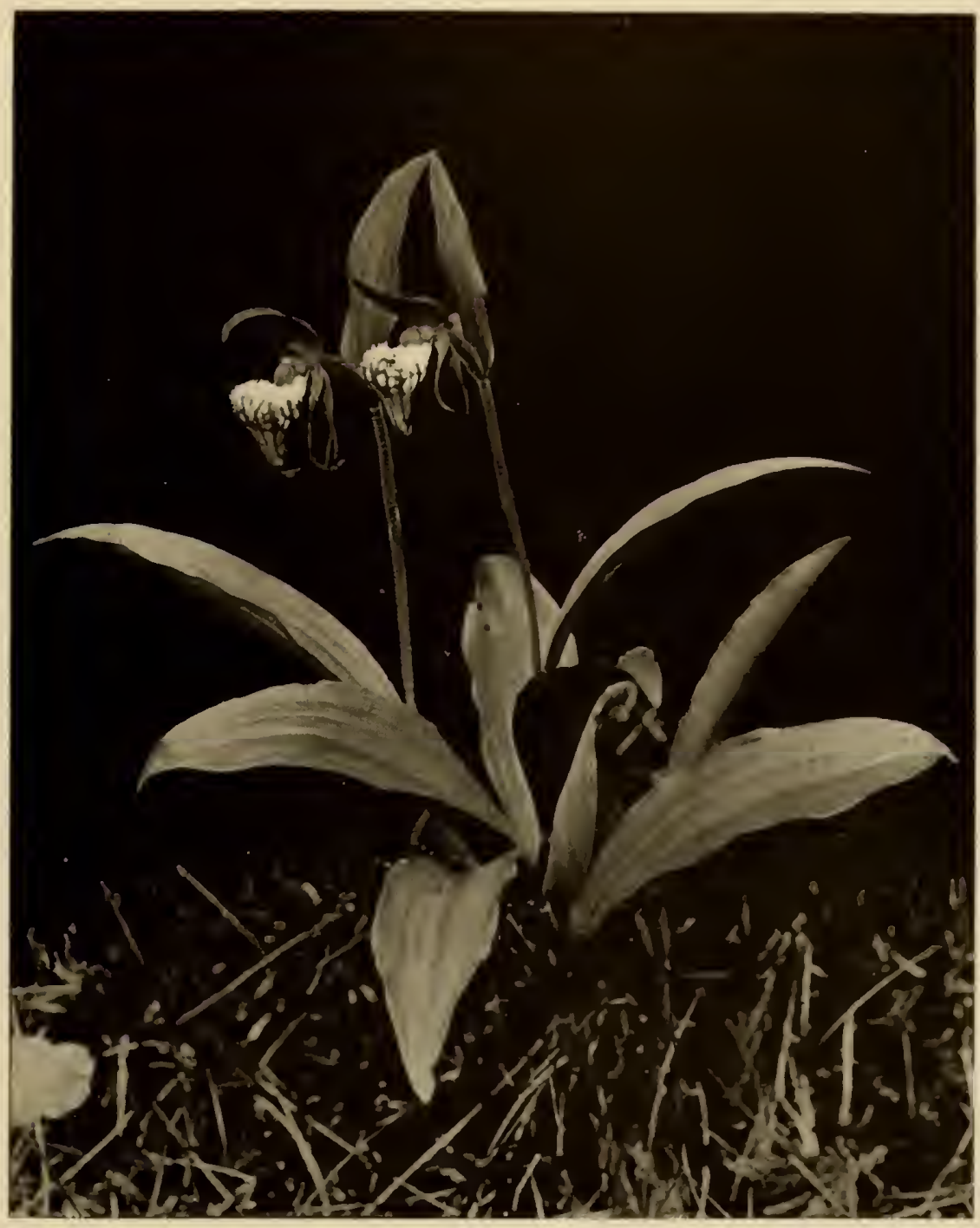

Figure $V$

(Photograph by G. A. Bailey)

Ram's-head Lady's-slipper

(Criosanthes arietina (R. Brown) House) 
separate, lanceolate, one-half to seven-eighths of an inch long, longer than the lip; petals linear, greenish brown, about as long as the sepals; lip onehalf to three-fourths of an inch long, red and white, veiny, prolonged at the apex into a long blunt spur, somewhat distorted at the upper end, which gives the plant its eommon name of Ram's-head Lady's-slipper.

A very rare species of cold and damp woods from Quebec to Manitoba, Massachusetts, New York and Minnesota. It has been collected but a few times in the northern counties of this State. The eolored illustration is made from a photograph taken in southern Herkimer eounty by $\mathrm{Mr}$ Edward H. Eames of Buffalo and the accompanying halftone from a photograph by Mr G. A. Bailey of Geneseo.

\section{Moccasin Flower; Stemless Lady's-slipper}

Fissipes acaulis (Aiton) Small

(Cypripedium acaule Aiton)

- $\quad$ Plate 33 and Figure VI

A short-stemmed plant with only two large, basal, elliptic leaves, 6 to 8 inches long and 2 to 3 inches wide, thick and dark green. The single fragrant flower borne on a scape 6 to I 5 inches high; sepals greenish purple, spreading, $I \frac{1}{2}$ to 2 inches long, lanceolate, the two lateral ones united; petals narrower and somewhat longer than the sepals; lip a large, drooping, inflated sac with a closed fissure down its whole length in front, $I \frac{1}{2}$ to $2 \frac{1}{4}$ inches long, somewhat obovoid, .pink with darker veins, rarely white, the upper part of the interior surface of the lip crested with long, white hairs. Fruit an ascending eapsule, pointed at each end.

In sandy or rocky woods, Newfoundland to Manitoba, south to North Carolina, Tennessee and Minnesota. One of the few conspieuous wild flowers that appears to be equally at home in the pine lands of the northern coastal plain and the rocky woods of the central and northern part of the State. On Long Island it sometimes blooms in May but in the north it usually blooms in June. 
W I L, D F L, O WERS O F NEW YOR K

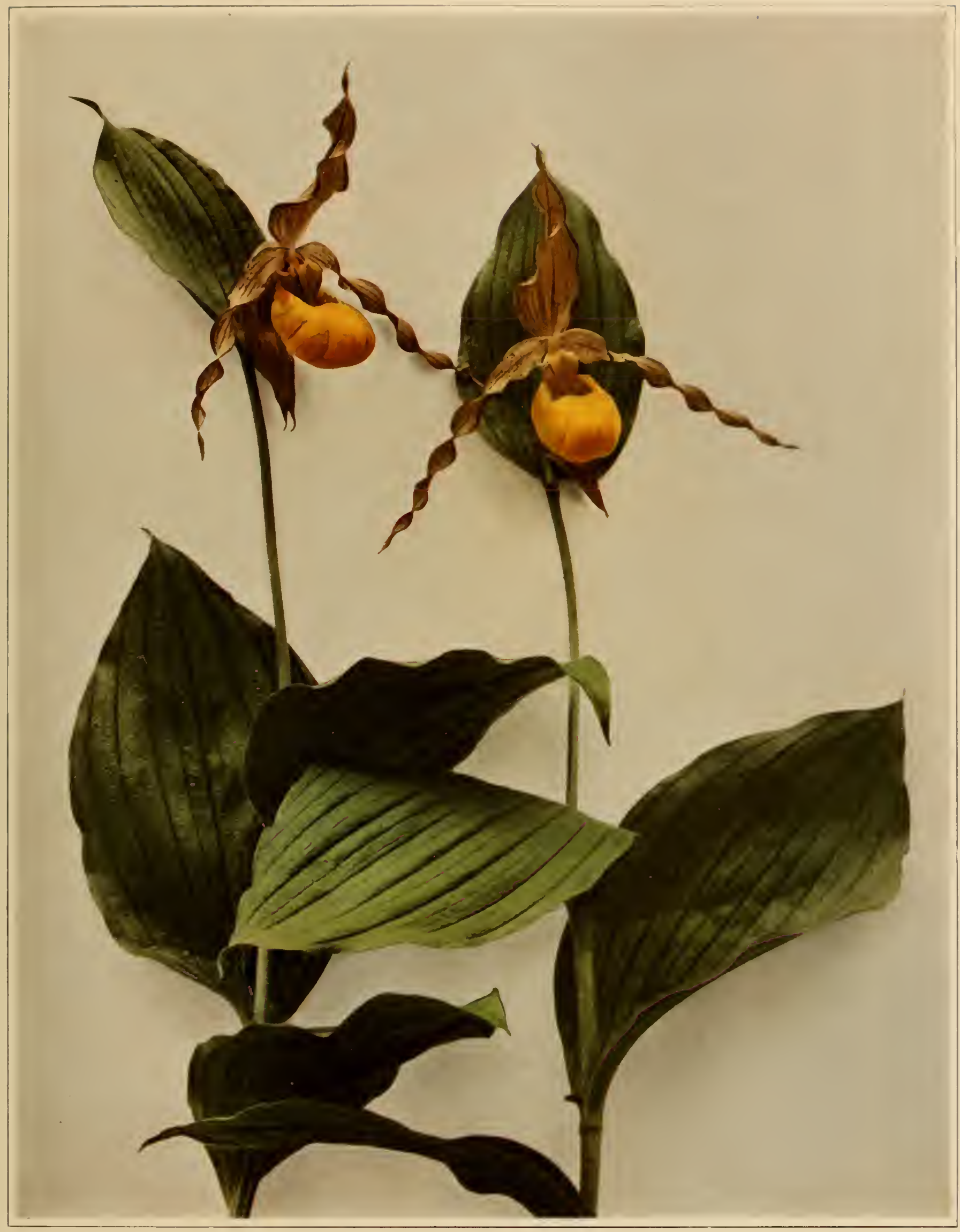

YELLOW OR DOWNY LADY'S-SLIPPER

Cypripedium pubescens 



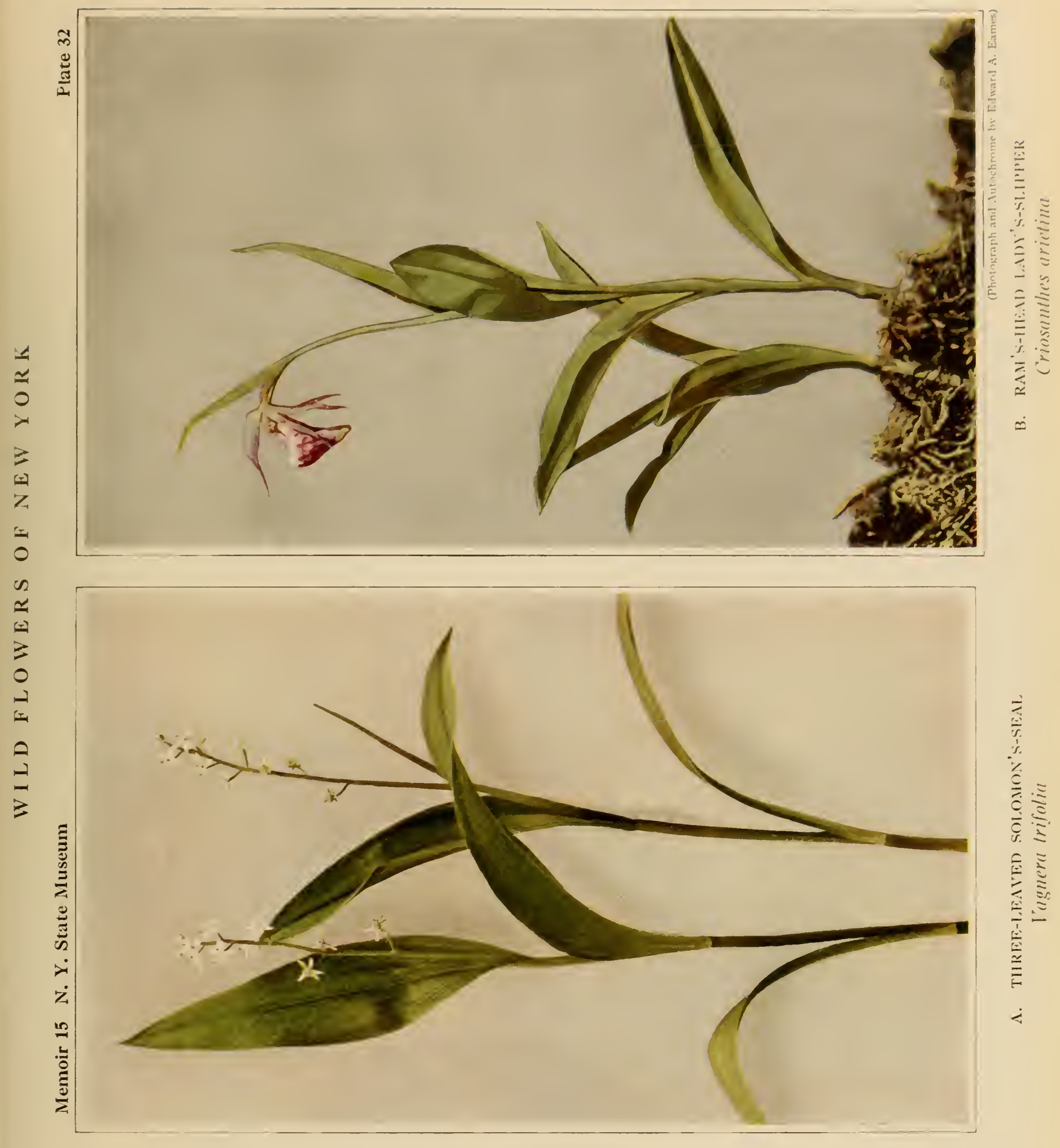





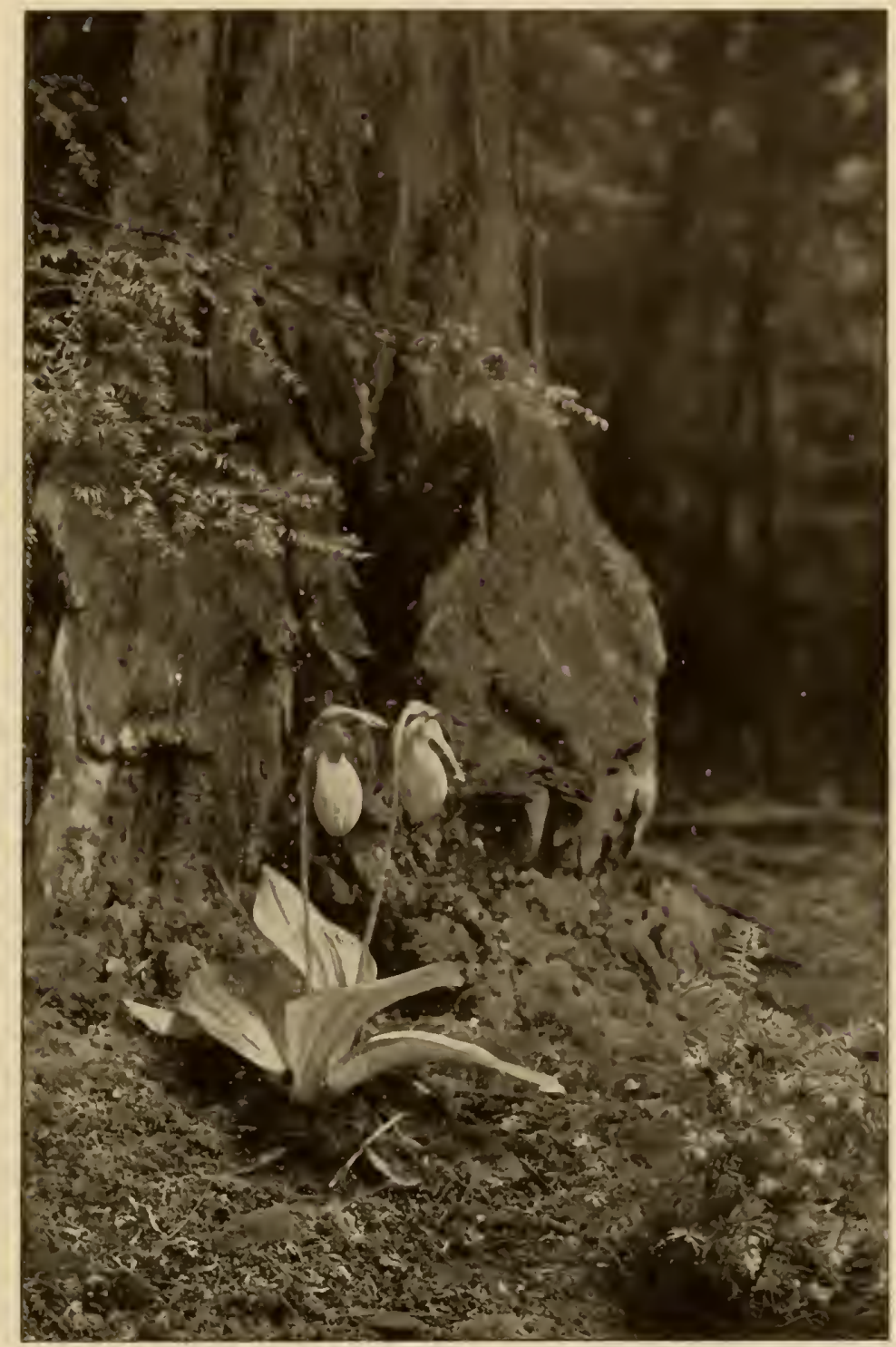

Figure VI

(Photograph by E. A. Eames)

Moccasin Flower; Stemless Lady's-slipper (Fissipes acaulis (Aiton) Small) 


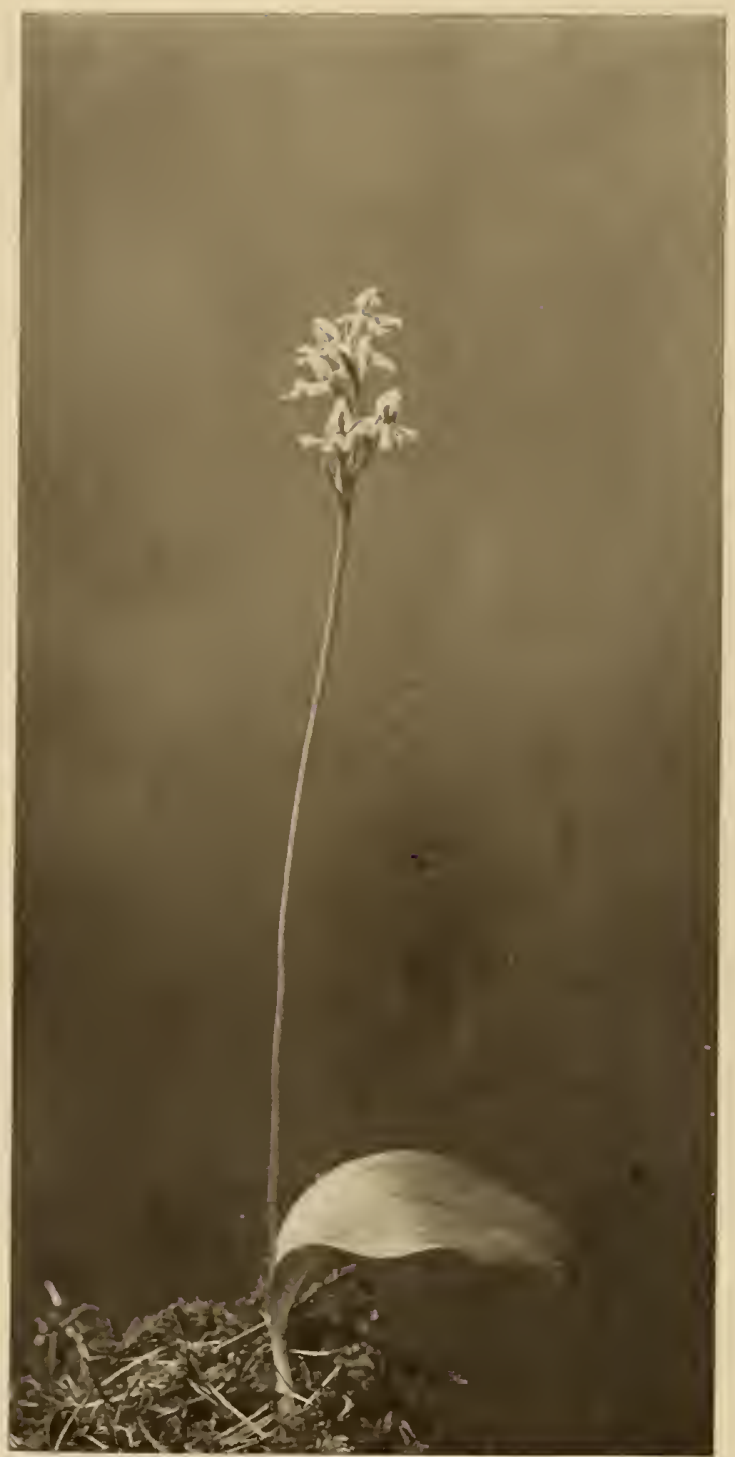

Figure VII

(Photograph by O. O. Ny:lander)

Small Round-leaved Orchis

(Orchis rotundifolia Pursh)

\section{Small Round-leaved Orchis}

Orchis rotundifolia Pursh

Figure VII

Along with the Calypso, this small orchis shares the distinction of being the rarest wild flower of the State. Its slender stem rises to a height of 6 to 10 inches and bears near the base a single oval or orbicular leaf, I to 3 inches long, with one or two scales sheathing the stem below the leaf. Flowers in a short terminal spike, usually five to ten in number, each flower subtended by a small green bract. Sepals and petals oval, rose-colored, the lateral sepals spreading and usually slightly shorter, but sometimes longer than the petals; lip white, beautifully spotted with purple, longer than the petals, three-lobed, the middle lobe larger, dilated and two-lobed or notched at the apex; spur slender, shorter than the lip or barely equalling it in length.

In damp, mossy woods, Greenland to the Rocky mountains, Maine, New York and Wisconsin. The records of its occurrence in this State are very few. It has been found in Oneida, Herkimer and Lewis counties, but not in recent 


\section{WIL, FI, OWERS OF NEW YORK}

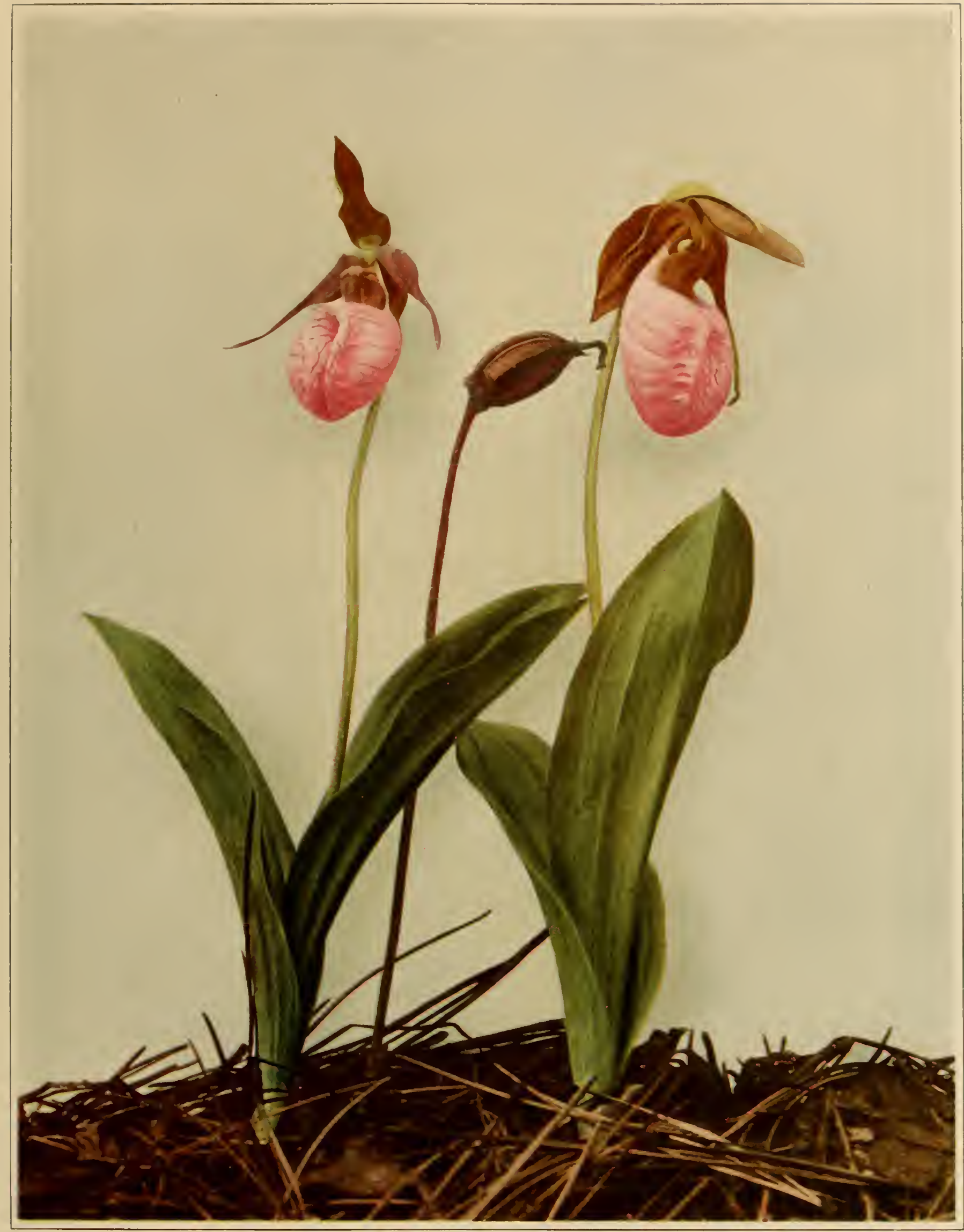

MOCCASIN FLOWER; STEMLESS LADY'S-SLIPPER Fissipes acaulis 
W I L D F L OWERS OF NEW YORK

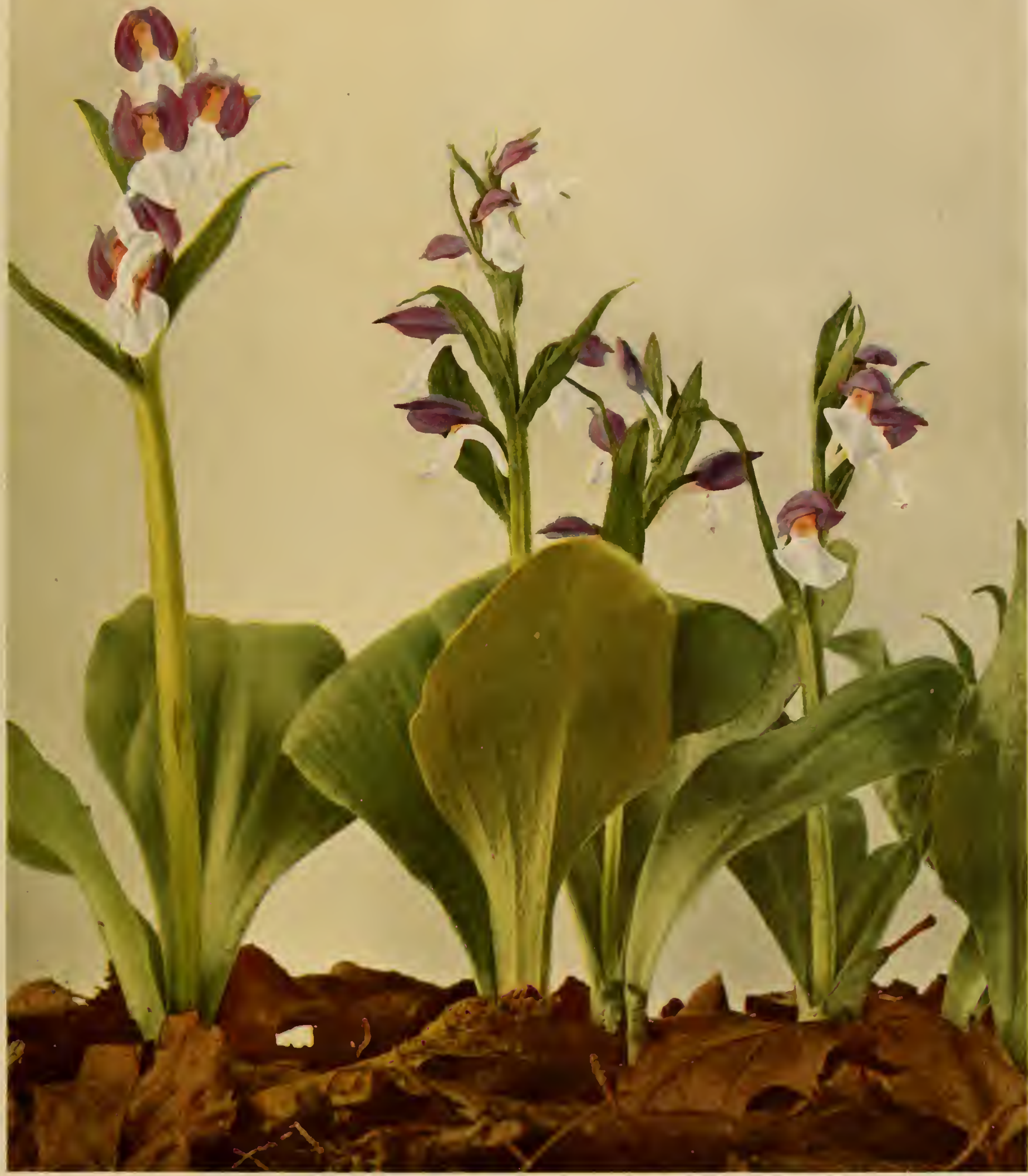

SHOWY ORCHIS

Galeorchis spectabilis 

years. Our illustration is from a photograph by ()laf $O$. Nylander, taken in Maine.

\author{
Showy Orchis \\ Galeorchis spectabilis (Linnacus) Rydberg \\ (Orchis spectabilis Linnacus) \\ Plate 34
}

Entire plant rather fleshy; stems short, five-angled, + to 12 inches high from a short rootstock provided with numerous fleshy roots. Leaves two, near the base of the stem, obovate, dark glossy green, + to 8 inches long and 2 to + inches wide, clammy to the touch; the threc to ten flowers in a terminal spike, each flower about I inch long, violet-purple mixed with lighter purple and white, the subtending bracts sheathing the ovaries; sepals united above forming a hood; petals connivent under the scpals and more or less attached to them; lip whitish, wavy, produced into an obtuse spur, about as long as the petals; column short, scarcely extcnding above the base of the lip, violet on the back.

In rich woods, New Brunswick to Ontario, Dakota, Georgia, Kentucky, Missouri and Nebraska. Flowering in May and June or as late as July in the extreme northern part of its range.

\title{
Tall Leafy Green Orchis
}

\section{Limnorchis hyperborea (Linnaeus) Rydberg Plate 37a}

A rather inconspicuous orchis with small flowers, the stem usually stout, Io inches to 3 feet high. Leaves lanceolate, pointed, 3 to Io inches long, one-half to $\mathbf{I} \frac{3}{4}$ inches wide. Flowers numerous in a narrow terminal spike, small, greenish or greenish yellow; sepals and petals free and spreading, ovate, blunt; lip entire, lanceolate, blunt, about one-fourth of an inch long; spur about as long as the lip, blunt, slightly incurved or often thickened at the end (clavate).

In bogs, wet woods and swamps, Greenland to Alaska, New Jersey, Colorado and Oregon. Flowering in May and June or later in cold bogs and woods of the north. 
The Tall White Bog Orchis (Limnorchis dilatata (Pursh) Rydberg) is usually more slender, with small white flowers; the ovate or lanceolate sepals nearly one-fourth of an inch long; petals lanceolate, pointed; lip entire, dilated or obtusely three-lobed at the base, blunt at the apex, about as long as the blunt and incurved spur. In similar situations, but southward only to Maine and New York.

\section{Large Round-leaved Orchis \\ Lysias orbiculata (Pursh) Rydberg \\ Plate 35 and Figure VIII}

Flowering scape rather stout, I to 2 feet high, with a few inconspicuous bracts, and at the base, spreading flat on the ground, two large orbicular or orbicular-elliptical, dark-green, shining leaves, silvery beneath, 4 to 8 inches in diameter. Flowers forming a loose raceme, each flower on a pedicel about one-half of an inch long, erect in fruit, greenish white; upper sepal short and rounded; lateral sepals spreading, falcate-ovate and blunt; one-third to one-half of an inch long; petals smaller and narrower; lip entire, oblong-linear, blunt, white, about one-half of an inch long; spur longer than the ovary, about $I \frac{1}{2}$ to 2 inches long.

In rich woods, Newfoundland to Minnesota, south to Pennsylvania. Flowering in June and July.

Plate 35 shows the flowers after they have begun to fade. The detail of the flowers is shown better in figure VIII. Oakes Ames regards the looseflowered form with long spurs as $\mathrm{Habenaria}$ macrophylla Goldie, and restricts $\mathrm{L} y \mathrm{sias}$ or bic ulat a to the form with dense inflorescence and spurs $\mathbf{I}$ to $\mathbf{I} \frac{\mathbf{1}}{4}$ inches long.

\section{Hooker's Orchis}

\section{Lysias hookeriana (A. Gray) Rydberg Plate 36}

Stem or flowering scape 8 to ${ }_{5}$ inches high, stout, smooth, without bracts, but with two fleshy, shining, dark-green, oval-orbicular or obovate, spreading or ascending leaves at the base, 3 to 6 inches long, rarely flat on the ground. Flowers in a rather loose raceme, $t$ to 8 inches long, yellowish 
W I L D FLOWERS OF NEW YORK

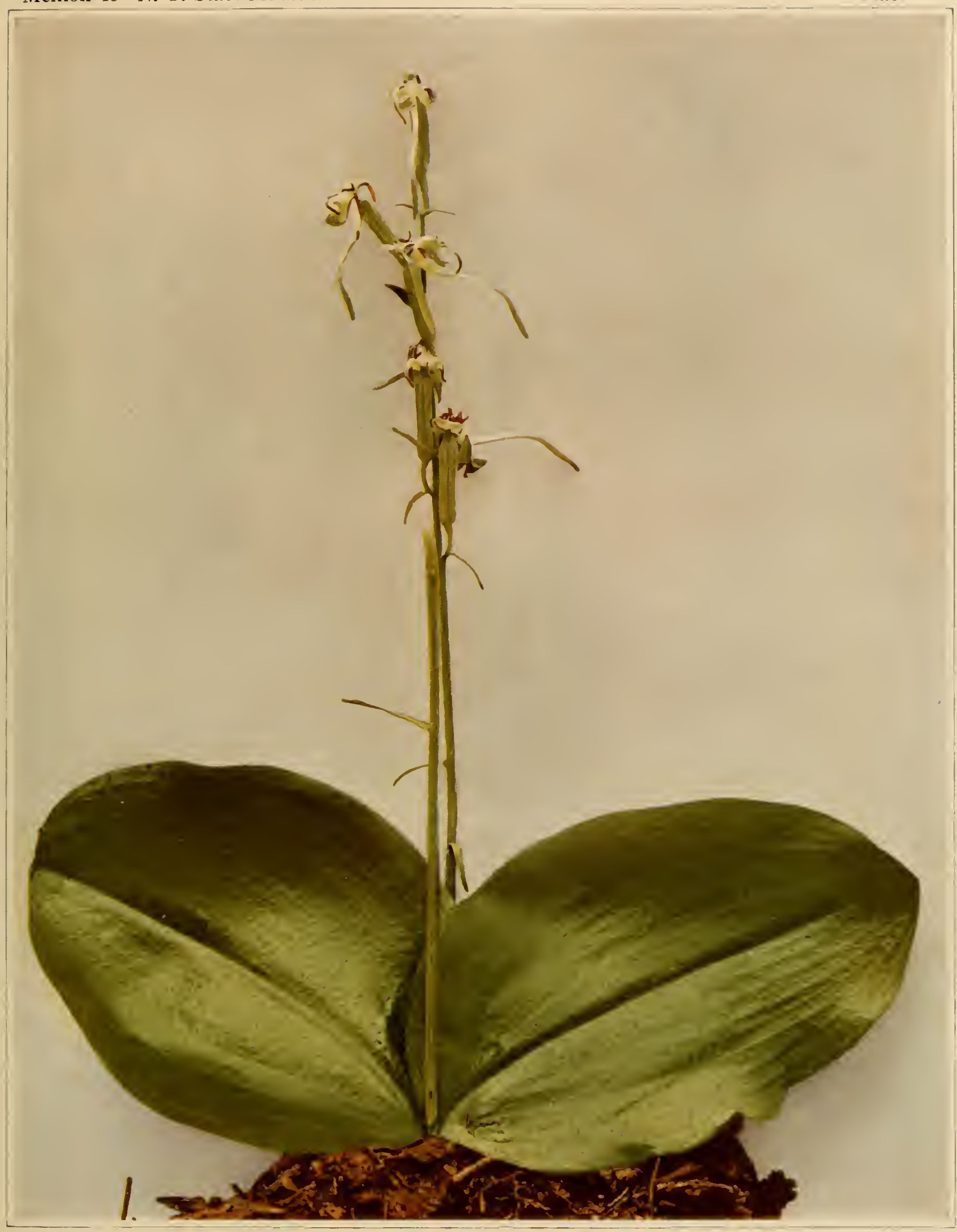

LARGE ROUND-LEAVED ORCHIS Lysias orbiculata 



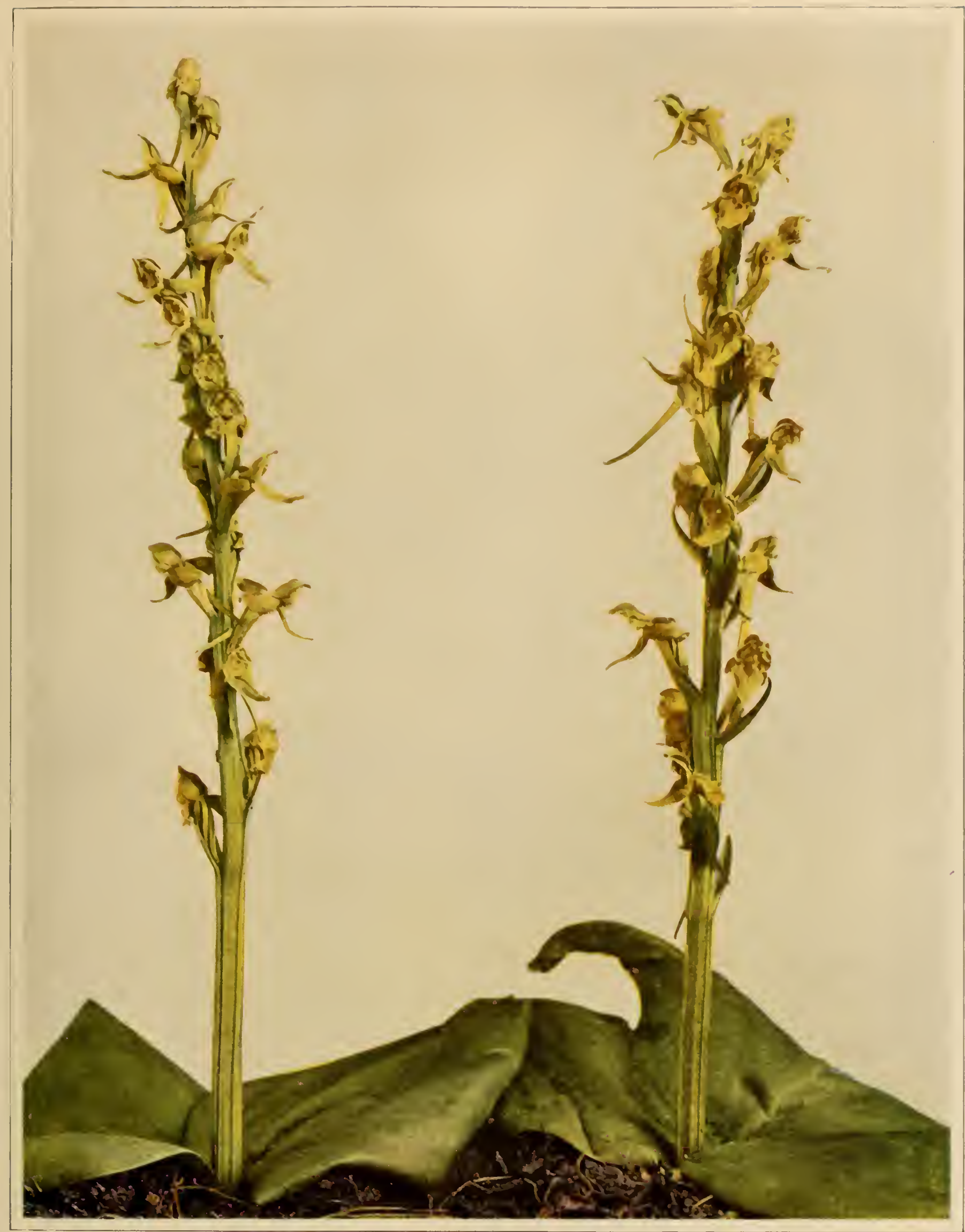

HOOKER'S ORCHIS

Lysias hookeriana 



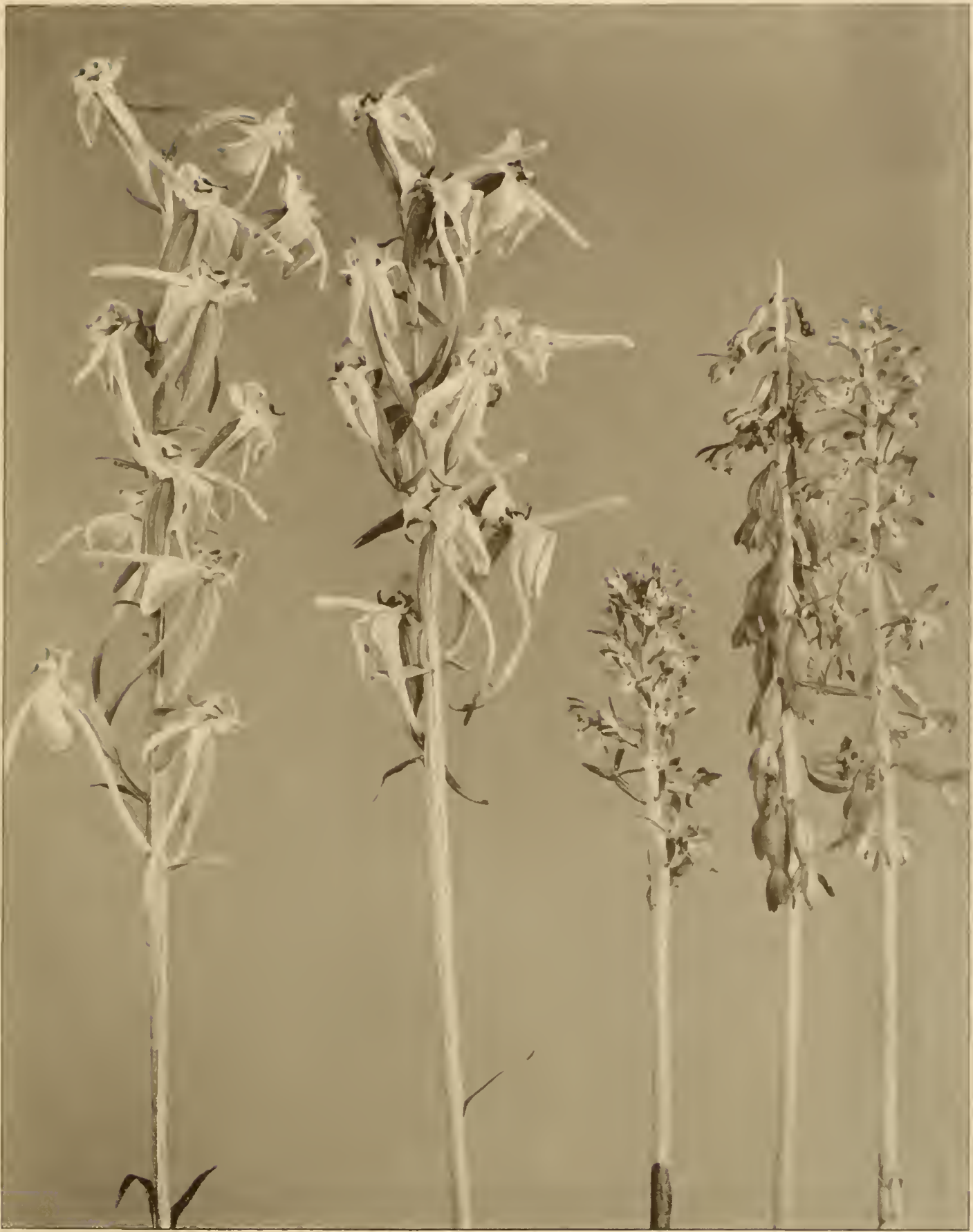

Figure VIII

Flowers of Large Round-leaved Orchis (L y s i a s or b i c u l a t a (Pursh) Rydberg), left; and Large Coralroot (Cora 11 orrhiza maculat a Rafinesque) at right 
green; each flower about two-thirds of an inch long; lateral sepals greenish, lanceolate and spreading, about one-third of an inch long; petals narrowly linear; lip lincar-lanceolate, pointed, one-third to nearly one-half of an inch long; spur slender, pointed, two-thirds of an inch or more long, as long or longer than the ovary.

In cool, moist woods, Nova Scotia to Minnesota, south to New Jersey, Pennsylvania and Iowa. Flowering in June and July or later, in the north.

\section{Yellow-fringed Orchis}

\section{Blephariglottis ciliaris (Linnaeus) Rydberg}

Plate $3 \% \mathrm{~b}$

Stem slender, I to $2 \frac{1}{2}$ feet high. Leaves lanceolate, pointed, + to 8 inches long, one-half to $\mathrm{I} \frac{1}{2}$ inches wide, the upper ones much smaller. Flowers orange or yellow, large and showy in a terminal, many-flowered spike, 3 to 6 inches long; sepals orbicular or broadly ovate, oblique at the base, the lateral ones mostly reflexed; petals much smaller, oblong or cuneate, usually toothed; lip oblong, about one-half of an inch long, copiously fringed more than halfway to the middle; spur I to $\mathbf{I} \frac{1}{2}$ inches long and very slender.

In meadows and open places in woods, especially in sandy regions, Vermont and Ontario to Michigan, Missouri, Florida and Texas. In New York State it is rare and local north of the coastal plain, occurring on the Schenectady plains and several other places, especially on the Ontario lowlands, from Rome west to Lake Erie.

\section{White-fringed Orchis}

Blephariglottis blephariglottis (Willdenow) Rydberg

Plate 38

A plant similar to the Yellow-fringed Orchis, but with a densely or rather dense, many-flowered spike of pure-white flowers, the petals toothed or somewhat fringed at the apex, rarely entire, the lip copiously or sparingly fringed. 
W I L, I F L, OWERS OF NEW YORK

Memoir 15 N. Y. State Museum

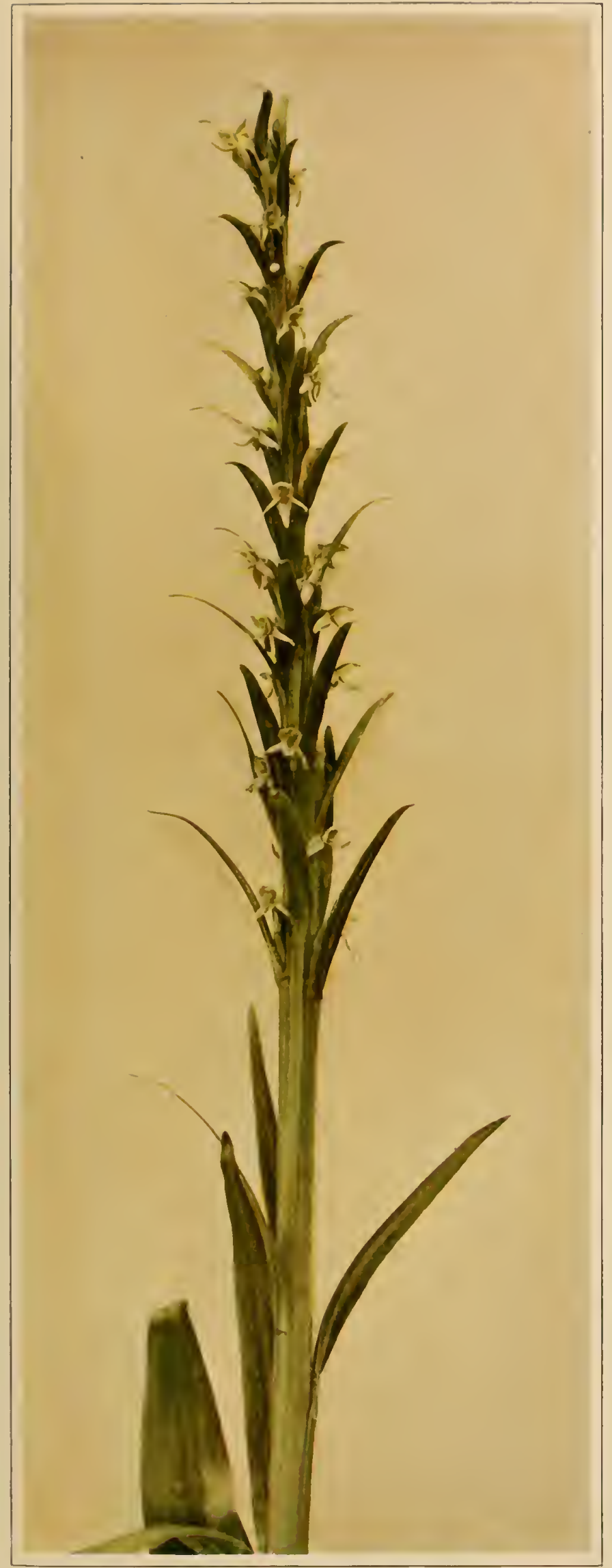

A. TALL LEAFY GREEN ORCHIS Limnorchis hyperborea

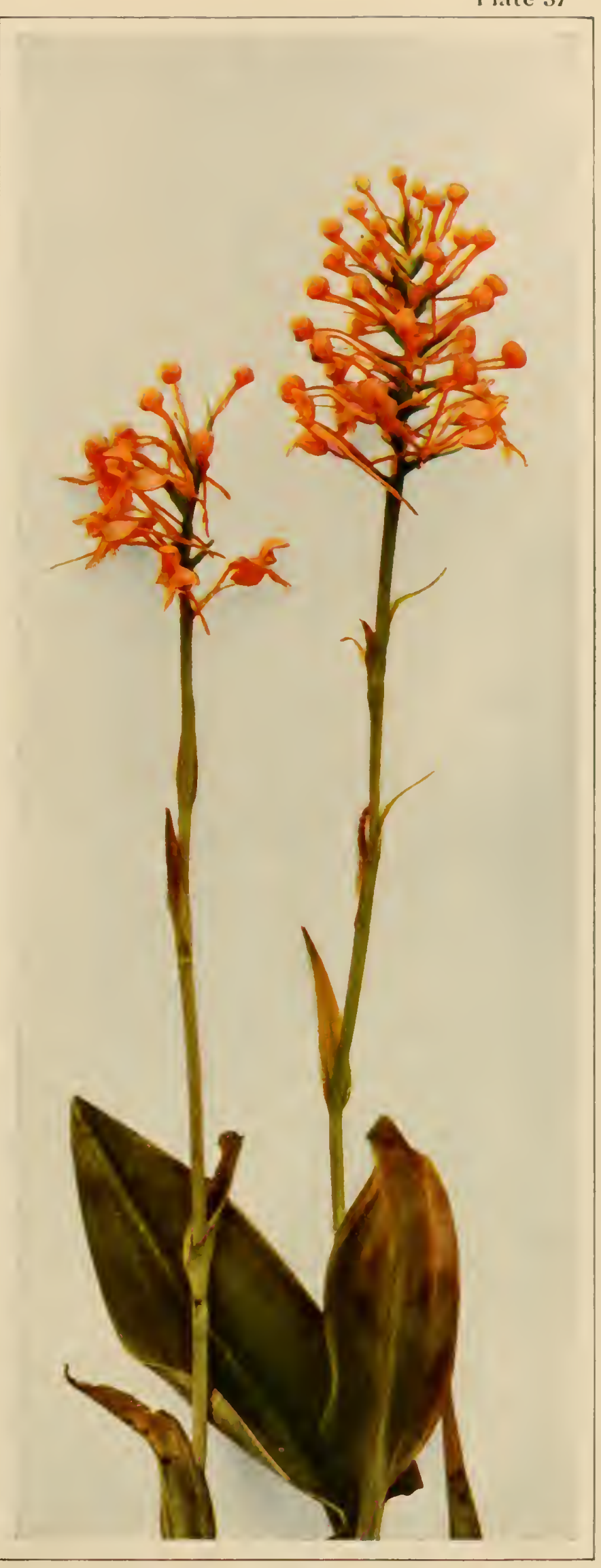

B. YELLOW-FRINGED ORCHIS Blephariglottis ciliaris 
WII, D F L O WERS OF NEW YORK

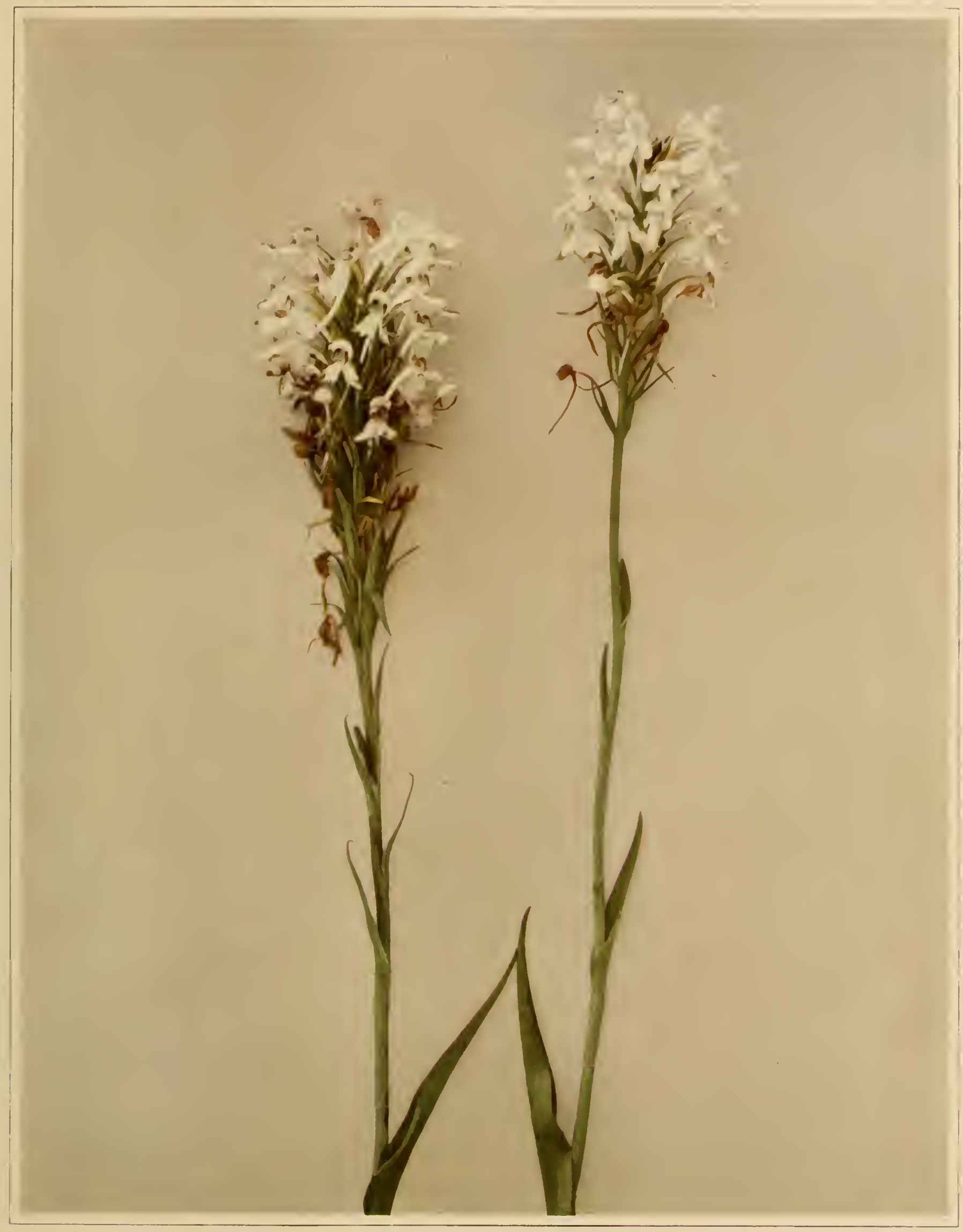

WHITE-FRINGED ORCHIS

Blephariglottis blephariglottis 

In bogs and swamps, Newfoundland to Minnesota, Florida and Mississippi. When growing with the Ycllow-fringed Orchis, it blooms a few lays earlier. It is found in nearly all the sphagnum bogs of northern Ncw York and is not uncommon in moist depressions of the sandy coastal plain. Flowering from late June until carly August in northern New York.

The Prairie Whitc-fringed Orchis (Blcphariglottis leucophaca (Nuttall) Farwell) has larger, whitc, fragrant flowers, sometimes tinged with green; the lip thrce-parted, the segments broadly wedge-shaped and copiously fringed. Most abundant westward but occurring castward to New England.

\section{Ragged or Green-fringed Orchis Blephariglottis lacera (Michaux) Farwell \\ Plate $39 \mathrm{~b}$}

Stcms varying from slender and I foot or less high to stout and 2 to 3 feet high. Leaves firm, lanceolate, 3 to 8 inches long, two-thirds to $1 \frac{3}{4}$ inches wide, decreasing in size upward. Flowers greenish yellow or greenish, in a loose spike, 2 to several inches long; petals lincar, blunt, about as long as the sepals; lip three-parted, the segments narrow, dceply fringed or lacerate with a few threads about one-half of an inch long; spur one-half to three-fourths of an inch long. curved and thickened at the cnd, shorter than the ovary.

Common in swamps, low meadows and wet woods, Newfoundland to Minnesota, south to Georgia and Arkansas. Flowcring in June and July. Forms frequently occur in which the fringe of the lip is very short.

\section{Smaller Purple-fringed Orchis \\ Blephariglottis psycodes (Linnaeus) Rydberg \\ Plate $39 \mathrm{a}$}

Stem rather slender, I to 3 fcet high. Leaves oval, clliptic or lanceolate, 3 to Io inches long, two-thirds to 3 inches wide, becoming smaller above, dark green and glossy above. Flowers lilac-purplc or rarely white, fragrant, in a dense, many-flowered terminal raceme, 2 to 8 inches long; petals oblong or oblanceolate, toothed on the upper margin; lip three- 
parted, one-fourth to one-half of an inch broad, the segments fan-shaped and eopiously fringed, the fringe of the middle segment shorter than that of the lateral ones; spur somewhat thickened at the tip, about three-fourths of an inch long, and longer than the ovary.

In meadows, swamps and wet woods, Newfoundland to Minnesota, North Carolina and Tennessee. Flowering in July and August.

The Large or Early Purple-fringed Orehis (Blephariglottis grandiflora (Bigelow) Rydberg) has a large, dense raeeme of lilac or purplish, fragrant flowers, the lower lip, three-parted, the segments broadly fan-shaped and eopiously fringed to about the middle. The flowers average one-third or one-half larger than those of B. psyeodes: otherwise they are very similar and this may be only a large-flowered raee of that species. Growing in similar situations.

\section{Rose Pogonia; Snakemouth Pogonia ophioglossoides (Linnaeus) Ker Plate 40}

A slender plant with fibrous roots and stems 8 to $I_{5}$ inehes high, propagating by runners. Leaves one to three on each stem, one-half to t inches long, lanceolate or ovate, ereet, pointed or rather blunt. Flowers solitary or sometimes in pairs with leaflike bracts, fragrant, pale rosecolored, slightly nodding, I to 2 inches broad; sepals and petals similar, two-thirds to I ineh long; lip spatulate, crested and fringed with white.

In swamps, low meadows and boggy depressions, especially in sandy regions, Newfoundland to Ontario, Florida, Kansas and Texas. Flowering in June and July, and in the north sometimes in flower as late as August.

\section{Whorled Pogonia}

Isotria a'erticillata (Willdenow) Rafinesque

Figure $\mathrm{IX}$

Stems io to 15 inehes high, from long, perennial, horizontal, fleshy rootstoeks, which give rise to new stems by buds. Stems bearing a whorl of five leaves at the summit. Leaves obovate, abruptly pointed at the 


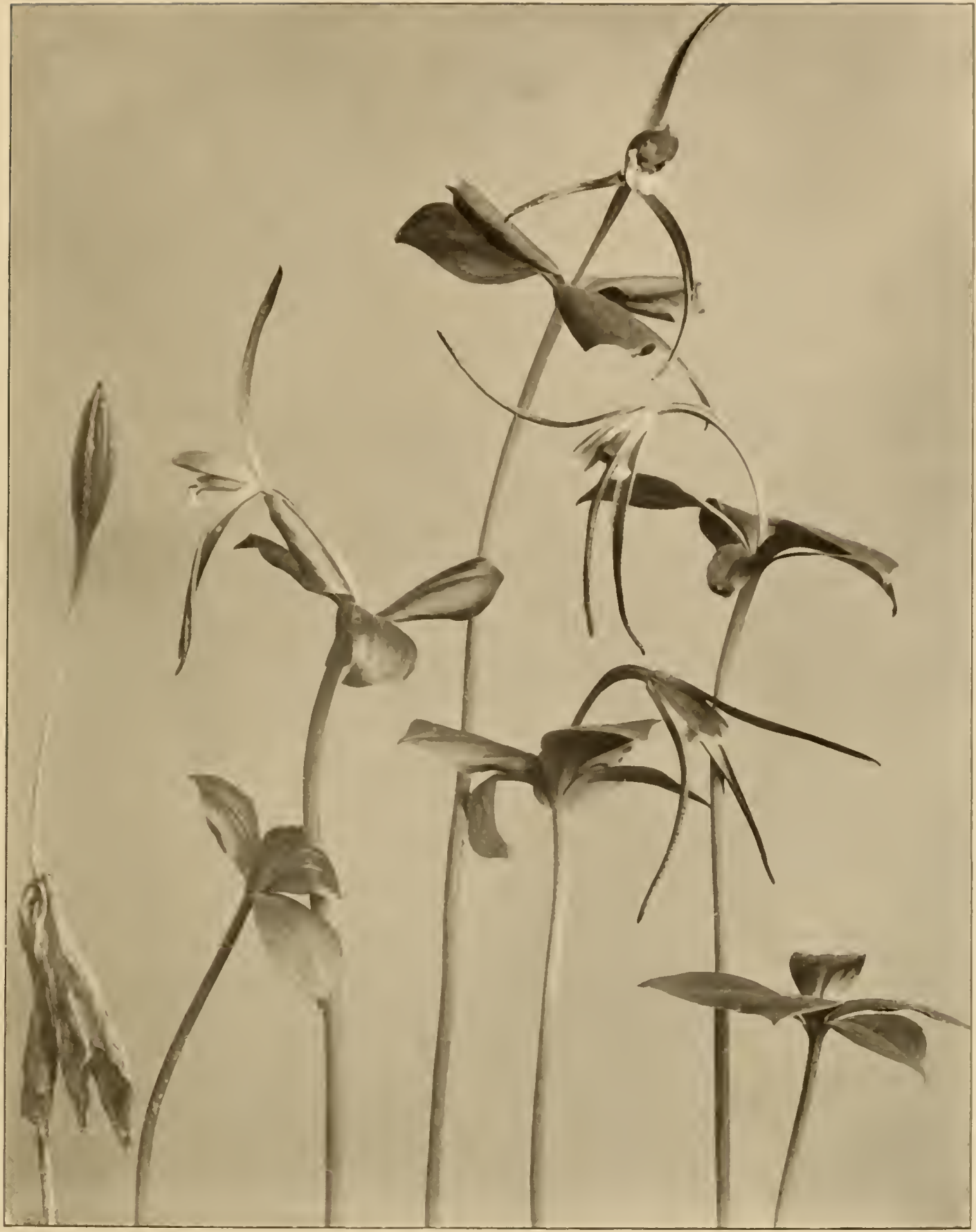

Figure IX

Whorled Pogonia

(I sotria verticillata (Willdenow) Rafinesque) 
apex, sessile, I to + inches long, usually only partially developed at flowering time. Flowers solitary, erect or declined, on a peduncle one-half to twothirds of an inch long; sepals linear, dull reddish purple, spreading, $I \frac{1}{2}$ to 2 inches long and about one-twelfth of an inch wide; petals linear, erect, blunt, light green and arching above the lip, about five-sixths of an inch long; lip three-lobed at the end, middle lobe broadest, white and crenulate on the margin; two lateral lobes of the lip and the lateral margins tinged and veined with bright crimson-purple, most vivid at the apex of the two lateral lobes, crest of the lip green and papillose. Capsule erect, I to $\mathrm{I} \frac{1}{2}$ inches long.

In moist soil of woods and thickets, often around cold sphagnum bogs, Ontario and Massachusetts to Michigan, Indiana and Florida. Flowering in May and June.

\section{Arethusa; Dragon's-mouth; Wild Pink}

\section{Arethusa bulbosa Linnaeus}

A low, scapose, smooth plant, 5 to 10 inches high from a small bulb, stem bearing one to three loose sheathing bracts on the stem and a single linear leaf hidden at first in the upper bract and developing after the flower has faded. The single flower arising at the top of the stem from between a pair of small unequal scales, rose-purple, I to 2 inches high; sepals and petals similar, linear to elliptic in shape, obtuse, connivent, hooded, and arching over the column; lip usually drooping beneath the sepals and petals, the apex broad, variegated with purplish blotches and crested down the face with three hairy ridges, the margin fringed or toothed. Capsule about I inch long, ellipsoid, strongly six-ribbed.

In bogs, low meadows and mossy depressions or moist thickets, Newfoundland to Ontario and Minnesota, South Carolina and Indiana. Flowering in May and June. One of the most dainty and beautiful of our native orchids. 
WIL D F L O WERS OF NEW YORK

Memoir 15 N. Y. State Museum

Plate 39
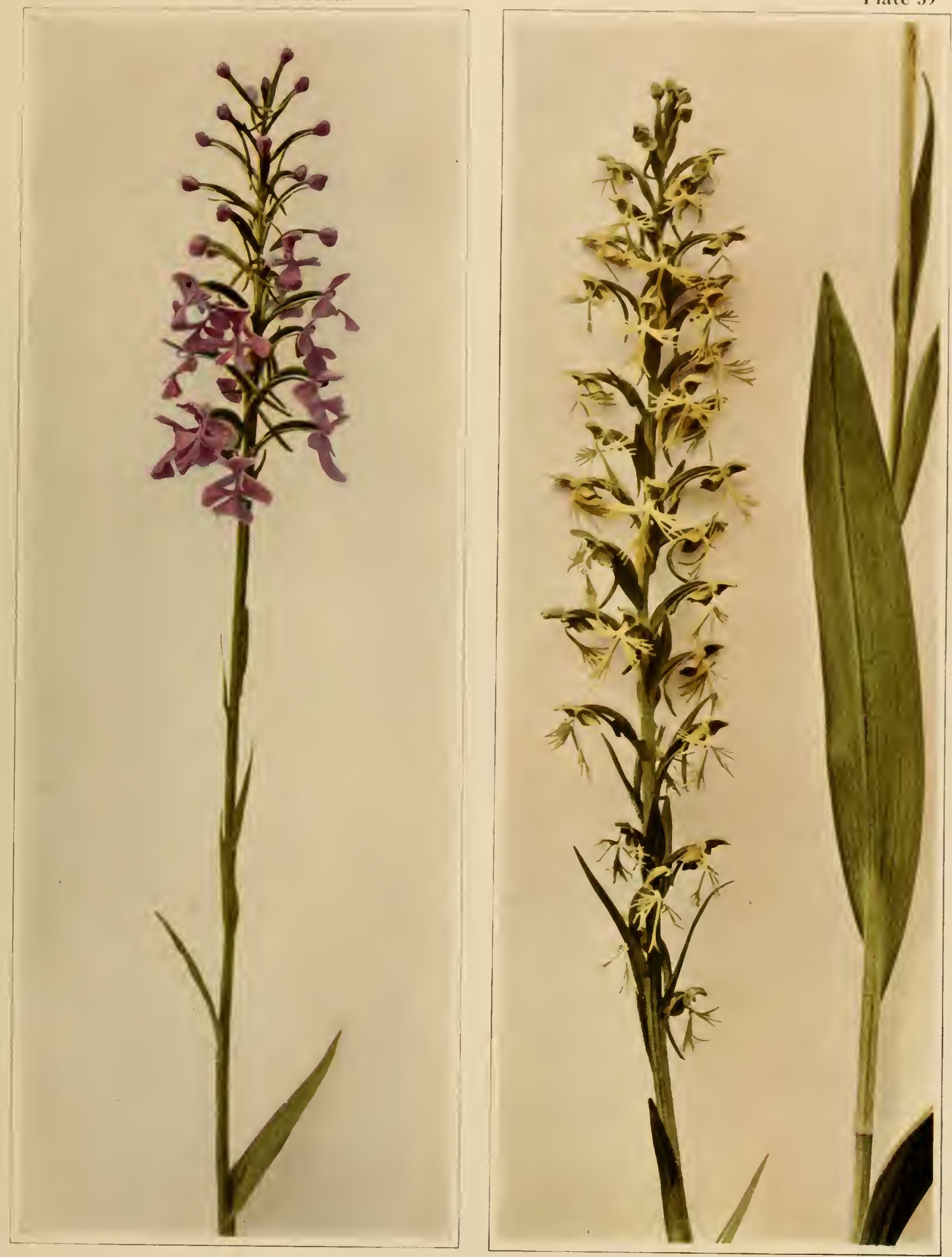

A. SMALLER PURPLE-FRINGED ORCHIS Blephariglottis psycodes

B. RAGGED OR GREEN-FRINGED ORCHIS Blephariglottis lacera 

W I L D F L OWERS OF NEW YORK

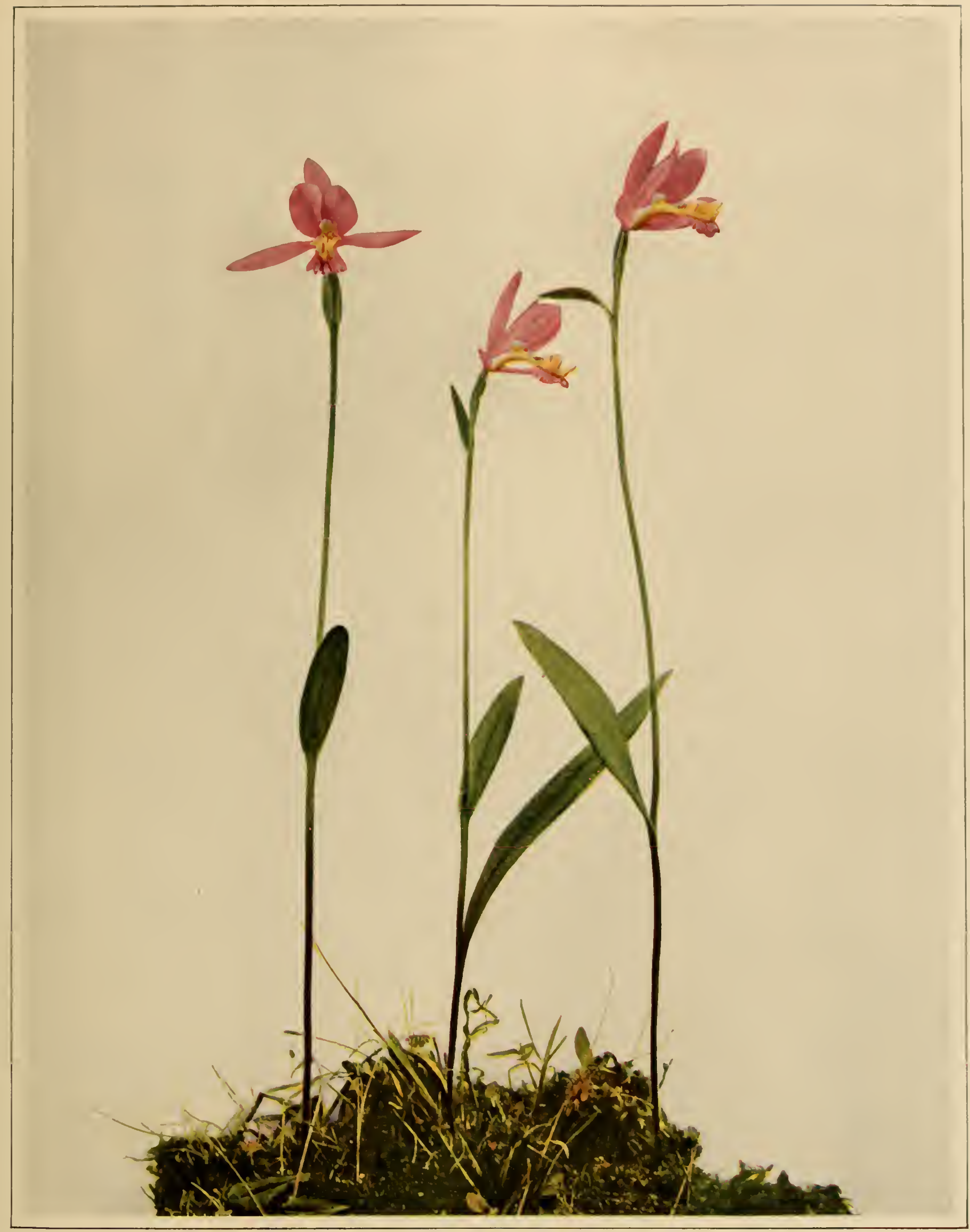

ROSE POGONIA; SNAKEMOUTH

Pogonia ophioglossoides 



\section{Grass Pink; Calopogon \\ Limodorum tuberosum Linnacus \\ Plate 4 ia}

Scape slender, $\mathbf{I} 2$ to $\mathbf{1} 8$ inches high from a round, solid bulb, arising from the bulb of the previous year, a single leaf appearing the first scason, followed the next year by the flowering stem and a single linear-lanceolate leaf, 8 to 12 inches long, onc-fourth to I inch wide. Flowers thrce to fiftecn, forming a loose, terminal spike or raceme, each about I inch broad, purplish pink; sepals and petals nearly alike, separatc, obliquely ovate-lanceolate, acute; lip broadly triangular and dilated at the apex, bcarded along the face with yellow, orange and rose-colored hairs.

Common in bogs or boggy meadows. Newfoundland to Ontario and Minnesota, south to Florida and Missouri. Flowering in June and July.

\section{Wide-leaved Ladies'-tresses}

Ibidium plantagineum (Rafinesque) House

Plate $+2 \mathrm{a}$

A rather inconspicuous little orchid, + to Io inches high with tuberousfleshy roots. Leaves three to five to a stem, mostly near the base, lanceolate, 2 to 5 inches long. Flowers spreading in a dense, terminal spike, I to 2 inches long, one-third to one-half of an inch thick, each flower about one-fourth of an inch long; petals and sepals white, the lateral sepals free, narrowly lanceolate, the upper sepals somewhat united with the petals; lip pale yellow on the face, oblong, not contracted in the middle, the wavy apex rounded, crisped or fringed, the base short clawed, bearing mere traces of callosities at the base.

Moist banks, meadows and bogs, Nova Scotia to Minnesota, south to Virginia and Wisconsin. Flowers in June and July.

The most showy species of Ladies'-tresses is Ibidium cernuum (Linnaeus) House (figure X), which is 6 to $2+$ inches high and pubescent above. Leaves mainly toward the base of the stem, linear-lanceolate or linear, 3 to It inches long; flowers very fragrant, white or yellowish, forming 


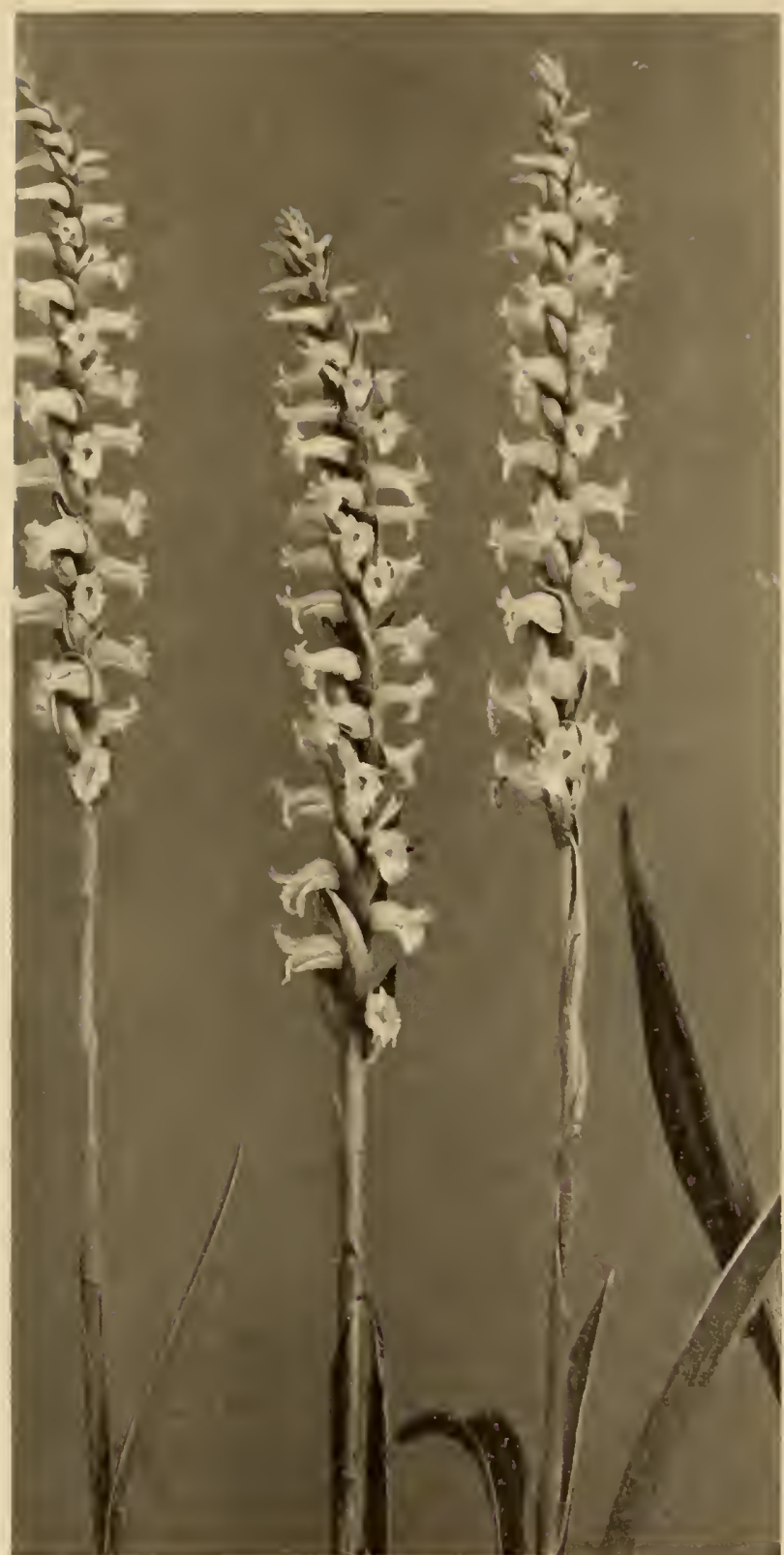

Figure X

Showy Ladies'-tresses

(I b i d i u m cer 1 u u m (Linnaeus) House) a spike, 4 to 5 inches long and one-half to two-thirds of an inch thick; flowers spreading or nodding, each about five-twelfths of an inch long in three rows; lip oblong or ovate, rounded at the apex, crenulate or crisped on the margin. Flowering in late summer and autumn.

Another common species of Ladies'-tresses is I bidium strictum (Rydberg) House, perhaps only a race of $\mathrm{Ibid}$ ium romanzoffianum, which has the sepals and petals coherent and connivent into a hood. It is common in bogs and swamps during July and August.

\section{Southern Twayblade}

(Ophrys australis (Lindley) House)

\section{(Listera australis Lindley)} Figure XI

The Twayblades are among the smallest of our native orchids and require sharp eyes to detect them among the recesses of the forest or bogs. The Southern Twayblade is about 5 to Io inches tall, with two ovate, rather pointed, smooth and shining sessile leaves slightly above the middle of the stem 
W I L D F L O WERS OF NEW YORK

Memoir 15 N. Y. State Museum

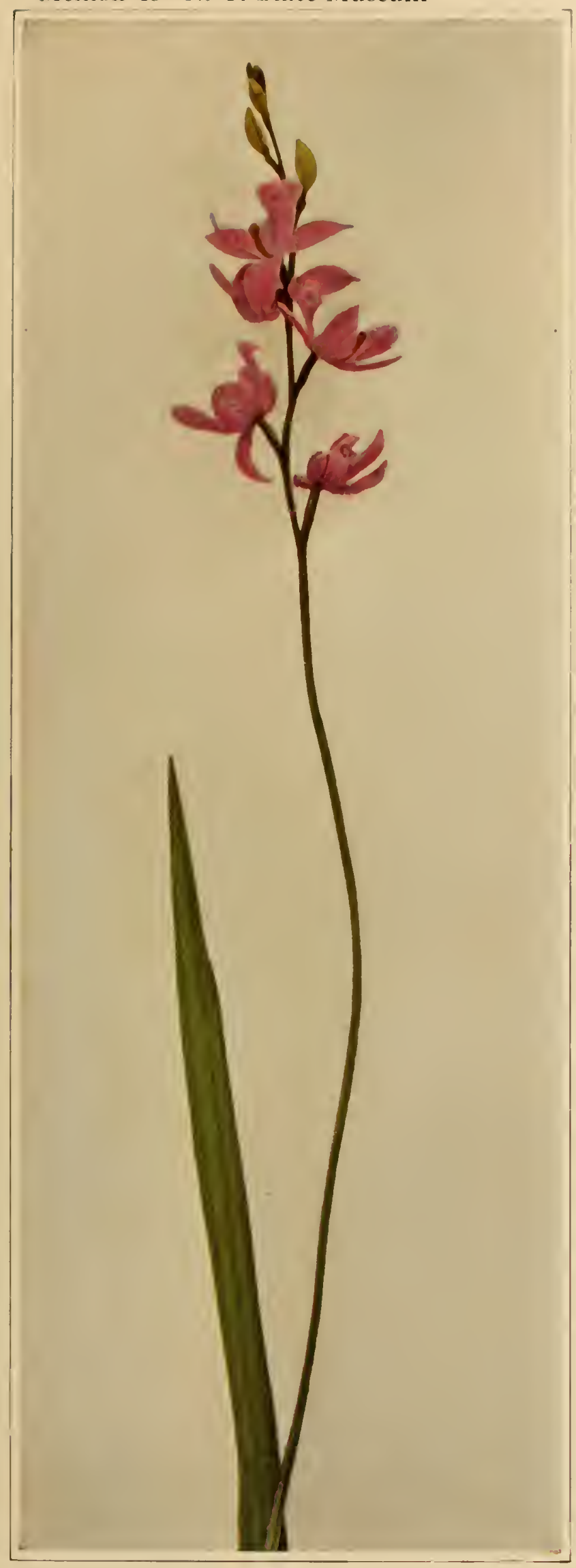

A. GRASS PINK; CALOPOGON Limodorum tuberosum
Plate 41

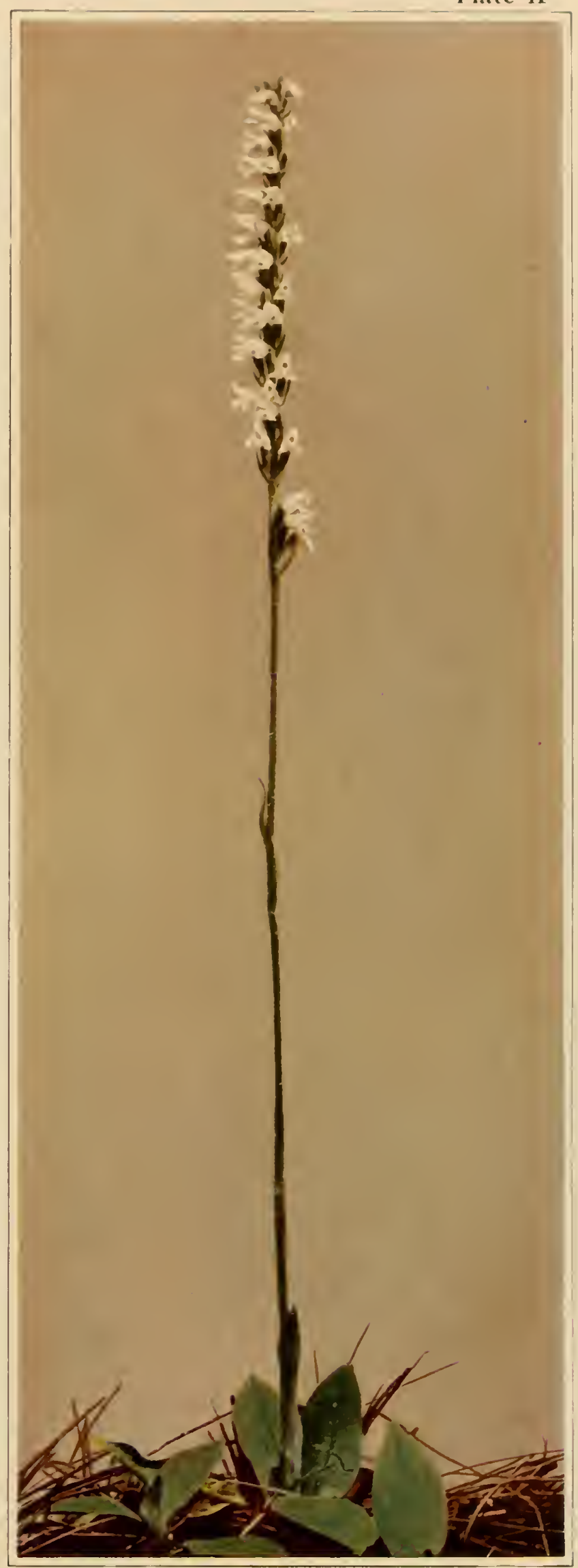

B. LOdDiges's RattlesNake PlaNtain Peramium tesselatum 


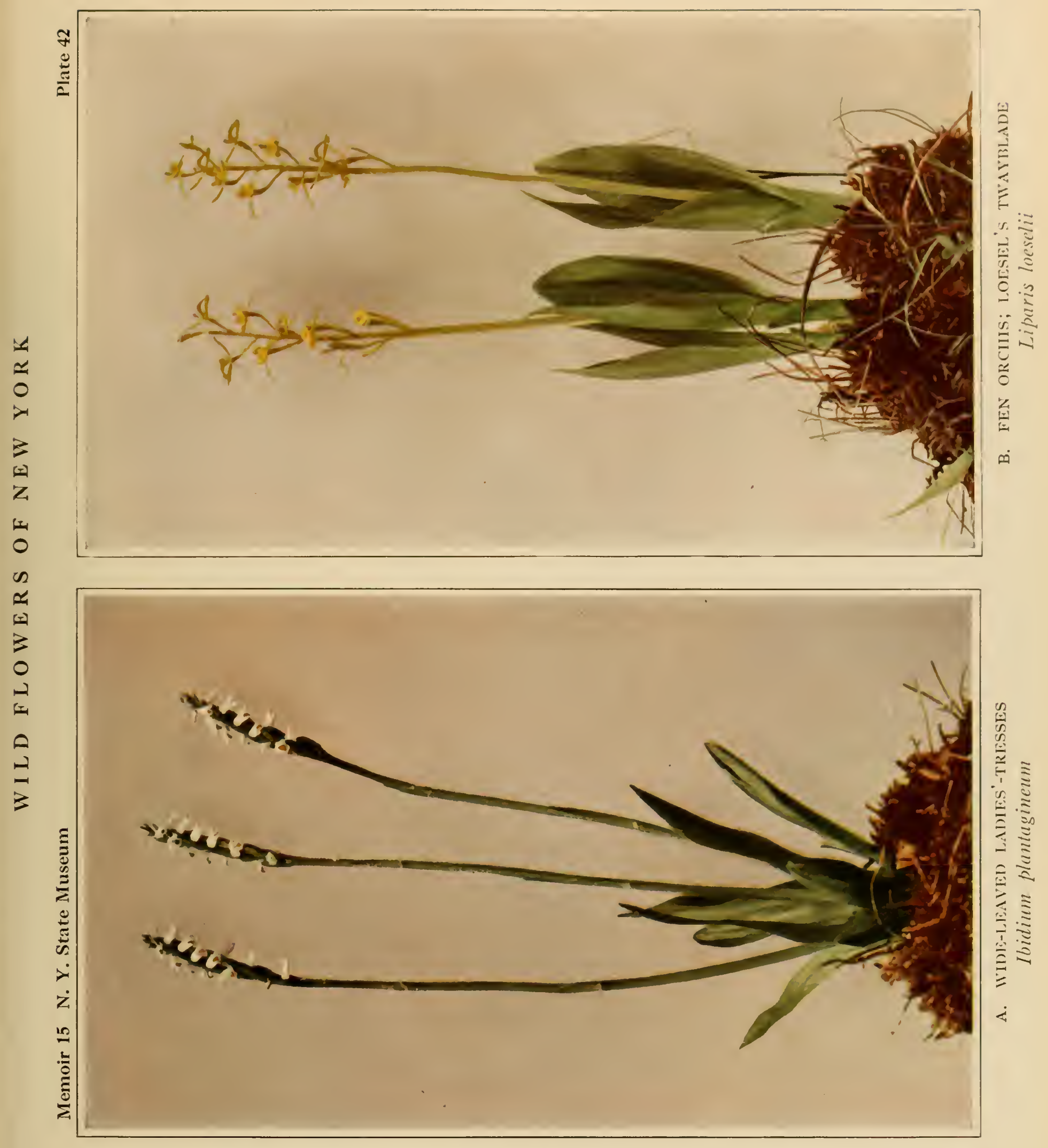



at the top of which is a loose raceme of six to fifteen small, yellowish green flowers; sepals and petals minute, the lip one-fourth to onehalf of an inch long, and two-parted or split nearly to the base four to eight times as long as the tiny petals.

A rare plant of cold, sphagnous bogs in the northern counties, west to Wayne and Onondaga counties and south to Fulton county. In the Appalachian region south to Georgia, this is not a rare species.

Very similar to the Southern Twayblade is the Heart-leaved Twayblade (Ophrys cordat a Linnaeus) in which the two sessile leaves are rounded or slightly heartshaped, and the lip of the flower only two or three times as long as the petals. It is not rare in the Adirondack region but on account of its small size is easily overlooked. It has also been found in deep cedar swamps in certain other portions of the State.

\section{Downy Rattlesnake Plantain} Peramium pubescens (Willdenow) MacMillan

Figure XII

Flowering scape 6 to 20 inches

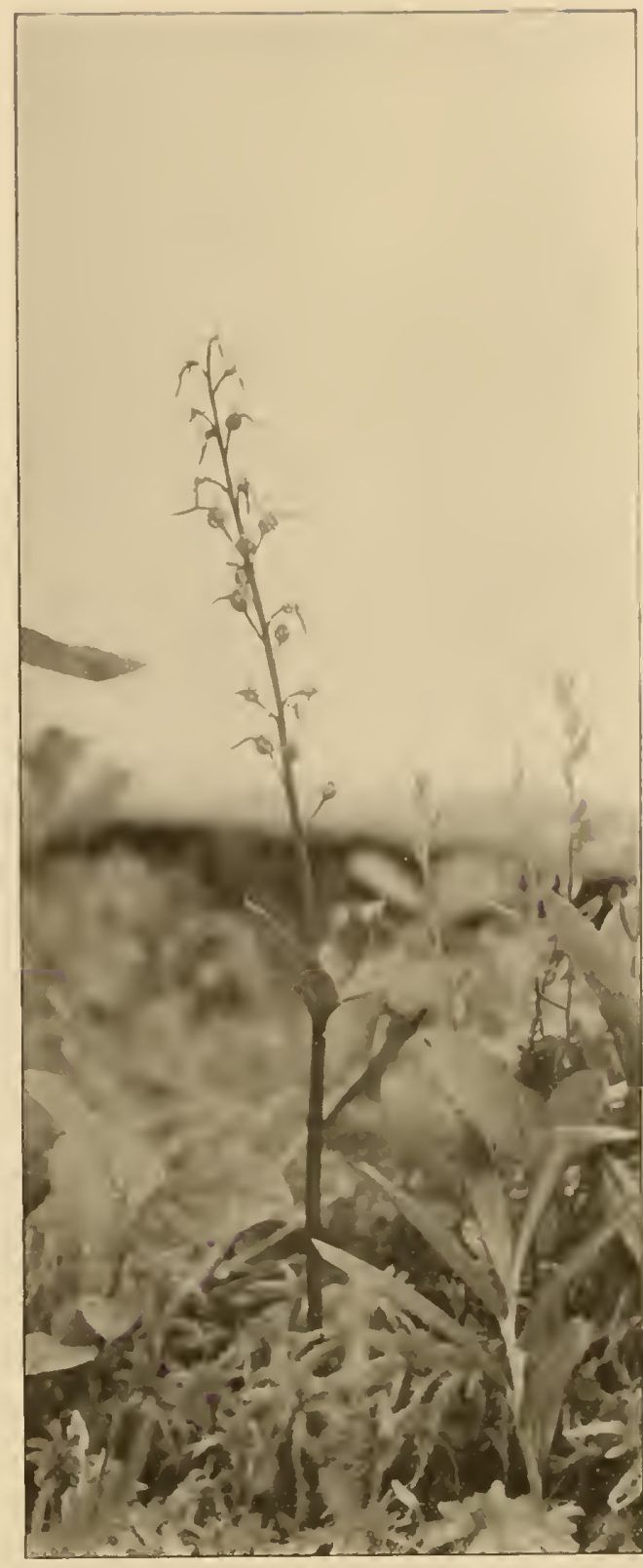

Figure XI

(Photograph by E. A. Eames) Southern Twayblade

high, densely glandular-pubescent, (O phrys a ustralis (Lindiey) House) 


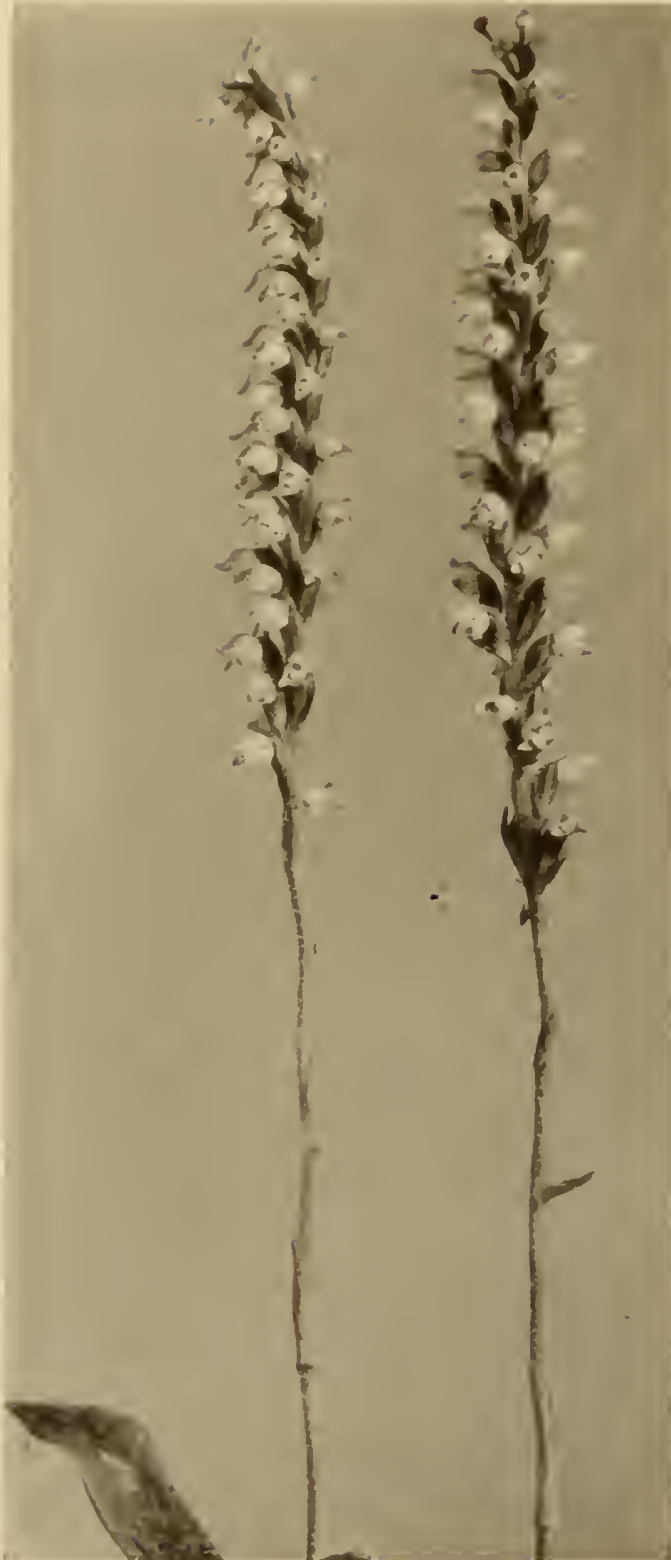

Figure XII

Downy Rattlesnake Plantain Peramium pubescens (Willdenow) (MacMillan) bearing several lanceolate scales, from a branching, fleshy, perennial rootstock. Leaves all near the base of the scape, I to 3 inches long, twothirds to $I$ inch wide, pointed at the apex, rather abruptly contracted into short petioles, oval or ovate in shape, rather strongly reticulated with white along the principal veins on the upper surface, pale green beneath. Flowers white or tinged with green, forming a rather dense terminal spike which is not one-sided; each flower about one-fourth of an inch long or slightly less; lateral sepals ovate; upper sepals united with the petals to form an ovate hood (galea); lip saccate with a short broad blunt recurved or spreading tip.

In dry woods, Maine to Ontario and Minnesota, south to Florida and Tennessee. Flowering in July and August.

The Lesser Rattlesnake Plantain (Peramium ophioides (Fernald) Rydberg) is only about 6 to Io inches high, with smaller, ovate, white-blotched leaves and small, greenish white flowers, one-eighth to one-sixth of an inch long in a one-sided spike. Frequent in woods. 


\section{Loddiges's Rattlesnake Plantain}

Peramium tesselatum (Loddiges)

\section{Heller}

Plate aib

Leaves oblong-ovate or ovatelanceolate, I to 2 inches long, onethird to one-fourth of an inch wide, bright green, abruptly narrowed into the petioles which sheathe the base of the stem, more or less marked on the upper surface with white; stem 6 to I4 inches high, glandular-pubescent and scaly, bearing at the summit a loosely spiral spike of flowers $\mathbf{I}$ to 5 inches long; flowers whitish, lateral sepals free, the upper ones united with the petals to form a hood (galea), 2 to 3 lines long, broad and recurved at the tip; lip roundish-ovate, slightly saccate at the base, the long tip somewhat recurved.

In coniferous woods, more rarely in open places, Newfoundland to Ontario, Pennsylvania and Michigan. Flowering from July to September.

\section{White Adder's-mouth}

Malaxis monophylla (Linnaeus) Swartz Figure XIII

Stem very slender, 4 to 8 inches high, smooth, bearing below the middle a single leaf which sheathes the stem,

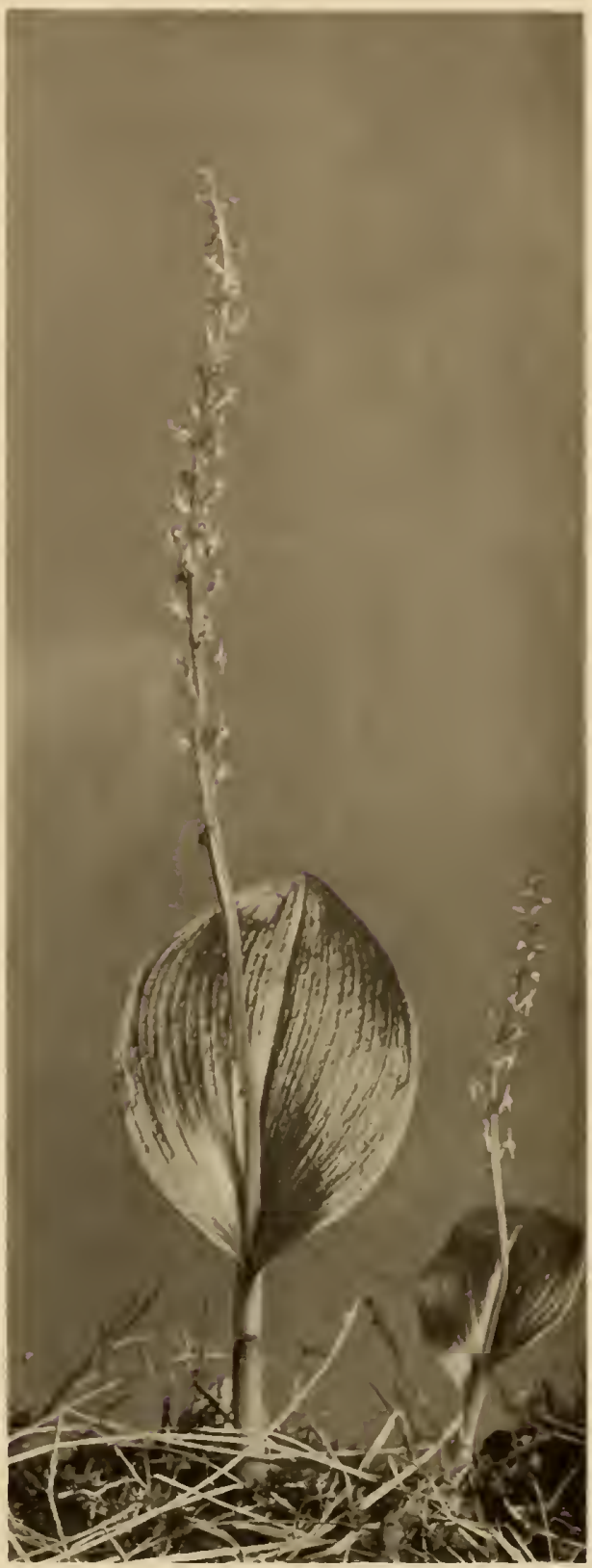

Figure XIII

White Adder's-mouth

(Malaxis monophylla (Linnaeus)

(Swartz) 
the blade I to 3 inches long, one-half to $I_{\frac{3}{4}}$ inches wide. Flowers whitish, very small, in a slender raceme, I to 4 inches long; each flower about onehalf of an inch long on a very short, nearly erect pedicel; lip triangular or ovate and long pointed.

In woods, thickets and recent clearings, Quebec to Manitoba, south to Pennsylvania and Nebraska. Flowering in July.

The Green Adder's-mouth (M a 1 a $x$ is u n ifoli a Michaux) has the single leaf clasping the stem near the middle; flowers greenish on slender pedicels; lip broad and three-toothed at the apex. Small and inconspicuous as well as rather rare.

\section{Large Twayblade}

\section{Liparis liliifolia (Linnaeus) L. C. Richard \\ Figure XIV}

Scapes 4 to 10 inches high, striate and smooth from a perennial solid bulb, the base of the stem sheathed by several scales and two ovate or oval, blunt, shining, light-green leaves, 2 to 5 inches long, i to $2 \frac{1}{2}$ inches wide. Flowers yellow, numerous, rather showy, forming a loose terminal raceme; petals very narrow and threadlike; lip erect, large, fully one-half inch long, wedge-obovate in shape. Capsule club-shaped and about one-half inch long.

In moist woods, thickets and recent clearings, Maine to Minnesota, south to Georgia and Missouri. Flowering from latter part of May to July.

\section{Fen Orchis; Loesel's Twayblade \\ Liparis loeselii (Linnaeus) L. C. Richard \\ Plate $42 b$}

A low bog orchis with two light-green, shining, elliptic or ellipticlanceolate leaves, 2 to 6 inches long, one-half to 2 inches wide and obtuse, arising with the short stem from a solitary bulb which, with the base of the stem, is sheathed by several scales and the remains of leaves of former seasons; flowers greenish yellow, about one-fourth of an inch long, in a 


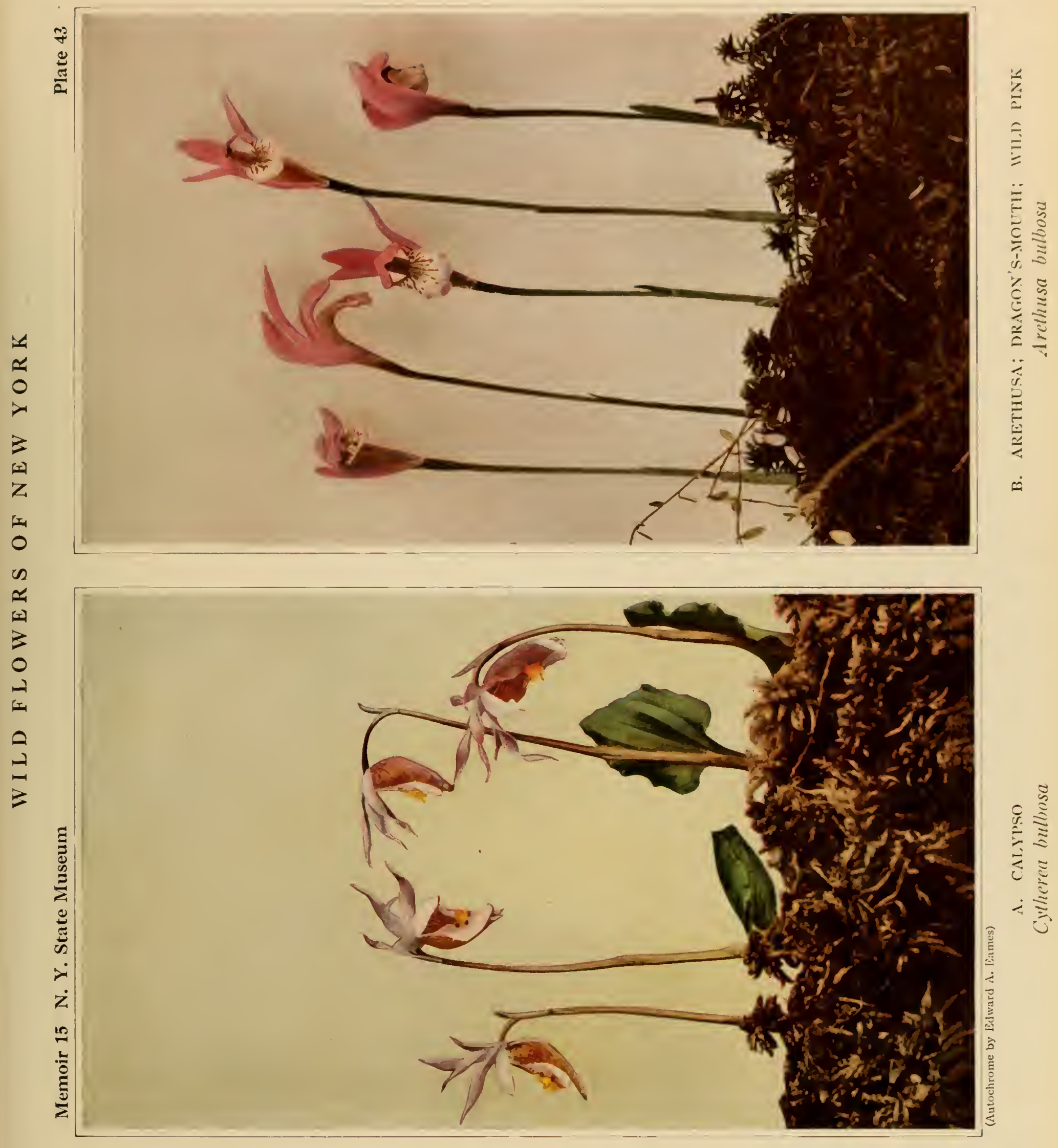





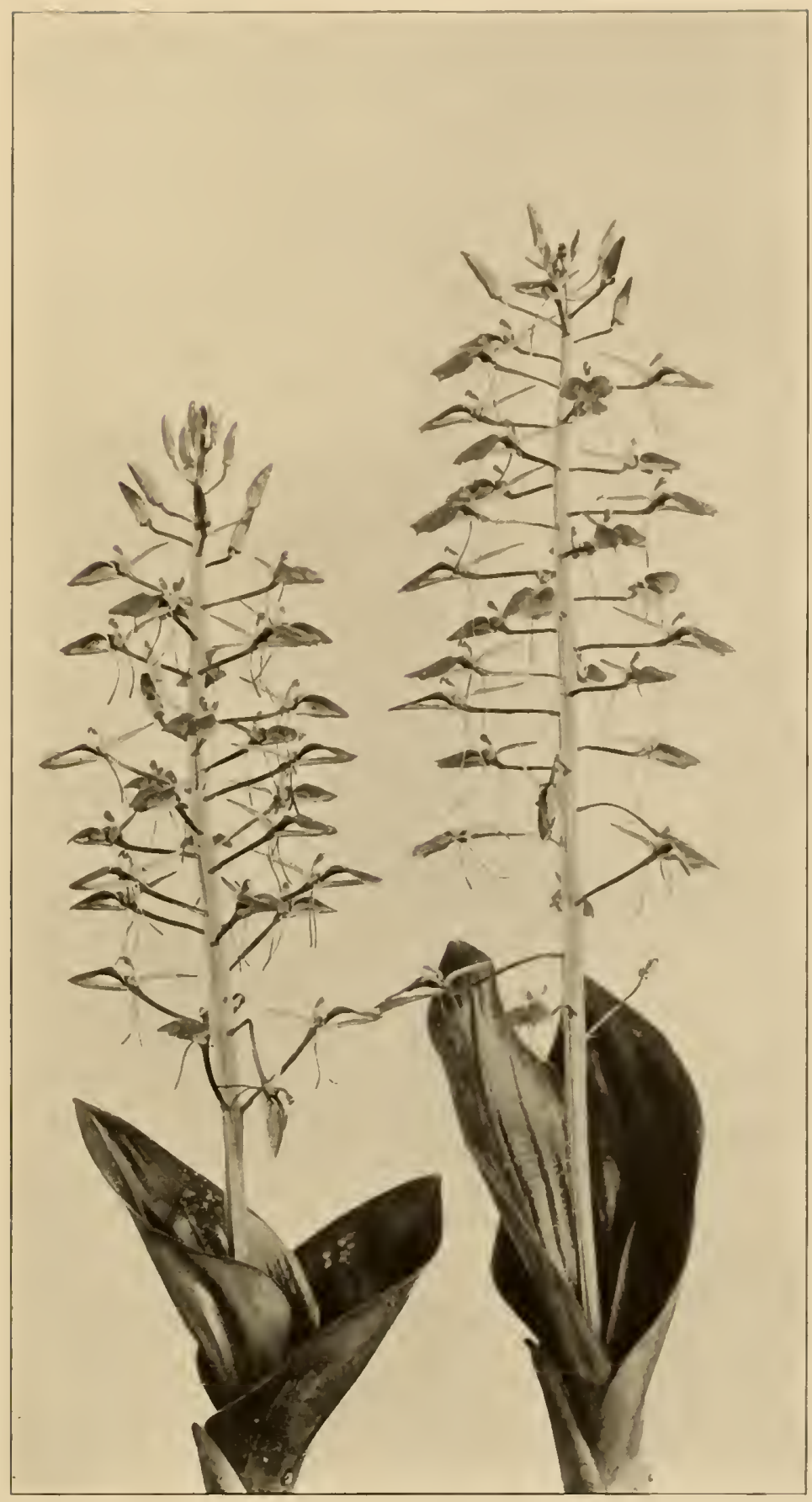

Figure XIV

Large Twayblade

(Liparis 1 il i if olia (Linnaeus) L. C. Richard) 
terminal, loosely flowered raceme; petals linear, somewhat reflexed; lip obovate, pointed, a little shorter than the petals and sepals, its tip incurved; capsules about one-half of an inch long, wing-angled.

In wet thickets, springy banks, and bogs or boggy meadows, Nova Scotia to Saskatchewan, south to Alabama and Missouri. Flowering from late May to July and sometimes later.

\section{Calypso}

Cytherea bulbosa (Linnaeus) House

(Caly'pso borealis Salisbury)

Plate $43 a$

Stem or scape 3 to 7 inches high from a perennial bulb one-half of an inch or less thick with coralloid roots. The scape bears two or three loose sheathing scales and at the base a single round-ovate leaf, I to 2 inches long, blunt or pointed at the apex and rounded or heart-shaped at the base, the petiole I to 2 inches long. Flower showy, solitary, I to $\mathrm{I} \frac{1}{2}$ inches broad, at the summit of the scape, variegated with purple, pink and yellow; petals and sepals similar, nearly equal, linear, erect or spreading, each with three longitudinal purple lines. Lip saccate, large, two-divided below, spreading or drooping, with a patch of yellow woolly hairs. Column erect, broadly ovate and petallike, shorter than the petals, bearing the lidlike anther just below the summit.

In bogs and cold Arbor Vitae swamps, Labrador to Alaska, south to Naine, New York, Michigan, California and in the Rocky mountains to Arizona and New Mexico. Also in Europe.

One of the rarest and at the same time most beautiful of our native Orchids, appearing much like a small Cypripedium (Lady's-slipper). In New York it has been found in several localities in southern Herkimer, in Lewis, Oswego and Onondaga counties. The writer found it several years ago in Lodi or Tamarack swamp near Syracuse, but the place has since been obliterated by the growth of the city. For the illustration used here we are indebted to Edward A. Eames of Buffalo. 


\section{Large Coralroot}

Corallorrhiza maculata Rafinesque

Figure VIII, page 73

Stems stout or slender, 8 to 20 inches high, with a large mass of corallike branching rootstocks, the stem purplish, clothed with several appressed scales, devoid of green lcaves or green color. Flowers ten to thirty, forming a terminal raceme 2 to 8 inches long, purplish brown; scpals and pctals linear-lanceolate, about one-fourth of an inch long; lip white, spotted and lined with crimson, oval or ovate in outline, deeply three-lobed, crenulate; spur yellowish. Fruiting capsules ovoid or oblong, one-half to two-thirds of an inch long and drooping.

In woods, Nova Scotia to British Columbia, south to Florida, Missouri, New Mexico and California. Flowering from July to September.

The Early Coralroot (Corallorrhiza corallorrhiza (Linnaeus) Karsten) blooms in May and June. It has smaller flowers of a dullpurple color; sepals and petals about one-fourth of an inch long and a whitish, oblong lip; spur reduced to a small protuberance adnate to the summit of the ovary. Common in moist woods.

The Small or Late Coralroot (Corallorrhiza odontorhiza (Willdenow) Nuttall) blooms from July to September. It is 6 to 15 inches high and very slender. Flowers purplish; sepals and petals about onesixth of an inch long or less, marked with purple lines; lip entire or denticulate, whitish, spotted with purple. A rather rare plant of moist woods. All the species of Coralroot are devoid of green leaves or green coloring matter in the stems, because of their parasitic or saprophytic habit.

\section{Lizard's-tail Family}

S a u rurace a e

\section{Lizard's-tail}

Saururus cermuns Linnaeus

Plate 44

Stem 2 to 5 feet high from a slender rootstock, jointed, pubescent when young, becoming smooth. Leaves ovate, thin, palmately five to nineribbed, dark green, entire, deeply cordate at the base, acuminate, 3 to 6 
inches long, 2 to $3 \frac{1}{2}$ inches wide; petioles sheathing the stem at the enlarged nodes; the stem terminating in one or two elongated white spikes, their tips drooping in flower. Flowers fragrant, small, white, without any perianth; stamens six to eight, white, spreading; ovary consisting of three or four carpels united at the base, becoming slightly fleshy and strongly wrinkled in fruit.

In swamps and shallow water, Rhode Island to Florida west to southern Ontario, Minnesota and Texas. Flowering from June to August.

\section{Nettle Family}

Urticaceae

\section{False Nettle}

Boehmeria cylindrica (Linnaeus) Swartz

Plate 45

A perennial, rough-pubescent or nearly smooth, erect plant, I to 3 feet tall, not provided with stinging hairs as are the true nettles. Leaves mostly opposite, thin, petioled, ovate to ovate-lanceolate, coarsely toothed, I to + inches long, one-half to $I \frac{1}{2}$ inches wide. Flowers greenish, small and dioecious, that is, some of the axillary spikes containing only staminate flowers, and others only pistillate flowers, or some of the spikes containing both kinds of flowers (androgynous); the staminate spikes interrupted, the pistillate mostly continuous, one-fourth to $I \frac{1}{2}$ inches long, often terminated by small leaves.

In moist soil and thickets, Quebec and Ontario to Minnesota, Florida, Texas and the West Indies. Flowering from July to September. Not an attractive plant but figured here as a representative of the Nettle family, none of our species having conspictious flowers. The True or Stinging Nettle (Urtica dioica Linnaeus), naturalized in the eastern states from Europe, the Slender Wild Nettle ( $\mathrm{Crtica}$ gracil is Aiton) and the Wood Nettle (Lrticastrum divaricatum (Linnaeus) Kuntze) are all provided with stinging hairs and are most unpleasant plants to encounter unexpectedly in the woods. 
W I I, D F L O WER S O N EW Y O R K

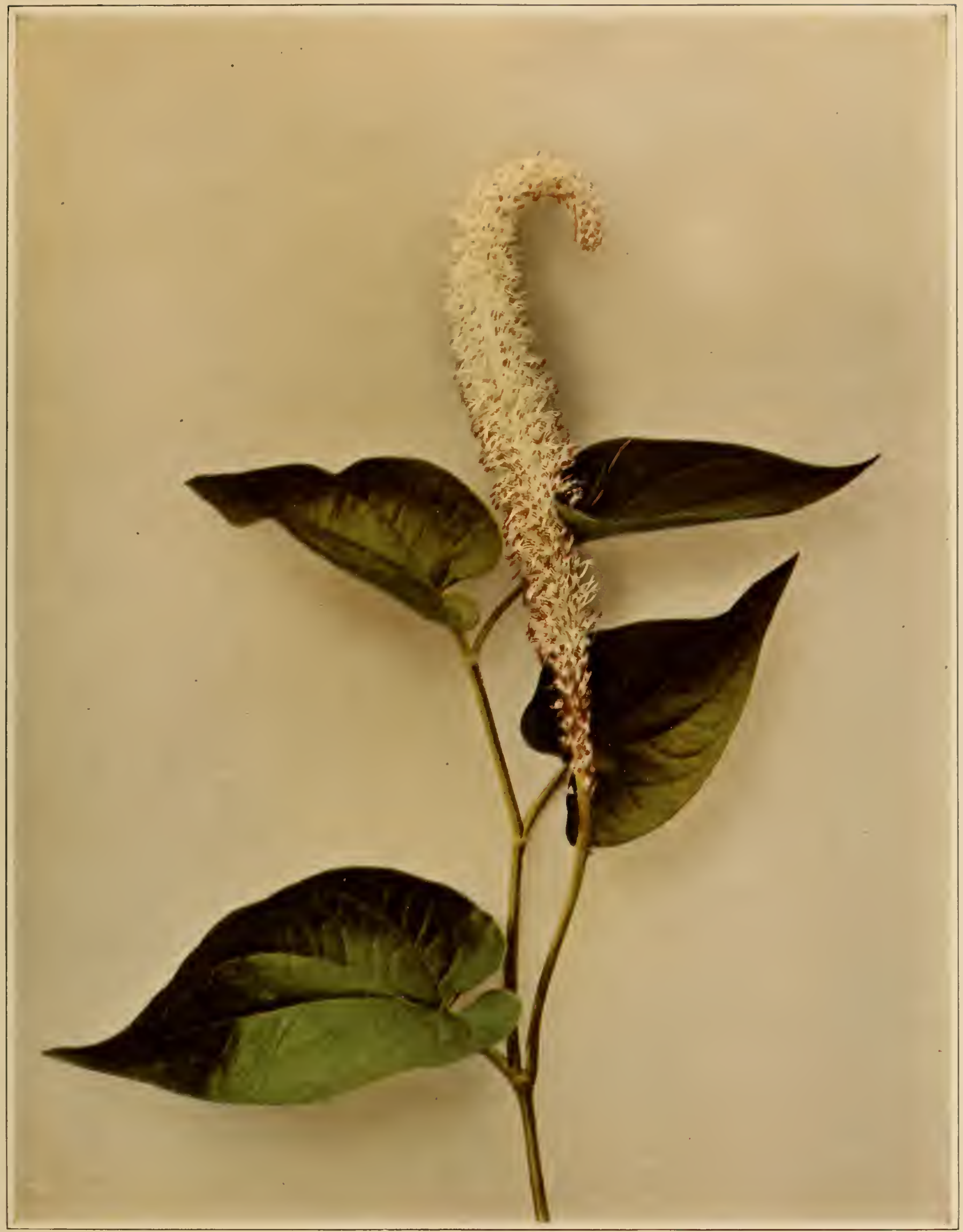

LIZARD'S-TAIL

Saururus cermuus 

W I I, D F I, OWERS OF NEW YORK

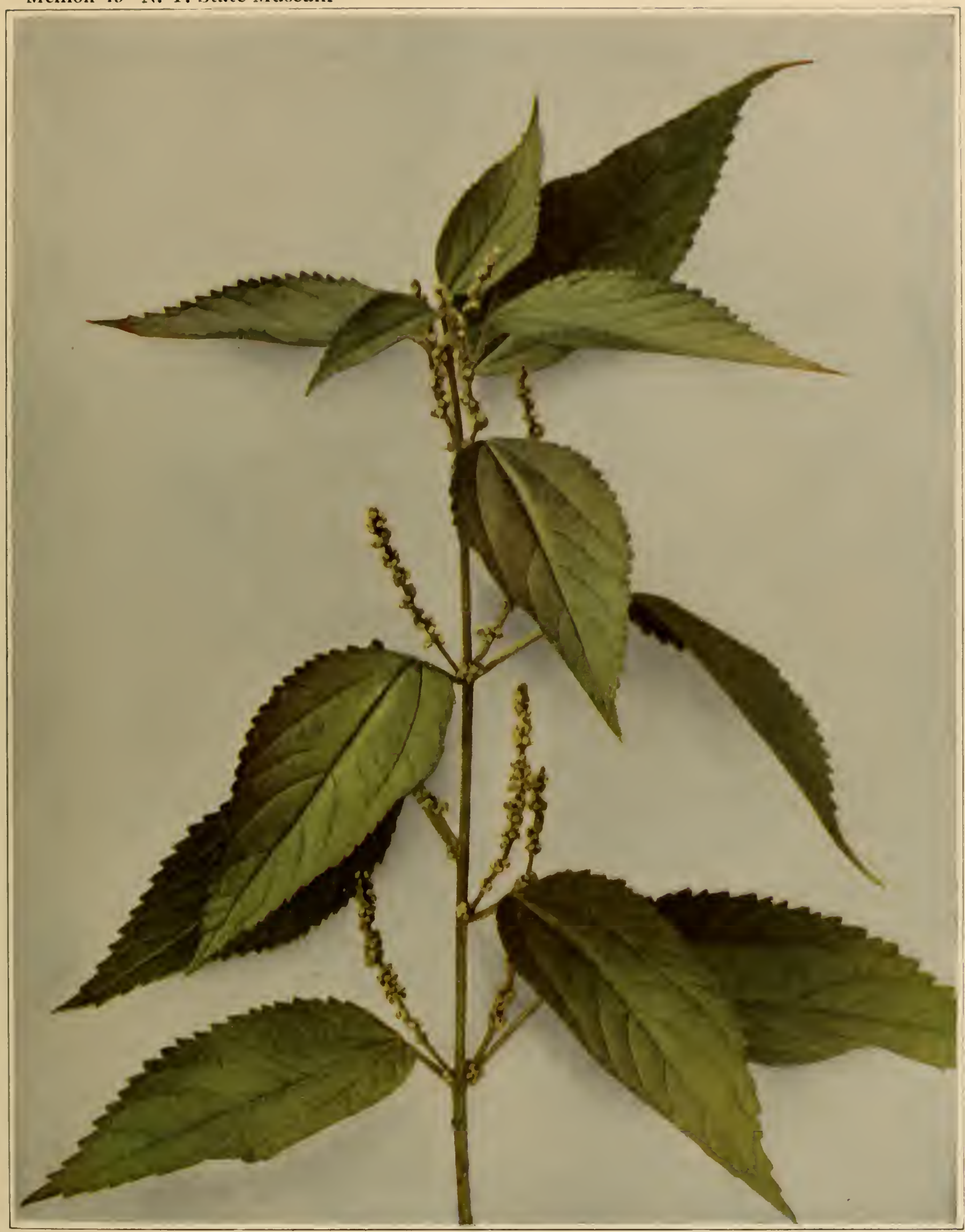

FALSE NETTLE

Boehmeria cylindrica 



\section{Sandalwood Family}

Sa ti t a la ceac

\section{Bastard Toadflax}

Comandra umbellata (Linnaeus) Nuttall

Plate $28 \mathrm{~b}$

Stems numcrous from a horizontal, branching rootstock, said to be parasitic on the roots of adjacent herbs, 6 to i 8 inches tall, usually branched and very leafy. Leaves oblong or oblong-lanccolatc, pale grcen, pointed at each cnd, sessile, onc-half to $1 \frac{1}{2}$ inches long, the lower ones smaller. Flowers numcrous in terminal cymes, corymbose at the summit of the stem, or also axillary, their branches divergent or ascending, greenish white, white, or purplish, about one-fifth of an inch long, calyx usually five-lobed, corolla none. Fruit a globose drupe about onc-fourth of an inch in diameter, crowned by the upper part of the calyx tube and its fivc oblong lobes.

In dry fields and thickets, especially sandy soil, Cape Breton Island to Ontario and Assiniboia, south to Georgia, Kansas and Arkansas. It Bergen swamp in Genesee county, New York, it grows in an open marl bog, which, however, is dry in certain seasons, in company with A rethusa bulbosa, Cypripedium candidum, Scirpus caespitosus, Anticlea chlorantha, Triantha glutinosa, Solidago houghtonii, and other bog plants, a habitat most unusual for this specics.

\section{Birthwort Family}

Iristolochiaceac

\section{Wild or Indian Ginger}

Asarum canadense Linnaeus

Plate $; 0$

Leaves clustcred in pairs from a slcnder, branching, aromatic rootstock, having the flavor of ginger. Leaf blades long petioled, reniform, thin, short pointed at the apex, 3 to 7 inches broad, dark green, the base 
decply cordate. Entire plant densely and finely pubescent. Flowers on a short, slender peduncle from betwcen the bases of the petioles, often concealed or partly buried in old leaves on the ground, I inch or morc broad, brownish purple; calyx ovoid, its tube completely adnatc to the ovary, its three lobes inflexed in bud, ovate-lanccolate, acute or long-acuminate, spreading; stamens twelve in number, the stout, short filaments inserted on the inferior six-celled ovary.

In rich woods, New Brunswick to Manitoba, south to North Carolina, Missouri and Kansas. Flowering in April and May.

In southern New York occurs also the Short-lobed Wild Ginger (Asarum reflexum Bicknell) with smaller flowers, the calyx tube white within, and the triangular, acute lobes strongly reflexed.

\section{Buckwheat Family}

Poly gon a c a e

\section{Swamp Smartweed \\ Persicaria muhlenbergii (S. Watson) Small \\ Plate 47 a}

Perennial by long rootstocks, rooting in the mud or in the water, stem erect, glabrous, or somewhat pubescent, enlarged at the nodes, I to 3 feet high. Leaves ovate-lanceolate or oblong-lanceolate, the upper ones often narrower, 2 to 8 inches long, acute or acuminate at the apex, rounded or cordate at the base, petioled, ocreae cylindric, becoming loose, not ciliate. Flowers in linear-oblong, dense; terminal racemes, I to 3 inches long; calyx dark rose-colored, five-parted; stamens five in number.

In swamps, marshes and moist soil, Ontario to British Columbia, Virginia, Louisiana and Mexico. Flowering from July to September.

\section{Lady's-thumb; Heartweed}

Persicaria persicaria (Linnaeus) Small

Plate $47 \mathrm{~b}$

Annual, smooth or somewhat puberulent, stems one-half to 2 feet high, erect or nearly so, simple or branched. Leaves lanceolate or linear-lanceo- 
WIL, I L OWERS OF NEW YORK

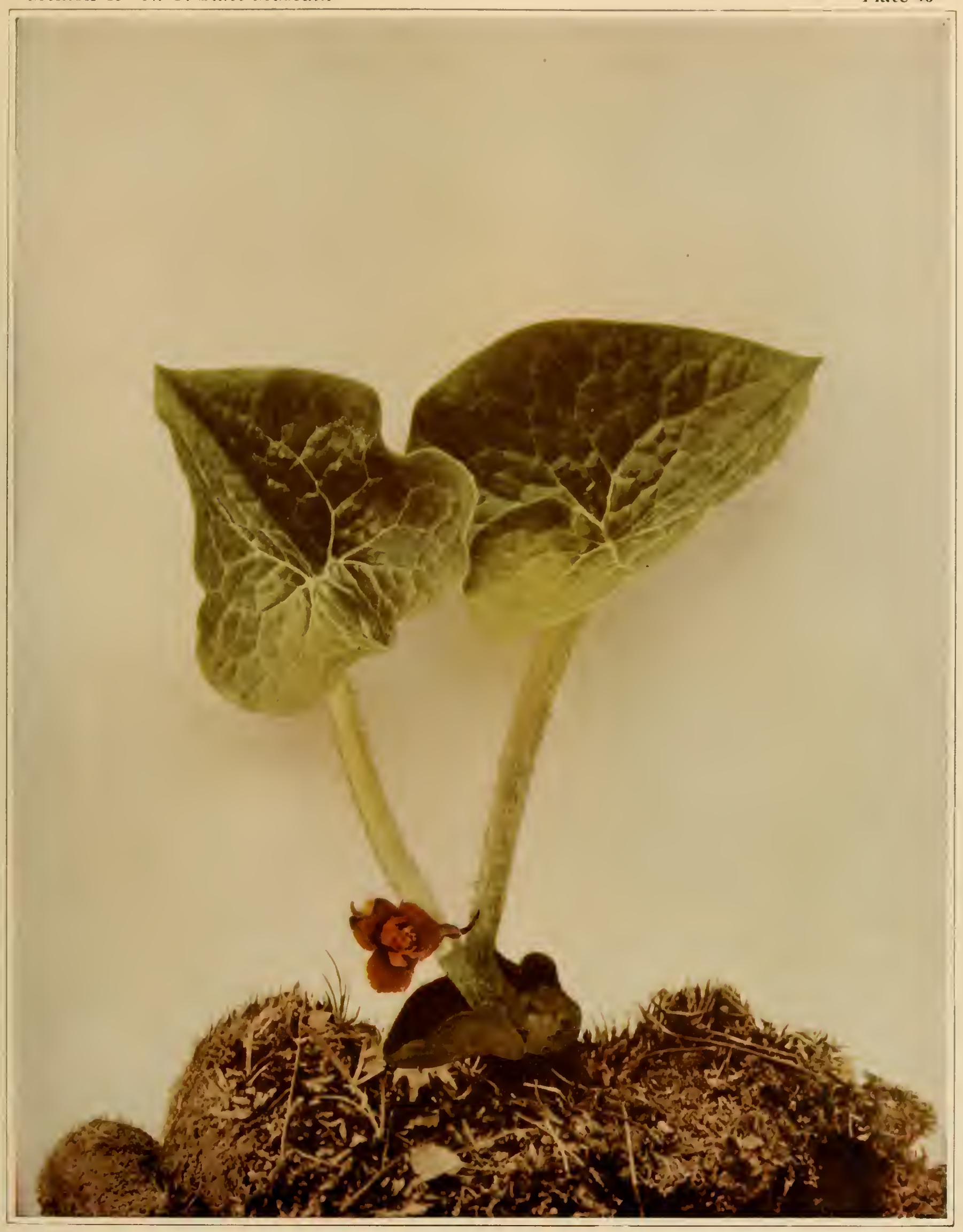

WILD OR INDIAN GINGER

Asarum canadense 



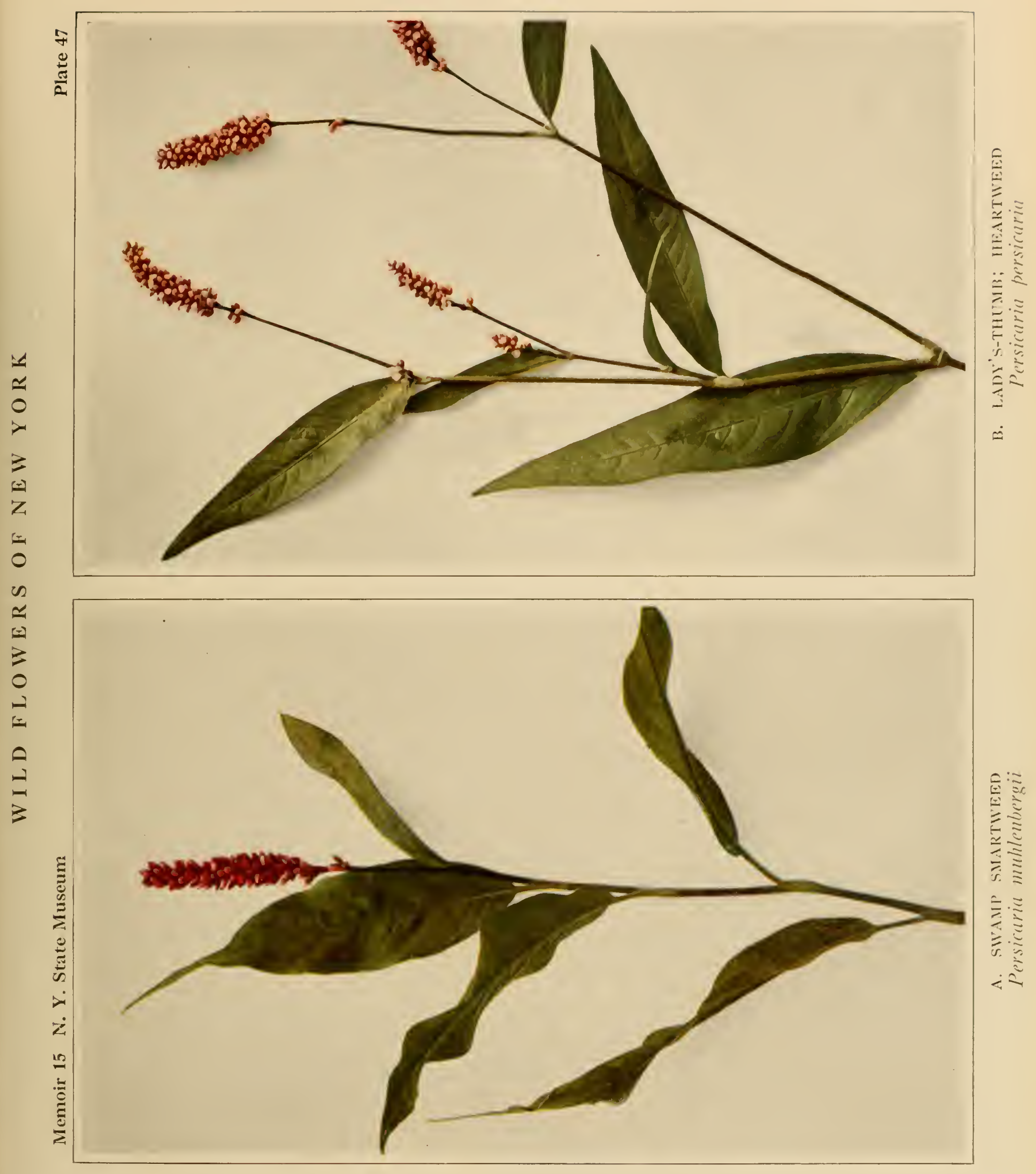



late, 2 to 6 inches long, nearly sessile, acuminate at both ends, conspicuously dotted, usually with a triangular or lunar dark bloteh near the center; ocreac eylindric, fringed with short bristles. Flowers in dense, erect, ovoid or oblong racemes, one-half to 2 inches long, pink to dark purple; stamens usually six.

Native of Europe but naturalized and often an abundant weed in waste places throughout North Ameriea, exeept in the extreme north.

\section{Arrow-leaved Tearthumb}

Tracaulon sagittatum (Linnacus) Small

Plate $48 \mathrm{a}$

Stems slender, weak, annual, deeumbent, or climbing over other plants by the numerous sharp, recurved prickles which arm its four prominent angles. Lcaves lanceolate-sagittate or oblong-sagittate, I to 3 inches long, pointcd at the apex, slightly rough margined, the lower leaves petioled, upper ones sessile or nearly so, prickly on the petioles and beneath on the midribs; ocreae oblique, not eiliate. Flowers in terminal heads or racemes, rosc-colored or greenish; stamens usually eight in number; style threeparted.

In wet soil, Newfoundland and Nova Scotia to the Northwest Territory, south to Florida and Kansas. Flowering from July to September.

\section{Halberd-leaved Tearthumb}

Tracaulon arifolium (Linnaeus) Rafinesque

Plate $48 \mathrm{~b}$

Stems angled, reclining, 2 to 6 feet long from a perennial root, armed with recurved prickles. Leaves broadly hastate, long petioled, I to 8 inches long, pubescent or glabrous beneath, the apex and basal lobes sharp pointed; petioles and larger nerves prickly; peduncles and pedicels glandular; ocreae oblique, fringed at the summit with short bristles and at the base with slender prickles. Flowers in terminal and axillary heads or racemes, rosecolored or greenish, four parted. Stamens six; style two-parted. 
In moist or wet soil and thickets, New Brunswick and Ontario to Minnesota, south to Georgia. Flowering from July to September.

\author{
Climbing False Buckwheat \\ Bilderdykia scandens (Linnaeus) Greene \\ (Polygonum scandens Linnaeus) \\ Plate $15 \mathrm{~b}$
}

Stems slender or stout, glabrous, high climbing, 2 to 20 feet long from a perennial root, somewhat rough on the ridges which mark the stem. Leaves ovate, sharp pointed, cordate at the base, I to 6 inches long, or the upper ones smaller, finely dotted, ocreae oblique, smooth and glabrous. Flowers in numerous panicled racemes, 2 to 8 inches long, usually interrupted with small leaves, yellowish green or whitish; calyx five-parted; stamens eight; calyx in fruit about one-half of an inch long with crisped wings.

In woods, thickets and on banks and along fence rows, Nova Scotia to Ontario and British Columbia, south to Florida, Nebraska and Texas. Flowers in August and September.

\title{
Coast Jointweed
}

\section{Polygonella articulata (Linnaeus) Meisner}

Plate $49 a$

Stems slender, wiry, erect or somewhat diffusely spreading, annual, glaucous, simple or the larger ones often much branched, 4 to 12 inches high. Leaves linear or linear-subulate, with revolute margins, sessile, one-third to $\mathrm{I} \frac{1}{2}$ inches long, jointed to the summits of the ocreae. Flowers small, in numerous terminal racemes on reflexed pedicels; calyx five-parted, its segments white with a conspicuous purple midrib.

In sand near or on the seashore from Maine to Florida, and inland on the Schenectady plains, those east of Oneida lake, and along the Great Lakes. 


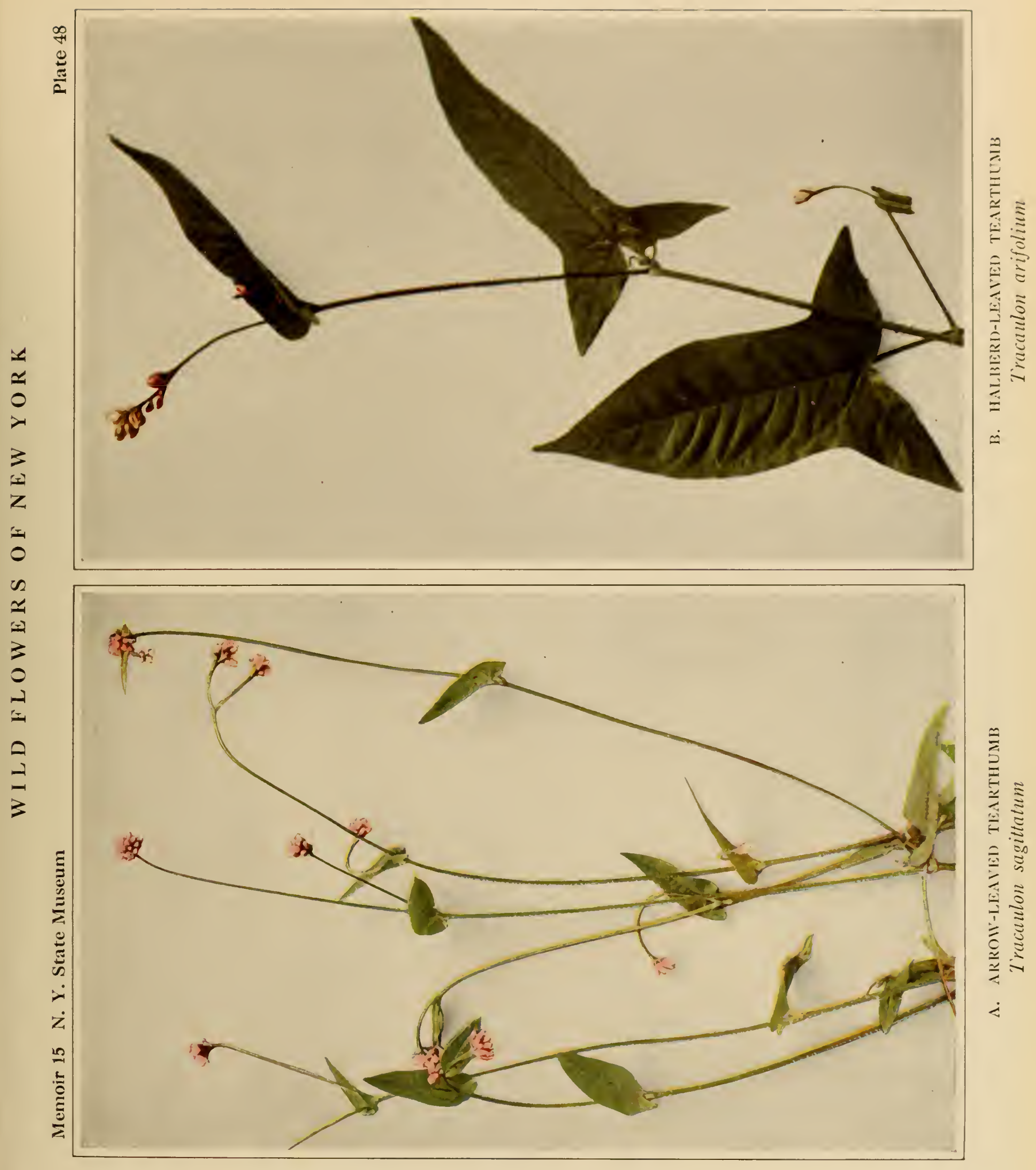




\section{Goosefoot Family \\ Chenopodiaceac \\ Slender or Jointed Glasswort; Saltwort \\ Salicomia curopaca Linnacus \\ Plate $\downarrow$ )}

A fleshy, glabrous annual plant, + to 20 inches high, usually erect and much branched, with opposite, ascending branches, their joints two to four times as long as thick. Leaves reduced to mere scales. Fruiting spikes I to 3 inches long. Flowers three at each joint, the middle one as high as the lateral ones. Each flower consists of a fleshy, obpyramidal three-toothed calyx, two stamens and an ovoid ovary. Seed inclosed by the spongy fruiting calyx.

Common in salt marshes along the coast from Anticosti to Georgia, and at the head of Onondaga lake.

\section{Pokeweed Family}

Phy to 1 a c c a c e a e

\section{Poke; Scoke; Pigeon Berry; Garget \\ Phytolacca americana Linnaeus \\ Plate 50}

A tall, strong-smelling, succulent and glabrous plant with an erect herbaceous stem 3 to io feet tall, from a large, perennial, poisonous root, the pith of the stem divided into discs separated by lens-shaped cavities. Leaves oblong-lanceolate or ovate-lanceolate, pinnately veined, acute or acuminate at both ends, petioled, 5 to 12 inches long. Flowers in terminal racemes, which become opposite the leaves by continued growth of the stem. Each flower about one-fourth of an inch broad, consisting of four or five rounded, white sepals; ten stamens, slightly shorter than the sepals; and a ten-celled green ovary. Fruit a long raceme of dark-purple berries, each one-fourth to three-eighths of an inch in diameter.

In waste places, fields, woods and thickets, usually in moist soil, often in stony fields and frequently a troublesome weed. Distributed from Maine 
and Ontario to Minnesota, Arkansas, Florida, Mexico and Bermuda. Europe has contributed many weeds to America, but the Pokeweed or Scoke is one of the few American plants, often reckoned as a weed, which has become thoroughly naturalized in many parts of Europe.

\section{Purslane Family}

Portul a c a ce a

\section{Narrow-leaved Spring Beauty}

\section{Claytonia iirginica Linnaeus}

Plate 51a

Stems 6 to 12 inches long, ascending or decumbent from a deep, tuberous, perennial root. Leaves linear or linear-lanceolate, glabrous and somewhat fleshy, blunt or pointed, narrowed below into a petiole, the lower leaves 3 to 7 inches long, one-eighth to one-half of an inch wide, the twostem leaves opposite and shorter. Flowers one-half to seven-eighths of an inch broad, white or pink with darker pink veins, in a loose terminal raceme, often becoming 3 to 6 inches long. Sepals two, ovate, persistent; petals five, emarginate; pedicels slender, becoming recurved.

In moist woods, Nova Scotia to Saskatchewan, south to Georgia, Montana and Texas. Flowering in early spring. More frequently found in low woodlands and along streams in the upper part of the State, and not so frequent as the next species except near the coast.

\section{Carolina or Wide-leaved Spring Beauty}

\section{Claytonia caroliniana Michaux}

Plate 69a

Closely resembling the Narrow-leaved Spring Beauty, but usually more crect. Basal leaves ovate-lanceolate or oblong, I to + inches long, one-half to I inch wide, obtuse; stem leaves petioled; flowers fewer. The corm is usually thicker and depressed at the top.

In damp roods, Nova Scotia to Saskatchewan, Connecticut, south to North Carolina along the mountains, and to Ohio and Missouri. Rare or absent near the coast in New York, but very abundant in the interior where it occurs in almost every moist woodland. Flowering in the early spring. 


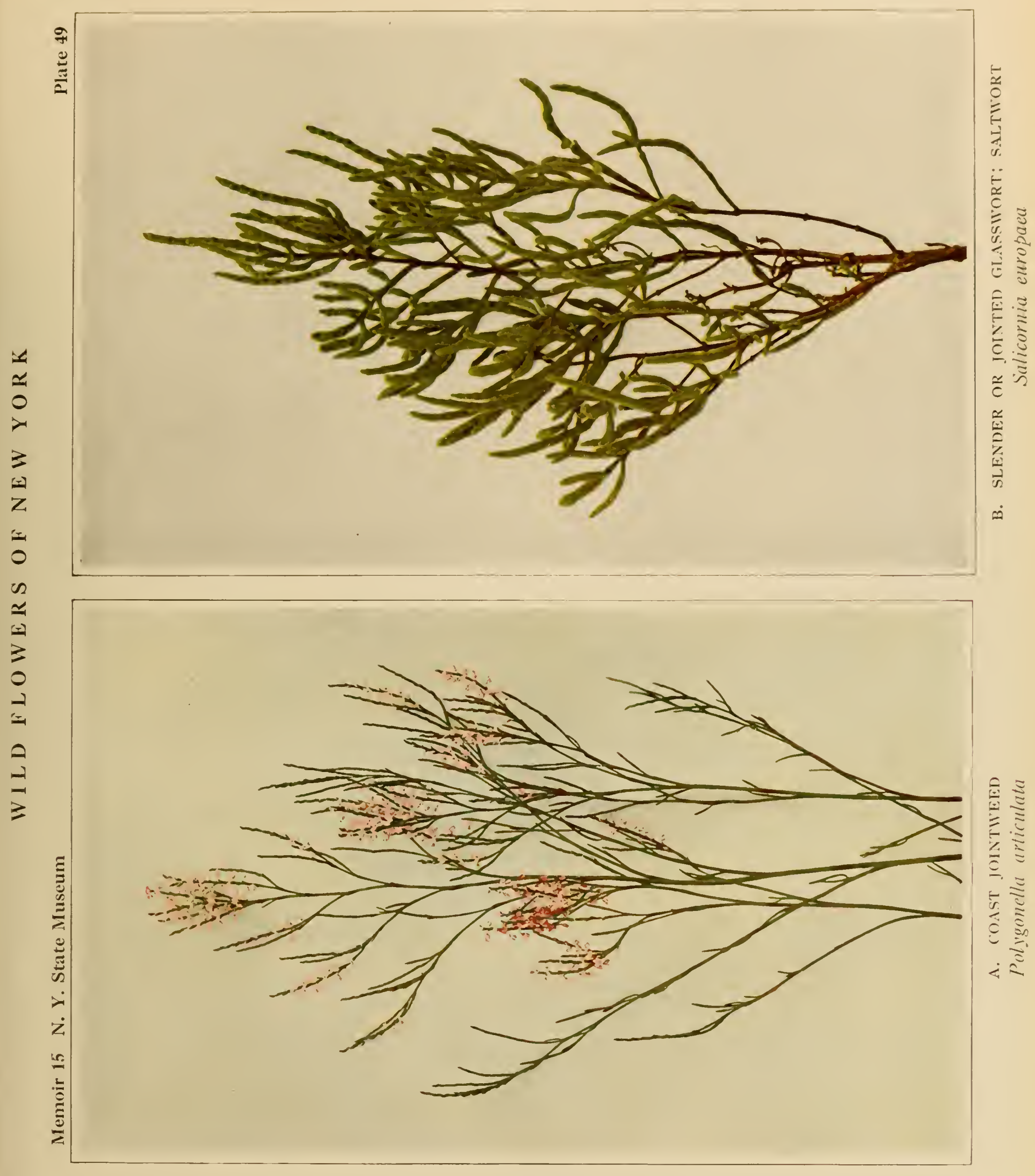



W I L D F L OWERS OF NEW YORK

Memoir 15 N. Y. State Museum

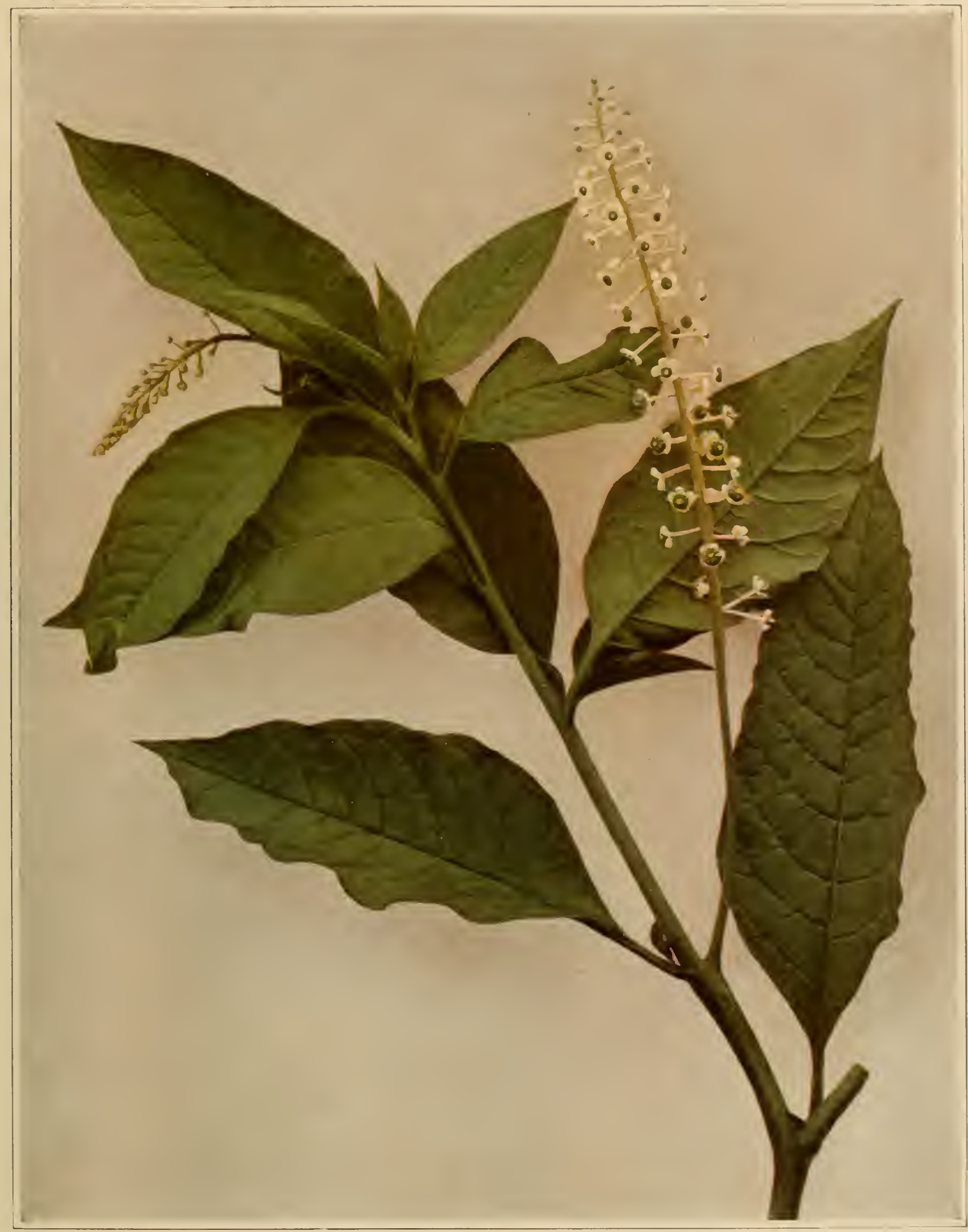

POKE; SCOKE; PIGEON BERRY; GARGET

Phytolacca americana 


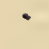




\section{Chickweed Family}

A 1 sin a cea e

\section{Field or Meadow Chickweed}

Cerastium ariense Linnacus

Plate 6.33

A densely matted or tufted perennial plant, usually more or less pubescent. Flowering stems + to io inches high, simple or sparingly branched. Lower leaves and those of the numerous sterile shoots linearoblong, close together, slightly narrowed at the base. Leaves of the flowering stems more distant, linear or narrowly lanceolate, one-half to $I \frac{1}{2}$ inches long, one-eighth of an inch wide or slightly wider. Flowers white, one-half to three-fourths of an inch broad, several in a cymose inflorescence. Petals five, obcordate or deeply notched at the ends, much longer than the lanceolate, acute sepals. Fruit a small, cylindrical capsule, a little longer than the sepals and slightly oblique at its apex.

In dry, rocky places, stony fields or ledges, Labrador to Alaska, south to Georgia, Missouri, Nevada and California. Also found in Europe and Asia. Flowering from April to July. In New York usually in bloom during some part of May.

This is a much larger flowered and more attractive plant than the Mouse-ear Chickweed (Cerastium vulgatum Linnaeus), which is naturalized almost everywhere, especially in the stony or rocky places where the Field Chickweed is found.

\section{Pink Family}

Caryophy 11 a ce a e

\section{Bladder Campion; White Ben}

\section{Silene latifolia (Miller) Britten \& Rendel}

Plate 52

Stems herbaceous, from a perennial root, glaucous and glabrous, or rarely pubescent, extensively branching from the base, 6 to 20 inches high. 
Leaves opposite, ovatc-lanceolate, pointed, variable in sizc, the lower ones oftcn spatulate. Flowers white, two-thirds to seven-eighths of an inch broad, in loose cymosc panicles, often drooping; calyx tubular-campanulate, bccoming globose and much inflated, about one-half of an inch long, strongly veincd, with five triangular, acute lobes; petals five, each two-cleft, with or without a small crown.

In fields, mcadows and wastc places, New Hampshire to Ontario, New Jersey and Missouri. Native of Europe and naturalized in this country. Flowering in July and August.

\section{Wild Pink}

Silene caroliniana Walter

Plate 53

Densely tufted and perennial from a stout root, + to so inches high, viscid-pubescent, especially above, often glabrous below. Basal and lower leaves spatulate or oblanceolate, pointed or blunt, 2 to 4 inches long; stem leaves sessile, shorter, oblong or lanceolate. Flowers pink, about I inch broad, in terminal cymes. Calyx narrow and tubular, much enlarged by the ripening pod, its teeth ovate, pointed; petals cuneate, emarginate, eroded or finely toothed at the apex, crowned at the base of the claw.

In dry, sandy or rocky soil, Maine to Georgia, west to central New York, Pennsylvania and Kentucky.

\section{Cuckoo-flower; Ragged Robin}

\section{Lychnis flos-cuculi Linnaeus} Plate 5 ta

Stems slender, erect, I to 2 feet high, simple or branching, from a thick, perennial root, downy-pubescent below, slightly viscid above. Lower and basal leaves spatulate or oblanceolate, 2 to + inches long; upper leaves lanceolate or linear-lanceolate, opposite and sessile, the uppermost leaves reduced to small bracts; flowers pink, purplish, blue, or white, threefourths to I inch broad, in many-flowered panicles at the summit of the 


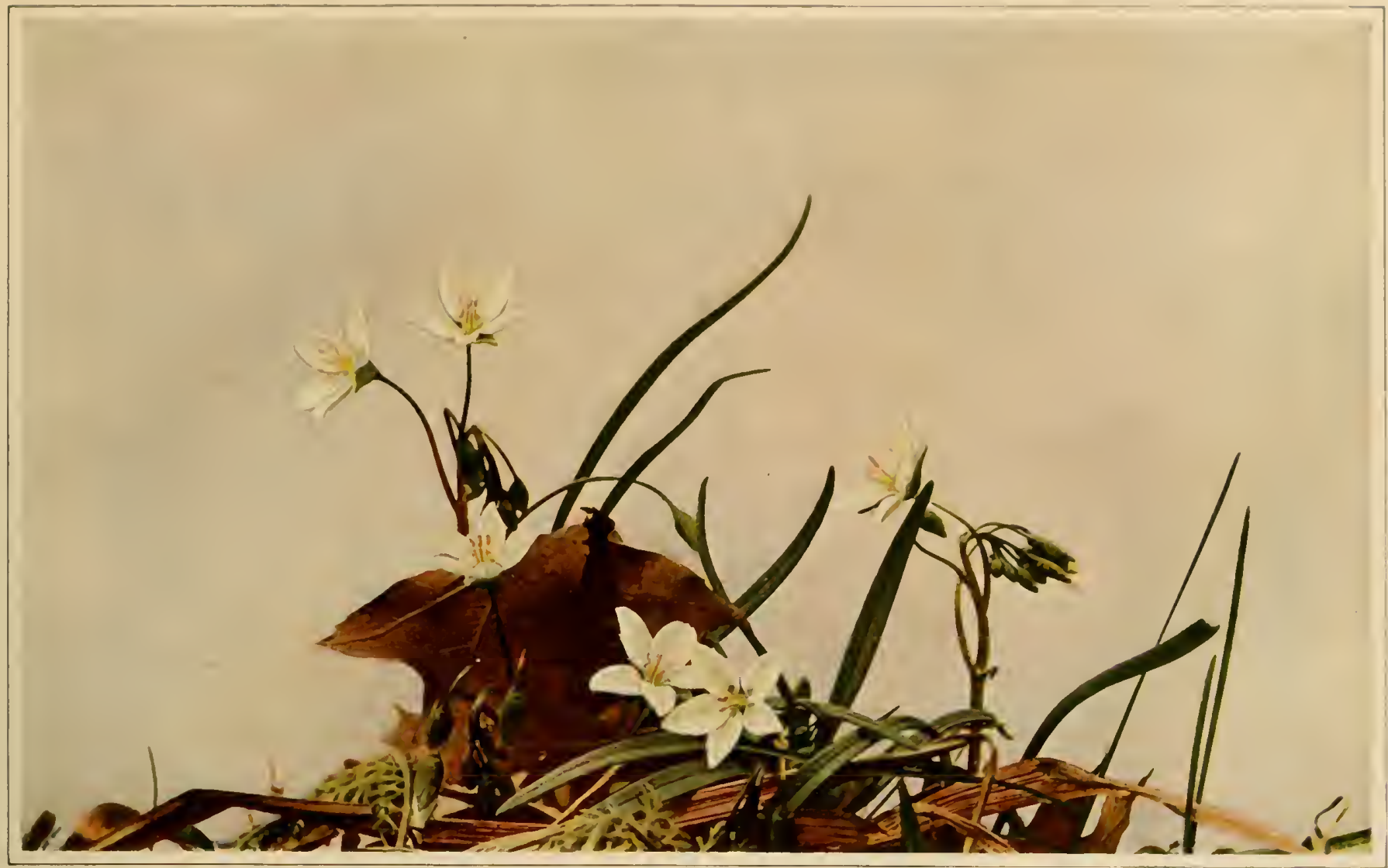

A. NARROW-LEAVED SPRING BEAUTY

Claytonia iirginica

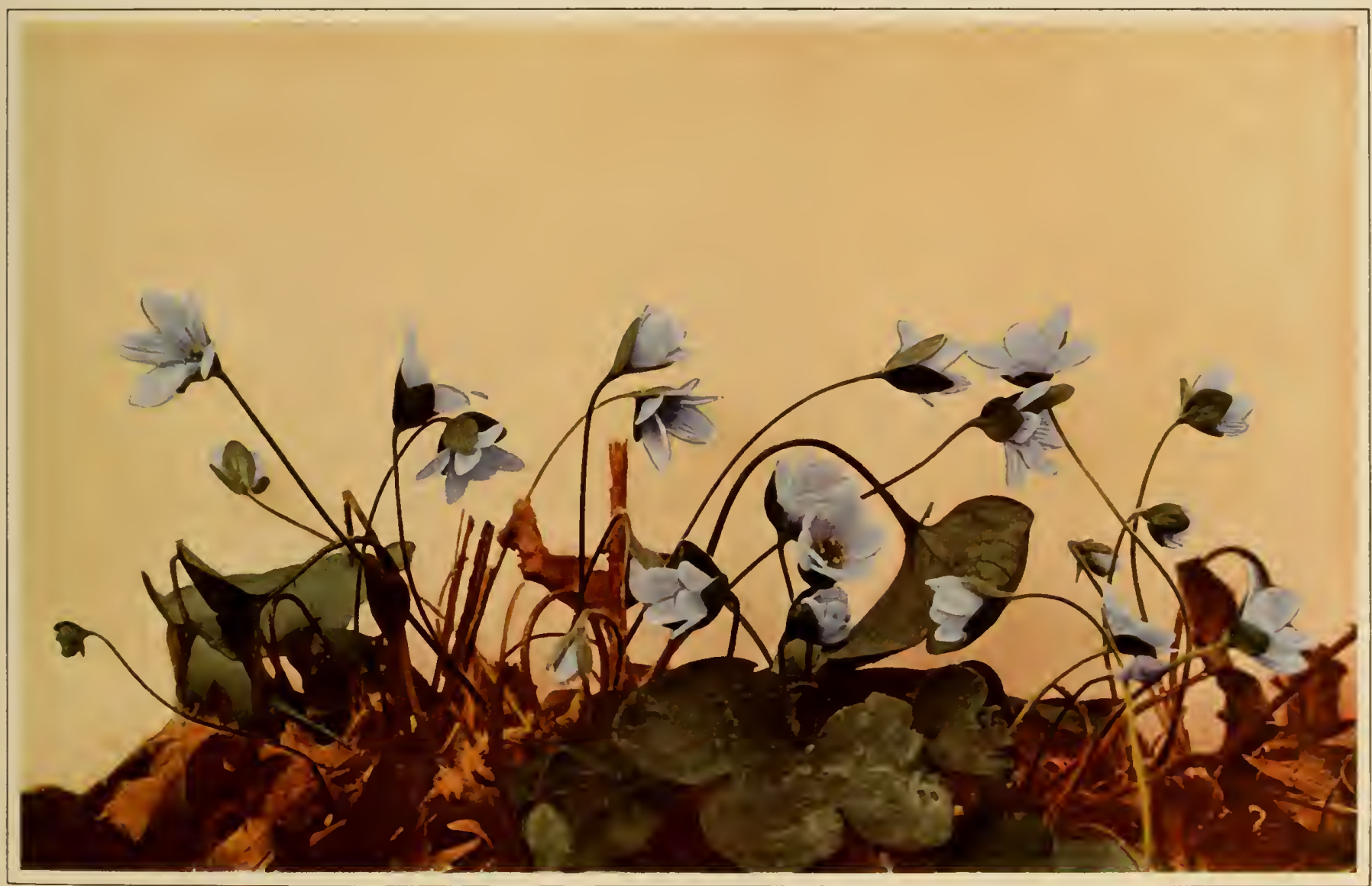

B. ROUND-LOBED HEPATICA OR LIVERLEAF IIepatica hepatica 
. 
WII.D FL, OWERS OF NEW YOR K

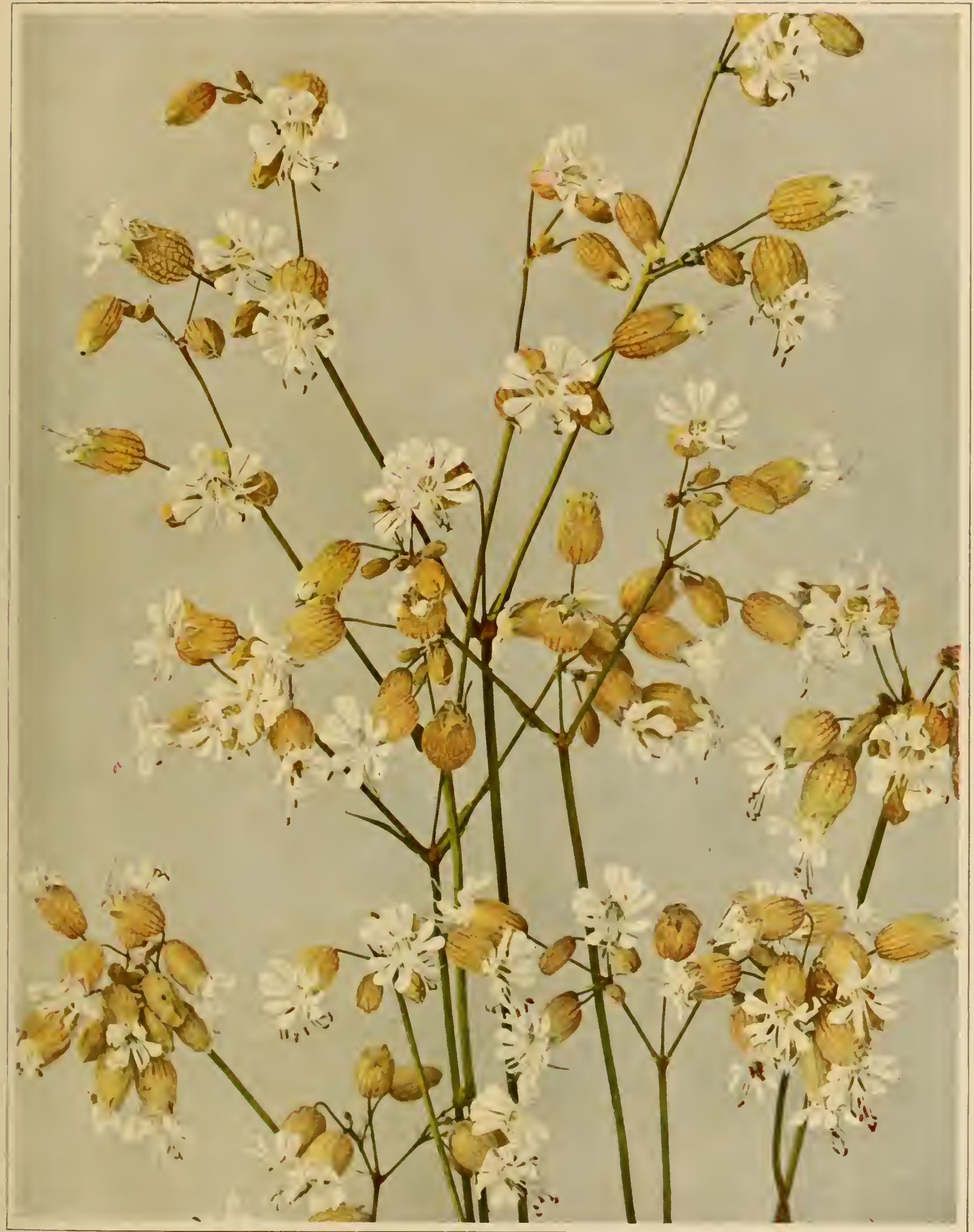

BLADDER CAMPION: IHHTE BEN silene latifolic: 
. 
WILD FLOWERS OF NEW YORK

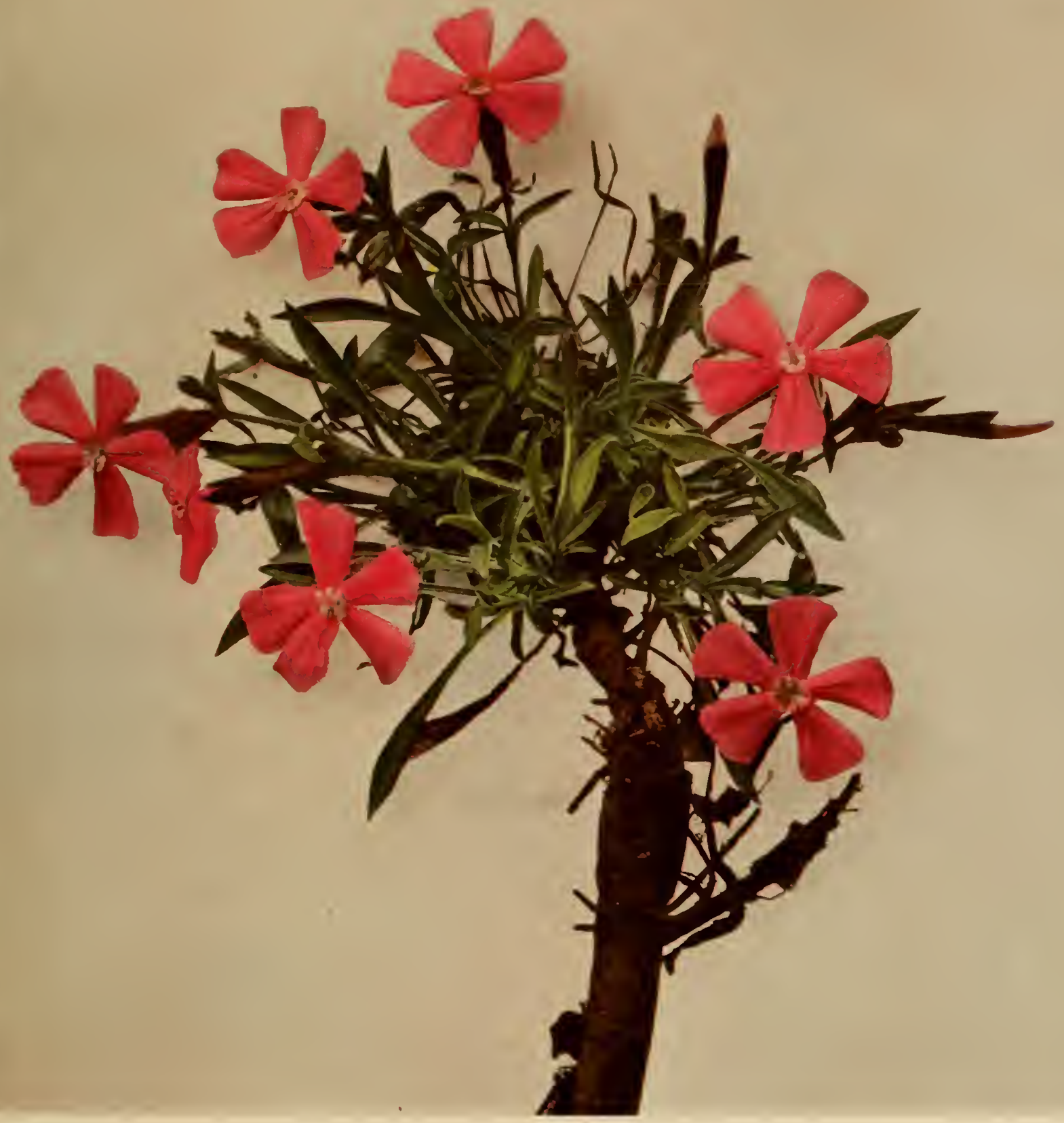

WILD PINK

Silene caroliniana 
. 
stems; calyx one-fourth of an inch long, ten-nerved, cylindrical, becoming campanulate in fruit, its apex with five triangular, pointed teeth; petals five, narrowly clawed, the spreading limbs each cleft in to four linear lobes, of which the middle pair is longest.

Moist meadows, ficlds and waste places, Ncw Brunswick to New Jersey and Pennsylvania. Frequent in cultivation. A native of Europe but thoroughly naturalized in many places in the castcrn states. Flowering in July and August.

\section{Sacred Bean Family}

$\mathrm{N}$ el u m bon a c e a

\section{American Nelumbo or Lotus}

\section{Nelumbo lutea (Willdenow) Persoon}

Plate 55

Rootstock stout, nearly horizontal, tuberiferous, in mud beneath 2 to 6 feet of water. Leaves I to 2 feet broad, orbicular, or somewhat constricted in the middle, centrally peltate, floating or raised a foot or two out of the water, prominently veined, smooth and dark green above, more or less pubescent and finely scaly beneath; leaf petioles and flower stems 3 to 7 feet long, rigid and tough, with several large air canals. Flowers pale yellow, fragrant, + to io inches broad; petals concave, obovate, blunt, numerous, surrounded by four or five overlapping scales. Carpels numerous, contained in pits in the large convex receptacle which becomes 3 to + inches long and obconic in fruit. Seeds about one-half of an inch in diameter.

In rivers and lakes, locally distributed from Massachusetts to Minnesota, Nebraska, Louisiana and Cuba. Flowering in August at Sodus bay, where a large colony of it cxists. Tubers and seeds farinaceous and edible. The local distribution in the north may be due to introduction by the Indians. The Indian Lotus or Sacred Bean ( $\mathrm{N}$ e $1 \mathrm{um}$ b o $\mathrm{ne} l \mathrm{um} \mathrm{bo}$ (Linnaeus) Karsten), with large pink flowers, is frequent in cultivation. 


\section{Water Lily Family}

Nymphacaceac

\section{Large Yellow Pond Lily; Spatter-dock \\ Nymphaea adrena Solander \\ Plate 56}

Floating and emersed leaves 5 to 12 inches long and 5 to 9 inches broad, ovate or orbicular-oval, thick, with a sinus 2 to 5 inches deep and generally open; submerged leaves, when present, thin and membranous; petioles, peduncles and lower surfaces of the leaves usually pubescent. Flowers $1 \frac{1}{2}$ to $2 \frac{1}{2}$ inches broad, depressed, globose, yellow, usually tinged with purple within; sepals six, oblong; petals fleshy, oblong truncate, onehalf to two-thirds of an inch long; stamens numerous in five to seven rows; carpels numerous, united into a compound pistil which is surmounted by an undulate, yellow or pale-red stigmatic disc with twelve to twenty-four rays, ripening into an ovoid, berrylike fruit, I to 2 inches long and about I inch thick, maintained at the surface of the water or above it.

In ponds, lakes, slow streams or often subterrestrial in boggy meadows, Labrador and Nova Scotia to the Rocky mountains, south to Florida, Texas and Utah. Flowering from May to September. Consists of several races or perhaps species, differing in the character of the pistil, stigmatic disc and leaf outline. In the lakes and ponds throughout the north the small Yellow Pond Lily ( $\mathrm{ym} \mathrm{mhaea} \mathrm{microphylla}$ Persoon) is also found, with flowers I inch broad or less, and small leaves 2 to 4 inches long and $\mathrm{I}$ to 3 inches broad. The northern form of the larger Yellow Pond Lily is described in some books under the name of $\mathrm{Nym} \mathrm{pha} \mathrm{e} \mathrm{a} \mathrm{vari-}$ e g a t a (Morong) Greene, and a hybrid between the two, N y m p h a e a $\mathrm{rubrod}$ is c a (Morong) Greene, is of frequent occurrence, having fewer stigmatic rays than $\mathrm{N}$. v a ri e g a t a and spatulate petals. Our illustration is from a plant on Long Island. 


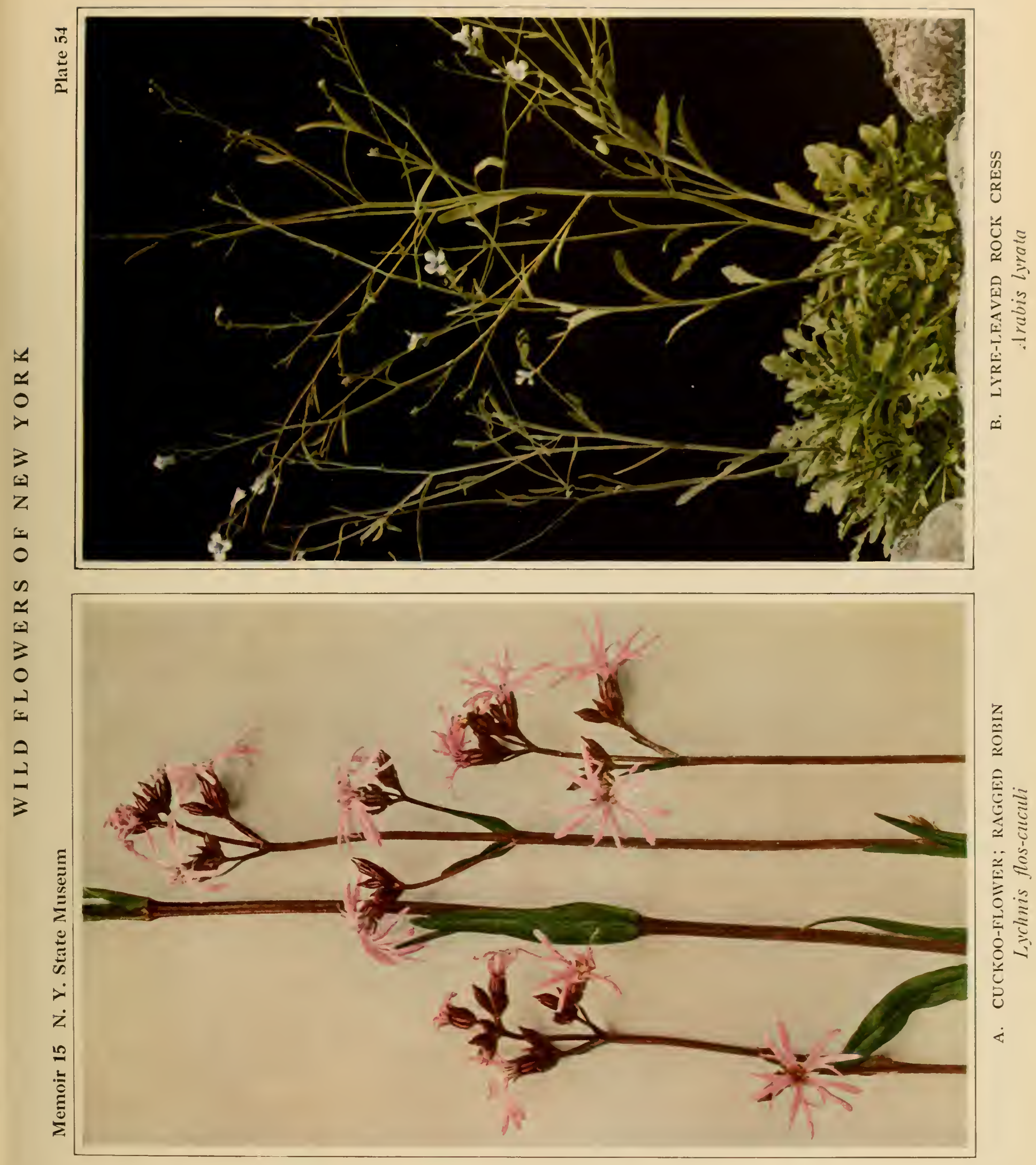




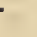


IV I I, I) F LOWERS O F NEW YOR K

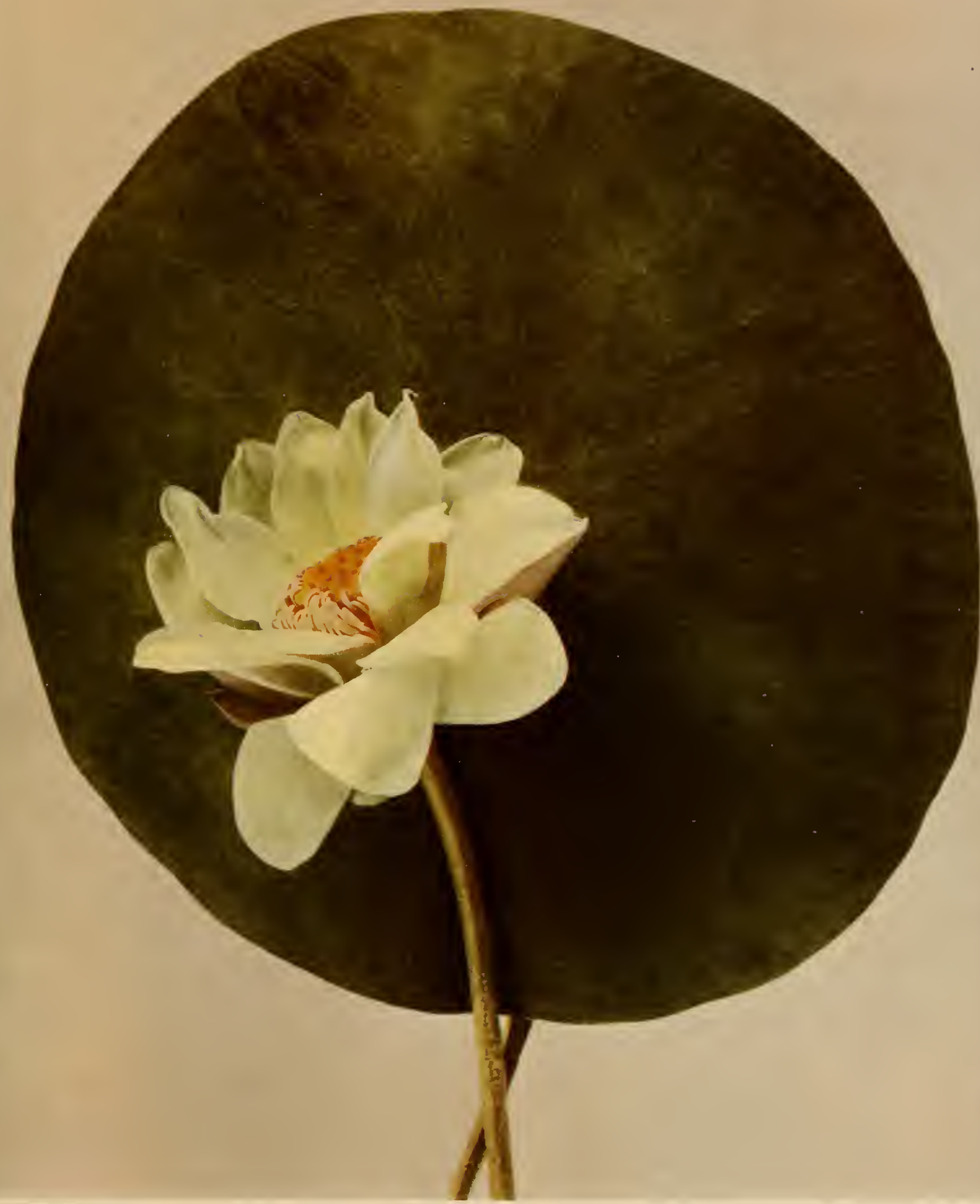

AMERICAN NELL'MBO OR LOTUS

Nelumbo lutea 


$$
\text { . }
$$




\section{Sweet-scented White Water Lily}

\section{Castalia odorata (Aiton) Woodville \& Wrood}

Plate 57

Aquatic, with a thick, horizontal rootstock. Lcaves floating, orbicular or nearly so, + to 2 inches in diameter, glabrous, green and shining above, purple and somewhat pubescent beneath, the sinus open or almost closed, petioles and pcduncles slender with four main air channels. Flowcrs white or in some varicties pink or rose-colorcd, 3 to 6 inches broad, very fragrant, with four greenish sepals and numerous, narrowly oblong, blunt petals, the inner ones shorter and narrower and gradually passing into stamens; stamens numerous and yellow. Carpels numerous, united into a compound pistil with radiating, linear, projecting stigmas, becoming a globosc, fleshy fruit and ripcning beneath the surface of the water by the coiling of the peduncles.

In ponds, lakes and slow streams, Newfoundland to Manitoba, south to Florida, Louisiana and Kansas. Flowering from June to August.

\section{Tuberous White Water Lily}

\section{Castalia tuberosa (Paine) Greene}

Plate 58

Leaves orbicular, 5 to 12 inches in diameter, floating, green on both sides, sometimes slightly pubescent beneath, sinus open or closed. Rootstock thick, with numerous lateral tuberous-thickened branches which become detached and propagate the plant. Flowers white, 4 to 9 inches broad, slightly fragrant or inodorous; petals oblong, broader than those of C. o d o r a t a, obtuse. Fruit depressed-globose.

In shallow water of bays and protected coves, Lake Champlain, Lake George, Oneida lake and along the Great Lakes to Michigan, south to Delaware and eastern Nebraska and Arkansas. Flowering in July and August. 


\section{Crowfoot Family}

R a nu culaceac

\section{Marsh Marigold; Cowslip}

Caltha palustris Linnaeus

Plate 59

A succulent, herbaceous plant with stout, glabrous, hollow stems, erect or ascending, I to 2 feet high, branching and bearing several or numerous bright-yellow flowers. Lower leaves long petioled, the blades cordate or reniform, 2 to $\delta$ inches broad, with a narrow sinus, crenate. dentate, or nearly entire on the margin. Upper leaves smaller, with short petioles or sessile with nearly truncate bases. Flowers I to $\mathbf{I} \frac{1}{2}$ inches broad; sepals oval, obtuse, petallike. True petals none. Stamens numerous, obovoid. Carpels several, in fruit forming follicles which are slightly compressed, about one-half of an inch long, and slightly curved outward.

In swamps, wet meadows and marshes, Newfoundland to South Carolina, west to Saskatchewan and Nebraska. Flowering in May and June.

\section{Goldenseal; Orange-root}

\section{II yrastis canadensis Linnaeus}

Figure XT

An erect, perennial herb with a thick yellow rootstock. Stems io to I 5 inches high. Usually each plant with a single, long-petioled basal leaf which is 5 to 8 inches broad and palmately 5 to 9-lobed, the lobes broad. pointed, sharply and unequally toothed. Stem leaves two, borne at the summit of the stem, similar in shape but smaller than the basal leaf, the uppermost leaf just below the solitary, greenish white flower, which is one-third to one-half of an inch broad. Sepals three, petallike and falling away as the flower opens. Petals none. Stamens numerous, their filaments widened and about one-sixth of an inch long; anthers oblong, obtuse. Carpels several, ripening into an ovoid, crimson head of fruit about two- 


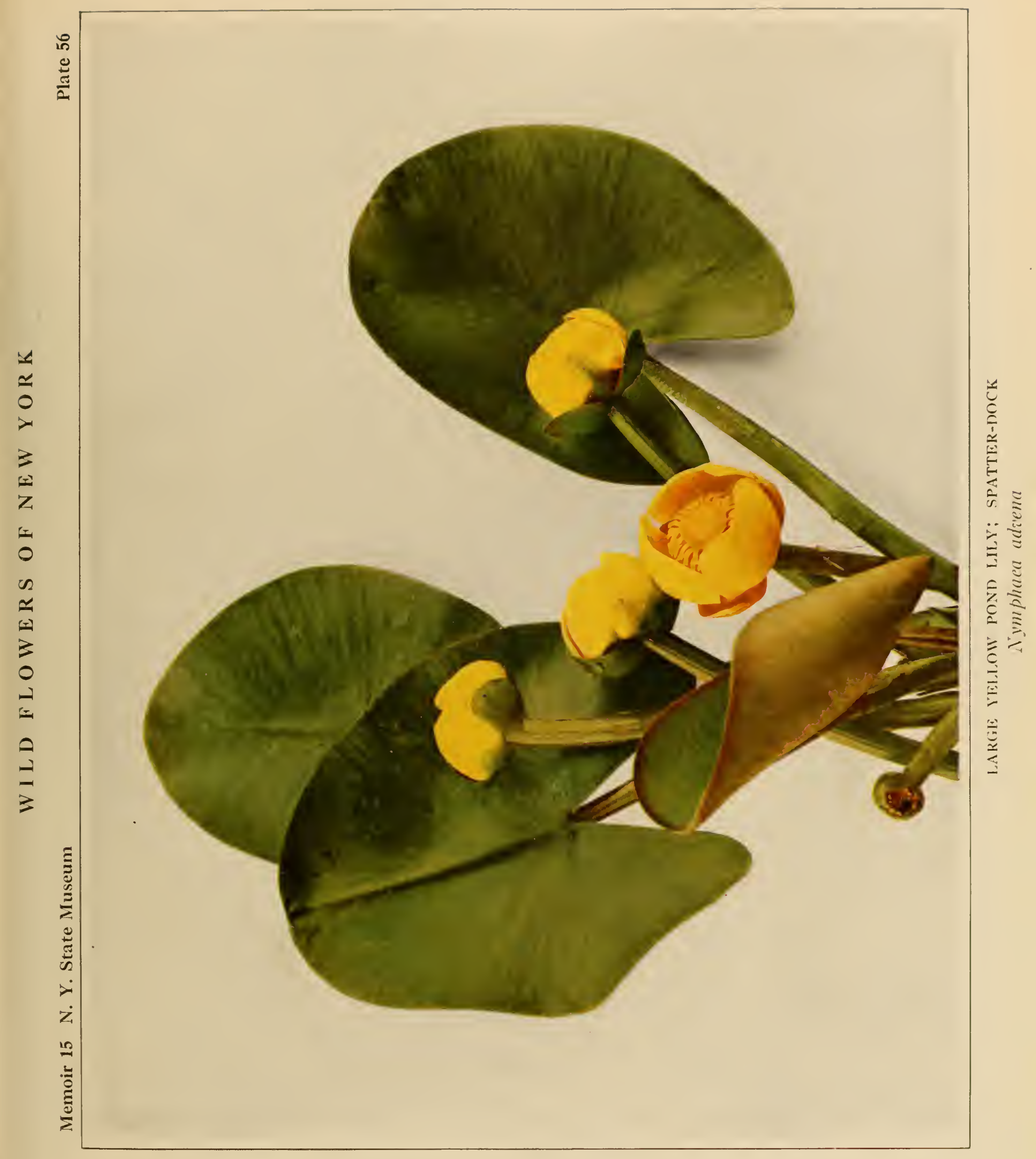


WI L, D IE L OWERS OE NEW YORK

Memoir 15 N. Y. State Museum

Plate 57

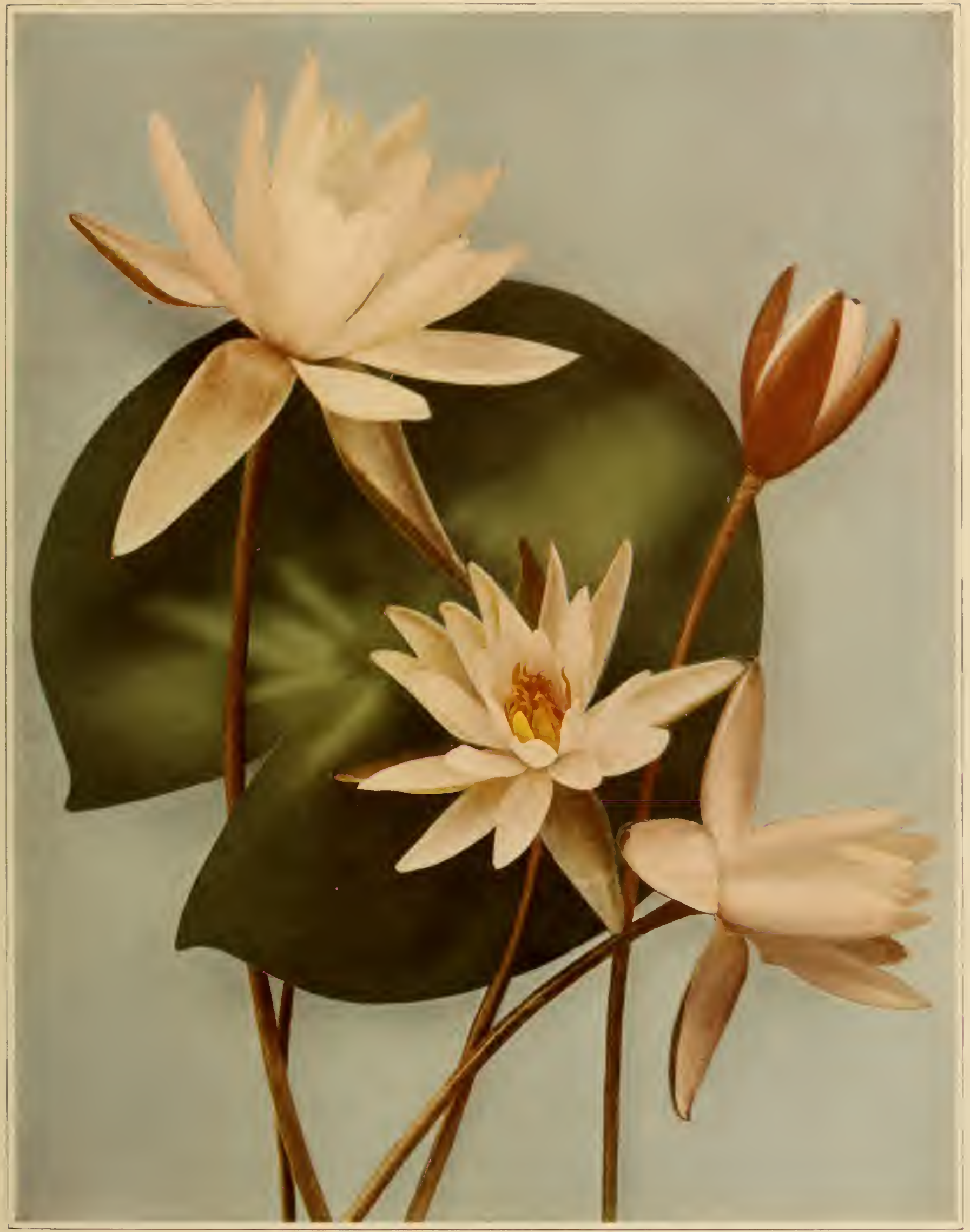

SWEET-SCENTED WHITE WATER LILY

Castalia odorata 


$$
\text { - }
$$


WILD I I, O WERS OF NEW YORK

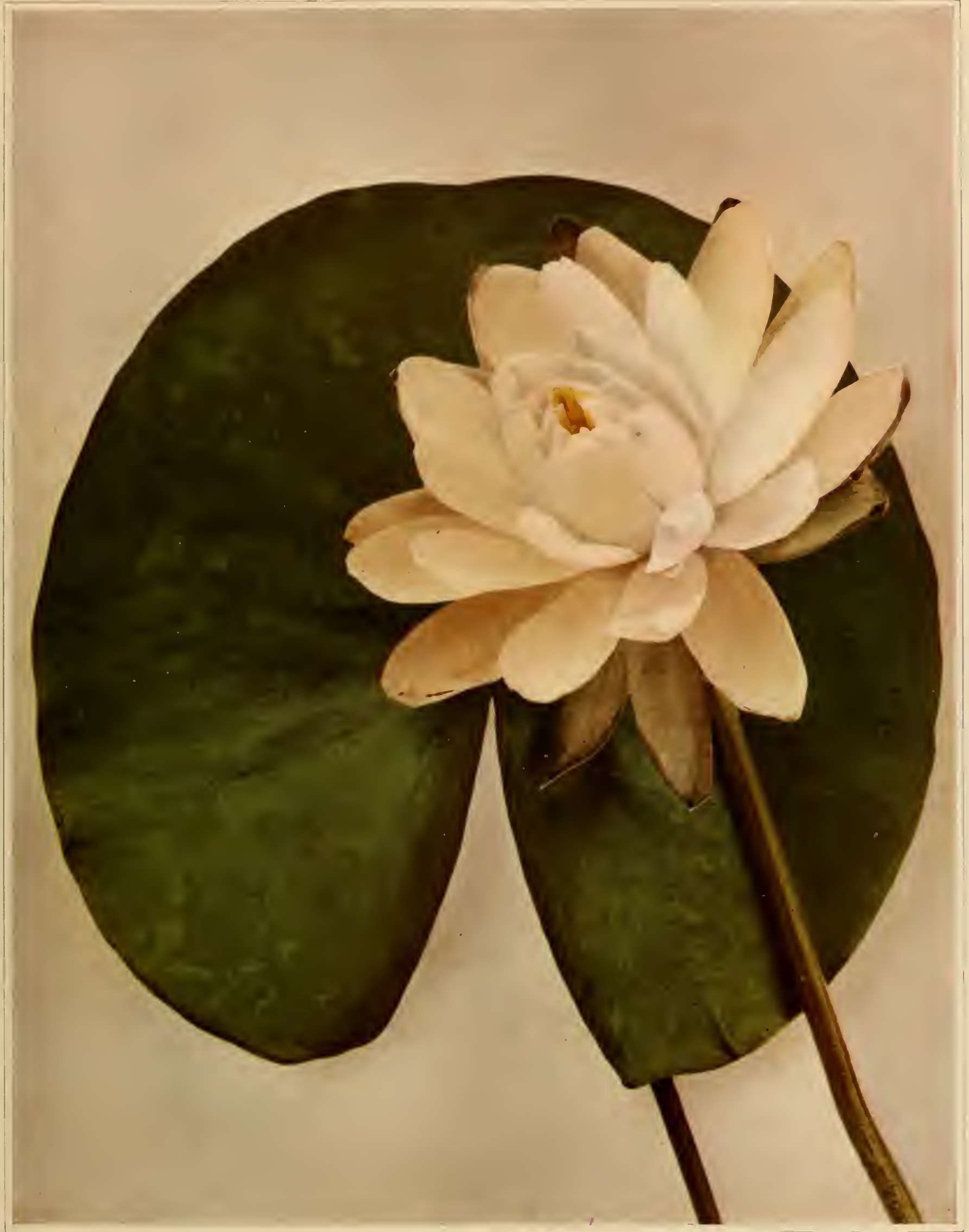

TLBEROY'S WHITE WATER LILY

Castalia tuberosa 


$$
\bullet
$$


thirds of an inch long, each carpel in fruit tipped with a short rccurved bcak.

In moist or low woodlands, Connecticut to Minncsota, Ontario, Kansas and Missouri, south to Gcorgia.

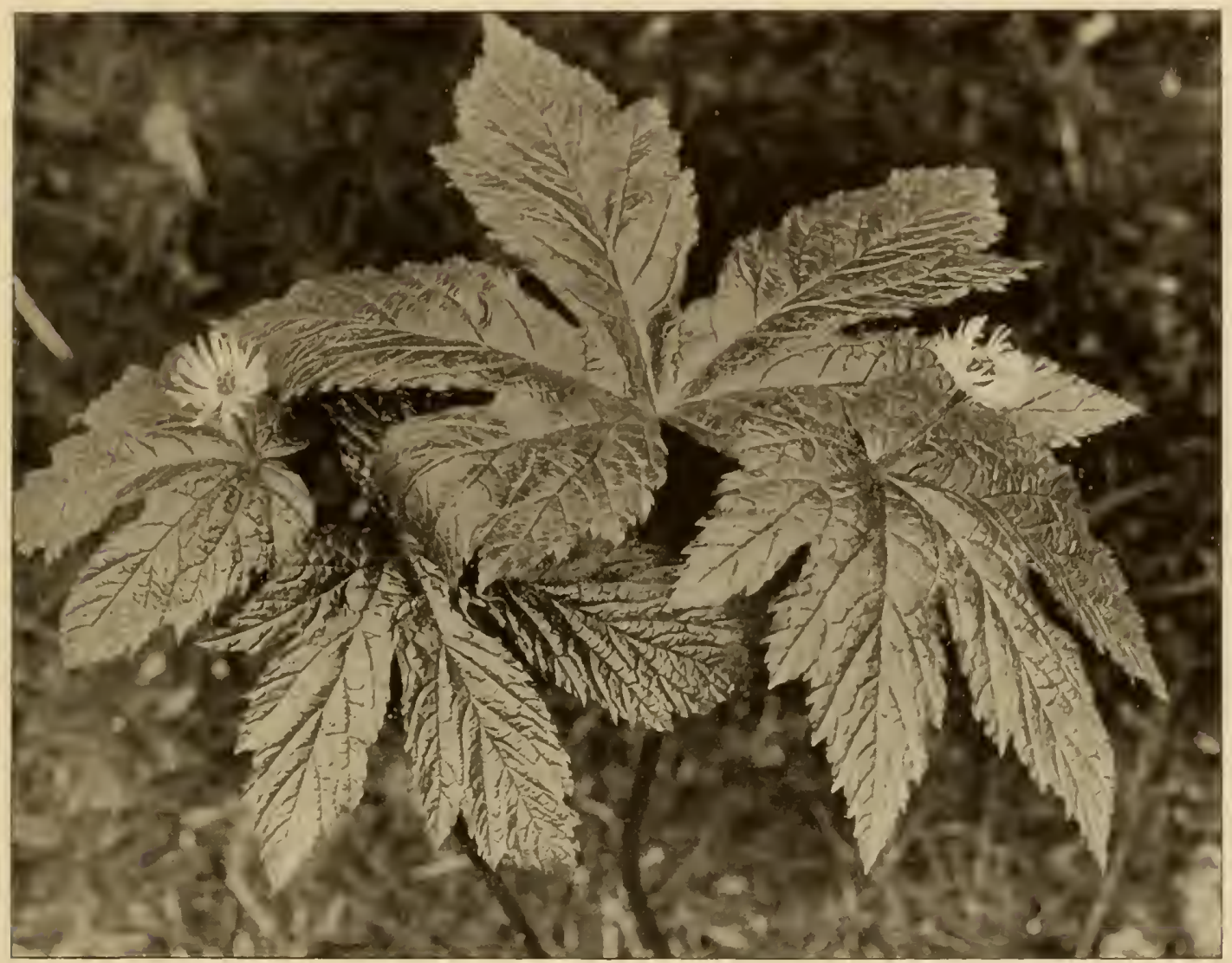

Figure XV

Goldenseal or Orange-root

(H y drastis can a densis Linnaeus)

\section{American Globeflower}

Trollius laxus Salisbury Plate 6I

Stems few or several from a perennial fibrous root, erect or ascending, often slightly fleshy but weak, from a few inches to 2 feet long. Lower 
leaves long-stalked; upper ones short-stalkerl or sessile; blades 3 to 5 inches broad, parted into five to seven wedge-shaped, cleft or toothed segments, the blades small at flowering time, much enlarged later. Flowers $\mathbf{I}$ to $\mathbf{I} \frac{\mathbf{1}}{2}$ inches broad, with five to seven spreading, yellowish green, petallike sepals; true petals minute, fifteen to twenty-five in number and much shorter than the numerous yellow stamens. Fruit about I inch broad, consisting of several small pods (follicles) each about one-fourth of an inch long and tipped with a straight, slender beak of about one-fourth its length.

A rare or local plant of low or swampy woodlands, New England to Delaware, central and western New York to Michigan. Flowering from April to June.

\section{Goldthread}

Coptis trifolia (Linnaeus) Salisbury

A low, herbaceous plant with a slender or filiform bright-yellow, bitter rootstock. Leaves all basal, evergreen, long petioled, the blade reniform, I to 2 inches broad, divided to the petiole into three wedge-shaped, obtuse segments, dark green, shining above, paler beneath, sharply toothed. Scape one-flowered, slender; sepals five to seven, oblong, obtuse, white; petals small and club-shaped; carpels three to seven, spreading, about one-fourth of an inch long, on stalks of about their own length, tipped with a beak.

In damp, mossy woods and bogs, Newfoundland to Virginia and eastern Tennessee, Iowa, Minnesota and Alaska.

In the Memoirs of Bastram and Marshall, page 20, it is stated that John Ellis, the eminent naturalist, in a letter to Linnaeus, dated London. April 25. I758, says: "Mr Colden of New York, has sent Dr. Fothergill a new plant, described by his daughter (Miss Jane Colden). It is called Fibraurea, gold thread. This young lady merits your esteem and does honor to your system. She has drawn and described $t 00$ plants in your method only. She uses the English terms. Her father has a plant called after him, Coldenia; suppose you should call this Coldenella, or any other 
WII, I) FI, OWERS OF NEW YORK

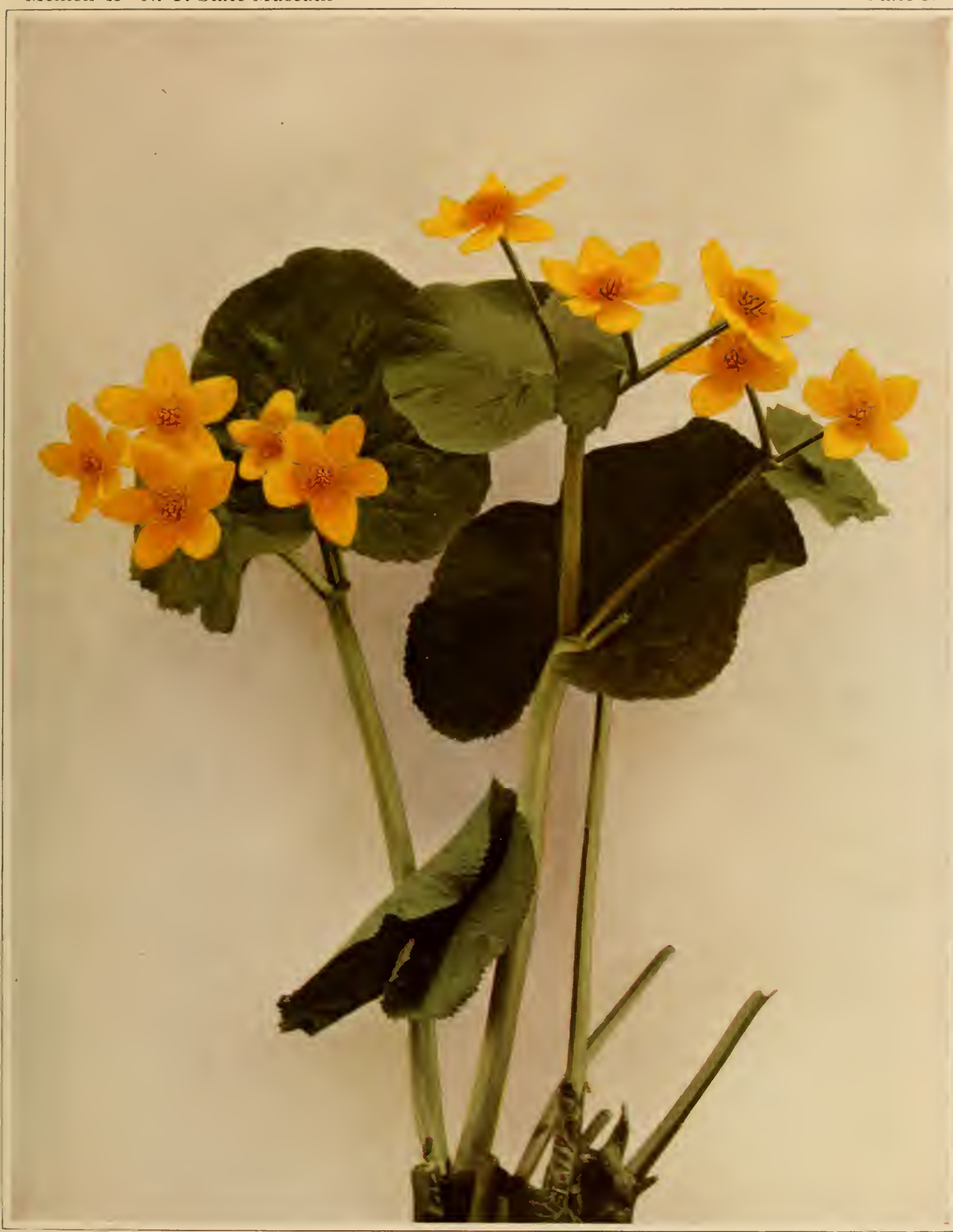

MARSH MARIGOLD; COWSLIP

Caltha palustris 

WIL,D FI, OWERS OF NEW YORK

Memoir 15 N. Y. State Museum

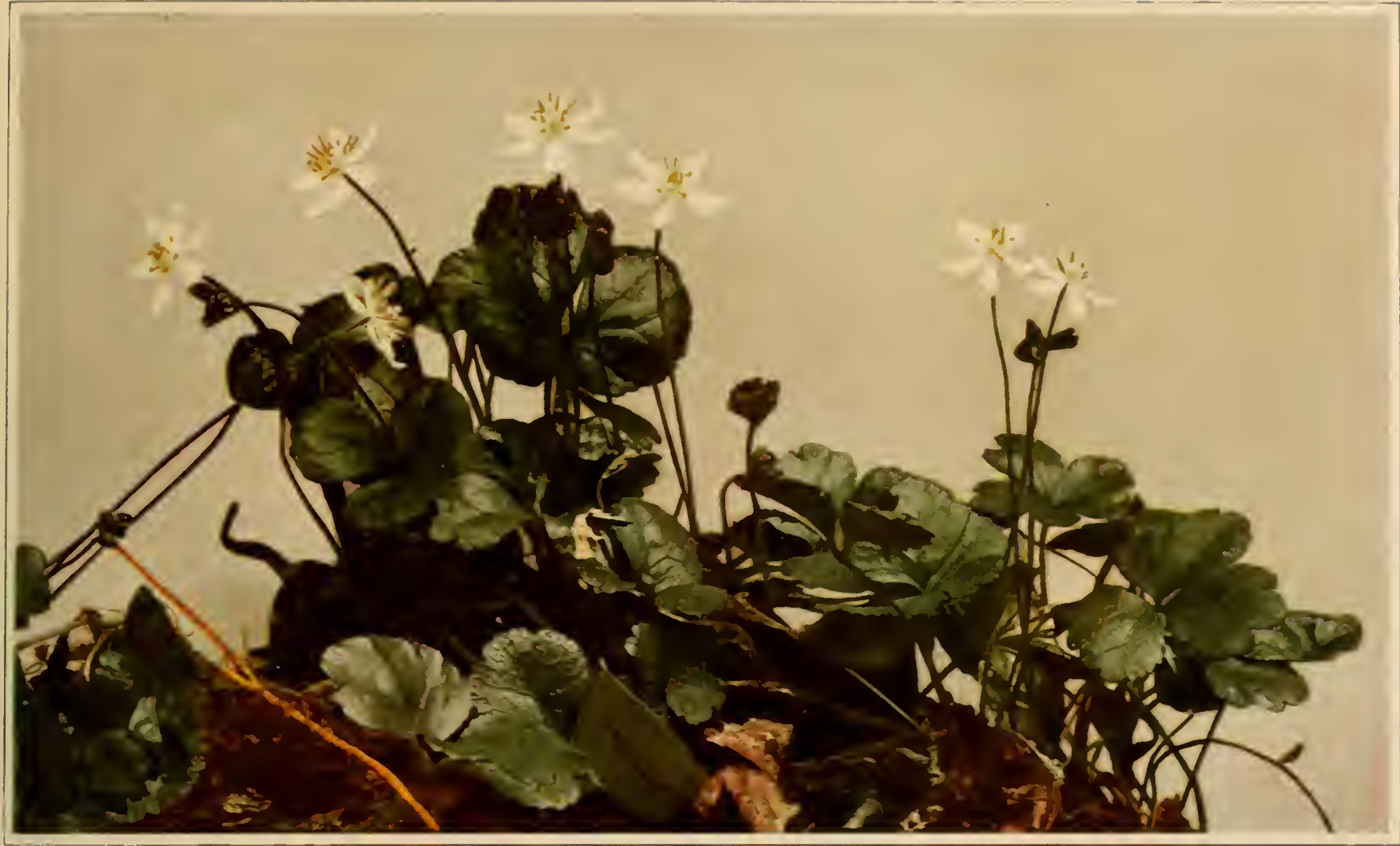

A. GOLDTHREAD

Coptis trifolia

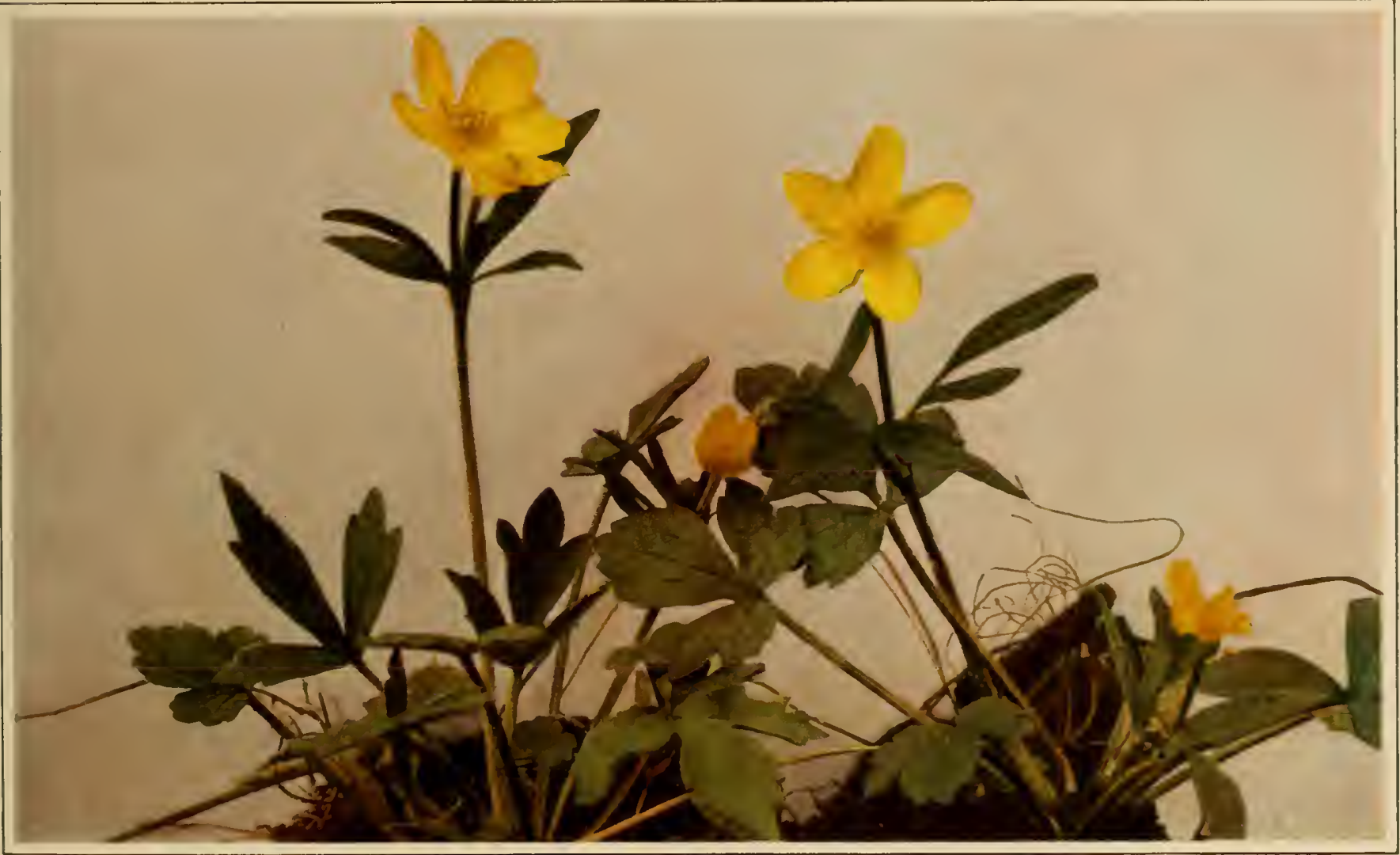

B. HISPID BUTTERCUP

Ranunculus hispidus 

WI I D F I, O WERS OF NEIV YORK

Memoir 15 N. Y. State Museum

Plate 61

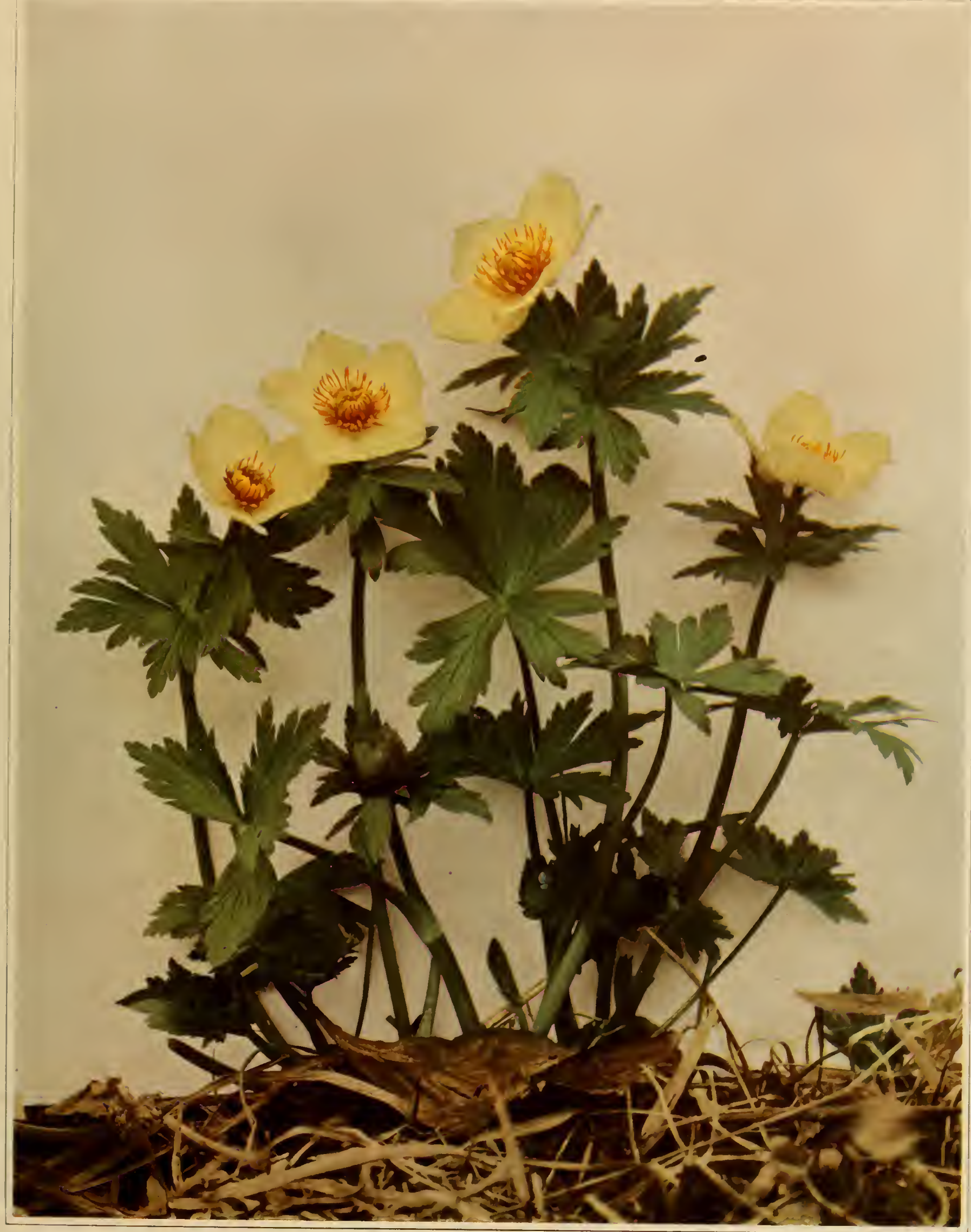



name that might distinguish her among your genera." Linnacus, however, referred the plant to his genus Helleborus, and when it was subsequently ascertained to be distinct, Salisbury, regardless alike of gallantry and justice, imposed on it the name of Coptis.

\section{Red Baneberry; Black Cohosh \\ Actaea rubra (Aiton) Willdenow Plate 62}

Stems erect, I to 2 fect high, from a percnnial root, pubcscent or smooth. Leaves tcrnately divided, the divisions pinnatc with the lower ultimate leaflets sometimes again compound; leaflets ovate or the terminal ones obovate, toothed or more or less clcft or inciscd with pointed or rounded teeth. Flowers small in a dense tcrminal, ovoid racemc; sepals three to five, petaloid and fugacious. Petals four to ten, spatulate, shorter than the numerous white stamens; pedicels slender, one-half to two-thirds of an inch long. Fruit consisting of a raceme of bright-red, oval or ellipsoid berries, each berry about one-half of an inch long.

In woods, thickets and shaded banks, Nova Scotia to New Jersey and Pennsylvania, west to South Dakota and Nebraska. Flowering from April to early June. A variety with red berries on slender pedicles (A c ta e a neglect a Gillman) is occasionally found.

\section{White Baneberry; Snakeroot Actaea alba (Linnaeus) Miller Plate 63b}

Resembling the Red Baneberry in general habit and aspect. Leaflets usually more cut and the teeth and lobes sharply pointed. Flowers in oblong racemes; petals truncate at the apex; fruiting pedicels as thick as the peduncle or in fruit even thicker, with swollen ends, often reddish; berries short-oval, white, sometimes purplish at the ends. A variety with berries on thickened pedicels is occasionally seen.

In rich woods, Nova Scotia to Georgia, west to Minnesota and Missouri. Flowering in April and May or as late as the middle of June. 


\section{Black Snakeroot; Black Cohosh}

\section{Cimicifuga racemosa (Linnaeus) Nuttall}

Plate 04

Stcms tall and slcnder, 3 to 8 fect high, leafy above, rootstock thick and perennial. Lcaves ternate with pinnate divisions; lcaflets ovate or oblong, the terminal ones usually obovate, pointed at the apex, truncate or narrowed at the base, margins coarscly toothcd, cleft or divided, rather thick tcxture, smooth or nearly so. Flowers white, with a somewhat fetid odor, in tall, terminal, simple or compound racemes, 6 to 30 inches long, each flower about one-half of an inch broad; petals four to eight, two-clcft; stamens very numerous; pistils one or two, sessile. Fruiting follieles oval, about one-fourth of an inch long, minutely beaked.

In woods and shaded rocky places, Maine and Ontario to Wisconsin, south to Georgia and Missouri. Flowering in July and August.

\section{Wild Columbine; Rock Bells}

\section{Aquilegia canadensis Linnaeus}

Plate 65

Erect and branching, glabrous or somewhat pubeseent, I to 2 feet high, from a perennial root. Leaves ternately decompound, the lower and basal leaves slender-petioled, + to 8 inches broad, the ultimate leaflets I to 2 inches broad, sessile or short stalked, obovate, obtuse, cuneate, obtusely lobed and toothed, pale beneath; leaves of the upper part of the stem lobed or divided. Flowers nodding, I to 2 inches long, searlet or rarely white or yellow; sepals five, regular, petaloid; petals concare, produced backward between the sepals into hollow, nearly straight spurs, one-half to three-fourths of an ineh long, thickened at the end; stamens numerous, with the styles long exserted. Fruit erect, consisting of five united carpels with slightly spreading filiform beaks.

In roeky woodlands and clearings, Nova Scotia to the Northwest Territory, south to Florida and Texas. Flowering from the latter part of April until June. 


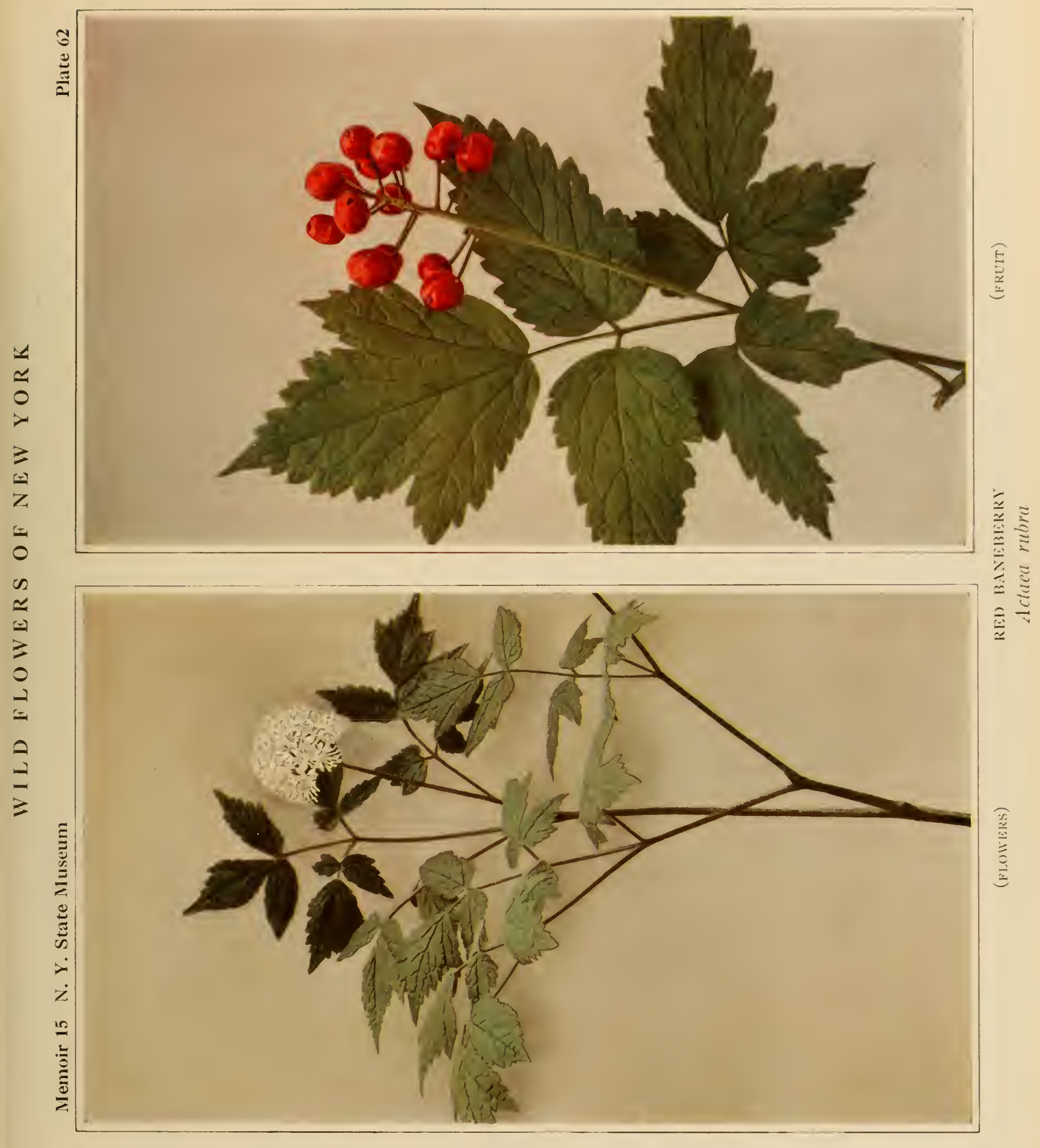





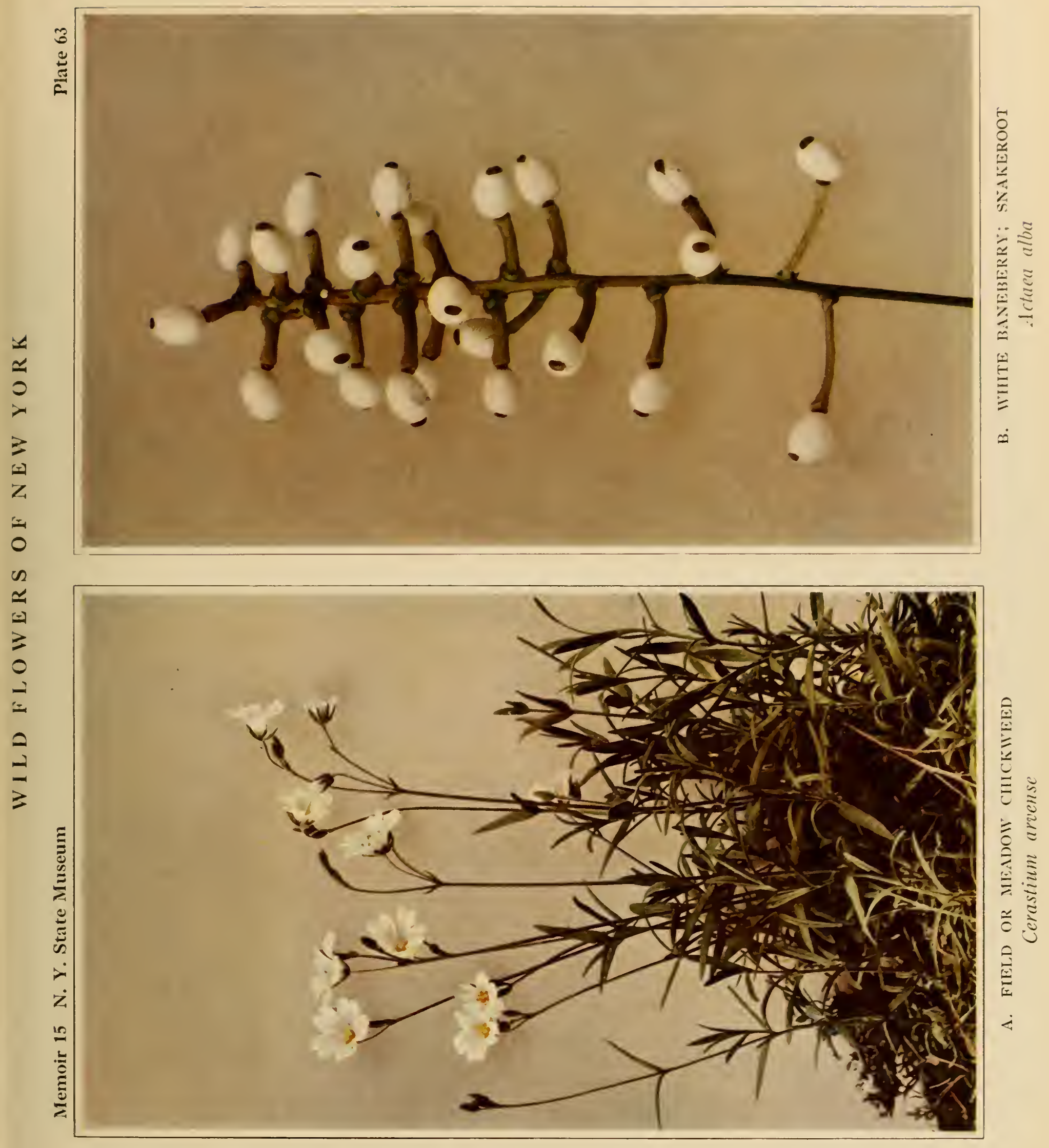


- 
Known in many localitics as Honcysuckle, a name which should more properly be applicd to species of the genus Loniccra. The European Columbine (A quilegia vulgaris Linnacus) with showy, blue, purple or whitc flowers is an occasional cscape from gardens into woods and fields.

\section{Tall Anemone; Thimbleweed}

Anemone virginiunc Linnacus

Plate 66

Stem stout, hairy, 2 to 3 fect tall, branching above at the involucre which is composed of two to five, usually three, short-petioled leaves; the latcral peduncles often bearing secondary involucres of smaller leaves. Basal leaves long petioled, broader than long, threc-parted, the divisions broadly cuncate-oblong, variously cleft and divided into acute, serratc lobes; those of the involucres similar. Flowers two-thirds to $\mathrm{I} \frac{1}{2}$ inches broad, on peduncles + to Io inches long; sepals five, white, obtuse: stamens numcrous, shorter than the sepals. Carpels numerous, forming an oblong to subcylindric head, two-thirds to I inch long and about one-half as thick.

In woods, thickets and clearings, Nova Scotia to Alberta, south to South Carolina, Arkansas and Kansas. Flowering from May to July or August. Consists of several races, differing in size and color of flower, shape of fruit, and in the styles. Of these, the most distinct is Anemone r i p a ri a Fernald, with smaller greenish flowers and pointed sepals.

The Slender-fruited Anemone (A ne m o ne cylindric a A. Gray), which is frequent in sandy woods and thickets in the castern states has silky hairy stems and tufted basal leaves with narrower divisions, white or grcenish flowers about three-fourths of an inch broad and the head of fruit cylindric, I inch long or often longer and one-fourth to one-third as thick.

\section{Canada or Round-leaved Anemone}

\section{Anemone canadensis Linnaeus} Plate 67

Stems slender or stout, I to 2 feet tall, somcwhat hairy, especially on the lower surfaces of the leaves, branching at the involucre. Basal leaves 
long petioled, broader than long, three to five-pointcd, the divisions broad, oblong, acute, variously cleft or toothed, those of the primary and secondary involucres similar but scssilc. Flowers $\mathrm{I}$ to $\mathbf{I} \frac{1}{2}$ inches broad; sepals white or somctimes tingcd with pink, oblong, obtusc; head of fruit globose, consisting of numerous flattened, orbicular, pubescent achenes, tipped with stout, persistent styles.

Low grounds, along roadsides, railroads and in open woods, Labrador to Assiniboia, Massachusctts, Maryland, Illinois, Kansas and Colorado Very closely related to A n e m o n e d i c h o t o m a of Siberia. Flowering from May to August, by the development of secondary involucres.

\section{Windflower; Wood Anemone \\ Anemone quinquefolia Linnaeus \\ Plate 68a}

Smallest of our wild anemones. Stems simple, glabrous, 4 to ro inches high, from horizontal, perennial rootstocks. Basal leaves long petioled, usually developing after "the flowering stem, five-parted, the divisions oblong, cuneate, dentate; those of the single involucre on slender petioles one-half to I inch long, three- to five-parted, the divisions about $\mathrm{I} \frac{1}{2}$ inches long, acute, variously cut and lobed. Flowers solitary, about I inch broad; sepals four to nine, obovate or oval, white or purplish without; head of fruit globose, inclined, consisting of several pubescent, oblong achenes, tipped with hooked styles.

Common in moist or low woodlands, Nova Scotia to Minnesota, south to Georgia and Tennessee. Flowering in April and May.

\section{Round-lobed Hepatica or Liverleaf}

IIepatica hepatica (Linnaeus) Karsten

Plate 5 ib

Leaves long pctioled, arising with the flowering scapes directly from the fibrous roots, reniform, hairy, 2 to $2 \frac{1}{2}$ inches broad when mature, spreading on the ground, three-lobed (occasionaily the lateral divisions again lobed), obtuse. Flowers blue, purple or white, one-half to $\mathrm{I}$ inch 
W IL D FLOWERS OF NEW YORK

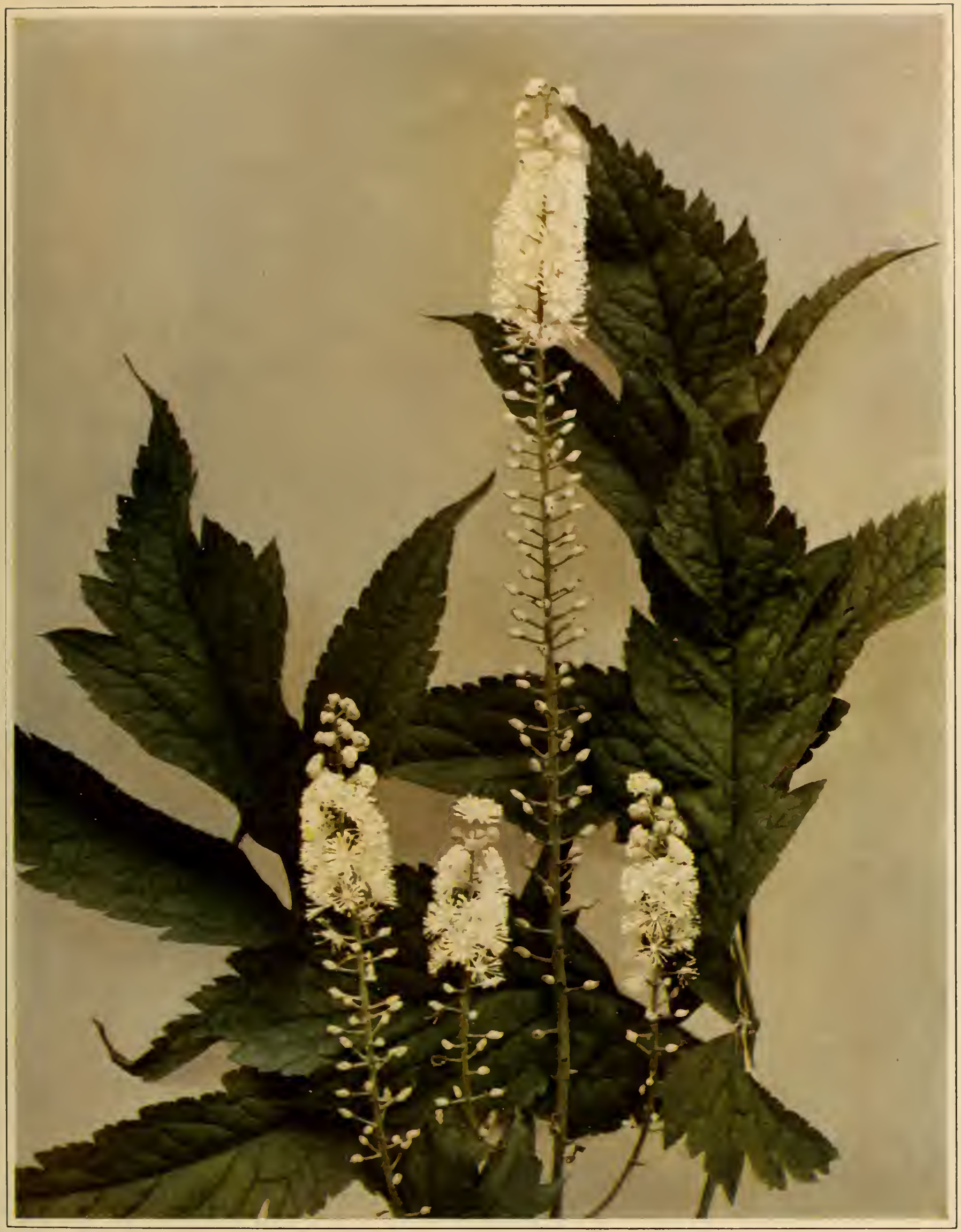

BLACK SNAKEROOT; BLACK COHOSH Cimicifuga racemosa 
- 
WIL, F I, O WERS O I NEIV YOR K

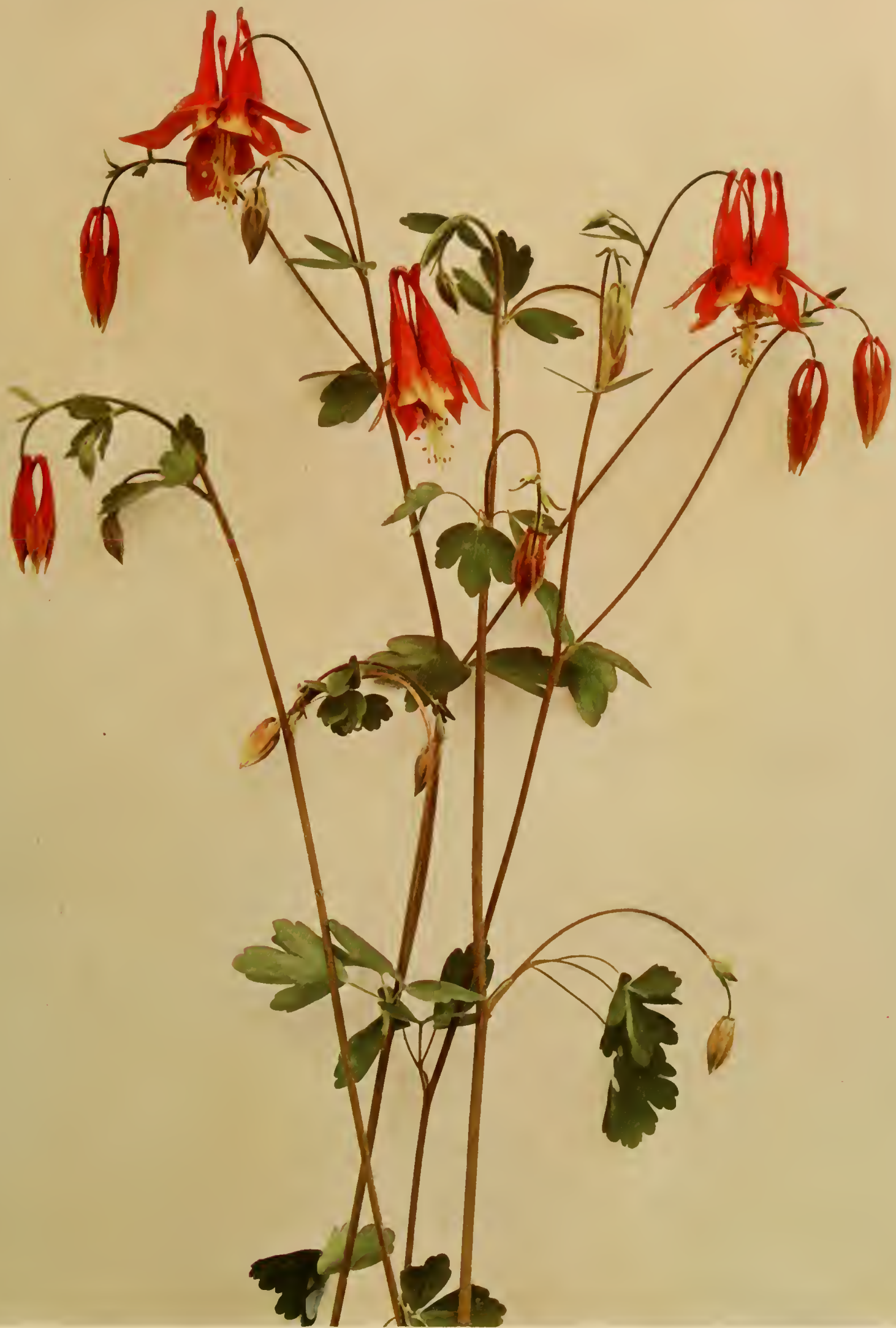

WILD COLLMBINE; ROCK BELLS

Aquilegia canadensis 

WI I, I) I:I, O WERS O I: NEW YORK

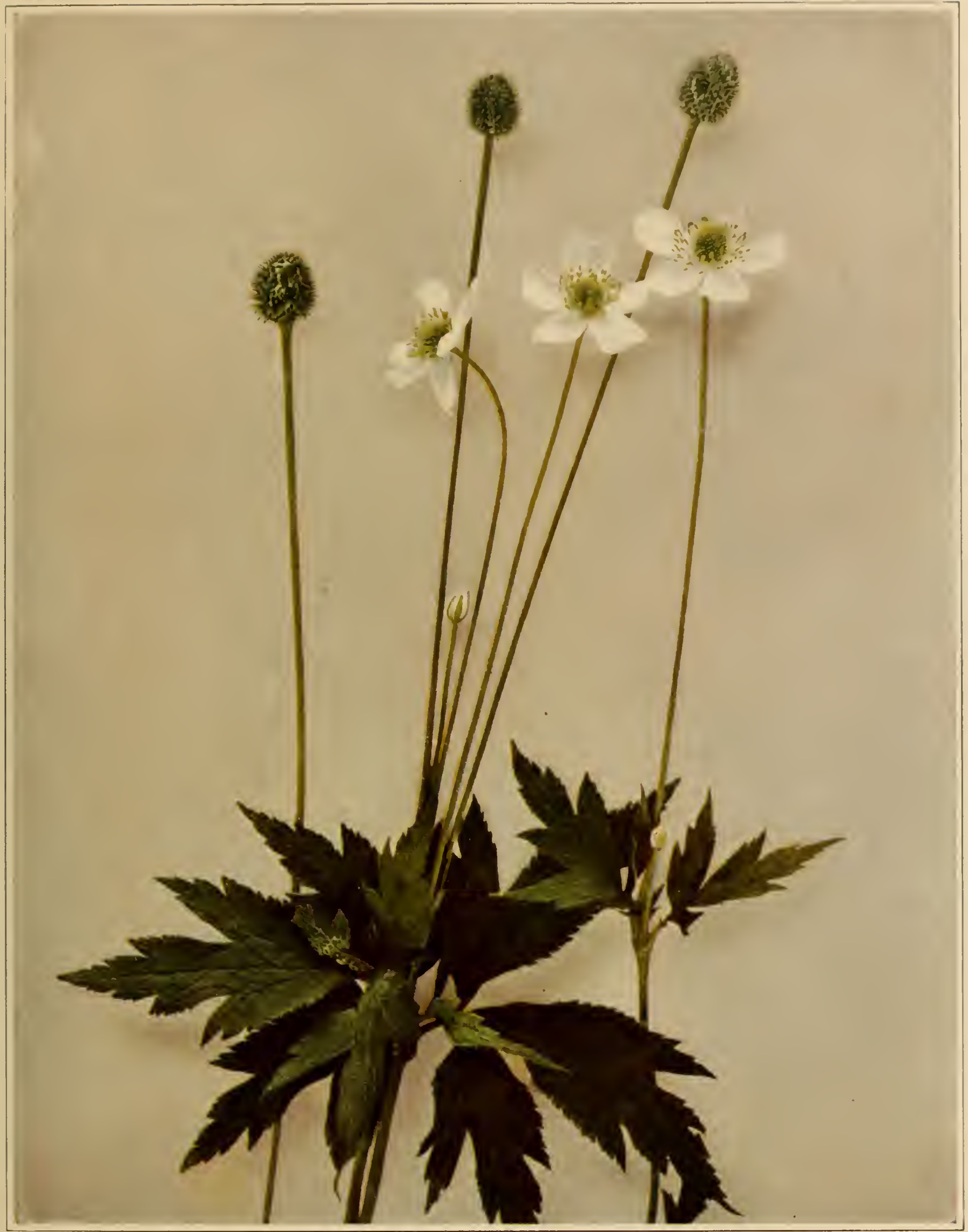

TALL ANEMONE; THIMBLEWEED Anemone rirginiana 

broad on hairy scapes + to 6 inches high. Each flower subtended by an involucre of three sessile, obtuse, oblong, small leaves immediately under the flowers. Sepals oval or oblong, obtuse, longer than the numerous stamens. Fruit consisting of several oblong, aeute, hairy achenes.

In woods, often in large tufts. Nova Scotia to northern Florida, west to Manitoba, Iowa and Missouri. Also in Alaska, Europe and Asia. Flowering in carliest spring, with us usually carly in April but sometimes in March, and even unseasonably warm spells in midwinter may find it in flower. The leaves of $\mathrm{Hepatica}$ hepatica in central Europe possess blunt lobes, while our form usually has perfectly rounded lobes.

\section{Sharp-lobed Hepatica or Liverleaf \\ Hepatica acutiloba DeCandollc \\ Plate 6ob}

Resembling in most respects the Round-lobed Hepatica but the leaf lobes and the leaves of the involucre are pointed, the scapes usually a little longer, and the flowers somewhat larger. The flowers are oftcn dioecious.

In woods, Maine, Quebec and Ontario; south in the Alleghanies to Georgia; west to Missouri and Minnesota. Rare or absent near the Atlantic coast.

Puzzling forms sometimes occur which are intermediate between this and the preceding species.

\section{Rue Anemone}

Syndesmon thalictroides (Linnaeus) Hoffmannsegg

Plate 68b

Stems slender and weak, glabrous, + to $\mathrm{s}$ inches high; the flowering stem appearing in early spring from a cluster of tuberous roots, the ternately compound basal leaves appearing later and resembling those of the Meadow Rue, but smaller. Leaves of the involucre similar, sessile, the leaflets long petioled. Flowers perfect, few or several forming a loose umbel immediately above the involucre, white or pinkish, one-half to I inch broad; sepals five to ten, thin and soon falling, longer than the numerous stamens. 
In woods, Ncw Hampshire and Massachusetts to Florida, Ontario, Minnesota and Kansas. Flowering in early spring, March to carly Junc.

\section{Swamp or Marsh Buttercup \\ Ramunculus septentrionalis (Linnaeus) Poiret \\ Piate 70}

Stcms branching, I to 2 feet long, or becoming longer in summer, ascending, the later branches procumbent and often rooting at the nodes. Roots simply fibrous; stems glabrous or pubescent. Leaves largc, petioled, three-divided, the divisions mostly stalked, usually cuneate at the base, cleft into broad lobes: petioles of the lower leaves sometimes a foot long. Flowers bright yellow, I to $\mathbf{I} \frac{1}{4}$ inches broad; petals five, obovate, twice as long as the spreading sepals. Stamens numerous. Fruit a globose or oval head of flat, strongly margined achenes, each achene tipped by the subulate, persistent, sword-shaped style.

Marshes, swamps, ditches and low meadows, New Brunswick to Manitoba, Georgia and Kansas. Flowering from April to July.

\section{Hispid Buttercup}

\section{Ranunculus hispidus Michaux}

Plate 6ob

Plant usually hairy when young, sometimes merely appressedpubescent or glabrate when old; stems ascending or spreading, usually several from a thickened, fibrous, perennial root; at flowering time the stems only a few inches long, later becoming I to 2 feet long, but not stoloniferous. Leaves pinnately three to five divided, the divisions ovate, oblong or obovate, narrowed or cuneate at the base, sharply cleft or lobed, usually thin; flowers one-half to $\mathbf{I} \frac{1}{2}$ inches broad; petals usually five, oblong, about twice as long as the spreading sepals and entire or sometimes slightly notched at the apex; achenes of fruit oval, lenticular, narrowly margined, abruptly tipped by a subulate style of about one-half their length. 


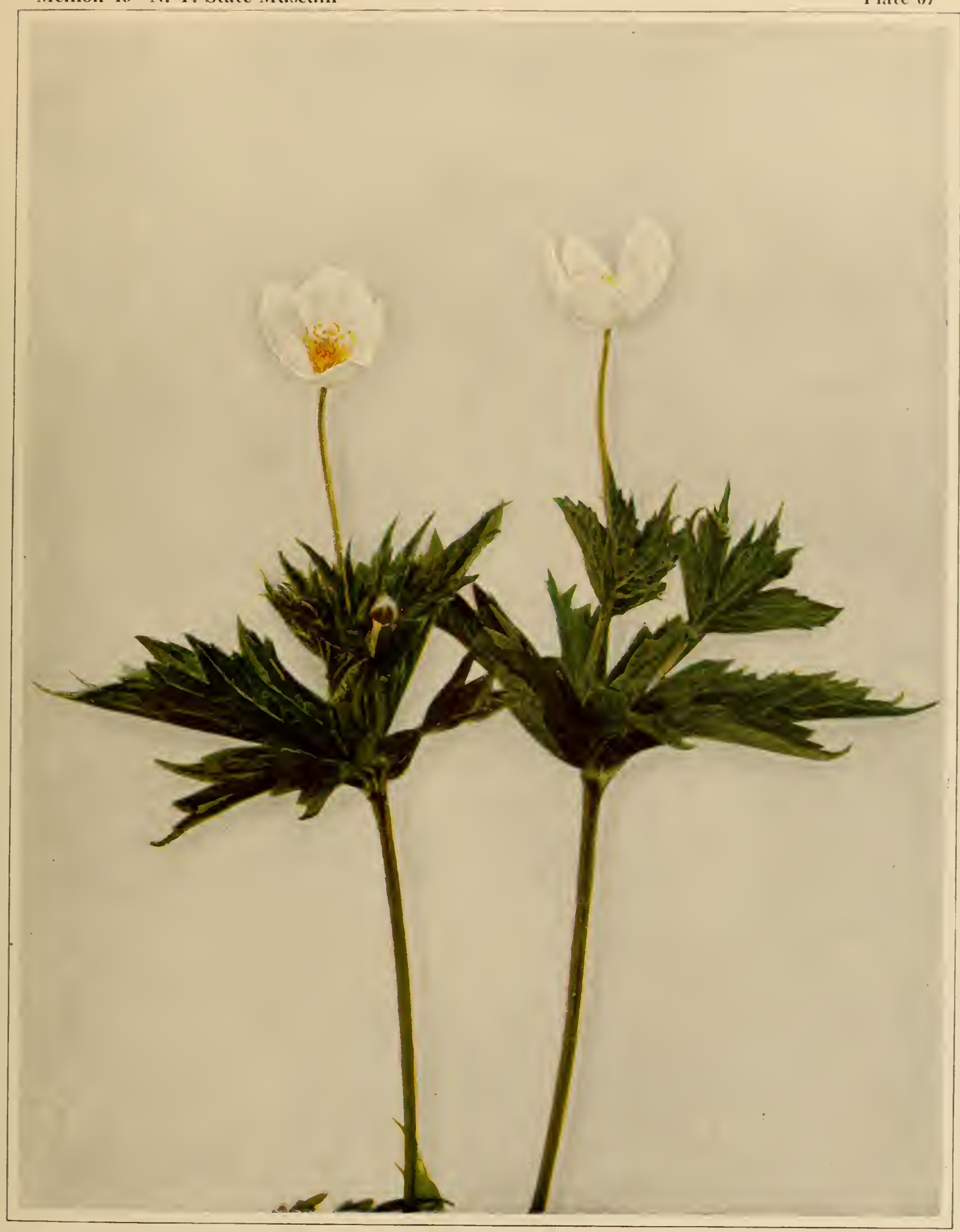






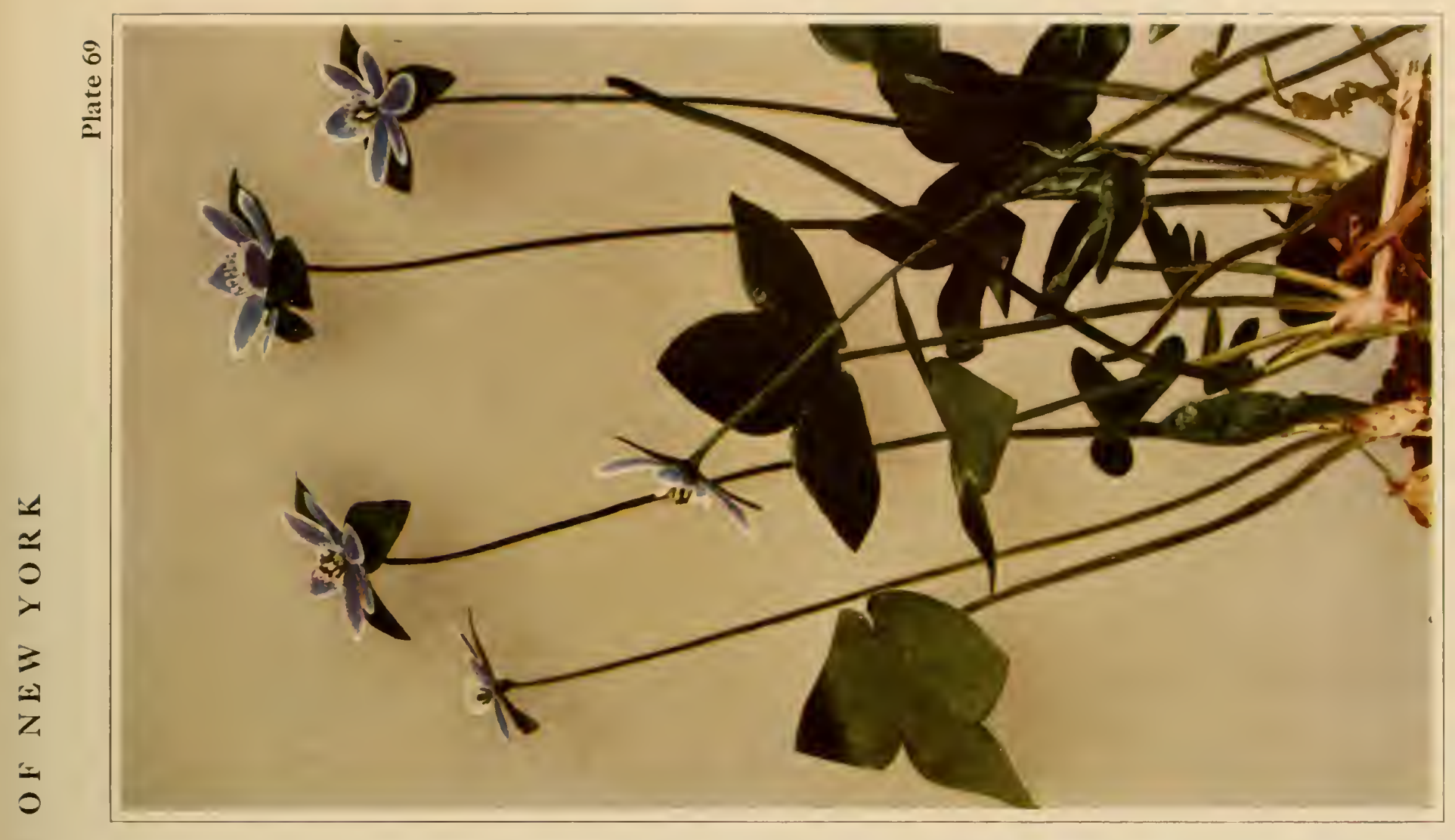

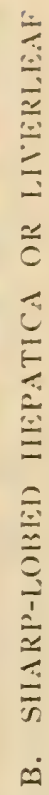

2
$\simeq$
$=$
0
0
$=$
$=$
$=$
2

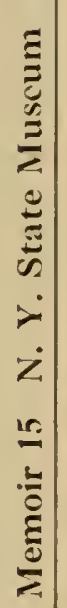

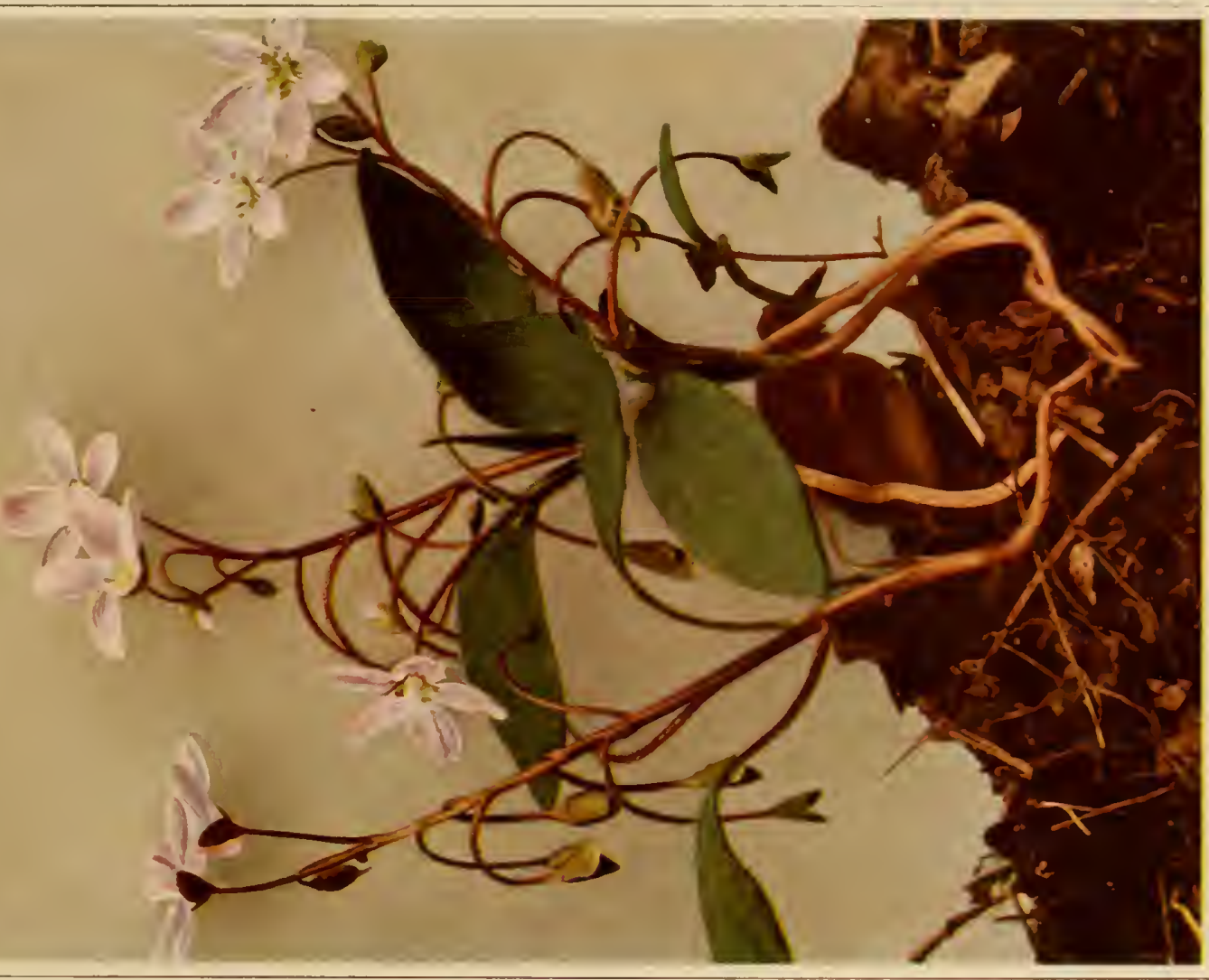

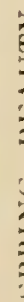

5 

In dry woods and thickets, Vermont and Ontario to North Dakota, south to Georgia and Arkansas. Flowering from March to May.

\section{Stiff White Water Crowfoot}

\section{Butrachium circinutum (Sibthorp) Reichenbach}

Plate 79?

Plant entirely submerged, except the flowers. Stems branching, usually I foot long or longer. Leaves about I inch long, spreading nearly at right angles from the stcm, only slightly or not at all collapsing when drawn from the water, repeatedly forked into capillary divisions. Fiow white, one-third of an inch broad on stout peduncles, I to 2 inches long opposite the leaves, flowering just above the surface of the water; sepals and petals five; petals oblong-oval and blunt. Fruit a small cluster of tiny, apiculate achenes.

In ponds and slow streams, Nova Scotia to British Columbia, south to North Carolina, also in Europe and Asia. Flowering from June to September.

The form illustrated here has the beak of the achenes about I $\mathrm{mm}$ long, so that it should be classed as Batrachium longirostre (Godron) F. Schultz.

\section{Early Meadow Rue \\ Thalictrum dioicum Linnaeus \\ Plate $7 \mathrm{r}$}

Stems glabrous, erect, I to 2 feet high, slender and leafy from brown perennial roots. Leaves three to four-ternate. Leaflets thin, pale beneath, orbicular or broader, often cordate and the terminal one somewhat cuneate five to nine-lobed. Flowers dioecious, grcenish or greenish yellow, drooping or spreading; panicle elongated, of numerous lateral corymbs or umbels; sepals ustually four, blunt; petals none; stamens numerous, filaments longer than the sepals; anthers linear, blunt, longer than the filaments. Achenes in fruit ovoid, sessile or minutely stipitate, strongly ribbed, much longer than the style. 
In woods and on shaded banks, Mainc to Alabama, Saskatchewan and Missouri. Flowering in April and May.

\section{Fall Meadow Rue \\ Thalictrum polygamum Muhlcnberg \\ Plate 72}

Stems stout, smooth or pubescent but not glandular or waxy, 3 to io feet high, branching. Leaves three to four-tcrnate; leaflets thickish, light green above and pale bencath, oblong or orbicular with three main apical pointcd or blunt lobes; panicle compound, leafy, a foot long or more. Flowers polygamous, white or purplish, usually the pistillate flowers purplish and the staminate flowers white; filaments broad, narrowly clavate; anthers oblong, short. Fruiting achenes ovoid, sessile or short-stipulate, six to eight-winged, glabrous or pubescent.

Marshes, open sunny swamps and low meadows. Newfoundland to Florida, Ontario and Ohio. Flowering from July to September.

\section{Virgin's Bower; Woodbine; Wild Clematis}

Clematis virginiana Linnaeus Figure XVI and Plate 73

A long vine, climbing over bushes in low woodlands, and along fences and watercourses. Stems somewhat woody below but only the root perennial in the north at least. Leaves opposite, glabrous, trifoliate; leaflets broadly ovate, acute at the apex, toothed or lobed, sometimes slightly cordate. Flowers in leafy panicles, white, polygamo-dioecious, twothirds to $\mathbf{I}_{\mathbf{4}}^{\mathbf{1}}$ inches broad when expanded. Sepals usually four, spreading, petallike; petals none; stamens numerous, spreading; filaments glabrous; pistils numerous. In fruit the styles become an inch long or more, plumose and persistent on the achenes (figure XVI).

Nova Scotia to Georgia, west to Manitoba and Tennessee. Flowering in midsummer, July to September. 
W I I, D FI, O WERS OF NEW YORK

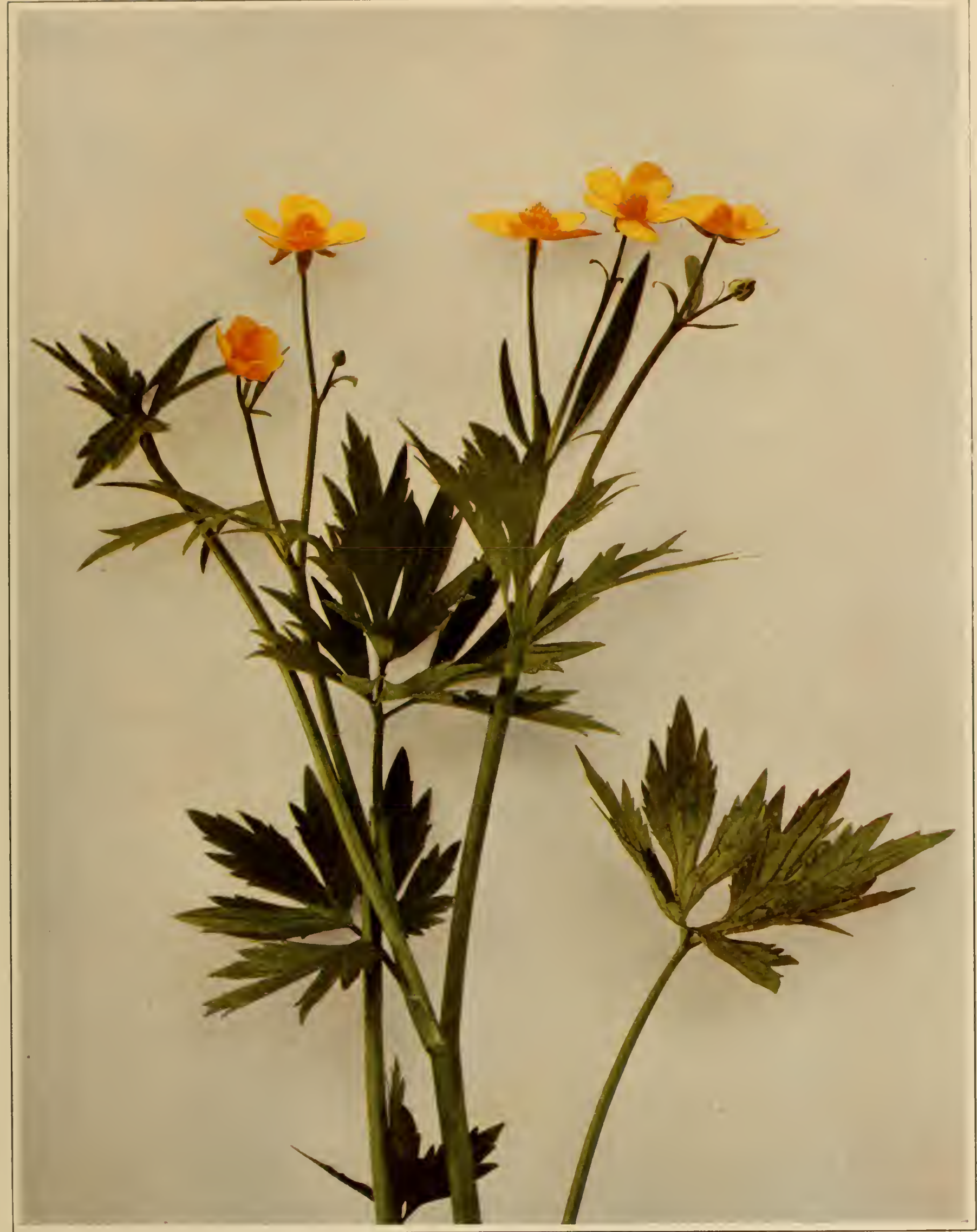

SWAMP OR MARSH BUTTERCUP

Ramunculus septentrionalis 



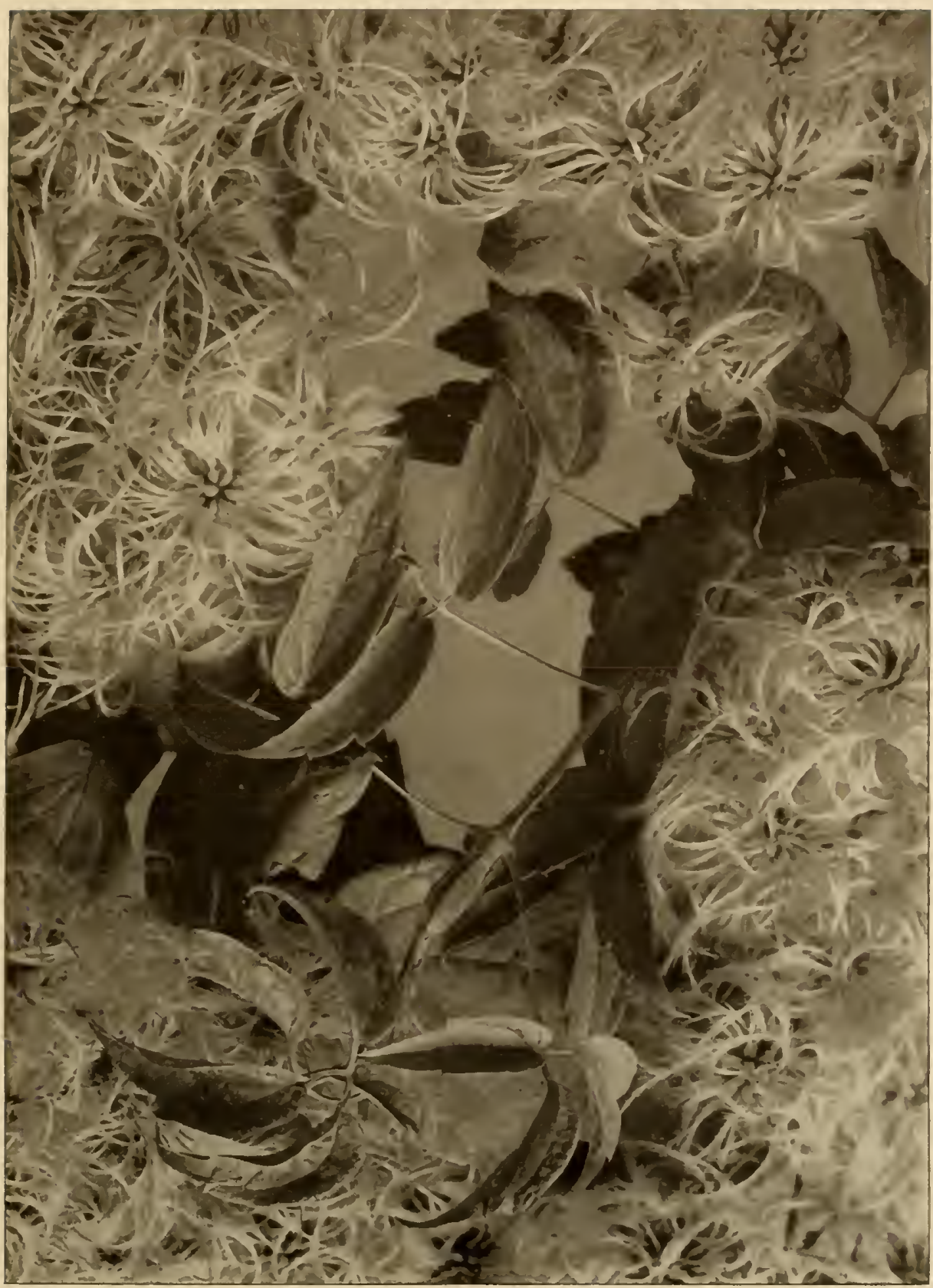

Figure XVI

Virgin's Bower (C le matis virgin i n a Linnaeus), in fruit 


\section{Purple Virgin's Bower \\ Atragene americana Sims \\ (Clematis arerticillaris De Candolle) \\ Figure XIII}

A trailing or partly climbing vine, somewhat woody and perennial below, glabrous or nearly so. Leaves trifoliate; leaflets thin, ovate, acute, toothed or entire and more or less cordate; petioles and petiolules slender. Flowers purplish blue, 2 to + inches broad, solitary on slender peduncles in the axils of the leaves or at the ends of the branches. Sepals four, thin and translucent, strongly veined, silky along the margins and veins; petals four, spatulate, one-half to two-thirds of an inch long: stamens very numerous, the outer ones usually with broadened filaments; styles long, persistent, plumose throughout and about 2 inches long in fruit.

Rocky woodlands and thickets, Hudson bay to Manitoba, south to Connecticut, Virginia and Minnesota. Flowering in May and June. One of our rarest wild flowers.

\section{Erect Silky Leather Flower}

Viorna ochroleuca (Aiton) Small

Plate 74

Stems erect, silky-hairy, I to 2 feet high and somewhat woody at the base from a thickened, woody, perennial root. Leaves opposite, simple, sessile, ovate or elliptical-ovate, blunt, smooth and glabrous above, silky and reticulate-veined beneath, entire or rarely somewhat lobed; each stem with a single terminal nodding flower about I inch long or less. Calyx rather broadly cylindric in shape, composed of four or five thick sepals, very silky without, their yellowish-green tips recurved; petals none. Stamens numerous, parallel with the sepals, their anthers very narrow. Pistils very numerous, their styles silky or plumose. In fruit the fleshy sepals fall away leaving an erect head of small achenes plumose with the long, yellowish-brown, persistent styles which are I to 2 inches long. 
WILD FLOWERS OF NEW YORK

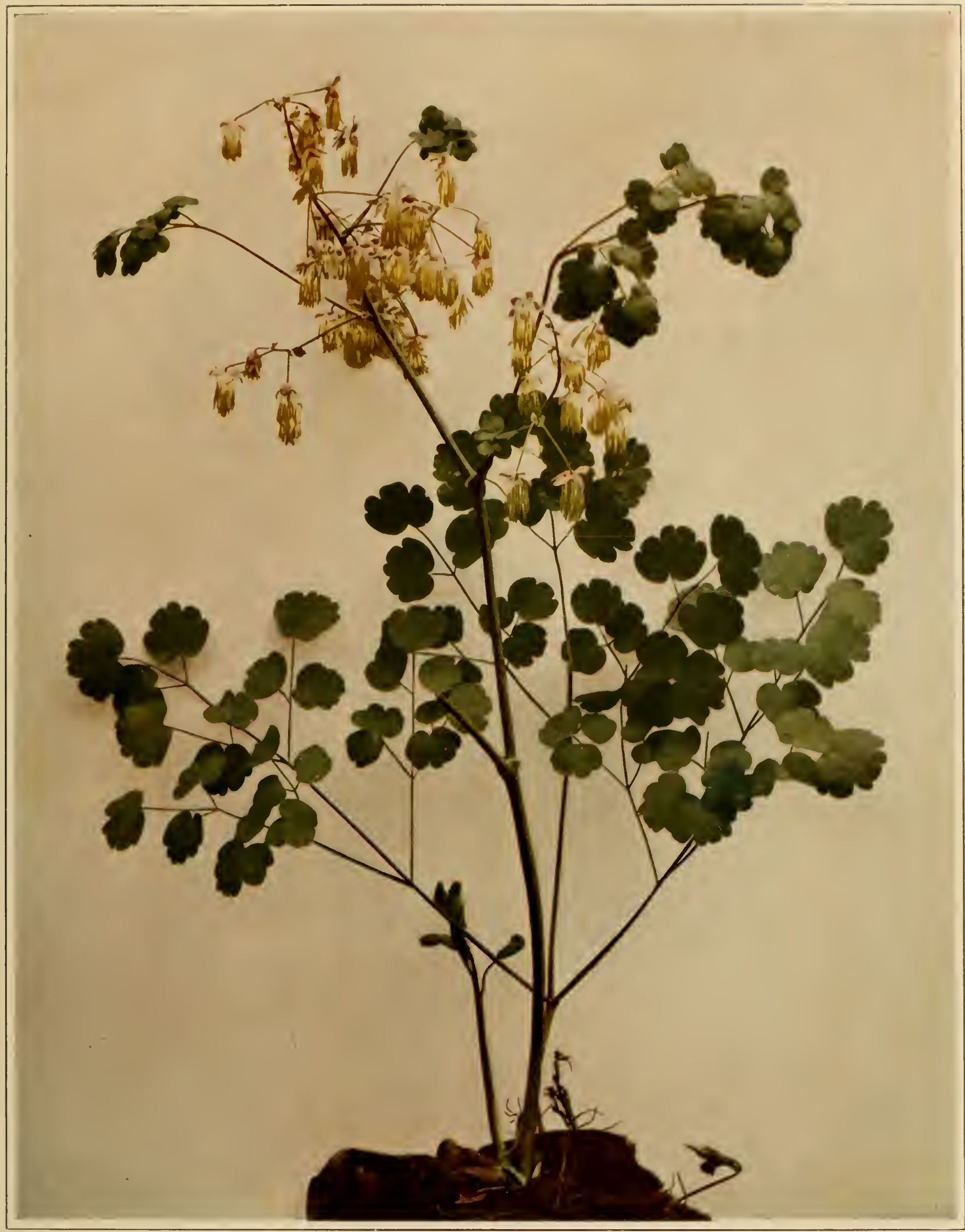

EARLY MEADOW RUE

Thalictrum dioicum 
. 
W I L D F L, OWERS OF NEW YOR K

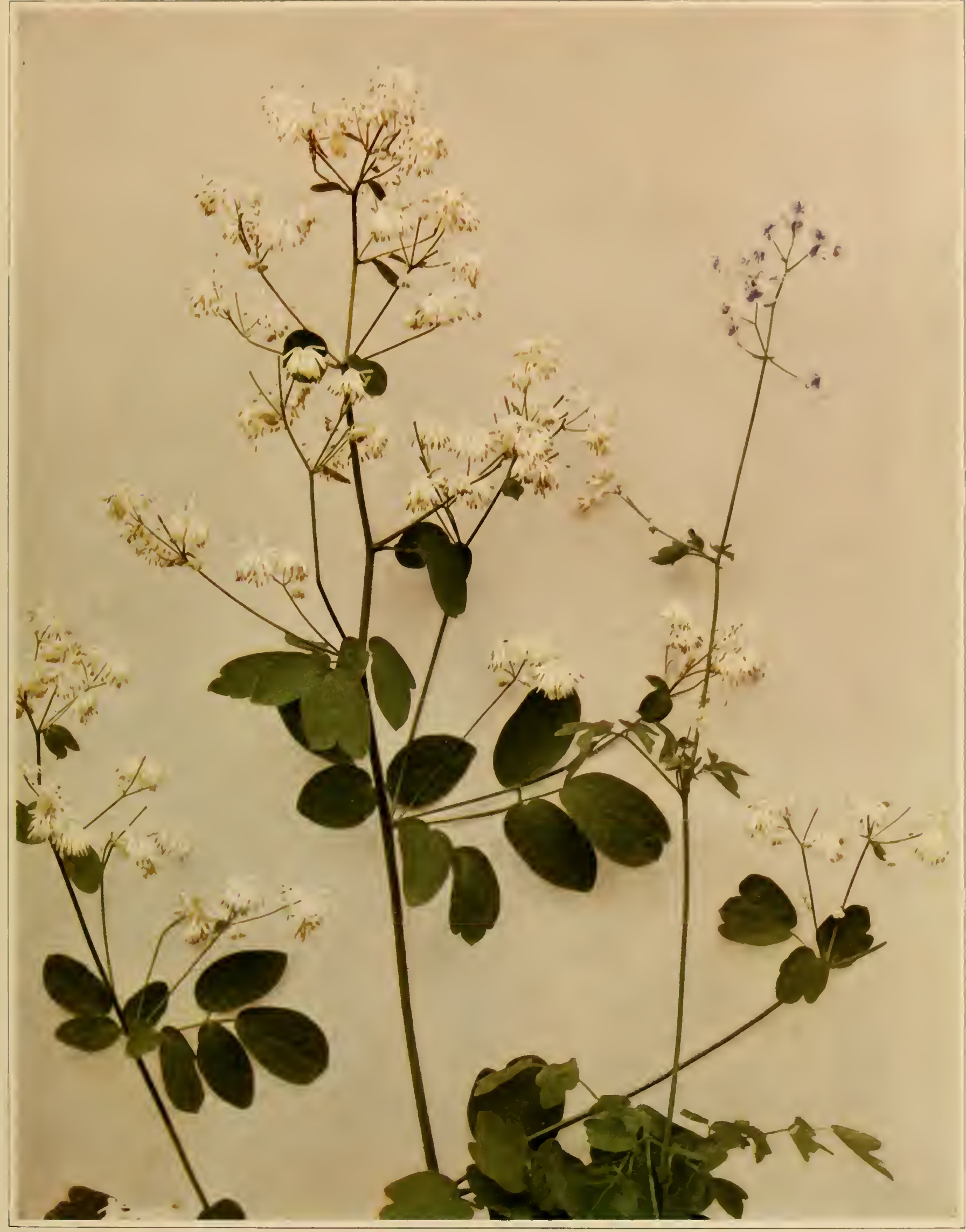

FALL MEADOW RUE

Thalictrum polygamum 

WILD FLOWERT OF NEW YORK

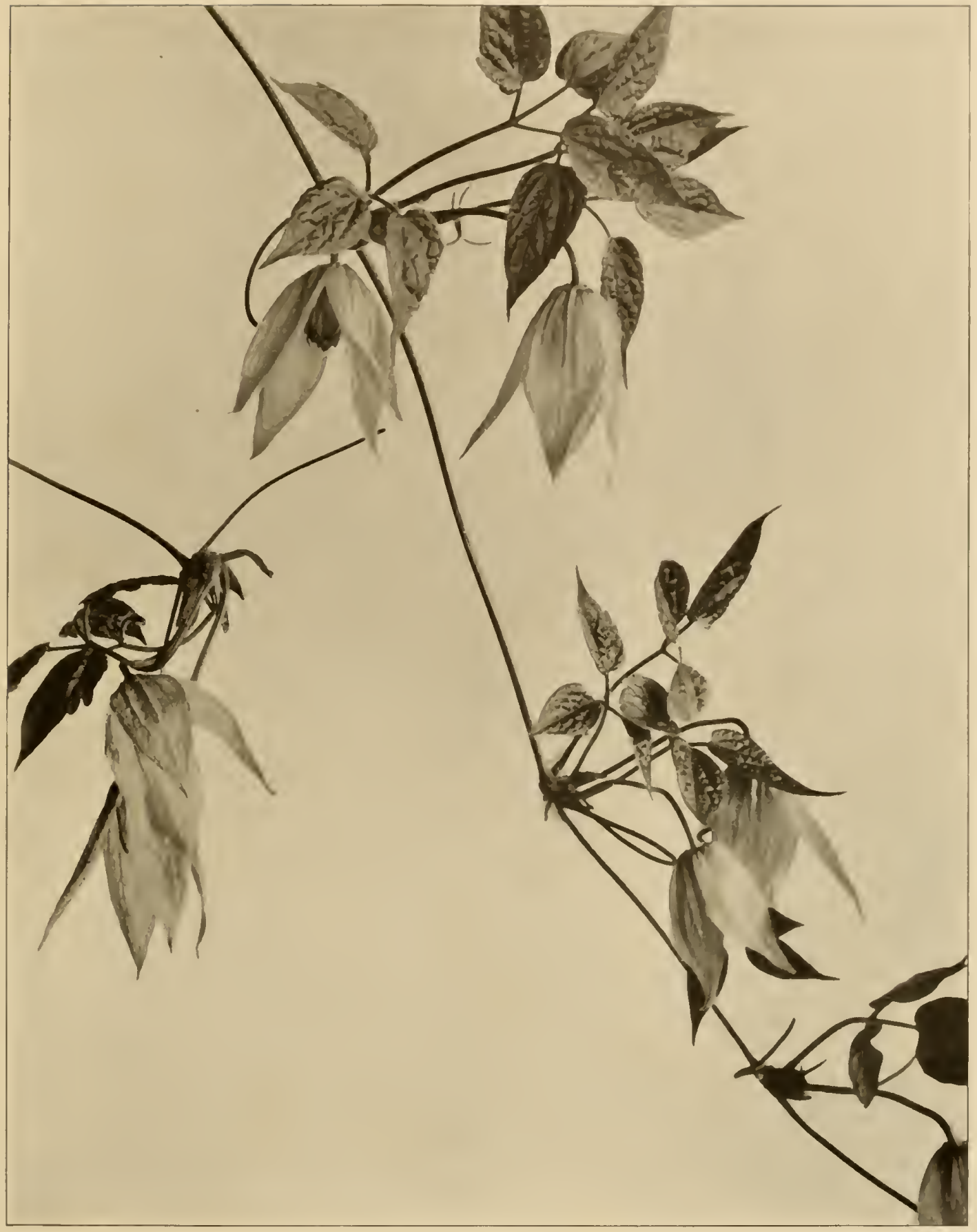

Firure XVII

Purple Virgin's Bower

(Atragene americana Sims) 
Sandy fields and thickets, Staten Island and Pennsylvania, south to Georgia. Flowering in late May and Junc. In the southern states several additional speeies of Leather Flower (Viorna) are found, but this is the only one which enters New York.

\section{Barberry Family}

Berberidaceae

\section{Blue Cohosh}

\section{Caulophyllum thalictroides (Linnaeus) Michaux}

Plate 75

Stems erect, glabrous and glaueous when young, I to 3 feet high from a thickened, perennial rootstock; the base of the stem with two or three large, sheathing braets, near the top of the stem a single, large, triternate. nearly sessile leaf and usually a similar but smaller leaf near the base of the inflorescence. Leaflets thin, oval, oblong or obovate, I to 3 inches long when mature, usually only partly developed at flowering time, three to five-lobed at the apex. Flowers several in a loose terminal panicle, greenish purple, one-quarter to one-half of an inch broad; sepals six, oblong; petals six, smaller, cucullate and opposite the sepals; stamens six. Each flower contains a single pistil with two ovules, which ripens into a globose, blue, glaucous, berrylike fruit, about one-third of an ineh in diameter. As the seed grows it ruptures the thin, transparent pericarp before maturity.

In woods and thickets, New Brunswick to South Carolina, west to Manitoba, Tennessee, Nebraska and Missouri. Flowering in April and May.

\section{May Apple; Wild Mandrake \\ Podophyllum peltatum Linnaeus \\ Plate 76}

Stems erect, I to $I \frac{1}{2}$ feet high, from a perennial, horizontal, poisonous rootstock. Basal leaves centrally peltate, often nearly a foot in diameter, long petiolcd, deeply five to nine-lobed, glabrous or pubescent and light green on the lower surface, darker above; lobes two-cleft and toothed at 
W I L F F O WERS OF NEW YORK

Memoir 15 N. Y. State Museum

Plate 73

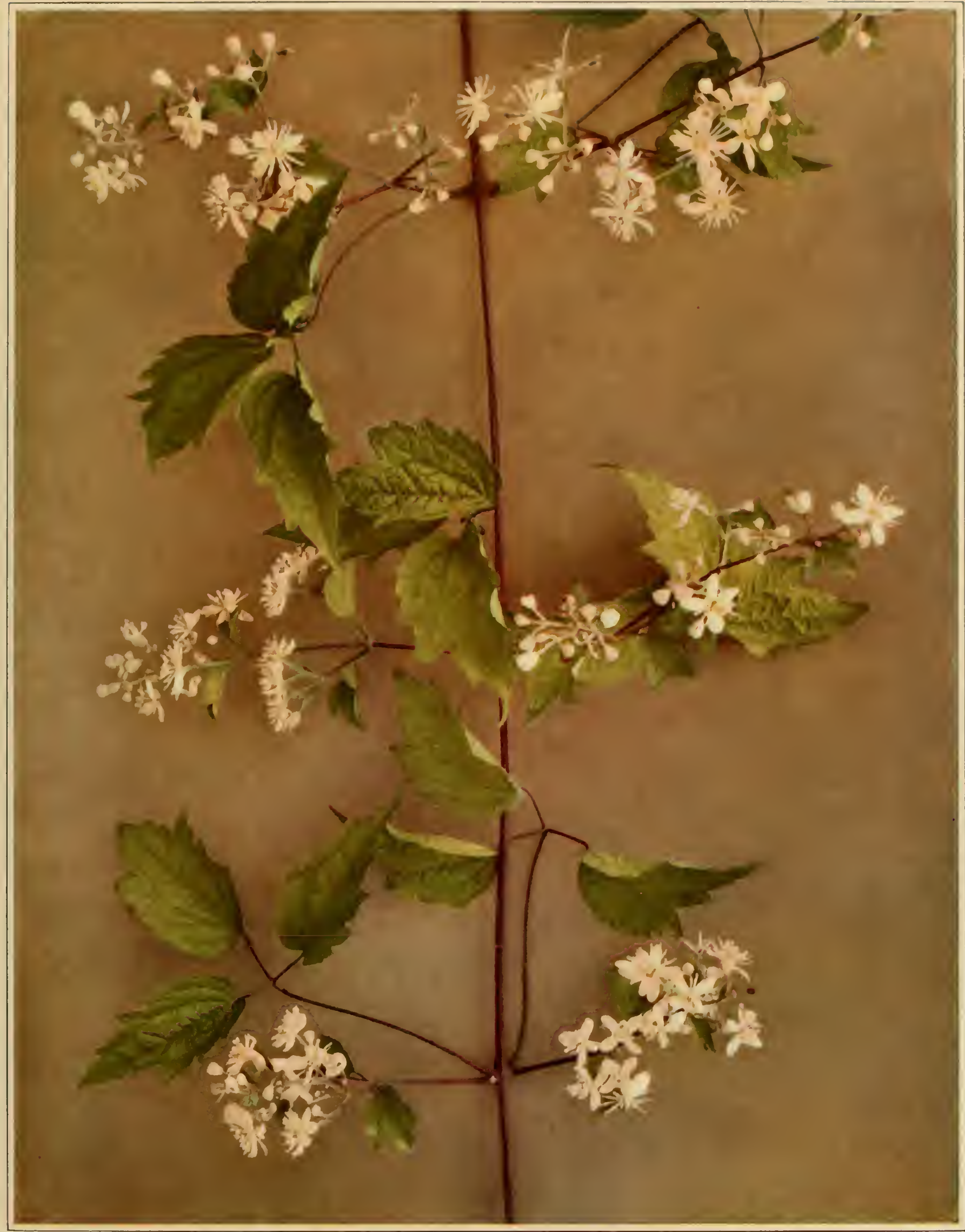

VIRGIN'S BOWER; WOODBINE; WILD CLEMATIS

Clematis sirginiana 
- 
W I L D F L O W R S O F N W YORK

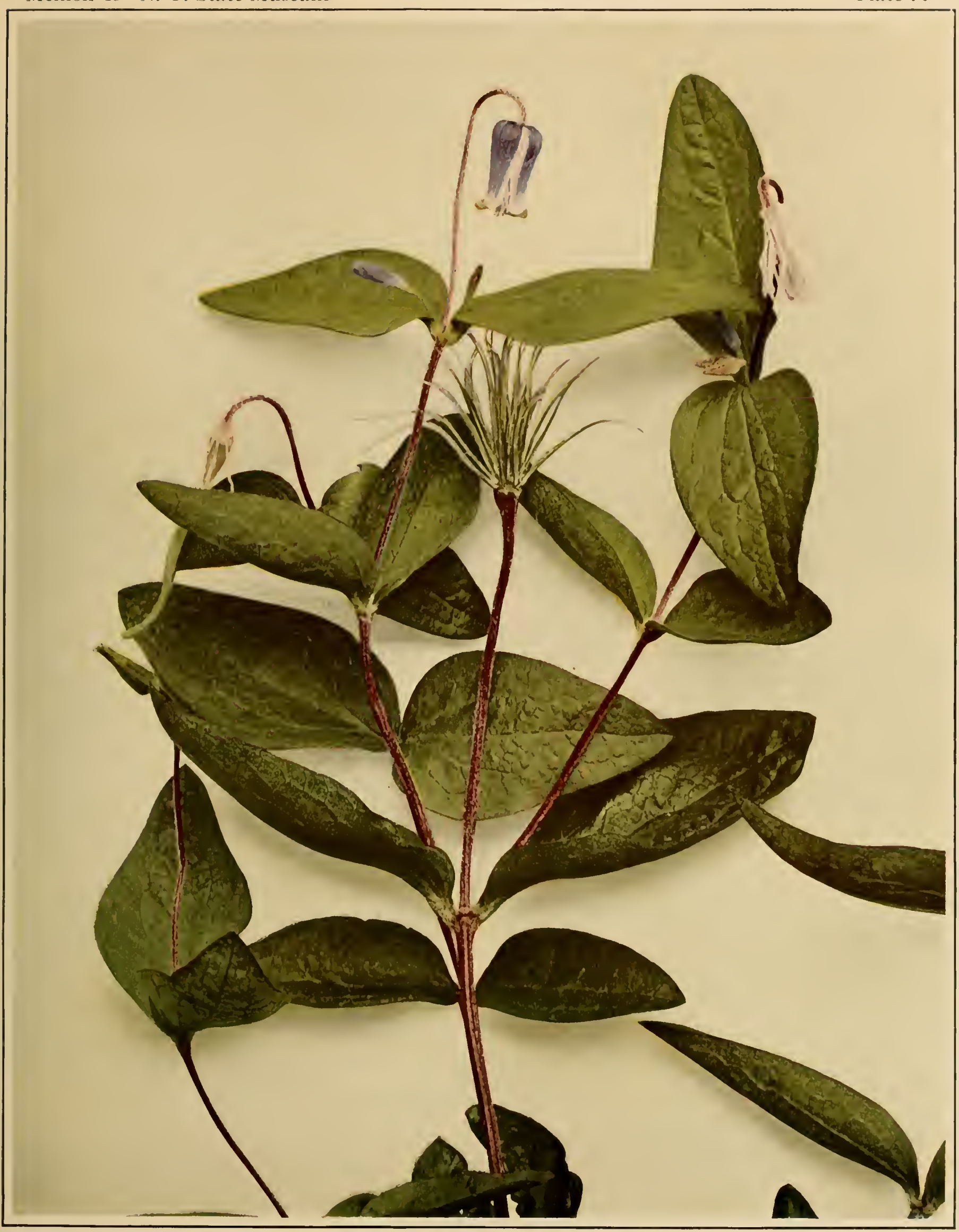

ERECT SILKY LEATHER FLOWER

Viorna ochroleuca 
the apex. Flowering stems appearing from different rootstocks, bearing one to three, usually two, similar leaves (rarely leaflets). Flowers $1 \frac{1}{2}$ to 2 inches broad, white, fragrant, on stout, nodding peduneles one-half to 2 inches long, appearing from the base of the upper leaf or usually from the fork between the two leaves; sepals six, petallike and soon falling. Petals six to nine, flat, obovate, longer than the sepals; stamens twice as many as the petals. Ovary ovoid, forming in fruit a large, yellowish, ovoid, cdible berry, $1 \frac{1}{2}$ to 2 inches long, the numerous seeds inclosed in fleshy arils within the fruit.

In low woods, moist banks and elearings, western Quebee and southern Ontario to Minnesota, Kansas, Florida, Louisiana and Texas. Flowering in May and June.

The fruit is edible and harmless, although somewhat insipid and to many people its taste is disagreeable. Both foliage and root are said to be poisonous and serious results have followed the use of the leaves as greens. The root is a violent purgative, resembling jalap in its action. Its popular name, Mandrake, relates it in no way to the Mandrake or Mandragora of the ancients and, notwithstanding its poisonous character it is a very respectable herb in comparison with the traditions of the Mandrake of the ancients, deseribed as flourishing best under a gallows, with a root resembling a man in shape, uttering terrible shrieks when it was torn from the ground, and possessing the power of transforming men and beasts.

\section{Twin-leaf Jeffersonia diphylla (Linnaeus) Persoon Figure XVIII}

A smooth, perennial, fibrous-rooted plant, 6 to 8 inches high when in flower, later becoming in to 18 inches high. Leaves and flowering stems arising from a scaly base. Leaves glaucous beneath, long petioled, cordate or reniform, 3 to 6 inches long, 2 to 4 inches wide when mature, parted longitudinally into two obliquely ovate, blunt, lobed or entire divisions; lobes rounded with sinuses sometimes three-fourths of an inch deep. At 


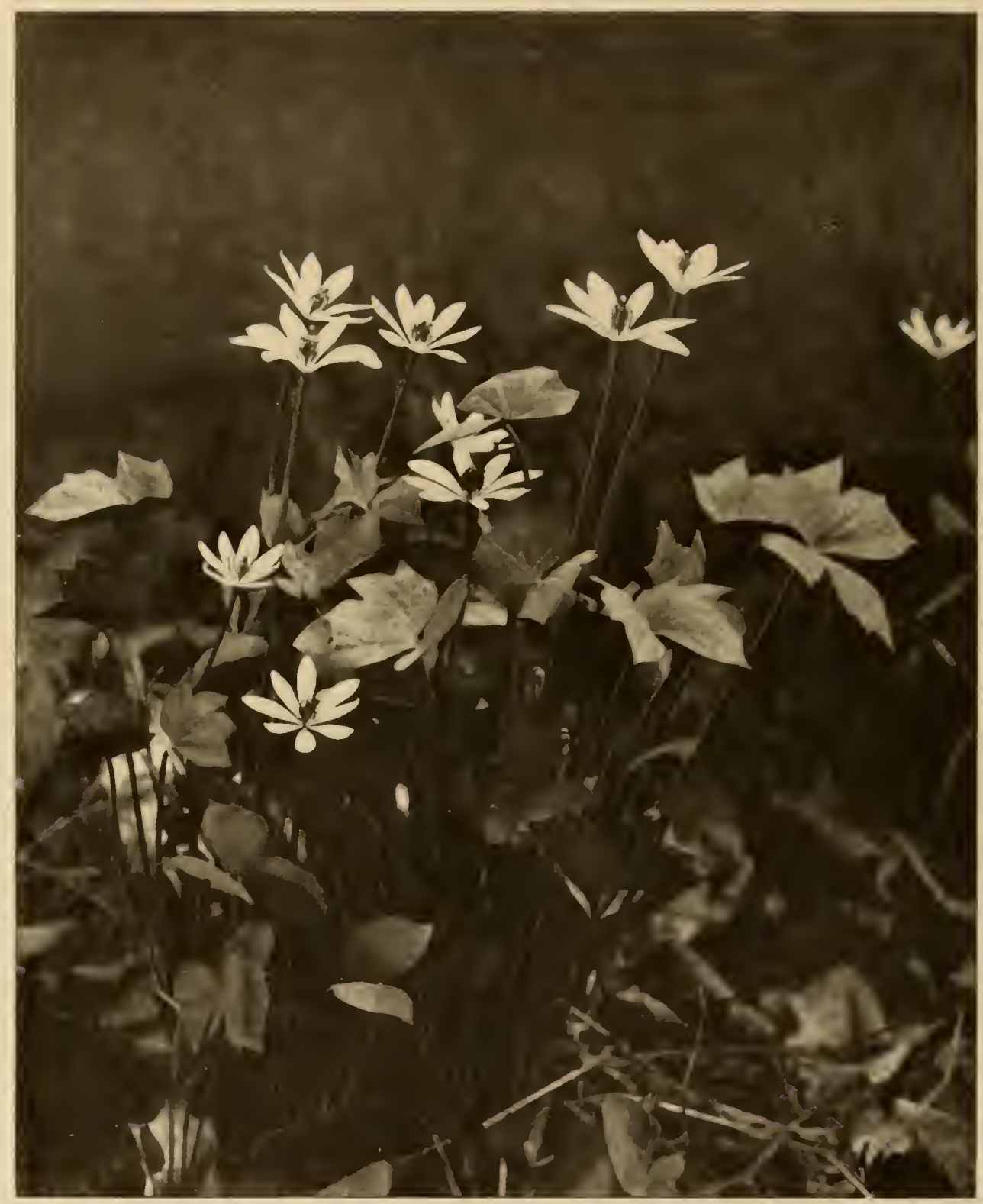

Figure XYIII

(Photograph by G. A. Bailey)

Twin-leaf

(J effersonia diphylla (Linnaeus) Persoon) 
W I L D F L O IVERS OF NEIV YORK

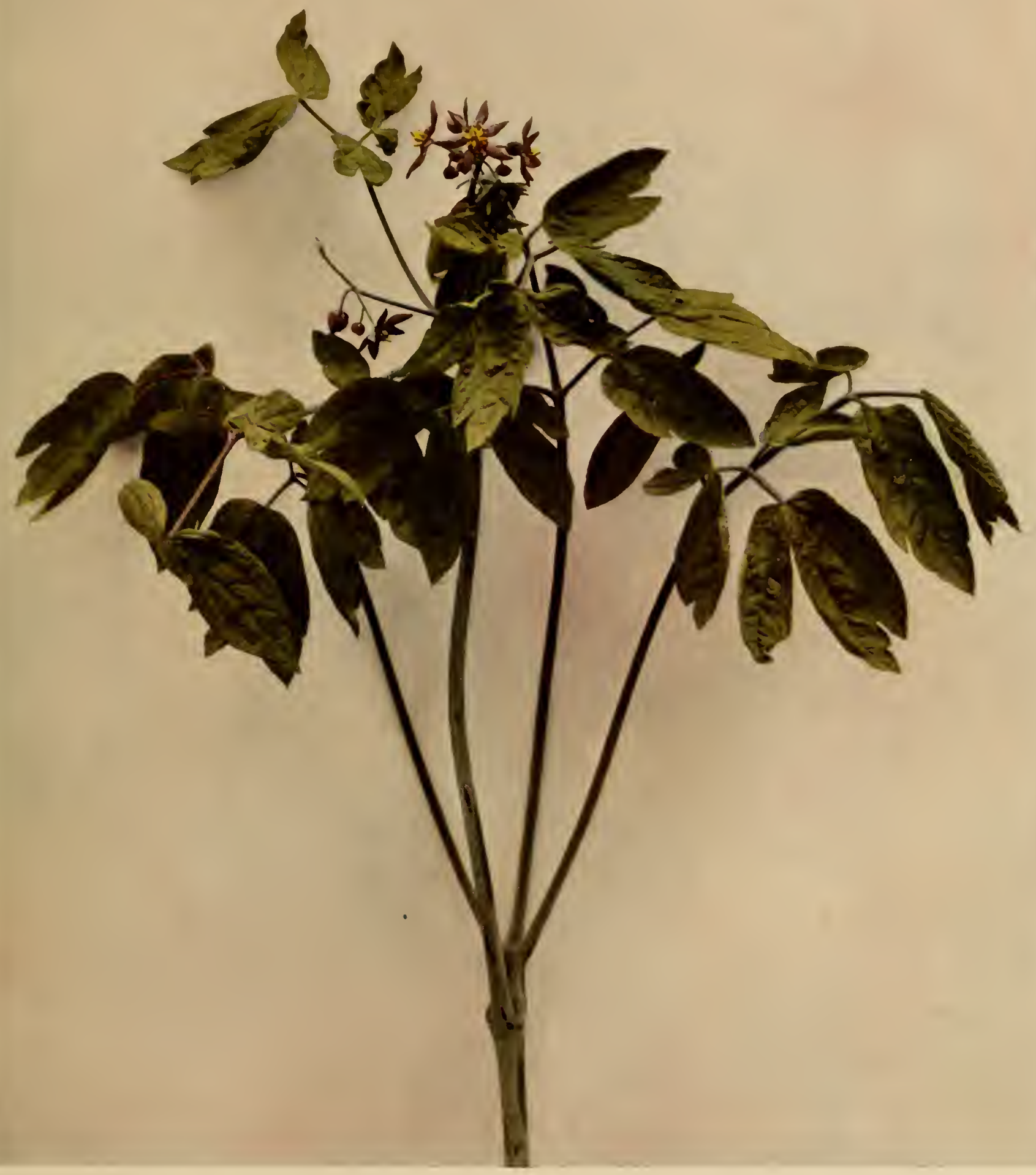




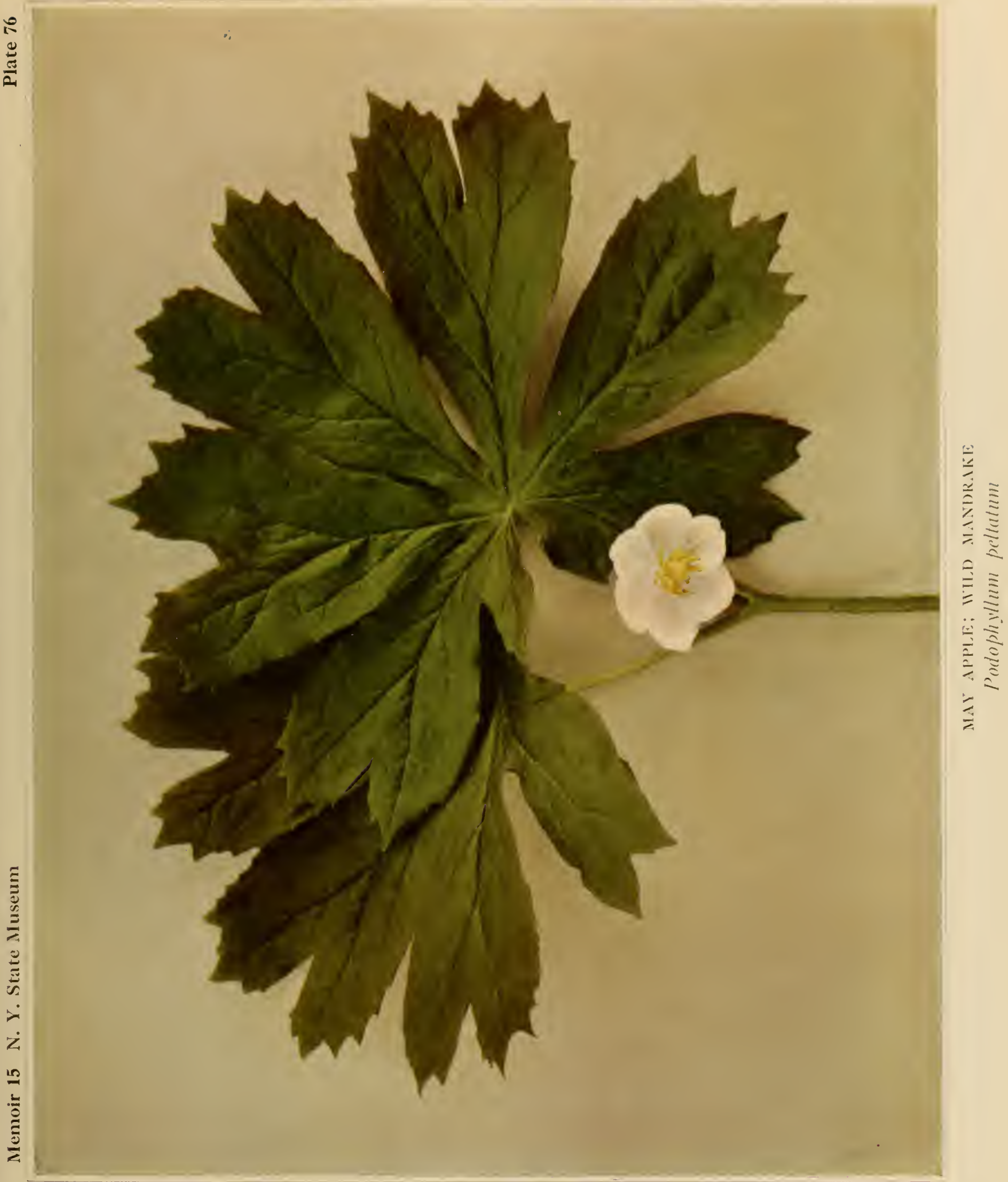




\section{-}


flowcring time the lcaves are but partially developed. Flowcring stcms without leaves and onc-flowered. Flowers white, about I inch broad; the calyx with four (sometimes three or five) caducous, petallike divisions. Petals eight, flat, oblong, longer than the sepals. Stamens eight with slender filaments. Fruit a short-stalked capsule about I inch long, opening at maturity near the summit by a half-circumscisslc cleft.

In moist woods, New York, Ontario and Pennsylvania to Wisconsin, Iowa, Virginia and Tennessee. Flowering in April and May.

\section{Poppy Family \\ Papaveraceae \\ Bloodroot; Puccoon-root \\ Sanguinaria canadensis Linnaeus \\ Plate 77}

Leaves and stems glabrous, especially when young, from a stout, horizontal rootstock, one-half to I inch thick, densely clothed with thick, fibrous roots. Juice of the roots and stems red. Leaves basal on pctioles 6 to I4 inches long, palmately five to nine-lobed, the lobes repand or cleft at the apex and palmately veined. Flowering scapes, one-flowered, at length overtopped by the mature leaves, but at flowering time longer than the partially unfolded immature leaves. Flowers white or sometimes pinkish, I to $I \frac{1}{2}$ inches broad; sepals two, soon falling. Petals eight to sixteen, oblong-spatulate, arranged in two or three rows and soon falling; stamens numerous, yellow. Fruit a narrow, one-celled, two-valved capsule, pointed at both ends, about $\mathrm{I}$ inch long.

In rich woods and on shaded banks, Nova Scotia to Manitoba and Nebraska, south to Florida, Alabama and Arkansas. Flowering in April and May. 


\section{Fumewort Family}

Fumariaceae

\section{Dutchman's-breeches}

\section{Bicuculla cucullaria (Linnaeus) Miłlspaugh}

Plate 78

A rather delicate, smooth and somewhat tufted herbaceous plant from a bulbous, perennial base. Leaves all basal, numerous and slender-stalked, pale beneath, finely divided into many narrow segments. Flowers nodding, fragrant, few or several on a slender stalk which rises above the leaves; each flower about one-half to two-thirds of an inch long, and somewhat broader than long across the spreading basal spurs, white or faintly pink, yellow at the summit; the four petals in two pairs, the outer pair oblong, concave, each with a divergent spur at the base and the tip spreading, the inner pair narrow and minutely crested. Fruit an oblong pod, opening into two parts to the base, when mature.

In rich woods, Nova Scotia to North Carolina, west to Minnesota, Kansas and Missouri. Flowering in April and May.

The Squirrel Corn or Turkey Corn (B i c u c u 11 a c a n a den s is (Goldie) Millspaugh) is similar, but the spurs of the two outer petals are shorter, rounded and not divergent, the inner pair of petals is conspicuously crested and the roots have numerous small tubers. The Wild Bleeding Heart (B i cuculla eximia (Ker) Millspaugh) of the western part of the State has pink flowers.

\section{Mountain Fringe; Alleghany Vine \\ Adinmia fungosa (Aiton) Greene \\ Plate $79 b$}

Stems weak, slender, climbing several feet over other plants by its slender petioles from a biennial root. Leaves two to three-pinnate, the leaflets slender stalked, lobed or entire, very thin, ovate or cuneate, about one-fourth of an inch long and pale beneath. Flowers numerous in axillary 


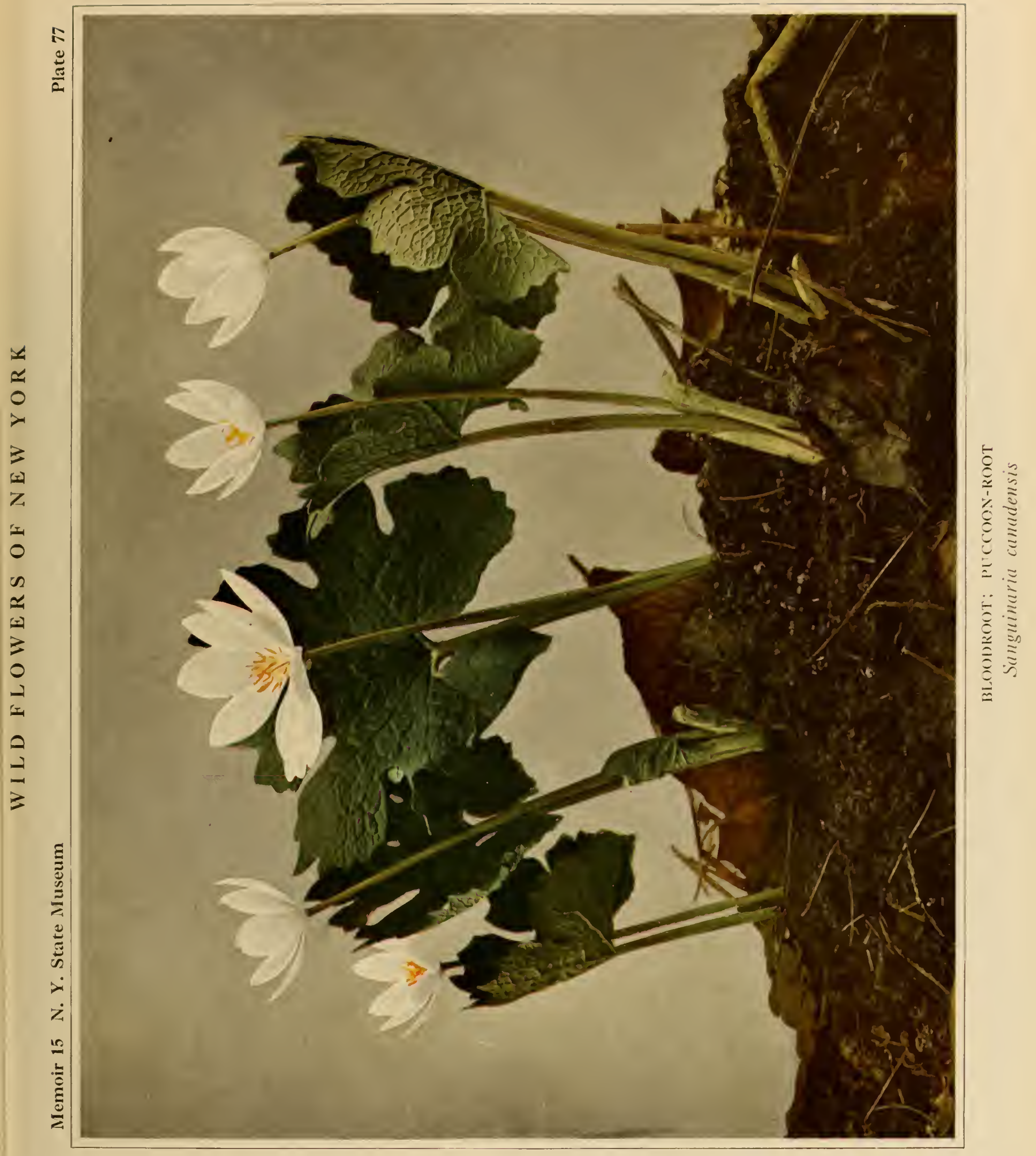


- 
drooping cymes; petals four, united into a narrowly ovatc-cordate, spongy corolla about onc-half of an inch long and onc-fourth of an inch broad at the basc, four-lobed at the apcx, grecnish purple, or pink, usually rather persistent, dry and brownish with age; stamens six, united below and adherent to the pctals. Fruiting capsulc oblong, included in the persistent, dry corolla.

In moist woods, thickcts and shaded cliffs, Ncw Brunswick to Ontario and Michigan, south to North Carolina and Tcnncsscc. Flowcring from Junc to October. Frequent in cultivation.

\section{Pink or Pale Corydalis}

\section{Capnoides sempervirens (Linnaeus) Borkhauscn}

Plate 80

Stems and leaves glabrous, glaucous, erect or ascending, 6 inches to 2 feet high and freely branching. Lower leaves I to 5 inches long, short petioled, the upper leaves sessile or nearly so, all divided into numerous obovate or cuneate segments, toothed or entire, obtuse. Flowers numerous, panicled, borne in cymose clusters at the ends of the branches. Each flower one-half to two-thirds of an inch long, pink or rarely white with a yellow tip; sepals two, small; corolla irregular, deciduous; petals four, erect-connivent, one of the outer pair with a spur at the base about oneeighth of an inch long, the inner pair narrower, keeled at the back. Capsules narrowly linear, erect, I to 2 inches long.

In rocky piэres, Nova Scotia to Alaska, Georgia, Minnesota, Montana and British Columbia. Flowering from May to September.

Two other species of this genus are occasionally found in this State, both with low, diffusely spreading stems and with yellow flowers. They are the Yellow Corydalis (Capnoidcs flavulum (Rafinesque) Kuntze) with flowers about one-fourth of an inch long and short spurred; and the Golden Corydalis (C. a u re u m (Willdenow) Kuntze) with flowers slightly more than one-half of an inch long and spurs one-half the length of the corolla. 


\section{Mustard Family}

Cruciferac

\section{Lyre-leaved Rock Cress}

A rabis lyrata Linnaeus

Plate $54^{\mathrm{b}}$

A low, tufted perennial or biennial plant with ascending or erect stems, 4 to 2 inches high, smooth above, pubescent below or glabrous throughout. Basal leaves lyrate-pinnatifid, I to 2 inches long, spatulate or oblanceolate, pubescent or glabrous; stem leaves entire or toothed, spatulate or linear, one-half to I inch long. Flowers white, one-fourth of an inch broad or less, several or numerous in a terminal raceme which elongates in fruit; pedicels ascending, about one-third of an inch long or longer in fruit; pctals four, much longer than the four stamens. Fruit a linear, slightly flattened pod three-fourths to $\mathrm{I} \frac{\mathbf{1}}{4}$ inches long; seeds in one row, oblong and wingless.

Rocky and sandy places, Connecticut and Ontario west to Manitoba and Alaska, south to Virginia, Tennessee, Missouri and British Columbia. Flowering from April to September.

\section{Bulbous Cress; Cuckoo-flower}

Cardamine bulbosa (Schreber) Britton, Sterns \& Poggenberg Plate 9o:

A slender, erect, herbaceous plant with smooth stems, 6 to 20 inches high from a perennial, tuber-bearing root, simple or rarely branched. Leaves of two sorts, those of the stem sessile and clasping or the lower ones very short petioled, rather distant from one another, oblong or lanceolate, blunt, toothed or entire, I to 2 inches long; the basal leaves oval or orbicular, one-half to 2 inches broad, often slightly heart-shaped, toothed or usually entire, with long, slender petioles. Flowers white, about onehalf of an inch broad, in a terminal, several to many-flowered cluster; petals four, three to four times the length of the four sepals. Fruit a 


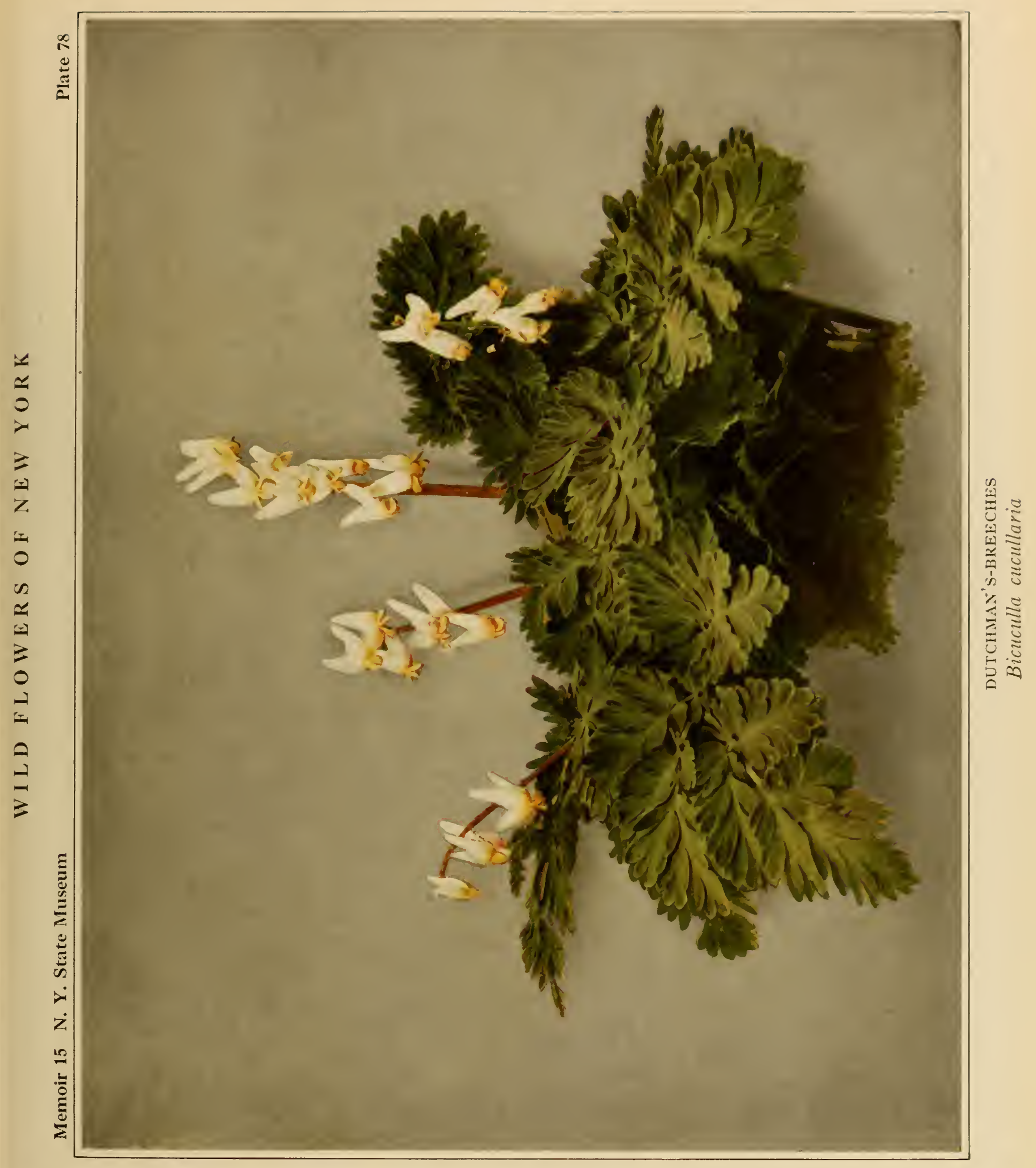




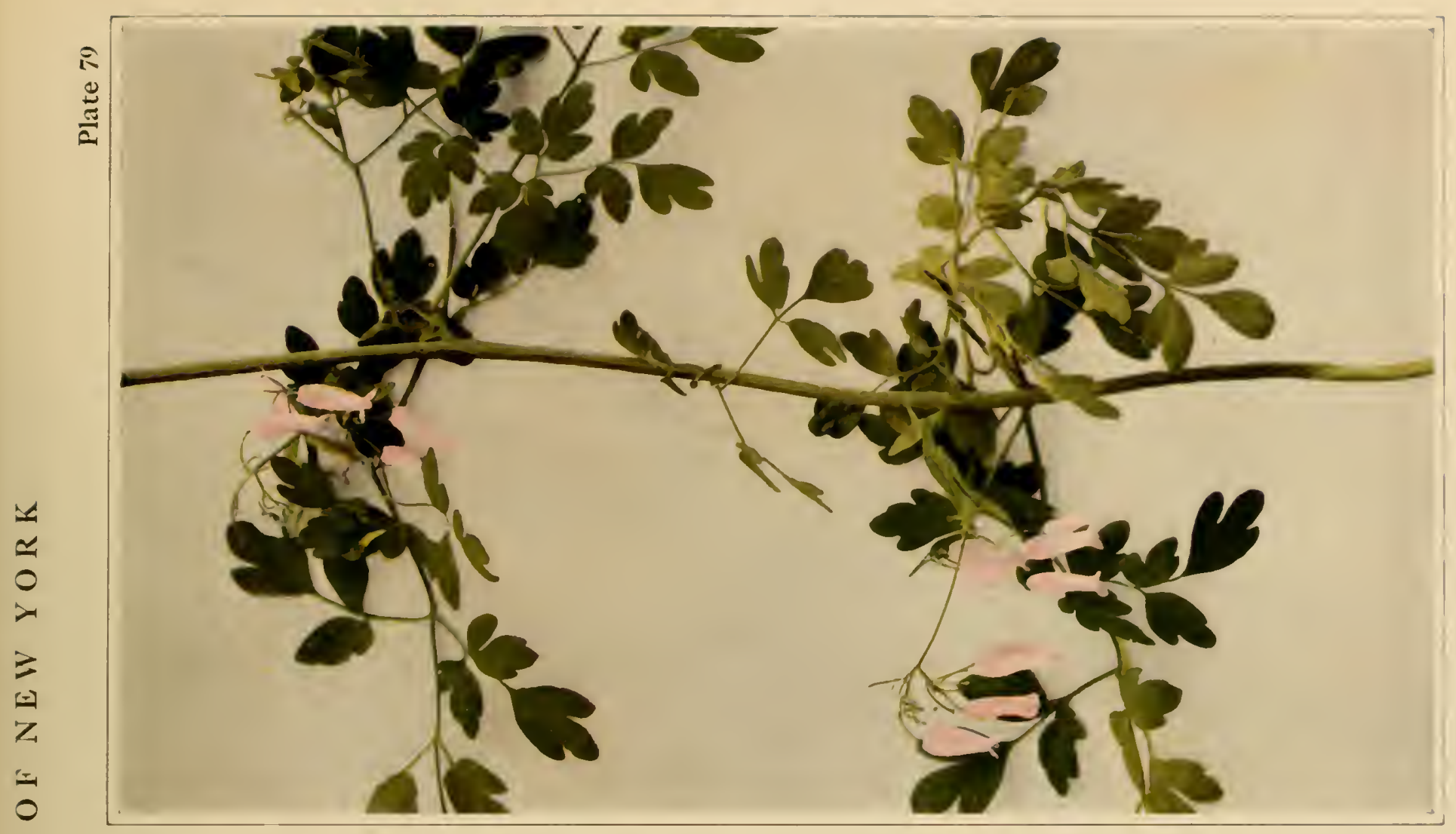

要
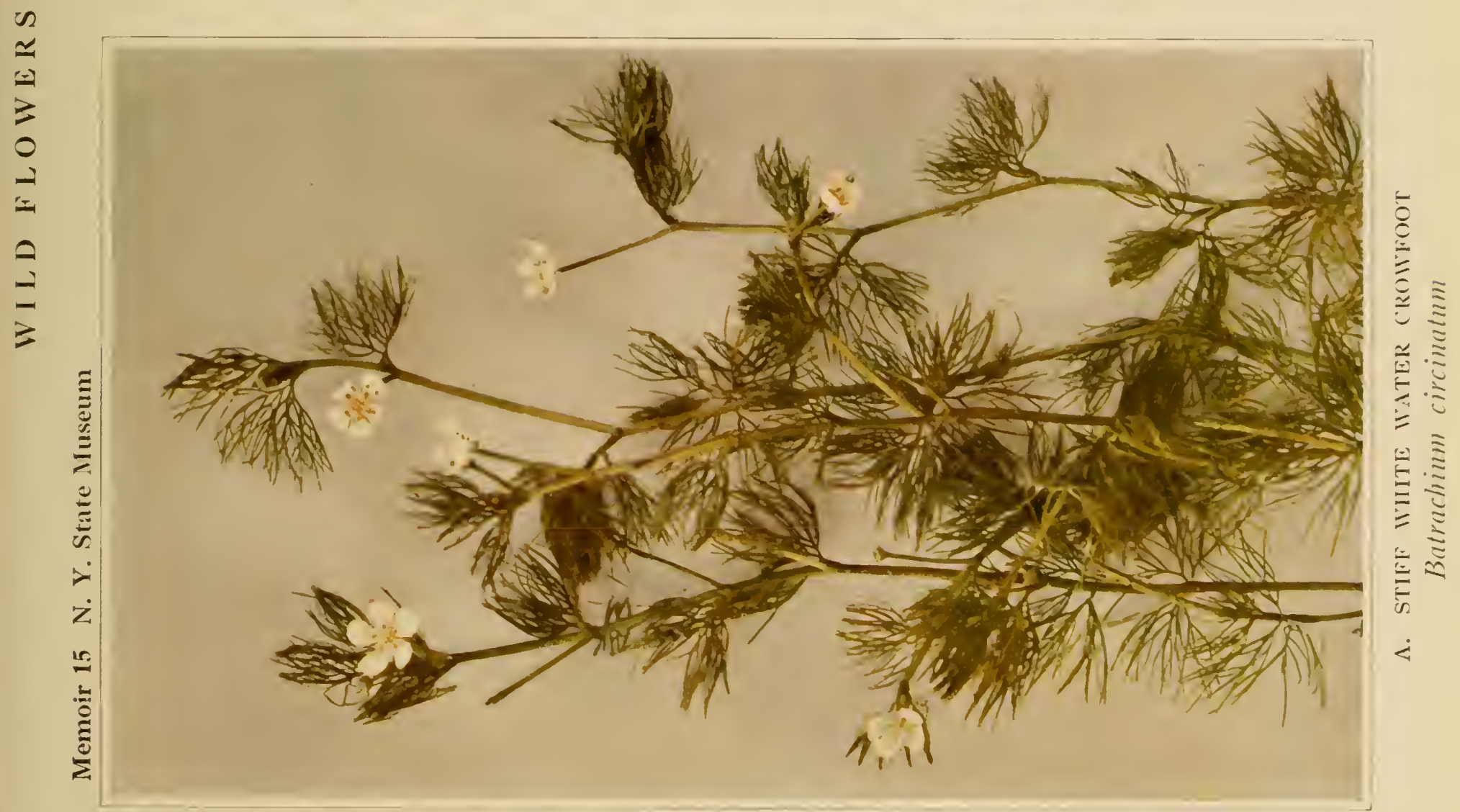


$$
\text { - }
$$


WI I, D F L, OWERS O I NEW YORK

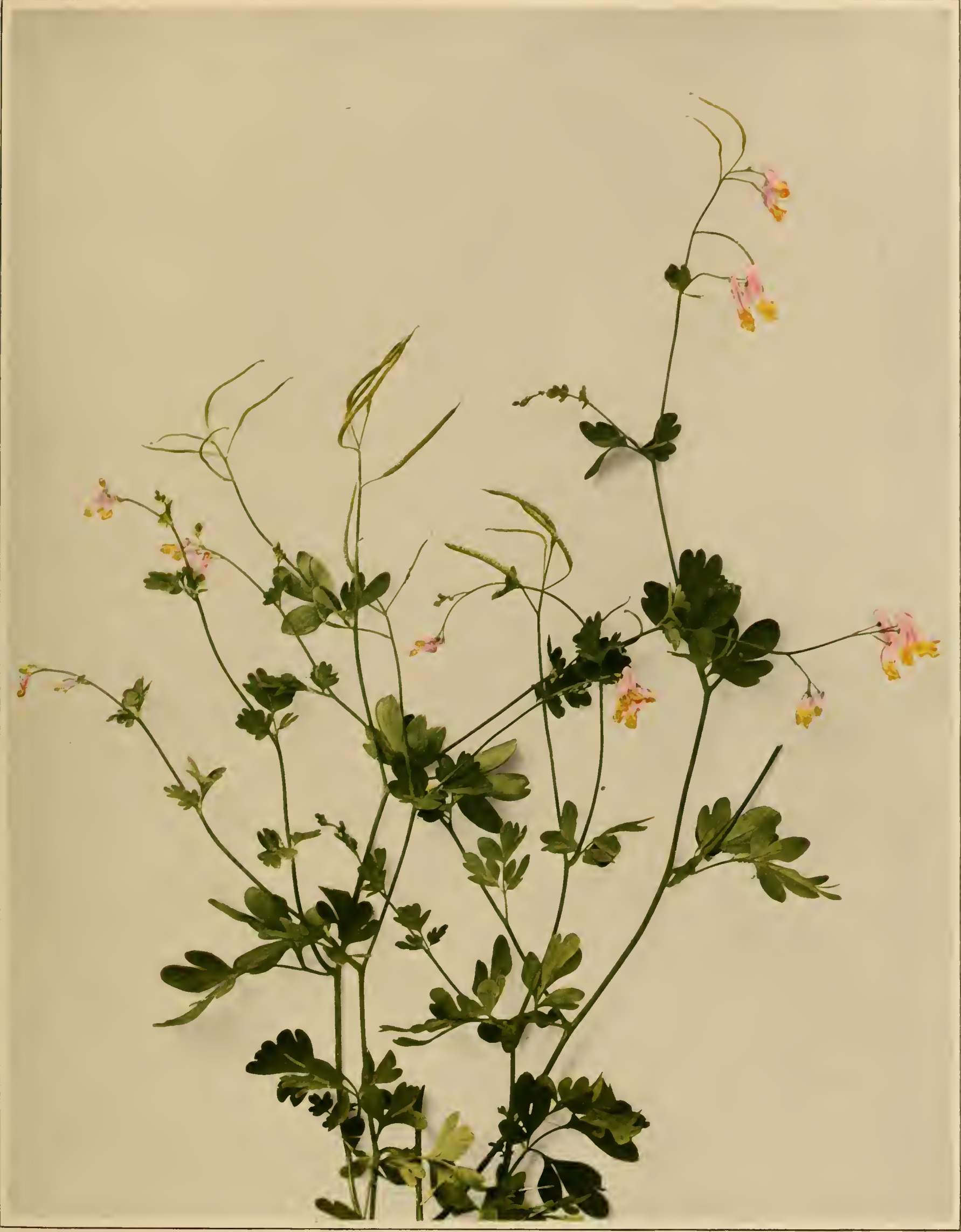

PINK OR PALE CORYDALIS

Capnoides semperitirens 

. 
number of erect, very slender pods, narrowed at each end and about an ineh long.

In low, wet woods, thickets and wet meadows, New Brunswiek to Vermont, southern Ontario and Minnesota, south to Florida and Texas. Flowering in April and May, or in cool woods as late as early June.

The Purplc Cress (C a r d a m in c d o uglas s i (Torrey) Britton) has leaves which are more angularly toothed and showy purple flowers often thrce-fourths of an inch broad. It is found in cold, springy places in the northern part of the State.

The True Water-eress (Sisy mbrium nasturtium-a quat i e $u \mathrm{~m}$ Linnaeus) is a native of Europe, but is common in brooks and streams in most parts of New York.

\section{Cut-leaved Toothwort or Pepperroot}

Dentaria laciniata Muhlenberg

Plate 8 ra

Stems erect, pubescent or glabrous, 8 to 15 inches high from a deep, perennial, tubereled, jointed rootstoek, the joints easily separable. Leaves all petioled, 2 to 5 inches broad, those on the stem usually three and forming a whorl, rarely distant, three-parted nearly to the base, the divisions lanceolate, linear or oblong, the lateral ones often deeply cleft, all deeply toothed or lobed; basal leaves similar, usually developing later than the flowering stems. Flowers numerous in a stout, broad raceme, two-thirds to threefourths of an ineh broad, pink or white. The four petals longer than the sepals. Stamens six. Fruiting pod linear, aseending, I to $\mathrm{I} \frac{1}{2}$ inches long.

In moist or rich woods, Quebee to Florida, west to Minnesota, Kansas and Louisiana. Flowering in April and May.

\section{Two-leaved Toothwort or Crinkleroot}

Dentaria diphylla Michaux

Plate 8xb

Stems stout, simple, glabrous, 6 to i 4 inches high from a perennial. notched but continuous rootstoek. Basal leaves long petioled, 4 to 5 inehes 
broad, with thrce broadly ovate, dentate or somewhat lobed leaflets each about 2 inches long; stcm leaves usually two, opposite or nearly so, short petioled and also three-divided, the leaflets often narrower than those of the basal leaves. Flowers whitc, one-half to two-thirds of an inch broad.

In rich woods, Nova Scotia and New Brunswick to Minncsota, south to South Carolina and Kentucky. Flowcring usually in late April and in May.

The Large Toothwort (Dentaria maxima Nuttall) has a jointed rootstock and three stem lcaves (sometimes two or as many as five or six), alternate, with ovate and obovate toothed and cleft leaflets and large pale-purple flowers. It is rare and local in distribution.

The species of Dentaria are members of the Mustard family (Cruciferae) which contains a very large number of small-flowered, inconspicuous plants, many of them weeds, as well as a number of cultivated species which have become naturalized or established throughout the State.

\section{American Sea Rocket}

\section{Cakile edentula (Bigelow) Hooker \\ Plate $82 a$}

Plant very fleshy throughout, bushy branched from a deep, annual root, the lower branches spreading or ascending, the center ones erect, a few inches to a foot high. Leaves oblanceolate or obovate, obtuse, lobed or toothed, narrowed at the base, the lower leaves 2 to 5 inches long, the upper leaves smaller. Flowers light purple, less than one-fourth of an inch broad, the four petals long-clawed, more than twice the length of the sepals; fruit one-half to I inch long, the upper joint slightly longer than the lower, ovoid, angled, flattened, narrowed above into a bcak; lower joint obovoid, not flattened.

Sandy places along the seashore, Ncwfoundland to New Jersey and Florida, and along the Great Lakes, New York to Minnesota. 


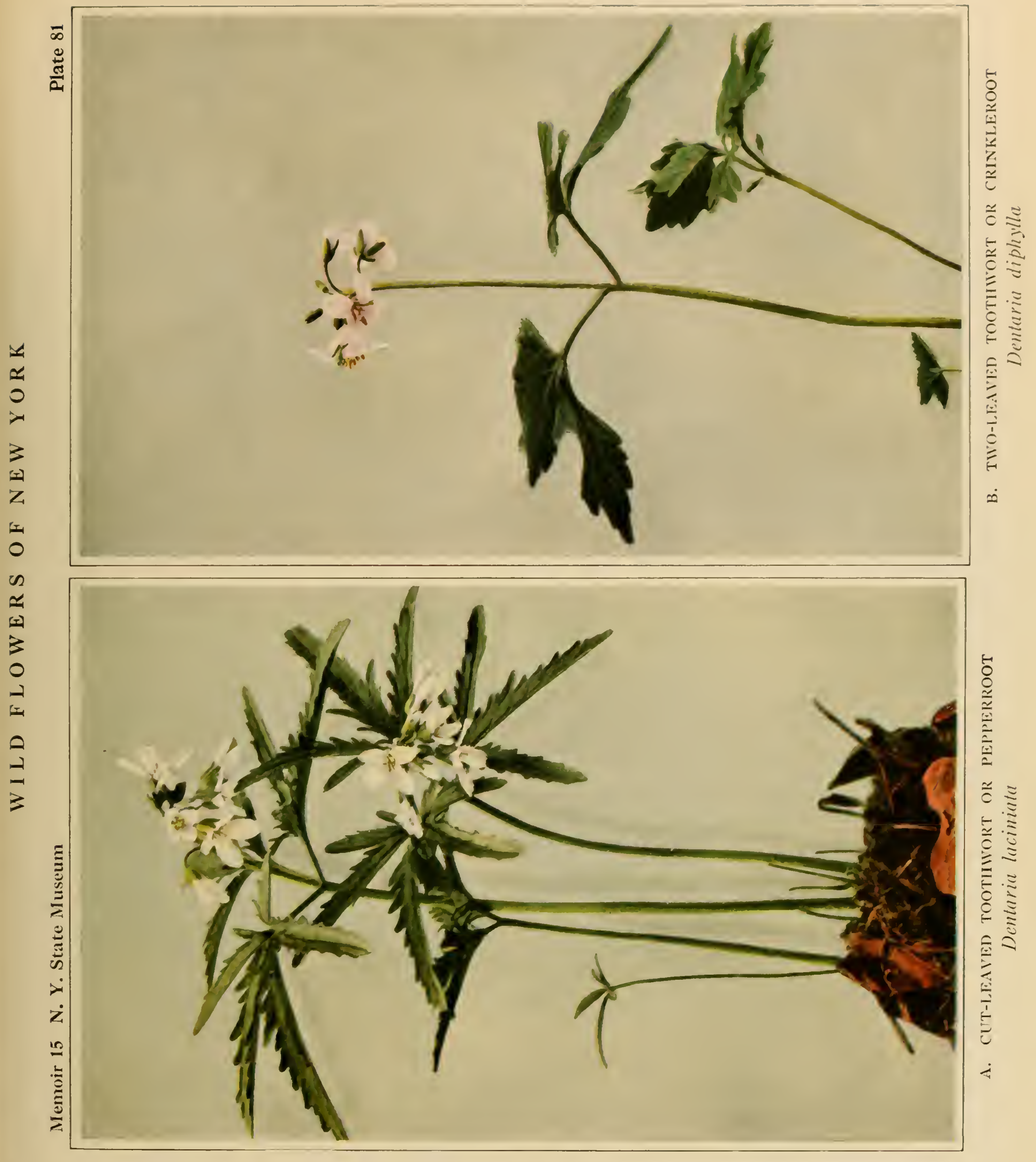



WILD FI, OWERS OF NEW YORK

Memoir 15 N. Y. State Museum

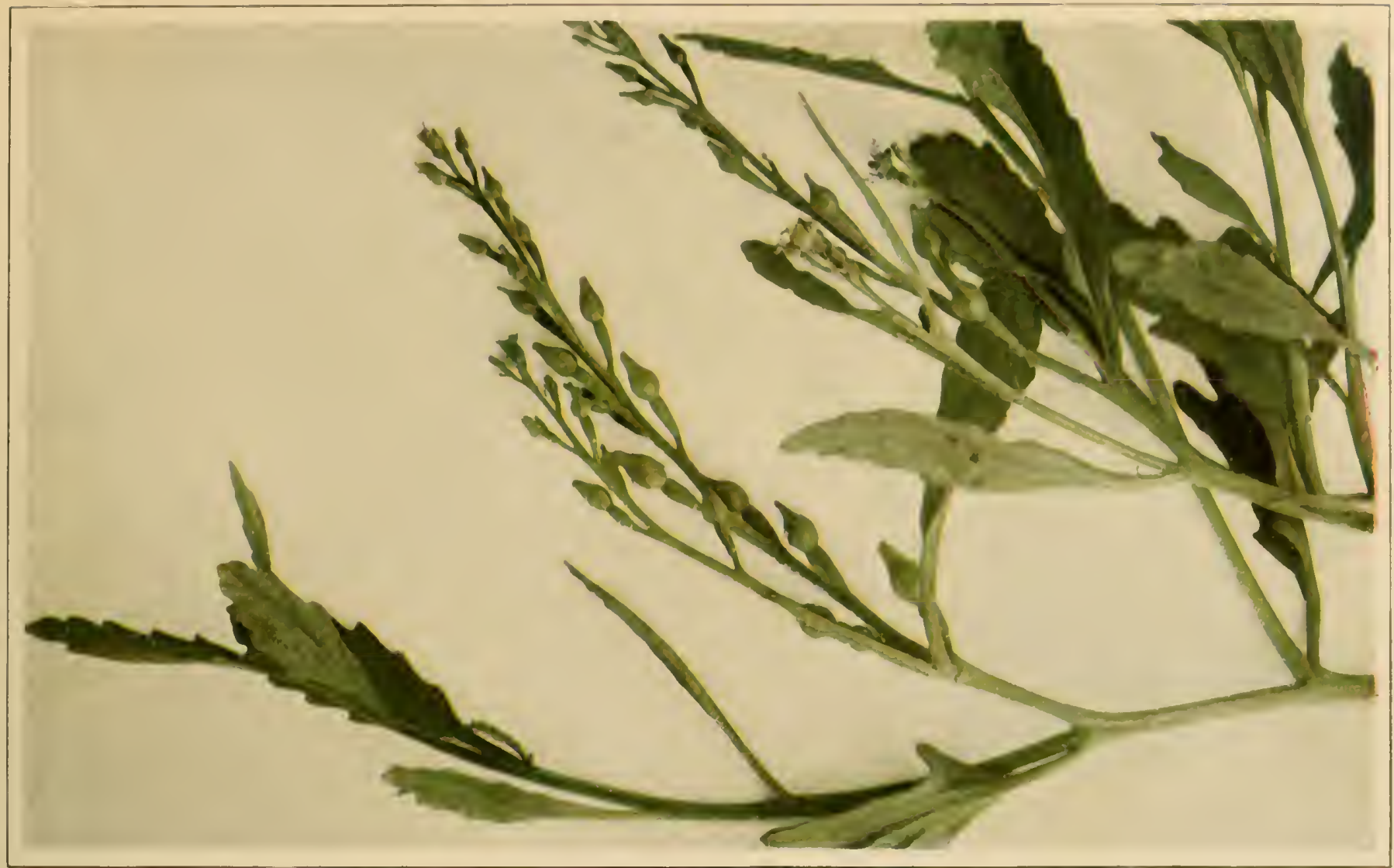

A. AMERICAN SEA ROCKET

Cakile edentula

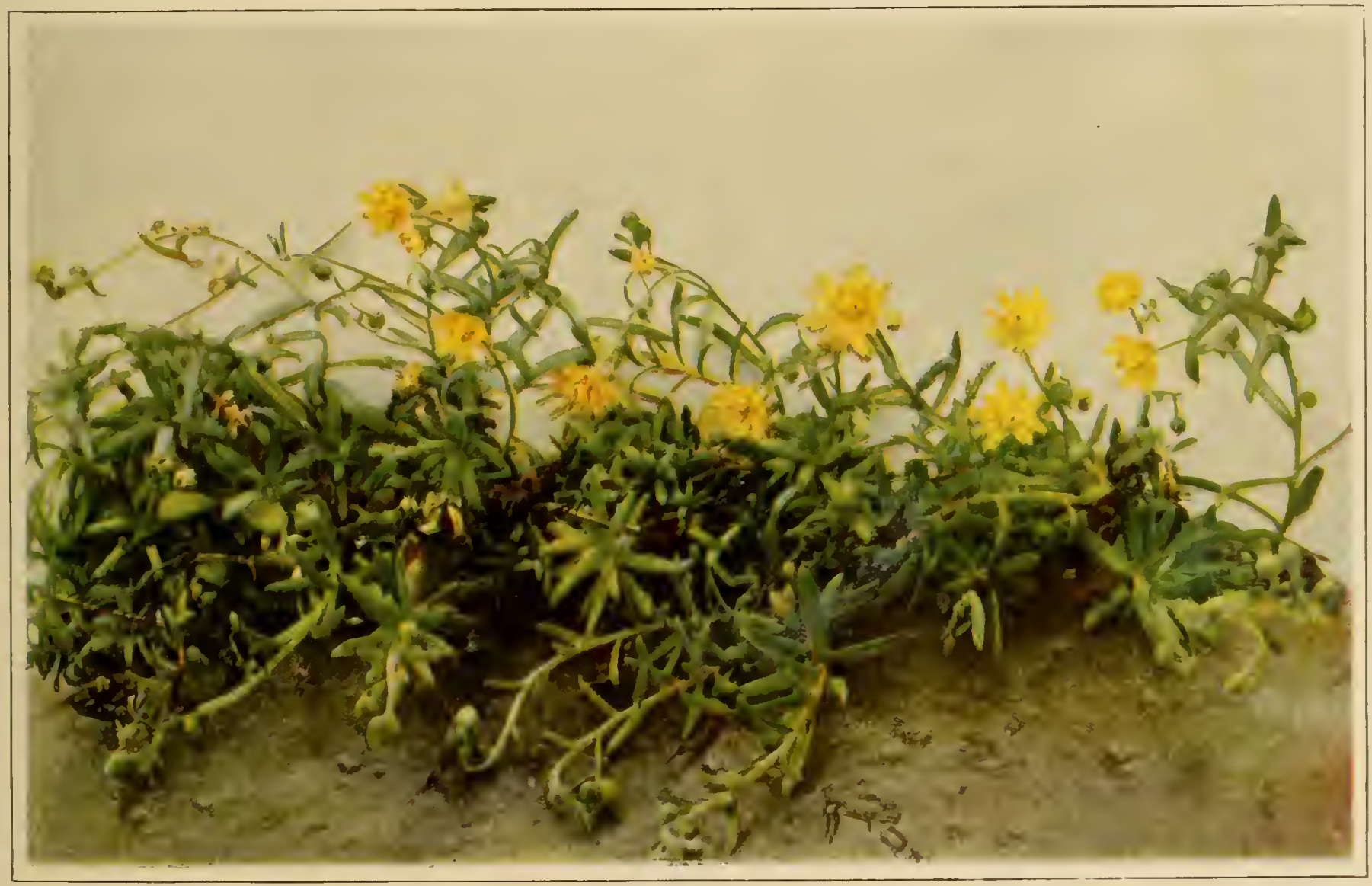

B. YELLOW MOUNTAIN SAXIFRAGE

Leptasia aizoides 


$$
\text { - }
$$




\section{Pitcher Plant Family}

Sarraceniaceac

\section{Pitcher Plant; Sidesaddle Flower \\ Sarracenia purpurea Linnaeus \\ Plate 83}

Leaves tufted, ascending, hollow, much inflated and trumpet-shaped, + to 2 inches long, with a broad, lateral wing and an erect terminal lid or lamina, glabrous except the inner side of the lamina and the inner surface of the pitchers, which are densely clothed with stiff, reflexed hairs, purpleveined or sometimes green, yellowish or reddish all over, narrowed into petioles below, persistent over winter. Roots large, stout and fibrous. Flowers solitary on slender scapes, I to 2 feet high, nodding, deep purple or rarely yellow, nearly globose, $\mathbf{I} \frac{1}{2}$ to $2 \frac{1}{4}$ inches broad; sepals five, green, with three or four bracts at the base; petals five, obovate, narrowed in the middle, incurved over the yellowish style. Style dilated at the apex into a peltate umbrellalike structure with five rays which terminate under its angles in hooked stigmas.

In peat bogs and wet sphagnous places, Labrador to the Canadian Rocky mountains, Florida, Kentucky and Iowa. Flowering in May and June. The pitcher-shaped leaves usually contain more or less water in which are numerous drowned insects which furnish food for the larvae of a fly which is instrumental in the cross-pollination of the flowers.

\section{Sundew Family \\ Droseracea e Spatulate-leaved Sundew Drosera intermedia (Linnaeus) Hayne Plate 84}

A tufted bog plant with erect, flowering scapes, 2 to 8 inches high, and elongated rootstocks. Leaf blades ascending, spatulate, obtuse at the apex, one-fourth to three-fourths of an inch long, one-half to one-third as 
wide as long, clothed above with long, glandular hairs secreting a fluid which entraps insects, narrowed below into glabrous petioles one-half to I $\frac{1}{2}$ inches long; usually the entire foliage reddish or greenish red in color. Flowers several in one-sided racemes; petals five, white, slightly longer than the greenish sepals; the one-celled ovary surmounted by three styles, each deeply two-parted so as to appear like six.

In bogs and sphagnous places, Newfoundland to Saskatchewan, south to Florida and Louisiana, and also in northern Europe. Flowering from June to August.

The Spatulate-leaved Sundew is not so common as the Round-leaved Sundew (Drosera rotundifolia Linnaeus), with orbicular leaf blades. Two additional Sundews occur in New York, namely the Oblongleaved Sundew (D rosera 1 ong if olia Linnaeus), with leaf blades elongated-spatulate, six to eight times as long as wide; and the Threadleaved Sundew (D. f i 1 if orm is (Linnaeus) Rafinesque), with linear leaves ten to fifteen times as long as wide and purple flowers. The last grows in wet sand near the coast, the others in bogs.

\section{Virginia Stonecrop Family}

Penthoraceae

\section{Ditch or Virginia Stonecrop}

Penthorum sedoides Linnaeus

Plate $87 \mathrm{~b}$

Stems erect, glabrous, often branched and angled above, 6 inches to 2 feet high, from a perennial root. Leaves alternate, sessile, lanceolate or narrowly elliptic, acuminate at each end, finely toothed, 2 to + inches long, one-half to I inch wide. Flowers perfect, yellowish green, in two or three forked, one-sided cymes, the branches I to 3 inches long. Each flower about one-fifth of an inch broad; calyx five-parted, the sepals triangular-ovate, pointed, shorter than the flattish capsule; stamens ten; petals often lacking, when present, linear or linear-spatulate. Fruit a depressed, five-lobed capsule with five divergent tips. 
W I L D F I, O IVER S O F N E W O R K

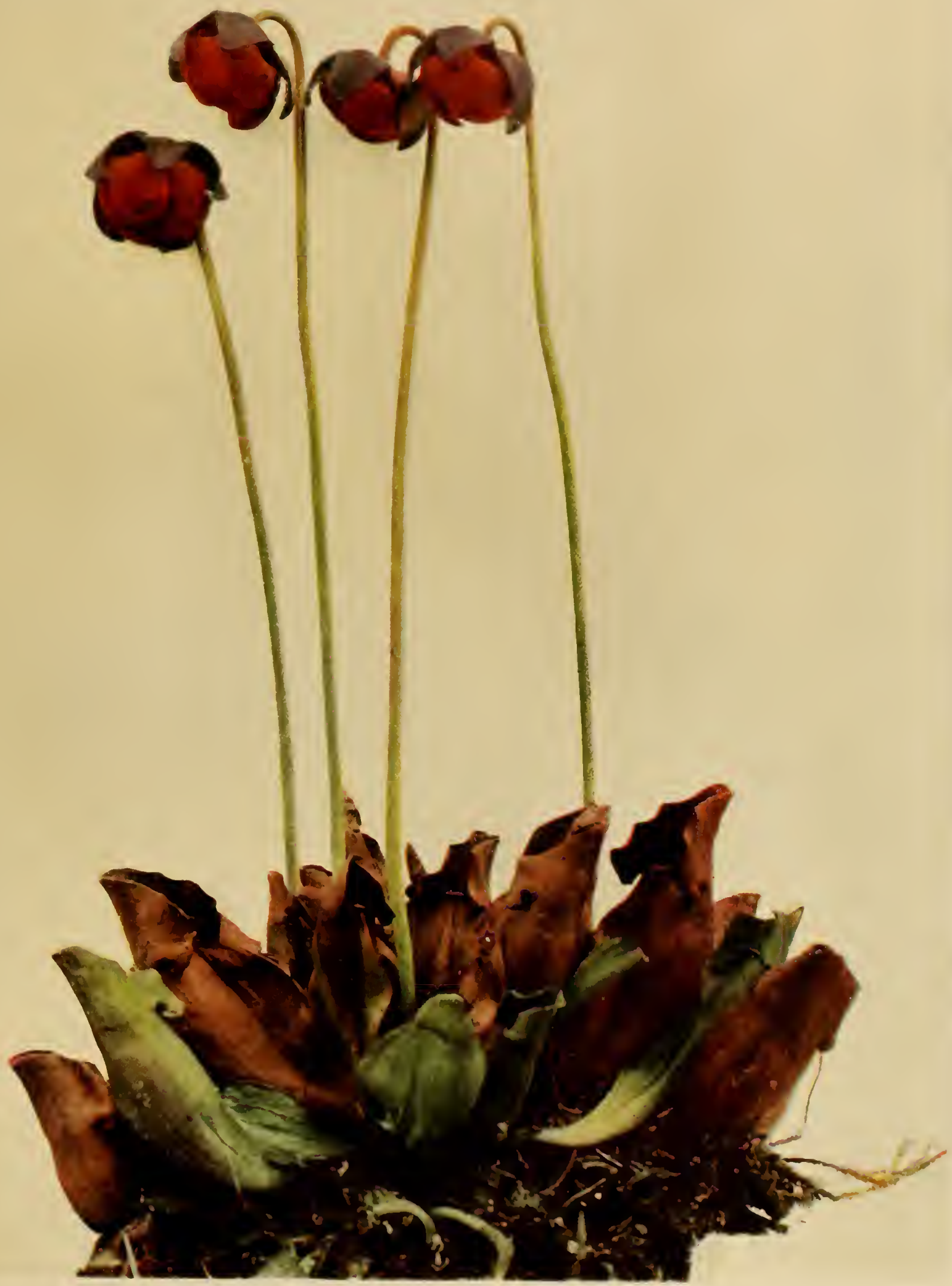

PITCHER PLANT; SIDESADDLE FLOWER

Sarracenia purpurea 


$$
\text { - }
$$




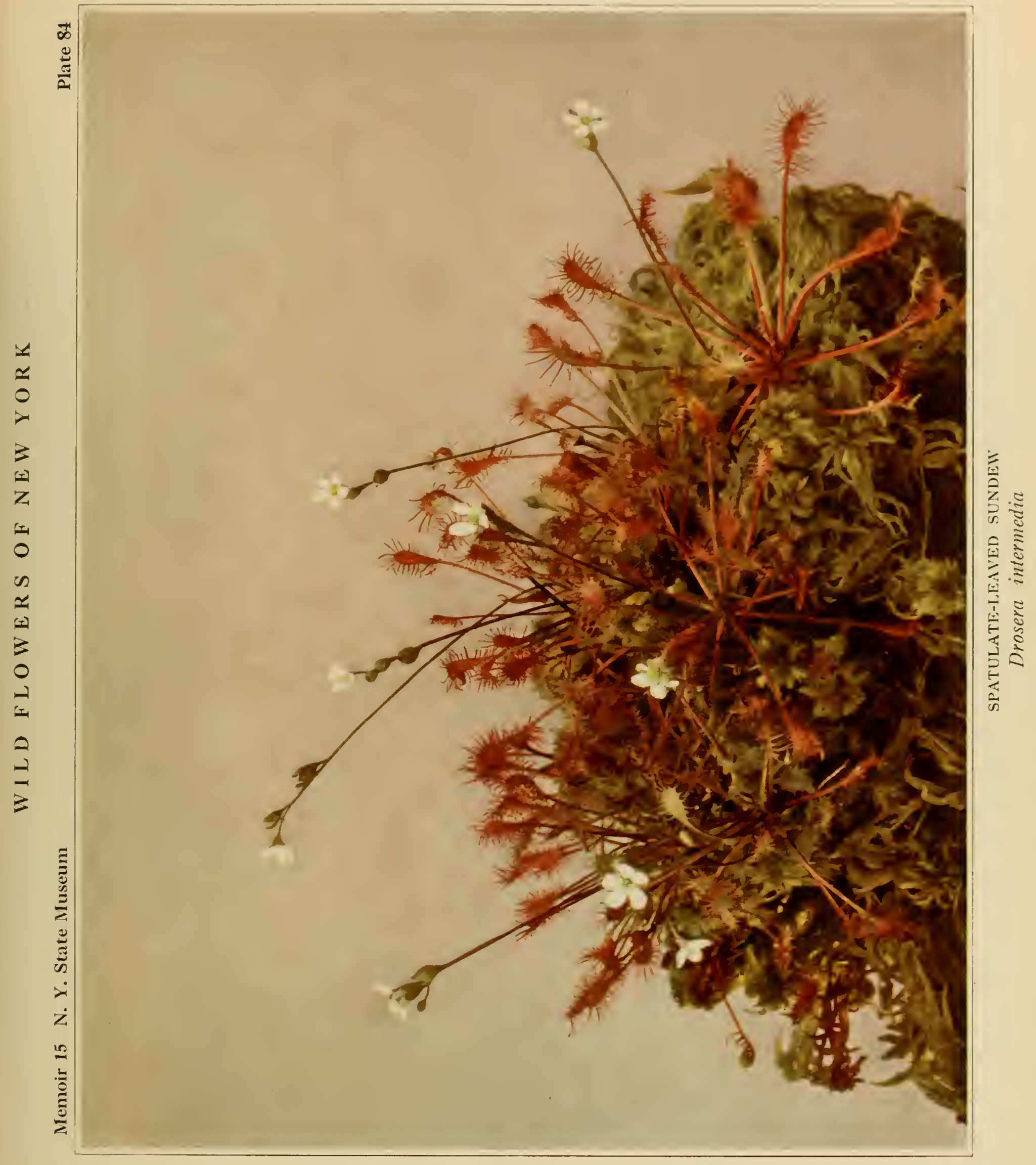




$$
\text { - }
$$


Common in ditches and swampy places, New Brunswick to Florida, west to Nebraska, Kansas and Texas. Flowering from July to September.

Not a very attractive plant, but the only American representative of the Penthoraceae (Virginia Stonecrop family), which is joined with the Saxifrage family by some authors and to the Orpine family by others.

\section{Grass-of-Parnassus Family}

Parnasiaceac

\section{Carolina Grass-of-Parnassus}

Parnassia caroliniana Michaux Plate 85

Flowering scape 6 to 20 inches high, with a sessile, ovate, clasping leaf below the middle. Basal leaves very numerous, ovate, oval, or nearly orbicular, obtuse at the apex, rounded or slightly cordate at the base, or decurrent on the petiole, $I$ to 2 inehes long, on petioles 2 to 6 inches long. Flowers three-fourths to $\mathrm{I} \frac{1}{2}$ inches broad; calyx lobes five, ovate-oblong, obtuse and much shorter than the five broadly oval, white, greenish veined petals; each petal with a set (usually three) of gland-tipped staminodia at the base which do not exeeed the five fertile stamens in length, the latter alternate with the petals. Fruit a one-celled capsule about one-half of an inch long.

In swamps, low meadows and boggy places, New Brunswick to Manitoba, south to Virginia, Illinois and Iowa. Flowering from July to September, rarely earlier than July in our latitude. At Taberg growing on wet cliffs with the Yellow Mountain Saxifrage and Dwarf Canadian Primrose.

\section{Saxifrage Family}

Saxifragaceae

Yellow Mountain Saxifrage

\section{Leptasea aizoides (Linnaeus) Haworth}

Plate $82 \mathrm{~b}$

Stems tufted, forming loose or dense leafy mats, 2 to 7 inches high. Leaves alternate, linear, thick, fleshy, sharply pointed at the apex, sessile, 
one-third to three-fourths of an inch long, one-eighth of an inch wide or usually less, sometimes sparingly ciliate on the margins. Flowers several, corymbose, one-third to two-thirds of an inch broad on slender pedicels; petals five, oblong, yellow and often spotted with orange, longer than the ovate calyx lobes and alternate with them. Stamens ten; ovary almost superior, the two capsules united to above the middle.

On wet or dripping rocks, Newfoundland and Labrador to Vermont, northern and western New York, and west through Arctic America to the Rocky mountains. Also in Alpine and Arctic Europe and Asia. Flowering in July and August.

\section{Early Saxifrage}

\section{Micranthes virginiensis (Linnaeus) Small}

\section{Plate 87 a}

Flowering stem 4 to 12 inches high, viscid-pubescent with whitish hairs, leafless or with a few green bracts at the base of the inflorescence. Leaves all basal, I to 3 inches long, obovate, or oval, toothed, blunt or pointed at the apex, spatulate at the base and narrowed into a margined petiole; inflorescence cymose, becoming paniculate by the elongation of the lower branches. Flowers white, less than one-fourth of an inch broad; calyx of five erect, triangular, pointed lobes; petals five, oblong-spatulate, obtuse, longer than the calyx; stamens ten, carpels of the fruit usually two, nearly separate, widely divergent when mature.

In dry or rocky woodlands, banks and ledges, New Brunswick to Minnesota, south to Georgia and Tennessee. Flowering from April until June.

\section{Swamp Saxifrage}

Micranthes pennsylianica (Linnaeus) Haworth

Plate 86

Flowering scape stout, viscid-pubescent, I to $3 \frac{1}{2}$ feet high, with green bracts at the inflorescence, otherwise leafless. Leares all basal, large, oval, ovate, obovate or oblanceolate, pubescent or nearly glabrous, + to Io inches long, obtuse at the apex, narrowed below into a broad petiole, 
W ILD FLO WERS OF NEW YORK

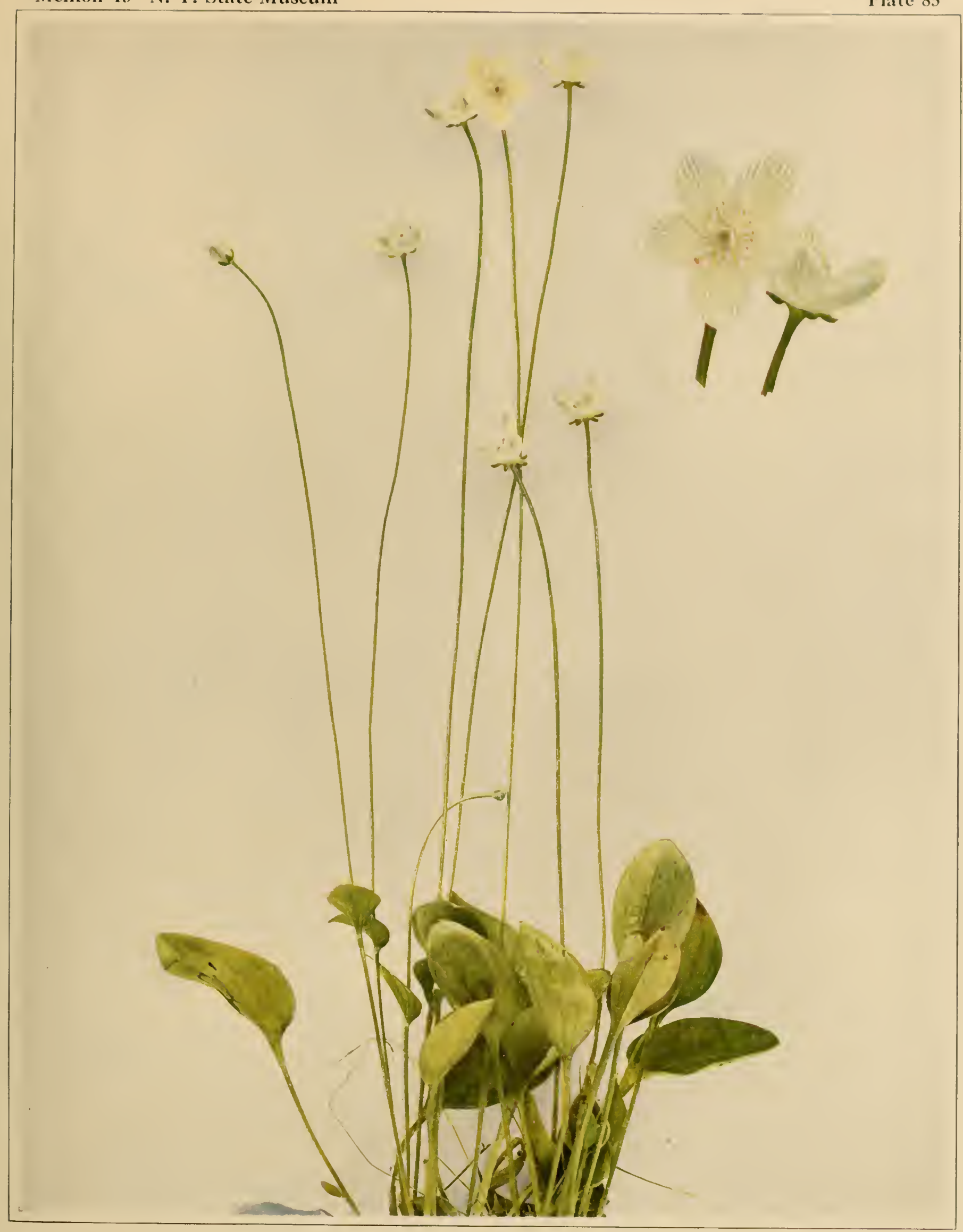

GRASS-OF-PARNASSUS

Parnassia caroliniana 


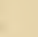


the margins denticulate or repand. Flowers in elongated, loosc, terminal panicles, grecnish. Each flower about one-eighth of an inch broad or slightly broader; the obtuse calyx lobes reflected; petals five, lanceolate or linear-lanceolate, twice as long as the calyx.

Swamps, wet banks and wet woods, Maine to Ontario, Minnesota, Virginia, Iowa and Missouri. Flowcring in May and June.

\section{Foamflower; False Miterwort \\ Tiarella cordifolia Linnaeus \\ Plate 88}

Flowering scapes 6 to 12 inches high, slender and pubescent, from a rather stout, perennial root. Leaves all basal, long petioled, broadly ovate or nearly orbicular, cordate at the base, three to seven-lobed, blunt or pointed at the apex, 2 to 4 inches long, margins crenate or dentate, pubescent above with scattered hairs, glabrate or downy along the veins beneath. Flowers white, forming a terminal raceme, I to 4 inches long. Each flower about one-fourth of an inch broad; petals five, oblong, entire or slightly toothed, somewhat longer than the five white calyx lobes; stamens ten, anthers reddish or yellowish. Fruit of two very unequal carpels, about one-fourth of an inch long, reflexed on slender pedicels.

In rich, moist woods, Nova Scotia to Ontario and Minnesota, south along the mountains to Georgia, and west to Indiana and Michigan. Flowering from April to June. Also known as Coolwort.

\section{Alumroot \\ Heuchera americana Linnaeus \\ Plate so}

Flowering stem rather stout, $\mathrm{I} \frac{1}{2}$ to 3 feet high, leafless, glandular, hirsute. Leaves basal, long petioled, 3 to 4 inches wide with seven to nine rounded, crenate-dentate lobes; the older leaves glabrous or with scattered hairs on the upper surfaces. new leaves usually somewhat pubescent. Flowers greenish yellow, in elongated panicles; calyx tube broadly 
campanulate, nearly regular, somewhat less than one-fourth of an inch long, five-lobed; petals five, very small, greenish and alternate with the lobes of the calyx which they do not exceed in length. Stamens five, projecting out from the calyx more than one-half their length, anthers orange.

In dry or rocky woods and banks, Ontario to Connecticut, west to Minnesota, south to Alabama and Louisiana. Flowering from May to August.

\section{Two-leaved Bishop's Cap; Miterwort}

\section{Mitella diphylla Linnaeus}

Plate gob

Stems erect, often several together from a perennial root, 8 to $i 7$ inches high, pubescent, each stem bearing a pair of opposite, sessile or nearly sessile leaves near or above its middle. Basal leaves broadly ovate, cordate at the base, acute or long pointed at the apex, three to five-lobed, toothed, rather rough-hairy, on both sides, I to 2 inches long. Flowers small, white, rather distant from one another, in a very narrow, elongated, erect raceme, 3 to 8 inches long; calyx tube bell-shaped, five-lobed; petals five, finely pinnatifid. Fruiting capsules one-celled, two-valved at the apex, many seeded, somewhat flattened and broad, seeds smooth, black and shiny.

In rich woods, Quebec to Minnesota, North Carolina and Missouri. Flowering in April and May.

In cold woods and bogs of the northern part of the State occurs a smaller species of Miterwort, $\mathrm{Ni}$ t e $1 \mathrm{la} \mathrm{n} \mathrm{u} \mathrm{d}$ a Linnaeus, with reniformorbicular, basal leaves and the stems usually without leaves; flowers greenish yellow. Another species, M. op positifolia Rydberg, has been described from central New York which differs from M. d i p h y 11 a only in having long-petioled stem leaves, lanceolate calyx lobes and filiform divisions to the petals. 
W I L, D I L, OWERS O F NEW YOR K

Memoir 15 N. Y. State Museum

Plate 86

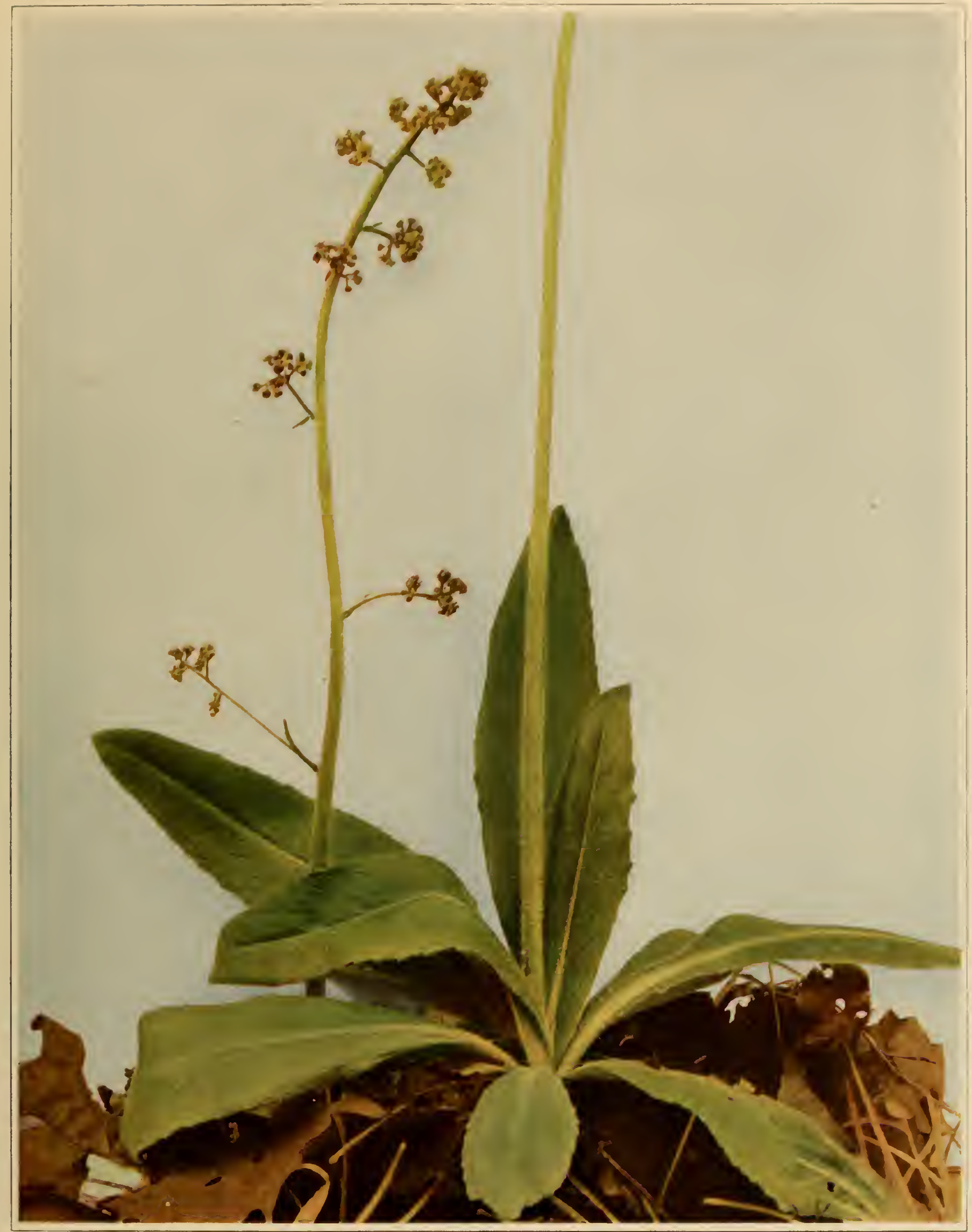

SWAMP SAXIFRAGE

Micranthes pennsylianica 


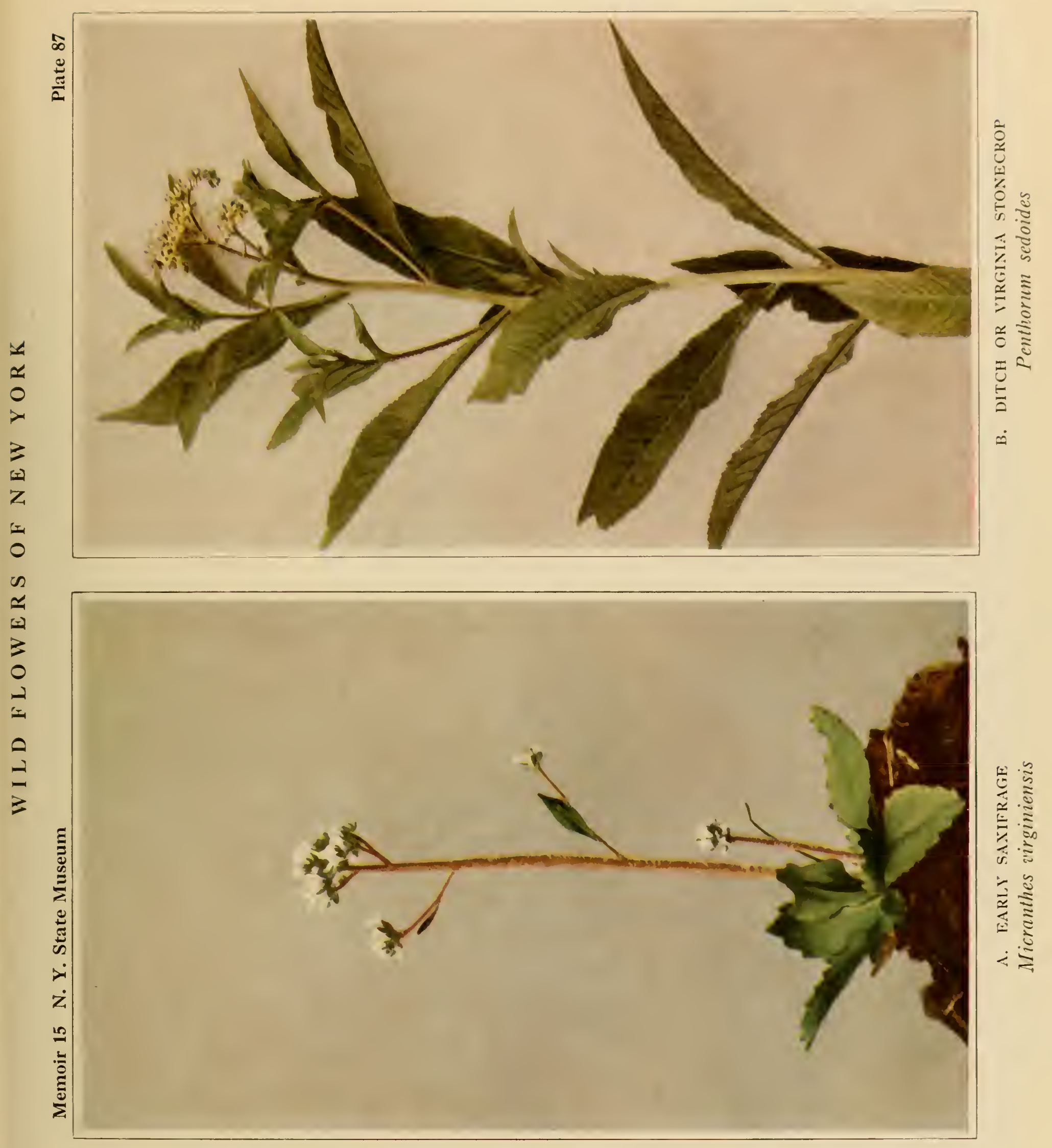


. 
W I L D F L OWERS O F NEW YOR K

Memoir 15 N. Y. State Museum

Plate 88

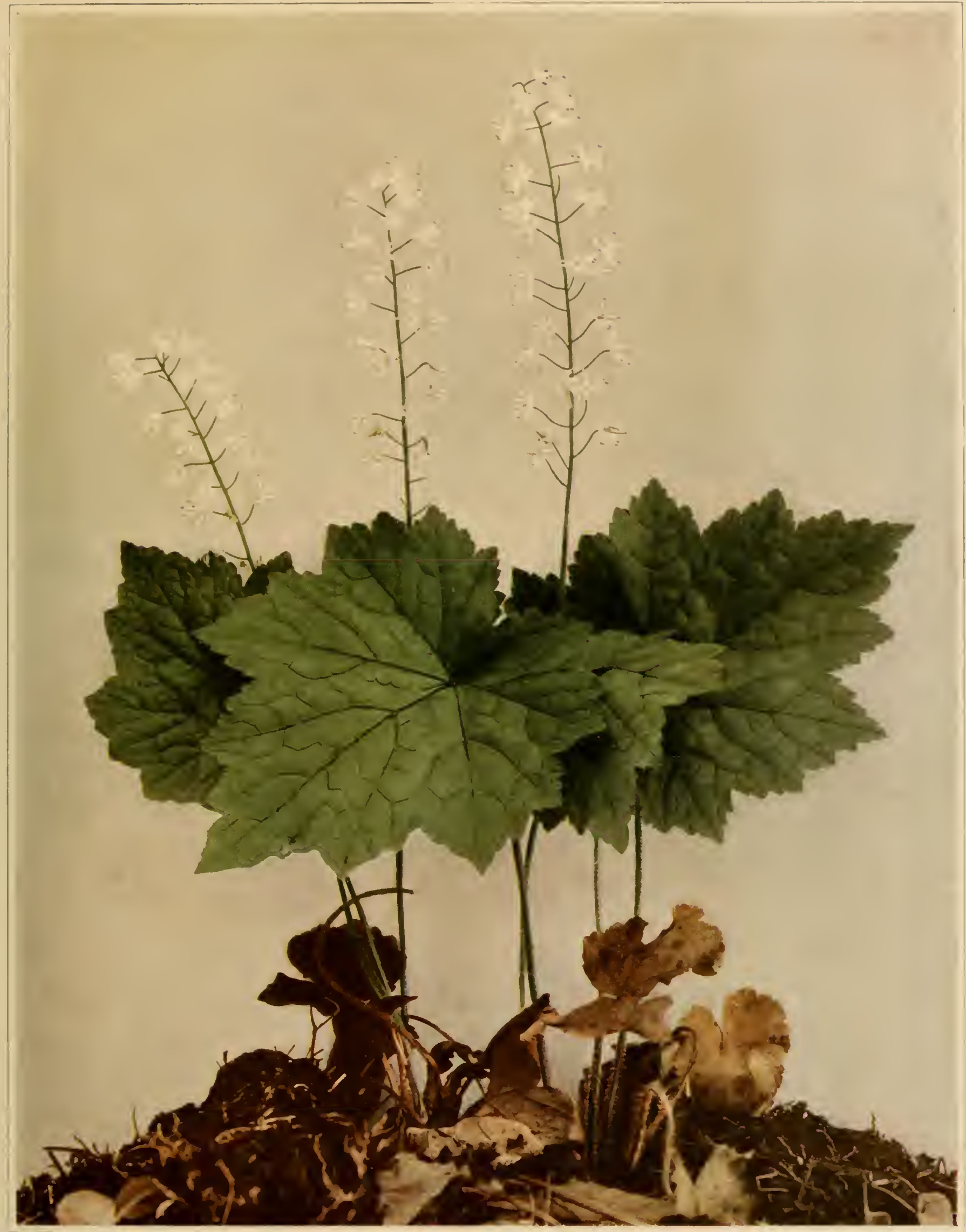

FOAMFLOWER; FALSE MITERIORT

Tiarella cordifolia 



\title{
Rose Family
}

\author{
Rosaceac
}

\section{Meadowsweet; Quaker Lady}

Spiraea latifolia (Aiton) Borkhausen

Plate 9.3a

An erect shrub, 2 to 6 feet high, usually more or less branched above and smooth with reddish stems. Leaves short petioled, blades oblanceolate or obovate, glabrous or nearly so, coarsely toothed, I to 2 inches long, onehalf to $\mathbf{I} \frac{1}{2}$ inches wide, usually larger on young shoots, obtuse or slightly pointed at the apex, rounded or tapering at the base, pale beneath. Flowers white or pinkish, in dense terminal panicles, each flower about one-fourth of an inch broad or less; petals four or five, inserted on the calyx; stamens numerous. Pistils commonly five, alternate with the calyx lobes.

In moist or rocky places, in open woods, or in old meadows and along roadsides, Newfoundland to Saskatchewan, Virginia and western Pennsylvania. Flowering from June to August.

The Narrow-leaved Meadowsweet (Spiraea alba Du Roi) has yellowish brown branches, narrowly oblanceolate to oblong leaves and white flowers. It is much less abundant than Spiraea lat if olia, and is found in wet soil, Ontario to New York, south to North Carolina, west to Indiana, Missouri and Saskatchewan.

\section{Hardhack; Steeplebush}

\section{Spiraea tomentosa Linnaeus}

Plate $9+3$

Erect, shrubby and perennial at least below, the tops usually dying back, I to 3 feet tall, usually simple; stems floccose-pubescent. Leaves short petioled, ovate or oval, I to 2 inches long, one-half to I inch wide, unequally toothed, blunt or pointed at the apex, narrowed or rounded at the base, smooth and dark green above, woolly-pubescent with whitish hairs beneath. Flowers pink or purplish, rarely white, in dense terminal 
panicles, each flower about one-fifth of an inch broad; divisions or follicles of the fruit pubescent.

In wet meadows, swamps and low ground, Nova Scotia to Manitoba south to Georgia and Kansas. Flowering from July to September.

The Corymbed Spiraea (S piraea corymbos a Rafinesque). with oval, ovate or orbicular leaves, slightly cordate at the base, or rounded, and with small white flowers in dense terminal, often leafy corymbs, is found occasionally on rocky banks and in wood of the southern part of the State.

\section{Indian Physic; Bowman's Root}

\section{Porteranthus trifoliatus (Linnaeus) Britton}

Plate 9I

Stems erect, herbaceous, 2 to + feet high, from a perennial root, usually branched, glabrous or slightly pubescent. Stipules small, one-eighth to one-fourth of an inch long, entire or toothed. Leaves sessile or nearly so, three-foliate; leaflets oval, ovate, lanceolate or slightly obovate, long pointed at the apex, narrowed at the base, 2 to 3 inches long, irregularly toothed. Flowers white or pinkish, one-half to two-thirds of an inch long on slender peduncles, in loose, terminal, leafy panicles; calyx reddish, five-toothed, ten nerved; petals five, linear-lanceolate, somewhat unequal.

In woods and thickets, Ontario and New York to Michigan, Georgia and Missouri. Flowers in June and July.

A closely related species, Porteranthus stipulatus (Muhlenberg) Britton, has incised leaflets, broad, foliaceous, incised stipules and slightly smaller flowers. Its range is about the same.

\section{Common Five-finger or Cinquefoil}

\section{Potentilla canadensis Linnaeus}

Plate 92a

Stems ascending, a few inches high, spreading by slender runners 3 inches to I or 2 feet long; the pubescence of the stem, petioles and peduncles spreading. Leaves petioled, digitately five-foliated; leaflets oblanceolate 
W I L D F LOWERS O F NEW YORK

Memoir 15 N. Y. State Museum

Plate 89

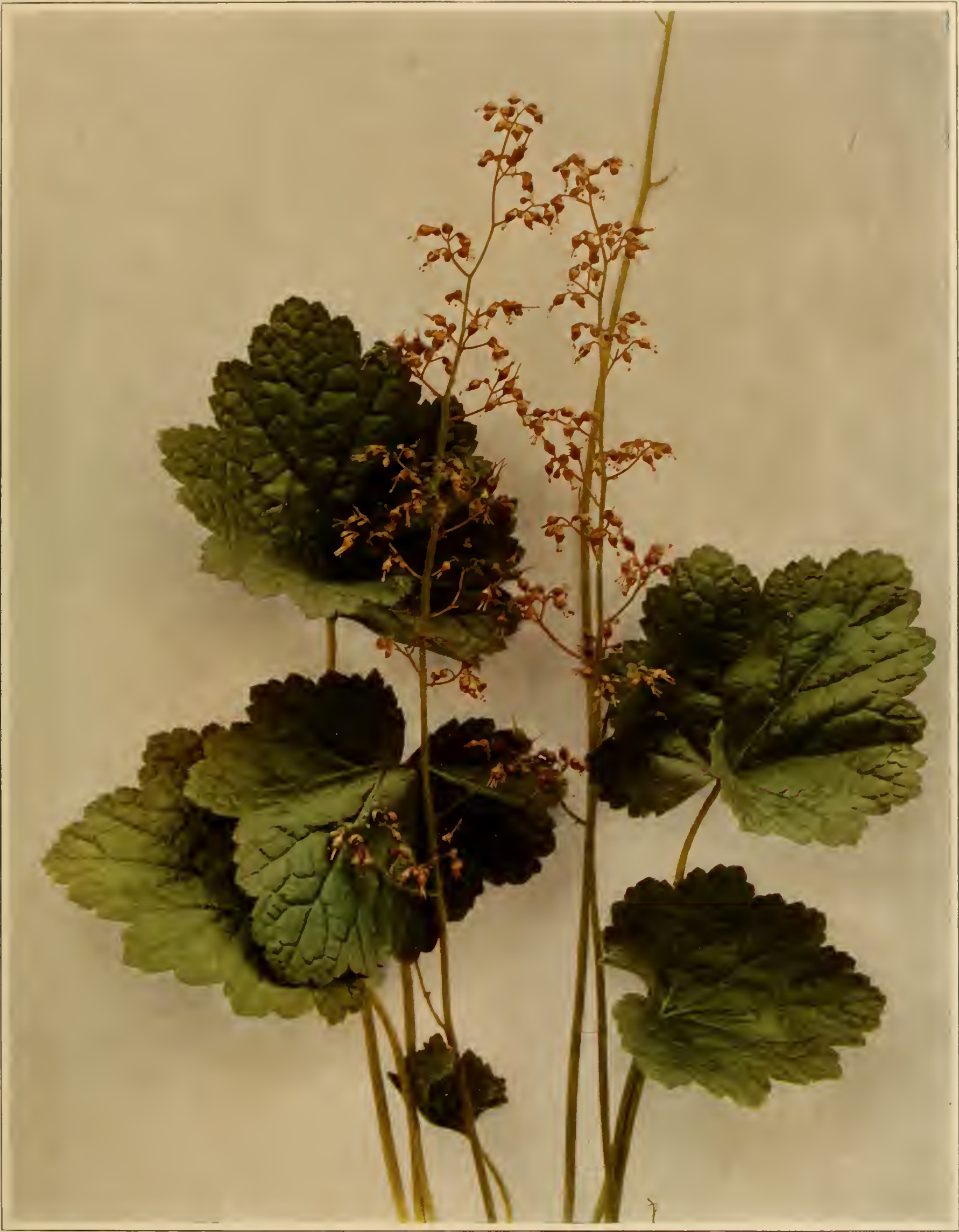

ALUMROOT

Heuchera americana 


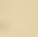


WILD FLOWERS OF NEW YORK

Memoir 15 N. Y. State Museum

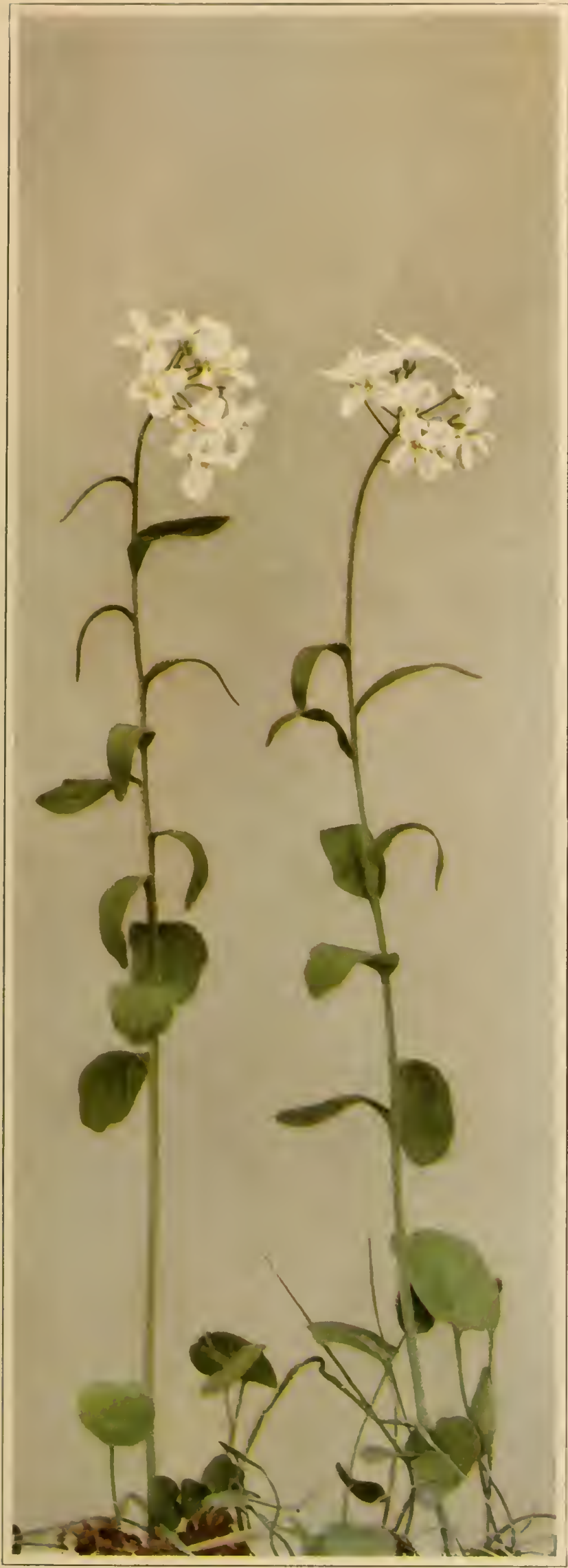

A. BULBOUS CRESS; CUCKOO-FLOWER Cardamine bulbosa
Plate 90

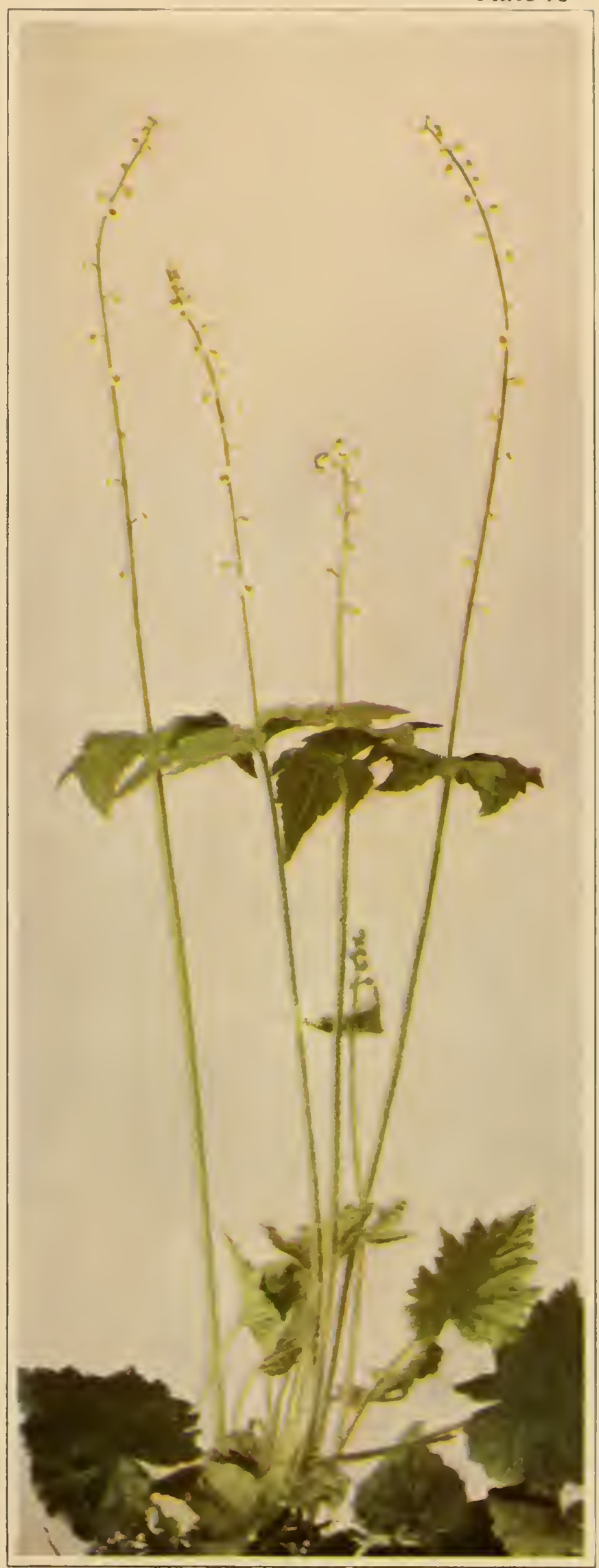

B. TWO-LEAYED BISHOP'S CAP OR MITERWORT Witella diphylla 

WILD FLO WERS OF NE W YORK

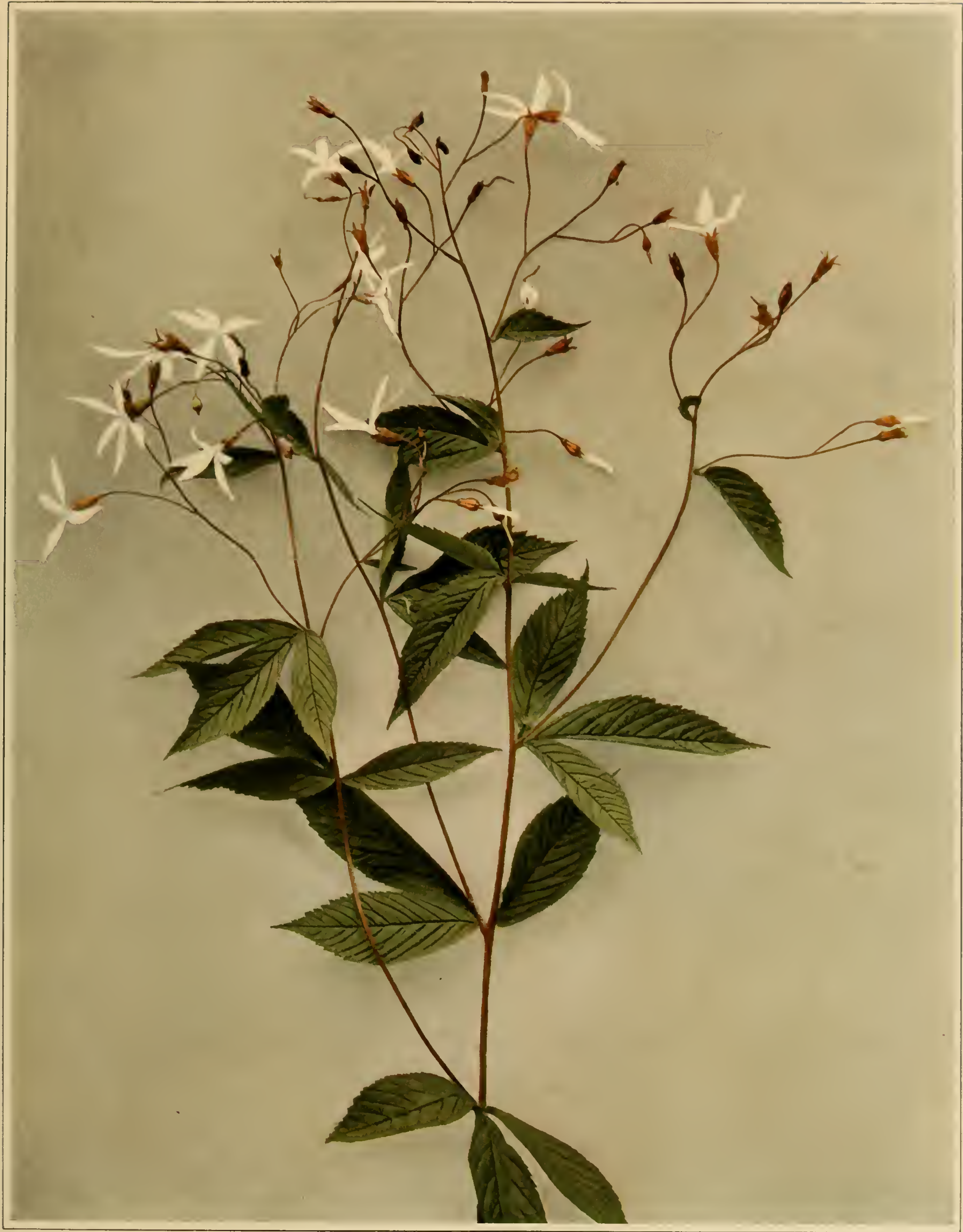



to oblong, blunt at the apex, narrowed at the base, one-half to I inch long, toothed. Flowers yellow, one-fourth to three-fourths of an inch broad on slender, axillary, one-flowered peduncles; the first flower appearing from the axil of the second stem leaf; petals five, broadly oval, slightly longer than the acute calyx lobes and the linear-lanceolate bractlets; stamens about twenty.

In dry soil of meadows and fields, New Brunswick to Georgia, Minnesota and Texas. Flowering from April to August.

The genus Potentilla contains a number of representatives in New York, several of which are introduced species. Of these, the most common is the Rough Cinquefoil (Potentilla monspeliensis Linnaeus), with stout, erect, hairy stems and leaves, and yellow flowers in which the calyx lobes exceed the petals in length.

The Silvery Cinquefoil (Potentilla a rge nte a Linnaeus) is a native species of dry soils or rocky places, with spreading or ascending, white, woolly-pubescent stems, leaflets green and smooth above and whitetomentose beneath, the margins revolute, and small yellow flowers.

\section{Rough-fruited Cinquefoil \\ Potentilla recta Linnaeus \\ Plate 95}

Stems erect, stout, branched above, villous-pubescent, I to 2 feet high from a stout, perennial root, with ovate-lanceolate stipules, the lower foliaceous and cut. Leaves digitately five to seven-foliate, petioled or the upper leaves nearly sessile; leaflets oblanceolate, blunt at the apex, narrowed at the base, pubescent with scattered hairs above, more densely pubescent beneath, sharply toothed, I to 3 inches long. Flowers numerous, bright or dull yellow, about three-fourths of an inch broad, in terminal, cymose clusters; stamens about twenty.

Roadsides, fields and waste places, Maine to Ontario, New York, Virginia and Michigan. Naturalized from Europe and Asia. Flowering from June to September. 


\section{Silverweed; Wild or Goose Tansy Argentina anserina (Linnaeus) Rydberg \\ Plate $92 \mathrm{~b}$}

Stems and leaves herbaeeous and tufted from a perennial root; spreading by slender runners, 8 inches to 3 feet long. Leaves pinnate, 3 to 18 inehes long; leaflets seven to twenty-five, oblong, oblanceolate or obovate, obtuse, the lower leaflets usually smaller, often with still smaller ones interspersed, all sharply toothed, nearly glabrous above, white or silky-pubeseent beneath. Flowers yellow, three-fourths to $\mathbf{I}_{8}^{1}$ inehes broad, solitary on erect axillary peduneles; petals five, broadly oval or obovate, longer than the five ovate, pointed sepals and the five oval braetlets; stamens about twenty, borne around the base of the hemispherie, villous reeptaele.

Lake shores, sandy fields and salt meadows, New Jersey to Greenland, west to Nebraska, British Columbia and Alaska, south in the Rocky mountains to New Mexieo and California; also in Europe and Asia. Flowering from May to September. Consists of several or numerous raees, differing in the size and shape of the leaflets, and slightly in the aehenes. Small northern plants have been referred to A. egedii of Greenland, and a form from Oneida lake has been deseribed as A. b a be ockian a Rydberg.

\section{Purple or Marsh Cinquefoil; Purplewort \\ Comarum palustre Linnaeus plate $96 a$}

Stems deeumbent, often rather long, somewhat woody and perennial at the base; pubescent above. Leaves pinnate, upper leaves three to five-foliate, nearly sessile, lower ones sueeessively longer petioled, five to seven-foliate; leaflets oblong or oval, sharply toothed, blunt or pointed at the apex, narrowed at the base, I to 3 inches long; petioles sheathed at the base by large membranous stipules. Flowers eonspieuous, threefourths to $1 \frac{1}{4}$ inehes broad; calyx deeply five-lobed with five narrow braetlets, 


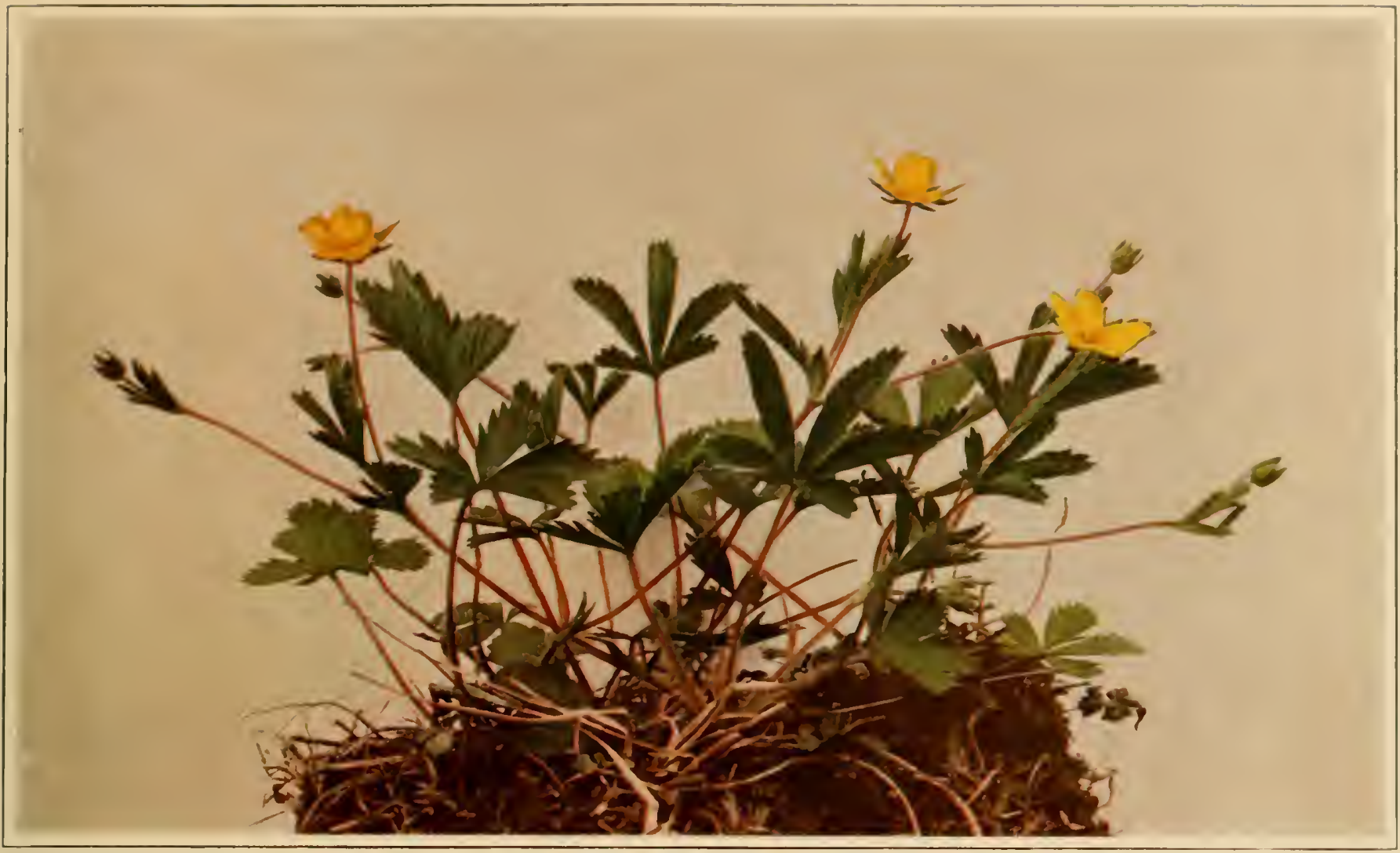

A. COMMON FIVE-FINGER OR CINQUEFOIL Potentilla canadensis

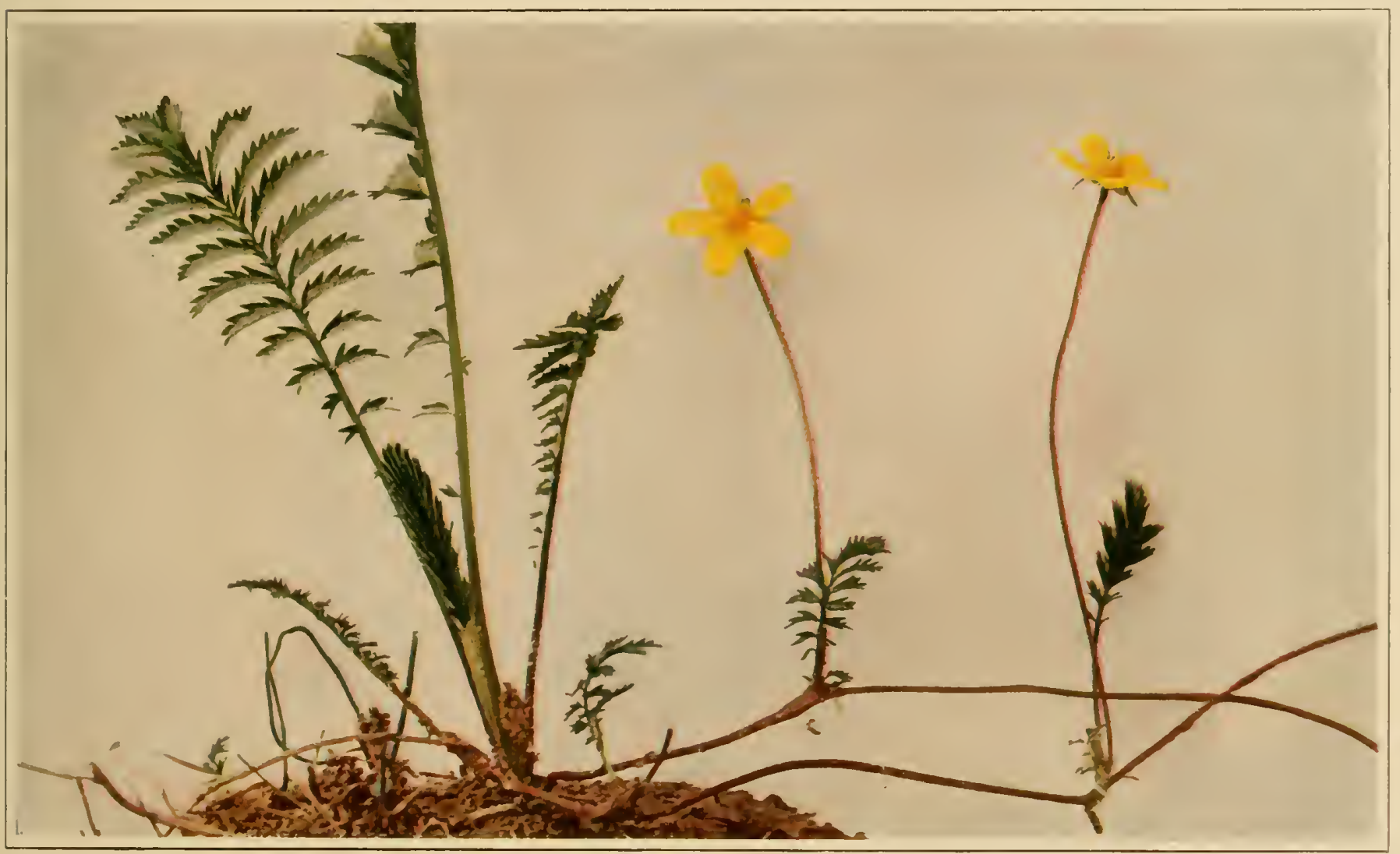

B. SILVERIIEED; WILD OR GOOSE TANSY 


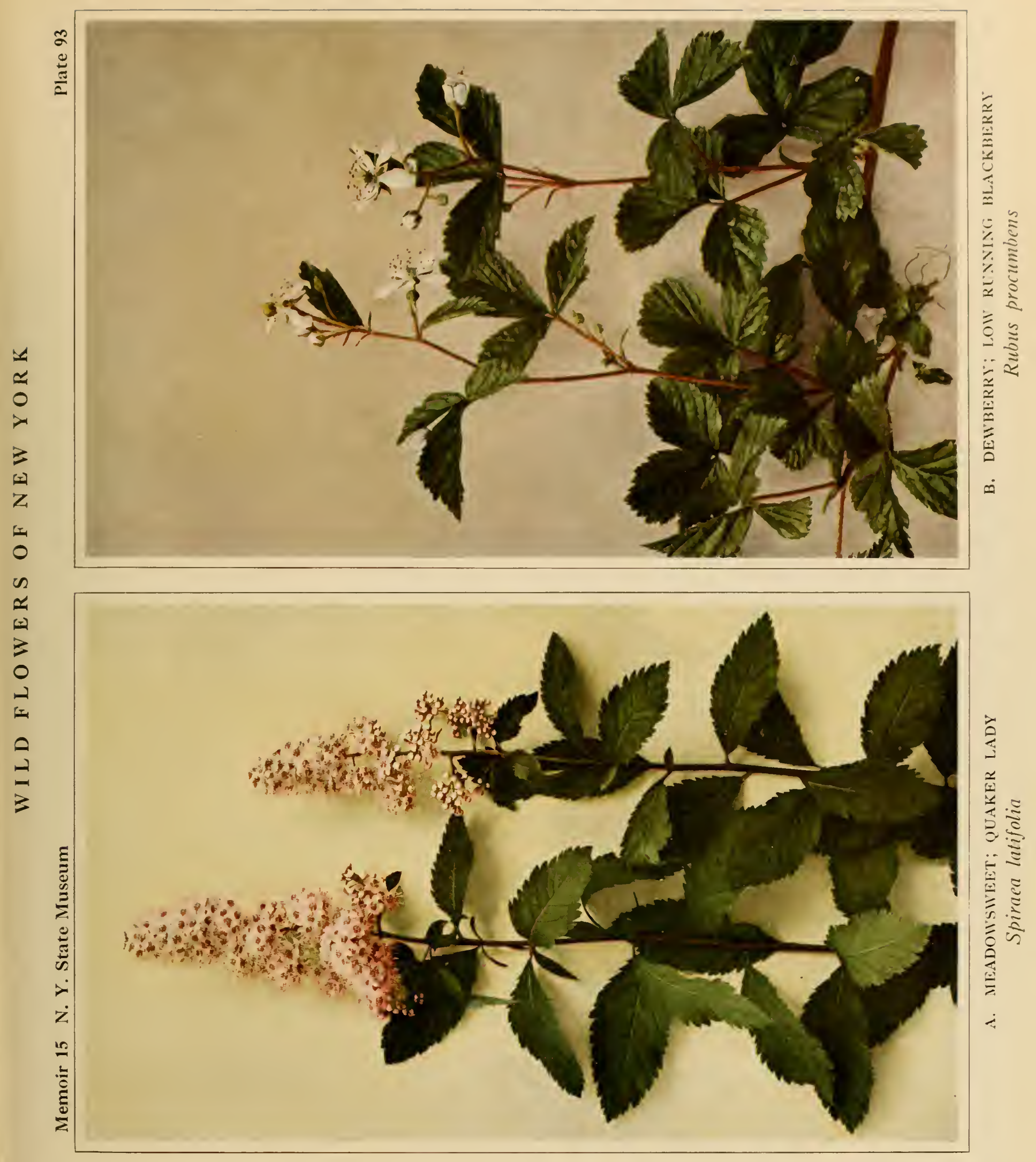



WII, D FLOWERS OF NEW YORK

Menoir 15 N. Y. State Museum

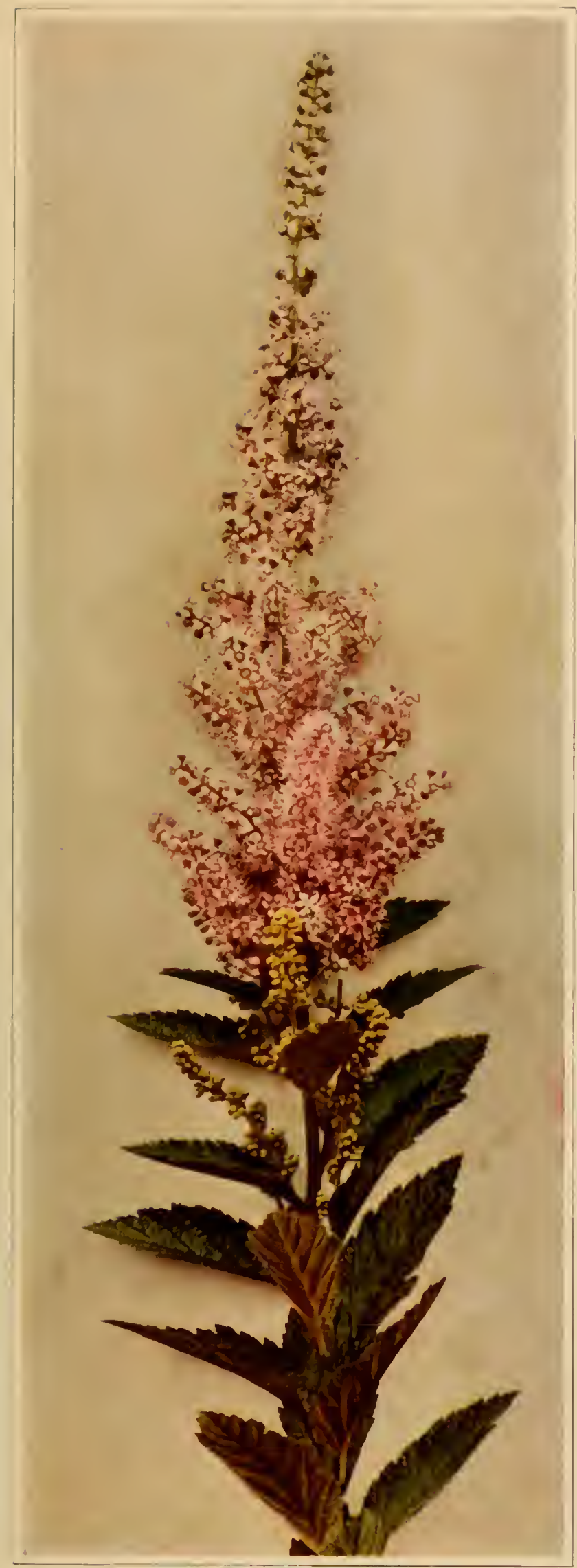

A. HARDHACK; STEEPLEBUSH

Spiraea tomentosa
Plate 94

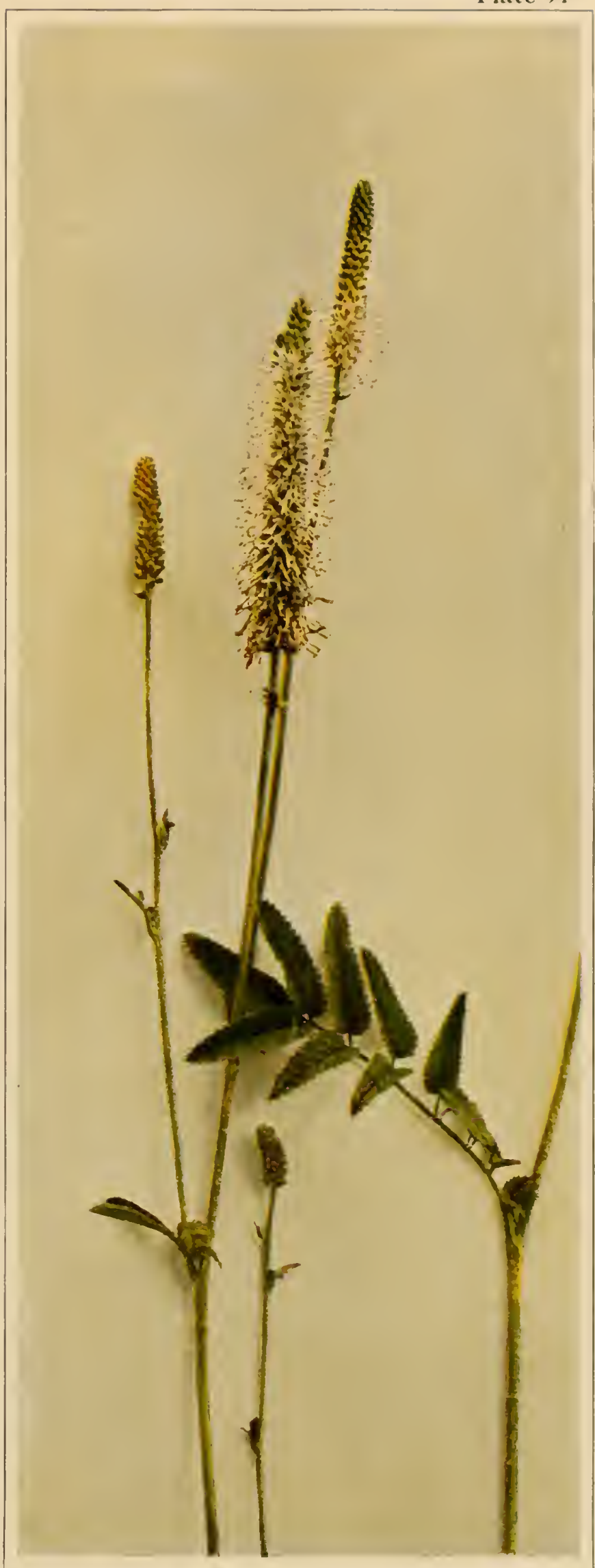

B. AMERICAN GREAT BURNET Sanguisorba canadensis 

the calyx lobes ovate, acuminate, red or purple within, much exceeding the purplc, ovate-lanceolate petals; pistils numerous, scated on an enlarged, pubescent receptacle which becomes spongy in fruit.

In swamps and peat bogs, Grecnland and Labrador to Ncw Jcrsey, Iowa, British Columbia, Wyoming, Alaska and California; also in northern Europe and Asia. Flowering from June to August.

\section{Wild or Scarlet Strawberry}

\section{Fragaria virginiana (Linnaeus) Duchesne}

Plate $97 \mathrm{a}$

Plants tufted, usually several or many together, dark green, foliage villous-pubescent with spreading hairs. Leaves thick, with three broadly oval or obovate, coarsely toothed leaflets, the terminal one usually narrowed at the base; petioles 2 to 6 inches long. Flowering scapes as long or shorter than the leaves, bearing several white flowers on appressed-pubescent pedicels. Flowers one-half to three-fourths of an inch broad, white, petals obovate. Fruit red, ovoid, the achenes imbedded in pits.

In rather dry soil, fields, hillsides etc., Newfoundland to South Dakota, Florida and Oklahoma. Flowering in April and May.

The European Wood Strawberry (F r a garia ve s c a Linnaeus) is a common escape everywhere in the east and frequently hybridizes with F. virginiana, so that some forms are difficult to classify. The American Wood Strawberry (Fragaria a mericana (Porter) Britton), with longer flowering scapes and elongated-conic fruit, with achenes borne on its shining, even surface and but slightly attached to it, is a common species in rocky woodlands. The Northern Wild Strawberry (Fragaria can a de $n \mathrm{~s}$ is Michaux) has a long, slender fruit with the achenes sunk in pits and oblong or narrowly obovate leaflets. It ranges across the northern part of the state. 


\section{Shrubby Five-finger or Cinquefoil Dasiphora fruticosa (Linnaeus) Rydberg Plate $96 \mathrm{~b}$}

A branching shrub with ascending or erect, leafy branches, I to + feet high. Leaves pinnate, leaflets five to seven, linear-oblong or oblanceolate, pointed at each end, one-half to I inch long, silky-pubescent, the margins cntire and revolute; stipules membranous, ovate-lanceolate, entire and pointed. Flowers terminal, in dense or loose cymose clusters, or solitary, bright yellow, three-fourths to $\mathrm{I} \frac{\mathbf{1}}{4}$ inches broad; the five calyx lobes ovate, with five bractlets; petals five, nearly orbicular and longer than the calyx lobes. Achenes of the fruit covered with long straight hairs.

In swampy or marshy places, often in moist rocky places, Labrador and Greenland to Alaska, south to New Jersey, Illinois, Minnesota, Rocky mountains and California; also in northern Europe and Asia. In northern New England it is often a troublesome, bushy weed. Flowering from June to September.

\section{American Great Burnet}

\section{Sanguisorba canadensis Linnaeus}

Plate 94b

An erect, leafy, herbaceous plant from a thick, perennial root; stems sometimes decumbent at the base, glabrous or somewhat pubescent below, simple or branched above, I to 6 feet high. Leaves odd-pinnate, the lower leaves long petioled, sometimes I to $\mathrm{I} \frac{\mathrm{I}}{2}$ feet long; leaflets seven to fifteen, ovate, oblong or oval, blunt or pointed at the apex; pointed, blunt or even cordate at the base, sharply toothed. Flowers white, in dense terminal spikes, I to 6 inches long; petals none; calyx tube turbinate, constricted at the throat, four-winged, four-lobed, the lobes petallike, concave and deciduous; stamens four, their filaments long and white.

In swamps and low meadows, sometimes in bogs, Newfoundland to Michigan, south to Georgia. Flowering from July to September or even later. 
WIL I) FI, OWERS OF NEW YORK

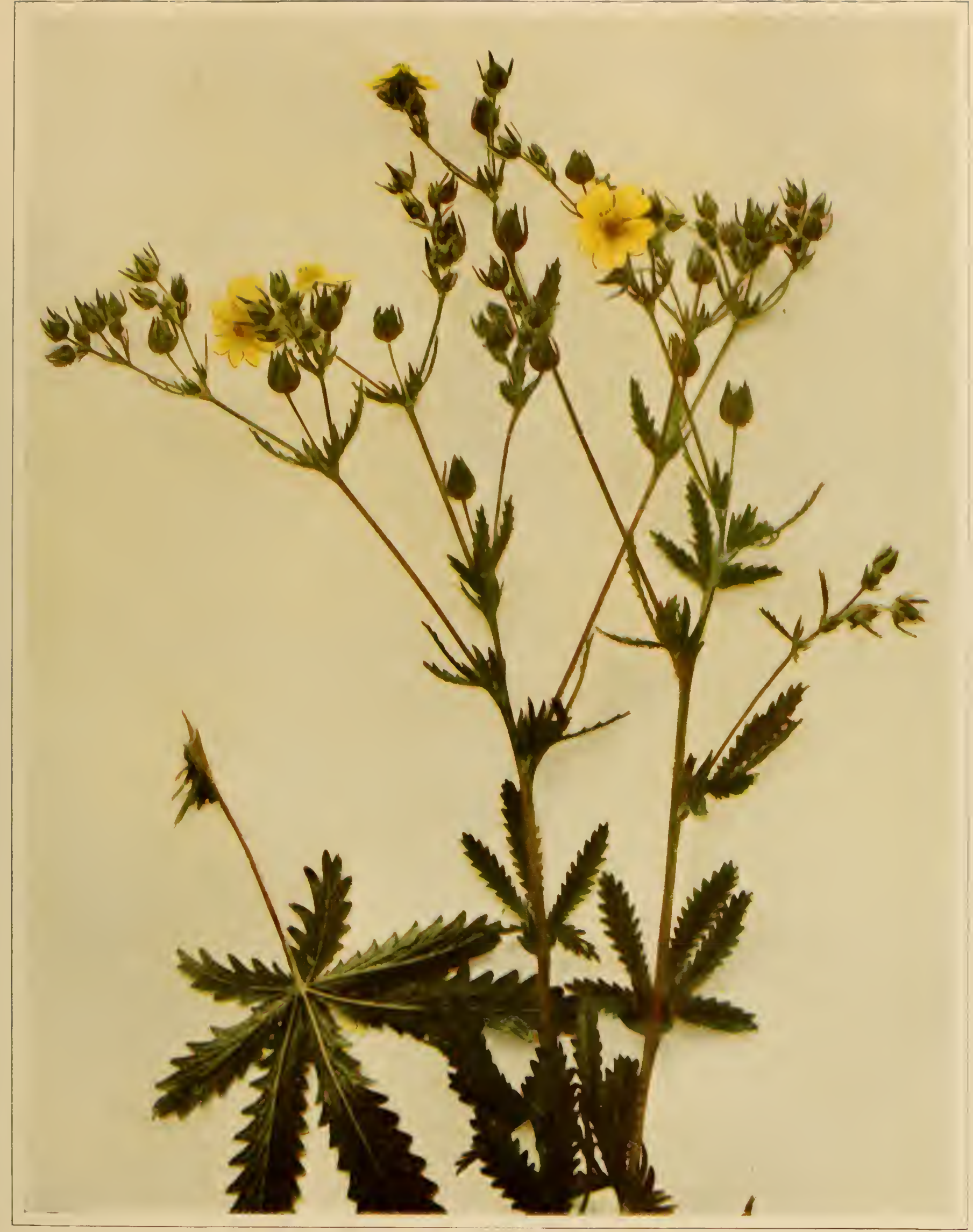

ROUGH-FRUITED CINQUEFOIL

Potentilla recta 



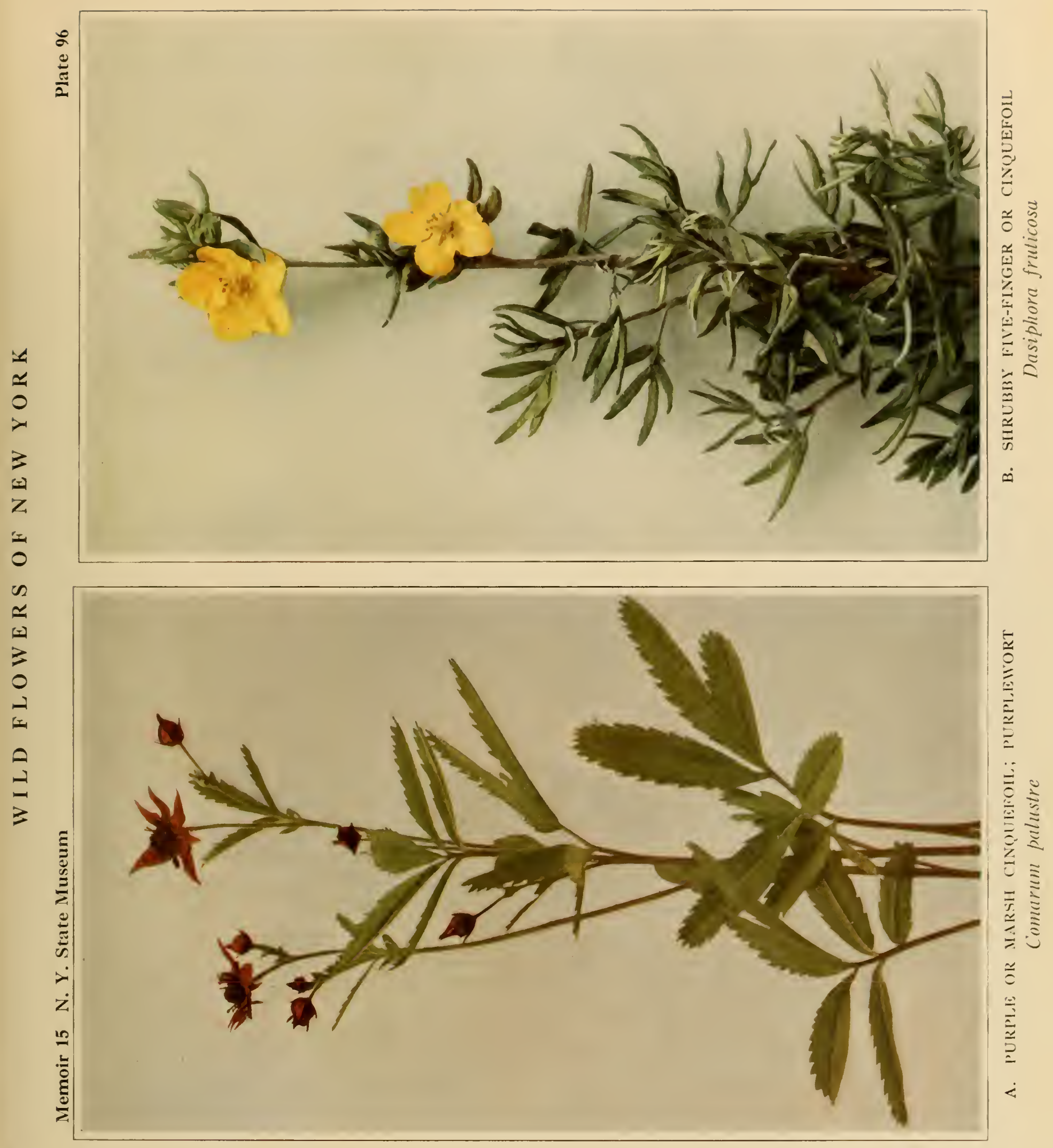





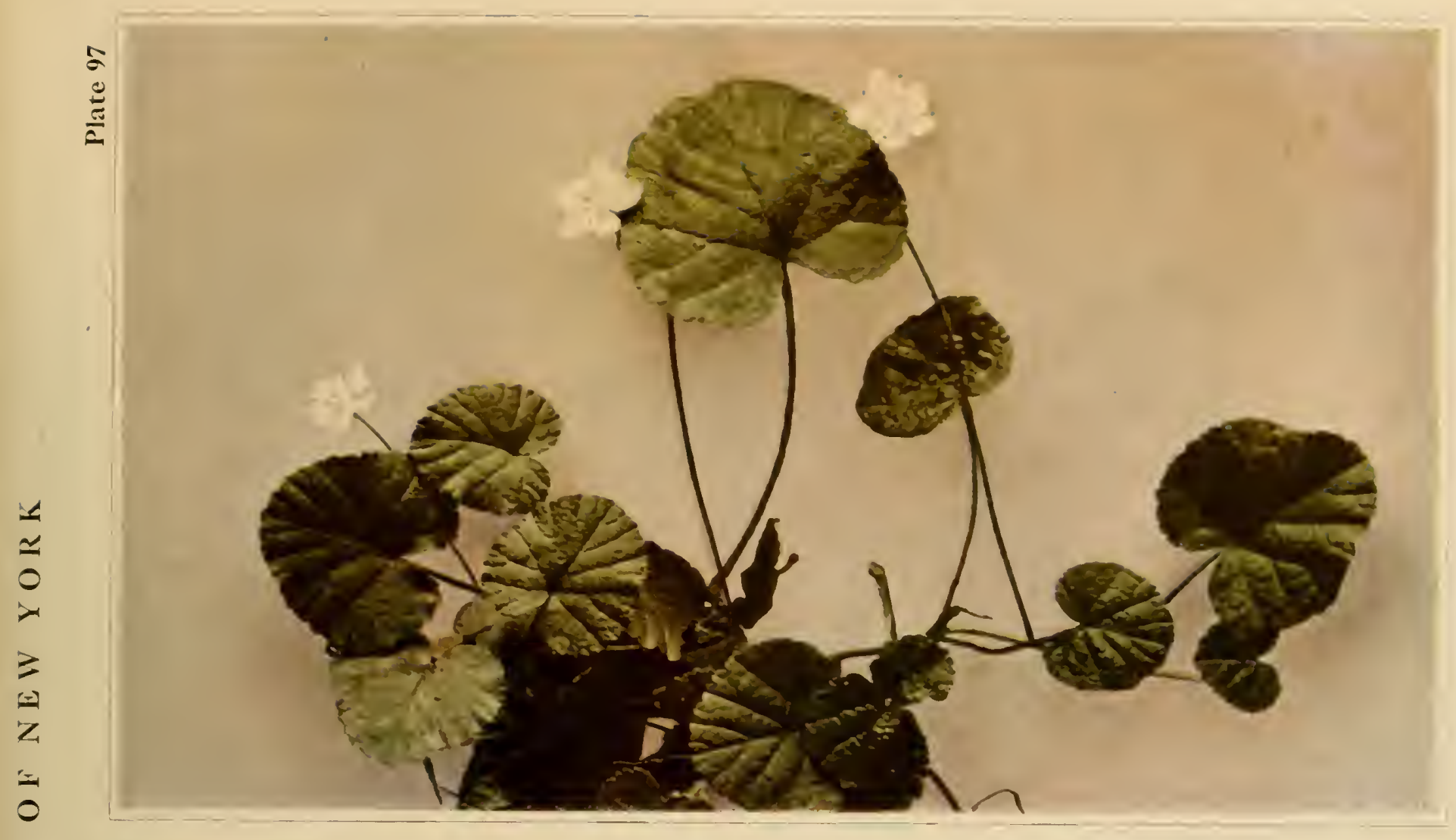

要

0
$\simeq$
3
0
$=$
$=$

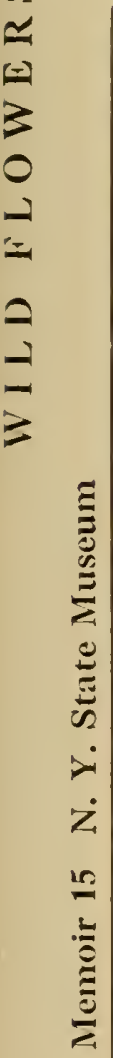

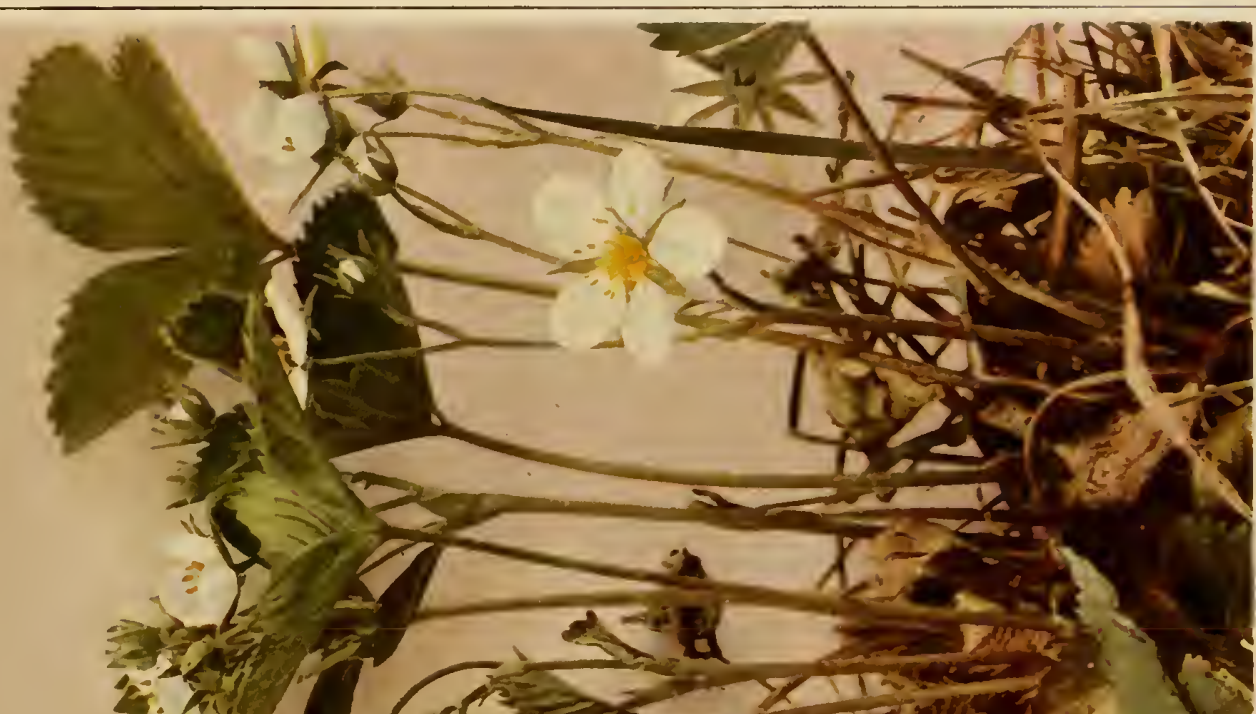

a.

$=142$

$l_{1} 12$

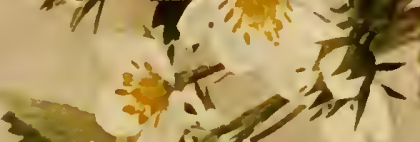

हो

$\frac{1}{2}-8$

3

13.i.

13

I

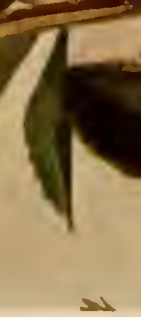

要 $=$ $\approx$

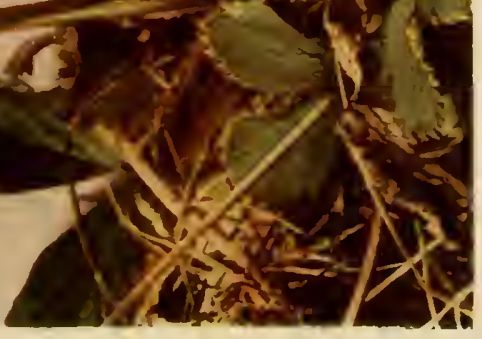





\section{Common Agrimony \\ Agrimonia striata Michaux \\ (.1grimonia brittoniana Bicknell) \\ Plate 98b}

Stem rather stout and usually with some straight, nearly erect branches, 2 to 6 feet tall from a perennial fibrous root, pubescent with short, spreading, brownish hairs, somewhat appressed above. Leaves numerous, aiternate, compound with seven to nine, or rarely eleven, oblique leaflets, tetragonalelliptic to rhomboid-lanceolate, pointed and sharply toothed, rather thick and somewhat rough, dull green above, softly pubescent beneath, usually several pairs of small, interposed leaflets; stipules lanceolate, pointed and cut-toothed. Flowers numerous in long, erect or ascending racemes; each flower about one-fourth of an inch wide; petals five, bright yellow; calyx tube in fruit long-turbinate, about one-fourth of an inch long, deeply grooved, unmargined; the bristles numerous, often purplish, short, crowded, inflexed and connivent over the sepals.

Thickets, open woods and roadsides, Newfoundland to Saskatchewan, south to West Virginia, Nebraska and Mexico. Flowering from June to September.

\section{Barren or Dry Strawberry \\ IIaldsteinia fragarioides (Nichaux) Trattinnick Plate 99}

A perennial, herbaceous plant resembling a strawberry, with creeping, rather stout rootstock. Leaves tufted, mainly basal, long petioled, glabrous or somewhat pubescent, three-foliate; leaflets obovate, obtuse at the apex, tapering at the base with crenate or sometimes incised margins, $\mathrm{I}$ to 2 inches long. Flowering scapes slender, erect, bracted, corymbosely three to eight-flowered; pedicels slender, often drooping; flowers yellow, one-half to two-thirds of an inch broad; petals five, obovate and longer than the five ovate-lanceolate, acute calyx lobes; stamens eight, inserted on the throat of the calyx; achenes of the fruit four to six, finely pubescent.

Rocky woods, shaded hillsides and banks, New Brunswick to Ontario, Minnesota, Michigan, Indiana and Oregon. Flowering in May and June. 


\section{Yellow Avens; Camproot \\ Geum strictum Aiton \\ Plate $98 \mathrm{a}$}

Stems erect or nearly so, pubescent, somewhat branched, 2 to + feet high, basal leaves lyrate-pinnate with five to seven obovate, cuneate, toothed or lobed leaflets, with a few smaller leaflets interspersed, terminal leaflets largest, broadly ovate or cuneate; stem leaves short petioled or sessile with three to five ovate or oblong, acute segments. Flowers yellow, several, terminal and short peduncled, one-half to three-fourths of an inch broad; petals obovate, exceeding the five calyx lobes. Stamens numerous.

In low, shaded ground, swamps and wet meadows, Newfoundland to British Columbia, south to New Jersey, Pennsylvania, Missouri and New Mexico. Flowering from June to August.

\section{Purple or Water Avens \\ Geum rivale Linnaeus \\ Plate 100}

Stems simple or nearly so, erect, pubescent, I to 3 feet high, from stout perennial roots. Basal leaves lyrately and interruptedly pinnate, petioled, the lateral segments generally few and small, the terminal one to three leaflets much larger, all sharply and irregularly lobed and toothed; stem leaves rather far apart, short petioled or sessile, simple or threefoliated. Flowers few, terminal, purple or purplish, nodding, three-fourths to I inch broad; petals obovate emarginate, abruptly narrowed into a claw; calyx lobes spreading, purple; head of the fruit stalked in the calyx; achenes pubescent, style jointed, plumose below, about one-fourth of an inch long.

In swamps and low grounds, Newfoundland to British Columbia, New Jersey, Pennsylvania, Michigan and Colorado; also in northern Europe and Asia. Flowering from early June until the latter part of July. 
W IL D FL OWERS OF NEW YORK

Memoir 15 N. Y. State Museum

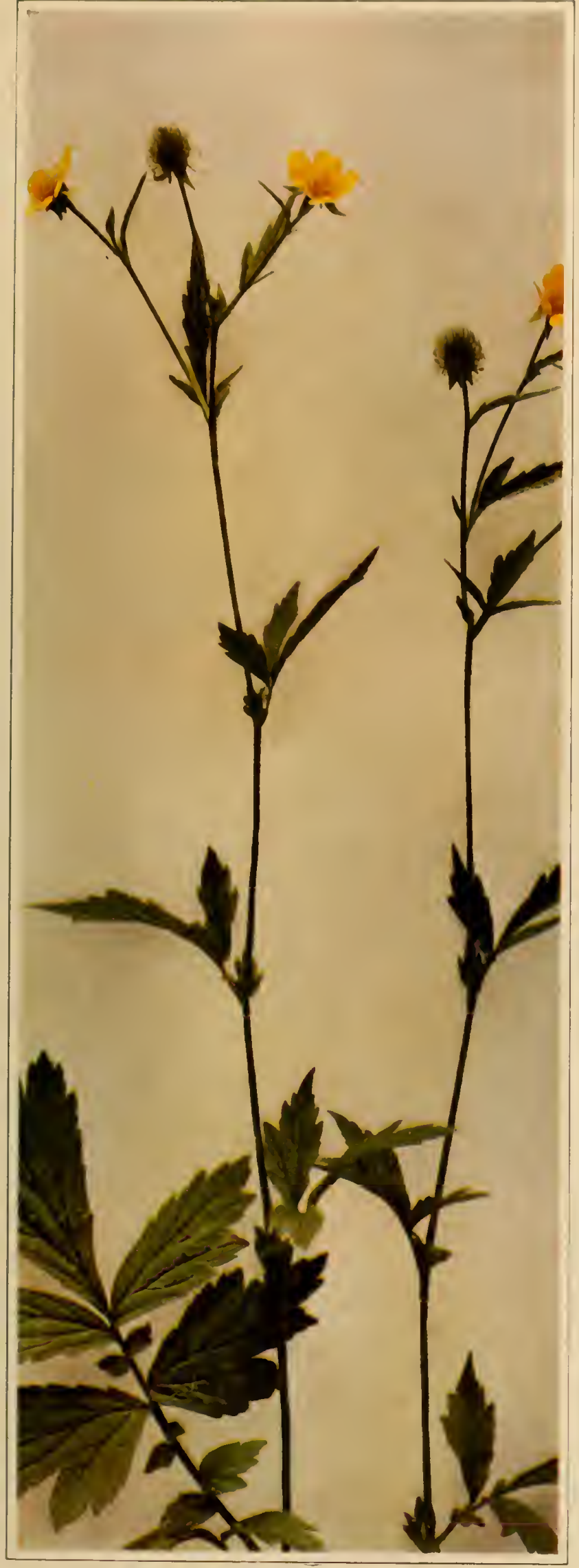

A. YELLOW AVENS; CAMPROOT Geum strictum
Plate 98

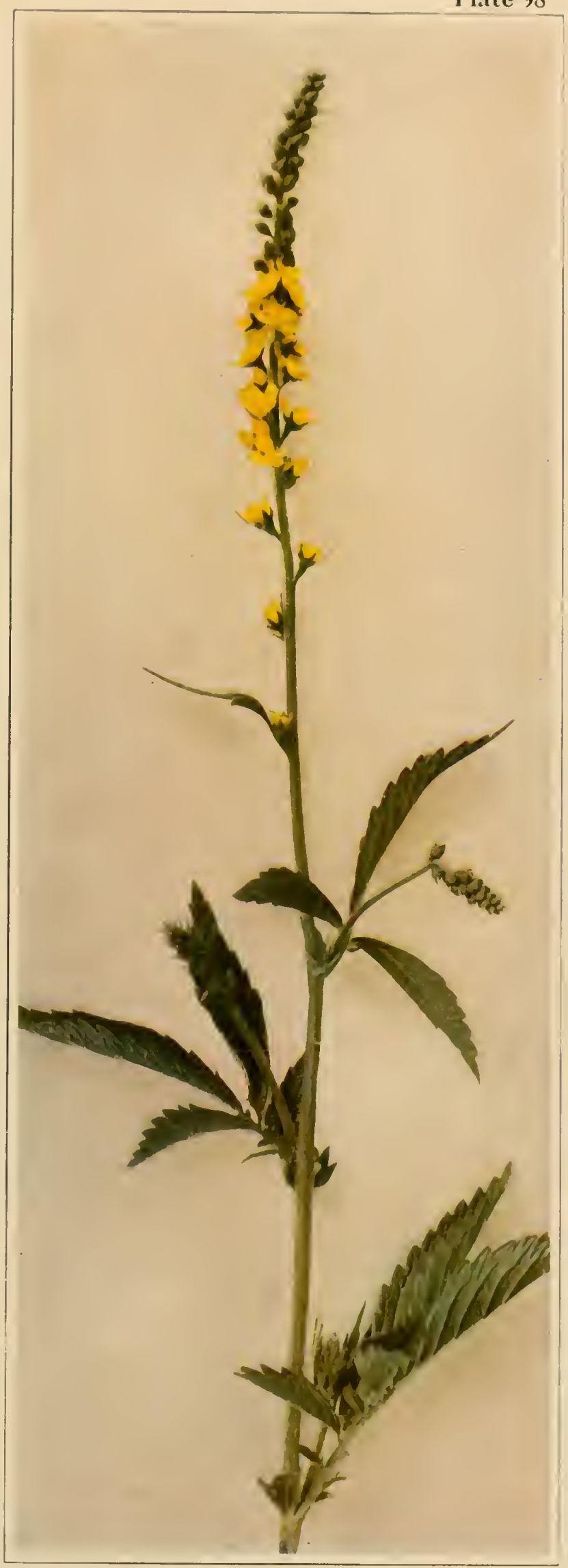

B. COMMON AGRIMONY Agrimonia striata 



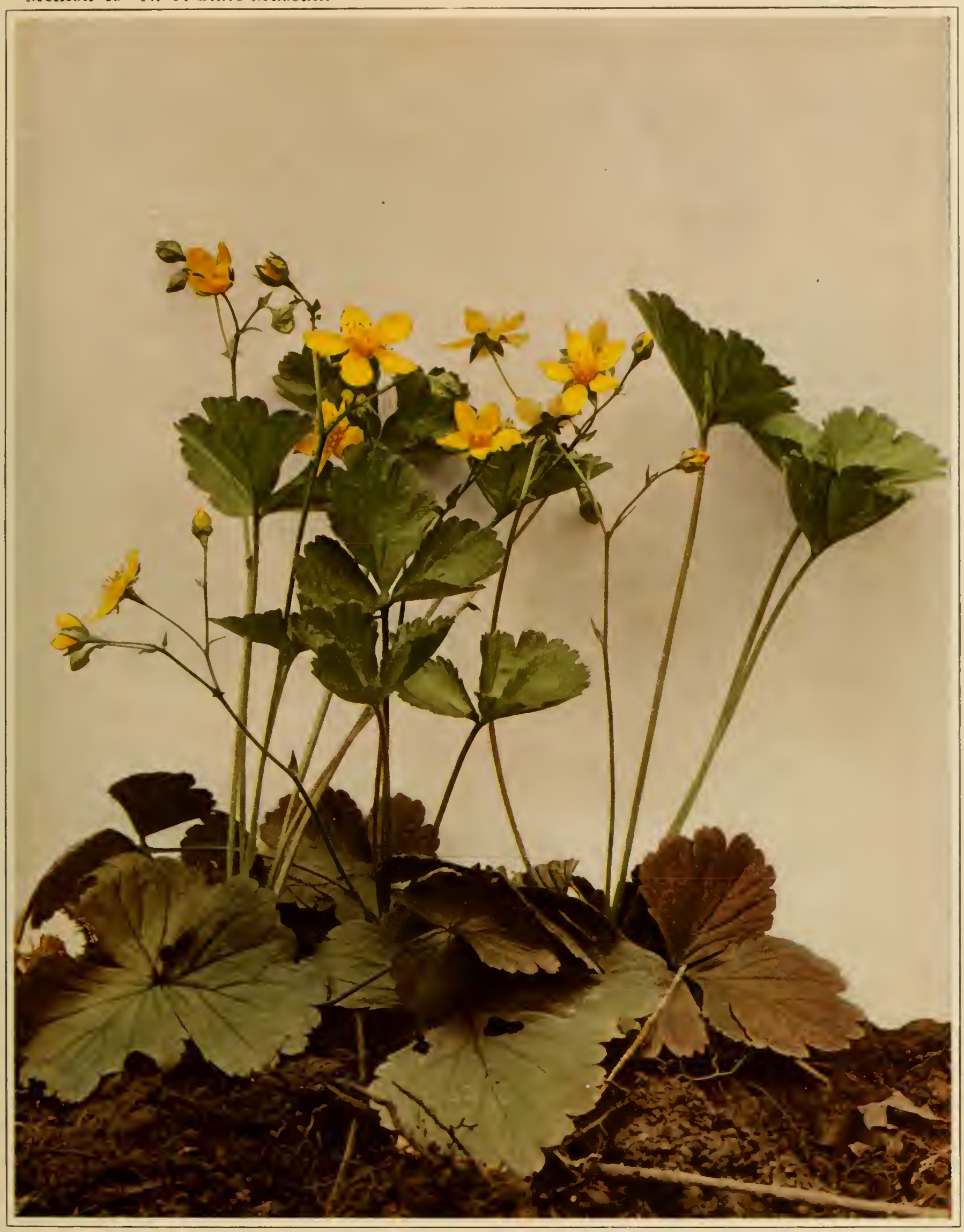



There are several other Avens in Ncw York, all excent G. rivale with reflexed calyx lobes. G. virgin ian um Linnacus and C. c a n a dense Jacquin have white flowers. G. vernum (Rafinesque) Torrey \& Gray; G. strictum Aiton (described above), and G. m e y c ria n u m Rydberg, have yellow flowers. G. ma croph y $11 \mathrm{um}$ Willdenow, a boreal species found only in the Adirondacks, in this State, also has yellow flowers. For complete descriptions of these additional species the student should refer to Gray's Manual or Britton and Brown's Illustrated Flora.

\section{Purple-flowering Raspberry; Thimbleberry}

\section{Rubus odoratus Linnaeus}

Plate ror

Shrubby, erect and branched, perennial; new growth glandular-pubescent and somewhat bristly but not prickly, 3 to 5 feet high. Leaves simple, petioled, large, 5 to 10 inches broad, three to five-lobed, cordate at the base, pubescent, especially on the veins beneath, the lobes long pointed, the middle lobe usually longer than the others; flowers rather numerous in corymbose, terminal clusters, purple, I to 2 inches broad; calyx lobes tipped with long, slender appendages; petals five; fruit red when ripe, broad and thin, scarcely edible.

In rocky woods and thickets, Nova Scotia to Ontario and Michigan, south to Georgia and Tennessee. Flowering from June to August.

New York contains a large number of native raspberries and blackberries. The principal species of Raspberries are R. st rigos us Michaux (red); R. neglectus Peck (purple), and R. occidentalis Linnaeus (Black Raspberry). The Blackberries are R. trif 1 or u s Richards (Dwarf Red Blackberry), R. c a nadensis Linnaeus (Northern Blackberry), R. allegheniensis Porter (Mountain Blackberry), R. argutus Link (Tall Blackberry), and also the Dewberries. See Britton and Brown's Illustrated Flora for complete descriptions. 


\section{Dewberry; Low Running Blackberry \\ Rubus procumbens Muhlenberg \\ Plate 93b}

Stems trailing, shrubby and perennial, often several feet long, armed with numerous or very few prickles. Branches erect, 4 to 12 inches long, slightly pubescent, often prickly and glandular. Leaves three to sevenfoliate, usually three-foliate; leaflets ovate or ovate-lanceolate, thin, pointed at the apex, rounded or narrowed at the base, sharply toothed. Flowers few in terminal racemes, white, about I inch broad; the five petals usually as long or slightly longer than the calyx lobes. Fruit black, usually at least one-half of an inch long and sometimes I inch long, fine flavored but with large seeds.

In dry soil, especially in sandy sections, Nova Scotia to Ontario and Michigan, south to Virginia, Louisiana and Oklahoma. Flowering in May and June. Fruit ripe in June and July.

A similar species, $\mathrm{R} u \mathrm{~b}$ u $\mathrm{s}$ h is p id us Linnaeus (Hispid or Running Swamp Blackberry), with the stems densely beset with weak, retrorse bristles, is also common in swamps and low grounds throughout our area.

\section{Dalibarda; Dewdrop or False Violet \\ Dalibarda repens Linnaeus \\ Plate $97 \mathrm{~b}$}

Stems very slender, much tufted, several inches long. Leaves downypubescent on both sides, three-fourths to 2 inches broad, long petioled. ovate-orbicular, cordate, the margin with low, blunt or sometimes mucronulate crenations; stipules setaceous. The scapelike peduncles $\mathrm{I}$ to 5 inches long, bearing one or two large, perfect white flowers, each flower about onehalf of an inch broad; calyx deeply five or six-parted, three of the divisions larger than the other two or three; petals five; stamens numerous. Fruit composed of five to ten nearly dry drupelets, inclosed by the calyx segments. Stems also have short, recurved peduncles bearing several or numerous small cleistogamous flowers. 
WII, D FLOWERS OF NEW YORK

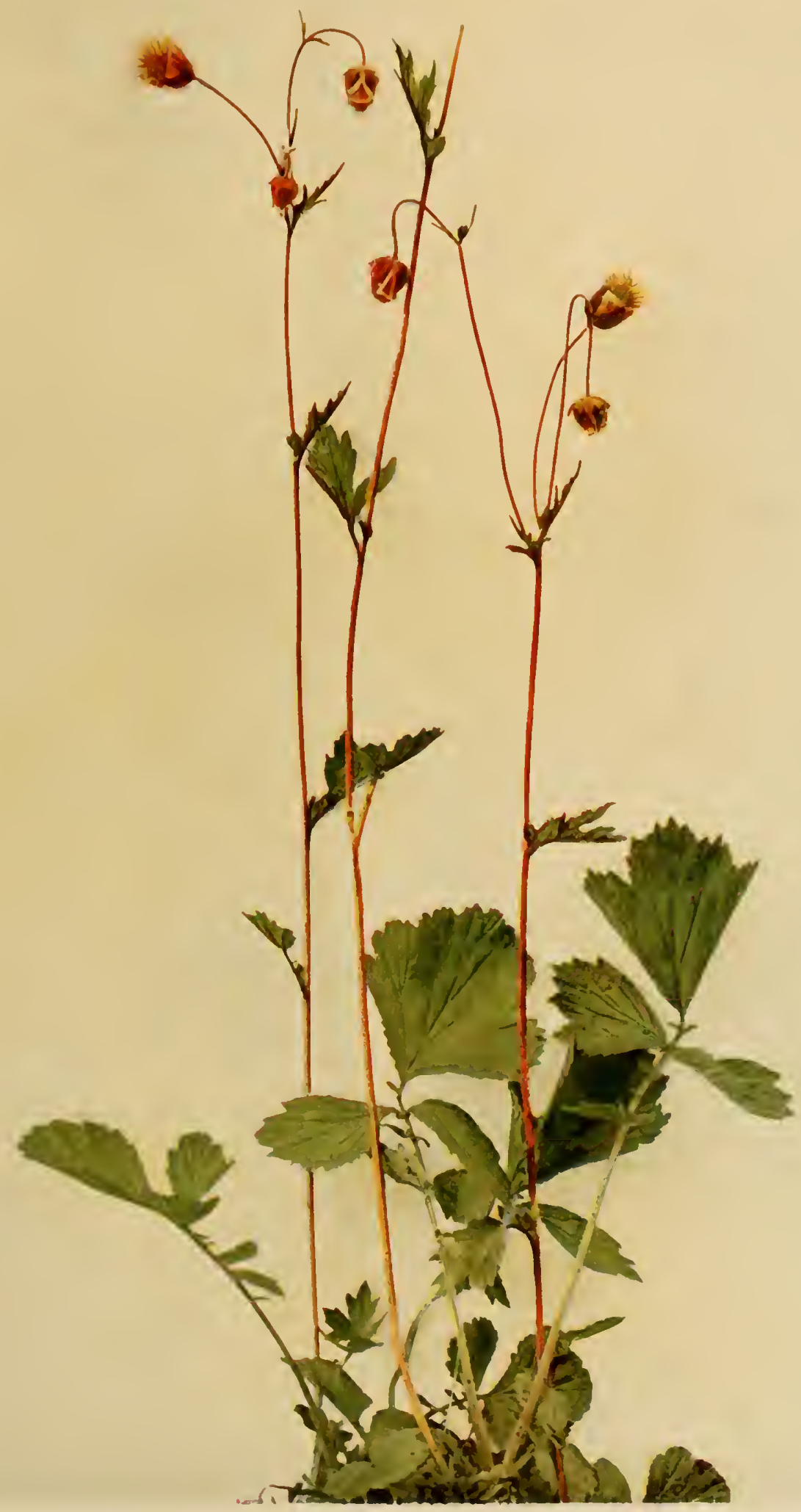

PURPLE OR WATER AVENS

Geum rivale 



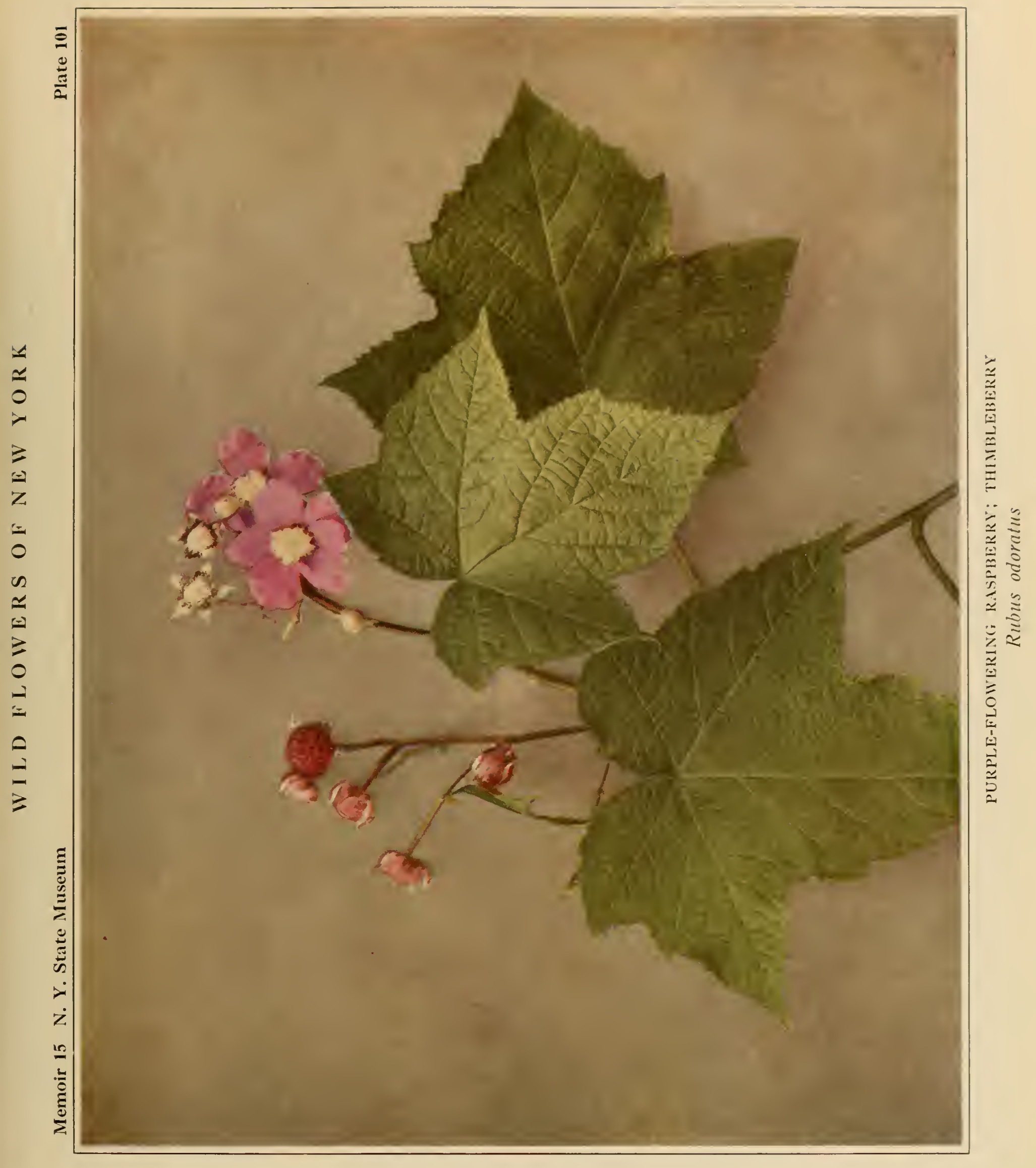



In rich woods, Nova Scotia to Minnesota, south to Pennsylvania, southern New Jersey, North Carolina, Ohio and Michigan. Flowering from June to September.

\section{Low or Pasture Rose \\ Rosa virginiana Miller \\ Plate 102}

A bushy shrub, a few inches to 3 or 4 fect high, somctimes higher; the stcms armed with slender or stout, straight or curved infrastipular spincs, and morc or less prickly. Stipules entirc. Lcaves altcrnatc with five or sometimes seven rather thin ovate-oval or obovate leaflets, dull grecn or somewhat shiny, coarsely toothed, onc-half to 2 inches long, usually pointcd at the end, glabrous or pubescent bencath. Flowers few or solitary, 2 to 3 inches broad; pedicels and calyx usually glandular; calyx five-lobed, the segments lanceolate, long pointed, sometimes dilated toward the end, spreading and deciduous; petals fivc, obcordate, rose or pink, fading after opening. Fruit globose or depressed-globose, glandular-hispid, about onethird of an inch high.

In dry or rocky soil, Newfoundland to Ontario and Wisconsin, south to Georgia, Louisiana and Missouri. Flowering from May to July. The Swamp Wild Rose (Rosa carolina Linnaeus) is frequent in open or wooded swamps and marshes.

\section{Apple Family}

M a 1 a c e a e

\section{Black Chokeberry}

\section{Aronia melanocarpa (Michaux) Britton}

Plate ro3

An extensively branching shrub, 3 to 8 feet high. Leaves obovate to oval, the apex varying from blunt to pointed, narrowed or cuneate at the base, short petioled, the margins crenulate, dark green above, paler beneath, glabrous or nearly so when mature. Flowers numerous in terminal, compound, leafy cymes; each flower about one-half of an inch broad; calyx and 
pedicels glabrous or nearly so; calyx lobes glandular; petals five, concave, white or tinged with pink, spreading; stamens numerous, filaments rosecolored to white; anthers black or dark red. Fruit globose or oval, nearly black, or purplish black, about one-quarter of an inch in diameter.

In low grounds, swamps or open woods, sometimes in drier situations, Nova Scotia to western Ontario, south to Florida and Michigan. Flowers in April and May. Fruit ripe in August and September.

The Red Chokeberry (A. arbutifolia (Linnaeus) Elliott) has the cymes and lower surface of the leaves woolly and the mature fruit is bright red. The Purple-fruited Chokeberry (A. a tropurpurea Britton) also has the cymes and lower leaf surfaces woolly but the mature fruit is purple-black.

\section{Senna Family}

Caesalpiniacea e

Wild or American Senna

Cassiza marilandica Linnaeus

Plate 104

Stems 3 to 7 feet high, sparingly branched or simple, glabrous or with scant pubescence, from a perennial root. Leaves evenly pinnate, not sensitive to the touch, petioled and with a club-shaped gland near the base of the petiole; leaflets twelve to twenty, oblong, blunt but mucronate at the apex, rounded at the base, ciliate, I to 2 inches long, one-fourth to twothirds of an inch wide. Flowers yellow, about two-thirds to three-fourths of an inch broad, numerous, in pubescent axillary racemes on the upper part of the plant. Calyx lobes five, nearly equal, ovate or oblong, obtuse; corolla nearly regular, of five spreading, nearly equal, clawed petals; stamens ten, the upper three imperfect. Fruit a flat linear pod, 3 to + inches long and about one-fourth of an inch wide, curved, pubescent, containing flat, suborbicular seeds. The segments of the pod are about as long as broad.

In moist meadows, marshes and swamps, sometimes on springy hillsides, Massachusetts to central New York, Ohio, Tennessee and North 
W I L D FLOWERS OF NEW YORK

Memoir 15 N. Y. State Museum

Plate 102

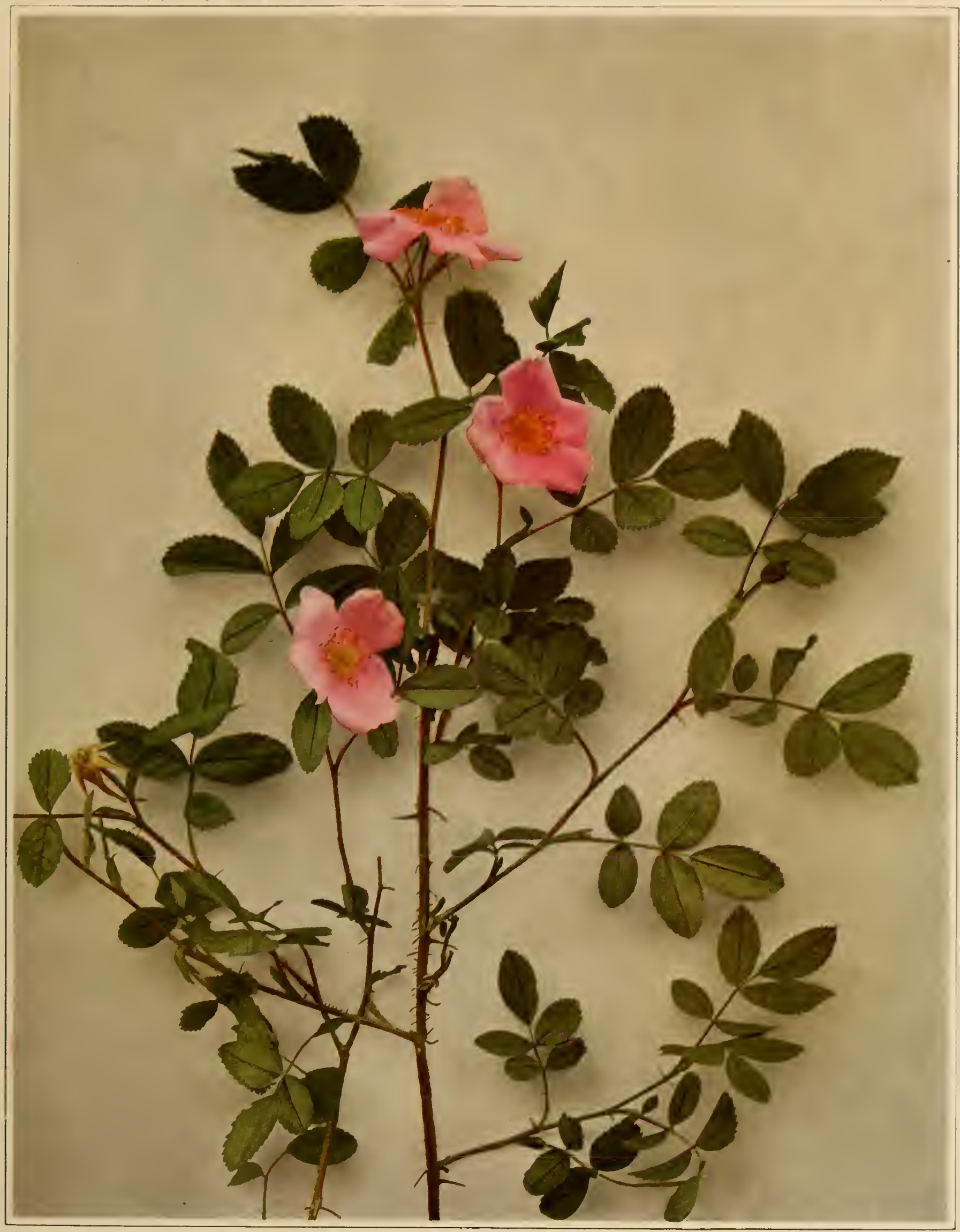

LOW OR PASTURE ROSE

Rosa virginiana 



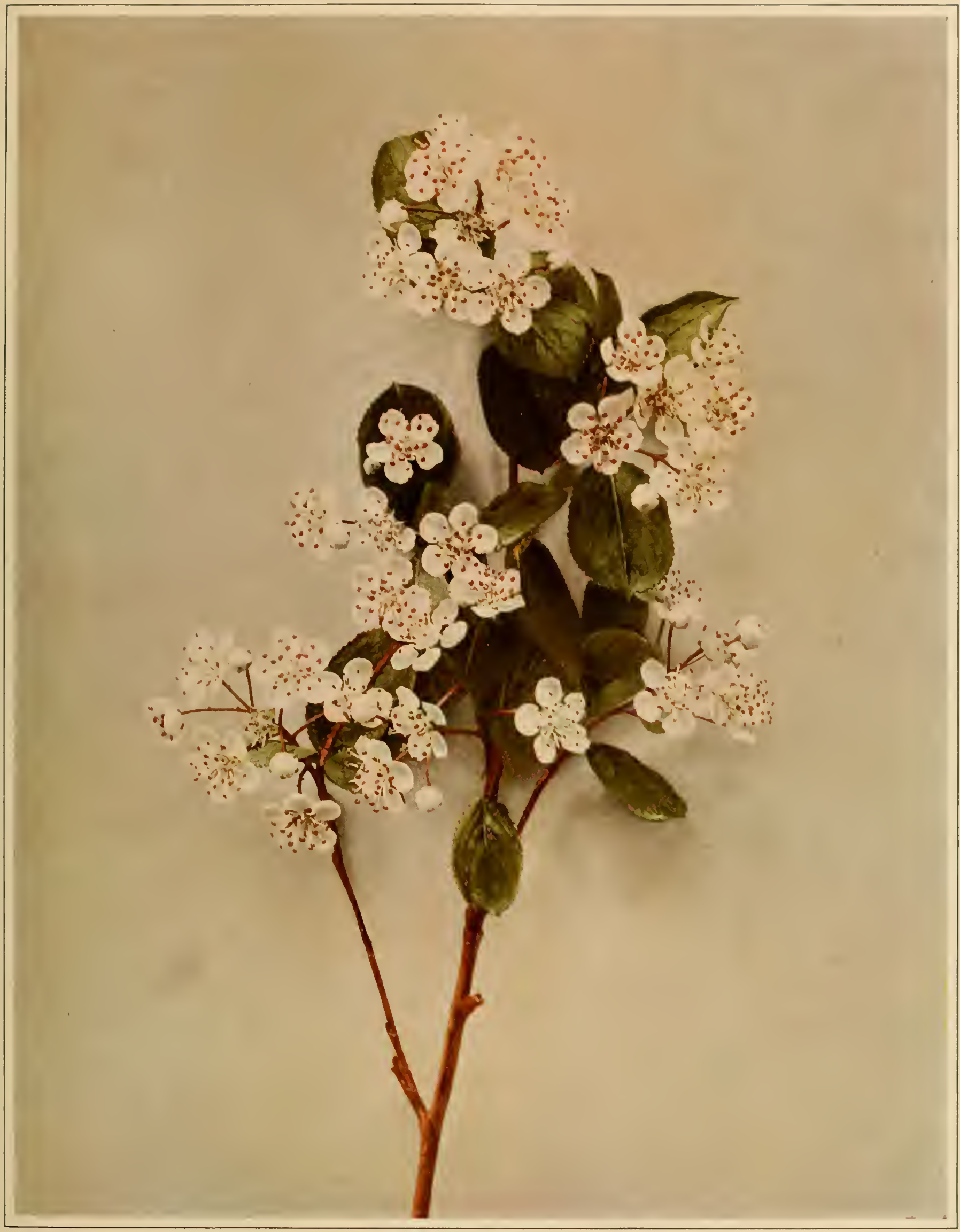



Carolina. Rather rare and local in New York, frequently seen along the Hudson River valley and up the Mohawk, northward along West Canada creek to Newport in Herkimer county, which appears to be the northern limit of its range. Flowering in July and August.

\section{Sensitive Pea; Wild Sensitive Plant \\ Chamaecrista nictitans (Linnaeus) Moenchhausen Plate 105a}

An annual plant, 5 to 16 inches high with erect or decumbent, branching and somewhat pubescent stems. Leaves evenly pinnate, sensitive to the touch, bearing a small gland near the base of the petiole; leaflets twelve to forty, linear-oblong, blunt and mucronate at the apex, rounded and oblique at the base, inequilateral, one-fourth to two-thirds of an inch long, about one-fourth as wide. Flowers two or three together in the axils, one-fourth of an inch broad or less; calyx lobes five, pointed; corolla yellow, somewhat irregular, three of the five petals smaller than the others; stamens five, all perfect. Fruit a small, linear, pubescent or smooth pod, I to $1 \frac{1}{2}$ inches long.

In dry and sandy soil, Maine to Georgia, west to Indiana, Kansas and Texas. Flowering from July to September.

\section{Partridge Pea; Large-flowered Sensitive Pea \\ Chamaecrista fasciculata (Michaux) Greene \\ Plate ro5b}

Stems annual, rather widely branched and pubescent with spreading hairs or nearly smooth, I to 2 feet high. Leaves with a sessile gland on the petiole, sensitive, similar to the preceding species but the twenty to thirty leaflets somewhat larger. Flowers two to four together in the axils, I to $\frac{1}{2}$ inches broad and slender-pediceled; calyx lobes long pointed; petals yellow, sometimes purple spotted; stamens ten, all perfect; four of the anthers yellow, six of them purple. Fruit a linear, pubescent, or glabrous flattened pod, I $\frac{1}{2}$ to $2 \frac{1}{2}$ inches long ard one-fourth of an inch wide or less. 
In dry or sandy soil, Massachusetts to Florida, Minnesota, Texas and Mexico. Flowering from July to September.

\section{Pea Family}

$\mathrm{F}$ a b a ce a e

\section{Wild Indigo; Horsefly Weed}

\section{Baptisia tinctoria (Linnaeus) R. Brown \\ Plate 107a}

Stems glabrous, erect, much branched, 2 to 4 feet high from a perennial root, blackening in dying. Leaves petioled, three-foliate, alternate; leaflets obovate, one-half to $1 \frac{1}{2}$ inches long, nearly sessile, blunt, tapering at the base, entire. Flowers bright yellow, rather showy, in numerous, fewflowered, terminal racemes. Each flower about one-half of an inch long; calyx campanulate, the upper two lobes united into a lobe larger than the other three; corolla consisting of a standard (upper petal), two wings (lateral petals), and a keel (two lower petals); stamens ten, distinct; fruit a short ovoid or nearly globose pod, one-fourth to one-half of an inch long, and tipped with the subulate style.

In dry or sandy soil, Maine to Vermont, Ontario, Minnesota, Florida and Louisiana. Flowering from June to September.

The Blue Wild or Blue False Indigo, Baptisia australis (Linnaeus) R. Brown, has indigo blue flowers nearly an inch long and is naturalized in eastern and southern New York from the south.

\section{Wild or Perennial Lupine \\ Lupinus perennis Linnaeus \\ Figure XIX and Plate 106}

Stems 8 to 24 inches high, erect, pubescent and often branched, from a perennial root. Leaves digitately compound with seven to eleven (usually about eight), oblanceolate, sessile leaflets, blunt and mucronate at the apex, tapering to the base, I to 2 inches long, one-fourth to one-half of an inch wide, appressed-pubescent or glabrate; flowers blue, rarely white or pink, in terminal racemes; each flower one-half to two-thirds of an inch 


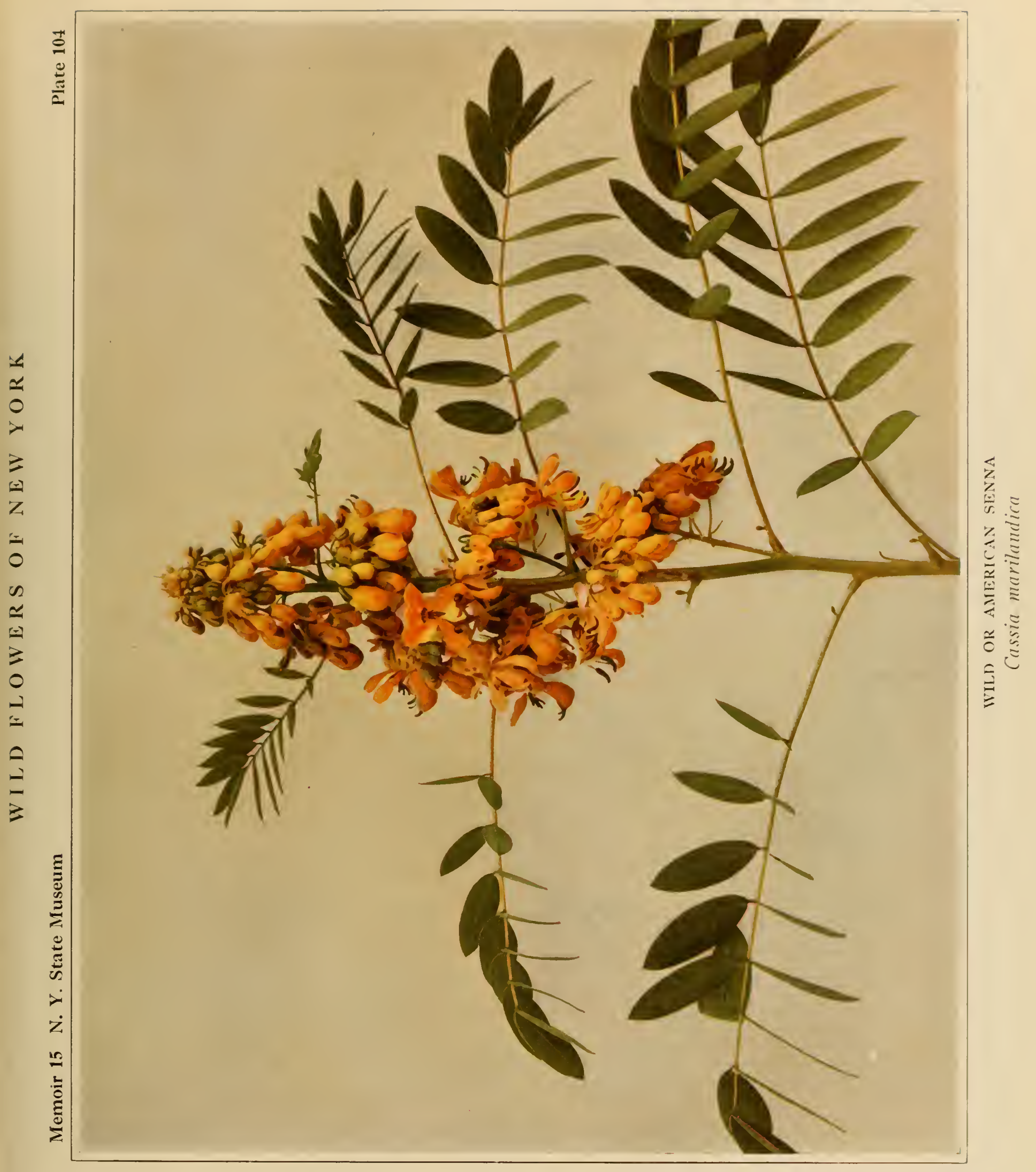





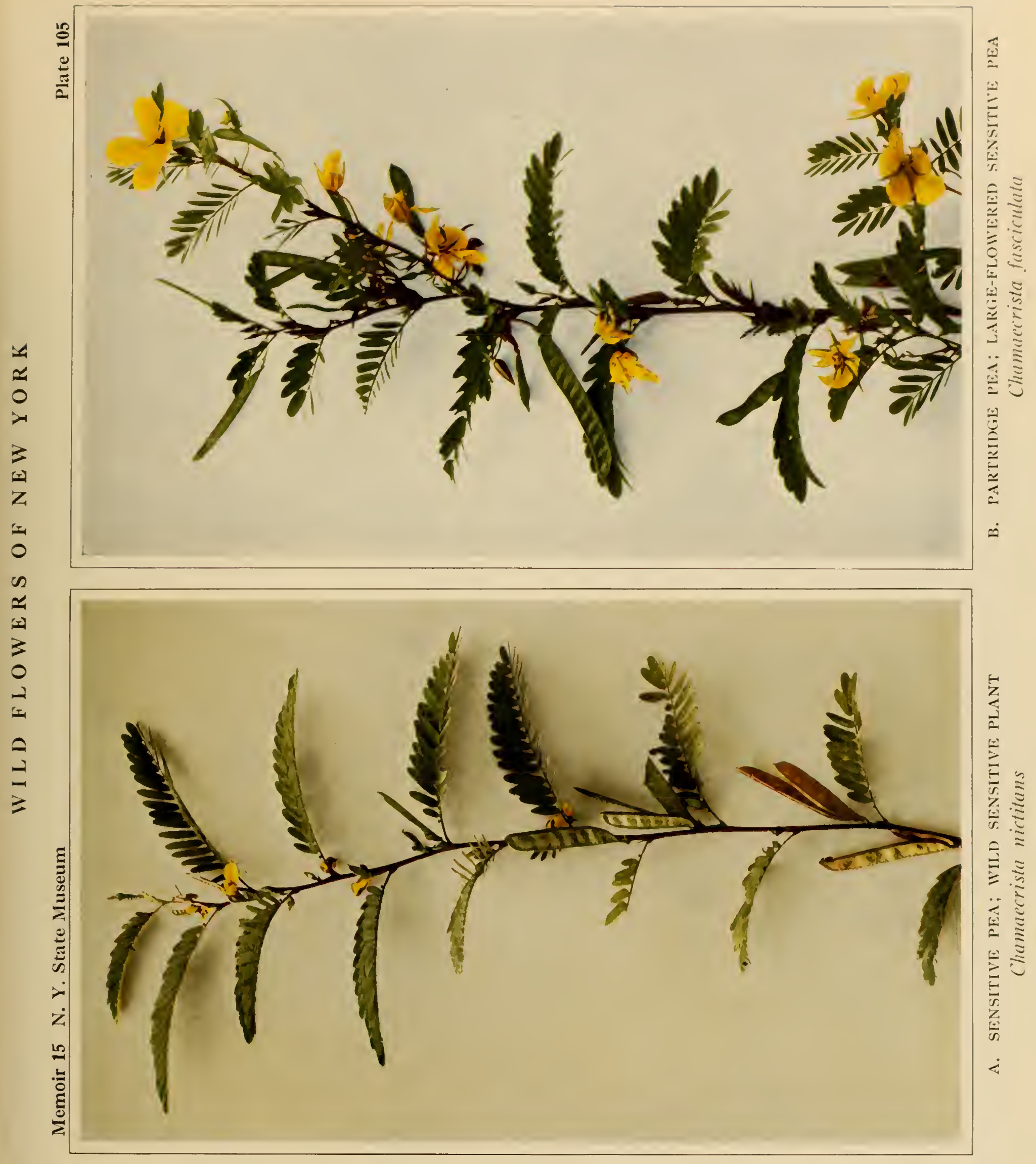



W IL D FLOWERS OF NEW YORK

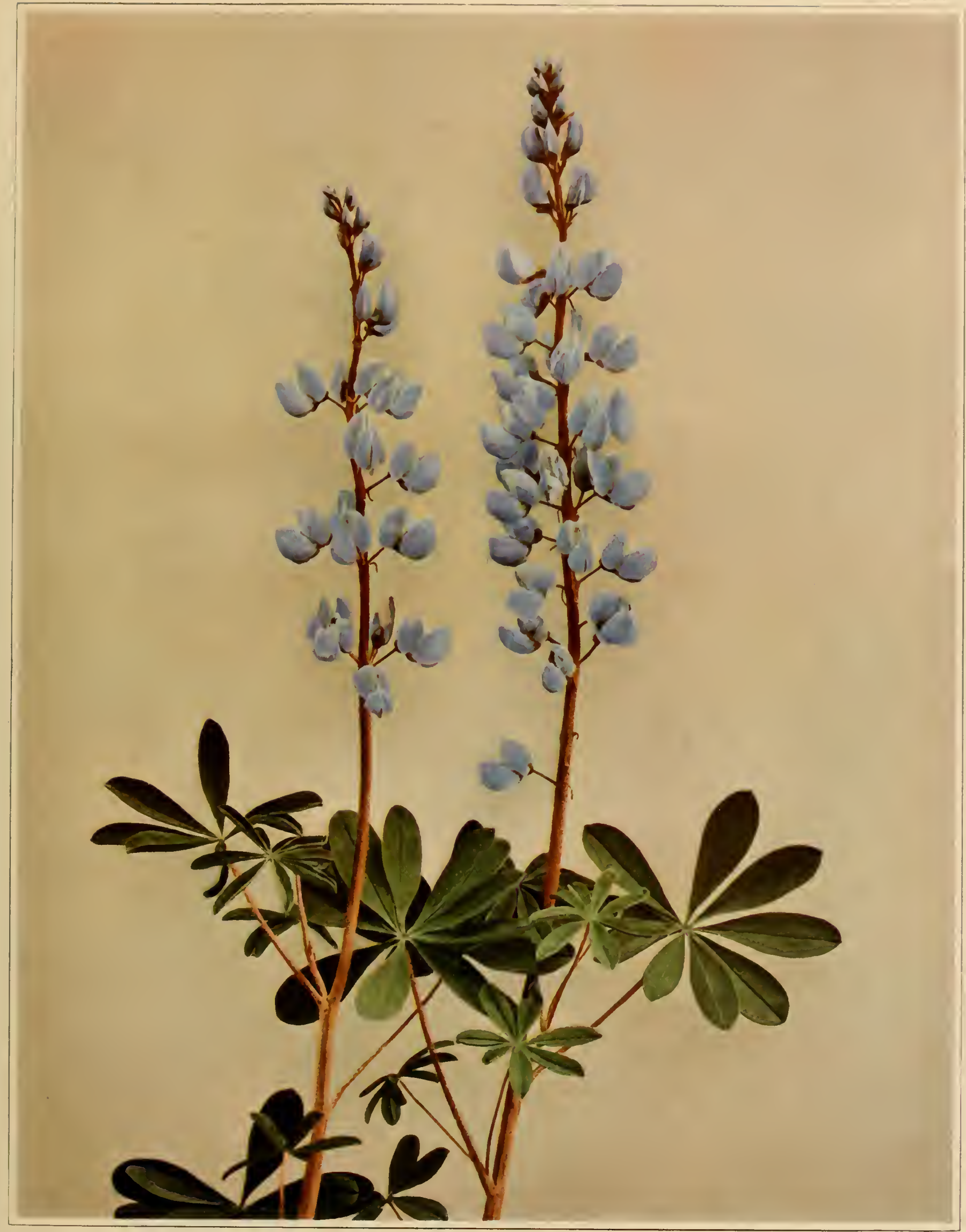

WILD OR PERENNIAL LUPINE

Lupimus perennis 

long, on pedicels one-fourth to one-half of an inch long; calyx two-lipped; standard (upper petal) orbicular with reflexed margins, wings (two lateral petals) obovate; stamens monadelphous, with two forms of anthers. Fruit a linear-oblong, very hairy pod, $I \frac{1}{2}$ to 2 inches long and about onefourth of an inch wide, with three to six seeds; the two valves of the pod coiling when it dehisees.

In dry, sandy soil, Maine and Ontario to Minnesota, Florida, Missouri and Louisiana. Flowering in May and June. This is the only native species of Lupine in New York, although there are about fifty species in the western states.

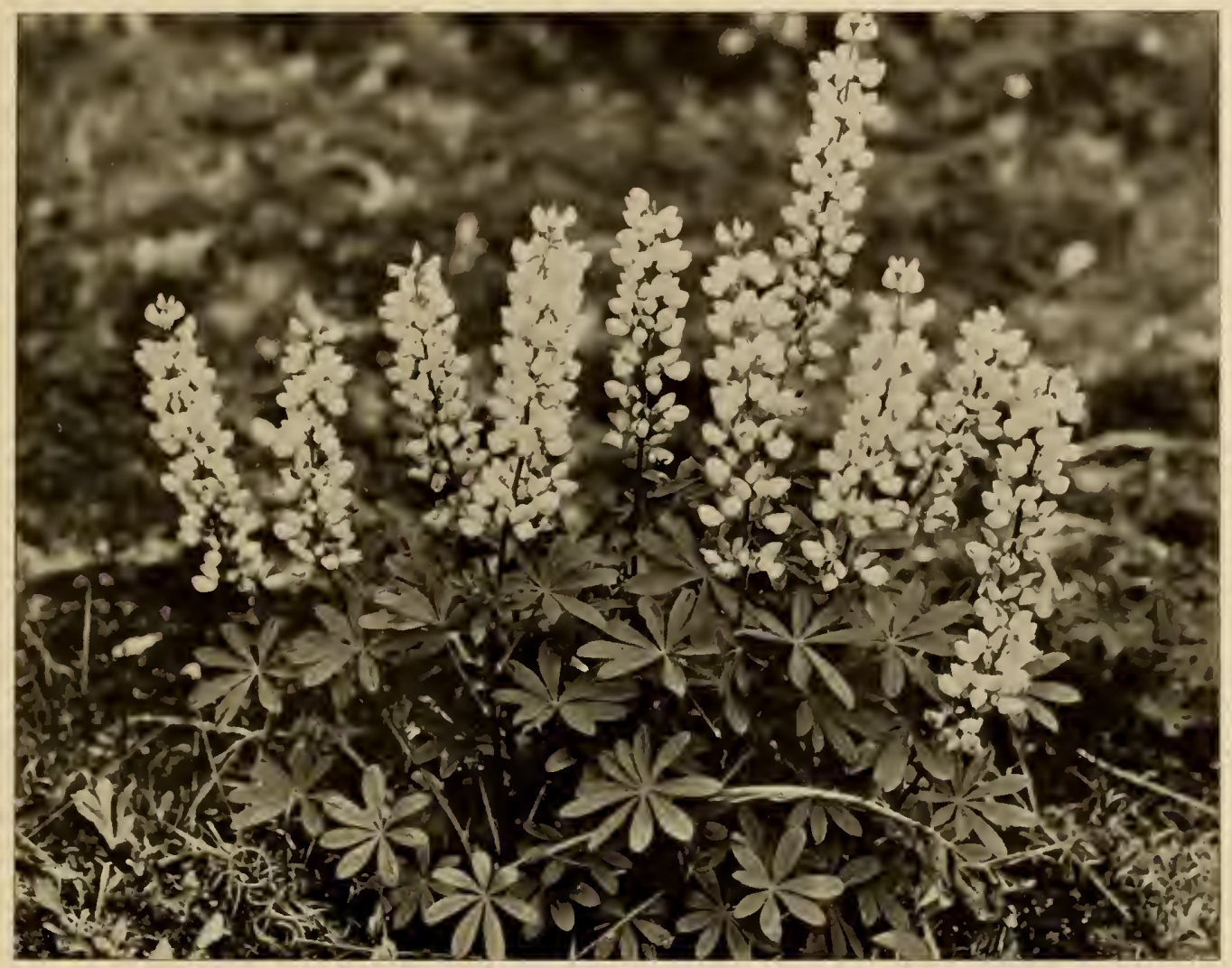

Figure XIX

Wild or Perennial Lupine

( $L$ u p in us perennis Linnaeus) 


\section{Rabbit-foot, Old Field, or Stone Clover \\ Trifolium are'ense Linnaeus \\ Plate 10 sa}

An erect, usually much-branched annual, 5 to is inches high, silkypubescent. Leaves very short petioled, three-foliate, oblanceolate or linear, minutely toothed, blunt and sometimes notched at the apex, narrowed at the base, one-half to I inch long. Flowers sessile in dense, terminal, peduncled, oblong or cylindric heads, one-half to I inch long; calyx very silky; corolla whitish, shorter than the elongated, slender, plumose calyx lobes. Fruiting pod very small.

In waste places, dry and sandy fields, roadsides etc., Quebec and Ontario to South Carolina, Florida, Tennessee and Missouri. Naturalized from Europe. Flowering from May to September.

The only Clover native to New York is the Buffalo Clover (Trifolium reflex um Linnaeus), which occurs from the western part of the State westward and southward. Our flora contains a large number of introduced species of clovers and related plants. Among them are the following:

Yellow or Hop Clover. Trifolium

a grarium

Low or Smaller Hop Clover.................. " procumbens

Crimson Clover incarnatum

Red or Meadow Clover..................... "

pratense

Alsike or Alsatian Clover...................

hybrid u m

White Clover....................... "

Alfalfa.............................. e d i ca go

Black or Hop Medic

IV'hite Sweet Clover Melilotus

Yellow Sweet Clover.......................... " repens s a tiva lu pulina a 1 b a

Bird's-foot Trefoil............................ ot us officinalis corniculatus 
W I L, D FI, O WERS O F NEW YOR K

Memoir 15 N. Y. State Museum

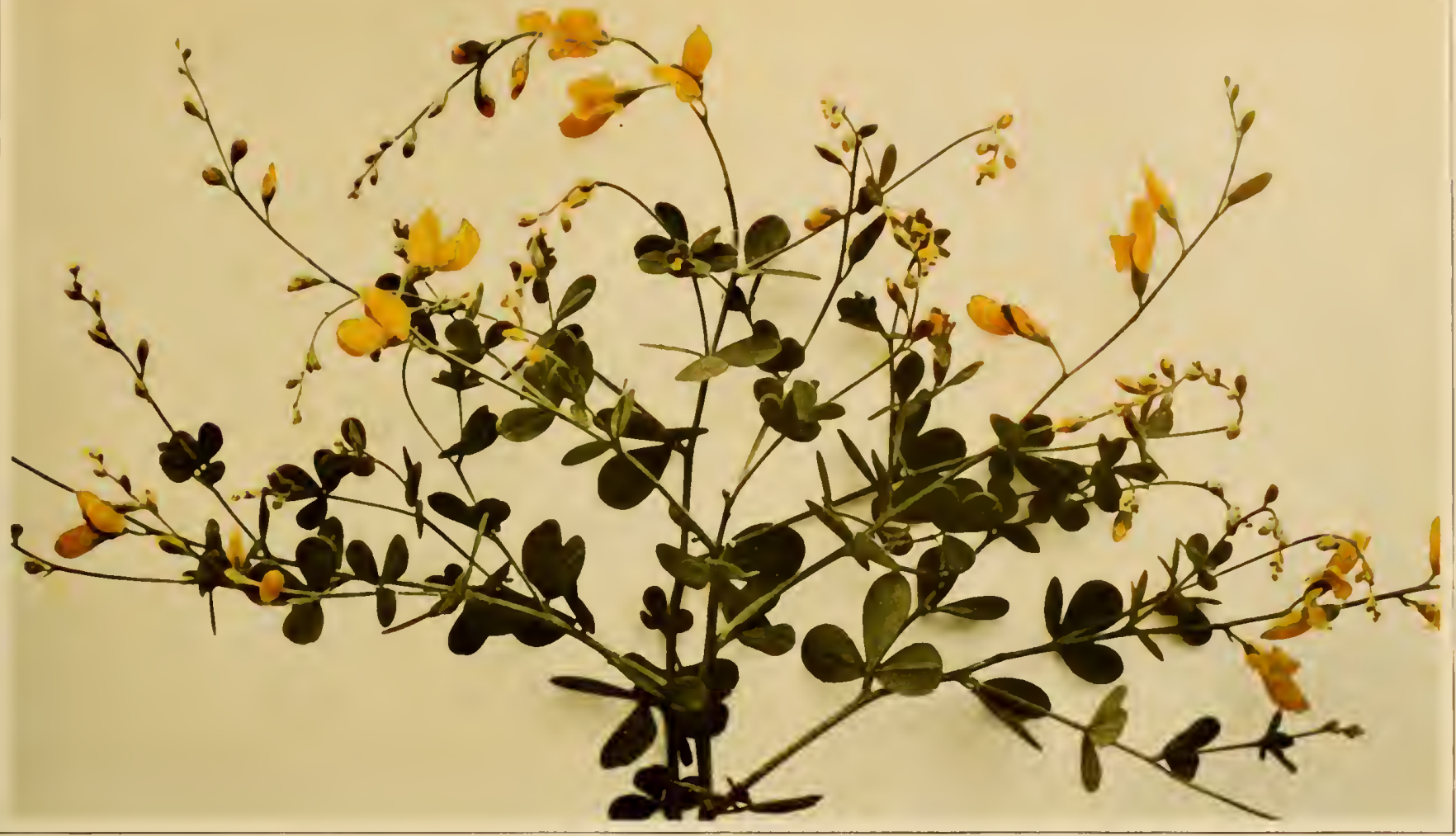

A. WILD INDIGO; HORSEFI,Y WEED

Baptisia tinctoria

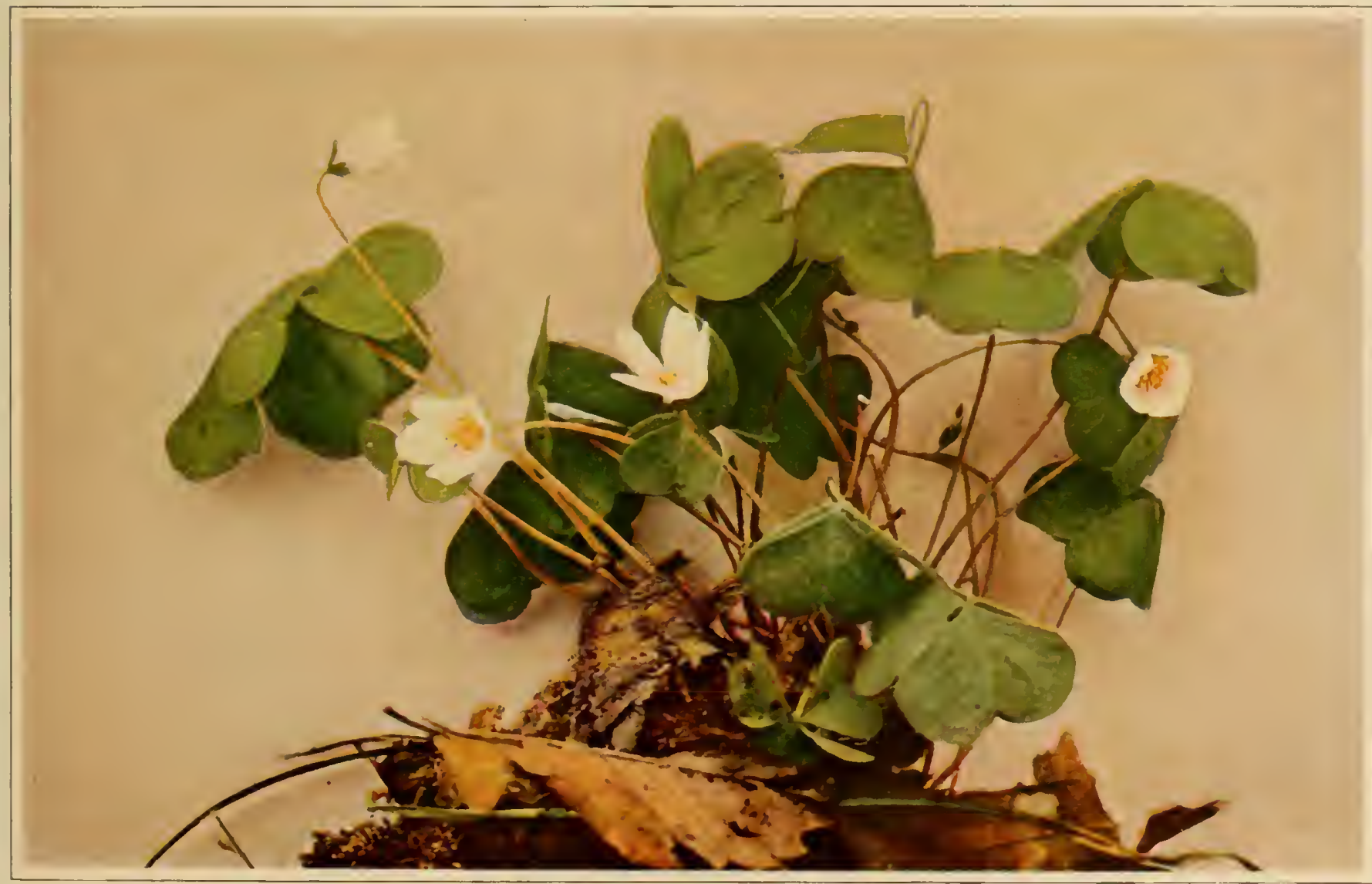

B. WHITE OR TRUE WOOD SORREL; ALLELUIA

Oxalis acetosella 



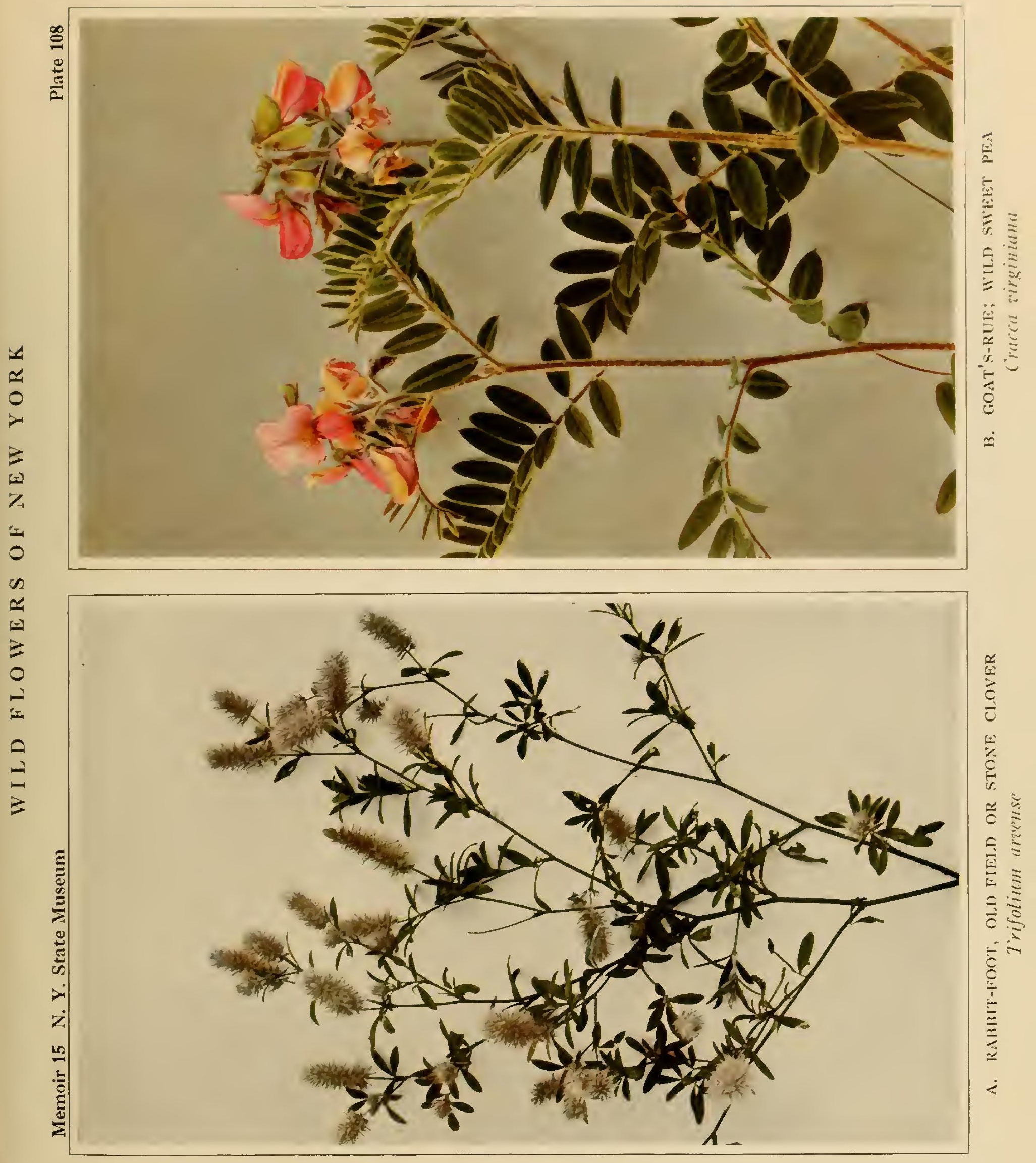





\section{Goat's-rue; Wild Sweet Pea \\ Cracca rirginiana Linnacus \\ Plate 10 sb}

Stems from a few inches to nearly 2 feet high, few or many in a clense cluster, erect or nearly so, from a stout, perennial root which is elongated, tough and fibrous. Stems and leaves silky with whitish hairs. Leaves odd-pinnate, short petioled; leaflets nine to twenty-five, oblong, linearoblong or the terminal one oblanceolate, narrowed at the base, rounded and mucronate at the apex or sometimes notched, three-fourths to 1 inch long and one-eighth to one-third of an inch wide. Flowers crowded in a terminal, often compound and nearly sessile racemelike cluster; each flower one-half to three-fourths of an inch long on a short pedicel. Calyx with five nearly equal teeth; petals clawed, the standard rounded, yellow and conspicuous, wings and keel reddish or purplish. Fruiting pod narrow, densely hairy, I to 2 inches long.

In dry and sandy soil, Maine to Minnesota, Arkansas, Florida, Louisiana and Northern Mexico. Flowering in June and July or sometimes as late as August in the north.

\section{Coronilla; Axseed; Axwort \\ Coronilla z'aria Linnaeus Plate 109}

Stems ascending or straggling, glabrous and usually much branched, I to 3 feet long from perennial roots. Leaves sessile; odd-pinnate; leaflets eleven to twenty-five, oblong or obovate, blunt and mucronate at the apex, narrowed or rounded at the base, one-half to three-fourths of an inch long, one-eighth to one-fourth of an inch wide. Flowers numerous in dense umbels terminating peduncles several inches in length; each flower onethird to one-half of an inch long on very short pedicels; standard (upper petal) pink, wings (lateral petals) white or purple-tipped. Fruit pod coriaceous, linear, four-angled, with two or three joints, each about onefourth of an inch long or slightly longer. 
IVaste places, fields and roadsides, Massachusetts to southern New York, Maryland and Missouri. Adventive or naturalized from Europe. Flowering from June to August.

\section{THE TICK TREFOILS}

M e i b o m i a

The Tick Trefoils are all perennial herbs, often with stout roots, erect, ascending or trailing stems and three-foliolate leaves. The flowers are usually rather small, purplish in terminal or axillary, compound or simple racemes or panicles. Calyx two-lipped, the upper lip two-toothed, the lower lip with three acute or attenuate teeth. Stamens monadelphous or diadelphous (nine and one); anthers all alike. Fruit (loment) flat, sessile or stalked with several joints which are easily separable at maturity.

A large genus of plants with about sixteen representatives in New York State. The following key is given as an aid in placing the various species not fully described and illustrated here.

Loment not constricted above, deeply constricted below, long-stalked; leaflets broad

Panicle terminal on the leafy stem

Leaves crowded at the base of the panicle.............. gra n d if 1 o $\mathrm{r}$ a

Leaves scattered along the stem.................. p a u c if 1 or a

Panicle arising from the base of the plant, its stalk usually leafless.

M. nu diflora

Loment constricted on both margins, more deeply below than above

Stems trailing or reclining

Leaflets orbicular, I to 2 inches long and pubescent.......... m i ch a $\mathrm{u} x \mathrm{i}$ i

Leaflets ovate or oval, dull green ...................... g 1 a be 11 a

Stems erect or ascending

Leaves sessile or nearly so; leaflets linear or lanceolate........ s e s s il if o 1 i a

Leaves petioled

Joints of the loment notably longer than broad

Leaflets obtuse, yellowish green, rough-pubescent.....M. c a n e s c e n s

Leaflets long-acuminate.

MI. bracteos a

Joints of the loment little longer than broad

Loment distinctly long-stalked in the calyx 
WI LD FLO WERT OF NEW YORK

Memoir 15 N. Y. State Museum

Plate 109

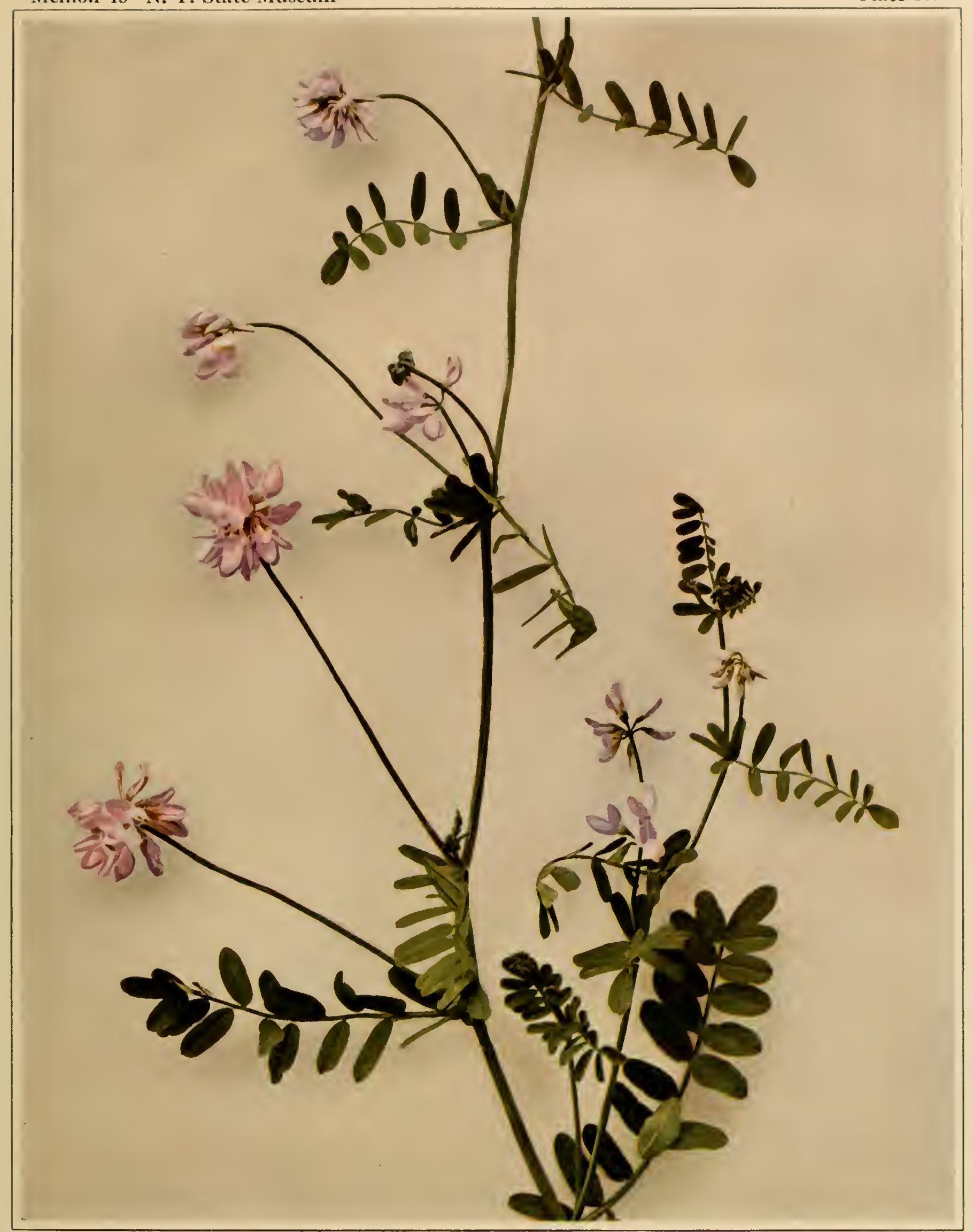

CORONILLA; AXWORT: AXSEED

Coronilla aria 
Plants glabrous or nearly so (except varietics of M. p) a n ic u la t a)

Leaflets lanceolate or oblong.

11. pan iculat a

Leaflets broadly ovate or oval, glaueous beneatl

M. laevigata

Plants pubescent

Leaves velvety-pubescent beneath, thick and coriaceous.

M. viridiflora

Leaves appressed-pubeseent or villous beneath and seareely coriaceous

M. dille ni i

Loment sessile in the ealyx or nearly so

Loment joints four to seven, flowers showy; leaflets not coriaceous..

II. c a nadens is

Loment joints one to three

Leaflets scabrous, $\mathrm{I}$ to 2 inches $\operatorname{long} \ldots . . \ldots \ldots . . . \mathrm{I}$. $\mathrm{ig}$ id a

Leaflets not scabrous, one-half to $\mathrm{r}$ inch long

Plant nearly glabrous throughout. . M. m a r y 1 a n $\mathrm{d}$ i c a

Stem pubescent; leaflets and petioles ciliate. MI. o b t u s a

\section{Prostrate Tick Trefoil \\ Meibomia michauxii Vail \\ Plate I 10}

Stems prostrate, 2 to several feet long, softly pubescent or villous. Leaves petioled; leaflets nearly orbicular, pubescent, I to 2 inches long; stipules triangular-ovate, persistent, pointed, striate. Flowers in loose terminal and axillary panicles, purple, one-fourth to one-half of an inch long: calyx lobes ciliated. Loment about I inch long, three to five-jointed, the joints obliquely rhomboid below, slightly concave above, pubescent with hooked hairs, on a stipe about equaling the calyx lobes or slightly longer.

Dry or sandy woods, New England and Ontario to Minnesota, Florida, Missouri and Louisiana. Flowering from July to September. 


\section{Large-bracted Tick Trefoil}

\section{Meibomia bracteosa (Michaux) Kuntze}

$$
\text { Plate II }
$$

Stems erect, 2 to 6 feet high, glabrous or pubescent below, finely pubescent above in the panicle. Leaflets 2 to 8 inches long, longer than the petioles, ovate or ovate-lanceolate, long pointed, smooth or nearly so above, usually pubescent beneath; stipules lanceolate, sharp pointed. Flowers large, purple, one-third to one-half of an inch long with cuspidate, striate, deciduous bracts; calyx deeply two-lipped, the upper lip two-toothed. Loment I to 3 inches long, three to seven-jointed, the joints obliquely oblong, about twice as long as wide, pubescent with hooked hairs, on a stipe about as long as the lower calyx lobes.

In open woods and thickets, Maine to Ontario, Minnesota, Florida, Missouri, Arkansas and Texas. Flowering in August and September.

\section{Dillen's Tick Trefoil \\ Meibomia dillenii (Darlington) Kuntze \\ Plate II 2}

Stems erect, pubescent with scattered hairs, 2 to 3 feet high. Leaflets rather thin, oval or oblong-ovate, blunt, $1 \frac{1}{2}$ to 4 inches long, one-half to $\mathrm{I}_{2} \frac{1}{2}$ inches wide, sparingly pubescent or glabrous above, softly pubescent beneath; petioles much shorter than the leaflets. Flowers one-fourth to one-third of an inch long, purple, in loose, terminal, compound racemes with small, deciduous bracts. Loment I to 2 inches long, two to fourjointed, the joints nearly triangular, about one-fourth of an inch long, slightly convex on the back, pubescent with hooked hairs, with a stipe shorter than the calyx lobes.

In woods and thickets, Maine to Ontario, Minnesota, Alabama, Tennessee. Missouri and Texas. Flowering from the last of June to September. 
WIL I) FLOWERS OF NEW YORK

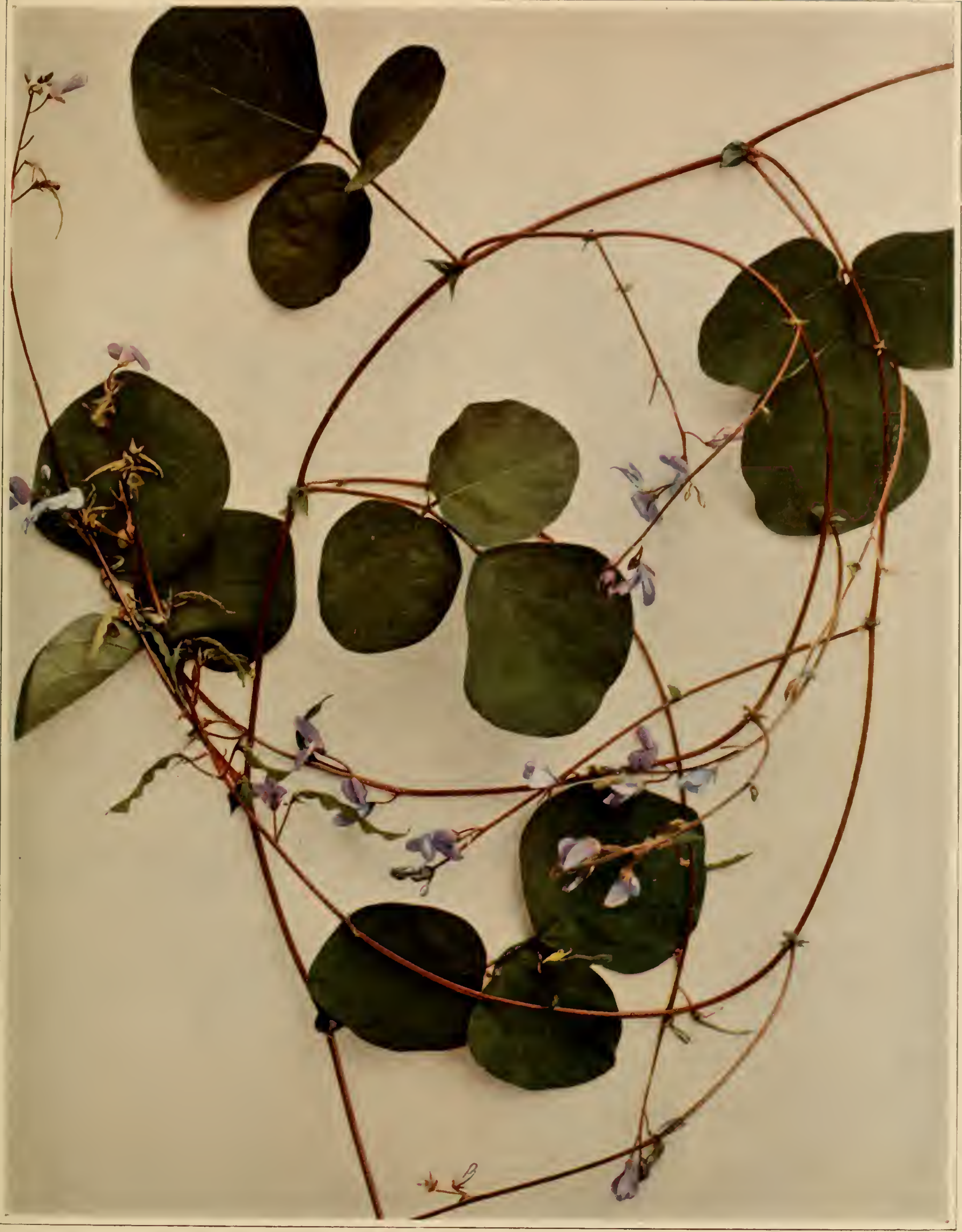


W I L D F L O WERS OF NEW YORK

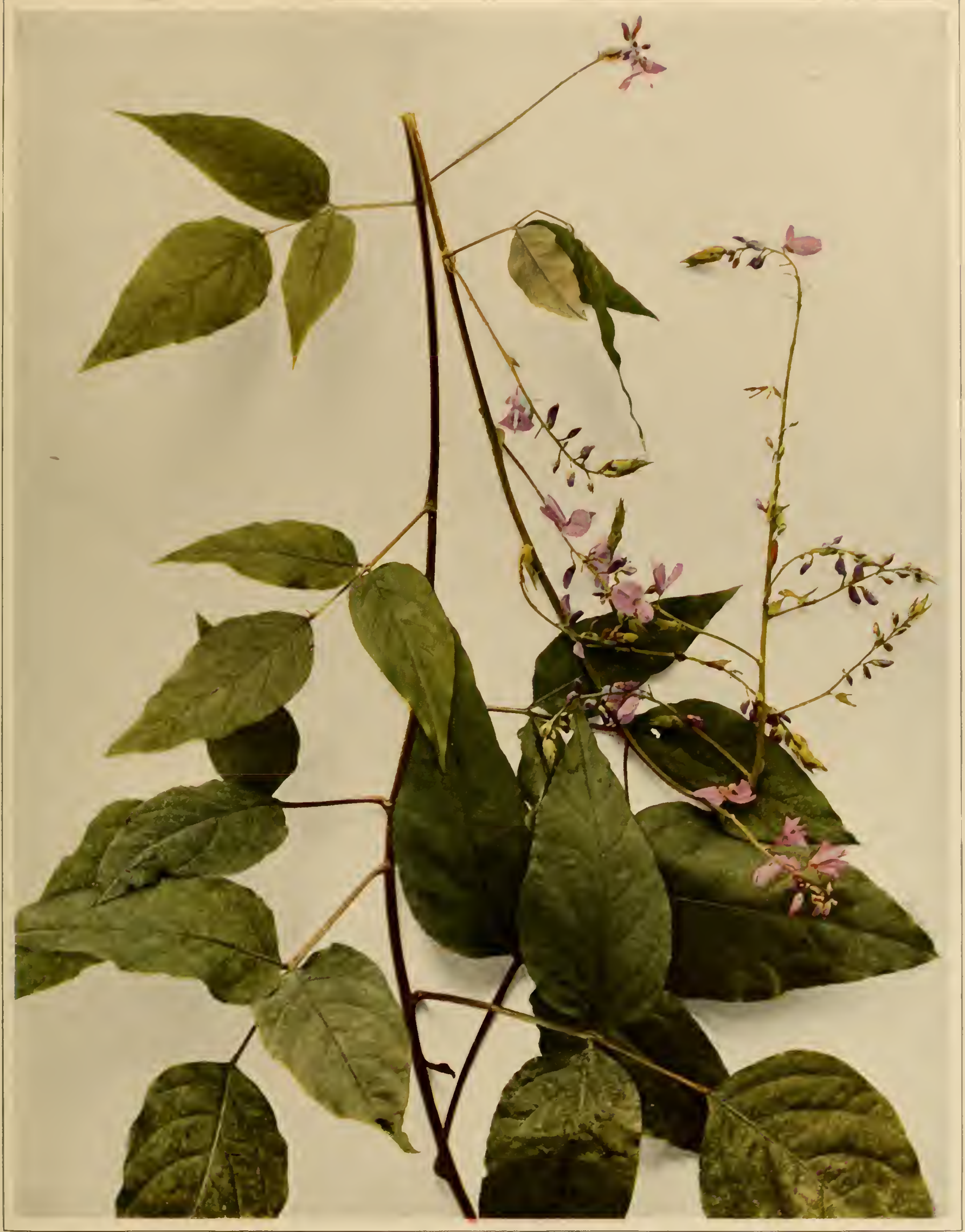

LARGE-BRACTED TICK TREFOIL

Meibomia bracteosa 
WIIL ILOWERS OF NEW YORK

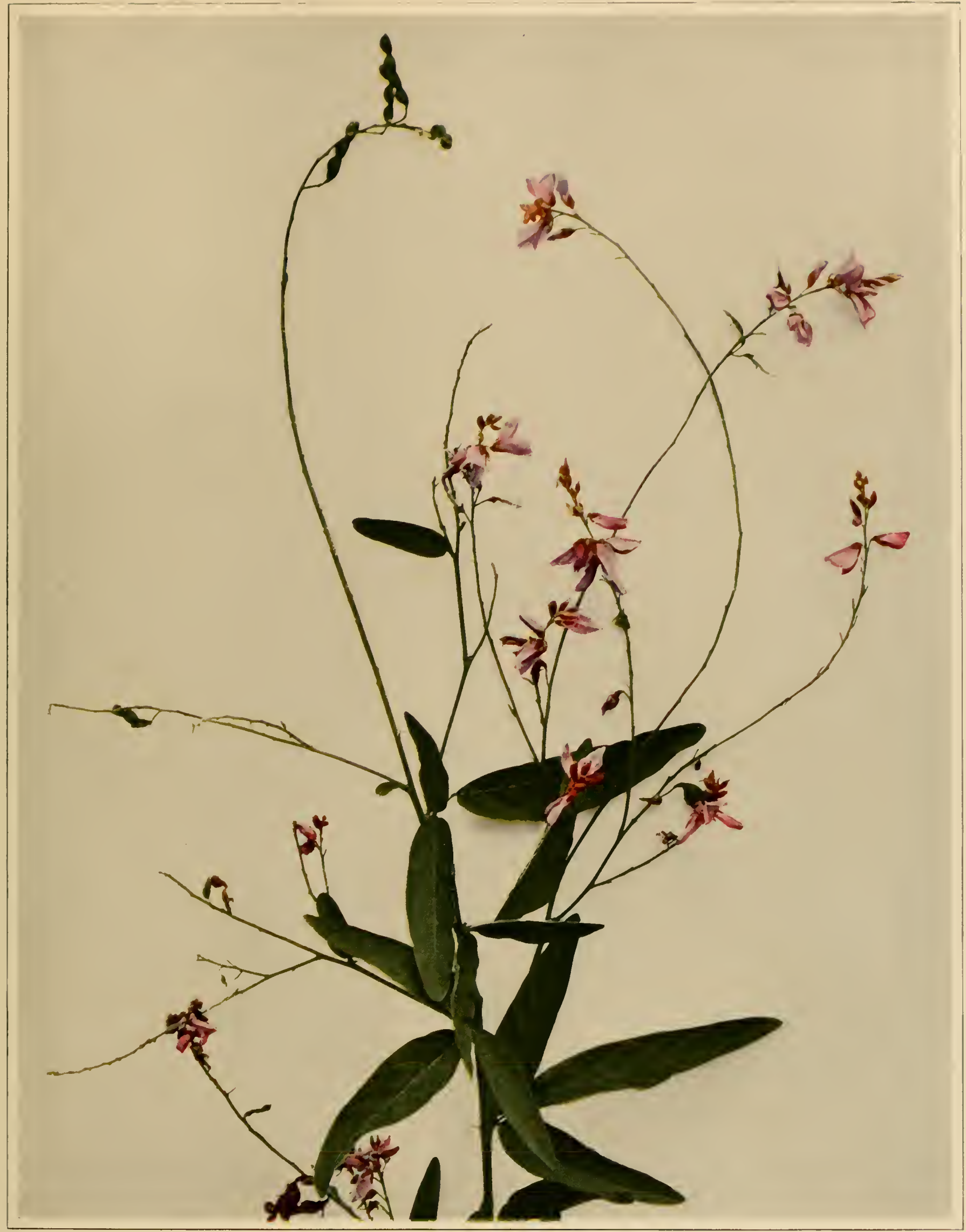

DILLEN'S TICK TREFOIL

Meibomia dillenii 


\section{THE BUSH CLOVERS}

$$
\text { L, es pedez a }
$$

Herbs, often with perennial roots and erect or ascending stems. In a few species the stems trailing. Leaves three-foliolate. Iilowers small, purple or whitish, in axillary clusters, heads or panicles. Frequently the flowers are of two kinds intermixed, one petaliferous but sterile, the other minute, apetalous and fertile. Calyx lobes nearly equal, those of the petaliferous flowers usually longer than those of the apetalous flowers. Upper petal (standard) obovate or oblong, the lower petals forming an incurved keel. Stamens usually diadelphous (nine and one); anthers all alike. Ovary one-ovuled, ripening into a flat, indehiscent, reticulated, mostly one-jointed and one-seeded pod.

\section{Key to the New York Species of Lespedeza}

Corolla purple or purplish; plants bearing both petaliferous and apetalous flowers

Stems prostrate or trailing

Foliage glabrous or somewhat appressed-pubescent............ re pens

Foliage downy-pubescent or tomentose.............. procu mbens Stems erect or ascending

Peduncles distinct and mostly longer than the leaves

Bushy-branched; petaliferous flowers paniculate

L. violace a

Stems simple or little branched; flowers racemose or subspicate

Stems tomentose; leaves tomentose beneath.......... L. brit t o n i i

Stems and leares glabrate or appressed-pubescent; leaflets oval to suborbicular.

L. nut a $11 \mathrm{i}$

Peduncles shorter than the leaves or the flower clusters sessile

Leaflets densely tomentose beneath; calyx of the petaliferous flowers less than one-half as long as the pod.

L. sturei

Leaflets appressed pubescent beneath or glabrate

Calyx of petaliferous flowers less than one-half as long as the pod; leaflets oval to oblong.................. frutescens

Calyx of the petaliferous flowers two-thirds as long as the pod or more; leaflets silvery-pubescent beneath.............. s i m u la ta 
Corolla whitish or yellowish; flowers all complete; pod included or scarcely exserted from the calyx

Leaflets oblong, ovate-oblong, or nearly orbicular

Peduncles mostly exceeding the leaves................... h irt a

Peduncles shorter than the leaves. L. c a pitat a

\section{Stuve's Bush Clover \\ Lespedeza sturei Nuttall \\ Plate I $13 \mathrm{~b}$}

Stems erect or nearly so, simple and wandlike or slightly branched, densely velvety or downy-pubescent all over, 2 to 4 feet high; petioles as long as the leaves or usually shorter; leaflets oval, oblong or suborbicular, blunt or retuse at the apex, one-half to I inch long. Flowers of both kinds in nearly sessile, axillary clusters; corolla violet-purple, one-fourth of an inch long or less. Pod oblong-ovate to orbicular, pointed, about one-fourth of an inch long or less, downy-pubescent, much longer than the calyx.

In dry or sandy soil, Vermont and Massachusetts to Virginia, Alabama, Michigan, Arkansas and Texas. Flowering in August and September.

\section{Wandlike Bush Clover \\ Lespedeza frutescens (Linnaeus) Britton \\ Plate II 4}

Stems erect, I to 3 feet high, simple or somewhat branched, finely pubescent or nearly smooth; petioles as long as the leaflets or shorter; leaflets oval, oblong or elliptic, blunt, truncate or notched at the apex, narrowed or rounded at the base, one-half to $\mathrm{I} \frac{1}{2}$ inches long, smooth and dark green above, paler and pubescent beneath. Flowers of both kinds in short-stalked axillary clusters which are more or less crowded toward the summit of the stem; corolla violet-purple, about one-fourth of an inch long; pod ovate, pointed, pubescent, about one-fifth of an inch long.

Dry soil in open woods, old fields, etc., Maine to Ontario, Minnesota, Florida, Illinois and Texas. Flowering in August and September. 
W I I, D I L, O W E R S Memoir 15 N. Y. State Museum

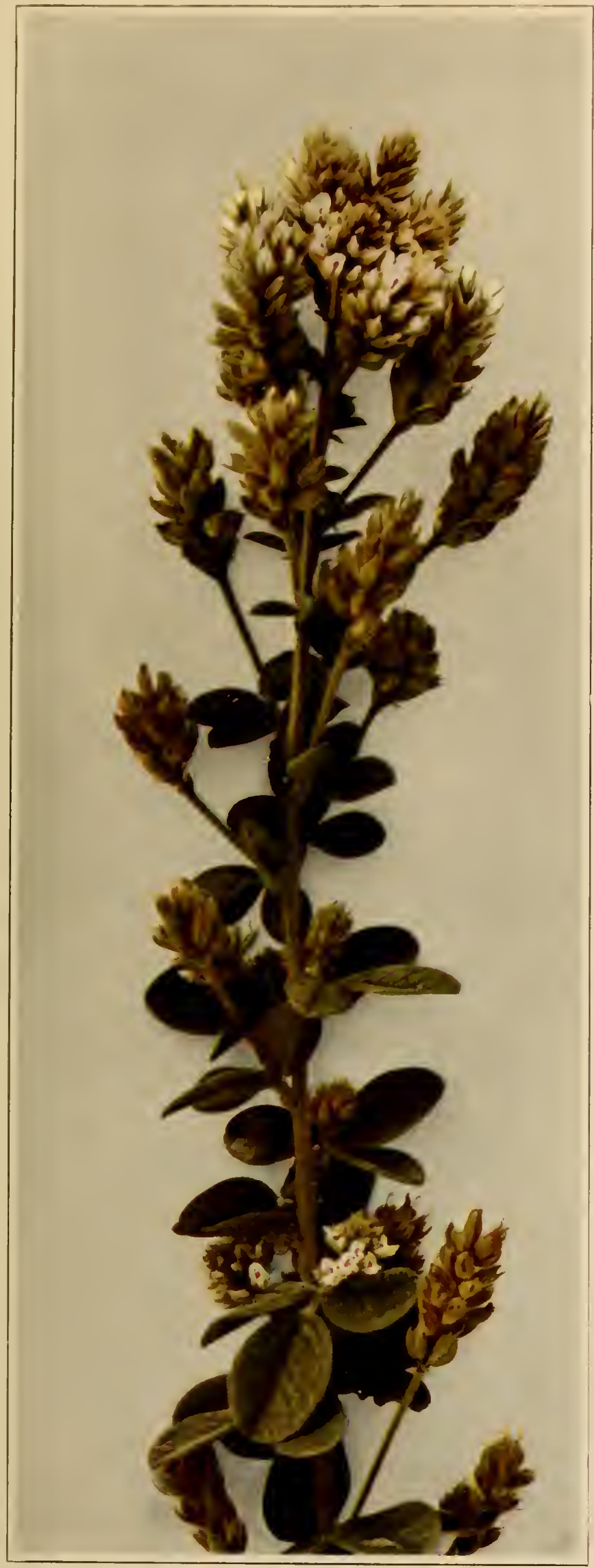

A. HAIRY BUSH CLOVER Lespedeza hirta
O F N E IV Y R K

Plate 113

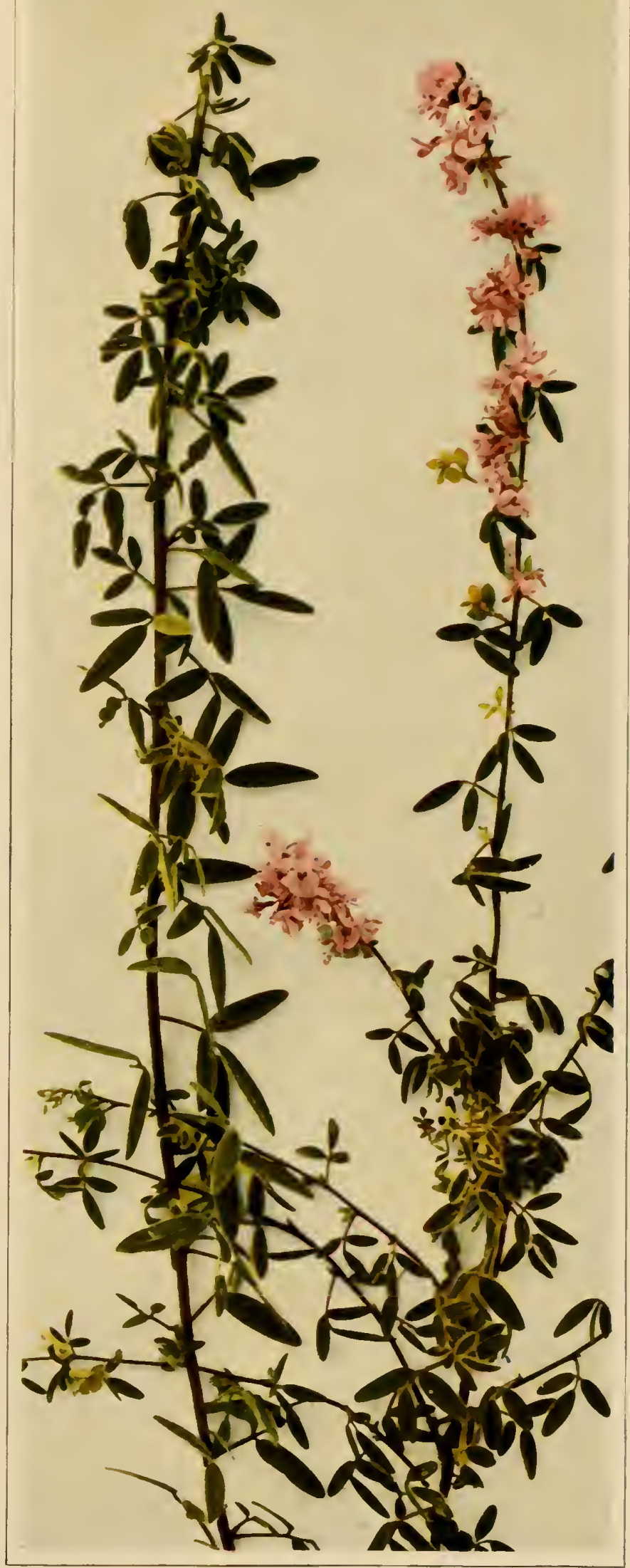

B. STUVE'S BUSH CLOVER Lespedeza sturei 


\section{'}




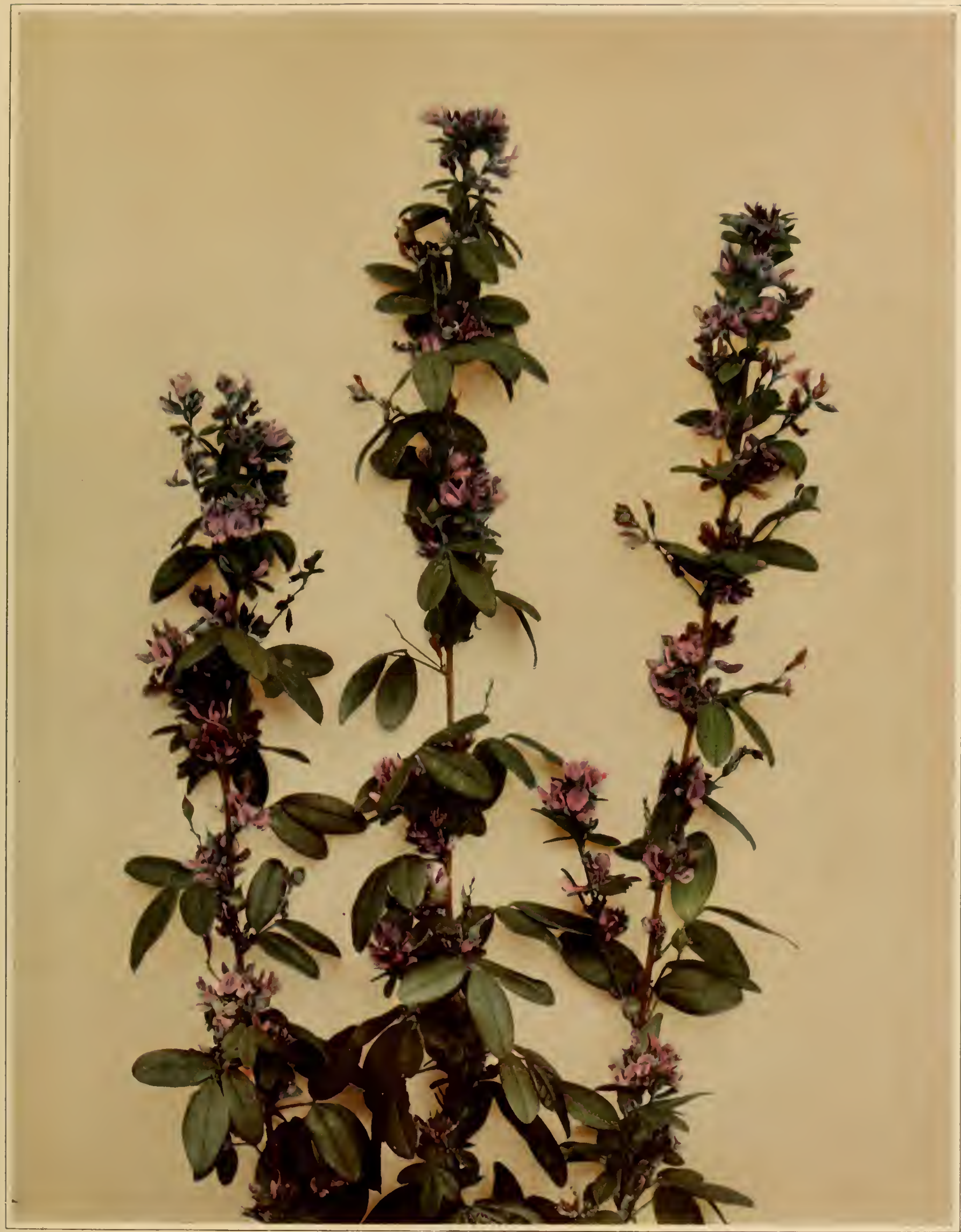




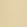




\section{Hairy Bush Clover \\ Lespedeza hirta (Linnaeus) Hornemann \\ Plate 3 ra}

Stems rather stiff, erect and usually stout, simple or branched above, densely hairy or softly pubescent, 2 to 5 feet high. Leaflets three, oval or suborbicular, blunt at each end, or often notched at the apex, one-half to 2 inches long; the petioles shorter than the leaflets. Flowers in oblongcylindric, rather dense heads on stalks which are much longer than the leaves; flowers all complete; corolla yellowish white, usually the standard with a purple spot near its base. Fruiting pod oval, pointed, hairy and about as long as the slender calyx lobes.

In dry or sandy soil, Maine to Ontario and Minnesota, south to Florida, Louisiana and Texas. Flowering from August to October.

The Round-headed Bush Clover (Lespedeza capitat a Michaux) is similar but the stalks bearing the flower clusters are shorter than the leaves, forming a more compact inflorescence. Its range and period of flowering are about the same.

\section{Beach Pea; Seaside Pea \\ Lathyrus maritimus (Linnaeus) Bigelow \\ Plate II5}

Root perennial, stem glabrous or nearly so, stout, somewhat fleshy and slightly glaucous, angled, decumbent, I to 2 feet long with broad foliaceous, hastate, pointed stipules I to 2 inches long. Leaves nearly sessile, pinnate, the rachis terminating in a slender, forked tendril; leaflets six to twelve, oblong, oval or obovate, blunt and mucronulate at the apex, usually narrowed at the base, I to $2 \frac{1}{2}$ inches long, one-half to three-fourths of an inch wide. Flowers six to ten on peduncles 3 to 4 inches long, purple, three-fourths to I inch long; calyx teeth often ciliate. Fruit a sessile, linear-oblong, nearly glabrous, veined pod, $\mathbf{I} \frac{1}{2}$ to 3 inches long and about one-half of an inch wide. 
Sea bcaches and sandy fields near the coast, New Jerscy to Arctic America, also Oneida lakc, Great Lakes, Pacific coast and in northern Europe and Asia. Flowcring from May to August.

\section{Myrtle-leaved Marsh Pea}

\section{Lathyrus myrtifolius Muhlenberg \\ Plate 110}

Stems very slcnder, smooth, angled but not winged, weak, 1 to 3 feet long with obliquely ovate or half-sagittate stipules, one-half to I inch long, one-third to one-half of an inch wide and toothed; leaflets usually six, varying from four to eight, oval or ovate, pointed and mucronate at the apex, narrowed at the base, thrce-fourths to 2 inches long, one-fourth to two-thirds of an inch wide, the rachis terminating in a forkcd tendril. Flowering peduncles as long as the leaves or shorter, with three to nine flowers, yellowish in bud but turning purple as the flower opens; each flower about one-half of an inch long. Fruit a narrow, smooth pod without visible stalk, I to 2 inches long and somewhat less than one-fourth of an inch wide.

In moist thickets, wet ground, swamps and shores, New Brunswick to Manitoba, south to North Carolina and Tennessee. Flowering from late in May until June or July.

The members of the genus Lathyrus are often called Vetchlings, because of their close relationship to the true Vetches (genus Vicia), most of which are cultivated or naturalized species in our State. Another native Vetchling is the Marsh Vetchling (Lathyrus palustris Linnaeus), a boreal species found in the northern part of the State. It has linear leaflets and the stems are usually winged. The flowers are purple. The Creamcolored Vetchling (L a thy rus ochroleucus Hooker) with rather large crcam-colored flowers, and broadly oval, acute leaflets, occurs throughout the western part of the State. 
WI L, D FLOWERS OF NEW YORK

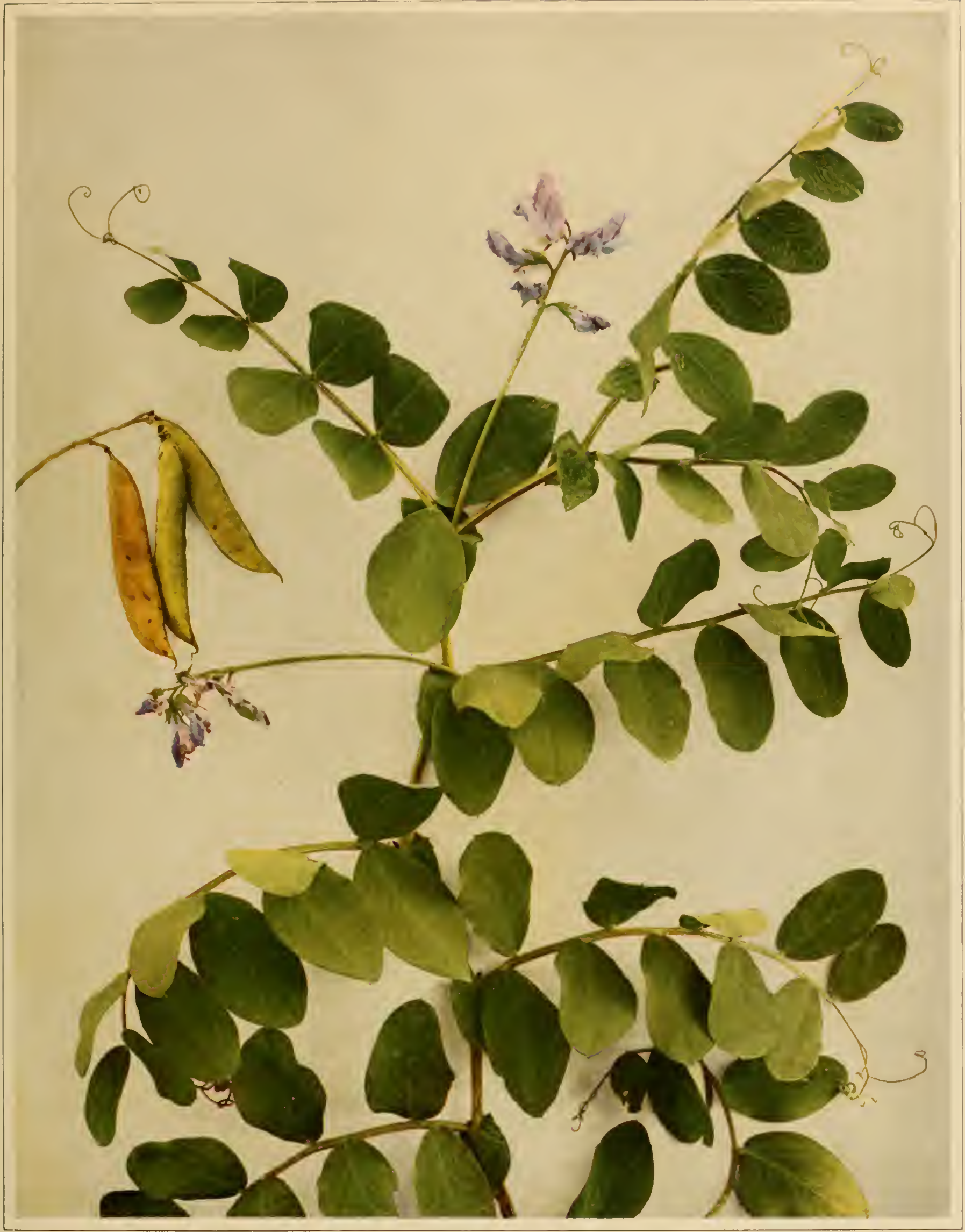

BEACH PEA; SEASIDE PEA

Lathyrus maritimus 
- 
W I I, D F L OWERS OF NEW YORK

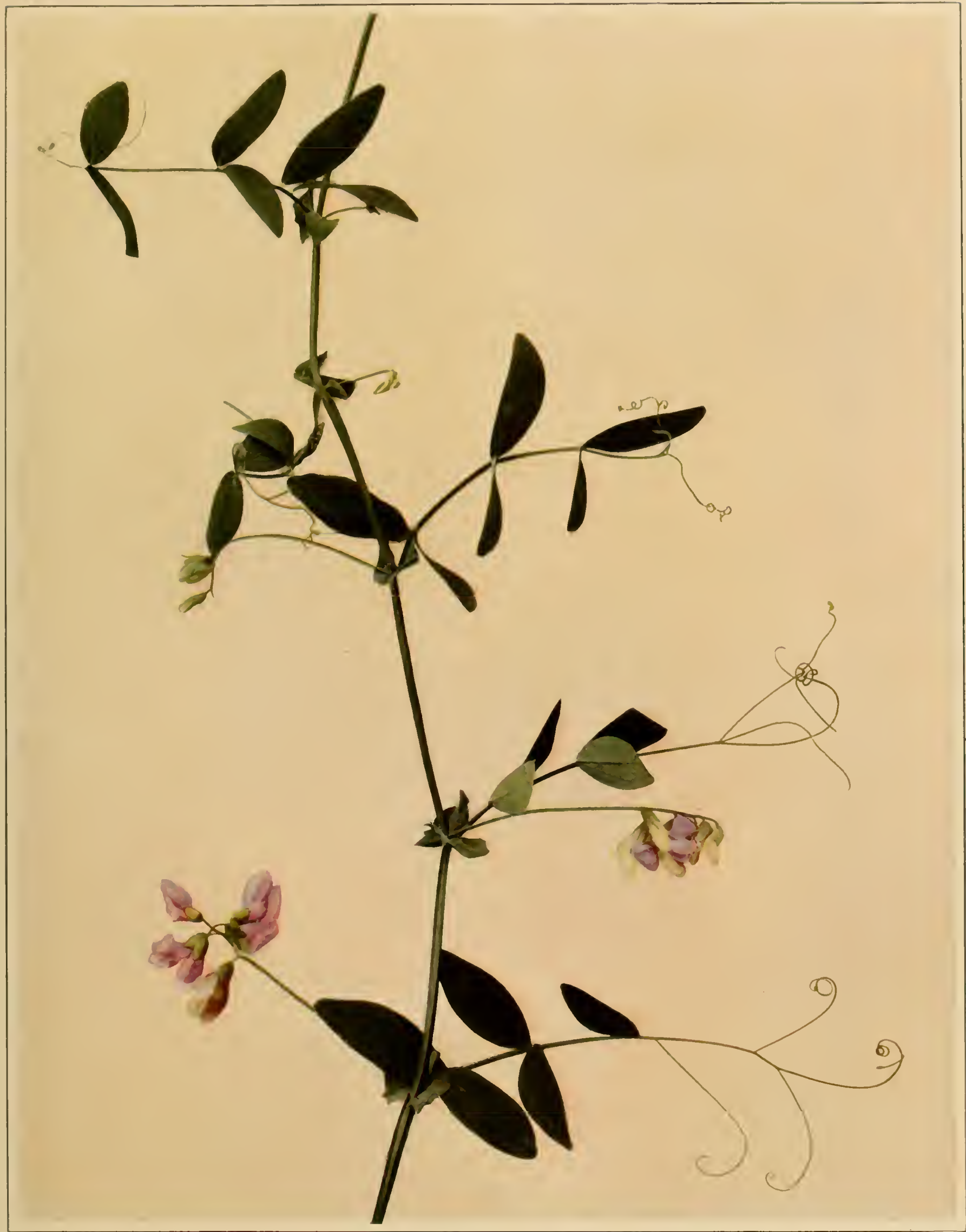


- 


\section{Groundnut; Wild Bean}

Glycine apios Linnacus

Plate 117

Stems slender, hairy or nearly smooth, with milky juice, climbing over herbs and bushes to a height of several feet, from a perennial rootstock of several necklace-shaped, edible tubers. Leaves pinnately compound, five- to seven-foliolate; leaflets ovate to ovate-lanceolate, pointed at the apex, rounded at the base, I to 3 inches long. Flowers brownish purple, fragrant, about one-half of an inch long, in axillary racemes; peduncles shorter than the leaves; rachis of the inflorescence knobby; calyx two-lipped, the two lateral teeth very small, the two upper united and short, the lower one long and acute; standard ovate or orbicular and reflexed, wings obliquely obovate, adherent to the elongated, incurved and at length twisted keel; pod narrow, straight or slightly curved, 2 to $4 \frac{1}{2}$ inches long and about one-fourth of an inch wide or less, many-seeded and rather thick in texture.

Moist thickets along streams, bottomlands, or low woods. New Brunswick to Florida, west to Ontario, Minnesota, Nebraska, Kansas and Texas. Flowering from July to September.

\section{Wild or Hog Peanut}

\section{Falcata comosa (Linnaeus) Kuntze \\ Plate risa}

Stems very slender, simple or somewhat branched, twining and climbing over herbs and shrubs, I to 6 feet long, more or less pubescent. Leaves with three rhombic-ovate or broadly ovate leaflets pointed at the apex, rounded at the base, I to 3 inches long. Flowers purplish or nearly white in axillary, slender-stalked clusters or racemes. In the lower axils are solitary, apetalous, fertile flowers. Calyx of the petaliferous flowers four to five-toothed, tubular; the oblong wings of the corolla curved and adherent to the recurved, blunt keel and inclosed by the erect, 
obovate standard; pods oblong-lanceolate, pointed and hairy, about I inch long.

In moist, shaded places, New Brunswick to Florida, west to Manitoba, Nebraska and Louisiana. Flowering from early in August until late in September.

F a lcata pitcheri (Torrey \& Gray) Kuntze, very closely related to the preceding species, has leaves of a firmer texture and the stems, petioles and flowering stalks villous-pubescent with conspicuous brown hairs.

\section{Trailing Wild Bean \\ Strophostyles helvola (Linnaeus) Britton Plate II $8 \mathrm{~b}$}

A twining or trailing and climbing, herbaceous, rough-pubescent vine. Stems more or less branched below, 2 to 7 feet long, or dwarfed and almost erect, from an annual root. Leaves pinnately three-foliolate; leaflets ovate, pointed or blunt at the apex, the base rounded, thickish in texture, usually bluntly lobed, I to 2 inches long, the two lower leaves unequal at the base. Flowers greenish purple, about one-half of an inch long, three to twelve together in dense, capitate clusters at the ends of long, axillary stalks which are longer than the leaves; keel of the corolla strongly curved and slender. Fruiting pod round in cross-section, somewhat hairy, linear and without a stalk, $\mathbf{I} \frac{1}{2}$ to 3 inches long.

In sandy fields and thickets, mainly near the coast, Quebec to Massachusetts and Florida, less frequent westward through Ontario to South Dakota and Kansas. Flowering from the latter part of July to September and October.

A closely related species of Long Island and southward, S. $\mathrm{u} \mathrm{m} \mathrm{b} \mathrm{e} \mathrm{1-}$ 1 a t a (Muhlenberg) Britton, has shorter pods, slightly larger flowers, entire leaflets and perennial roots. 
W ILD FL OWERS OF NEW YORK

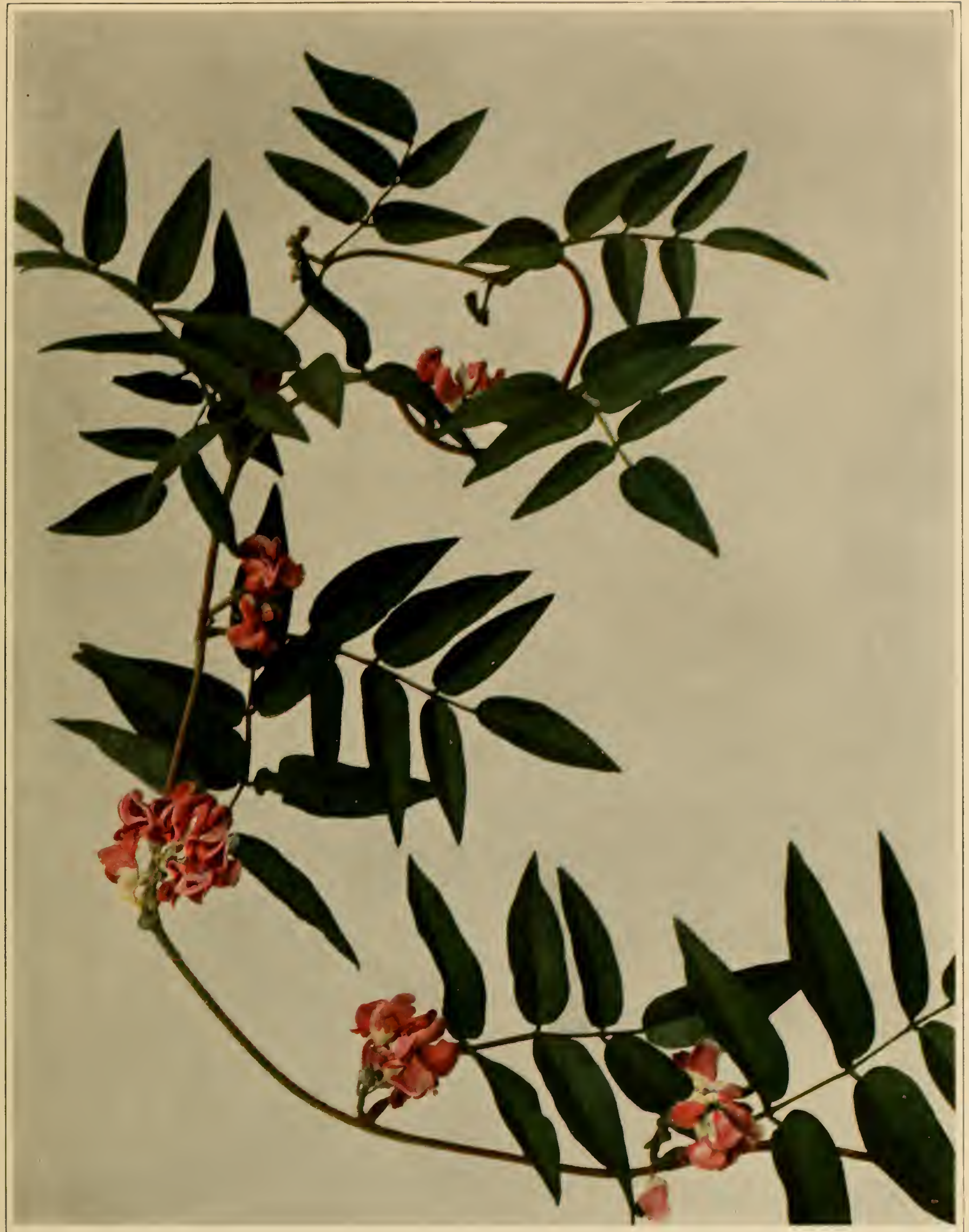

GROUNDNUT; WILD BEAN

Glycine apios 



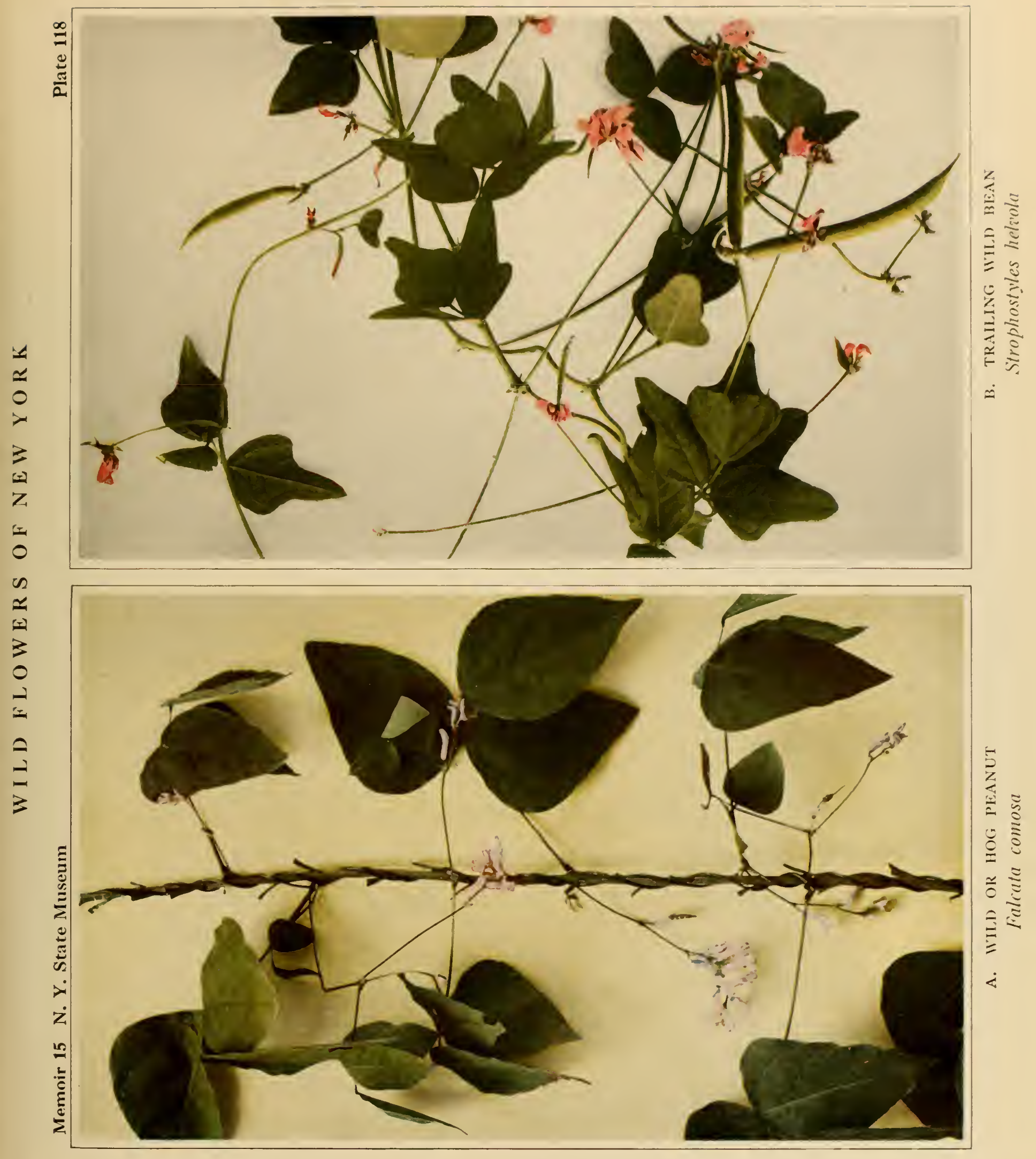





\title{
Geranium Family
}

Geraniacea e

\author{
Herb Robert; Red Robin \\ Robertiella robertiana (Linnaeus) Hanks \\ (Geranium robertianum Linnaeus) \\ Plate I 10
}

Roots mostly biennial, sometimes annual, giving rise to one or several ascending or nearly erect, glandular-pubescent stems 5 to 18 inches high. Entire plant with a strong, disagreeable odor. Leaves rounded-ovate in outline, the divisions deeply cleft or lobed, the margins with oblong, mucronate teeth. Flowers reddish purple, about one-half of an inch broad, two on each stalk; sepals five, each tipped with an awn. Petals five, each with a slender claw and an obovate, rounded blade. Stamens ten; ovary fivelobed and five-celled. Fruiting capsule about I inch long, awn-tipped, separating at maturity into five carpels, the bodies deciduous from the styles at maturity, each with two fibrous appendages near the top.

In rich soil of rocky woodlands, Nova Scotia to Manitoba south to Pennsylvania and Missouri; also in Europe and Northern Africa. Flowering from May to September.

\section{Wild Geranium; Wild or Spotted Crane's-bill}

\section{Geranium maculatum Linnaeus} Plate $x 20$

Stems mainly simple from a stout, perennial rootstock, often much branched above, hairy, Io to 20 inches high. The basal leaves nearly orbicular, broadly heart-shaped, on long leaf-stalks; the blades 3 to 5 inches wide, deeply three to five-lobed with wedge-shaped divisions, the margins cleft or toothed; leaves of the stem two, opposite, short-stalked, similar to the basal leaves. Flowers rose-purple, I to $\mathbf{I} \frac{1}{2}$ inches broad, terminal in two to five-flowered, loose, leafy-bracted umbels; sepals sharp pointed; petals five, woolly at the base, thin, broad and overlapping one another. Fruit an elongated capsule tipped with the persistent compound style, 
which in fruit is I or more inches long; carpels of the fruit permanently attached to the styles, separating from the base and curved upward in dehiscence.

In rich or moist woodlands, Maine and Ontario west to Manitoba, south to Georgia and Alabama. Flowering from late in April to June or July.

'There are several other species of Geranium in New York, most of them small-flowered, introduced species. Of the native ones, Bicknell's Geranium (Geranium bicknellii Britton) is an annual with small, purple flowers, somewhat less than one-half of an inch broad in a loose cluster, on two-flowered peduncles, with the beak of the fruit long pointed. The Carolina Geranium (Geran i u m c a rolin ia n u m Linnaeus) has a more compact inflorescence and a short-pointed fruit.

\section{Wood Sorrel Family}

$\mathrm{O} \times \mathrm{a} 1 \mathrm{id}$ ác e a e

\section{White or True Wood Sorrel; Alleluia \\ Oxalis acetosella Linnaeus \\ Plate rozb}

Rootstock perennial, slender, scaly and little branched. Leaves basal, three to eight together, each 2 to 6 inches high, pubescent; petioles broadened at the base and jointed. Leaflets three, obcordate, wider than long, one-half to I inch wide. Flowers one-half to three-fourths of an inch broad, solitary on stalks as long or longer than the leaves; petals white or pink with deep pink veins, three or four times longer than the calyx; stamens ten. Fruit a subglobose, cylindric capsule about onesixth of an inch long. At the base of the leaves are also found short-stalked flowers.

In cool, damp woods, or shaded mossy banks, Nova Scotia to the north shore of Lake Superior, south to North Carolina. Also in Europe, Asia and northern Africa. Flowering from May to July. 
W I I, D F L O WERS OF NEW YORK

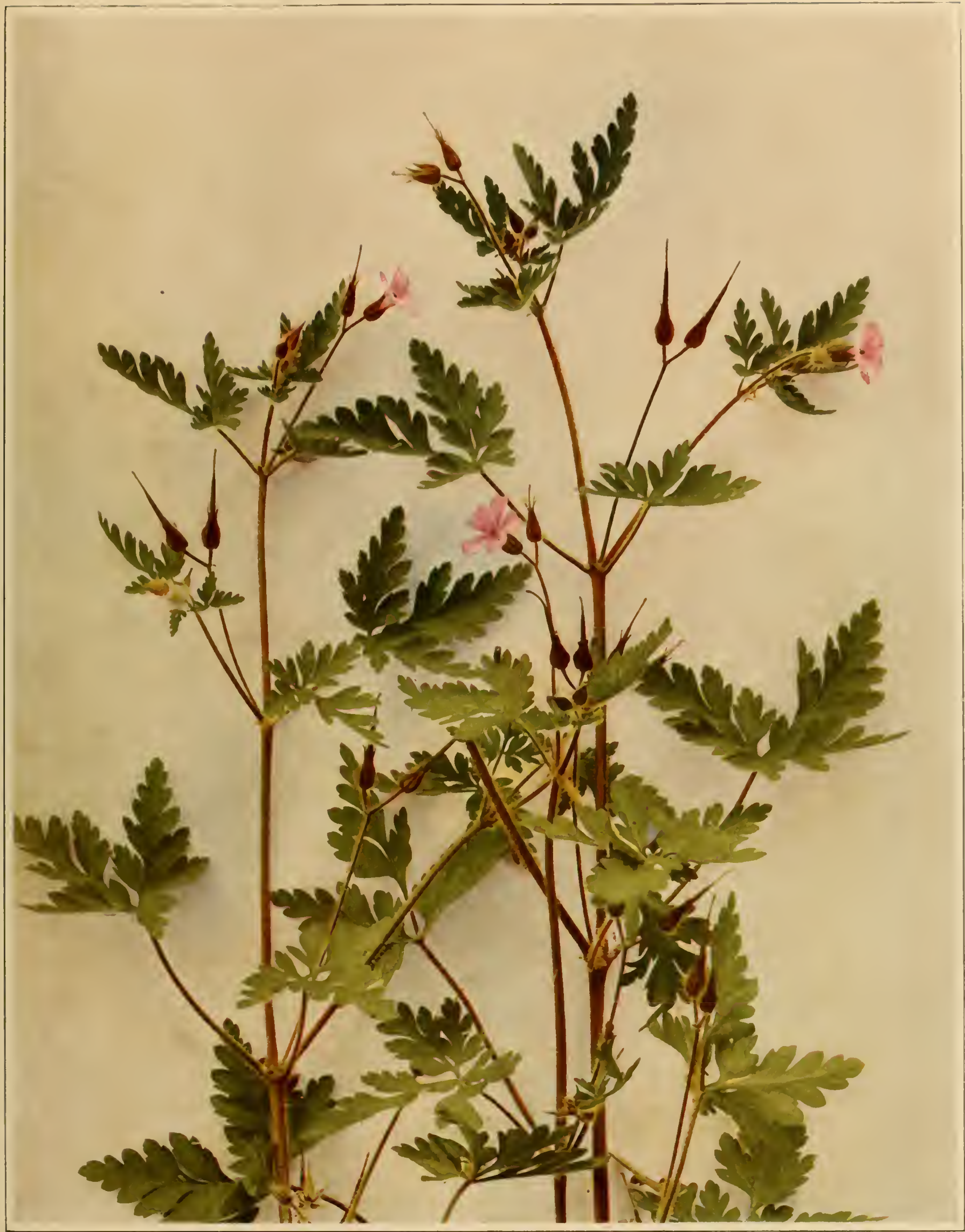

HERB ROBERT; RED ROBIN

Robertiella robertiana 

W I L D FL OWERS OF NEW YOR K

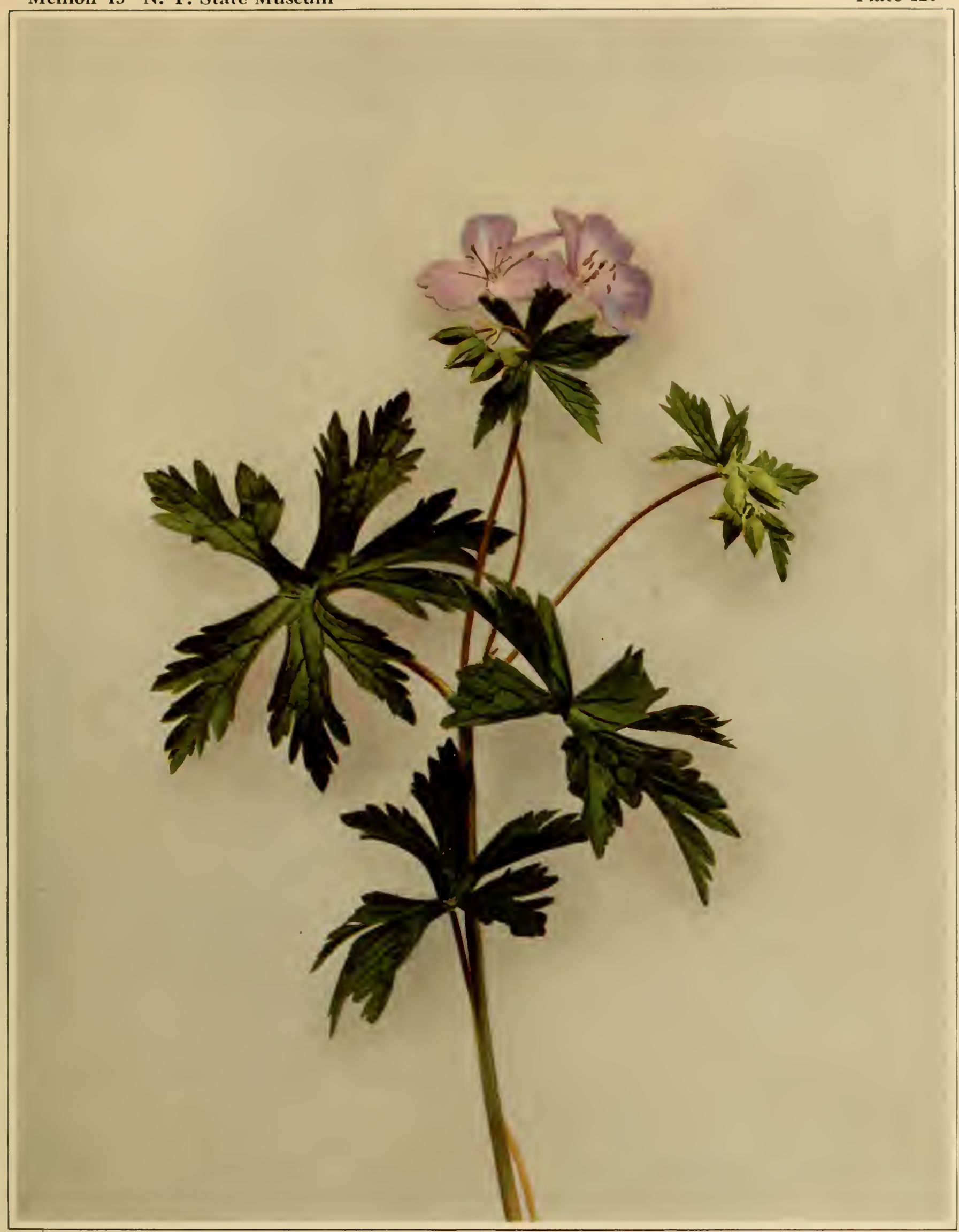

WILD GERANIUM; WILD OR SPOTTED CRANE'S-BILL

Geranium maculatum 



\section{Violet Wood Sorrel}

\section{Ionovalis violacea (Linnaeus) Small \\ Plate 12ra}

Flowering stalks and leaves smooth, 3 to 8 inches tall, arising from a perennial, brownish, scaly bulb. Leaves few or several, slender-stemmed, one-half to $\mathbf{I} \frac{1}{4}$ inches wide. Leaflets three, broader than long, notched at the apcx. Flowers threc to ten, or rarcly more on cach stalk, forming a loose, umbellate inflorescence at the summit, which is taller than the leaves. Each flower two-thirds to three-fourths of an inch long on a short, slender pedicel; sepals blunt, five in number, with tubercles at the apex; petals five, rose-purple, lighter toward the basc, blunt, about three times as long as the sepals; stamens ten; capsule ovoid, about one-fifth of an inch in diameter.

In open, usually rather dry woodlands, shaded hillsides and thickets; sometimes in open, recently cleared land, Massachusetts to Florida and Texas, west to Minnesota. Flowering in May and June.

\section{Tall Yellow Wood Sorrel \\ Xanthoxalis cymosa Small Plate I2 Ib}

Stems ascending or erect, branched above, 6 inches to 3 or + feet high and frequently reclining on surrounding vegetation, usually hairy, reddish or brown. Leaves bright green, three-fourths to $\mathrm{I} \frac{1}{2}$ inches broad on petioles I to 3 inches long; leaflets broader than long, sharply notched. Flowers yellow, in forking cymes; each flower on a pedicel one-fourth to one-third of an inch long, which is more or less hairy and erect or ascending. Sepals five, lanceolate or narrowly elliptic, one-sixth to one-fourth of an inch long, spreading in fruit; petals five, obtuse or notehed at the apex, one-third to nearly one-half of an inch long. Fruit a slender, columnar, erect capsule, about one-half of an inch long, gradually narrowed to the summit; seeds obovoid-oblong with nearly continuous ridges.

In fields, thickets and woods, Ontario to Michigan, south to Florida and Texas. Flowering from May to October. 
There are scveral closely related species of Ycllow Sorrel. Those of the northeastcrn states are illustrated and described by Britton \& Brown (Illus. Flora, 2: 432-35, cd. 2) (X. stricta, X. bushii, X. rufa and $\mathrm{X}$. brittoniae).

\section{Jewelweed Family}

$\mathrm{B}$ a $1 \mathrm{~s}$ a $\mathrm{m}$ in a c e a

\section{Spotted or Wild Touch-me-not}

Impatiens biflora Walter

Plate I $22 a$

A tall, glabrous annual, 2 to 6 feet high and much branched, more or less purplish. Leaves alternate, thin, ovate and elliptic, glaucous beneath, I to 3 inches long, blunt, the margins toothed. Flowers horizontal, orange-yellow, mottled with reddish brown, or rarely nearly white and not mottled, three-fourths to I inch long, on slender, pendant stalks. Sepals three, the two lateral ones small, green, nerved, the other one large, conic, petallike, saccate and spurred, longer than broad, contracted into a slender incurved spur, two-toothed at the apex. Petals three, with two of them two-cleft into dissimilar lobes; stamens five. Fruit an oblong capsule, violently and elastically dehiscent at maturity into five spirally coiled valves, expelling the oblong, ridged seeds. Also developing small, cleistogamous flowers later in the season.

Low grounds, thickets, ditches, along streams and low, moist woodlands, Newfoundland to Saskatchewan, south to Florida and Nebraska. Flowering from July to September.

\section{Pale Touch-me-not; Jewelweed \\ Impatiens pallida Nuttall \\ Plate 1 22b}

Resembling the Spotted Touch-me-not, but usually stouter and higher. Flowers pale yellow, sparingly spotted with reddish brown or without spots, I to $\mathbf{I} \frac{\mathbf{1}}{2}$ inches long, the saccate sepal dilated-conic, as broad as long, abruptly contracted into a short, scarcely incurved spur, which is less than one-third the length of the saccate sepal. 


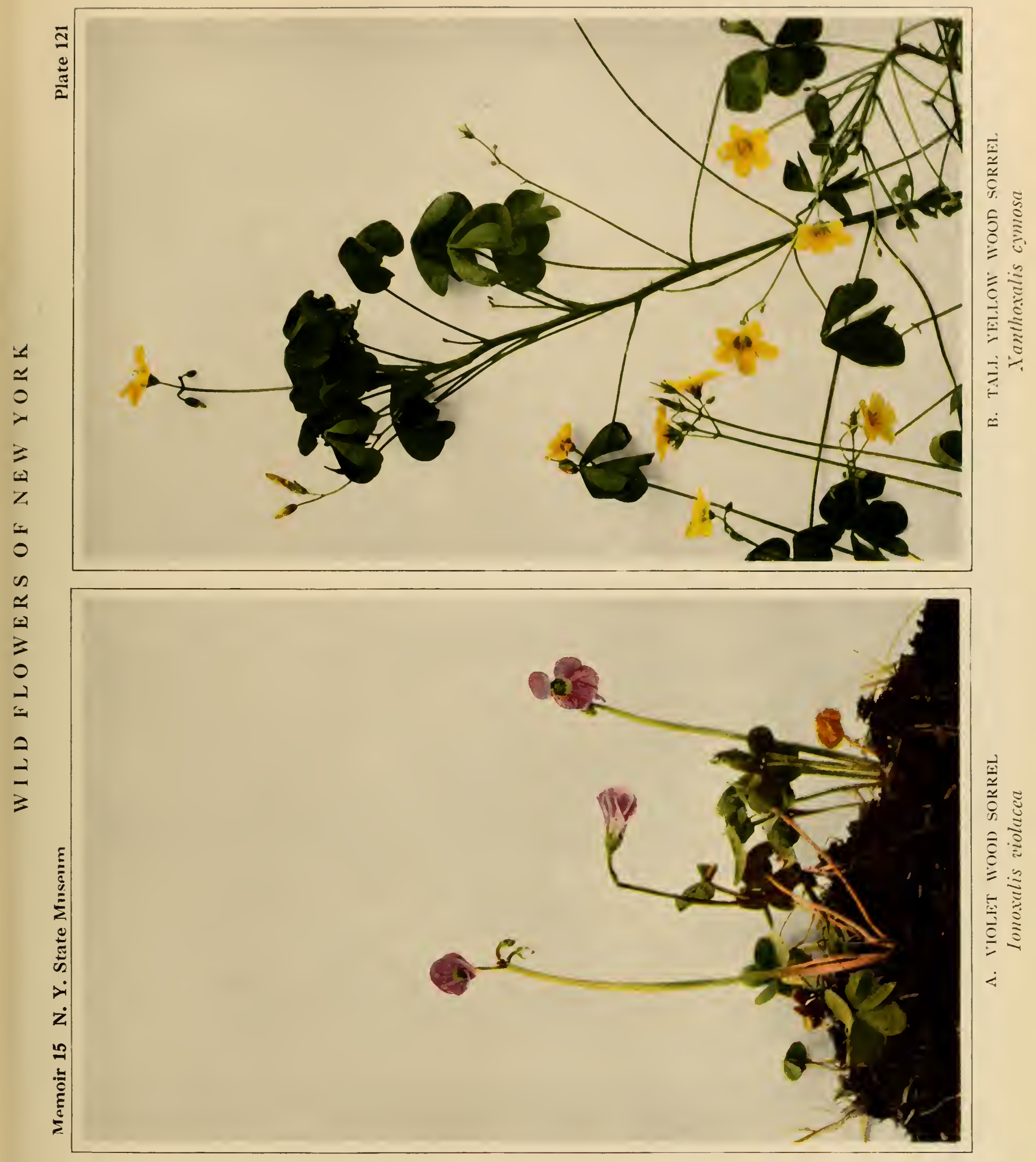





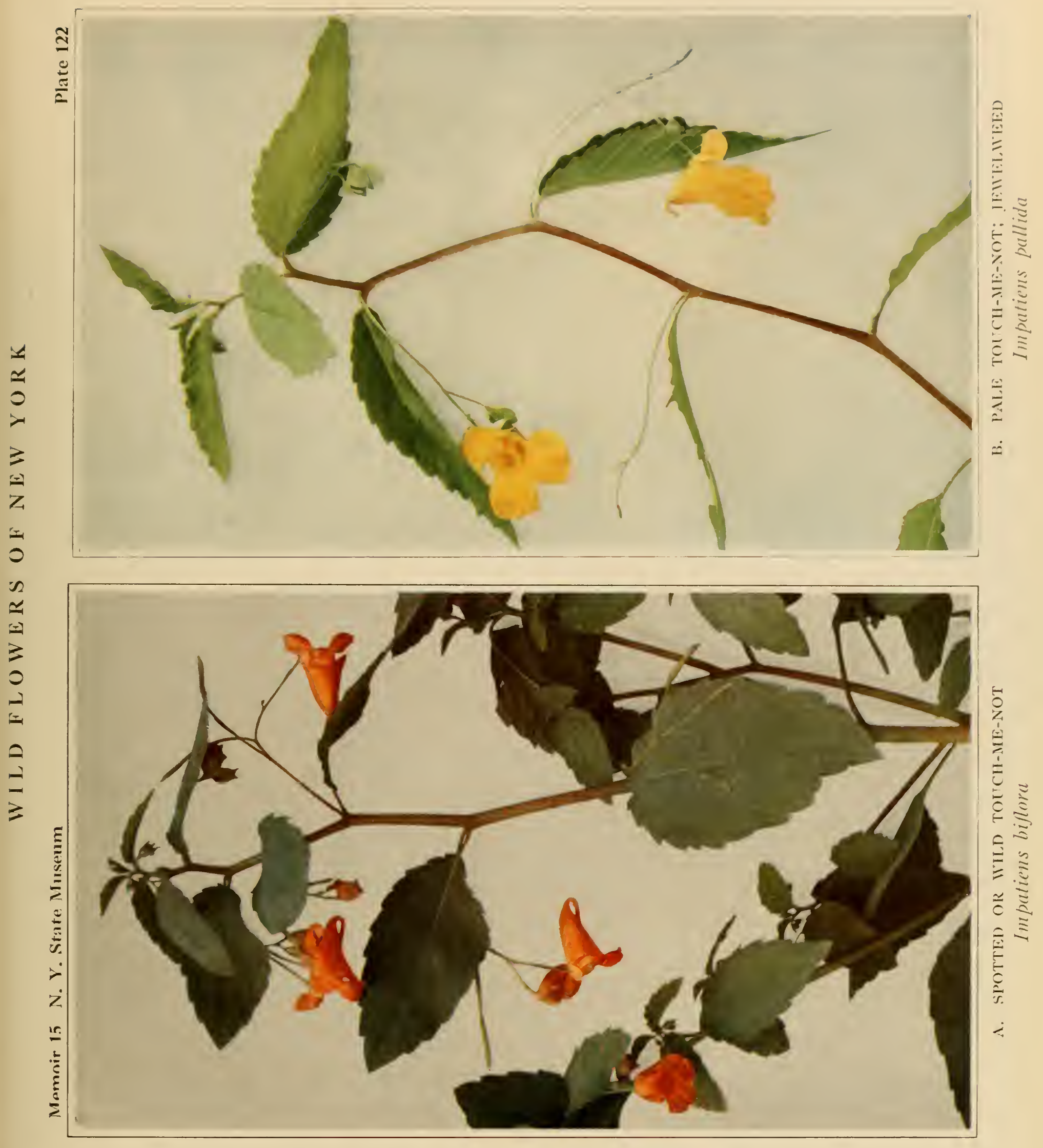



In situations similar to the preceding species but more common northward, Nova Scotia to Saskatchewan, south to Georgia and Kansas. Flowering from July to September.

\section{Milkwort Family}

Polyg a laceac

A family of small herbs (our species) with alternate, opposite or whorled leaves. Flowers racemose, spicate or capitate, rarely solitary and axillary, sometimes also with cleistogamous and subterranean flowers. Sepals very unequal, the two lateral ones large and petallike. Petals three, united into a tube which is split on the back, and more or less adnate to the stamens. Stamens eight or six, monadelphous below, or diadelphous. Capsule membranaceous, compressed, dehiscent along the margin. Seeds one in each cavity of the capsule and usually hairy.

Our species all belong to Polygala, a very large genus of plants, containing about sixty species in North America, of which about eleven are found in New York State. The following key may be of service in identifying them.

Flowers orange-yellow in a dense oblong spike; basal leaves spatulate ..... I P. 1 u t e a Flowers rose or purple, distinctly racemose ............. P. po 1 y g a m a Flowers rose-purple to white, one to four in number, axillary, but apparently terminal... .

3 P. paucifolia

Flowers in terminal, more or less elongated spikes, or if the spikes oblong, flowers not yellow and no basal leaves

Leaves at least the lower, verticillate, spikes 4 to 9 lines thick, blunt; flowers purple to greenish white

Spikes sessile or nearly so; wings deltoid .............. P. cruciat a

Spikes peduncled; wings lanceolate-ovate........... P. b revifolia

Leaves verticillate and alternate; spikes 2 to 3 lines thick and acute

Verticillate leaves predominating; spikes dense; flowers green to purplish........

6 P. verticillata

Alternate leaves predominating; spikes loose; flowers more purple........... 7 P. a m bigua 
Leaves all alternate

Petals united into a tube which is cleft and about one-fourth of an inch long: flowers pink 8 P. incarnata

Petals not conspicuously united into a tube

Spikes oroid to globose; bracts persistent; flowers rose-purple to white...

Spikes cylindric

9) P. viridescens

Leaves oblanceolate to linear, 2 to 6 lines long; flowers greenish to purplish. . . .

Io P. nutta $11 \mathrm{i}$

Leaves lanceolate, I to 2 inches long; flowers white to greenish.......

II P. senega

\section{Orange Milkwort; Wild Bachelor's-button}

\section{Polygala lutea Linnaeus}

Plate I 233

Stems annual, smooth, tufted from fibrous roots, erect or ascending, sometimes becoming branched, 6 to I 2 inches high. Stem leaves oblonglanceolate, pointed or blunt, three-fourths to $\mathbf{I} \frac{1}{2}$ inches long, one-fourth of an inch wide or less, entire; basal leaves broader and usually larger, obovate or spatulate, blunt. Flowers in terminal, blunt, spikelike racemes which are dense and oroid or oblong in shape, one-half to $\mathbf{I} \frac{1}{2}$ inches long, one-half to three-fourths of an inch thick. Individual flowers about onefourth of an inch long, orange-yellow, preserving their color in drying; wings oblong-ovate, abruptly pointed; crest of the corolla tube minute; caruncle lobes linear, about equaling the hairy seed, or shorter.

In pine-barren depressions and swamps, Long Island to New Jersey and eastern Pennsylvania to Florida and Louisiana. Flowering from June to August or September.

\section{Cross-leaved or Marsh Milkwort \\ Polygala cruciata Linnaeus \\ Plate $123 \mathrm{~b}$}

A small annual, 3 to 5 inches tall, with three or four alternate branches above, the stems angled or square. Leaves all on the stem and mostly 


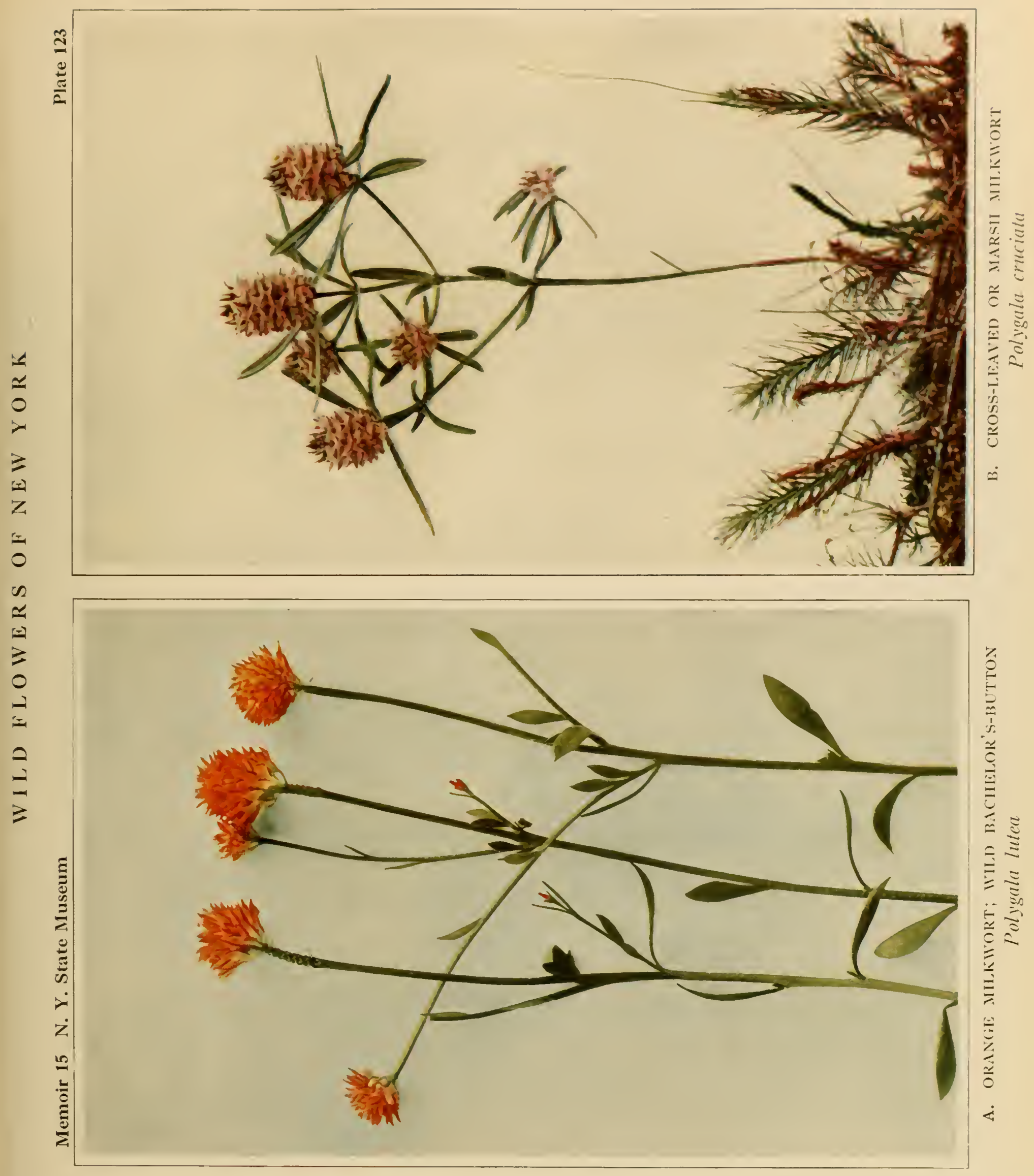





verticillate in fours, oblanceolate or linear-lanceolate, one-half to $\mathrm{I} \frac{1}{2}$ inches long and about one-eighth of an inch wide, entire, blunt and mucronulate at the apex. Flowers in short-stalked, oval, blunt racemes, about onethird to one-half of an inch thick, purplish green or nearly white; wings triangular-ovate, sessile, somewhat heart-shaped, pointed or awned, onefourth of an inch long or less, longer than the pods; crest of the corolla minute; seeds oblong and somewhat hairy.

In low grounds and marshes along the coast and sandy swamps inland. Maine to Florida west to Michigan, Minnesota, Nebraska and Louisiana. Flowering from July to September.

\section{Field or Purple Milkwort}

\section{Polygala riridescens Linnaeus}

Plate 12 .

Stems leafy, branched above, annual, smooth and somewhat angled, 5 to 5 inches high. Leaves all on the stem, oblong to linear-oblong in shape, three-fourths to $\mathbf{I} \frac{1}{2}$ inches long, one-eighth or one-sixteenth of an inch wide, pointed and mucronulate. Flowers purplish, greenish purple. whitish or greenish in terminal, globose, blunt heads about one-half of an inch thick, becoming oval; wings of the flowers sessile, ovate, often slightly cordate, longer than the pod, bracts usually persistent on the elongating axis as the lower flowers fall away.

In meadows, fields and sandy depressions, Nova Scotia to Ontario and Minnesota, south to North Carolina, Kansas and Arkansas. Flowering from June to September.

\section{Seneca Snakeroot; Mountain Flax \\ Polygala senega Linnaeus \\ Plate $125 a$}

Stems usually several from a perennial, woody rootstock, ascending or erect, 5 to I 8 inches high, usually simple, occasionally branched above, glabrous or nearly so. Leaves alternate, the lowest ones very small, closer together and scalelike, the upper ones oblong-lanceolate or ovate, some- 
times lanceolate, sessile, I to 2 inches long, about one-fourth to one-third of an inch wide, minutely toothed. Flowers white, sometimes tinged with green, in dense, terminal, pointed spikes, I to 2 inches long. Each flower about one-eighth of an inch long; wings of the flower orbicular-obovate, concave: crest of the corolla short and few-lobed.

In dry or rocky woodlands, New Brunswick to Hudson bay and Alberta, south along the mountains to North Carolina and west to Missouri and Arkansas. Flowering in May and June.

\section{Racemed Milkwort \\ Polygala polygama Walter \\ Plate $124 \mathrm{~b}$}

Stems usually several or many from a deep, slender, perennial root. smooth and simple, + to 15 inches high. Leaves crowded along the stems, oblong or broadly lanceolate, blunt, mucronulate, two-thirds to I inch long and about one-sixth of an inch wide or less, the lower leaves usually smaller. Flowers purple, rarely whitish, in a loose, terminal raceme, I to 3 inches long or less; wings of the flower broadly ovate; crest of the corolla large and fringed; stamens eight. Numerous cleistogamous flowers are developed upon conspicuous, whitish subterranean branches which rise from the base of the stems.

In dry or sandy fields and meadows. Nova Scotia to Manitoba, south to Florida, Texas and Michigan. Flowering in June and July.

\section{Fringed Milkwort; Flowering Wintergreen}

\section{Polygala paucifolia Willdenow Plate $125 \mathrm{~b}$}

Flowering and leaf-bearing stems smooth, ascending or erect, 3 to 7 inches high from slender, prostrate, perennial stems and rootstocks which are often several inches in length. Leaves few, clustered at the summit of the stems, ovate or oblong. I to $\mathrm{I} \frac{1}{2}$ inches long, two-thirds to I inch wide, pointed at each end, rough-margined. Flowers one to five on a stem, axillary to the upper leaves, rose-purple or rarely white, two-thirds to 


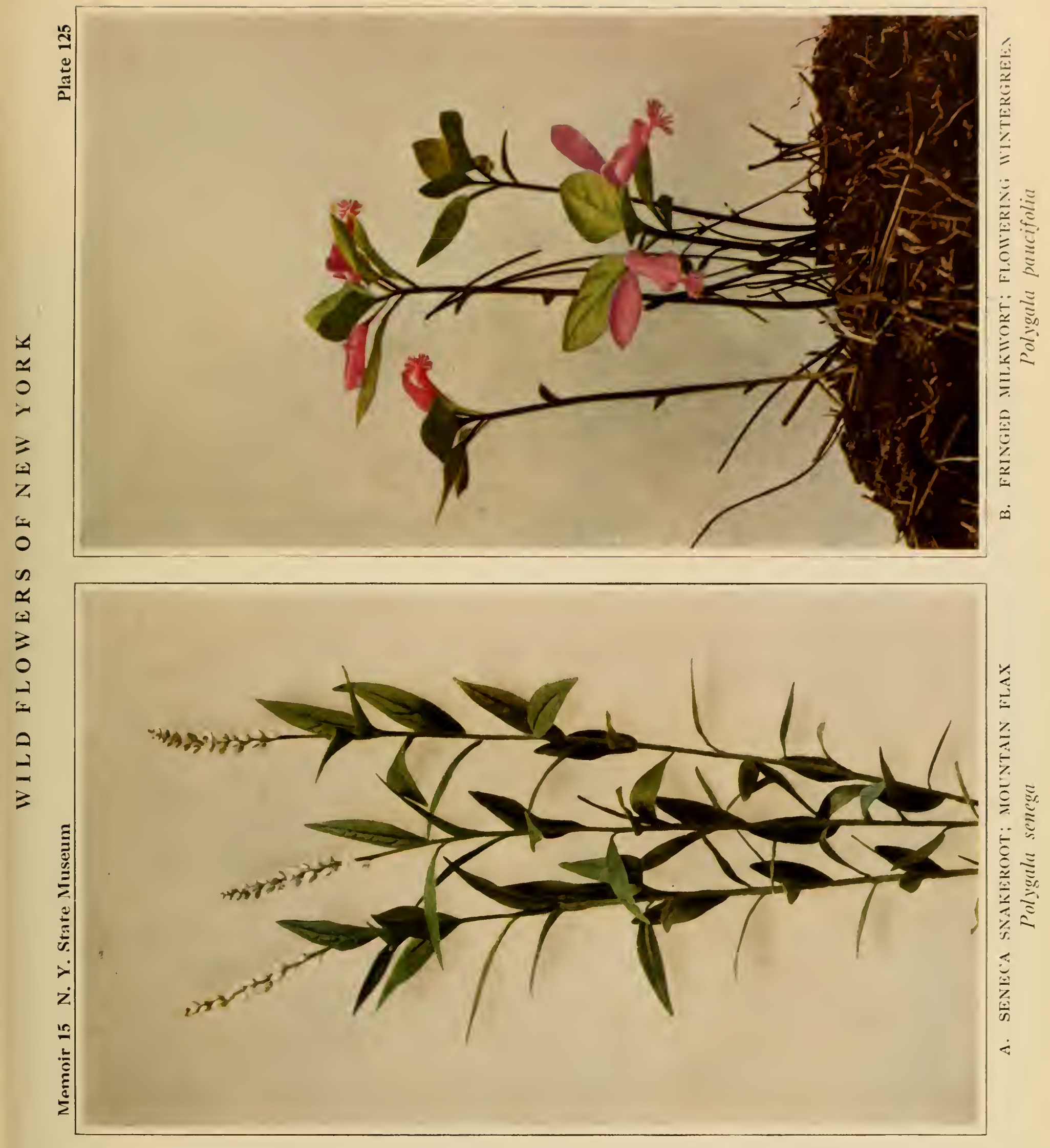


- 
I inch long on slender, short flower stalks; wings of the flower obovate; crest of the corolla beautifully fringed. The base of the stems and rootstocks bear numerous cleistogamous flowers on short, lateral, subterranean branches.

In rich, moist woods, New Brunswick to Saskatchewan south to Georgia, Illinois and Minnesota. Flowering in May and June.

\section{Buckthorn Family}

$\mathrm{R} h$ a $\mathrm{mn}$ ac e a e

\section{New Jersey Tea; Redroot \\ Ceanothus americanus Linnaeus \\ Plate 126}

A low shrub with several or many ascending stems from a deep reddish root. Leaves alternate, ovate or oblong-ovate, I to 3 inches long, one-half to $\mathrm{I} \frac{1}{2}$ inches wide, pointed at the apex, blunt or slightly heart-shaped at the base, pubescent, especially beneath, the margins finely toothed, the blade conspicuously three-nerved; petioles usually less than one-half of an inch long. Flowers small and white, in dense, oblong clusters on terminal or elongated axillary stalks; limb of the calyx tube five-lobed; petals five, with narrow claws and bearded blades; stamens five, their filaments slender and elongated. Fruit dark colored or nearly black when mature, three-lobed, about one-sixth of an inch long.

In sandy or dry open woods and fields, Maine to Ontario and Manitoba south to Florida and Texas. Flowering from the latter part of May to July.

\section{Mallow Family}

$\mathrm{M}$ a $1 \mathrm{v}$ ace a e

\section{Marsh Mallow; Wymote \\ Althaea officinalis Linnaeus \\ Plate 127}

An introduced plant, well established in certain salt marshes along the coast, with erect, herbaceous stems, 2 to 6 feet high from perennial roots, 
densely velvety-pubcscent all over. Leaves ovate, pointed or blunt at the apex, toothed and usually somcwhat threc-lobed, the lower leaves usually cordate, veins conspicuously raised on the lower surfaces. Flowers pink or nearly white, about $I_{2} \frac{1}{2}$ inches broad in terminal and axillary leafy clusters. Calyx segments fivc, ovate-lanceolatc, subtended by six to nine linear bractlets; petals five; stamens numerous, forming a central column around the pistil and united with the bases of the petals; styles united below. Carpcls fifteen to twenty, each one-seeded, arrangcd in a circle around the axis of the fruit.

Flowering in June and July. The photograph for the illustration of this species was taken near Port Washington, Long Island.

\section{Musk Mallow; Musk Plant}

\section{Malia moschata Linnaeus}

Plate 128

Stems erect, I to $2 \frac{1}{2}$ feet high, more or less branching and hairy, from a perennial root. Leaves orbicular in outline, 3 to + inches broad with several broad, rounded, toothed lobes; stem leaves deeply cut into narrow segments. Flowers $I \frac{1}{2}$ to 2 inches broad, pink or white, slightly muskscented, clustered in leafy racemes at the summits of the stems and branches; petals five, notched at the apex, several times longer than the pointed, triangular-ovate calyx lobes; stamens numerous, forming a column in the center of the flower; carpels of the fruit fifteen to twenty in number, densely hairy, rounded at the back.

Roadsides, fields and waste places throughout the eastern states. Native of Europe and thoroughly naturalized in many places. Flowering from July to September.

Other Nallows, native of the Old World and adventive or naturalized in the eastern states, are the High Mallow (Malva sylvestris Linnaeus), the Low, Dwarf or Running Mallow, also known as Cheeses (Malva rotundifolia Linnaeus), the Whorled Mallow or Curled Nallow (Malva verticillata Linnaeus) and the Vervain Mallow 
IV IL, D FLOWERS OE NEW YORK

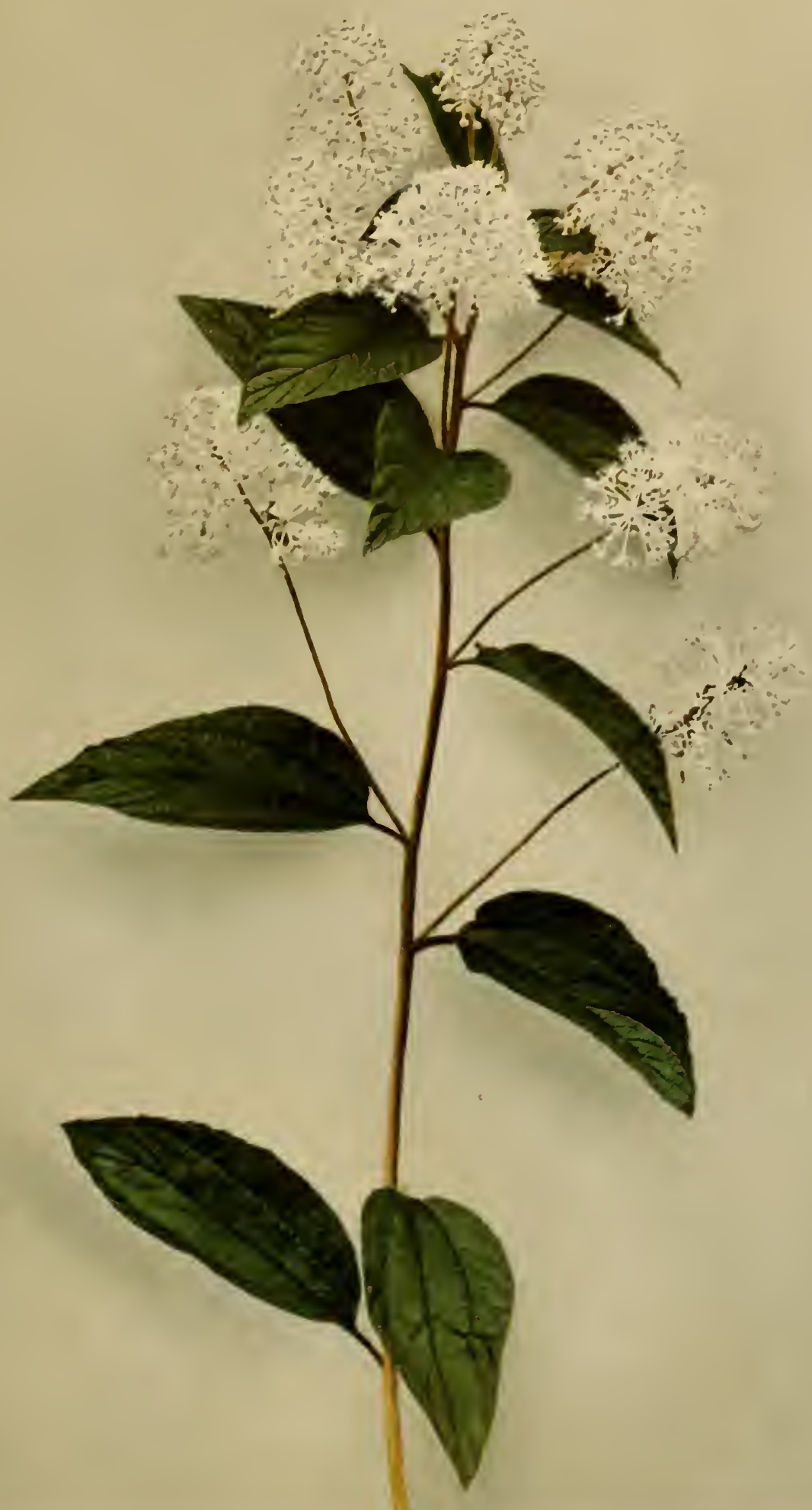


. 
WII, D FOWERS OF NEW YORK

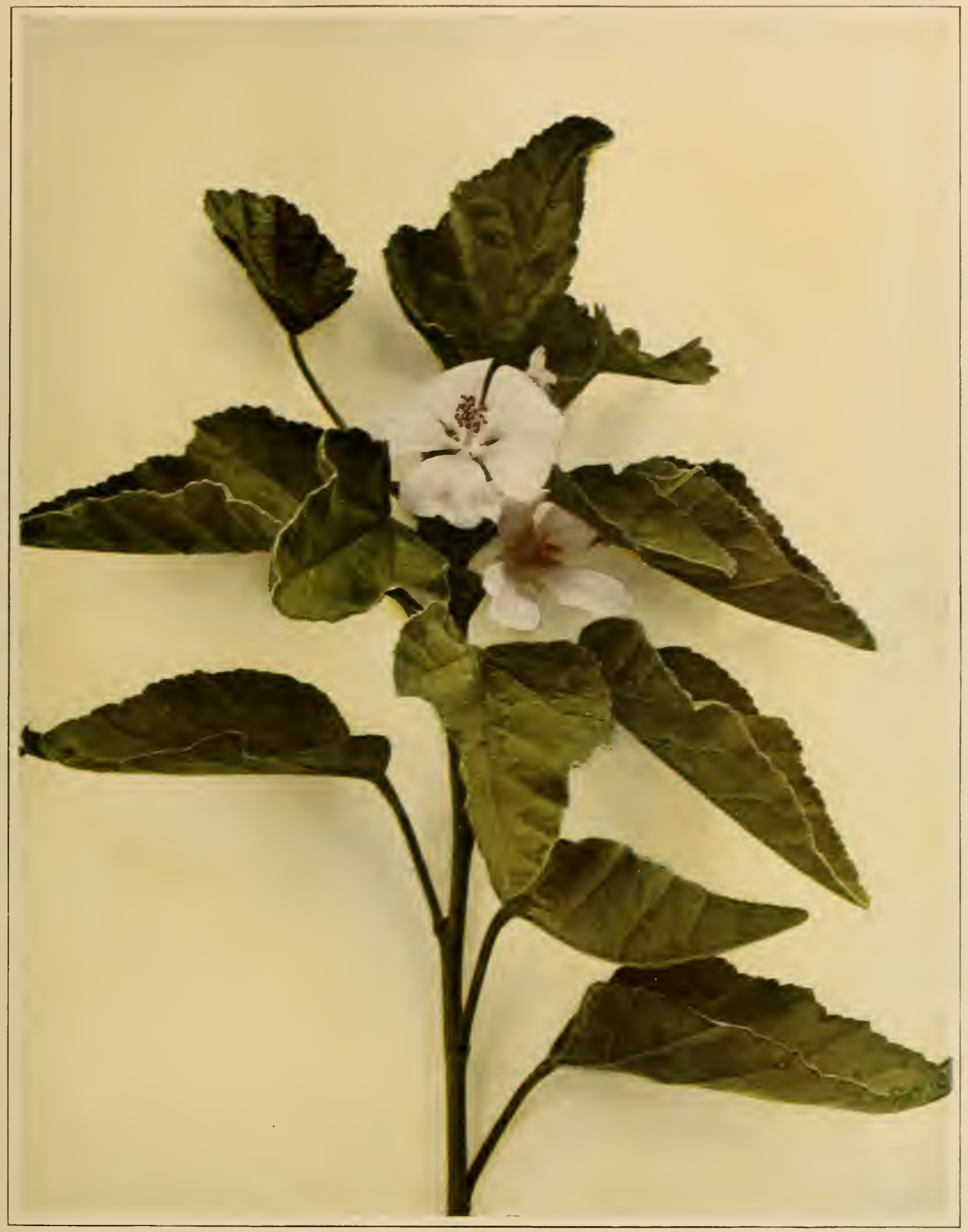



WILD I L O WERS OF NEW YORK

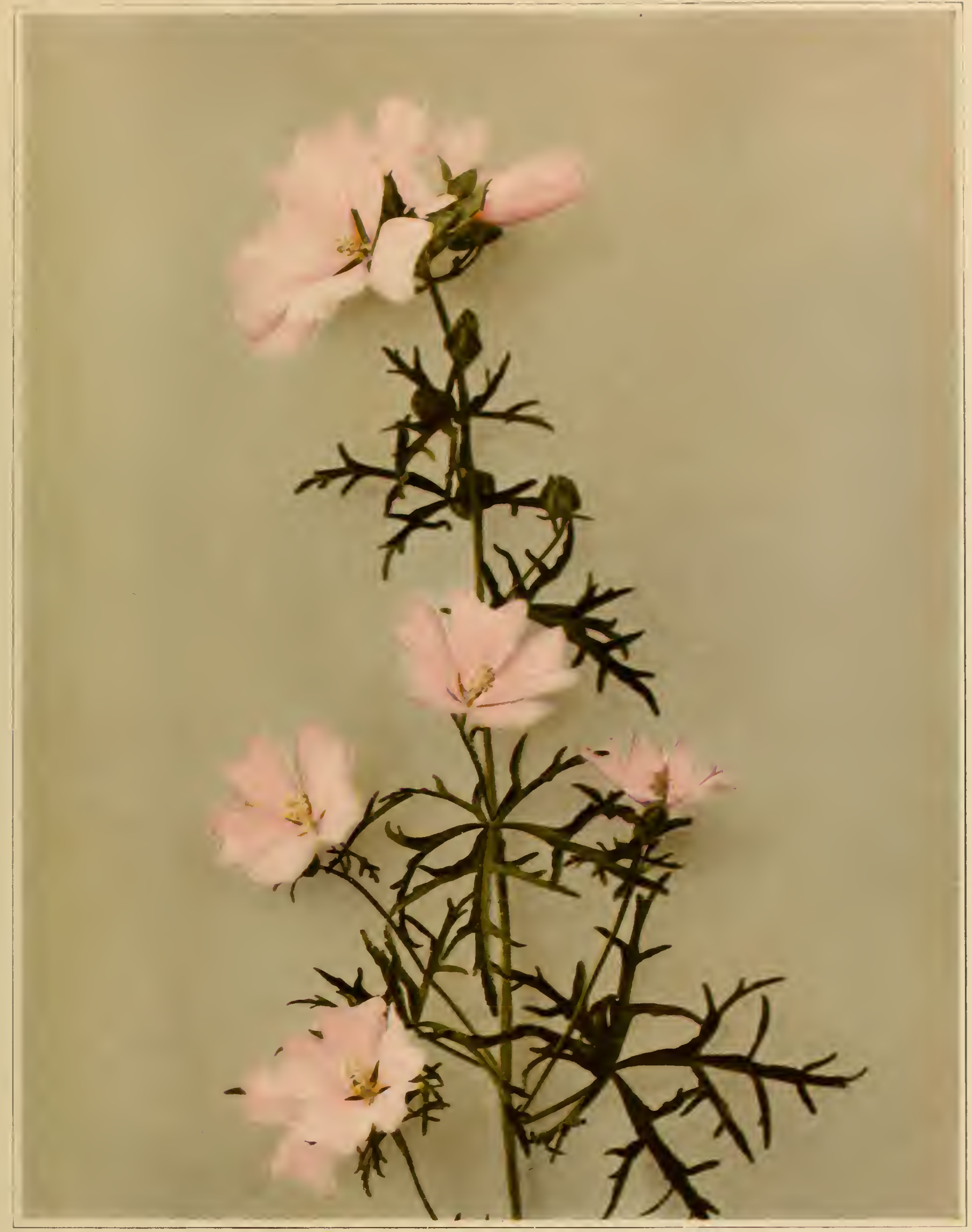

MUSK MALLOW; MUSK PLANT

Malía moschata 
- 
(Ma lva a leca Linnacus). Descriptions of thesc may be found in the current floras or manuals of botany of the northeastern statcs.

\section{Swamp Rose Mallow; Mallow Rose \\ IIibiscus moscheutos Linnaeus \\ Plate 129}

Stcms tall and canclike from a perennial root, 3 to 6 fcet high. Leaves ovate-lanceolate or ovate, blunt or roundcd and often slightly heartshaped at the base, pointed or blunt at the apex, 3 to 5 inches long, the lowcr ones sometimes lobed, all conspicuously palmately veined, toothed, denscly hairy with white stellate hairs beneath, green and finely hairy or nearly smooth above. Flowers 4 to 7 inches broad, pink, clustercd at the top of the plant; calyx lobes five, ovate, pointed, subtended by several narrow bractlets; petals five, broadly obovate; stamens numerous in a column surrounding the style which is five-cleft at the summit with five stigmas. Fruit a five-chambered pod about I inch long, blunt or slightly pointed.

In marshes along the ocean or near the coast from eastern Massachusetts to Florida and in saline situations and marshy lake shores inland, especially throughout the Great Lakes region. Flowering in August and September.

The Crimson-eye Rose Mallow ( $\mathrm{H}$ i b is c us o culirose us Britton) is similar, but the flower is white with a dark-crimson center and the fruit pod is long pointed. It is found on Long Island, Staten Island and in New Jersey.

\section{Saint John's-wort Family}

Hy peric a cea e

A family containing about sixteen species in New York State, mostly herbs, some of them shrubs, chiefly with opposite leaves and yellow or rarely reddish flowers in terminal clusters. In many of them the foliage is pellucid-punctate or dotted. Flowers regular and perfect. Sepals four or five. Petals four or five. Stamens numerous or few, often in three or five sets. 


\section{Key to the New York State Species of the Saint John's-wort Family}

Sepals four, in unequal pairs; petals also four

Stems erect, I to 2 feet high; leares clasping, styles three to four.

$$
\text { I Ascyrum stans }
$$

Stems diffusely branched, 5 to ro inches high; leares sessile; styles two . . . . . . . .

Sepals and petals usually five

2 Ascyrum hypericoides

Petals pink or grcenish purple, imbricated in the bud; leaves sessile; capsules redpurple......................... Triaden $\mathrm{m}$ m $\mathrm{virginicum}$

Petals yellow, convolute in the bud

Leares reduced to minute appressed scales... $\mathrm{S}$ a r o th $\mathrm{ra}$ g e n t i a no ides Leaves normal

Styles five, large perennials

Flowers $\mathrm{I}$ to 2 inches broad; capsules three-fourths of an inch long.....

$$
5 \text { Hypericum ascyron }
$$

Flowers one-half to $\mathrm{I}$ inch broad; capsules about one-half of an inch long.................. H y pericum $\mathrm{kal} \mathrm{l}$ ia $\mathrm{num}$ Styles three or rarely four

Tall leafy shrubs with numerous flowers

Flowers one-half to three-fourths of an inch broad; pods one-third to one-half of an inch long...7 H y pericum prolificu $\mathrm{m}$

Flowers one-third to one-half of an inch broad; pods one-sixth to one-fourth of an inch long...8 $\mathrm{H}$ y pericum den if 1 or u $\mathrm{m}$

Herbaceous perennials, or woody at the base only

Stamens numerous (fifteen to forty); flowers one-fourth to $\mathrm{x}$ inch broad .

Capsules one-celled or incompletely three to four-celled

Capsules incompletely three to four-celled by the projecting placentae; leaves oblong.

9 H y pericum adpressum

Capsules strictly one-celled; placentae parietal; styles united into a beak, separate above; leaves elliptic.

Io $\mathrm{Hypericum} \mathrm{e} 11 \mathrm{ipticum}$

Capsules completely three-celled; styles separate

Leaves linear or oblong; sepals lanceolate. Introduced from Europe..... I H y pericum perforatum 
WIL, F L OWERS OF NEIV YORK

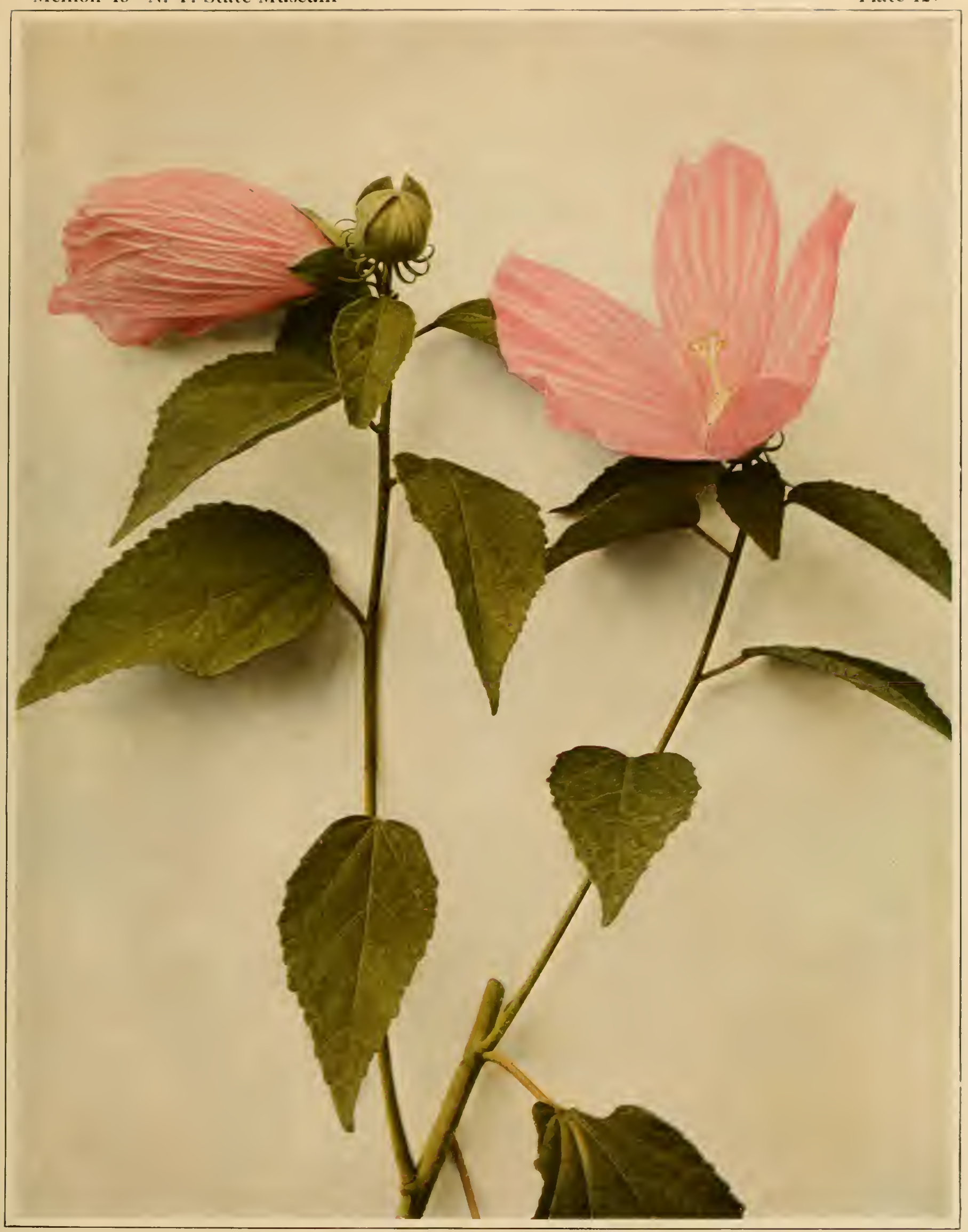


- 
Leaves broadly oblong, oval or ovate-lanceolate, native; sepals ovate to ovate-lanceolate, acute.

12 Hypericum punctatum

Stamens few (five to twelve); flowers one-tenth to one-fourth of an inch broad

Cyme leafy-bracted ......... iz H y perie um borea 1 e Cymes subulate-bractecl

Leaves ovate, oval or oblong; eapsules one-twelfth to five-twelfths of an ineh long.

I4 Hy pericum mutilum

Leaves laneeolate or oblong-laneeolate; eapsule one-third to one-half of an inch long.

${ }_{15} \mathrm{H}$ ypericum majus

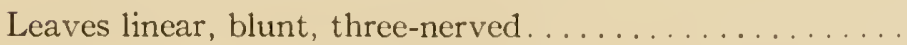
r6 Hy pericum canadense

\section{Great or Giant Saint John's-wort}

\section{IIypericum ascyron Linnaeus}

Plate I30a

Stems herbaceous, 2 to 5 feet tall from a perennial root, angled, branching and smooth. Leaves sessile, ovate-oblong to ovate-lanceolate, 2 to 5 inches long and three-fourths to $\mathrm{I} \frac{1}{2}$ inches wide, clasping the stem. Flowers bright yellow, showy, I to 2 inches broad, few or several in a loose, terminal cluster. Sepals five, ovate-lanceolate, about one-half of an inch long, pointed; petals five, obovate or oblanceolate; stamens numerous, united into five sets. Styles usually five in number, united below, the stigmas capitate. Fruit pod ovoid in shape, three-fourths to seven-eighths of an inch long.

Chiefly along streams, Quebec to Vermont and Manitoba south to Connecticut, Pennsylvania, Illinois and Missouri. Flowering in July and August.

The St Peter's-wort (A scyrum stans Michaux) and the St Andrew's Cross (Ascy rum hypericoides Linnaeus), two small, leafy, shrubby species of the coastal region, differ from the species of 
Hypericum by having four instead of five petals, as pointed out above in the key to the species of the family.

\section{Elliptic-leaved or Pale Saint John's-wort \\ IIypericum ellipticum Hooker \\ Plate $130 \mathrm{~b}$}

Stems herbaceous, slightly four-angled, mainly simple or with a few branches, erect, 6 to 20 inches high from a perennial root. Leaves oval or elliptic, sessile, spreading, thin in texture, three-fourths to $I_{4}^{\frac{1}{4}}$ inches long and one-fourth to one-half of an inch wide, blunt at the apex. Flowers pale yellow, few or several in terminal cymes, each flower about one-half of an inch broad, central flower of each cluster opening first, the lateral branches of the cluster developing later; sepals slightly shorter than the petals; styles three, united below; capsules or fruit ovoid-globose, about one-eighth of an inch long and one-celled. Sepals and petals occasionally four instead of five.

In low grounds, swamps and along streams, Nova Scotia to Manitoba, south to New Jersey, Maryland and Minnesota. Flowering in July and August. Our illustration was made from plants just beginning to flower, before the lateral branches of the cyme were developed.

\section{Common Saint John's-wort}

\section{Hypericum perforatum Linnaeus}

- Plate :3ra

Stems herbaceous, smooth, slender, I to 2 feet high from a perennial root, usually much branched and with several barren shoots at the base. Leaves sessile, linear or oblong, one-half to I inch long, one-tenth to onethird of an inch wide, blunt, black dotted. Flowers three-fourths to I inch broad, bright yellow, several or many in terminal cymes; petals five, black dotted, longer than the lanceolate pointed sepals; stamens numerous, united by their base into three sets; styles three; fruit pod or capsule ovoid, about one-fourth of an inch long or less, three-celled. 
WIL I) ILOWERS OF NEW YORK

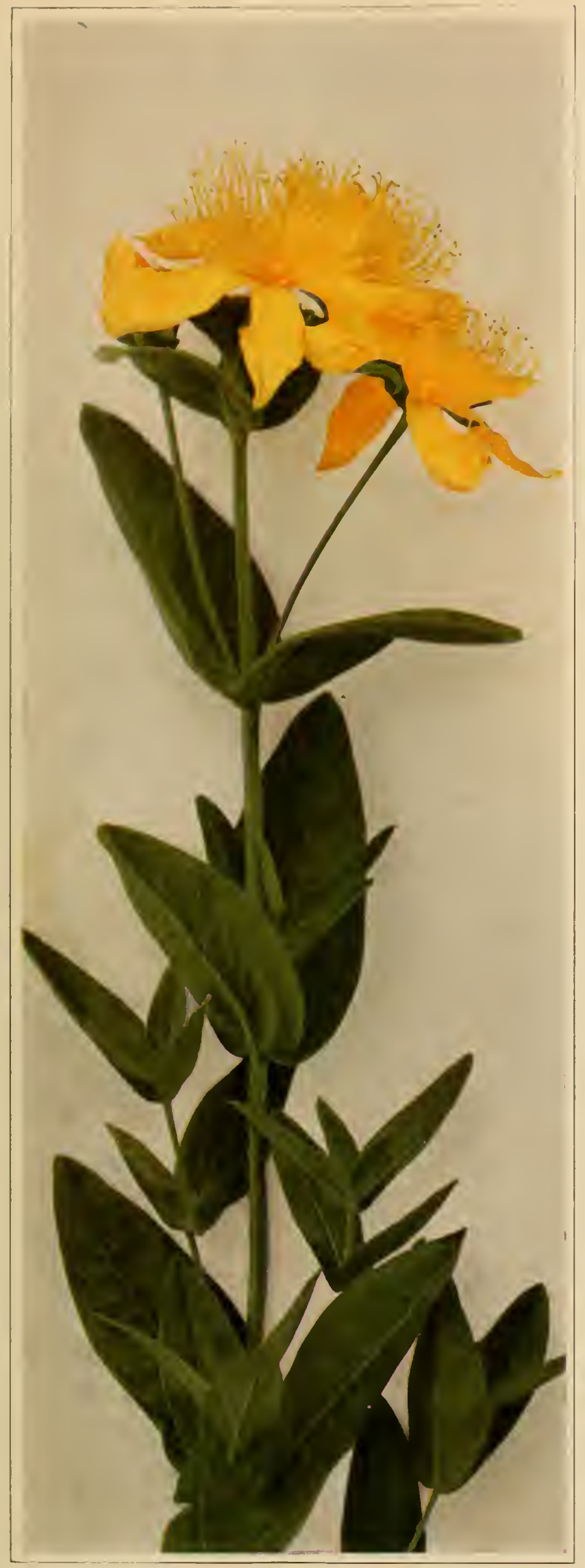

A. GREAT OR GIANT SAINT JOHN'S-WORT IIypericum ascyron

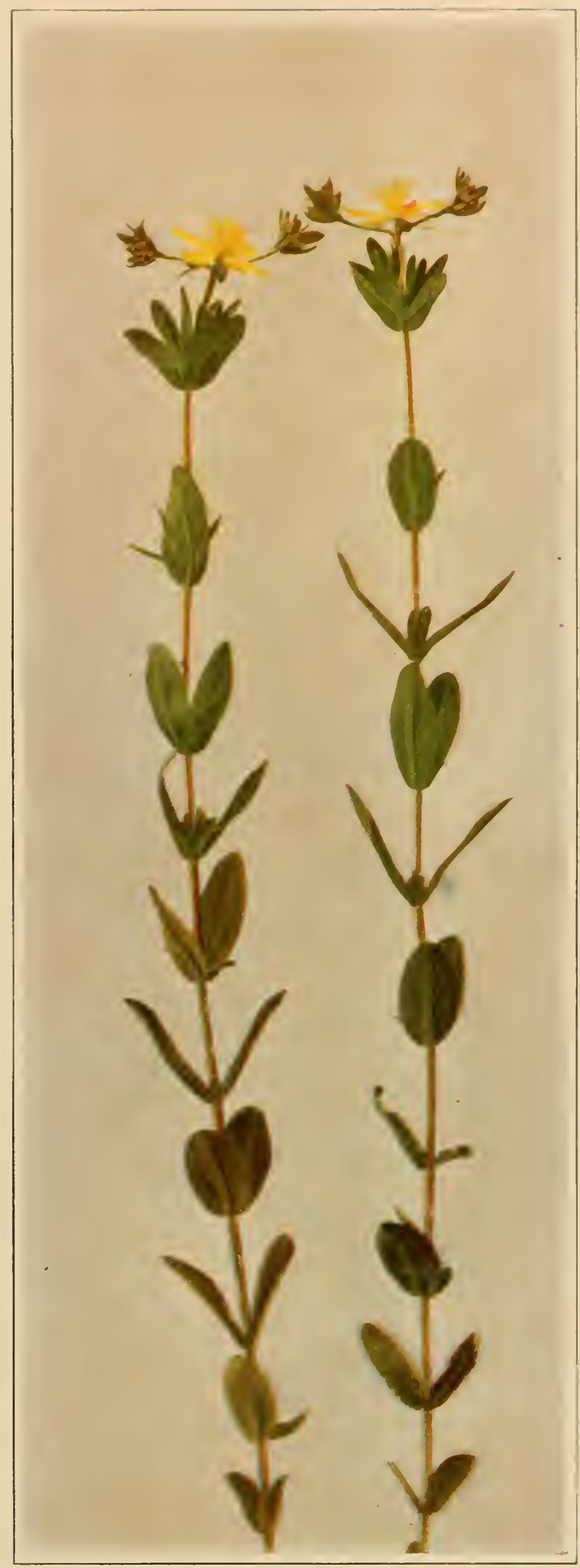

B. ELLIPTIC-LEAVED OR PALE SAINT JOHN'S-ITORT Hypericum ellipticum 


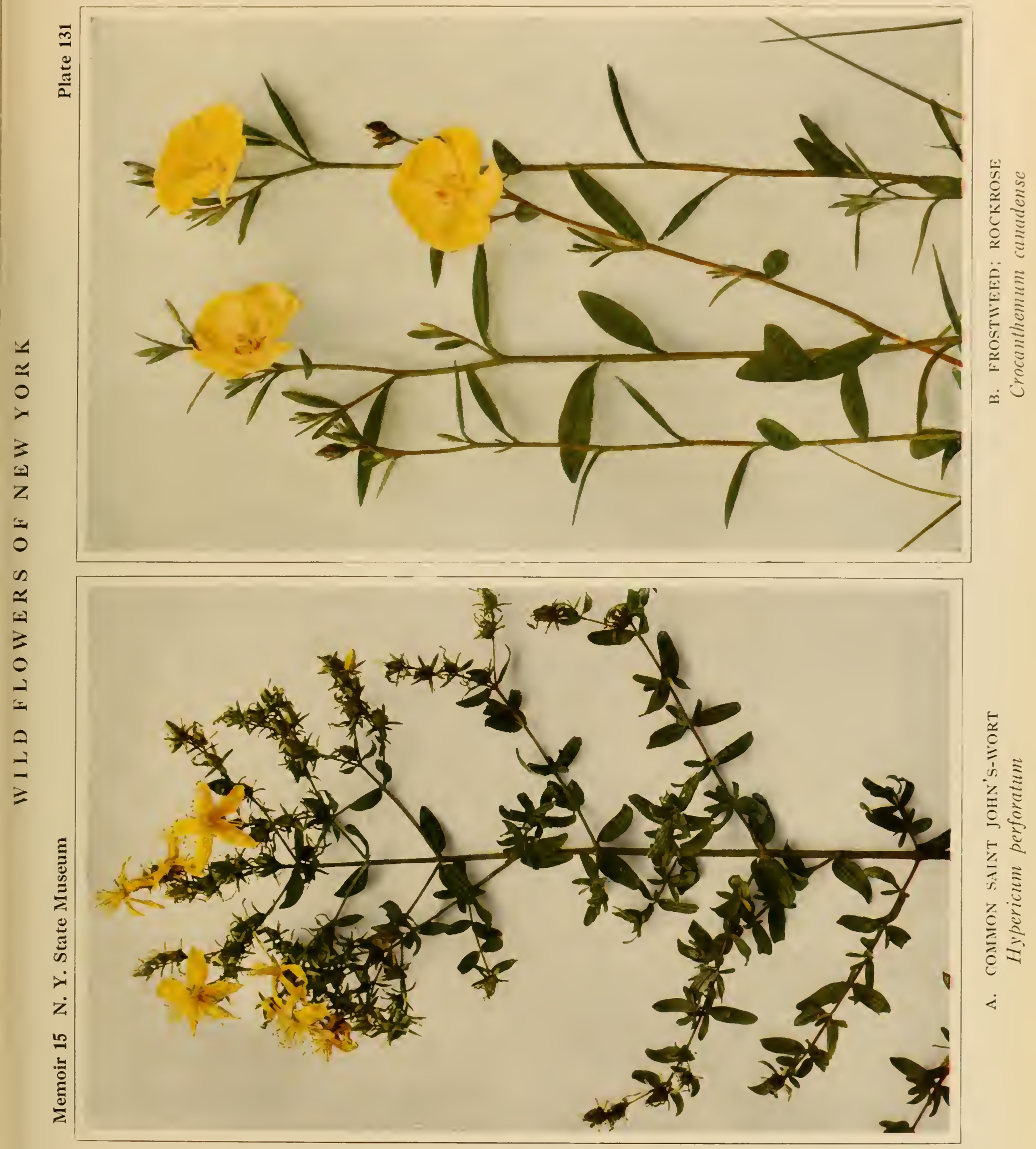



Native of Europe and naturalized as a weed in fields and waste places throughout the East.

\section{Rockrose Family}

Cista c c a e

Frostweed; Rockrose

\section{Crocanthemum canadense (Linnaeus) Britton Plate $131 \mathrm{~b}$}

Stems erect or diffuse from a perennial root, 5 to 20 inches high, fincly cancscent and becoming branched. Leaves nearly sessile, linear-oblong to oblanccolate, one-half to $\mathrm{I} \frac{1}{2}$ inches long, one-third of an inch wide or less, grecn above, canescent bencath. Flowers bright yellow, usually onc or two, I to $\mathbf{I} \frac{1}{2}$ inches broad; sepals five, the two outer ones much smaller; petals five, broadly obovate, soon withering and falling; capsule ovoid, about onethird of an inch long. After the petaliferous flowers fade and fall, the axillary branches elongate and bear numerous apetalous sessile flowers, which develop fruiting capsules about one-sixth of an inch in diameter.

In sandy fields or rocky soil, Maine to Ontario and Wisconsin, south to North Carolina and Mississippi. Flowering from May to July.

A closely related species of similar situations, C r o c a $\mathrm{n} t \mathrm{~h}$ e $\mathrm{m} \mathrm{um}$ $\mathrm{majus}$ (Linnaeus) Britton, is more canescent, the primary flowers clustered at the summit of the stem and not surpassed by the branches; the secondary or apetalous flowers very small and producing capsules which are only about one-twelfth of an inch in diameter.

\section{Woolly Hudsonia; False Heather}

\section{IIudsonia tomentosa Nuttall}

\section{Plate r $32 a$}

A diffusely branched, low-tufted or matted perennial, somewhat woody, 3 to 8 inches high, pale and hoary-pubescent, the branches stout and ascending. Leaves small and scalelike, about one-tenth or one-twelfth of an inch long, overlapping one another and appressed to the stem. Flowers numerous, almost sessile or on short, stout stalks less than one-fourth of an 
inch long, yellow, about one-fourth of an inch broad or slightly less; petals five, obovate-oblong; stamens numcrous, nine to cighteen in number; scpals blunt. Fruit a small, ovoid, smooth and onc-sccded capsule.

In sandy pine barrens and sandy shores along the coast, New Brunswick to Virginia and inland on sand hills and lake and river shores, west to Manitoba and North Dakota. Flowering from May to July.

\section{Violet Family}

Yiol a ce a e

Because of their abundance and beauty, the violets take rank with the favorites among our native flowers. Our species of violets are all low herbs, either lcafy-stemmed or stemless, that is, the leaves and flowers arising directly from the rootstock. The flowers possess five stamens, the two lowest with appendages that project into the spur or nectar sac of the lower and odd petal. Only these two stamens are developed in the apetalous flowers which come after the petaliferous flowers in most stemless species except the Bird's-foot Violet. The petaliferous flowers are somewhat irregular, the lower petal extended into a spur or sac back of the flower, the lateral petals usually narrower than the two upper petals, and usually only the spur and lateral petals adorned at the base in some species with hairs.

Allied species of some groups freely hybridize when growing together. The hybrids commonly display characters more or less intermediate to those of the parent species, and show marked vegetative vigor, but very often also impaired fertility. These violets of hybrid origin are frequently unlike the mother plant and unlike one another, reverting variously in succeeding generations to the characters of the two original species.

Two cultivated spccies of violets are common in the east, and sometimes escape from cultivation. They are the English, Marsh or Sweet Violct ( i ola odorata Linnaeus), and the Pansy or Heartsease (V iola tricolor Linnaeus) with variously colored flowers. The original form, and the one which the cultivated forms revert to sooner or latcr, has violet or purple flowers. The large Garden Pansy is the product 
WII, D FI, OWERS OF NEW YORK

Memoir 15 N. Y. State Museum

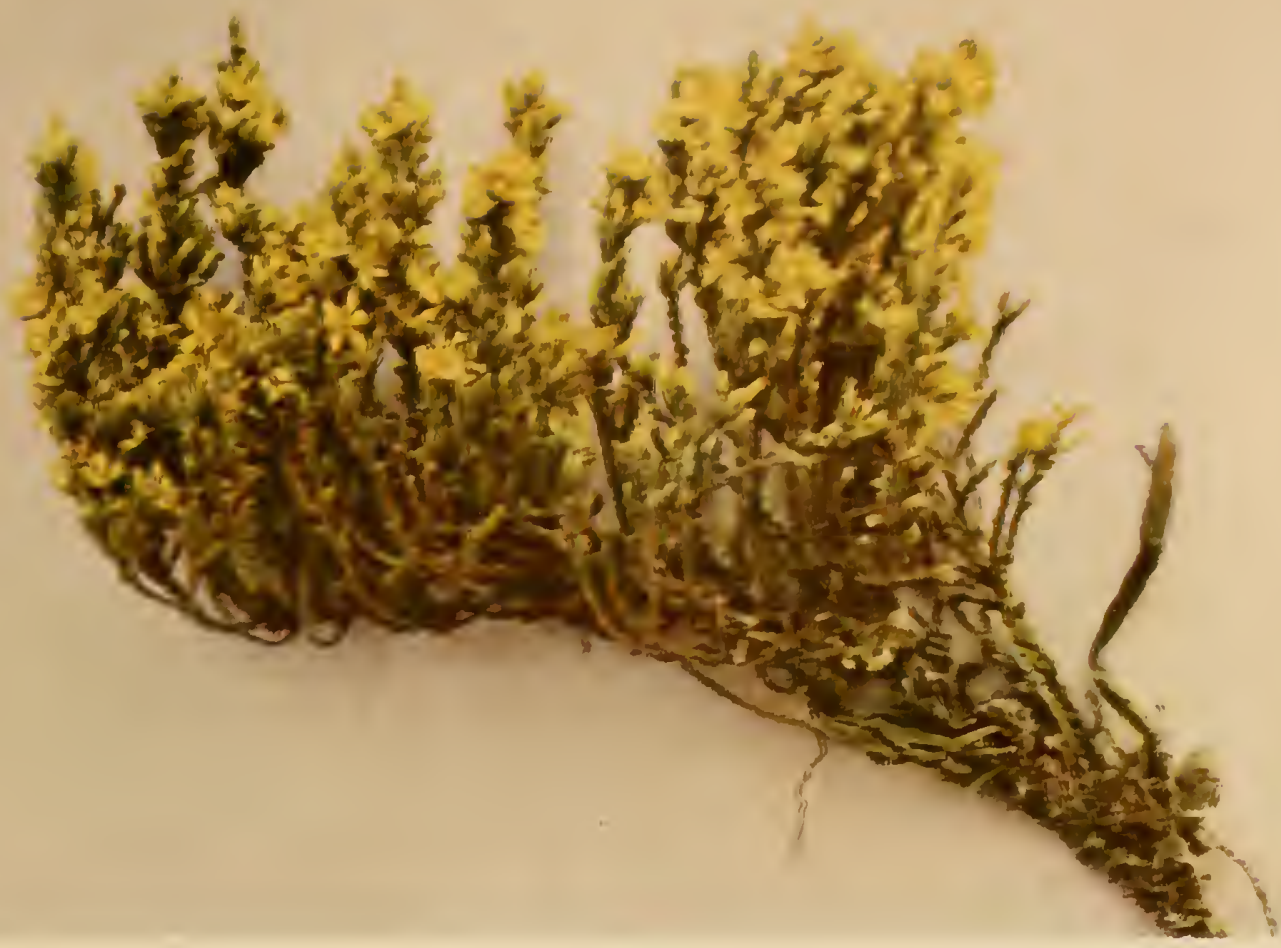

A. WOOLLY HUDSONIA; FALSE HEATHER

Iludsonia tomentosa

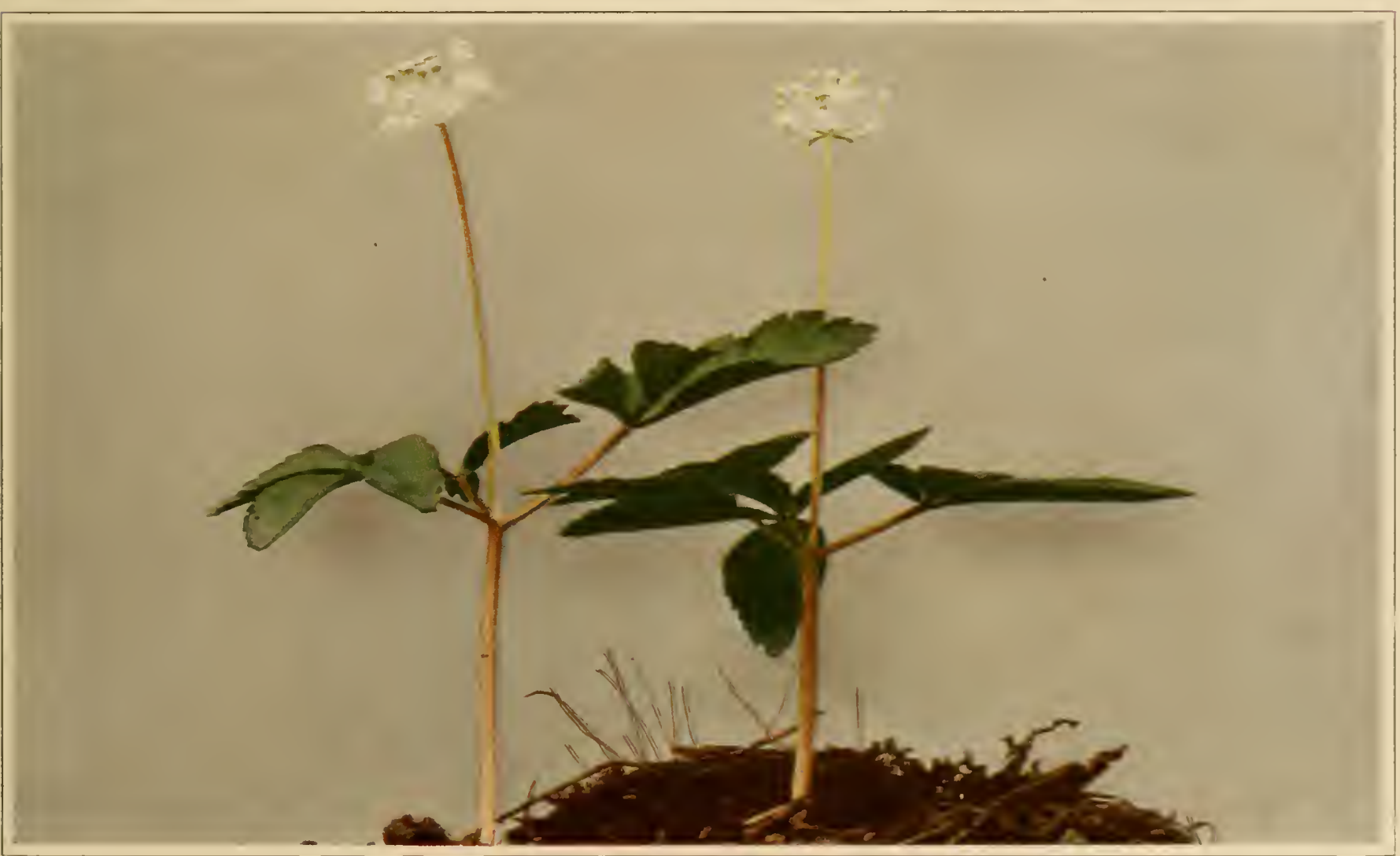

B. DWARF GINSENG OR GROUNDNUT

Panax trifolium 

of various crosses of $\mathrm{Viola} \mathrm{ricolor}$ with allied species of the Old World. In addition to these, there are about thirty-three native species of violets in New York, beside the many natural hybrids. The following key to the native species may be useful in determining certain species not illustrated here.

I Stemless; the leaves and scapes directly from a rootstock or from runners

Petals bright yellow; leaves orbicular................ . V. rotund if o li a Petals violet, purple or white

Cleistogamous flowers wanting; petals all beardless; leaves dividec1.

$2 V^{2}$. pedat a

Cleistogamous flowers present, at least later in the season

Rootstock thick, often stout, without stolons; lateral petals bearlecl

Cleistogamous flowers ovoid on short prostratc peduncles; their capsules mostly purplish

Leaves except rarely the earliest, palmatcly five- to elcren-lobed or parted; foliage villous-pubescent

Leaf-lobes blunt, lateral ones broad...... $\mathrm{r}$. p a $1 \mathrm{~m}$ a $\mathrm{t}$ a

Leaf-lobes acuminate, lateral ones linear...+ $V$. p e r p e n s a

Early and late leaves uncut; others three- to seven-lobed or parted

$5 \mathrm{~V}$. triloba

Leares all uncut; blades ovate to reniform, cordate, crenateserrate

Plants nearly or quite glabrous; petals violet-purple; seeds brown

Petioles smooth; plants of moist soil ...............

$6 \mathrm{~V}$. papilionacea

Petioles glandular roughened; plants of dry soil

7 V. 1 a tiuscula

Leares, very hairy, especially beneath and on the petioles; seeds dark brown. ............... $8 \mathrm{~V}$. sororia

Leaves hirsutulous above, otherwise smooth; seeds buff......

$9 \mathrm{~V}$. hirsutula

Cleistogamous flowers ovoid on ascending peduncles, soon elongated

Leaves pubescent beneath and on the petioles; sepals and their auricles ciliolate; blades broadly ovate, cordate..............

ro $r$. septentrionalis 
Leaves glabrous beneath and on the petioles..... I I $\mathrm{V}$. a f f i n is Cleistogamous flowers on erect peduncles, their capsules green

Leaves broarly ovate, blunt at the apex; sepals obtuse

Cleistogamous flowers ovoid; spurred petal villous.........

12 V. nephrophy 11 a

Cleistogamous flowers long and slender, spurred petal glabrous

I3 V. e u culla ta

Leaves lobed or the margins sharply ineised or toothed toward the subcordate or truncate base; spurred petal villous, lateral ones with capillary beard

Blade of the mature leaves ovate-oblong, ciliate, finely pubescent; petioles short........... I4 V. fi mbriat u 1 a

Blade of the mature leaves lanceolate, usually smooth; petioles long.................. s a g it t a t a

Blade of the mature leaves broadly ovate or deltoid

Margin coarsely toothed near the base; blades sometimes lobed................... e ma rgin a $\mathrm{ta}$

Margin sharply toothed toward the base and more or less pectinately incised........... I $\mathrm{V}$. pectin a t a

Blade of mature leaves primarily three-lobed or three-parted, the segments two to three-cleft into linear or oblanceolate lobes..................... $18 \mathrm{r}^{\mathrm{r}}$. brittoniana

Rootstock slender (or thicker and scaly with age); plants usually from stolons

Petals pale violet; leaves minutely hairy on the upper surface; spur large, 3 lines long................... se $\mathrm{V}$. $1 \mathrm{kirkii}$

Petals white, with dark purple lines on the lower three

Cleistogamous capsules ovoid, usually purplish; woodland plants

Leaves reniform, lateral petals beardless; stolons short.

$20 \mathrm{~V}$. renifolia

Leaves broadly ovate, acute; lateral petals bearded; seeds obtuse at the base............. $\mathrm{I}$. i incognit a

Leares ovate, acute or acuminate; lateral petals beardless; seeds acute at base................ $22 \mathrm{r}$. b lan da

Cleistogamous capsules ellipsoid; always green; peduncles erect; bog and wet meadow species 
Leaves broadly ovate or orbicular, cordate, obtuse....

$$
2.3 \mathrm{~V} \text {. pa } 11 \mathrm{ens}
$$

Leaves oblong to ovate, the base slightly corclate to tapering $24 \mathrm{l}$. primulifolia

Leaves lanceolate to elliptical........25 $\mathrm{V}$. 1 a n c eol a t a

2 Leafy-stemmed; the flowers axillary

Style capitate, beakless, bearded near the summit, spur short; stipules nearly entire, soon scarious

Petals yellow

Sparingly pubescent; root-leaves usually one to three..26 V. e r i o c a r p a Markedly pubescent; root-leaves usually wanting....2 $\mathrm{V}$. p u b es ce n s

Inner face of the petals white with yellow base, outer face usually violet; leares usually broadly ovate, acuminate, subglabrous.......28 V. c a n a d e n s is Style not capitate; spur long; stipules bristly toothed, herbaceous

Spur 2 to 4 lines long; lateral petals bearded; styles bent at tip, with short beard

Petals white or cream-colored...................29 V. stria ta

Petals violet-blue

Herbage glabrous or nearly so; leaves orbicular or suborbicular

Stipules ovate-lanceolate, bristly serrate; leaves often $I_{4}^{3}$ inches wide......................... $\mathrm{k}$. cons persa

Stipules linear, entire except at base; leaves not over three-fourths of an inch wide; alpine............. I $\mathrm{r} .1 \mathrm{ab}$ radorica

Herbage puberulent; stems ascending; blades mostly ovate.........

32 V. a dunca

Spur + to 6 lines long, lateral petals beardless; style straight and smooth........

33 V. rostrata

Style much enlarged upward into a globose, hollow summit; stipules large, leaflike, pectinate at base; upper leaves and middle lobe of stipules entire or nearly so; dry sandy places............................ rafinesqui

\section{Bird's-foot Violet \\ Viola pedata Linnaeus}

Plate 133

Leaves nearly smooth from a short, stout, erect rootstock, threedivided, the lateral divisions pedately three to five-parted or cleft, the 
segments linear to spatulate, often two to four-cleft or toothed near the apex. Early leaves usually smaller and less deeply dissected. Corolla two-thirds to $1 \frac{1}{2}$ inches broad, the upper petals dark violet, the lower three lilac-purple, or as in the common northern variety (var. lineariloba DeCandolle) here illustrated, all the petals lilac-purple, all beardless, the orange tips of the stamens large and conspicuous in the center of the flower. Seed pods smooth, green; seeds copper-colored.

Apetalous or cleistogamous flowers are never formed in this species, but petaliferous flowers are frequent in late summer and autumn.

Common in dry or sandy fields and open woods from Massachusetts

to Florida and Louisiana, less abundant or locally common inland to Minnesota. Flowering in May and June.

\section{Early Blue or Palmate-leaved Violet}

riola palmata Linnaeus

Plate $134^{2}$

Leaves palmately five to eleven-lobed or parted, erect or nearly so, from a thick, usually oblique, simple or branched rootstock, the leaf segments variously toothed or cleft, the middle segment usually the widest, more or less villous beneath, especially on the veins and on the petioles, the upper surface of the leaves often smooth; early leaves smaller and usually less divided than the later ones. Flowers on stalks about as long as the leaves, two-thirds to I inch broad, violet-purple; sepals blunt; cleistogamous flowers on prostrate peduncles; seeds brown.

In woods and thickets, rarely in open fields and most abundant in rather dry, rich soil on wooded hills, Massachusetts to Minnesota, south to Florida. Flowering from April to June. Like several of the other blue-flowered violets it is locally known as Johnny-jump-up.

Among its close relatives in the east is $\mathrm{Viola} t \mathrm{rilob}$ Schweinitz, in which the earliest leaves and those put forth in late summer are usually with uncut, reniform, cordate blades, the summer leaf blades + to 6 inches wide, densely villous beneath and on the petioles, three-lobed or three-parted. 
WII, I) I L, O WE E R O F N E W YORK

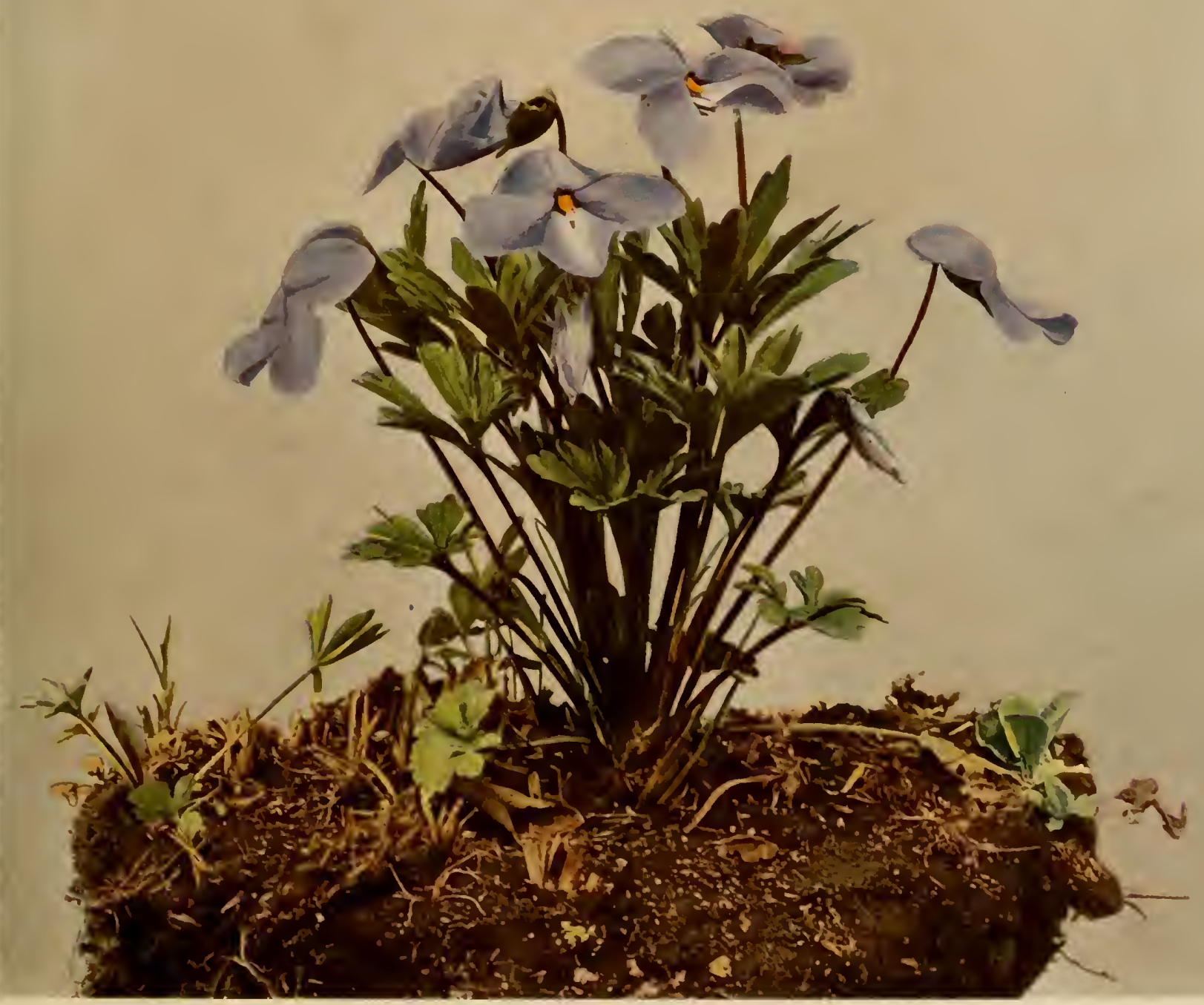

BIRD'S-FOOT VIOLET

Viola pedata var. lineariloba 



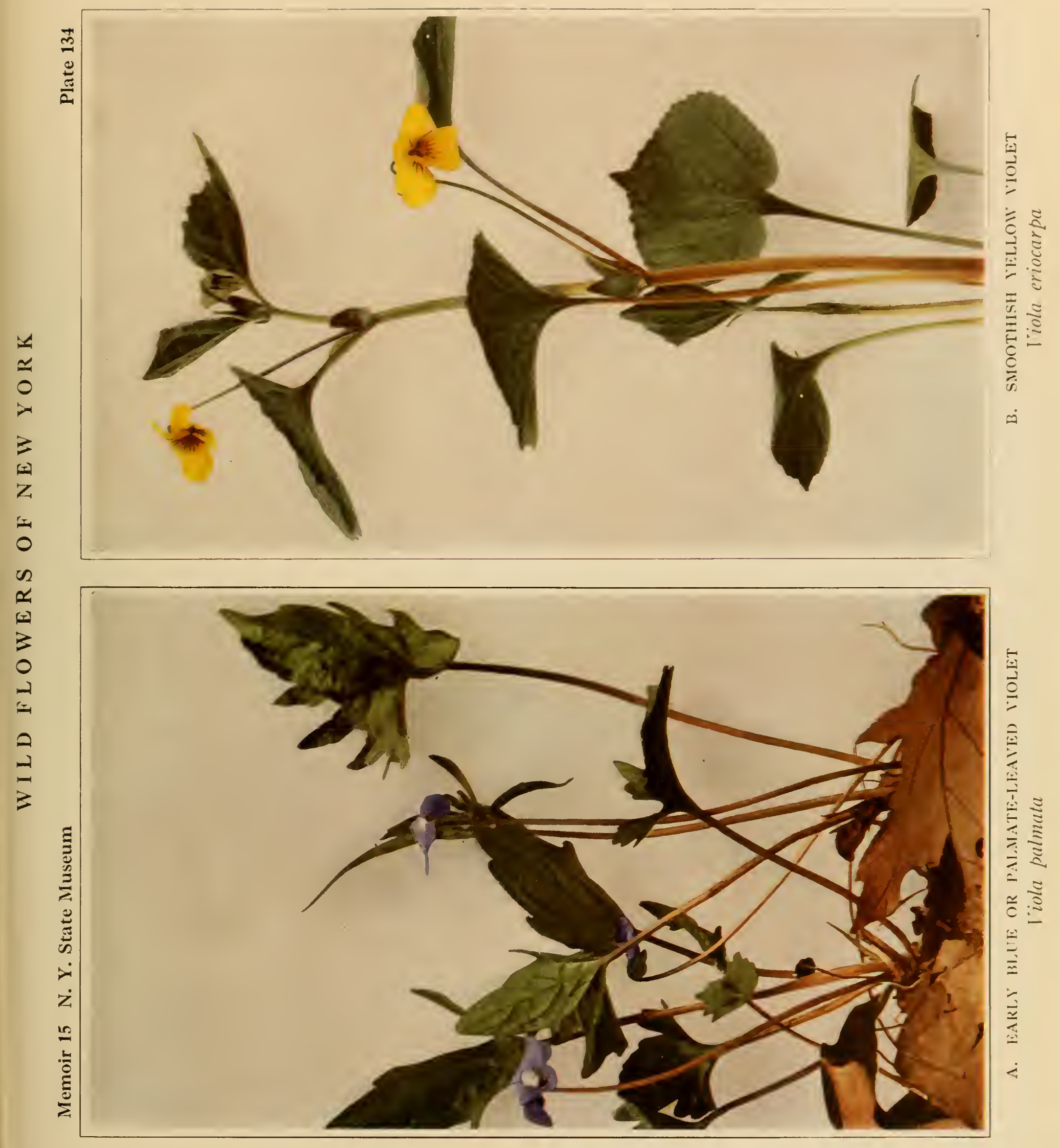


V i ola perpensa Grcene, of the Great Lakes region, possesses lincar, acuminate latcral lcaf lobes.

\section{Coast or Britton's Violet \\ Viola brittoniana Pollard \\ Plate 1 $36 \mathrm{~b}$}

Early leaves reniform to ovate in outline, entirc or incised, from a thick, erect rootstock; mature leaves threc-parted and the scgments two to four-clcft into linear or oblanceolate, acute lobes, the middle lobe somewhat the widest; smooth except for minute pubescence on the upper surface and margin. Flowering scapes as long or longer than the lcaves. Flowers large, I to $\mathrm{I} \frac{1}{2}$ inches broad, rich purple with a conspicuous white throat. Sepals linear-lanceolate, acuminate.

In peaty or moist, sandy soil along the coast, southern Maine to Virginia. Flowering in May and June. Next to $\mathrm{Vi}$ ola ped a ta, one of the most showy of our native species of violet.

\section{Woolly Blue Violet; Sister Violet}

\section{Viola sororia Willdenow}

Plate I $35 \mathrm{a}$

Leaves ovate to orbicular from a stout, simple or branched rootstock; petioles and under surfaces of the young leaves, and often the scapes, villouspubescent; leaf blades blunt or pointed, heart-shaped, the margins crenateserrate, sometimes becoming 4 inches wide when mature. Corolla violet to lavender, and occasionally white; sepals broad, usually blunt, finely ciliate below the middle; petals rather broad, the lower and lateral oncs densely bearded with white toward the center of the flower. Cleistogamous flowers ovoid on short, horizontal peduncles, usually underground, but lengthening and ascending as the capsule ripens; capsules green, mottled with brown; seeds dark brown.

In rocky or rich woodlands, moist meadows and on shady ledges, Quebec to Minnesota, south to North Carolina. Flowering in April and May. 
Quite as abundant is the Meadow or Hooded Blue Violet ( $\mathrm{V}$ i o l a pa pilion a cea Pursh) with nearly glabrous foliage, very large leaf blades which are reniform or ovate, deep-blue flowers, the odd petal often narrow and boat-shaped, usually beardless; capsules ellipsoid, green or dark purple. Common in moist fields and groves, frequently about dwellings.

The Broad-leaved Wood Violet ( $\mathrm{V}$ i ol a lati us cula Greene) possesses broadly ovate-deltoid leaf blades, the earliest ones blunt and tinged with purple beneath: petioles glandular-roughened: flowers rioletpurple. In dry, open woods in sand or gravel.

The Southern Mood Violet ( $\mathrm{iola}$ h i rsutula Brainerd) enters our range only in southern New York. It is a small species with leaves lying close to the ground, the blades orbicular to reniform. purplish beneath, silvery pubescent above: flowers reddish purple.

The Northern Wood Violet ( $\mathrm{V}$ iola septentrionalis Greene) is common in moist, open woodlands south to Connecticut and Pennsylvania. The foliage, except the earliest leares, is hirsutulous. The leaf blades are ovate to reniform, heart-shaped, ciliate and blunt; sepals blunt, closely ciliolate nearly to the tip: flowers deep violet to pale lilac.

\section{LeConte's Violet}

Triola affinis LeConte

Plate $135^{-b}$

Foliage nearly or quite smooth: rootstocks slender, branching, or the plants growing in matted clusters. Early leaves narrow orate and heartshaped. more or less long pointed toward the apex, the margins crenateserrate: petioles slender and smooth. Flowers violet with a conspicuous white center; the cleistogamous flowers small, on ascending stalks.

Common in moist meadows, low woodlands and shady borders of streams, New England to Wisconsin, south to Georgia and Alabama. Flowering from April until June. The mature leaves of midsummer are about 2 inches wide.

The Northern Bog Violet (Viola nephrophrlla Greene) resembles LeConte's Violet in some respects, but the leares are broader and more blunt. It occurs in cold, mossy bogs and sometimes along borders of streams and lakes from Quebec to British Columbia south to Connecticut and I Isconsin. It appears to be abundant in a bog in Bergen swamp. Genesee county. 


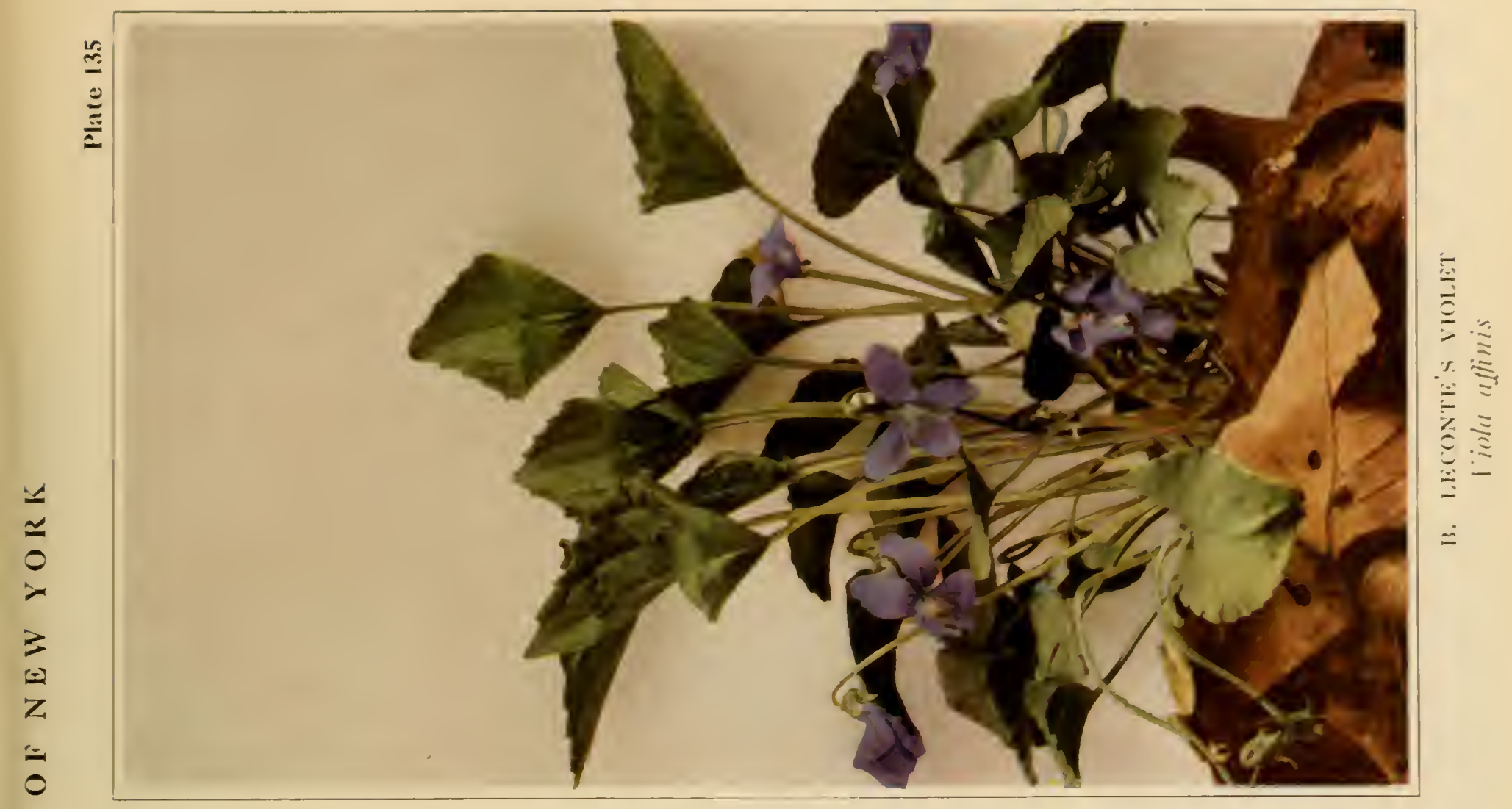

(

ב

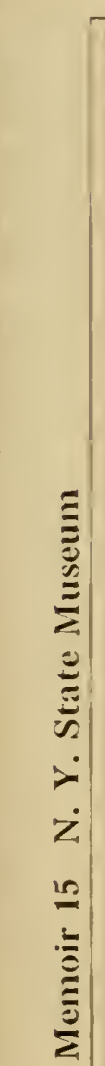

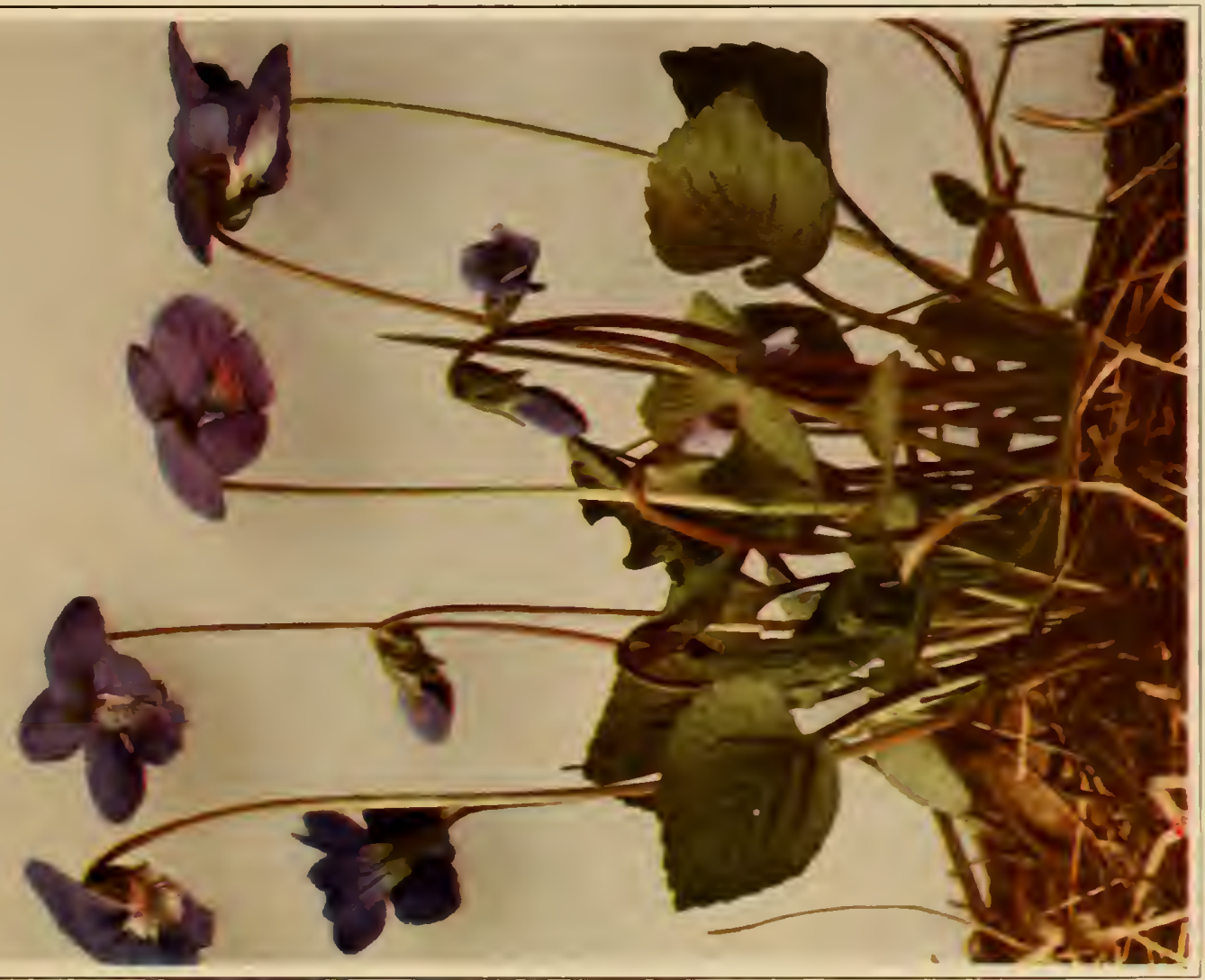

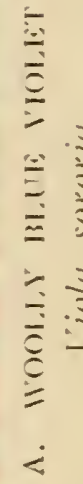




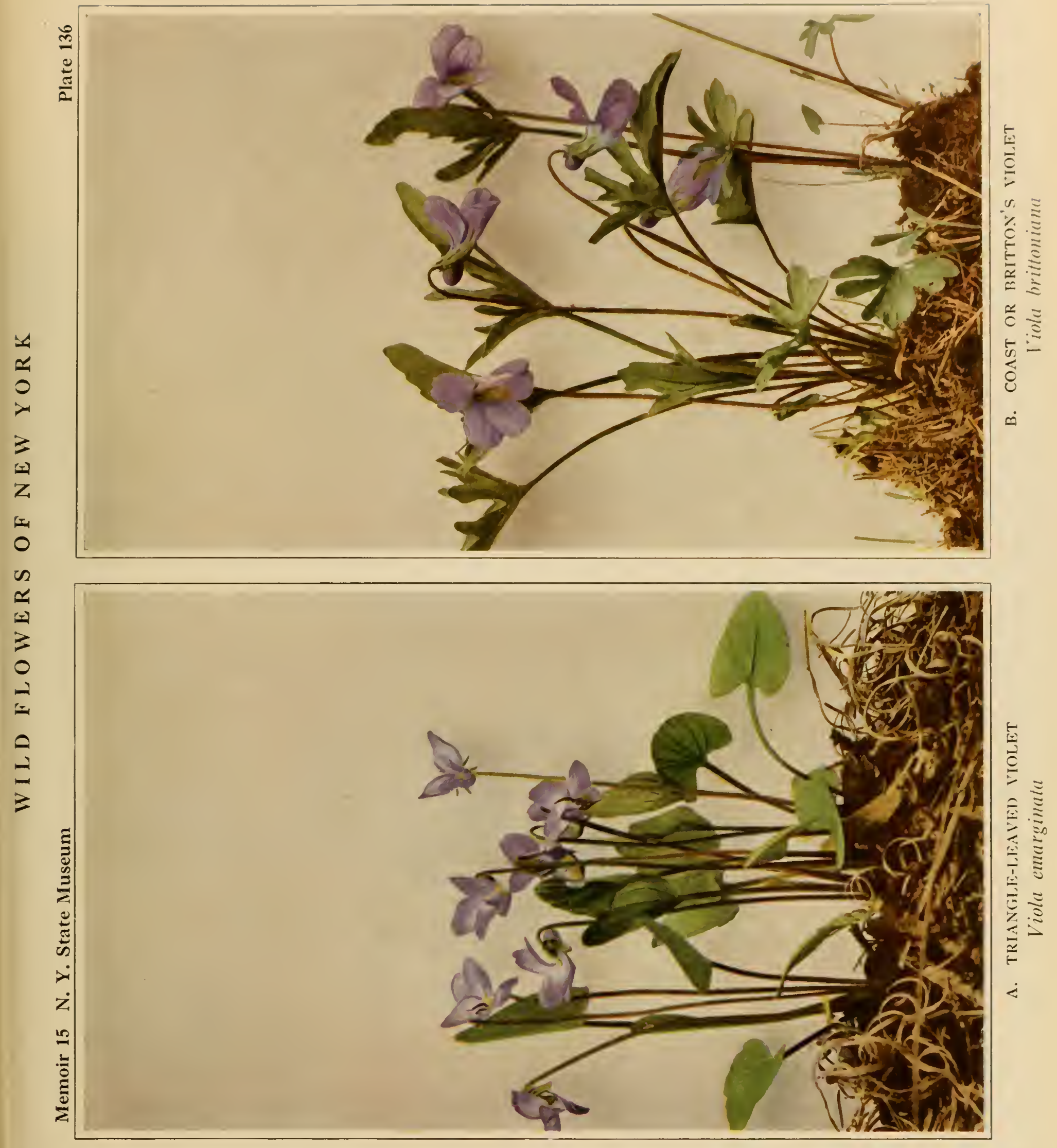




\section{Marsh Blue Violet}

I'iola cucullata Aiton

Plate $138 \mathrm{~b}$

Leaves and stems smooth or nearly so; leaf blades, except the earliest, broadly ovate to reniform, heart-shaped at the base, the margins strongly cucullate (rolled inward) when the leaves are young, the apex pointed. margins crenate-serrate; when mature 2 to $t$ inches broad. Flowering stalks much longer than the leaves. Flowers violet-blue with a dark-blue throat or center, or sometimes entirely white; lateral petals bearled, the lower or spur petal smooth and usually shorter than the lateral ones. Cleistogamous flowers on long, slender, erect stalks, their eapsules green: seeds nearly black.

In moist meadows, springy places in woodlands and along streams, Quebee to Georgia. Flowering from late in April until June.

\section{Ovate-leaved Violet \\ I'iola fimbriatula J. E. Smith Plate $\mathrm{t}_{3}$ ia}

Rootstoek long and stout, sometimes branching. The earliest leaf blades ovate and blunt; the later ones oblong-ovate, acute, finely pubescent, especially beneath, the margins erenulate toward the apex, the bases usually somewhat heart-shaped or truncate and sharply toothed, incised or auriculate. Flowering stalks about as long as the leaves when first in bloom or longer than the leaves in later flowers; the eorolla violet-purple. Capsules green; seeds brown. Cleistogamous flowers on ereet peduneles.

Dry fields and hillsides, throughout the eastern states and south to Georgia. Flowering in May and June.

\section{Arrow-leaved Violet \\ Tiola sagittata Aiton Plate $13 \% \mathrm{~b}$}

Leaves erect from a stout rootstock, smooth, or sometimes ciliate or finely pubescent; their petioles longer than the blades which are laneeolate 
or oblong-lanceolate, I to + inches long, truncate or heart-shaped at the base and blunt or pointed at the apex, the base hastately or sagittately toothed or eleft, the earliest leaves often deltoid-ovate, blunt, and merely erenate at the base. Flowers on stalks about as long as the leaves, the eorolla violet-purple.

Moist banks, fields and wet meadows, Massachusetts to Minnesota, south to Georgia and Louisiana. Flowering in May and June. The smooth form appears to be the eommoner on the coastal plain, while around the Crreat Lakes region and eastward to the Hudson River valley oecurs a form with pubescent foliage.

\section{Triangle-leaved Violet}

\section{Tiola emarginata (Nuttall) LeConte}

Plate $136 a$

Foliage glabrous, suceulent, frequently in dense tufts from stout or matted rootstocks. Leaf blades at flowering time narrowly ovate or triangular, slightly heart-shaped; the later ones broadly ovate or deltoid, I to 3 inehes wide, often as broad as long, the base truneate or slightly heart-shaped, coarsely toothed or incised toward the base. Flowering seapes usually longer than the leaves; flowers violet-blue, the petals often notched at the ends.

Dry woods, hillsides and fields, southern New York southward. Flowering in April and May.

Viola e marginata a e $\mathrm{t}$ i l oba Brainerd, found on Staten Island, possesses leaf blades (of mature leaves) which are five-cleft or fiveparted, the middle lobe long and narrow, the lateral ones shorter and narrower than the middle lobe.

Closely related to the Triangle-leaved Violet is the Cut-leaved Violet ( $\mathrm{V}$ iola peetinata Bicknell) in whieh the blades of the mature leares are ovate-deltoid, wider than long, the margin deeply dentate or peetinate with numerous small linear acute, entire lobes. Low meadows and edges of salt meadows near the eoast. 


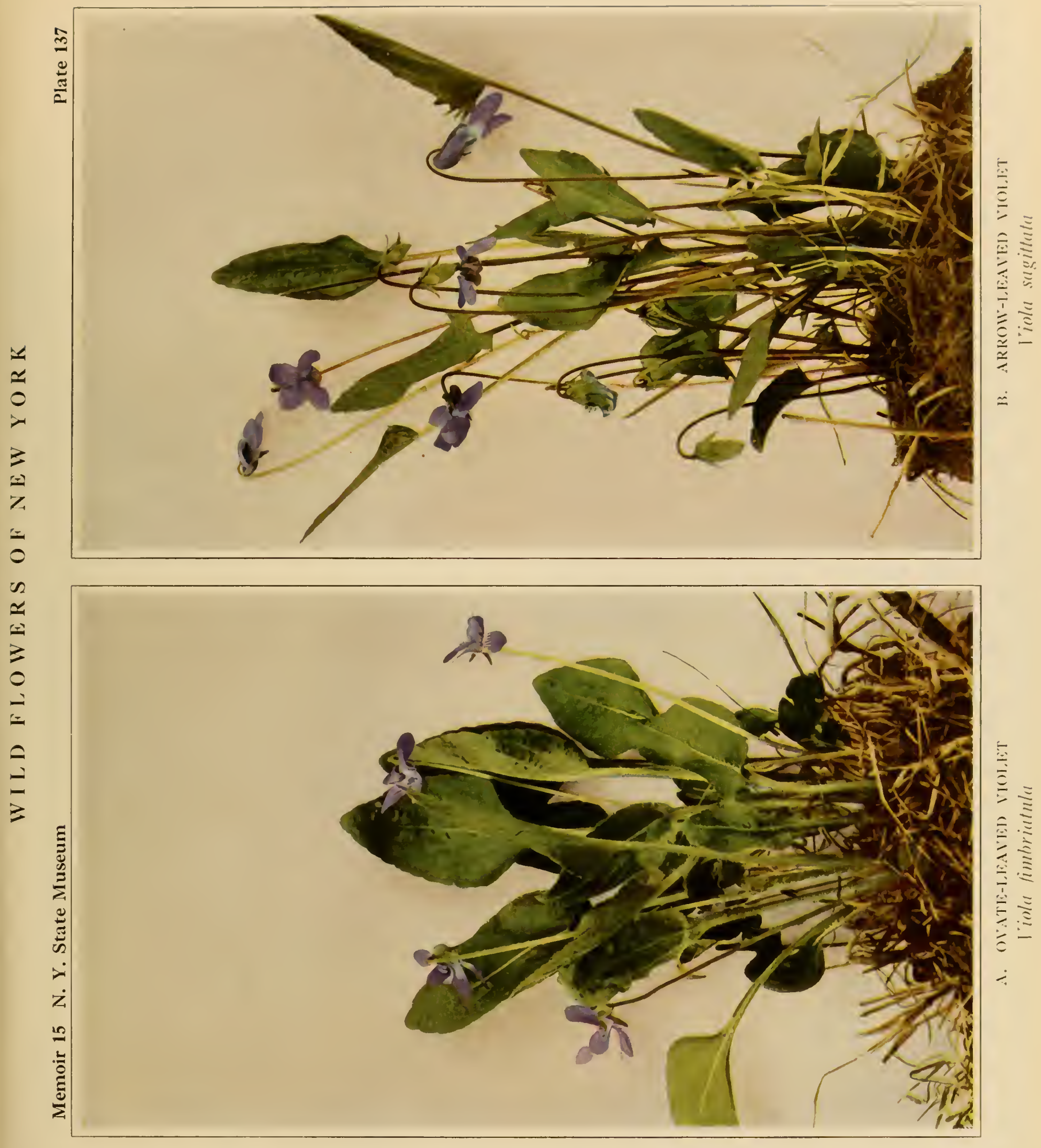


. 


\section{WILD FLOWERS OF NEW YORK}

Memoir 15 N. Y. State Museum

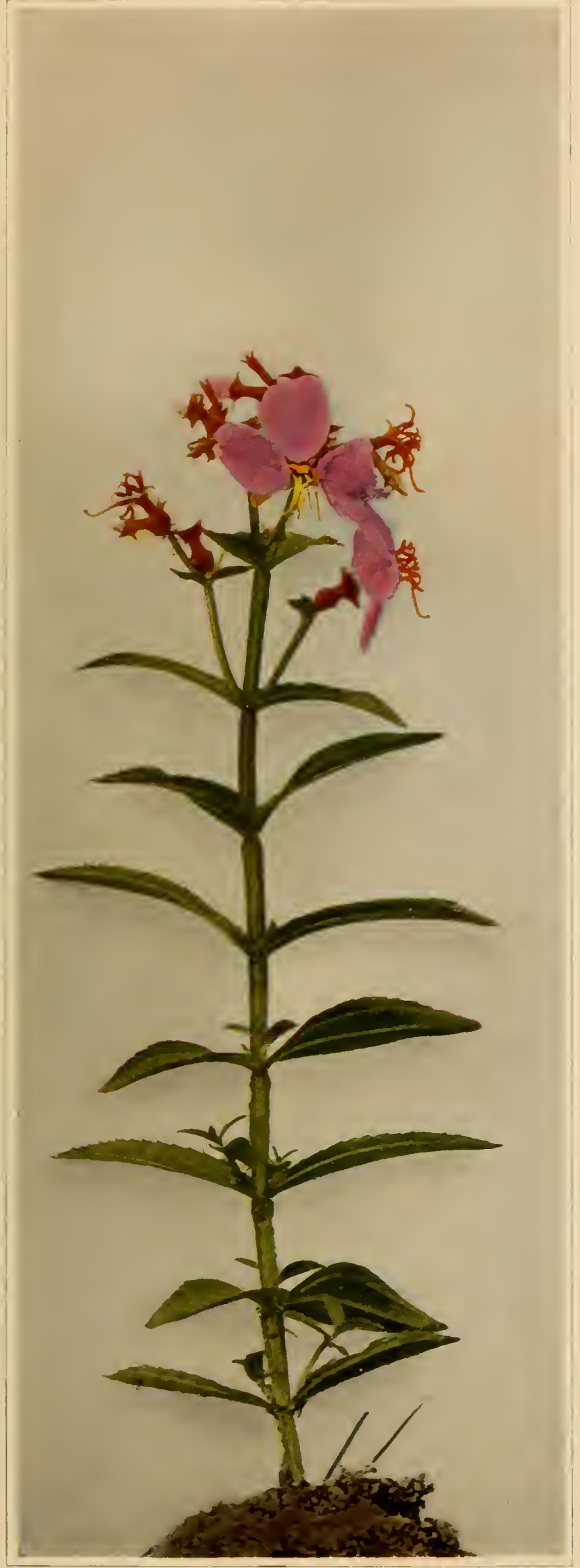

A. MEADOW BEAUTY; DEER GRASS Rhexia virginica
Plate 138

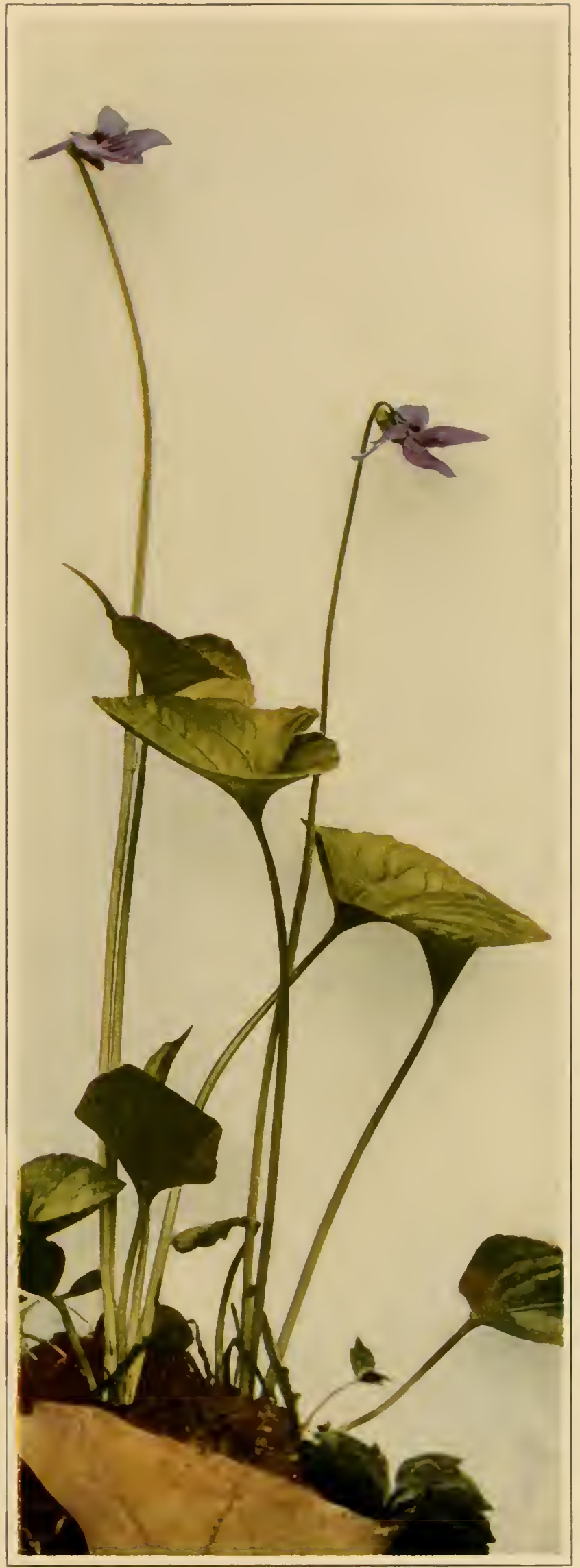

B. MARSH BLCE VIOLET Tiola cucullata 


\section{Great-spurred or Selkirk's Violet \\ Viola selkirkii Pursh \\ Plate $139 a$}

Leaves and scapes 2 to 4 inches high from a slender rootstock or stolon. Leaf blades thin, crenate margined, ovate to suborbicular, deeply heartshaped, the basal lobes converging or overlapping; leaves small at flowering time, when mature I to $2 \frac{1}{2}$ inches wide, smooth except for minute, spreading hairs on the upper surface of the leaves. Flowers pale violet, not bearded, the spur $2 \frac{1}{2}$ to + lines long and much enlarged toward the rounded end.

In shaded ravines and cool mountain forests, New Brunswick to Pennsylvania and Minnesota, north to Greenland. In central New York its favorite habitat is the moss-covered rocks and boulders beneath limestone cliffs and shaded by dense forests of mixed hardwoods and hemlock. Flowering in April and May.

\section{Large-leaved White Violet}

riola incognita Brainerd

Plate 1396

Foliage somewhat pubescent with soft, white hairs, especially when young, upper leaf surfaces smooth. Leaves ascending from slender rootstocks. Leaf blades at flowering time orbicular or reniform, two-thirds to 2 inches wide, abruptly short pointed at the apex, cordate at the base; summer leaves with large, somewhat roughened blades, broadly ovate, cordate with an open sinus, acute, 2 to $t$ inches wide or larger. Flowers white, on stalks as long as the leaves at flowering time, the lateral petals bearded, the upper pair obovate; seeds brown. In summer the plants produce numerous filiform runners.

Mountainous and low, moist woodlands, Newfoundland to Dakota and south to Tennessee.

The Kidney-leaved White Violet ( $\mathrm{V}$ iol a re n ifolia A. Gray) is densely pubescent throughout, with reniform leaf blades which are distantly crenate-serrate on the margins and rounded at the apex; petals white, all beardless, the three lower with brownish veins. In Arbor Vitae 
swamps and eold woods, Newfoundland to Mackenzie river, south to Pcnnsylvania and Minnesota and along the Rocky mountains to Colorado.

The Sweet White Violet (V i o l a b l a n d a Willdenow) has the petioles and scapes smooth and often tinged with red; smaller leaves, longer flowering stalks with very fragrant white flowers; lateral petals beardlcss, the upper pair of petals often long, narrow and strongly reflexed or sometimes twisted; seeds dark brown and minutely roughened.

The Northern White Violet ( $\mathrm{V}$ i o la pall e ns (Banks) Brainerd) has small, broadly ovate or orbicular, smooth. pale-green leaves; scapes much longer than the leaves, bearing whitc, slightly fragrant flowers. Common in mossy bogs and wet meadows.

\section{Primrose-leaved Violet \\ Viola primulifolia Linnaeus \\ Plate I $40 \mathrm{a}$}

Leaf blades oblong to ovate, obscurely erenate-serrate on the margins, smooth or somewhat hairy, especially toward the base of the petioles; the lcaves and flower stalks arising from slender rootstoeks or stolons. Flowering scapes 2 to $\mathrm{I}$ inehes high, usually 'longer than the leaves. Flowers white, the three lower petals purple-veined, the lateral ones slightly or not at all bearded; capsules green; seeds reddish brown. Numerous leafy stolons are developed in late summer.

A frequent violet of moist, open, especially sandy soil near the coast from New Brunswick to Florida and Louisiana. Flowering in May and June.

\section{Lance-leaved or Water Violet}

\section{Tiola lanceolata Linnaeus}

Plate I 403

Foliage smooth and plants usually profusely stoloniferous in late summer, the stolons rooting at the nodes and bearing numerous apetalous flowers; the rootstoeks slender. Flowering stalks 2 to + inehes high or higher: mature leaves laneeolate or elliptical in shape, the blade 2 to 6 inches long and one-eighth to three-fourths of an inch wide, tapering gradually below into the margined reddish petiole: margins of the leaves obscurely ercnulate. Flowers white, the three lower petals striped with purplish reins. Fruiting capsules green; seeds dark brown. 
W I L D I: L, O WERS O I NE IV YOR K

Memoir 15 N. Y. State Museum

Plate 139

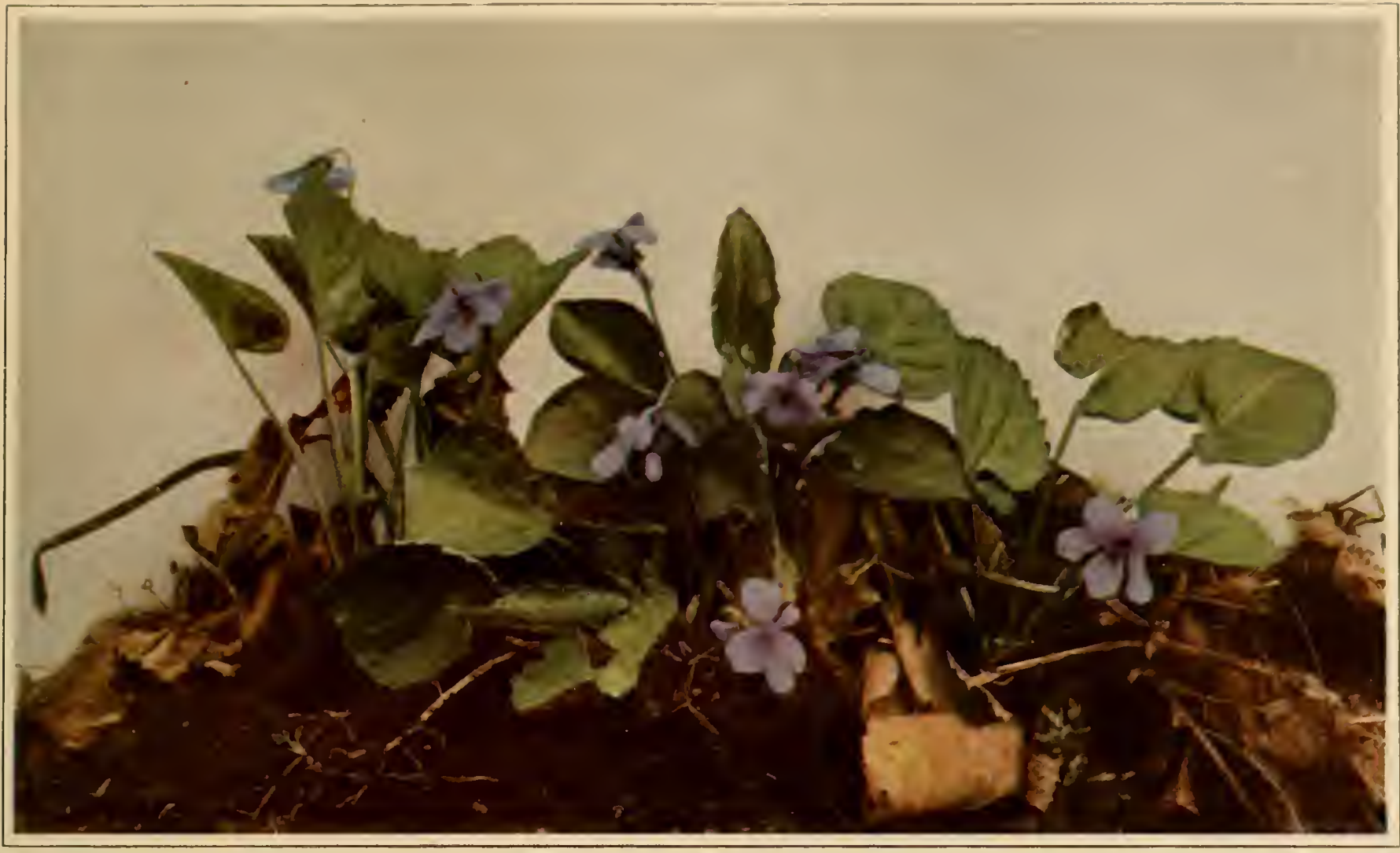

A. GREAT-SPURRED OR SELKIRK'S VIOLET

Viola selkirkii

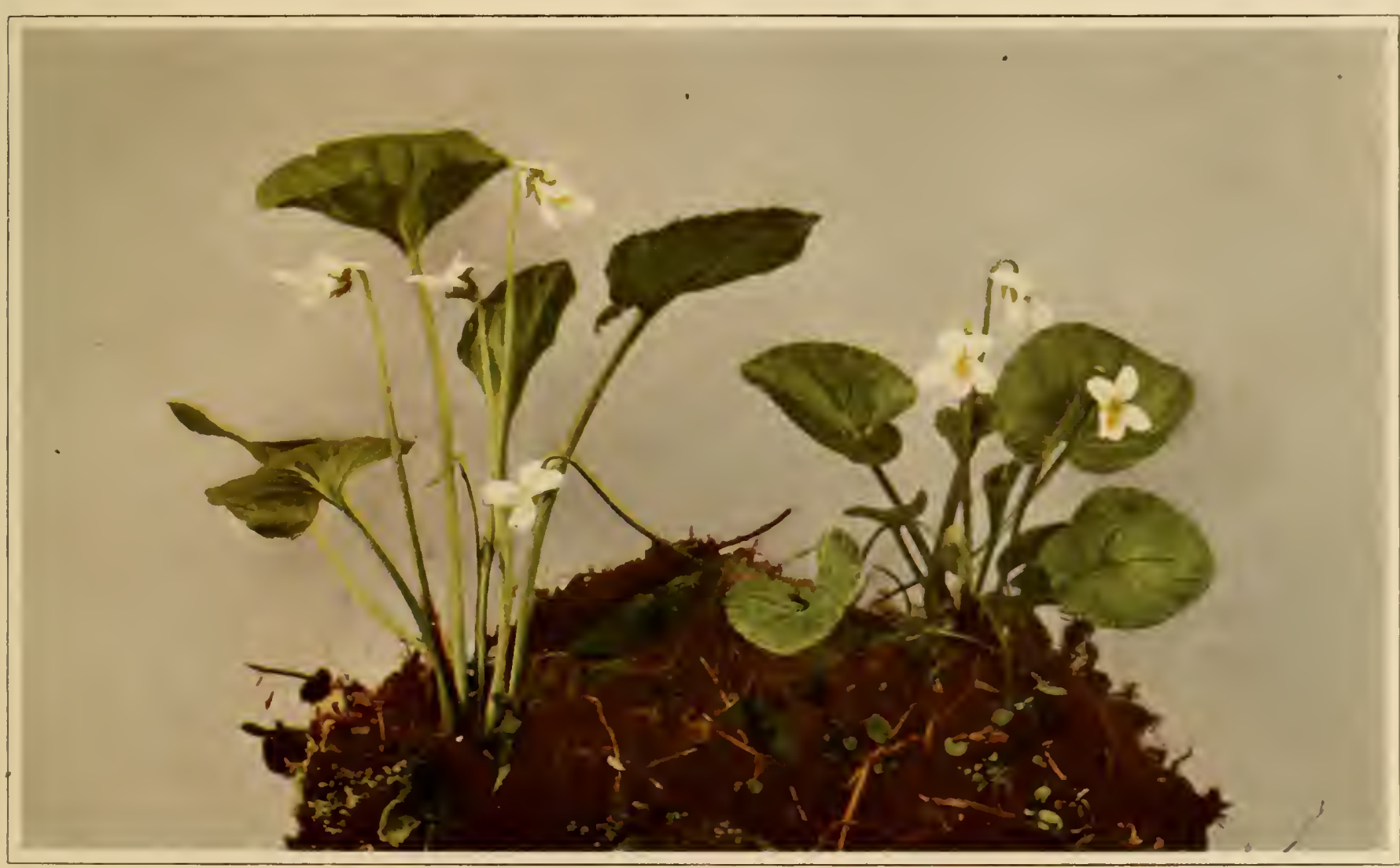

B. LARGE-LEAVED WHITE VIOLET

Tiola incognita 


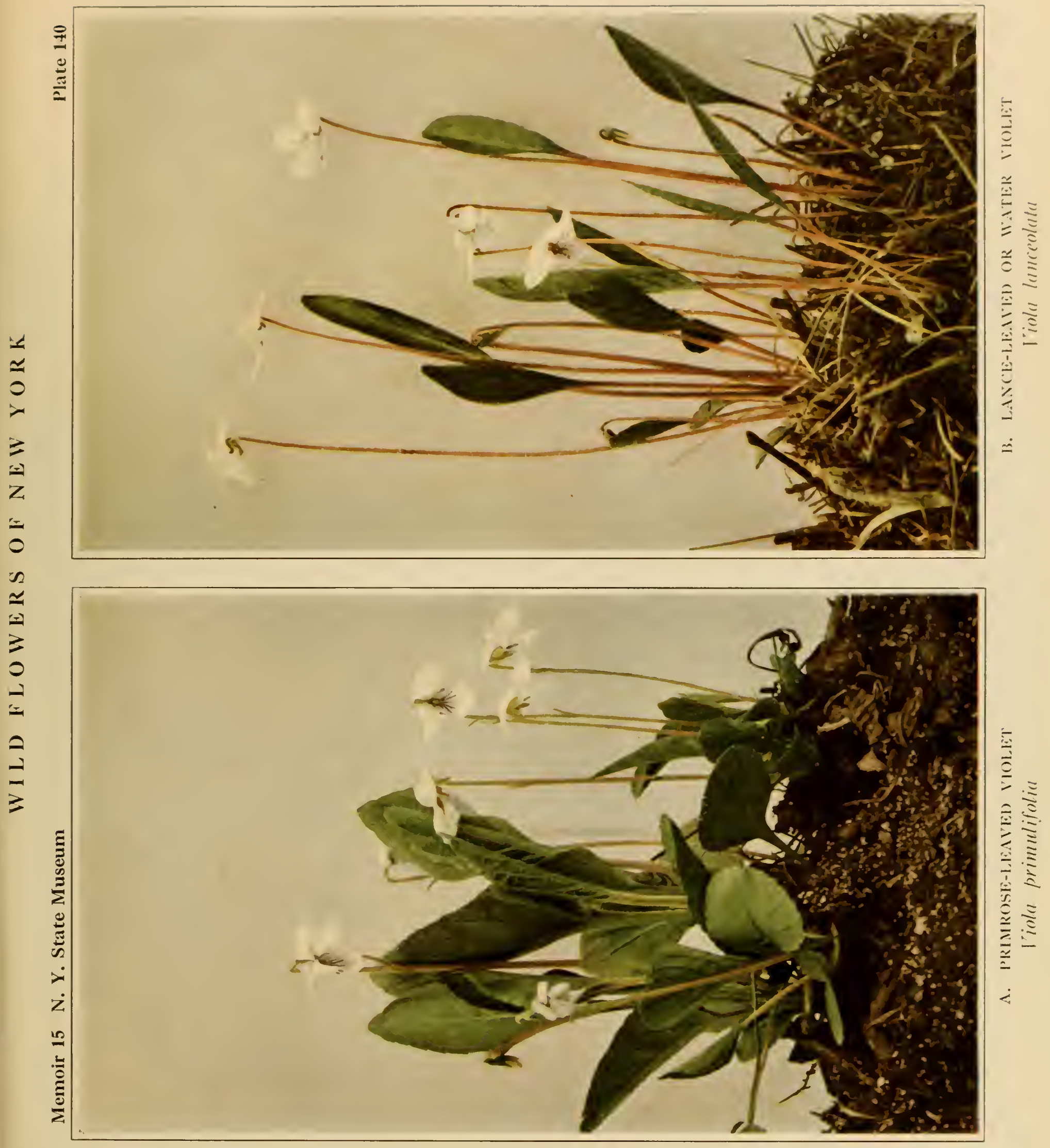




$$
\text { , }
$$


Open bogs, marshes and moist meadows, Nova Scotia to Minnesota and southward. Flowering in May and June or sometimes as early as the latter part of April.

The Round-leaved Yellow Tiolet ( $\mathrm{T}$ iola rot und ifolia Michaux) possesses oval or orbicular, blunt leaves, heart-shaped with repand-crenulate margins; at flowering time about I inch wide; in midsummer 2 to 4 inches wide and flat upon the ground; flowers bright yellow, the three lower petals with brown lines. In cold woods, Maine to Ontario, south to Georgia. Very common in the Adirondack and Catskill mountains. In other parts of the State rather rare or local.

\section{Smoothish Yellow Violet}

Viola eriocarpa Schweinitz

Plate $134 \mathrm{~b}$

Commonly with two to four ascending stems from a single rootstock. Basal leaves often several, long petioled with ovate to reniform blades, smooth except for minute pubescence on the upper part of the stem and on the lower leaf surfaces along the veins; the stems bearing one to three short-petioled leaves, each broadly ovate, slightly heart-shaped at the base and long pointed at the apex, the uppermost ones smaller and nearly sessile. Flowers in the upper axils, yellow, the lateral petals bearded. Fruiting capsules ovoid, woolly white or rarely nearly smooth; seeds brown.

In low, open, moist woods, Nova Scotia to Manitoba, south to Georgia and Texas. Flowering in May and June.

The closely related Hairy or Downy Yellow Violet (V i o l a $\mathrm{pu} \mathrm{b}$ e scen s Aiton) is softly pubescent throughout; stems usually but one from a rootstock; usually without basal leaves, but bearing one to three leaves on the stem, which are broadly ovate or reniform. In dry, rich woods, Nova Scotia to Dakota, south to Virginia and Missouri.

\section{Canada Violet}

Tiola canadensis Linnaeus

Plate IfI

Stems 6 to 18 inches high, usually several or many together from a perennial root, smooth or nearly so. Leaves broadly ovate, heart-shaped, 
pointed at the apex, the margins toothed. Basal leaves numerous on long petioles. Flowers in the axils of the stem leaves, of ten appearing throughout the season from May to July, whitish with a bright-yellow eye, the upper petals more or less tinged with violet on the outside, the lower petal striped with fine, dark lines.

In upland and mountainous forests, New Brunswick to Saskatchewan, south to South Carolina and Alabama.

The Pale or Striped Violet (V i o l a striat a Aiton) possesses less ascending and more angular stems than $\mathrm{V}$. $\mathrm{c}$ a $\mathrm{n}$ a d e $\mathrm{n} \mathrm{s}$ is, 6 to $\mathrm{I} 2$ inches high when in flower; the flowers white or cream-colored, densely bearded in the center. In low and shaded places, New York to Minnesota, south to Georgia.

\section{American Dog Violet}

Viola conspersa Reichenbach

Plate $142 \mathrm{~b}$

Usually several stems ascending from an oblique, branched rootstock, 3 to 6 inches long at flowering time. Leaf blades orbicular, heart-shaped, crenate-serrate on the margins, blunt, one-half to 2 inches wide, the upper ones smaller and more pointed. Flowers numerous, usually pale violet or rarely white, raised above the leaves on axillary stalks, 2 to 3 inches long.

Common in low ground or moist, shaded woods, Quebec to Minnesota, south to Georgia. Flowering from early spring until late in May.

Closely related, but more dwarfed, with small, orbicular blades and deep violet flowers is the Alpine Dog Violet ( $\mathrm{V}$ i o l a $\mathrm{la} \mathrm{brad} \mathrm{or} \mathrm{i} \mathrm{c} \mathrm{a}$ Schrank) occurring in New York only on the higher mountains of the Adirondacks.

The Sand Violet (Viola a dunca J. E. Smith; V. subvestita Greene) is finely puberulent, the stems only 2 to 6 inches long; leaf blades ovate, one-half to I inch long, crenulate, blunt, subcordate; flowers deep violet, with a straight, blunt spur about 3 lines long. Rather local in sandy or sterile soil or on dry stony ridges, Quebec to Maine and westward. 
WII,D FLOWERS OF NEW YORK

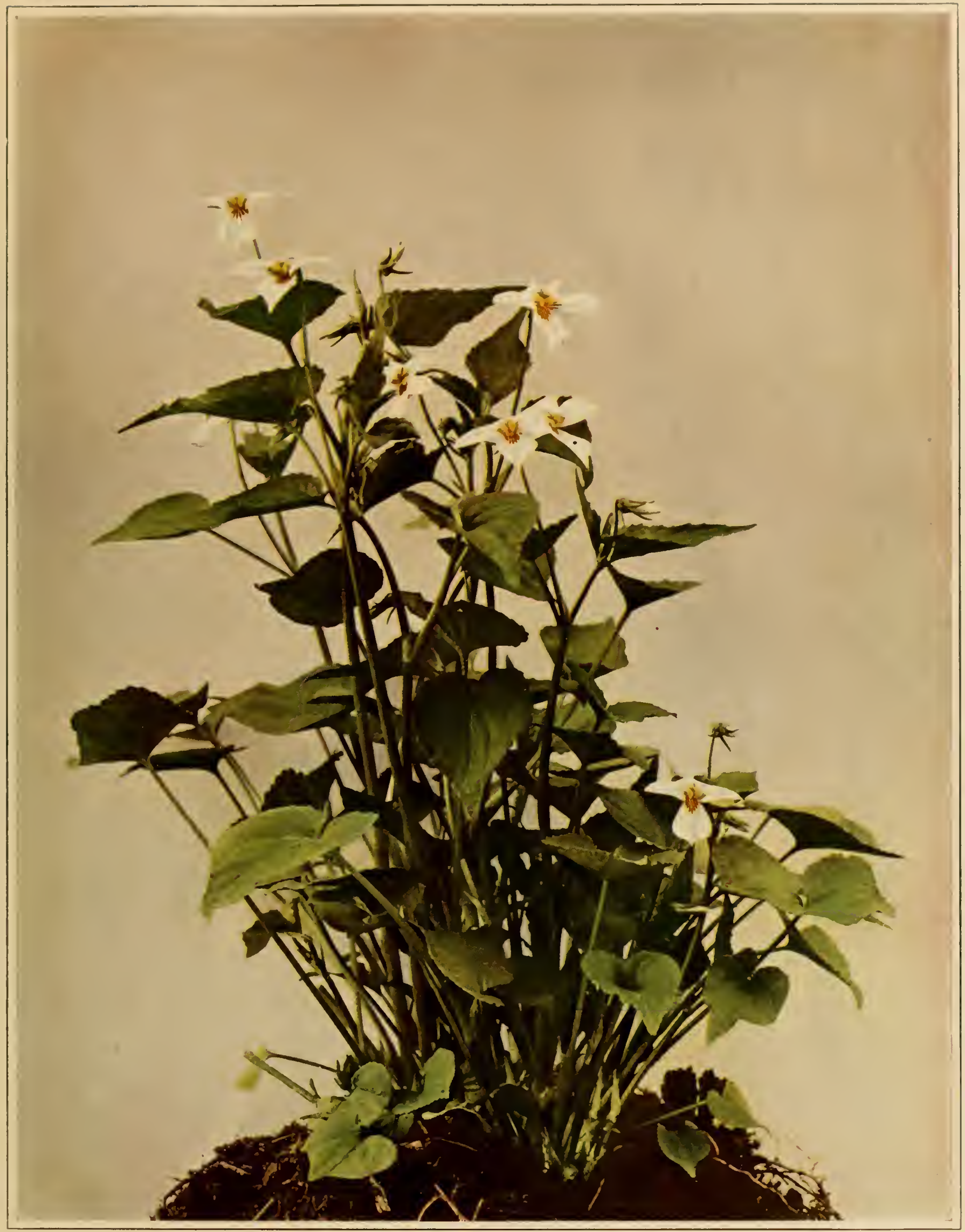




\section{Long-spurred Violet \\ Fiola rostrata Pursh \\ Plate 142a}

Stems usually numerous from an elongated, jointed rootstock, + to 8 inches high. Leaves orbicular to broadly ovate, heart-shaped, nearly or quite smooth, serrate on the margins, the upper ones pointed, the lower and basal leaves blunt. Petaliferous flowers on long, slender stalks, violet with a dark purple-violet center, not bearded, the spur slender and onehalf of an inch long or longer.

Shady hillsides and moist woods in leaf mold, Quebec to Michigan, south to Georgia. Flowering in May and June.

The Field Pansy (Viola rafinesqui Greenc) is an annual plant with slender, smooth, erect stems, 3 to 8 inches high, sometimes branched. Leaves small, somewhat rounded on slender petioles; their stipules large, conspieuous and deeply cut or fringed. Flowers small, bluish white to cream-colored. In fields and open woods, southern New York to Michigan and southward to Georgia and Texas. Flowering in April and May.

\section{Loosestrife Family}

Salicariacea e

(Lythraceae)

The Swamp Loosestrife and the Spiked or Purple Loosestrife belong to this family, which in addition to these two species illustrated here, is represented in this State by two smaller flowered species of Lythrum (L y th r m $\mathrm{m}$ ys sopifolia Linnaeus and L. a l a t u m Pursh) and the Clammy Cuphea or Blue Waxweed (Parsonsia petiolata (Linnaeus) Rusby).

\section{Swamp Loosestrife; Willow-herb \\ Decodon verticillatus (Linnaeus) Elliott \\ Plate $143 \mathrm{a}$}

An herblike perennial growing usually in swamps or shallow water. Although appearing like an herbaceous plant it is more or less shrubby. The stems are angular, recurved, smooth and somewhat woody below, 3 to I o feet long, often rooting at the tip when they reach the soil or mud. Leaves lanceolate, opposite or verticillate, 2 to 5 inches long, one-third 
to I inch wide, smooth above, somewhat hairy beneath, pointed at both ends, on very short petioles. Flowers numerous in cymelike axillary clusters; calyx broadly campanulate; corolla about an inch or less broad, petals cuneate at the base, pink-purple, the slender filaments of the stamens projecting from the flower. Fruiting capsule about one-fourth of an inch in diameter or slightly less.

In swamps, shallow water around the edges of lakes and ponds, or along slow streams, often forming thickets, Maine to Florida, west to Minnesota, Tennessee and Louisiana. Flowering in June and July. Also known as peatweed or slink-weed, wild oleander and grass poly.

\section{Spiked or Purple Loosestrife}

\section{Lythrum salicaria Linnaeus}

Plate r.43b

Stems four-angled, 2 to + feet high or sometimes taller from a perennial root, smooth or somewhat pubescent or tomentose above and more or less branched. Leaves opposite or sometimes in threes, sessile, lanceolate, clasping and heart-shaped at the base 2 to 3 inches long, one-fourth to one-half of an inch wide. Flowers purple, one-half to two-thirds of an inch long and half as broad, in dense, terminal, branched racemes interspersed with numerous small leaves; petals four or five, usually five; stamens eight or ten, the longer ones scarcely projecting beyond the flower.

Native of Europe but thoroughly naturalized and common in wet places and swamps throughout the east. Very common along the Hudson river from Albany to New York. Flowering in July and August.

\section{Meadow Beauty Family}

M e 1 a s t o m a c e a

\section{Meadow Beauty; Deer Grass}

Rhexia virginica Linnaeus

Plate $138 a$

Stems square, 8 to I 8 inches high, the angles of the stem usually slightly winged, hairy or nearly smooth; roots perennial and fibrous with a few small 
W I I, D FI, O WERS OF NEW YORK

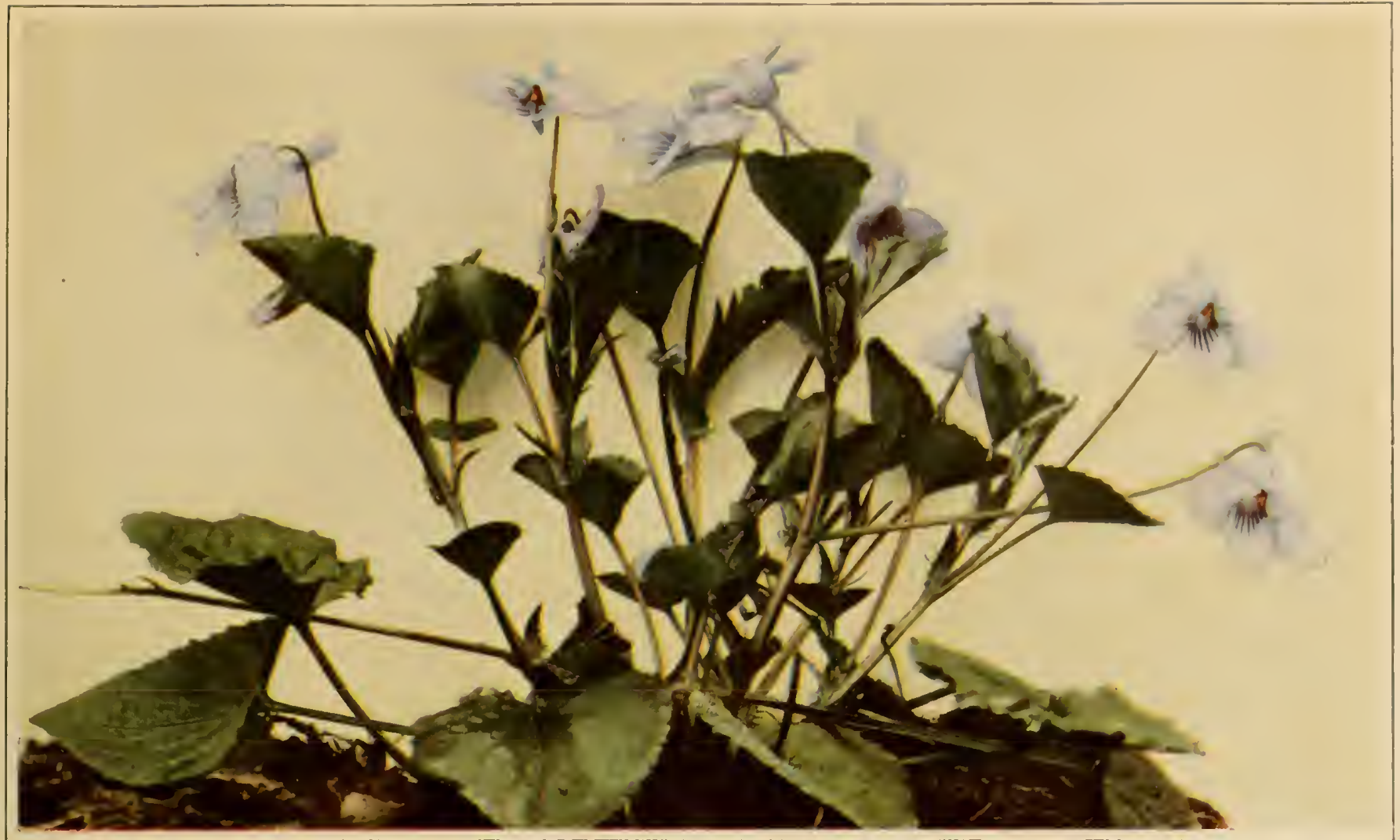

A. I.ONG-SPURRED VIOLET

Viola rostrata

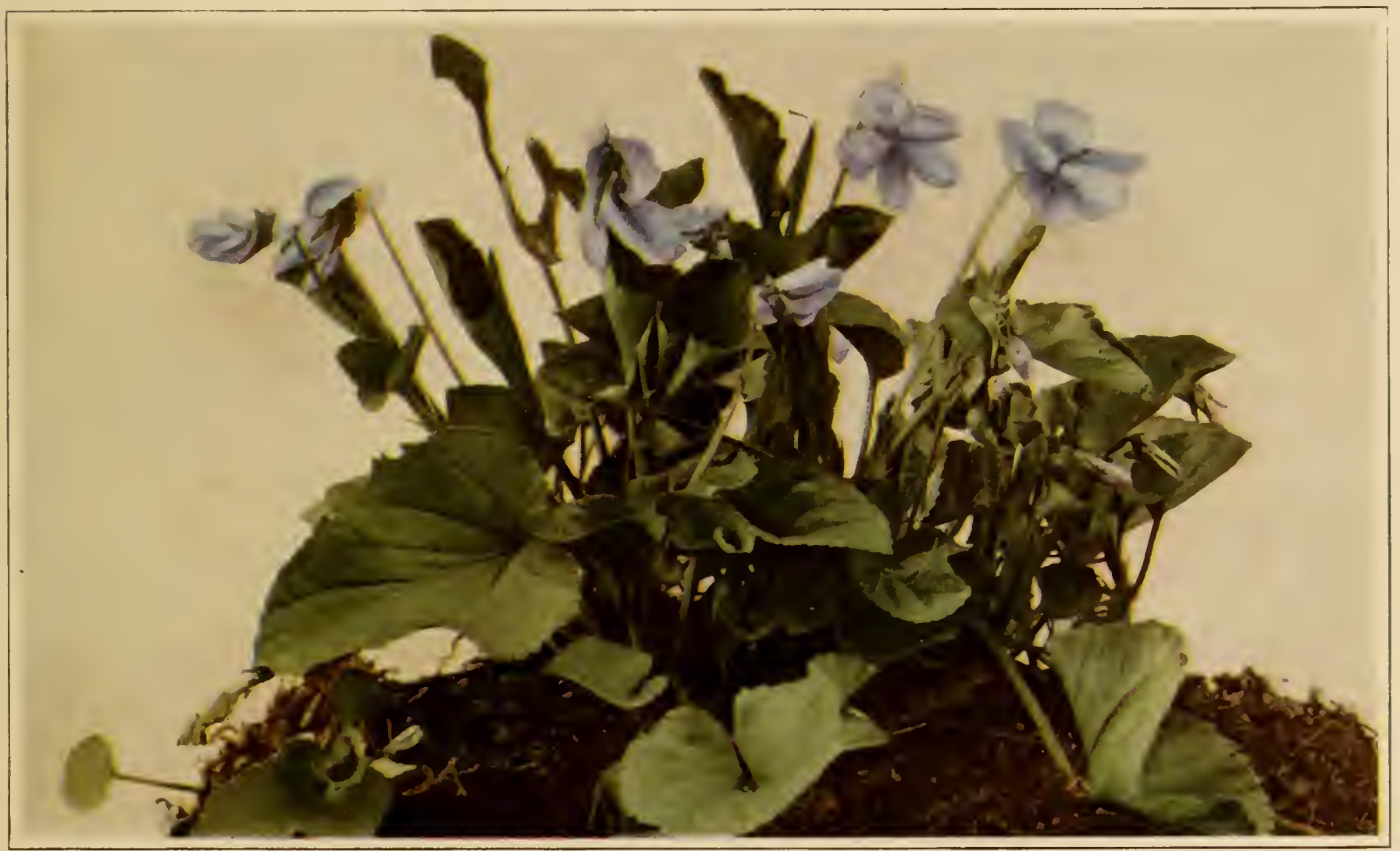

B. AMERICAN DOG VIOLET

riola conspersa 
$\checkmark$ 
W ILI) FLOWERS OF NEW YORK

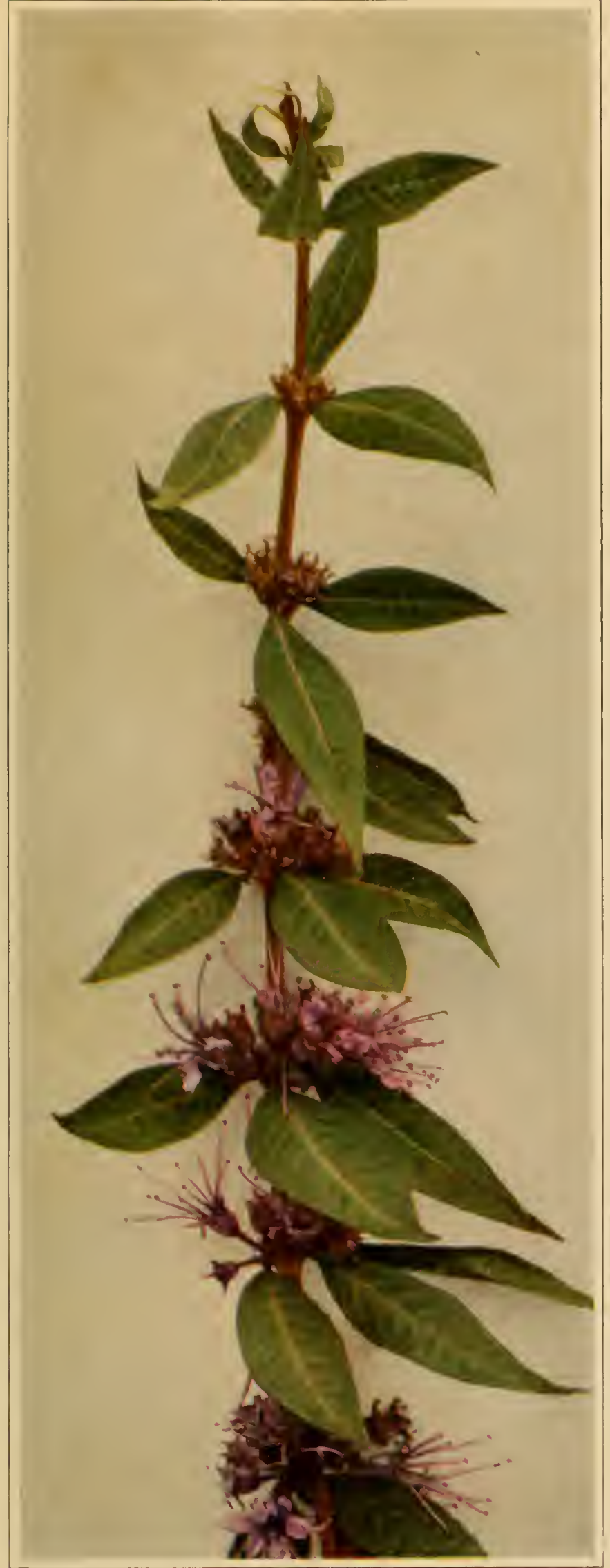

A. SWAMP LOOSESTRIFE; WILLOW-HERB Decodon ierticillatus

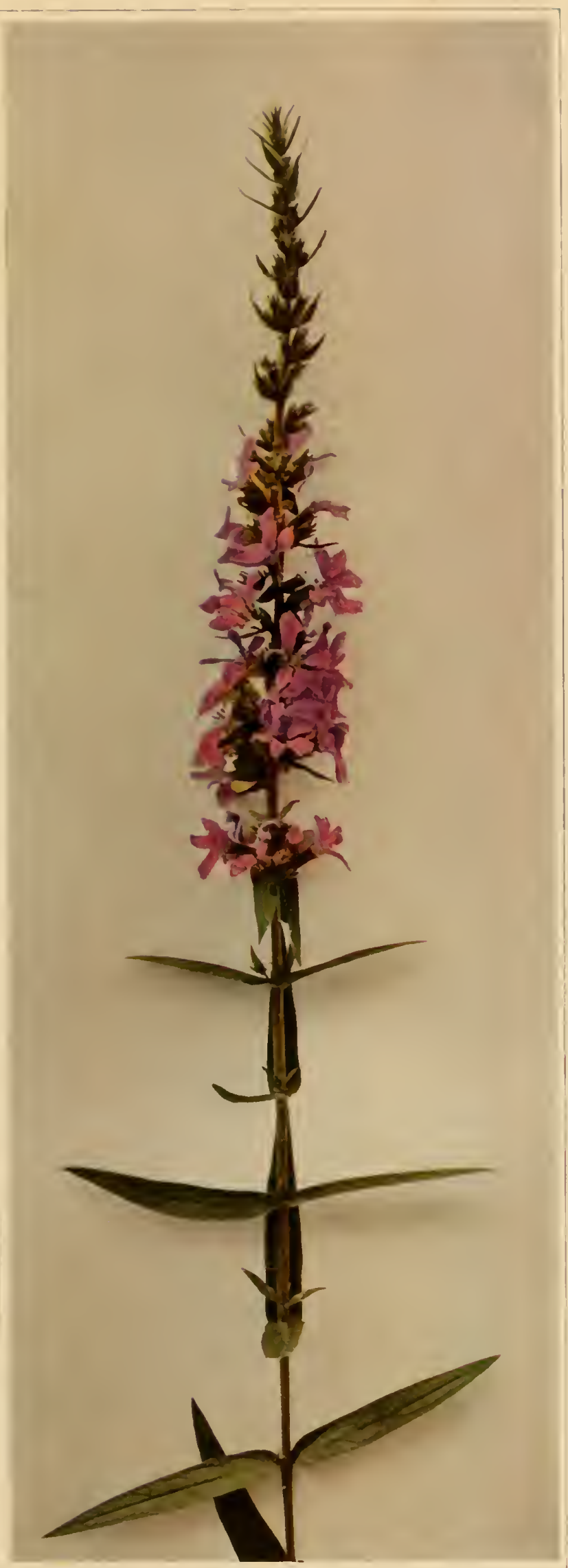

B. SPIKED OR PLRPLE LOOSESTRIFE Lythrum salicaria 


$$
\text { , }
$$


tubers. Lcaves opposite, sessile or nearly so, ascending, ovatc or ellipticalovate, pointed at the apex, narrowed or rounded at the base, 1 to 2 inches long, one-half to I inch wide, with a few scattered hairs on both surfaces, conspicuously three to five-nerved, the margins ciliate-serrulate. Flowers bright purple, $I$ to $I_{2}^{1}$ inches broad, few or several in terminal clusters; calyx-tube urn-shaped, constricted above with four triangular-pointed lobes, and like the stalk of the flower glandular-pubescent; petals four, broadly obovate; stamens eight, equal; anthers ycllow, lincar, curved and minutely spurred on the back. Fruit a four-celled, four-valved capsule with numerous small rough, bent seeds.

In moist, sandy meadows and marshes, Maine to northern New York, Ontario and Iowa, south to Florida, Louisiana and Missouri. Flowering from July to September. Common on the coastal plain, but rare or local inland, except east and north of Oneida lake, where it is very abundant in certain places.

The Maryland Meadow Beauty (R h exia marian a Linnaeus) occurs from Long Island southward. It is more densely hairy, the stems are not angled and the leaves are narrower and more spreading. 


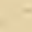





• 



